\title{
Interventional Treatments for Acute and Chronic Pain: Systematic Review
}




\section{Interventional Treatments for Acute and Chronic Pain: Systematic Review}

Prepared for:

Agency for Healthcare Research and Quality

U.S. Department of Health and Human Services

5600 Fishers Lane

Rockville, MD 20857

www.ahrq.gov

Contract No. 75Q80120D00006

Prepared by:

Pacific Northwest Evidence-Based Practice Center

Portland, OR

Investigators:

Roger Chou, M.D.

Rongwei Fu, Ph.D.

Tracy Dana, M.L.S.

Miranda Pappas, M.A.

Erica Hart, M.S.T.

Kimberly M. Mauer, M.D.

AHRQ Publication No. 21-EHC030

September 2021 
This report is based on research conducted by the Pacific Northwest Evidence-based Practice Center (EPC) under contract to the Agency for Healthcare Research and Quality (AHRQ), Rockville, MD (Contract No. 75Q80120D00006). The findings and conclusions in this document are those of the authors, who are responsible for its contents; the findings and conclusions do not necessarily represent the views of AHRQ. Therefore, no statement in this report should be construed as an official position of AHRQ or of the U.S. Department of Health and Human Services.

\section{None of the investigators have any affiliations or financial involvement that conflicts with the material presented in this report.}

The information in this report is intended to help healthcare decision makers - patients and clinicians, health system leaders, and policymakers, among others-make well-informed decisions and thereby improve the quality of healthcare services. This report is not intended to be a substitute for the application of clinical judgment. Anyone who makes decisions concerning the provision of clinical care should consider this report in the same way as any medical reference and in conjunction with all other pertinent information, i.e., in the context of available resources and circumstances presented by individual patients.

This report is made available to the public under the terms of a licensing agreement between the author and the Agency for Healthcare Research and Quality. This report may be used and reprinted without permission except those copyrighted materials that are clearly noted in the report. Further reproduction of those copyrighted materials is prohibited without the express permission of copyright holders.

AHRQ or U.S. Department of Health and Human Services endorsement of any derivative products that may be developed from this report, such as clinical practice guidelines, other quality enhancement tools, or reimbursement or coverage policies, may not be stated or implied.

AHRQ appreciates appropriate acknowledgment and citation of its work. Suggested language for acknowledgment: This work was based on an evidence report, Interventional Treatments for Acute and Chronic Pain: Systematic Review, by the Evidence-based Practice Center Program at the Agency for Healthcare Research and Quality (AHRQ).

Suggested citation: Chou R, Fu R, Dana T, Pappas M, Hart E, Mauer KM. Interventional Treatments for Acute and Chronic Pain: Systematic Review. Comparative Effectiveness Review No. 247. (Prepared by the Pacific Northwest Evidence-based Practice Center under Contract No. 75Q80120D00006.) AHRQ Publication No. 21-EHC030. Rockville, MD: Agency for Healthcare Research and Quality; September 2021. DOI: https://doi.org/10.23970/AHRQEPCCER247. Posted final reports are located on the Effective Health Care Program search page. 


\section{Preface}

The Agency for Healthcare Research and Quality (AHRQ), through its Evidence-based Practice Centers (EPCs), sponsors the development of evidence reports and technology assessments to assist public- and private-sector organizations in their efforts to improve the quality of healthcare in the United States.

The Centers for Medicare \& Medicaid Services requested this report from the EPC Program at AHRQ. AHRQ assigned this report to the following EPC: Pacific Northwest Evidence-based Practice Center (Contract Number: 75Q80120D00006).

The reports and assessments provide organizations with comprehensive, evidence-based information on common medical conditions and new healthcare technologies and strategies. They also identify research gaps in the selected scientific area, identify methodological and scientific weaknesses, suggest research needs, and move the field forward through an unbiased, evidence-based assessment of the available literature. The EPCs systematically review the relevant scientific literature on topics assigned to them by AHRQ and conduct additional analyses when appropriate prior to developing their reports and assessments.

To bring the broadest range of experts into the development of evidence reports and health technology assessments, AHRQ encourages the EPCs to form partnerships and enter into collaborations with other medical and research organizations. The EPCs work with these partner organizations to ensure that the evidence reports and technology assessments they produce will become building blocks for healthcare quality improvement projects throughout the Nation. The reports undergo peer review and public comment prior to their release as a final report.

AHRQ expects that the EPC evidence reports and technology assessments, when appropriate, will inform individual health plans, providers, and purchasers as well as the healthcare system as a whole by providing important information to help improve healthcare quality.

If you have comments on this evidence report, they may be sent by mail to the Task Order Officer named below at: Agency for Healthcare Research and Quality, 5600 Fishers Lane, Rockville, MD 20857, or by email to epc@ahrq.hhs.gov.

David Meyers, M.D. Acting Director Agency for Healthcare Research and Quality

Craig Umscheid, M.D., M.P.H.

Director

Evidence-based Practice Center Program

Center for Evidence and Practice Improvement Agency for Healthcare Research and Quality

Lauren Lowenstein, M.P.H., M.S.W.

Program Lead

Centers for Medicare \& Medicaid Services
Arlene S. Bierman, M.D., M.S.

Director

Center for Evidence and Practice Improvement Agency for Healthcare Research and Quality

Elisabeth Uphoff Kato, M.D., M.R.P. Task Order Officer

Center for Evidence and Practice

Improvement

Agency for Healthcare Research and Quality

Ellen Blackwell, M.S.W.

Senior Advisor

Centers for Medicare \& Medicaid Services 


\section{Acknowledgments}

The authors gratefully acknowledge the following individuals for their contributions to this project: Associate Editor Timothy J. Wilt, M.D., M.P.H., at the Minnesota EPC; Ellen Blackwell, M.S.W., and Lauren Lowenstein, M.P.H., M.S.W., both from the Centers for Medicare \& Medicaid Services; and Task Order Officer Elisabeth Uphoff Kato, M.D., M.R.P., at AHRQ.

\section{Technical Expert Panel}

In designing the study questions and methodology at the outset of this report, the EPC consulted several technical and content experts. Broad expertise and perspectives were sought. Divergent and conflicted opinions are common and perceived as healthy scientific discourse that results in a thoughtful, relevant systematic review. Therefore, in the end, study questions, design, methodologic approaches, and/or conclusions do not necessarily represent the views of individual technical and content experts.

Technical Experts must disclose any financial conflicts of interest greater than $\$ 5,000$ and any other relevant business or professional conflicts of interest. Because of their unique clinical or content expertise, individuals with potential conflicts may be retained. The TOO and the EPC work to balance, manage, or mitigate any potential conflicts of interest identified.

The list of Technical Experts who provided input to this report follows:

Timothy S. Carey, M.D., M.P.H.*

Professor

University of North Carolina

Chapel Hill, NC

W. Michael Hooten, M.D.

Professor

Mayo Clinic

Rochester, MN

Erin Krebs, M.D., M.P.H.*

Professor

Minneapolis VA Health Care System

University of Minnesota Medical School

Minneapolis, MN
Carl Noe, M.D.*

Professor

University of Texas Southwestern Medical

Center

Dallas, TX

Linda Porter, Ph.D.

Director, Office of Pain Policy

National Institute of Neurological Disorders and Stroke, National Institutes of Health

(NINDS)

Bethesda, MD

Steven Stanos, D.O.*

Executive Medical Director, Rehabilitation

and Performance Medicine

Medical Director

Swedish Health Systems, Pain Medicine and

Services Swedish Medical Group

Seattle, WA

*Provided input on Draft Report 


\section{Peer Reviewers}

Prior to publication of the final evidence report, EPCs sought input from independent Peer Reviewers without financial conflicts of interest. However, the conclusions and synthesis of the scientific literature presented in this report do not necessarily represent the views of individual reviewers.

Peer Reviewers must disclose any financial conflicts of interest greater than $\$ 5,000$ and any other relevant business or professional conflicts of interest. Because of their unique clinical or content expertise, individuals with potential nonfinancial conflicts may be retained. The TOO and the EPC work to balance, manage, or mitigate any potential nonfinancial conflicts of interest identified.

The list of Peer Reviewers follows:

Ambarish Bhat, M.D.

Assistant Professor

Radiologist

University of Missouri

Columbia, MO

Jianguo Cheng, M.D., Ph.D.

Professor

Cleveland Clinic

Cleveland, $\mathrm{OH}$
Jyme H. Schafer, M.D., M.P.H.

Contractor Medical Director

Novitas Solutions

Mechanicsburg, PA

Eric Sun, M.D., Ph.D.

Assistant Professor

Stanford University

Palo Alto, CA 


\section{Interventional Treatments for Acute and Chronic Pain: Systematic Review}

\section{Structured Abstract}

Objective. To evaluate the benefits and harms of selected interventional procedures for acute and chronic pain that are not currently covered by the Centers for Medicare \& Medicaid Services (CMS) but are relevant for and have potential utility for use in the Medicare population, or that are covered by CMS but for which there is important uncertainty or controversy regarding use.

Data sources. Electronic databases $\left(\right.$ Ovid $^{\circledR}$ MEDLINE $^{\circledR}$, PsycINFO ${ }^{\circledR}$, the Cochrane Central Register of Controlled Trials, and the Cochrane Database of Systematic Reviews) to April 12, 2021, reference lists, and submissions in response to a Federal Register notice.

Review methods. Using predefined criteria and dual review, we selected randomized controlled trials (RCTs) for 10 interventional procedures and conditions that evaluated pain, function, health status, quality of life, medication use, and harms. Random effects meta-analysis was conducted for vertebral compression fracture; otherwise, outcomes were synthesized qualitatively. Effects were classified as small, moderate, or large using previously defined criteria.

Results. Thirty-seven randomized trials (in 48 publications) were included. Vertebroplasty (13 trials) is probably more effective at reducing pain and improving function in older ( $>65$ years of age) patients, but benefits are small (less than 1 point on a 10-point pain scale). Benefits appear smaller (but still present) in sham-controlled ( 5 trials) compared with usual care controlled trials (8 trials) and larger in trials of patients with more acute symptoms; however, testing for subgroup effects was limited by imprecision. Vertebroplasty is probably not associated with increased risk of incident vertebral fracture (10 trials). Kyphoplasty ( 2 trials) is probably more effective than usual care for pain and function in older patients with vertebral compression fracture at up to 1 month (moderate to large benefits) and may be more effective at $>1$ month to $\geq 1$ year (small to moderate benefits) but has not been compared against sham therapy. Evidence on kyphoplasty and risk of incident fracture was conflicting. In younger (below age for Medicare eligibility) populations, cooled radiofrequency denervation for sacroiliac pain ( 2 trials) is probably more effective for pain and function versus sham at 1 and 3 months (moderate to large benefits). Cooled radiofrequency for presumed facet joint pain may be similarly effective versus conventional radiofrequency, and piriformis injection with corticosteroid for piriformis syndrome may be more effective than sham injection for pain. For the other interventional procedures and conditions addressed, evidence was too limited to determine benefits and harms.

Conclusions. Vertebroplasty is probably effective at reducing pain and improving function in older patients with vertebral compression fractures; benefits are small but similar to other therapies recommended for pain. Evidence was too limited to separate effects of control type and symptom acuity on effectiveness of vertebroplasty. Kyphoplasty has not been compared against sham but is probably more effective than usual care for vertebral compression fractures in older patients. In younger populations, cooled radiofrequency denervation is probably more effective 
than sham for sacroiliac pain. Research is needed to determine the benefits and harms of the other interventional procedures and conditions addressed in this review. 


\section{Contents}

Evidence Summary ........................................................................................................................... ES-1

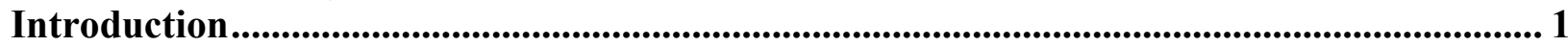

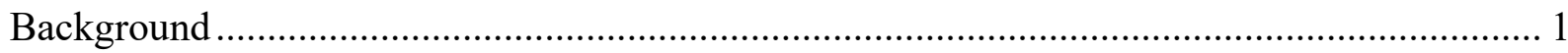

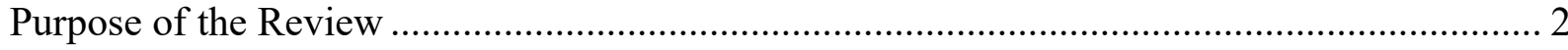

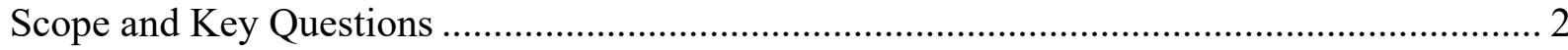

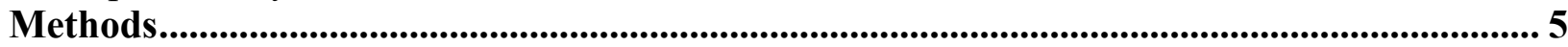

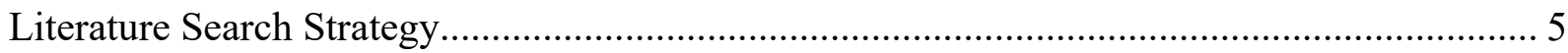

Inclusion and Exclusion Criteria and Study Selection............................................................ 5

Data Abstraction and Data Management .......................................................................... 8

Quality (Risk of Bias) Assessment of Individual Studies....................................................... 9

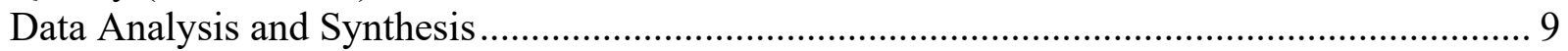

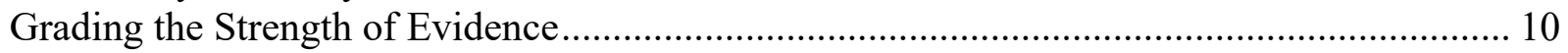

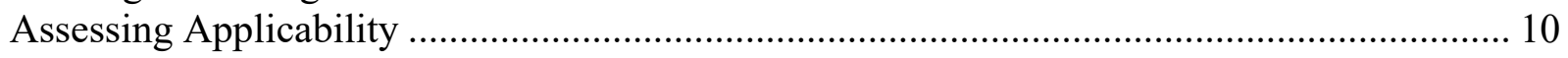

Peer Review and Public Commentary ......................................................................... 10

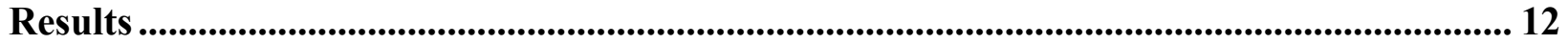

Results of Literature Search........................................................................................... 12

Vertebral Augmentation Procedures For Vertebral Compression Fractures........................ 13

Alternatives to Conventional Radiofrequency Ablation....................................................... 29

Intradiscal and Facet Joint Platelet-Rich Plasma For Low Back Pain of Presumed

Discogenic Origin or Into the Lumbar Facet Joint For Low Back Pain of Presumed Facet

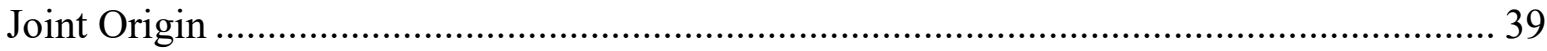

Intradiscal Stem Cells For Low Back Pain of Presumed Discogenic Origin ........................ 41

Intradiscal Methylene Blue For Low Back Pain of Presumed Discogenic Origin ............... 45

Intradiscal Ozone Injection For Radicular Low Back Pain or Nonradicular Low Back Pain

of Presumed Discogenic Origin ..................................................................................... 47

Sphenopalatine Block For Trigeminal Neuralgia and Headache......................................... 51

Occipital Nerve Stimulation for Headache .................................................................... 54

Piriformis Injection for Piriformis Syndrome..................................................................... 59

Peripheral Nerve Stimulation For Ulnar, Median, and Radial Neuropathy ........................... 63

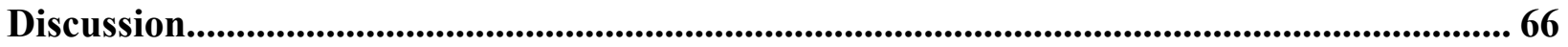

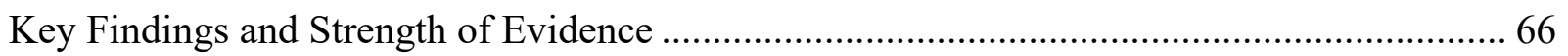

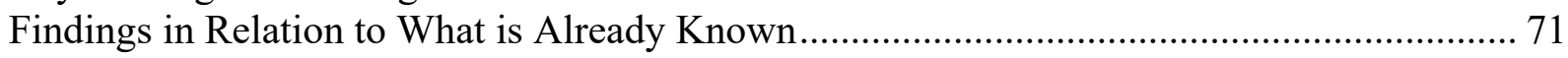

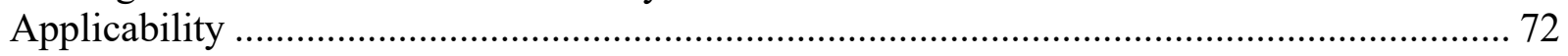

Implications for Clinical and Policy Decision Making......................................................... 72

Limitations of the Systematic Review Process .................................................................... 74

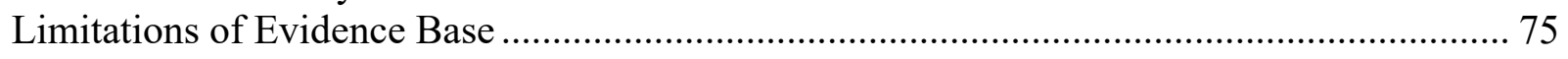

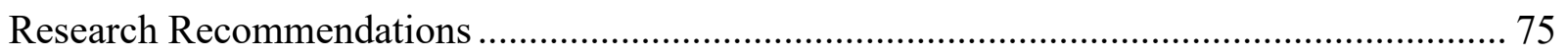

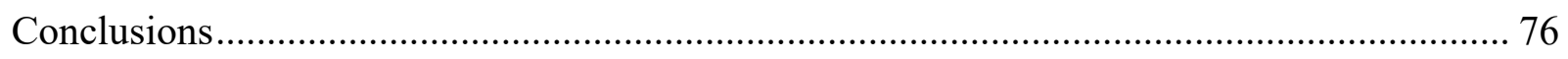

References................................................................................................................................... 77

Abbreviations and Acronyms ......................................................................................................... 87 


\section{Tables}

Table A. Interventional pain therapies for acute and chronic pain .........................................

Table 1. PICOTS (population, intervention, comparator, outcome, timing, setting) .................. 6

Table 2. Study characteristics of vertebroplasty trials ........................................................ 15

Table 3. Study characteristics of kyphoplasty trials ........................................................... 27

Table 4. Study characteristics and results for cooled radiofrequency ablation trials.................. 30

Table 5. Study characteristics and results of pulsed radiofrequency ablation trials ................... 35

Table 6. Study characteristics and results of platelet-rich plasma trial.................................... 40

Table 7. Study characteristics and results of intradiscal stem cell trial ................................... 43

Table 8. Study characteristics and results of intradiscal methylene blue trials ........................ 46

Table 9. Study characteristics and results of intradiscal ozone trials .................................... 49

Table 10. Study characteristics and results of sphenopalatine block trial ............................... 53

Table 11. Study characteristics and results of occipital nerve stimulation trials ....................... 56

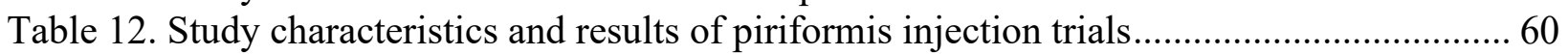

Table 13. Study characteristics and results of peripheral nerve stimulation trial ....................... 64

Table 14. Interventional pain therapies for acute and chronic pain ....................................... 67

\section{Figures}

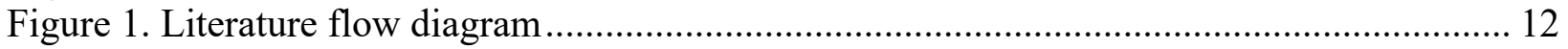

Figure 2. Vertebroplasty versus sham or usual care, pain (continuous) at 1 to 2 weeks ............. 17

Figure 3. Vertebroplasty versus sham or usual care, pain (continuous) at 2 to 4 weeks ............. 18

Figure 4. Vertebroplasty versus sham or usual care, pain (continuous) at 1 to 6 months ........... 18

Figure 5. Vertebroplasty versus sham or usual care, pain (continuous) at 6 to 12 months ......... 18

Figure 6. Vertebroplasty versus sham or usual care, pain (continuous) at 12 months and longer 19

Figure 7. Vertebroplasty versus sham or usual care and likelihood of a pain response ............. 20

Figure 8. Vertebroplasty versus sham or usual care, function (continuous) at 1 to 2 weeks....... 21

Figure 9. Vertebroplasty versus sham or usual care, function (continuous) at 2 to 4 weeks....... 22

Figure 10. Vertebroplasty versus sham or usual care, function (continuous) at 1 to 6 months.... 22

Figure 11. Vertebroplasty versus sham or usual care, function (continuous) at 6 to 12 months.. 22

Figure 12. Vertebroplasty versus sham or usual care, function (continuous) at 12 months and

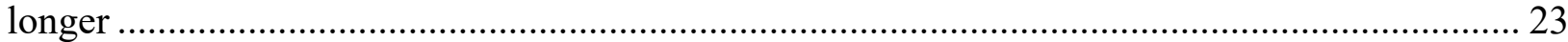

Figure 13. Vertebroplasty versus sham or usual care and risk of incident vertebral fracture....... 25

\section{Appendixes}

Appendix A. Search Strategies

Appendix B. List of Excluded Studies

Appendix C. Quality Rating Criteria

Appendix D. Detailed Statistical Methods

Appendix E. Grading the Strength of the Evidence

Appendix F. List of Included Studies

Appendix G. Data Abstraction Tables

Appendix H. Quality Table

Appendix I. Meta-Analysis Results

Appendix J. Strength of Evidence 


\section{Evidence Summary}

\section{Main Points}

- Vertebroplasty is probably more effective than sham or usual care for vertebral compression fractures for reducing pain and improving function in older (Medicareeligible) populations, but benefits are small. Benefits are smaller in sham compared with usual care controlled trials and larger in trials of patients with more acute symptoms.

- Kyphoplasty is probably more effective than usual care for vertebral compression fractures for reducing pain and improving function in older (Medicare-eligible) populations, but has not been compared against sham.

- Cooled radiofrequency denervation is probably moderately more effective for reducing pain and improving function than sham for sacroiliac pain in younger populations and similarly effective versus conventional radiofrequency for presumed facet joint pain and piriformis corticosteroid injection for piriformis syndrome may be similarly effective versus sham for pain at 1 week, but more effective for reducing pain at 1 month. These interventions were evaluated in younger (non-Medicare-eligible) populations, but findings can probably be applied to older populations.

- Research is needed to determine the benefits and harms of other interventional procedures addressed in this report. Ideally, future trials of interventional procedures should enroll older, Medicare-eligible populations, utilize sham controls, evaluate function as well as pain, include rigorous evaluation of harms, evaluate longer-term outcomes, and evaluate how benefits and harms according to demographic, clinical, and technical factors.

\section{Background and Purpose}

The purpose of this systematic review is to evaluate the effectiveness and harms of selected interventional procedures for acute and chronic pain in the Medicare population. The review focuses on procedures which are not currently covered for by the Centers for Medicare \& Medicaid Services (CMS) but are relevant for and have potential utility for use in the Medicare population, or procedures that are covered by CMS but for which there is important uncertainty or controversy regarding use.

\section{Methods}

Electronic databases $\left(\right.$ Ovid $^{\circledR}$ MEDLINE $^{\circledR}$, PsycINFO ${ }^{\circledR}$, the Cochrane Central Register of Controlled Trials, and the Cochrane Database of Systematic Reviews) were searched through April 12, 2021 for relevant publications. Searches were supplemented by reviewing reference lists and a Federal Register Notice.

Randomized controlled trials (RCTs) of populations undergoing the designated interventional procedures for the specified conditions versus usual care, no treatment, placebo, or sham were selected using predefined criteria and dual review. Observational studies were eligible for assessment of rare, serious adverse events. This review focused on 10 interventional procedures for specific conditions:

1. Vertebral augmentation procedures (vertebroplasty and kyphoplasty) for pain due to vertebral compression fracture 
2. Cooled radiofrequency denervation for degenerative back or hip pain and pulsed radiofrequency denervation for degenerative back pain

3. Intradiscal and facet joint platelet-rich plasma for presumed discogenic back pain

4. Intradiscal stem cells for presumed discogenic back pain

5. Intradiscal methylene blue for presumed discogenic back pain

6. Intradiscal ozone for radicular low back pain or nonradicular, presumed discogenic back pain (protocol modification to include intradiscal ozone plus corticosteroid)

7. Sphenopalatine block for trigeminal neuralgia or headache

8. Occipital stimulation for headache

9. Piriformis injection (local anesthetic, corticosteroid, and/or botulinum toxin) for piriformis syndrome

10. Peripheral nerve stimulation for ulnar, median, or radial neuropathy

The main outcomes were pain and function, and additional outcomes were quality of life, emotional function, global improvement, and harms. Outcomes were analyzed at 1 to 2 weeks, 2 to 4 weeks, 1 to 6 months, 6 to 12 months, and 12 months and longer. Meta-analyses were conducted for vertebroplasty versus no vertebroplasty (sham or usual care) and effects on pain, function, quality of life, and harms; analyses were conducted to assess how the control type, duration of symptoms, and other factors impacted findings. Otherwise, meta-analyses were not conducted due to small number of studies, methodological limitations, and study heterogeneity. The magnitude of effects was classified as small, moderate or large using previously defined criteria, and strength of evidence was assessed.

\section{Results}

The review included 37 RCTs on the comparative effectiveness of interventional therapies for acute and chronic pain. Evidence was most robust for vertebroplasty, followed by kyphoplasty and radiofrequency denervation, and limited for other interventions. Evidence on vertebroplasty and kyphoplasty was highly relevant to populations eligible for Medicare, based on mean age of over 65 years in the trials. For other interventions, patients were younger and populations eligible for Medicare for reasons other than older age were not addressed. Main findings (focusing on effects on pain and function) are summarized by interventional procedure.

\section{Vertebral Augmentation Procedures}

\section{Vertebroplasty}

- Vertebroplasty for vertebral compression fracture (13 trials, $\mathrm{N}=1685$ ) was associated with a small reduction in pain intensity versus sham vertebroplasty or usual care at 1 to 2 weeks ( 10 trials, $\mathrm{N}=1093$ ), 1 to 6 months ( 10 trials, $\mathrm{N}=1094), 6$ to 12 months ( 8 trials, $\mathrm{N}=993$ ), and 12 months and longer ( 9 trials, $\mathrm{N}=965$ ), and a moderate reduction at 2 to 4 weeks ( 8 trials, $\mathrm{N}=918$ ) (strength of evidence [SOE]: low at 1 to 2 weeks, moderate at other time points). Restricting to sham vertebroplasty controls ( 5 trials, $\mathrm{N}=536)$ tended to decrease benefits (no difference at 1 to 2 weeks and small at other time points), but the difference between sham and usual care trials was only statistically significant at 2 to 4 weeks ( $p$ for interaction=0.01). Benefits also tended to be larger in trials of patients with more acute compared with less acute pain, but differences were not statistically significant. 
- There was insufficient evidence to determine effects of vertebroplasty on function at 1 to 2 weeks ( 7 trials, $N=743$ ), due to marked inconsistency between sham trials (no benefit) and usual care trials (small benefit). Vertebroplasty was associated with a small improvement versus sham or usual care in function at 2 to 4 weeks ( 6 trials, $N=708), 1$ to 6 months ( 7 trials, $N=637$ ), 6 to 12 months ( 6 trials, $N=690$ ), and $\geq 12$ months ( 6 trials, $\mathrm{N}=612$ ). (SOE: insufficient for 1 to 2 weeks, moderate for 1 to 6 months and 12 months and longer, and high for 2 to 4 weeks and 6 to 12 months).

- Vertebroplasty was not associated with increased risk of incident vertebral fracture at 12 months and longer ( 7 trials, $\mathrm{N}=826$ ); evidence on serious adverse events was sparse and imprecise but did not indicate increased risk (SOE: moderate for vertebral fracture, low for serious adverse events).

- Three trials that conducted within-study subgroup analyses found no interaction between duration of symptoms and effects of vertebroplasty and one trial found no interaction between sex or prior vertebral fracture and effects of vertebroplasty.

- A stratified analysis of vertebroplasty trials found no interaction between polymethyl methacrylate (PMMA) volume and effects of vertebroplasty.

\section{Kyphoplasty}

- Kyphoplasty for vertebral compression fracture (2 trials, $\mathrm{N}=434$ ) was associated with large reductions in pain and moderate to large improvement in function versus usual care at 1 week and 1 month in patients with or without cancer. No trial compared kyphoplasty against sham (SOE: low for function at 1 week; moderate for pain and for function at 1 month).

- In 1 trial $(\mathrm{N}=300)$ of patients without cancer, effects on pain and function were small to moderate at 3 months to 2 years (SOE: low).

- Evidence on incident or worsening vertebral fracture was inconsistent and imprecise, based on two trials $(\mathrm{N}=434)$ ( $\mathrm{SOE}$ : insufficient).

\section{Cooled Radiofrequency}

- Cooled radiofrequency denervation for sacroiliac pain was associated with a moderate to large reduction in pain and small to large improvement in function versus sham radiofrequency at 1 month ( 2 trials, $N=79)$; improvements in pain and function at 3 months were moderate ( 1 trial, $\mathrm{N}=28$ ) ( $\mathrm{SOE}$ : moderate for pain and function at 3 months; low for function at 1 month).

- Cooled radiofrequency denervation for presumed facet joint pain was associated with a small, nonstatistically significant reduction in pain versus conventional radiofrequency at 6 months and no difference in function ( 1 trial, $\mathrm{N}=43$ ); there were no differences at earlier (1- or 3-month) followup (SOE: low).

\section{Pulsed Radiofrequency}

- Evidence was insufficient to assess pulsed radiofrequency denervation for presumed facet joint pain versus sham denervation ( 1 trial, $\mathrm{N}=40$ ) or continuous radiofrequency denervation (1 trial, $\mathrm{N}=40$ ) ( $\mathrm{SOE}$ : insufficient). 


\section{Intradiscal Platelet-Rich Plasma}

- Evidence was insufficient to assess intradiscal platelet-rich plasma injection for presumed discogenic back pain (1 trial, $\mathrm{N}=58$ ) (SOE: insufficient).

- There were no differences between intradiscal platelet-rich plasma injection and saline injection in harms, including no serious adverse events, at up to 3 years following treatment (SOE: low).

\section{Intradiscal Stem Cell Injection}

- Evidence was insufficient to assess intradiscal stem cell injection for presumed discogenic back pain (1 trial, $\mathrm{N}=100)$ (SOE: insufficient).

\section{Intradiscal Methylene Blue}

- Intradiscal methylene blue for presumed discogenic back pain ( 1 trial, $\mathrm{N}=81)$ was associated with no difference versus sham at 6 weeks and 3 months. Evidence was insufficient to determine effects of intradiscal methylene blue at 6 months ( 2 trials, $\mathrm{N}=153$, with conflicting results) and 12 months or longer ( 1 trial, $\mathrm{N}=72$ ) (SOE: low for no difference at 6 weeks and 3 months; insufficient for 6,12 , and 24 months).

\section{Intradiscal Oxygen-Ozone}

- Evidence was insufficient to assess intradiscal oxygen-ozone for radicular low back pain (1 trial, N=159) (SOE: insufficient).

- No trial evaluated intradiscal oxygen-ozone injection without corticosteroid or oxygenozone injection for presumed (nonradicular) discogenic low back pain.

\section{Sphenopalatine Block}

- Evidence was insufficient to assess sphenopalatine block versus sham for headache (1 trial, $\mathrm{N}=41$ ) (SOE: insufficient).

\section{Occipital Nerve Stimulation}

- Evidence was insufficient to assess occipital nerve stimulation versus sham stimulation for headache (1 trial, N=157) (SOE: insufficient).

- For headache, occipital nerve stimulation with adjustable parameters versus usual care at 3 months was associated with a small, nonstatistically significant reduction in pain intensity, moderate decrease in headache related disability, and decrease in headache days ( 1 trial, N=67) (SOE: low for headache related disability and headache days; insufficient for pain).

- Lead migration occurred in 14 to 24 percent of patients ( 2 trials, $\mathrm{N}=224)$, serious devicerelated complications requiring hospitalization occurred in 5.9 percent of patients ( 1 trial, $\mathrm{N}=67$ ), and persistent pain/numbness at implantation site in 13 percent of patients ( 1 trial, $\mathrm{N}=157$ ) (SOE: low).

- One trial $(\mathrm{N}=67)$ found occipital nerve stimulation with adjustable parameters associated with superior outcomes compared with stimulation using preset parameters. 


\section{Piriformis Injection}

- One trial $(\mathrm{N}=50)$ found piriformis injection with corticosteroid and local anesthetic for piriformis syndrome associated with no difference versus local anesthetic alone in pain at rest at 1 week; piriformis injection was associated with a moderate reduction in pain at rest versus local anesthetic at 1 month (SOE: low for no difference at 1 week and for benefit at 1 month).

- Evidence was insufficient to assess piriformis injection with botulinum toxin.

\section{Peripheral Nerve Stimulation}

- Evidence was insufficient to assess peripheral nerve stimulation for upper extremity peripheral neuropathic pain (SOE: insufficient).

\section{Limitations}

We excluded non-English-language articles and did not search for studies published only as abstracts. We did not conduct statistical and graphical methods for assessing for small sample effects (a potential marker for publication bias) due to small numbers of trials and heterogeneity in study design methods, patient populations, and outcomes.

The evidence base had important limitations. For vertebroplasty, trials varied with regard to patient selection criteria (e.g., duration of pain), technical factors (e.g., volume of PMMA), and sham interventions (e.g., sites of local anesthetic infiltration). In addition, the usual care interventions were not well standardized or defined. Pain and function were the most commonly reported outcomes, with limited evidence on quality of life, health status (e.g., Short-Form 36 Health Survey [SF-36]), mood, analgesic (including opioid) use, and other outcomes. Data on harms were relatively sparse and inconsistently reported. The trials were not designed to evaluate how benefits and harms varied in subgroups defined by demographic, clinical, or technical factors. Data on long-term ( $\geq 1$ year) outcomes was relatively limited.

For the other interventional procedures evaluated in this report, the major limitation was the small numbers of trials, with important methodological shortcomings (e.g., high attrition, lack of intent-to-treat analysis, baseline group differences, small sample sizes, inadequate or unclear randomization or allocation concealment methods, open-label design, and use of unvalidated outcome measures) in almost all eligible studies.

\section{Implications and Conclusions}

Vertebroplasty is probably effective at reducing pain and improving function in older patients with vertebral compression fractures, but benefits were small (Table A). Effects of vertebroplasty were reduced in sham versus usual care controlled trials and larger in trials of patients with more acute symptoms. However, it is not possible to attribute differences entirely to the control type used, given substantial other differences across trials with regard to duration of pain, PMMA volume, requirement for bone edema on magnetic resonance imaging (MRI), and other factors. Furthermore, there were not statistically significant interactions between control type and effects on pain intensity at other time points, there was heterogeneity among the shamcontrolled trials, and there is controversy regarding potential therapeutic effects associated with different sham procedures. To address outstanding questions regarding vertebroplasty, future trials should ideally include sham as well as usual care control groups and include patients with 
hyperacute (e.g., $<3$ weeks) and acute (e.g., 3 to 6 weeks) symptoms. Trials that include sham interventions with and without periosteal local anesthetic could also help clarify whether the sham treatment itself is associated with therapeutic benefits. Kyphoplasty is probably more effective than usual care for vertebral compression fractures in older patients (Table A). However, an important limitation of the evidence is the absence of sham-controlled trials of kyphoplasty. Until such evidence becomes available, kyphoplasty may be considered as an alternative to vertebroplasty, particularly in patients with more vertebral body collapse, as the purpose of kyphoplasty is to help restore vertebral body morphology.

Cooled radiofrequency denervation is probably more effective than sham denervation for sacroiliac pain, cooled radiofrequency may be as effective as conventional radiofrequency for presumed facet joint pain, occipital nerve stimulation may be more effective than usual care for headache, and piriformis corticosteroid injection may be more effective than sham for piriformis syndrome (Table A). Evidence on harms was limited, but lead migration was common following occipital nerve stimulation placement. Although evidence on these interventions was limited to younger (below the age for Medicare eligibility) populations, there is no obvious reason that findings would not apply to older patients. Evidence on the other interventions and conditions addressed in this review is sparse and insufficient, and additional research is needed to determine benefits of harms (Table A). To ideally inform Medicare coverage decisions, future trials of interventional procedures should enroll older, Medicare-eligible populations, utilize sham controls, evaluate function as well as pain, include rigorous evaluation of harms, evaluate longerterm outcomes, and evaluate how benefits and harms according to demographic (age, sex, race/ethnicity), clinical (pain severity, pain duration, use of opioids, psychiatric or medical comorbidities), or technical (dose, intensity, duration, frequency, techniques) factors. 
Table A. Interventional pain therapies for acute and chronic pain*

\begin{tabular}{|c|c|c|c|c|c|c|c|c|c|c|c|}
\hline Intervention & Condition & \begin{tabular}{|c|} 
Pain \\
1 to 2 \\
Weeks \\
Effect Size \\
SOE \\
\end{tabular} & \begin{tabular}{|c|} 
Pain \\
2 to 4 \\
Weeks \\
Effect Size \\
SOE \\
\end{tabular} & \begin{tabular}{c|} 
Pain \\
1 to 6 \\
Months \\
Effect Size \\
SOE \\
\end{tabular} & $\begin{array}{c}\text { Pain } \\
6 \text { to } 12 \\
\text { Months } \\
\text { Effect Size } \\
\text { SOE } \\
\end{array}$ & \begin{tabular}{|c|} 
Pain \\
$\geq 12$ months \\
Effect Size \\
SOE \\
\end{tabular} & $\begin{array}{c}\text { Function } \\
1 \text { to } 2 \\
\text { Weeks } \\
\text { Effect Size } \\
\text { SOE } \\
\end{array}$ & \begin{tabular}{|c|} 
Function \\
2 to 4 \\
Weeks \\
Effect Size \\
SOE \\
\end{tabular} & $\begin{array}{l}\text { Function } \\
1 \text { to } 6 \\
\text { Months } \\
\text { Effect Size } \\
\text { SOE } \\
\end{array}$ & $\begin{array}{l}\text { Function } \\
6 \text { to } 12 \\
\text { Months } \\
\text { Effect Size } \\
\text { SOE } \\
\end{array}$ & $\begin{array}{c}\text { Function } \\
\geq 12 \text { Months } \\
\text { Effect Size } \\
\text { SOE } \\
\end{array}$ \\
\hline $\begin{array}{l}\text { Vertebroplasty vs. } \\
\text { sham or usual care }\end{array}$ & $\begin{array}{l}\text { Vertebral } \\
\text { compression } \\
\text { fractures } \\
\end{array}$ & $\begin{array}{c}\text { Small }^{\dagger} \\
+\end{array}$ & $\begin{array}{c}\text { Moderate }^{\ddagger} \\
++\end{array}$ & \begin{tabular}{c|} 
Small \\
++
\end{tabular} & $\begin{array}{c}\text { Small } \\
++\end{array}$ & $\begin{array}{c}\text { Small } \\
++\end{array}$ & Insufficient ${ }^{\S}$ & $\begin{array}{c}\text { Small } \\
+++\end{array}$ & $\begin{array}{c}\text { Small } \\
++\end{array}$ & $\begin{array}{c}\text { Small } \\
+++\end{array}$ & $\begin{array}{c}\text { Small } \\
++\end{array}$ \\
\hline $\begin{array}{l}\text { Kyphoplasty vs. } \\
\text { usual care }\end{array}$ & $\begin{array}{l}\text { Vertebral } \\
\text { compression } \\
\text { fractures } \\
\end{array}$ & $\begin{array}{l}\text { Large } \\
+++\end{array}$ & $\begin{array}{l}\text { Large } \\
+++\end{array}$ & $\begin{array}{c}\text { Moderate } \\
+\end{array}$ & $\begin{array}{c}\text { Moderate } \\
+\end{array}$ & $\begin{array}{c}\text { Small } \\
+\end{array}$ & $\begin{array}{c}\text { Moderate } \\
+\end{array}$ & 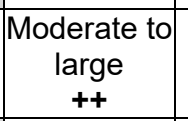 & $\begin{array}{c}\text { Moderate } \\
+\end{array}$ & $\begin{array}{c}\text { Moderate } \\
+\end{array}$ & $\begin{array}{l}\text { Small } \\
+\end{array}$ \\
\hline $\begin{array}{l}\text { Cooled } \\
\text { radiofrequency } \\
\text { ablation vs. sham }\end{array}$ & $\begin{array}{l}\text { Sacroiliac } \\
\text { pain }\end{array}$ & $\begin{array}{c}\text { No } \\
\text { evidence }\end{array}$ & \begin{tabular}{|c|} 
Moderate to \\
large \\
$\mathbf{+ +}$ \\
\end{tabular} & $\begin{array}{c}\text { Moderate } \\
\mathbf{+ +}\end{array}$ & $\begin{array}{c}\text { No } \\
\text { evidence }\end{array}$ & $\begin{array}{c}\text { No } \\
\text { evidence }\end{array}$ & $\begin{array}{c}\text { No } \\
\text { evidence }\end{array}$ & $\begin{array}{c}\text { Small to } \\
\text { large } \\
+ \\
\end{array}$ & $\begin{array}{c}\text { Moderate } \\
\mathbf{+ +}\end{array}$ & $\begin{array}{c}\text { No } \\
\text { evidence }\end{array}$ & No evidence \\
\hline $\begin{array}{l}\text { Cooled vs. } \\
\text { conventional } \\
\text { radiofrequency } \\
\text { denervation } \\
\end{array}$ & $\begin{array}{l}\text { Presumed } \\
\text { facet joint } \\
\text { pain }\end{array}$ & $\begin{array}{c}\text { No } \\
\text { evidence }\end{array}$ & $\begin{array}{c}\text { None } \\
+\end{array}$ & $\begin{array}{l}\text { None } \\
+\end{array}$ & $\begin{array}{l}\text { Small } \\
+\end{array}$ & $\begin{array}{c}\text { No } \\
\text { evidence }\end{array}$ & $\begin{array}{c}\text { No } \\
\text { evidence }\end{array}$ & $\begin{array}{c}\text { None } \\
+\end{array}$ & $\begin{array}{l}\text { None } \\
+\end{array}$ & $\begin{array}{l}\text { None } \\
+\end{array}$ & No evidence \\
\hline $\begin{array}{l}\text { Pulsed } \\
\text { radiofrequency } \\
\text { denervation vs. } \\
\text { sham" }\end{array}$ & $\begin{array}{l}\text { Presumed } \\
\text { facet joint } \\
\text { pain }\end{array}$ & $\begin{array}{c}\text { No } \\
\text { evidence }\end{array}$ & $\begin{array}{c}\text { No } \\
\text { evidence }\end{array}$ & $\begin{array}{c}\text { No } \\
\text { evidence }\end{array}$ & Insufficient & Insufficient & $\begin{array}{c}\text { No } \\
\text { evidence }\end{array}$ & $\begin{array}{c}\text { No } \\
\text { evidence }\end{array}$ & $\begin{array}{c}\text { No } \\
\text { evidence }\end{array}$ & Insufficient & Insufficient \\
\hline \begin{tabular}{|l} 
Pulsed vs. \\
conventional \\
radiofrequency \\
denervation" \\
\end{tabular} & $\begin{array}{l}\text { Presumed } \\
\text { facet joint } \\
\text { pain }\end{array}$ & $\begin{array}{c}\text { No } \\
\text { evidence }\end{array}$ & $\begin{array}{c}\text { No } \\
\text { evidence }\end{array}$ & $\begin{array}{c}\text { No } \\
\text { evidence }\end{array}$ & Insufficient & Insufficient & $\begin{array}{c}\text { No } \\
\text { evidence }\end{array}$ & $\begin{array}{c}\text { No } \\
\text { evidence }\end{array}$ & $\begin{array}{c}\text { No } \\
\text { evidence }\end{array}$ & Insufficient & Insufficient \\
\hline \begin{tabular}{|l|l} 
Cooled or pulsed \\
radiofrequency \\
denervation vs. \\
sham, usual care, or \\
conventional \\
radiofrequency \\
denervation
\end{tabular} & $\begin{array}{l}\text { Degenerative } \\
\text { hip pain }\end{array}$ & $\begin{array}{c}\text { No } \\
\text { evidence }\end{array}$ & $\begin{array}{c}\text { No } \\
\text { evidence }\end{array}$ & $\begin{array}{c}\text { No } \\
\text { evidence }\end{array}$ & $\begin{array}{c}\text { No } \\
\text { evidence }\end{array}$ & $\begin{array}{c}\text { No } \\
\text { evidence }\end{array}$ & $\begin{array}{c}\text { No } \\
\text { evidence }\end{array}$ & $\begin{array}{c}\text { No } \\
\text { evidence }\end{array}$ & $\begin{array}{c}\text { No } \\
\text { evidence }\end{array}$ & $\begin{array}{c}\text { No } \\
\text { evidence }\end{array}$ & No evidence \\
\hline \begin{tabular}{|l|}
$\begin{array}{l}\text { Facet joint platelet- } \\
\text { rich plasma vs. sham } \\
\text { or usual care }\end{array}$ \\
\end{tabular} & $\begin{array}{l}\text { Presumed } \\
\text { facet joint } \\
\text { pain }\end{array}$ & $\begin{array}{c}\text { No } \\
\text { evidence }\end{array}$ & $\begin{array}{c}\text { No } \\
\text { evidence }\end{array}$ & $\begin{array}{c}\text { No } \\
\text { evidence }\end{array}$ & $\begin{array}{c}\text { No } \\
\text { evidence }\end{array}$ & $\begin{array}{c}\text { No } \\
\text { evidence }\end{array}$ & $\begin{array}{c}\text { No } \\
\text { evidence }\end{array}$ & $\begin{array}{c}\text { No } \\
\text { evidence }\end{array}$ & $\begin{array}{c}\text { No } \\
\text { evidence }\end{array}$ & $\begin{array}{c}\text { No } \\
\text { evidence }\end{array}$ & No evidence \\
\hline
\end{tabular}




\begin{tabular}{|c|c|c|c|c|c|c|c|c|c|c|c|}
\hline Intervention & Condition & \begin{tabular}{|c|} 
Pain \\
1 to 2 \\
Weeks \\
Effect Size \\
SOE \\
\end{tabular} & \begin{tabular}{|c|} 
Pain \\
2 to 4 \\
Weeks \\
Effect Size \\
SOE \\
\end{tabular} & \begin{tabular}{|c|} 
Pain \\
1 to 6 \\
Months \\
Effect Size \\
SOE \\
\end{tabular} & $\begin{array}{c}\text { Pain } \\
6 \text { to } 12 \\
\text { Months } \\
\text { Effect Size } \\
\text { SOE }\end{array}$ & $\begin{array}{c}\text { Pain } \\
\geq 12 \text { months } \\
\text { Effect Size } \\
\text { SOE }\end{array}$ & \begin{tabular}{|c|} 
Function \\
1 to 2 \\
Weeks \\
Effect Size \\
SOE
\end{tabular} & $\begin{array}{c}\text { Function } \\
2 \text { to } 4 \\
\text { Weeks } \\
\text { Effect Size } \\
\text { SOE }\end{array}$ & \begin{tabular}{|c|} 
Function \\
1 to 6 \\
Months \\
Effect Size \\
SOE \\
\end{tabular} & \begin{tabular}{|l} 
Function \\
6 to 12 \\
Months \\
Effect Size \\
SOE \\
\end{tabular} & $\begin{array}{c}\text { Function } \\
\geq 12 \text { Months } \\
\text { Effect Size } \\
\text { SOE }\end{array}$ \\
\hline \begin{tabular}{|l|} 
Intradiscal platelet- \\
rich plasma vs. sham
\end{tabular} & $\begin{array}{l}\text { Discogenic } \\
\text { back pain }\end{array}$ & Insufficient & \begin{tabular}{|l|} 
Insufficient \\
\end{tabular} & Insufficient & $\begin{array}{c}\text { No } \\
\text { evidence }\end{array}$ & \begin{tabular}{|c|} 
No \\
evidence
\end{tabular} & Insufficient & Insufficient & \begin{tabular}{|l|} 
Insufficient \\
\end{tabular} & $\begin{array}{c}\text { No } \\
\text { evidence }\end{array}$ & No evidence \\
\hline $\begin{array}{l}\text { Intradiscal stem cells } \\
\text { vs. control* }\end{array}$ & $\begin{array}{l}\text { Discogenic } \\
\text { back pain }\end{array}$ & $\begin{array}{c}\text { No } \\
\text { evidence }\end{array}$ & Insufficient & Insufficient & Insufficient & Insufficient & $\begin{array}{c}\text { No } \\
\text { evidence }\end{array}$ & Insufficient & Insufficient & Insufficient & Insufficient \\
\hline $\begin{array}{l}\text { Intradiscal } \\
\text { methylene blue vs. } \\
\text { sham }\end{array}$ & $\begin{array}{l}\text { Discogenic } \\
\text { back pain }\end{array}$ & $\begin{array}{c}\text { No } \\
\text { evidence }\end{array}$ & $\begin{array}{c}\text { No } \\
\text { evidence }\end{array}$ & $\begin{array}{c}\text { None } \\
+\end{array}$ & $\begin{array}{c}\text { None } \\
+\end{array}$ & Insufficient & $\begin{array}{c}\text { No } \\
\text { evidence }\end{array}$ & $\begin{array}{c}\text { No } \\
\text { evidence }\end{array}$ & $\begin{array}{l}\text { Small } \\
+\end{array}$ & $\begin{array}{c}\text { None } \\
+\end{array}$ & Insufficient \\
\hline $\begin{array}{l}\text { Intradiscal ozone + } \\
\text { corticosteroid vs. } \\
\text { corticosteroid }\end{array}$ & $\begin{array}{l}\text { Discogenic } \\
\text { back pain }\end{array}$ & Insufficient & $\begin{array}{c}\text { No } \\
\text { evidence }\end{array}$ & Insufficient & Insufficient & $\begin{array}{c}\text { No } \\
\text { evidence }\end{array}$ & Insufficient & Insufficient & $\begin{array}{c}\text { No } \\
\text { evidence }\end{array}$ & Insufficient & Insufficient \\
\hline $\begin{array}{l}\text { Sphenopalatine } \\
\text { block vs. control }\end{array}$ & $\begin{array}{l}\text { Trigeminal } \\
\text { neuralgia }\end{array}$ & $\begin{array}{c}\text { No } \\
\text { evidence } \\
\end{array}$ & $\begin{array}{c}\text { No } \\
\text { evidence }\end{array}$ & $\begin{array}{c}\text { No } \\
\text { evidence } \\
\end{array}$ & $\begin{array}{c}\text { No } \\
\text { evidence } \\
\end{array}$ & $\begin{array}{c}\text { No } \\
\text { evidence } \\
\end{array}$ & $\begin{array}{c}\text { No } \\
\text { evidence } \\
\end{array}$ & $\begin{array}{c}\text { No } \\
\text { evidence }\end{array}$ & $\begin{array}{c}\text { No } \\
\text { evidence } \\
\end{array}$ & $\begin{array}{c}\text { No } \\
\text { evidence } \\
\end{array}$ & No evidence \\
\hline \begin{tabular}{|l} 
Sphenopalatine \\
block vs. control"
\end{tabular} & $\begin{array}{l}\text { Chronic } \\
\text { migraine }\end{array}$ & $\begin{array}{c}\text { No } \\
\text { evidence }\end{array}$ & Insufficient & $\begin{array}{c}\text { No } \\
\text { evidence }\end{array}$ & Insufficient & $\begin{array}{c}\text { No } \\
\text { evidence }\end{array}$ & $\begin{array}{c}\text { No } \\
\text { evidence }\end{array}$ & Insufficient & $\begin{array}{c}\text { No } \\
\text { evidence }\end{array}$ & Insufficient & No evidence \\
\hline \begin{tabular}{|l|} 
Occipital nerve \\
stimulation vs. sham"
\end{tabular} & $\begin{array}{l}\text { Chronic } \\
\text { migraine }\end{array}$ & $\begin{array}{c}\text { No } \\
\text { evidence }\end{array}$ & $\begin{array}{c}\text { No } \\
\text { evidence }\end{array}$ & Insufficient & $\begin{array}{c}\text { No } \\
\text { evidence }\end{array}$ & $\begin{array}{c}\text { No } \\
\text { evidence }\end{array}$ & $\begin{array}{c}\text { No } \\
\text { evidence }\end{array}$ & $\begin{array}{c}\text { No } \\
\text { evidence }\end{array}$ & Insufficient & $\begin{array}{c}\text { No } \\
\text { evidence }\end{array}$ & No evidence \\
\hline $\begin{array}{l}\text { Occipital nerve } \\
\text { stimulation vs. usual } \\
\text { care }\end{array}$ & $\begin{array}{l}\text { Chronic } \\
\text { migraine }\end{array}$ & $\begin{array}{c}\text { No } \\
\text { evidence }\end{array}$ & $\begin{array}{c}\text { No } \\
\text { evidence }\end{array}$ & Insufficient & $\begin{array}{c}\text { No } \\
\text { evidence }\end{array}$ & $\begin{array}{c}\text { No } \\
\text { evidence }\end{array}$ & $\begin{array}{c}\text { No } \\
\text { evidence }\end{array}$ & $\begin{array}{c}\text { No } \\
\text { evidence }\end{array}$ & Insufficient & $\begin{array}{c}\text { No } \\
\text { evidence }\end{array}$ & No evidence \\
\hline \begin{tabular}{|l|} 
Piriformis injection \\
with corticosteroid \\
plus local anesthetic \\
vs. corticosteroid \\
plus local anesthetic, \\
or sham"
\end{tabular} & $\begin{array}{l}\text { Piriformis } \\
\text { syndrome }\end{array}$ & $\begin{array}{c}\text { None } \\
+\end{array}$ & $\begin{array}{c}\text { Moderate } \\
+\end{array}$ & Insufficient & $\begin{array}{c}\text { No } \\
\text { evidence }\end{array}$ & $\begin{array}{c}\text { No } \\
\text { evidence }\end{array}$ & $\begin{array}{c}\text { No } \\
\text { evidence }\end{array}$ & $\begin{array}{c}\text { No } \\
\text { evidence }\end{array}$ & $\begin{array}{c}\text { No } \\
\text { evidence }\end{array}$ & $\begin{array}{c}\text { No } \\
\text { evidence }\end{array}$ & No evidence \\
\hline $\begin{array}{l}\text { Peripheral nerve } \\
\text { stimulation vs. sham }\end{array}$ & $\begin{array}{l}\text { Ulnar, median } \\
\text { or radial } \\
\text { neuropathy } \\
\text { pain }\end{array}$ & $\begin{array}{c}\text { No } \\
\text { evidence }\end{array}$ & $\begin{array}{c}\text { No } \\
\text { evidence }\end{array}$ & Insufficient & $\begin{array}{c}\text { No } \\
\text { evidence }\end{array}$ & $\begin{array}{c}\text { No } \\
\text { evidence }\end{array}$ & $\begin{array}{c}\text { No } \\
\text { evidence }\end{array}$ & $\begin{array}{c}\text { No } \\
\text { evidence }\end{array}$ & Insufficient & $\begin{array}{c}\text { No } \\
\text { evidence }\end{array}$ & No evidence \\
\hline
\end{tabular}

Abbreviations: $\mathrm{SOE}=$ strength of evidence

Effect size: none (i.e., no effect/no statistically significant effect), small, moderate, or large increased risk; SOE: $+=$ low, $++=$ moderate, $+++=$ high.

* Grey shading indicates insufficient or no evidence

tThere was no difference in trials with sham control and moderate difference in trials with usual care control, but no statistically significant interaction between control type and effects on pain ( $\mathrm{p}$ for interaction $=0.14$ )

¥There was a small difference in trials with sham control and large difference in trials with usual care control, with a statistically significant interaction between control type and effect on pain ( $p$ for interaction $<0.01$ )

$\S$ There was no difference in trials with sham control and small difference in trials with usual care control, but no statistically significant interaction between control type and effects on pain ( $\mathrm{p}$ for interaction $=0.19$ )

"Poor-quality trials excluded 


\section{Introduction}

\section{Background}

Pain is nearly universal, contributing substantially to morbidity, mortality, disability, and healthcare system burdens. ${ }^{1}$ Acute pain usually lasts for less than 7 days but often extends up to 30 days, and may recur periodically. Although acute pain usually resolves rapidly, in some cases it can persist to become chronic. Chronic pain, defined as pain lasting longer than 3 months ${ }^{1,2}$ is a serious public health issue in the United States, affecting approximately 50 million people and resulting in $\$ 635$ billion in costs. ${ }^{3,4}$ Chronic pain substantially impacts physical and mental functioning, reducing productivity and quality of life.

Patients eligible for Medicare due to age or disability are highly impacted by pain. Musculoskeletal conditions such as back pain are the most common Social Security Disability Insurance qualifying diagnosis, accounting for 34 percent of program participants in 2011..$^{5}$ In 2016, approximately 13.6 million Americans 65 years of age or older were estimated to have chronic pain and 5.4 million had high-impact chronic pain. ${ }^{4}$ The prevalence of chronic pain was 27.6 percent among those 65 to 84 years of age and 33.6 percent among those 85 years of age or older (exceeding any other age group). In older adults, management of pain is often complicated by medical comorbidities, polypharmacy, increased susceptibility to treatment harms, and assessment challenges due to impaired cognition, often resulting in untreated or under treatment of pain. 6,7

Opioids, traditionally considered the most potent analgesic, are frequently prescribed for acute or chronic pain, including in older adults and those with disabilities. ${ }^{5,8,9}$ Therefore, pain management must be considered within the context of the current opioid crisis (related to both illicit and prescription opioids). ${ }^{10}$ Opioid prescribing is highest among patients over 65 years of age, and studies indicate recent increases in hospitals admissions and emergency department visits related to opioid use disorder in this age group. ${ }^{11-14}$ Therefore, there is a need to identify effective and safe interventions that could augment or replace opioids for pain treatment in this population.

The key decisional dilemma for pain management in Medicare beneficiaries is providing adequate pain relief, in order to improve quality of life and improve function, while minimizing harms. Given concerns regarding opioids, there is great interest in nonopioid pharmacologic and nonpharmacologic therapies and they have become increasingly accepted as first-line therapies. The 2016 Centers for Disease Control and Prevention Guideline for Prescribing Opioids for Chronic Pain recommends nonopioid therapy as preferred for treatment of chronic pain, ${ }^{15-17}$ though opioids remain an option for appropriately selected and monitored patients. In the aging population, the Pain Management Best Practices Inter-Agency Task Force report recommended consideration of a multidisciplinary approach with nonpharmacologic emphasis. ${ }^{18}$ Interventional approaches were also specifically highlighted by the Task Force as an important nonpharmacologic option and data indicate that interventional procedures are frequently used in this population ( $\sim 5$ million procedures annually in Medicare fee-for-service). ${ }^{19}$

The term "interventional procedure" has been applied to a myriad of procedures, ranging from soft tissue injections to minimally invasive surgeries, but in this report it refers to nonsurgical interventional procedures (i.e., excluding minimally invasive surgical procedures). The Inter-Agency Task Force report suggested that a number of interventional procedures be considered for acute or chronic pain, ${ }^{18}$ but did not specifically make recommendations for use of these procedures in Medicare populations, in whom optimal management of pain must consider 
factors such as medical comorbidities, polypharmacy, presence of disability, falls risk, and cognitive issues. ${ }^{20}$

\section{Purpose of the Review}

The purpose of this systematic review is to evaluate the effectiveness and harms of selected interventional procedures in the Medicare population. The review focuses on procedures that are not currently covered by the Centers for Medicare \& Medicaid Services (CMS) but are relevant for and have potential utility for use in the Medicare population, or procedures that are covered by CMS but for which there is important uncertainty or controversy regarding use. The intended audiences for this review are CMS and other stakeholders including clinicians, policymakers, patients, and researchers. This review is part of the Dr. Todd Graham Pain Management Study and is sponsored by CMS. The Dr. Todd Graham Pain Management Study also includes three complementary topic briefs on pain topics in Medicare populations as well as a separate systematic review ${ }^{21}$ on integrated pain management and multidisciplinary multi-modal treatment models.

\section{Scope and Key Question}

The draft Key Question and scope were developed by the Evidence-based Practice Center with input from the Agency for Healthcare Research and Quality and CMS, and were revised based on input from a Technical Expert Panel prior to finalization. The interventional therapies were selected based on the following factors: (1) available in the United States but not currently covered by CMS; (2) relevance and potential utility in the Medicare population (i.e., use in Medicare-eligible patients or for pain conditions commonly encountered in this population); and (3) uncertainty or controversy regarding use.

Key Question 1: What are the effectiveness and harms of selected interventional procedures (vertebral augmentation procedures, cooled or pulsed radiofrequency ablation, intradiscal and facet joint platelet-rich plasma, intradiscal methylene blue, intradiscal ozone, sphenopalatine block, occipital nerve stimulation, piriformis injection, and peripheral nerve stimulation) versus placebo, a sham procedure, or no interventional procedure for Medicare beneficiaries with pain?

a. How do the effectiveness and harms vary according to demographic (age, sex, race/ethnicity), clinical (type of pain, severity of pain, prior treatments, medical and psychiatric comorbidities), and technical factors (variations in techniques, intensity, frequency, dose, and number of treatments)?

The interventional procedures and conditions for this review are:

1. Vertebral augmentation procedures (vertebroplasty and kyphoplasty) for vertebral compression fracture. These procedures are performed for vertebral compression fractures, which are common in the Medicare population and often are due to osteoporosis or metastatic disease. Vertebroplasty involves the injection of polymethyl methacrylate (PMMA), commonly known as bone cement, into the collapsed (fractured) vertebral body. In kyphoplasty, injection of PMMA is preceded by insertion and inflation of a balloon into the collapsed vertebral body to restore it. Although vertebral augmentation procedures are 
covered by CMS, they were selected for inclusion in this review because there is ongoing controversy about their role, due to conflicting trial results. ${ }^{22,23}$ The conflicting trial results could be due to use of a sham intervention (mimicking the vertebral augmentation procedure, without injecting PMMA, in order to blind participants to the treatment received) versus a usual care (open-label) control. Other factors that could impact trial results include the fracture age, presence of imaging findings indicating bone marrow edema in the fracture, the volume of PMMA used, and others.

2. Variations on radiofrequency ablation (cooled radiofrequency ablation for degenerative low back or hip pain and pulsed radiofrequency ablation for degenerative low back pain). Conventional radiofrequency ablation involves the application of continuous high frequency electrical current to ablate nerve tissue thought to be the cause of pain. Evidence indicates that conventional radiofrequency for low back and hip pain may be associated with improved short-term pain and function, ${ }^{24,25}$ and it is currently covered by CMS for these conditions as an option for patients with persistent symptoms who do not respond to standard treatments. Cooled and pulsed radiofrequency have been proposed as potential alternatives to conventional radiofrequency. Like conventional radiofrequency ablation, the cooled radiofrequency procedure involves the application of high frequency electrical current. It differs from conventional radiofrequency ablation by using a larger, "cooled" (relative to conventional radiofrequency; heat is still generated) radiofrequency probe, potentially allowing for more targeted, larger and more effective lesions. ${ }^{26,27}$ The Coolief ${ }^{\mathrm{TM}}$ cooled radiofrequency ablation probe was approved by the U.S. Food and Drug Administration (FDA) for treatment of knee pain. However, it has also been proposed as an alternative to conventional radiofrequency ablation for other indications, including degenerative back and hip pain. Pulsed radiofrequency differs from conventional radiofrequency by delivering a smaller current in brief bursts. Unlike conventional radiofrequency, it is not intended to destroy nerve tissue; rather, it is thought to reduce pain through neuromodulatory effects. ${ }^{28}$

3. Intradiscal and facet joint platelet-rich plasma for presumed discogenic back pain or presumed facet joint pain. This procedure involves the injection of autologous platelet-rich plasma, which is rich in growth factors, into the intervertebral disc for low back pain of presumed discogenic origin ${ }^{29}$ or into the lumbar facet joint for low back pain of presumed facet joint origin. ${ }^{30}$ Platelet-rich plasma is thought to promote endogenous healing processes, though the exact mechanism of action is not well understood.

4. Intradiscal stem cells for presumed discogenic back pain. This procedure involves the injection of stem cells, which have potential regenerative potential, into degenerative intervertebral discs for low back pain of presumed discogenic origin. ${ }^{31}$ Like platelet-rich plasma, stem cells are thought to promote healing.

5. Intradiscal methylene blue for presumed discogenic back pain. This procedure involves the injection of methylene blue, a dye that may prevent fibrosis or ablate sensory endings, into the intervertebral disc for low back pain of presumed discogenic origin. ${ }^{32}$ However, the mechanism of action is not well understood.

6. Intradiscal ozone injection for radicular or nonradicular back pain. This procedure involves the injection of ozone, a gas with potential anti-inflammatory or other effects, into the intervertebral disc for radicular low back pain due to herniated disk or nonradicular low 
back pain of presumed discogenic origin. ${ }^{32}$ Ozone may have nucleolytic effects on the intervertebral disc, reducing the size of the herniated disc and relieving pressure on compressed nerve roots, or reduce pain related to discogenic pain through antiinflammatory effects. ${ }^{33}$

7. Sphenopalatine block for trigeminal neuralgia or headache. This procedure is performed for trigeminal neuralgia, migraine headaches, cluster headaches, and other headache syndrome. ${ }^{34}$ It involves injection of the sphenopalatine ganglion with a local anesthetic; the FDA has approved three devices for this procedure (SphenoCath ${ }^{\circledR}$ [Dolor Technologies, Scottsdale, AZ], Allevio SPG Nerve Block catheter [Medical Components, Inc., Schwenksville, PA], and Tx360® Nasal Injector [Tian Medical, LLC, Libertyville, IL]). The most common method for approaching the sphenopalatine ganglion is via the transnasal approach.

8. Occipital nerve stimulator for headache. This procedure is performed for various headache disorders. Similar to spinal cord stimulation, it involves electrical stimulation of the occipital nerve through use of subcutaneously placed electrodes, which is thought to result in neuromodulation of pain via the gate control pathway. ${ }^{35}$ Typically, a successful trial of stimulation is performed before permanent electrodes and a generator are implanted.

9. Piriformis injection for piriformis syndrome. Piriformis syndrome results from compression of the sciatic nerve by the piriformis muscle. ${ }^{36,37}$ The injection may be performed using corticosteroids (for anti-inflammatory effects), local anesthetics (to decrease muscle spasm), and/or botulinum toxin (also to decrease muscle spasm).

10. Peripheral nerve stimulation for ulnar, median, and radial neuropathy. This procedure involves stimulation of peripheral nerves using a mild electrical current, in patients with chronic neuropathic pain such as upper extremity neuropathies. ${ }^{38}$ Like occipital nerve stimulation, peripheral nerve stimulation involves the subcutaneous placement of electrodes at the target nerves and is thought to have neuromodulatory effects. Successful trial stimulation is typically required prior to permanent placement.

This review did not address minimally invasive surgical procedures, or orthopedic procedures such as intra-articular or soft tissue corticosteroid, hyaluronic acid, or soft tissue or nonspinal intra-articular platelet-rich plasma injections. The review also did not address soft tissue injections with local anesthetic, corticosteroid, and/or other medications (e.g., botulinum toxin) that are commonly performed in primary care settings and do not require specialized training or expertise. With the exception of vertebral augmentation procedures, it also does not address interventional procedures conducted in the Medicare population that are covered by CMS, are recommended in clinical practice guidelines, and/or have been addressed in other recent and comprehensive systematic reviews (e.g., epidural steroid injection, perioperative peripheral and central regional anesthetic techniques, and spinal cord stimulation). ${ }^{32,39-44}$ 


\section{Methods}

This systematic review follows methods suggested in the Agency for Healthcare Research and Quality Methods Guide for Effectiveness and Comparative Effectiveness Reviews (hereafter the "AHRQ Methods Guide") developed for the Evidence-based Practice Centers (EPCs). ${ }^{45}$ Methods were determined a priori and a protocol was developed through a process that included public input and was published on the Agency for Healthcare Research and Quality (AHRQ) website (https://effectivehealthcare.ahrq.gov/products/interventional-treatments-pain/protocol) and on the PROSPERO systematic reviews registry (CRD42021226947).

\section{Literature Search Strategy}

We conducted electronic searches in Ovid ${ }^{\circledR}$ MEDLINE ${ }^{\circledR}$, PsycINFO ${ }^{\circledR}$, Cochrane CENTRAL, and Cochrane Database of Systematic Reviews in April 2021 (see Appendix A for full strategies). The search reached back to 1990 for each database. This date corresponds to publication of the earliest clinical studies on the interventional procedures addressed in this review. Reference lists of relevant systematic reviews were screened for additional studies.

\section{Inclusion and Exclusion Criteria and Study Selection}

The criteria for inclusion and exclusion of studies for this review were based on the Key Question. The population was adults ( $\geq 18$ years of age) undergoing one of the specified interventional procedures for pain. Details regarding the populations, interventions, comparators, outcomes, timing, and setting (PICOTS) are summarized in Table 1. Briefly, we included studies of populations undergoing the designated interventional procedures for the specified conditions. Pain could be of any duration, though for all of the conditions other than vertebral compression fracture, symptoms are typically subacute or chronic before interventional procedures are performed. Although the population of interest was patients eligible for Medicare, we did not restrict inclusion to studies of patients meeting Medicare eligibility criteria (e.g., based on age, presence of disability, or end-stage renal disease), in order to provide a more comprehensive synthesis of the available literature, and because findings in younger populations may be applicable to older populations. However, studies of patients eligible for Medicare were highlighted, when available.

We restricted inclusion to studies of the selected interventions administered as single therapy, in order to isolate the effects of the intervention. The exception was ozone therapy, for which we included trials of intradiscal ozone administered with an epidural corticosteroid, because there were no trials of ozone without corticosteroid. Comparisons were against a sham control, usual care, or no treatment. Sham controlled trials utilize a procedure that mimic the intervention of interest, without purported therapeutic benefit. Use of sham controls enables blinding of patients to the treatment received, avoiding placebo effects that could inflate estimates due to expectations of benefits. In usual care or no treatment trials, there is no attempt to blind patients to the treatment received. Although usual care or no treatment trials can overestimate benefits due to placebo effects, they are also more pragmatic, reflecting how treatments are administered in clinical practice. ${ }^{46}$ In addition to placebo effects, other reasons that sham and usual care trials may conflict include any therapeutic effects of the sham interventions or differences between sham and usual care trials with regard to the populations evaluated, intervention methods, or other factors. For cooled and pulsed radiofrequency denervation, we also included comparisons against conventional radiofrequency denervation, since these interventions are considered 
modifications of conventional radiofrequency denervation. For ozone plus corticosteroid therapy, we modified the protocol to also include trials with a corticosteroid control arm (with or without local anesthetic), in order to assess the incremental effects of ozone therapy in addition to a corticosteroid.

Outcomes were pain, function, quality of life, health status, mood, medication use (including opioids), and harms. The review focused on randomized controlled trials (RCTs), given the susceptibility of observational and other non-randomized studies to bias and confounding, particularly for more subjective outcomes such as pain and function. ${ }^{47,48}$ In the specific case of interventional pain treatments, there are a number of examples of non-randomized studies ${ }^{49-56}$ that overestimated benefits compared with RCTs. ${ }^{43,57}$ However, cohort studies were eligible for evaluation of benefits if no RCTs were available; large $(n>500)$ observational studies were eligible for evaluation of rare, serious harms. ${ }^{58}$

We excluded studies published only as conference abstracts, restricted inclusion to Englishlanguage articles, and excluded studies of nonhuman subjects. Studies had to report original data to be included.

All citations were reviewed by one investigator for potential inclusion and full text review. Excluded abstracts were reviewed by a second investigator to confirm the exclusion decision. Each full-text article was independently reviewed for eligibility by two team members. Disagreements were resolved by consensus.

Searches were updated for new publications while the draft report was posted for public comment. Literature identified during the update search was assessed using the process described above for the original search. Any new eligible literature identified in the update search was incorporated into the report prior to finalization.

Table 1. PICOTS (population, intervention, comparator, outcome, timing, setting)

\begin{tabular}{|l|l|l|}
\hline PICOTS & Inclusion & Exclusion \\
\hline Population & $\begin{array}{l}\text { Adults with pain of any duration (pain conditions } \\
\text { for each interventional procedure specified } \\
\text { below); will highlight studies of populations } \\
\text { applicable to Medicare, defined as patients } \\
\text { enrolled in Medicare, age } \geq 65 \text { years, or patients } \\
\text { with disability (including end-stage renal } \\
\text { disease), if available }\end{array}$ & $\begin{array}{l}\text { Patients undergoing end-of-life care, } \\
\text { terminally ill (e.g., hospice) patients; } \\
\text { those under supervised palliative care; } \\
\text { those with pain due to metastatic or } \\
\text { advanced cancer }\end{array}$ \\
& $\begin{array}{l}\text { Population subgroups of interest include those } \\
\text { Children }\end{array}$ & \\
& $\begin{array}{l}\text { based on demographics (age, sex, } \\
\text { race/ethnicity) and clinical factors (type of pain, } \\
\text { severity of pain, prior treatments, medical and } \\
\text { psychiatric comorbidities, including presence of } \\
\text { disability [including end-stage renal disease], } \\
\text { prior substance use disorder, and psychological } \\
\text { comorbidities) }\end{array}$ & \\
\hline
\end{tabular}




\begin{tabular}{|c|c|c|}
\hline PICOTS & Inclusion & Exclusion \\
\hline Intervention & $\begin{array}{l}\text { 1) Vertebral augmentation procedures } \\
\text { (vertebroplasty and kyphoplasty) for pain due to } \\
\text { vertebral compression fracture } \\
\text { 2) Cooled radiofrequency denervation for } \\
\text { degenerative back or hip pain and pulsed } \\
\text { radiofrequency denervation for degenerative } \\
\text { back pain } \\
\text { 3) Intradiscal and facet joint platelet-rich plasma } \\
\text { for presumed discogenic back pain } \\
\text { 4) Intradiscal stem cells for presumed } \\
\text { discogenic back pain } \\
\text { 5) Intradiscal methylene blue for presumed } \\
\text { discogenic back pain } \\
\text { 6) Intradiscal ozone for radicular low back pain } \\
\text { or nonradicular, presumed discogenic back } \\
\text { pain } \\
\text { - Protocol modification to include } \\
\quad \text { intradiscal ozone plus corticosteroid } \\
\text { 7) Sphenopalatine block for trigeminal neuralgia } \\
\text { or headache } \\
\text { 8) Occipital stimulation for headache } \\
\text { 9) Piriformis injection (local anesthetic, } \\
\text { corticosteroid, and/or botulinum toxin) for } \\
\text { piriformis syndrome } \\
\text { 10) Peripheral nerve stimulation for ulnar, } \\
\text { median, or radial neuropathy } \\
\text { Technical factors of interest as potential } \\
\text { modifiers of treatment effect include variations } \\
\text { in techniques, intensity, frequency, dose, or } \\
\text { number of treatments. }\end{array}$ & $\begin{array}{l}\text { - Minimally invasive surgical procedures } \\
\text { - Orthopedic intra-articular and soft tissue } \\
\text { injections } \\
\text { - Local soft tissue injections } \\
\text { - Other interventional procedures and } \\
\text { conditions not listed as included }\end{array}$ \\
\hline Comparator & $\begin{array}{l}\text { Placebo, sham interventional procedure, or no } \\
\text { interventional procedure } \\
\text { For cooled and pulsed radiofrequency } \\
\text { denervation: conventional (thermal, continuous) } \\
\text { radiofrequency denervation } \\
\text { - For intradiscal ozone, protocol } \\
\text { modification to include corticosteroid } \\
\text { without ozone }\end{array}$ & $\begin{array}{l}\text { Active treatments, other than conventional } \\
\text { radiofrequency denervation as a comparison } \\
\text { for cooled radiofrequency denervation }\end{array}$ \\
\hline Outcome & $\begin{array}{l}\text { - Primary: Pain, function } \\
\text { - Secondary: Health-related quality of life, } \\
\text { emotional function (e.g., depression, } \\
\text { anxiety), opioid use, surgery rates } \\
\text { - Global improvement } \\
\text { - Harms (e.g., bleeding, infection, other } \\
\text { complications), adverse events, unintended } \\
\text { consequences }\end{array}$ & $\begin{array}{l}\text { Patient-oriented outcomes } \\
\text { - Non-validated instruments for outcomes } \\
\text { (e.g., pain, function, health-related quality } \\
\text { of life, depression, etc.) } \\
\text { - Intermediate outcomes (e.g., range of } \\
\text { motion, physical strength, etc.) }\end{array}$ \\
\hline Timing & $\begin{array}{l}\text { Duration of followup: } \geq 1 \text { week; categorized as } 1 \\
\text { to } 2 \text { weeks, } 2 \text { to } 4 \text { weeks, } 1 \text { to } 6 \text { months, } 6 \text { to } 12 \\
\text { months, and } 12 \text { months and longer }\end{array}$ & $<1$ week \\
\hline Setting & Any & None \\
\hline $\begin{array}{l}\text { Study design, } \\
\text { publication } \\
\text { type }\end{array}$ & $\begin{array}{l}\text { Randomized clinical trials and cohort studies if } \\
\text { randomized clinical trials are not available } \\
\text { Large }(n>500) \text { case series for serious, rare } \\
\text { harms }\end{array}$ & $\begin{array}{l}\text { - Case reports } \\
\text { - Case series (other than large case series } \\
\text { for serious, rare harms) } \\
\text { - Case-control studies, cross-sectional } \\
\text { studies } \\
\text { - Conference proceedings, editorials, } \\
\text { letters, white papers, citations that have } \\
\text { not been peer-reviewed }\end{array}$ \\
\hline
\end{tabular}




\section{Data Abstraction and Data Management}

For studies meeting inclusion criteria, evidence tables were created to show data on study characteristics, outcomes, and applicability. If necessary, data were estimated from graphs provided in the studies. We also calculated standard deviations for baseline and followup data from standard errors or 95 percent confidence intervals (CIs) if necessary using standard formulas, ${ }^{59}$ and calculated mean differences or relative risks with 95 percent CIs using online calculators. ${ }^{60,61}$ Abstracted and calculated data were verified for accuracy and completeness by a second team member.

Effects on pain were abstracted as mean difference in pain intensity (continuous) and likelihood of experiencing improvement in pain (dichotomous) based on meeting a certain threshold ("pain response"). For pain and other outcomes evaluated as continuous outcomes, we abstracted adjusted mean differences at followup if available, as well as unadjusted differences in followup scores or change from baseline, and unadjusted differences in change from baseline. Pain intensity using a 0 to 100 scale was transformed to a 0 to 10 scale for ease of interpretation. For pain evaluated as a dichotomous outcomes (pain response), we abstracted (in descending order of prioritization) the proportion of patients experiencing improvement in pain intensity of at least 30 percent, at least 50 percent, or improvement in pain at an alternative threshold (e.g., $\geq 25 \%$, or $>2$ point improvement on a 0 to 10 scale), or pain relief rated as moderate, good, or similar using a categorical scale.

Effects on function were based on the mean improvement in a functional scale (dichotomous) or the proportion of patients meeting a defined threshold of functional improvement (dichotomous, e.g. improvement in function of at least 30 percent or at least "moderate" improvement on a categorical scale). The most common functional outcomes were the RolandMorris Disability Questionnaire (RDQ, 0 to 24 scale) or Oswestry Disability Index (ODI, 0 to 100 scale) for low back pain and the Migraine Disability Test (MIDAS) for migraine (based on number of disability days in the last 3 months for various activities; score $>20$ indicates severe disability); on each of these scales higher values indicate greater functional disability. Effects on health status (most commonly, the Short-form-36 Physical or Mental Component Summary Scales [0 to 100 scale, higher score indicate better health status]), generic quality of life (e.g., the EuroQOL 5-Dimension Questionnaire [EQ-5D, 0 to 1 scale, higher score indicates better quality of life]), condition-specific quality of life (e.g., the Quality of Life Questionnaire of the European Foundation for Osteoporosis [QUALEFFO, 0 to 100 scale, higher score indicates worse quality of life]), and mood (e.g., Beck Depression Inventory [BDI, 0 to 63 scale, higher value indicates more severe depression symptoms], Profile of Mood States [POMS, 0 to 200 scale, higher values indicates worse mood state], or others) were based on mean improvements in scales designed to assess these domains.

For pain, function, mood, and disease-specific quality of life (QUALEFFO), negative values for mean improvement indicate a better outcome; for health status and generic quality of life (EQ-5D), positive values indicate a better outcome. Effects on harms were based on the proportion of patients experiencing harms (mortality, serious adverse events, any adverse event, and incident vertebral fracture). The duration of pain symptoms at the time of study enrollment was classified as acute ( $<4$ weeks), subacute ( 4 to 12 weeks), or chronic ( $>12$ weeks). Outcomes were evaluated at predefined followup periods: $\geq 1$ to $\leq 2$ weeks (hereafter written as " 1 to 2 weeks"), $>2$ weeks to $\geq 1$ month (" 2 to 4 weeks"), $>1$ to $<6$ months (" 1 to 6 months"), $\geq 6$ to $<12$ months ("6 to 12 months"), and $\geq 12$ months (" 12 months and longer"). 
Study data was abstracted by one team member and all data were verified for accuracy and completeness by a second team member. A record of studies excluded at the full-text level with reasons for exclusion was maintained (Appendix B).

\section{Quality (Risk of Bias) Assessment of Individual Studies}

Methods from the AHRQ Methods Guide were used in concordance with the approach recommended in the chapter, Assessing the Risk of Bias of Individual Studies When Comparing Medical Interventions. ${ }^{45,62}$ RCTs were assessed based on criteria established in the Cochrane Handbook for Systematic Reviews of Interventions (Chapter 8.5 Risk of Bias Tool), ${ }^{63}$ and instruments tailored to observational studies were used for nonrandomized studies ${ }^{64}$ (Appendix C). Each study was independently reviewed for risk of bias by two team members. Any disagreements were resolved by consensus. Based on the risk of bias assessment, individual included studies were rated as "good," "fair," or "poor" quality as described below:

Poor quality studies were not excluded a priori. When meta-analysis was conducted subgroup analysis was performed based on study quality. When meta-analysis was not conducted, results from poor quality studies were described but conclusions were based on higher (fair and good) quality studies when available.

\section{Data Analysis and Synthesis}

We constructed evidence tables showing study characteristics, results, and quality ratings for all included studies, and summary tables to highlight the main findings, organized by Key Question (intervention and condition).

Meta-analysis were limited to vertebroplasty, due to the small number of studies for other interventions, methodological limitations in the studies, and variability in the studies, including outcome measures assessed, timing of assessment, and patient characteristics. ${ }^{65}$ For interventions other than vertebroplasty, evidence was synthesized qualitatively.

Subgroup analyses were conducted to evaluate how pain duration, volume, presence of bone marrow edema, and study quality impacted estimates. Details regarding meta-analysis methods are provided in Appendix D.

A sub-Key Question addressed how benefits and harms varied according to demographic (age, sex, race/ethnicity), clinical (type of pain, severity of pain, prior treatments, medical and psychiatric comorbidities), and technical factors (variations in techniques, intensity, frequency, dose, and number of treatments). Although planned techniques to assess these factors included sensitivity and stratified analyses, other than polymethyl methacrylate (PMMA) volume, evidence was too limited to apply these techniques. However, we evaluated findings from within-study subgroup analyses on these factors when available.

The magnitude of effects for pain and function were classified using used in other recent AHRQ reviews on pain conducted at our EPC. ${ }^{66-70}$ A small effect was defined for pain as a mean between-group difference following treatment of 0.5 to 1.0 points on a 0 - to 10 -point numeric rating scale (NRS) or visual analogue scale (VAS) and for function as a standard mean deviation (SMD) of 0.2 to 0.5 or a mean difference of 5 to 10 points on the 0 to 100-point ODI, 1 to 2 points on the 0 to 24-point RDQ, or equivalent. A moderate effect was defined for pain as a mean difference of 1 to 2 points on a 0 - to 10-point NRS or VAS and for function as an SMD of 0.5 to 0.8 , or a mean difference of 10 to 20 points on the ODI, 2 to 5 points on the RDQ, or equivalent. Large/substantial effects were defined as greater than moderate. We applied similar thresholds to other outcomes measures. ${ }^{71}$ Small effects using this system may not meet proposed 
thresholds for clinically meaningful effects. ${ }^{72}$ However, there is variability in estimated minimum clinically important differences across studies, therapies for pain (included those recommended in guidelines) are often associated with effects below minimum clinically important difference thresholds, ${ }^{44,73-76}$ and the clinical relevance of effects classified as small might vary for individual patients depending on preferences, baseline symptom severity, harms, cost, and other factors. ${ }^{77,78}$ For some individuals, a small improvement in pain, function, or other outcomes using a treatment with low cost or no serious harms may be important.

\section{Grading the Strength of Evidence}

Regardless of whether evidence was synthesized quantitatively or qualitatively, the strength of evidence (SOE) was assessed as high, moderate, low, or insufficient, using the approach described in the AHRQ Methods Guide, based on study limitations, consistency, directness, precision, and reporting bias (Appendix E). ${ }^{45}$ Based on input from the Technical Expert Panel, pain and function were classified as primary outcomes and the other outcomes were classified as secondary. When higher (fair- or good-quality) studies were available, poor-quality studies were not used to determine SOE. To ensure consistency and validity of the SOE evaluation, the initial assessment was made by one investigator and independently reviewed by at least one other investigator using the following criteria, with disagreements resolved by consensus.

Plain-language statements were used in the Abstract and Main Points to indicate the SOE. High SOE was described as "is associated with" or simply "reduces/increases;" moderate SOE was described as "probably;" and low SOE was described as "may".

\section{Assessing Applicability}

Applicability to U.S. practice settings and the Medicare population (i.e., patients eligible for Medicare due to age 65 or greater or disability [including end-stage renal failure (ESRD)]) were assessed based on the AHRQ Methods Guide, using the PICOTS framework.$^{45}$ Applicability refers to the degree to which outcomes associated with the intervention are likely to be similar across patients and settings relevant to the care of the Medicare population based on the populations, interventions, comparisons, and outcomes synthesized across included studies. Factors that may affect applicability, which we identified a priori, include: (1) patient factors (e.g., age and disability status, medical and psychiatric comorbidities, symptom severity, duration and underlying pain condition); (2) technical factors (e.g., medications used [for procedures that involve medications], intensity or dose, number of treatments, frequency of treatments, duration of treatment, use of imaging guidance, technique utilized, and clinical background of person performing the procedure [e.g., anesthesia pain medicine, interventional radiology, or other]); (3) comparators (e.g., sham procedure, no treatment, or usual care); (4) outcomes (e.g., use of nonstandardized or unvalidated outcomes); and (5) settings (e.g., country). We used information regarding these factors to assess the extent to which interventions and results are likely most relevant to real-world clinical practice in typical U.S. settings that include the Medicare population and provided a qualitative summary of our assessment.

\section{Peer Review and Public Commentary}

Experts were invited to provide external peer review of this systematic review; AHRQ and an associate editor also provided comments. In addition, the draft report was posted on the AHRQ website for 4 weeks for public comment. Comments were reviewed, considered, and addressed 
as appropriate. Edits were made for clarity and accuracy; however, no changes were made to the evidence or to our conclusions. 


\section{Results}

\section{Results of Literature Search}

A total of 3,032 references from electronic database searches and reference lists were reviewed. From these, 336 full-text papers were evaluated for inclusion. After review of full-text papers, 288 articles were excluded. Across all interventions, 37 randomized controlled trials (RCTs) (in 48 publications) were included (Figure 1 and Appendix F). Thirteen trials addressed vertebroplasty, two kyphoplasty, four piriformis injections, three occipital nerve stimulation, three cooled radiofrequency, three pulsed radiofrequency, two methylene blue, three ozone, and one each sphenopalatine block, platelet-rich plasma, stem cells, and peripheral nerve stimulation. See Appendix $\mathbf{G}$ for data abstraction tables, Appendix $\mathbf{H}$ for quality tables, and Appendix I for additional meta-analysis results.

\section{Figure 1. Literature flow diagram}

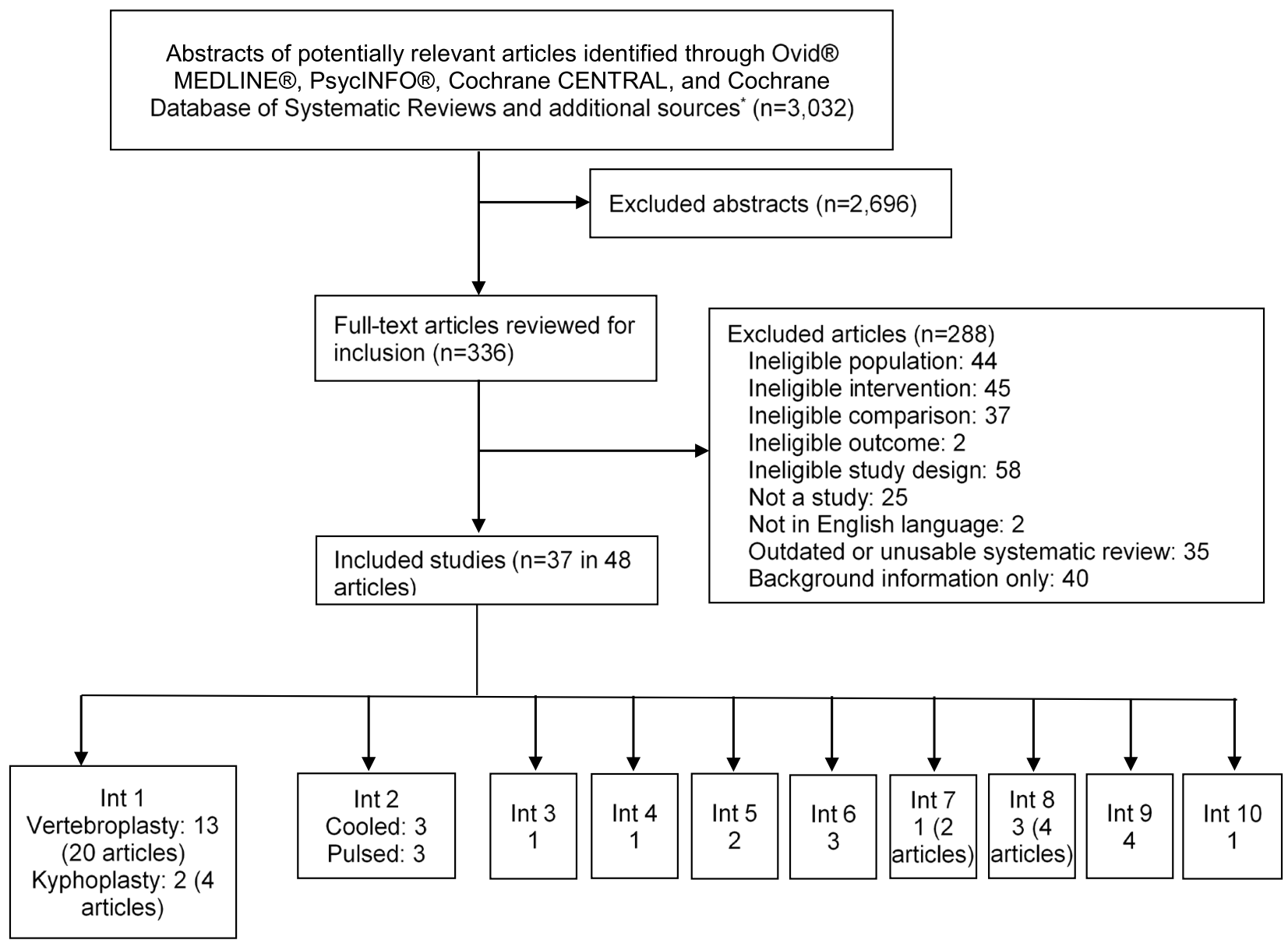

Abbreviations: Int $=$ interventional procedures and conditions ${ }^{\dagger}$

*Additional sources include suggested references, reference lists, etc.

$\dagger$ Int $1=$ vertebral augmentation procedures (vertebroplasty and kyphoplasty) for pain due to vertebral compression fracture, Int $2=$ cooled radiofrequency denervation for degenerative back or hip pain and pulsed radiofrequency denervation for degenerative back pain, Int 3=intradiscal and facet joint platelet-rich plasma for presumed discogenic back pain, Int 4=intradiscal stem cells for presumed discogenic back pain, Int 5=intradiscal methylene blue for presumed discogenic back pain, Int $6=$ intradiscal ozone for 
radicular low back pain or nonradicular, presumed discogenic back pain (protocol modification to include intradiscal ozone plus corticosteroid), Int $7=$ sphenopalatine block for trigeminal neuralgia or headache, Int $8=$ occipital stimulation for headache, Int 9=piriformis injection (local anesthetic, corticosteroid, and/or botulinum toxin) for piriformis syndrome, Int 10=peripheral nerve stimulation for ulnar, median, or radial neuropathy

\section{Vertebral Augmentation Procedures for Vertebral Compression Fractures}

\section{Vertebroplasty}

\section{Key Points}

- Vertebroplasty for vertebral compression fracture (13 trials, $\mathrm{N}=1685$, mean age 66 to 80 years) was associated with a small reduction in pain intensity versus sham vertebroplasty or usual care at 1 to 2 weeks ( 10 trials, $\mathrm{N}=1093), 1$ to 6 months ( 10 trials, $\mathrm{N}=1094), 6$ to 12 months ( 8 trials, $\mathrm{N}=993$ ), and 12 months and longer ( 9 trials, $\mathrm{N}=965$ ); and a moderate reduction at 2 to 4 weeks ( 8 trials, $\mathrm{N}=918$ ) (strength of evidence [SOE]: low at 1 to 2 weeks, moderate at other time points). Restricting to sham vertebroplasty controls (5 trials, $\mathrm{N}=536$ ) tended to decrease benefits (no difference at 1 to 2 weeks and small at other time points), but the difference between sham and usual care trials was only statistically significant at 2 to 4 weeks ( $p$ for interaction $=0.01$ ). Benefits also tended to be larger in trials of patients with more acute compared with less acute pain, but differences were not statistically significant.

- There was insufficient evidence to determine effects of vertebroplasty on function at 1 to 2 weeks ( 7 trials, $\mathrm{N}=743$ ), due to marked inconsistency between sham trials (no benefit) and usual care trials (small benefit) Vertebroplasty was associated with a small improvement versus sham or usual care in function at 2 to 4 weeks ( 6 trials, $N=708), 1$ to 6 months ( 7 trials, $\mathrm{N}=637$ ), 6 to 12 months ( 6 trials, $\mathrm{N}=690$ ), and $\geq 12$ months ( 6 trials, $\mathrm{N}=612$ ). (SOE: insufficient for 1 to 2 weeks, moderate for 1 to 6 months and 12 months and longer, and high for 2 to 4 weeks and 6 to 12 months).

- Vertebroplasty was not associated with increased risk of incident vertebral fracture at 12 months and longer ( 7 trials, $\mathrm{N}=826$ ); evidence on serious adverse events was sparse and imprecise but did not indicate increased risk (SOE: moderate for vertebral fracture, low for serious adverse events).

- Three trials that conducted within-study subgroup analyses found no interaction between duration of symptoms and effects of vertebroplasty and one trial found no interaction between sex or prior vertebral fracture and effects of vertebroplasty.

- A stratified analysis of vertebroplasty trials found no interaction between polymethyl methacrylate (PMMA) volume and effects of vertebroplasty.

\section{Description of Included Studies}

Thirteen trials (reported in 20 publications) compared vertebroplasty versus a sham procedure (5 trials) $)^{79-83}$ or usual care $(8 \text { trials })^{84-91}$ (Appendix Table G-1 to G-3 and Table 2). Sample sizes ranged from 34 to $400(\mathrm{~N}=1685)$. Seven trials were conducted in Europe, ${ }^{81,82,84,87-90}$ two trials in Australia, ${ }^{79,80}$ two trials in China, ${ }^{85,91}$ and one trial in Iran ${ }^{86}$ one trial ${ }^{83}$ was conducted in the United Kingdom, Australia, and the United States. The mean age of enrollees 
ranged from 66 to 80 years; in one trial ${ }^{88}$ that did not report the mean age the range was 56 to 82 years. One trial ${ }^{88}$ was restricted to females and in the others, the proportion female ranged from 64 to 87 percent. The trials focused on patients with osteoporotic compression fractures and excluded patients with fracture due to cancer. Two trials restricted inclusion to patients with acute pain (up to 4 to 6 weeks), ${ }^{88,91}$ five trials restricted inclusion to patients with acute or subacute pain (up to 6 to 10 weeks), ${ }^{80-82,87,89}$ three trials enrolled patients with acute, subacute, or chronic pain (up to 12 months), ${ }^{79,83,84}$ and three trials restricted inclusion to patients with subacute or chronic pain ( $\geq 3$ months, ${ }^{85} 4$ weeks to 1 year, ${ }^{86}$ or 6 weeks to 5 months ${ }^{90}$ ). Mean or median pain duration was $<4$ weeks in four trials, ${ }^{80,88,89,91} 4$ to 8 weeks in three trials (including one trial that did not report average pain duration but was restricted to patients with pain for $\leq 8$ weeks), ${ }^{81,82,87}$ and $\geq 8$ weeks in six trials. ${ }^{79,83-86,90}$ Ten trials $^{80-82,84-88,90,91}$ required participants to have magnetic resonance imaging (MRI) findings consistent with bone marrow edema at the vertebral fracture site, a marker of greater acuity. The average volume of PMMA used in vertebroplasty ranged from 2.6 to $7.5 \mathrm{ml}$; two trials ${ }^{80,81}$ reported use of greater than $5 \mathrm{ml}$ and the others reported less than $5 \mathrm{ml}$ or did not report the PMMA volume. The duration of followup ranged from 6 to 24 months.

Four trials were rated good quality, ${ }^{79-81,83}$ five trials were rated fair quality, ${ }^{82,84,85,87,90}$ and four trials poor quality ${ }^{86,88,89,91}$ (Appendix Table H-1). The good-quality trials utilized sham vertebroplasty for blinding; sham procedures consisted of needle insertion or pressure on the back to simulate needle insertion, tapping to simulate entry of the needle into bone, and preparation of PMMA to mimic the sounds and smells of vertebroplasty. In three of the five sham-controlled trials, patients randomized to sham received the same periosteal infiltration of local anesthetic as patients randomized to vertebroplasty. ${ }^{79,81,83}$ In one sham-controlled trial, ${ }^{82}$ local anesthetic was injected into the vertebral body and in the fifth trial, ${ }^{80}$ patients randomized to sham received subcutaneous but not periosteal local anesthetic. In the open-label trials, usual care consisted of various nonsurgical therapies (analgesics, physical therapy, graded activity, and braces or walking aids), but only one trial ${ }^{86}$ described specific medications and doses. In addition to open-label design, other limitations in the fair-quality trials (including one sham-controlled trial $)^{82}$ included failure to report randomization or allocation concealment methods, baseline group differences, high attrition, or lack of intent-to-treat analysis. One poor-quality trial ${ }^{88} \mathrm{did}$ not report efficacy outcomes in the usual care arm and another poor-quality trial ${ }^{86}$ had serious data discrepancies - implausible values for standard deviations or results (mean differences, 95\% confidence intervals [CIs], and p values) inconsistent with reported data. Therefore, neither of these trials was utilized in efficacy meta-analyses, but contributed data on harms. 
Table 2. Study characteristics of vertebroplasty trials

\begin{tabular}{|c|c|c|c|c|c|c|c|c|c|}
\hline $\begin{array}{l}\text { Study, Year } \\
\text { Country } \\
\text { Quality }\end{array}$ & $\begin{array}{l}\text { Mean } \\
\text { Age } \\
\text { (Years) }\end{array}$ & $\begin{array}{l}\text { Percent } \\
\text { Female }\end{array}$ & $\begin{array}{l}\text { Number } \\
\text { Randomized }\end{array}$ & $\begin{array}{l}\text { Pain Duration } \\
\text { Inclusion Criteria }\end{array}$ & $\begin{array}{l}\text { Mean/Median } \\
\text { Pain } \\
\text { Duration } \\
\text { (Weeks) }\end{array}$ & $\begin{array}{l}\text { PMMA } \\
\text { Volume } \\
\text { (ml) }\end{array}$ & $\begin{array}{l}\text { Bone Marrow } \\
\text { Edema on } \\
\text { MRI } \\
\text { Required }\end{array}$ & Control Type & $\begin{array}{l}\text { Duration } \\
\text { of } \\
\text { Followup } \\
\text { (Months) }\end{array}$ \\
\hline $\begin{array}{l}\text { Buchbinder, } \\
2009^{79,92,93} \\
\text { Australia } \\
\text { Good }\end{array}$ & 77 & 79 & 78 & Up to 12 months & 9.0 to 9.5 & 2.8 & No & $\begin{array}{l}\text { Sham (including } \\
\text { periosteal local } \\
\text { anesthetic) }\end{array}$ & 24 \\
\hline $\begin{array}{l}\text { Clark, 201680,94 } \\
\text { Australia } \\
\text { Good }\end{array}$ & 80 & 73 & 120 & $<6$ weeks & 2.6 & 7.5 & Yes & $\begin{array}{l}\text { Sham (subcutaneous } \\
\text { but not periosteal } \\
\text { local anesthetic) }\end{array}$ & 6 \\
\hline $\begin{array}{l}\text { Firanescu, } \\
2018^{81,95} \\
\text { the Netherlands } \\
\text { Good }\end{array}$ & 75.8 & 75 & 180 & $\leq 9$ weeks & 5 to 8 & 5.1 & Yes & $\begin{array}{l}\text { Sham (including } \\
\text { periosteal local } \\
\text { anesthetic) }\end{array}$ & 12 \\
\hline $\begin{array}{l}\text { Hansen, } 2019^{82} \\
\text { Denmark } \\
\text { Fair } \\
\end{array}$ & 69.9 & 87 & 52 & $\leq 8$ weeks & NR & 2 to 4 & Yes & $\begin{array}{l}\text { Sham (including local } \\
\text { anesthetic into } \\
\text { vertebral body) }\end{array}$ & 12 \\
\hline $\begin{array}{l}\text { Kallmes, } \\
2009^{83,96} \\
\text { U.K., Australia, } \\
\text { U.S. } \\
\text { Good }\end{array}$ & 73.8 & 76 & 131 & Up to 12 months & 17.8 & 2.6 & No & $\begin{array}{l}\text { Sham (including } \\
\text { periosteal local } \\
\text { anesthetic) }\end{array}$ & 12 \\
\hline $\begin{array}{l}\text { Blasco, } 2012^{84} \\
\text { Spain } \\
\text { Fair } \\
\end{array}$ & 73.2 & 78 & 125 & Up to 12 months & 20.4 & NR & Yes & Usual care & 12 \\
\hline $\begin{array}{l}\text { Chen, } 2014^{85} \\
\text { China } \\
\text { Fair } \\
\end{array}$ & 65.5 & 70 & 96 & $\geq 3$ months & 30.4 & 3.6 & Yes & Usual care & 12 \\
\hline $\begin{array}{l}\text { Farrokhi, } 2011^{86} \\
\text { Iran } \\
\text { Poor }\end{array}$ & $\begin{array}{l}72 \text { to } \\
74\end{array}$ & 73 & 82 & $\begin{array}{l}4 \text { weeks to } 1 \text { year, } \\
\text { mean } 27 \text { to } 30 \text { weeks }\end{array}$ & 27 to 30 & 3.5 & Yes & Usual care & 36 \\
\hline $\begin{array}{l}\text { Klazen, } 2010^{87,97} \\
\text { the Netherlands } \\
\text { and Belgium } \\
\text { Fair }\end{array}$ & 75.3 & 69 & 202 & $\leq 6$ weeks & 4 & 4.1 & Yes & Usual care & 12 \\
\hline $\begin{array}{l}\text { Leali, } 2016^{88} \\
\text { Italy, France, } \\
\text { Switzerland } \\
\text { Poor }\end{array}$ & $\begin{array}{l}\text { NR } \\
\text { (range } \\
56 \text { to } \\
82 \text { ) }\end{array}$ & 100 & 400 & Acute (not defined) & NR & 4 & Yes & Usual care & 6 \\
\hline
\end{tabular}




\begin{tabular}{|c|c|c|c|c|c|c|c|c|c|}
\hline $\begin{array}{l}\text { Study, Year } \\
\text { Country } \\
\text { Quality }\end{array}$ & $\begin{array}{l}\text { Mean } \\
\text { Age } \\
\text { (Years) }\end{array}$ & $\begin{array}{l}\text { Percent } \\
\text { Female }\end{array}$ & $\begin{array}{l}\text { Number } \\
\text { Randomized }\end{array}$ & $\begin{array}{l}\text { Pain Duration } \\
\text { Inclusion Criteria }\end{array}$ & $\begin{array}{l}\text { Mean/Median } \\
\text { Pain } \\
\text { Duration } \\
\text { (Weeks) }\end{array}$ & $\begin{array}{l}\text { PMMA } \\
\text { Volume } \\
\text { (ml) }\end{array}$ & $\begin{array}{l}\text { Bone Marrow } \\
\text { Edema on } \\
\text { MRI } \\
\text { Required }\end{array}$ & Control Type & $\begin{array}{l}\text { Duration } \\
\text { of } \\
\text { Followup } \\
\text { (Months) }\end{array}$ \\
\hline $\begin{array}{l}\text { Rousing, } \\
2009^{89,98} \\
\text { Denmark } \\
\text { Poor }\end{array}$ & 80 & 82 & 50 & $\leq 8$ weeks & 1.1 & NR & No & Usual care & 12 \\
\hline $\begin{array}{l}\text { Voormolen, } \\
2007^{90} \\
\text { the Netherlands } \\
\text { Fair }\end{array}$ & 73 & 82 & 34 & 6 weeks to 5 months & 11.7 & 3.2 & Yes & Usual care & 12 \\
\hline $\begin{array}{l}\text { Yang, } 2016^{91} \\
\text { China } \\
\text { Poor }\end{array}$ & 76.7 & 64 & 135 & Acute (not defined) & 0.8 & 4.5 & Yes & Usual care & 12 \\
\hline
\end{tabular}

Abbreviations: $\mathrm{MRI}=$ magnetic resonance imaging; $\mathrm{NR}=$ not reported; PMMA = polymethyl methacrylate 


\section{Detailed Synthesis}

\section{Pain}

At 1 to 2 weeks, the difference between vertebroplasty versus sham or usual care was small and not statistically significant (10 trials, mean difference -0.53 on a 0 to 10 scale, $95 \% \mathrm{CI},-1.36$ to $0.24, I^{2}=75 \%$, Figure 2). ${ }^{79-85,87,90,91}$ Vertebroplasty was associated with a moderate reduction in pain intensity versus sham vertebroplasty or usual care at 2 to 4 weeks to 1 month ( 8 trials, mean difference -1.05 on a 0 to 10 scale, $95 \%$ CI, -1.80 to $-0.32, \mathrm{I}^{2}=64 \%$, Figure 3), ${ }^{79-83,85,87,91}$ with a small reduction in pain intensity at 1 to 6 months (10 trials, mean difference $-0.76,95 \%$ CI, -1.17 to $-0.38, \mathrm{I}^{2}=5.5 \%$, Figure 4$),{ }^{79-85,87,89,91} 6$ to 12 months ( 8 trials, mean difference -0.73 , $95 \%$ CI, -1.33 to $-0.15, I^{2}=43 \%$, Figure 5), ${ }^{79-81,83-85,87,91}$ and 12 months and longer ( 9 trials, mean difference $-0.87,95 \% \mathrm{CI},-1.43$ to $-0.31, \mathrm{I}^{2}=42 \%$, Figure 6). ${ }^{79,81-85,87,89,91}$ At 2 to 4 weeks, the pain reduction between trials using sham control versus usual care was significantly different ( $p$ for interaction $=0.01)$. Pain reduction in sham controlled trials was significantly lower ( 5 trials, mean difference $-0.57,95 \% \mathrm{CI},-1.09$ to $-0.05, \mathrm{I}^{2}=0 \%$ ) than in trials of usual care ( 3 trials, mean difference $-2.27,95 \% \mathrm{CI},-3.20$ to $-0.94, \mathrm{I}^{2}=0 \%$ ). Among the sham controlled trials, the largest effect (mean difference $-1.40,95 \%$ CI -2.44 to -0.36 ) was observed in the trial that enrolled patients with the most acute symptoms ( $<6$ weeks, mean 2.6 weeks). ${ }^{80}$ At other time points, there were no statistically significant differences in pain reduction between trials using sham or usual care controls, though across time points estimates were smaller with sham than usual care and stratified estimates were imprecise (Appendix Tables I-1 and I-2). Benefits also tended to be larger in trials that enrolled patients with more acute pain. However, differences were not statistically significant, only one trial ${ }^{91}$ restricted enrollment to patients with acute pain, and only one sham-controlled trial ${ }^{80}$ reported mean pain duration of $<4$ weeks. Reductions in pain intensity also did not differ according to presence of bone marrow edema on MRI (required to be enrolled in trial versus not required), PMMA volume ( $>5$ or $\leq 5 \mathrm{ml}$ ), or study quality (good, fair, or poor). However, subgroup estimates were based on small numbers of trials and were imprecise. For analyses with at least 10 trials, graphical and statistical tests did not indicate small study effects ( $p$ for Egger's test $=0.59$ at 1 to 2 weeks [Appendix Figure I-1] and $p=0.62$ at 1 to 6 months [Appendix Figure I-2]).

\section{Figure 2. Vertebroplasty versus sham or usual care, pain (continuous) at 1 to $\mathbf{2}$ weeks}

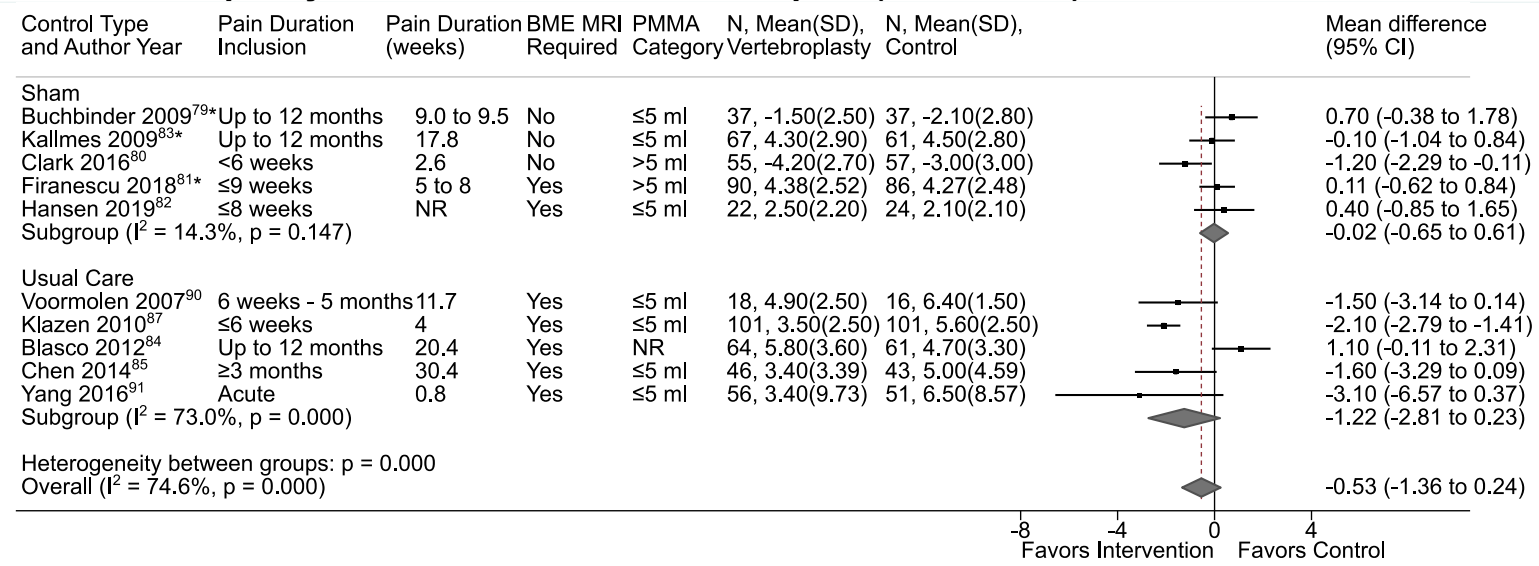

Abbreviations: $\mathrm{BME}=$ bone marrow edema; $\mathrm{CI}=$ confidence interval; $\mathrm{MRI}=$ magnetic resonance imaging; $\mathrm{PMMA}=$ polymethyl methacrylate; $\mathrm{SD}=$ standard deviation

*Adjusted mean difference from a regression model was used 
Figure 3. Vertebroplasty versus sham or usual care, pain (continuous) at 2 to 4 weeks

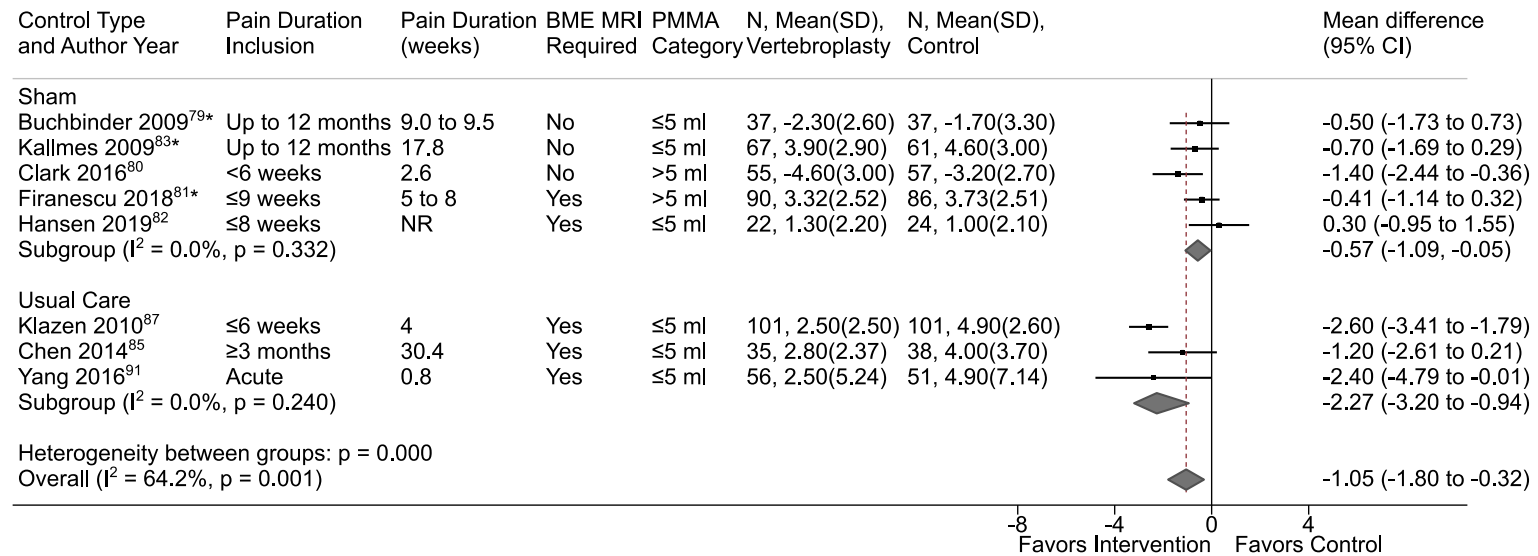

Abbreviations: $\mathrm{BME}=$ bone marrow edema; $\mathrm{CI}=$ confidence interval; $\mathrm{MRI}=$ magnetic resonance imaging; $\mathrm{PMMA}=$ polymethyl methacrylate; $\mathrm{SD}=$ standard deviation

Figure 4. Vertebroplasty versus sham or usual care, pain (continuous) at 1 to 6 months

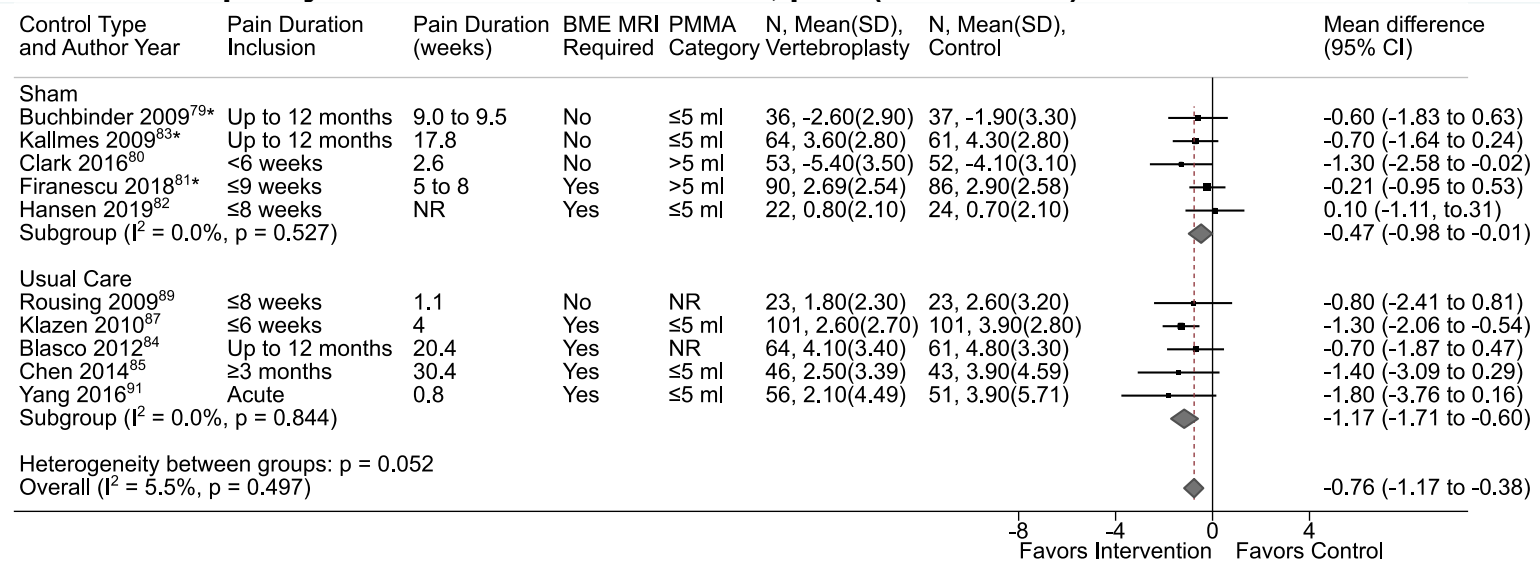

Abbreviations: $\mathrm{BME}=$ bone marrow edema; $\mathrm{CI}=$ confidence interval; $\mathrm{MRI}=$ magnetic resonance imaging; $\mathrm{PMMA}=$ polymethyl methacrylate; $\mathrm{SD}=$ standard deviation

*Adjusted mean difference from a regression model was used

Figure 5. Vertebroplasty versus sham or usual care, pain (continuous) at 6 to 12 months

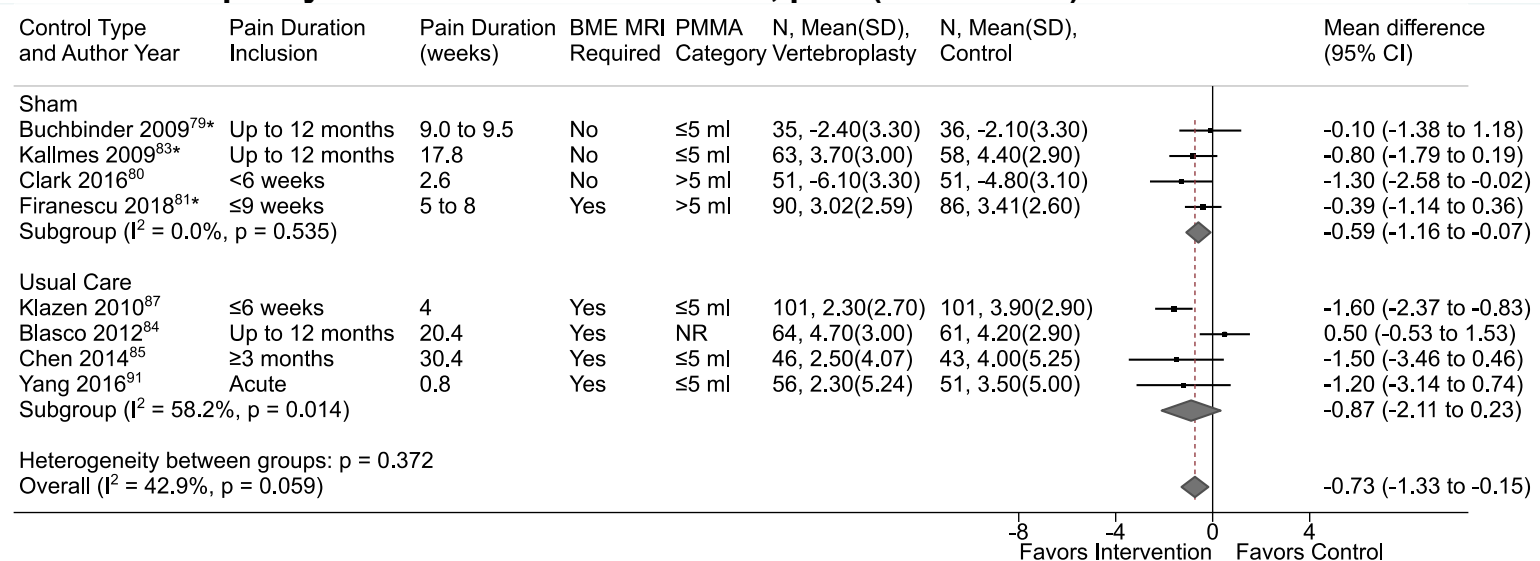

Abbreviations: $\mathrm{BME}=$ bone marrow edema; $\mathrm{CI}=$ confidence interval; $\mathrm{MRI}=$ magnetic resonance imaging; $\mathrm{PMMA}=$ polymethyl methacrylate; $\mathrm{SD}=$ standard deviation 
*Adjusted mean difference from a regression model was used

Figure 6. Vertebroplasty versus sham or usual care, pain (continuous) at 12 months and longer

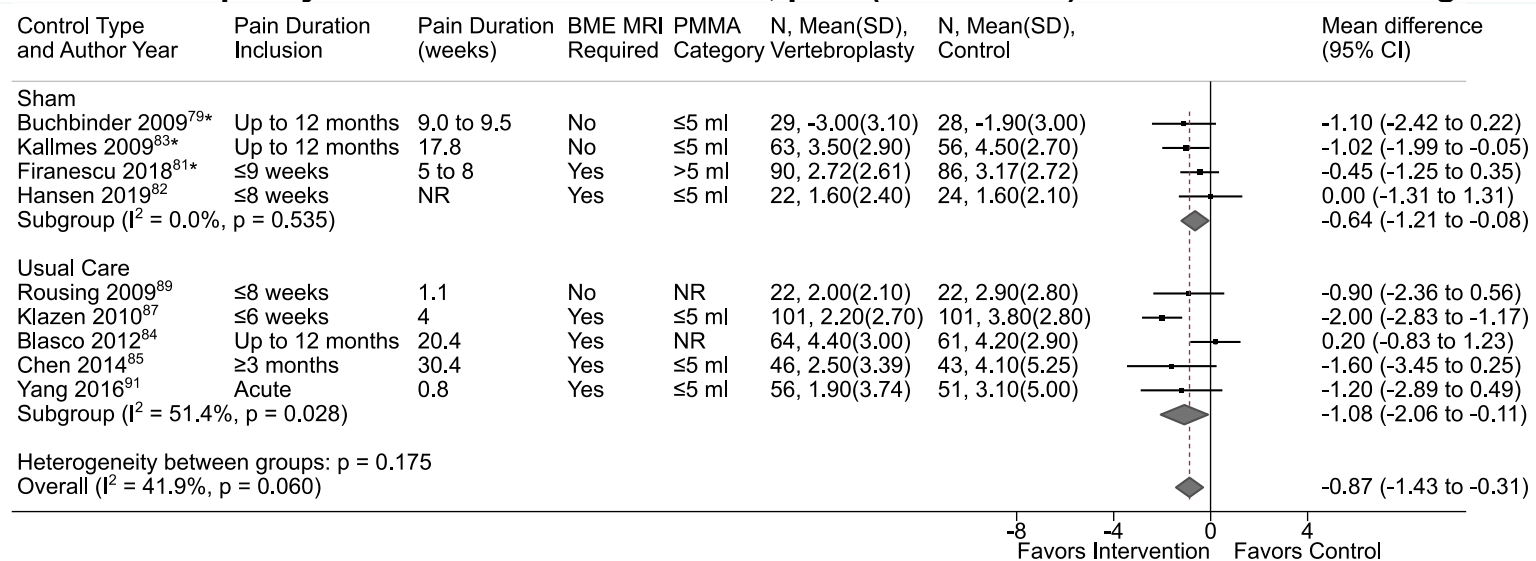

Abbreviations: $\mathrm{BME}=$ bone marrow edema; $\mathrm{CI}=$ confidence interval; $\mathrm{MRI}=$ magnetic resonance imaging; $\mathrm{PMMA}=$ polymethyl methacrylate; $\mathrm{SD}=$ standard deviation

*Adjusted mean difference from a regression model was used

Few trials evaluated the association between vertebroplasty versus sham or usual care and likelihood of experiencing a pain response (defined as pain at least moderately better, ${ }^{79}$ pain $<4$ on a 0 to 10 numeric rating scale (NRS), ${ }^{80,83,84}$ or pain improvement $\geq 30 \%{ }^{83}$ ). Results favored vertebroplasty at 2 to 4 weeks ( 3 trials), ${ }^{79,80,83} 1$ to 6 months ( 2 trials), ${ }^{79,80} 6$ to 12 months (2 trials), ${ }^{79,80}$ and 12 months and longer ( 2 trials), ${ }^{83,84}$ with relative risk (RR) estimates that ranged from 1.27 to 1.46 (Figure 7 and Appendix Table I-3). However, estimates were imprecise and nonstatistically significant. At 1 to 2 weeks, the estimate was very imprecise ( 2 trials, RR 1.05 , $95 \%$ CI, 0.16 to $\left.6.02, \mathrm{I}^{2}=75 \%\right) .{ }^{79,80}$ 
Figure 7. Vertebroplasty versus sham or usual care and likelihood of a pain response

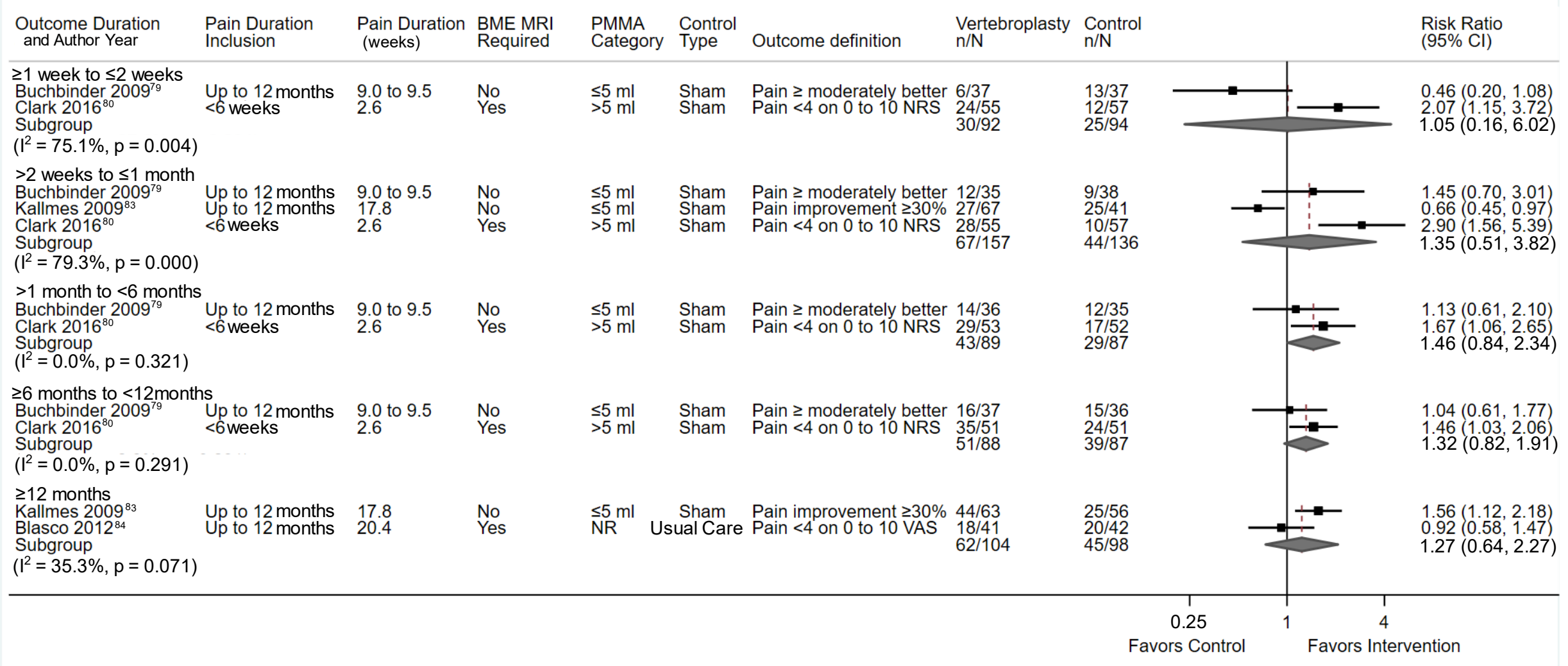

Abbreviations: $\mathrm{BME}=$ bone marrow edema; $\mathrm{CI}=$ confidence interval; $\mathrm{MRI}=$ magnetic resonance imaging; $\mathrm{PMMA}=$ polymethyl methacrylate; $\mathrm{SD}=$ standard deviation 


\section{Function}

Vertebroplasty was also associated with a small improvement in back-related function versus sham or usual care at 1 to 2 weeks (standard mean deviation [SMD] $-0.21,95 \%$ CI, -0.48 to 0.04 , $\mathrm{I}^{2}=49 \%$, Figure 8). ${ }^{79,80,83,85,87,90,91}$ However, the estimate was imprecise and statistical heterogeneity was present. Vertebroplasty was associated with a small improvement in backrelated function versus sham or usual care at 2 to 4 weeks ( 6 trials, SMD $-0.27,95 \% \mathrm{CI},-0.42$ to $-0.12, \mathrm{I}^{2}=0 \%$, Figure 9) ${ }^{79,80,83,85,87,91} 1$ to 6 months ( 7 trials, SMD $-0.28,95 \%$ CI, -0.43 to -0.11 , $\mathrm{I}^{2}=0 \%$, Figure 10) ${ }^{79,80,83,85,87,89,91} 6$ to 12 months (6 trials, SMD $-0.29,95 \% \mathrm{CI},-0.45$ to -0.14 , $\mathrm{I}^{2}=0 \%$, Figure 11), ${ }^{79,80,83,85,87,91}$ and at 12 months and longer (6 trials, SMD $-0.23,95 \%$ CI, -0.39 to $-0.06, \mathrm{I}^{2}=0 \%$, Figure 12). ${ }^{79,83,85,87,89,91}$ All trials except for two assessed function using the Roland-Morris Disability Questionnaire (RDQ) (scale 0 to 24) or modified RDQ (scale 0 to 23); differences on the RDQ or modified RDQ at these times points ranged from -1.64 to -1.90 points. At 1 to 2 weeks, there was marked inconsistency between the estimate from trials of sham ( 3 trials, SMD $0.03,95 \%$ CI, -0.36 to $0.44, \mathrm{I}^{2}=34 \%$ ) and usual care ( 3 trials, SMD $-0.38,95 \% \mathrm{CI}$, -0.61 to $-0.18, \mathrm{I}^{2}=0 \%$ ), though the difference was not statistically significant ( $\mathrm{p}$ for interaction $=0.10$ ). At other time points, estimates from sham and usual care trials were similar. Effects of vertebroplasty on function did not differ based on average pain duration at enrollment or study quality (Appendix Tables I-4 and I-5). However, subgroup analyses were limited by small numbers of trials, with imprecise estimates.

Figure 8. Vertebroplasty versus sham or usual care, function (continuous) at 1 to 2 weeks

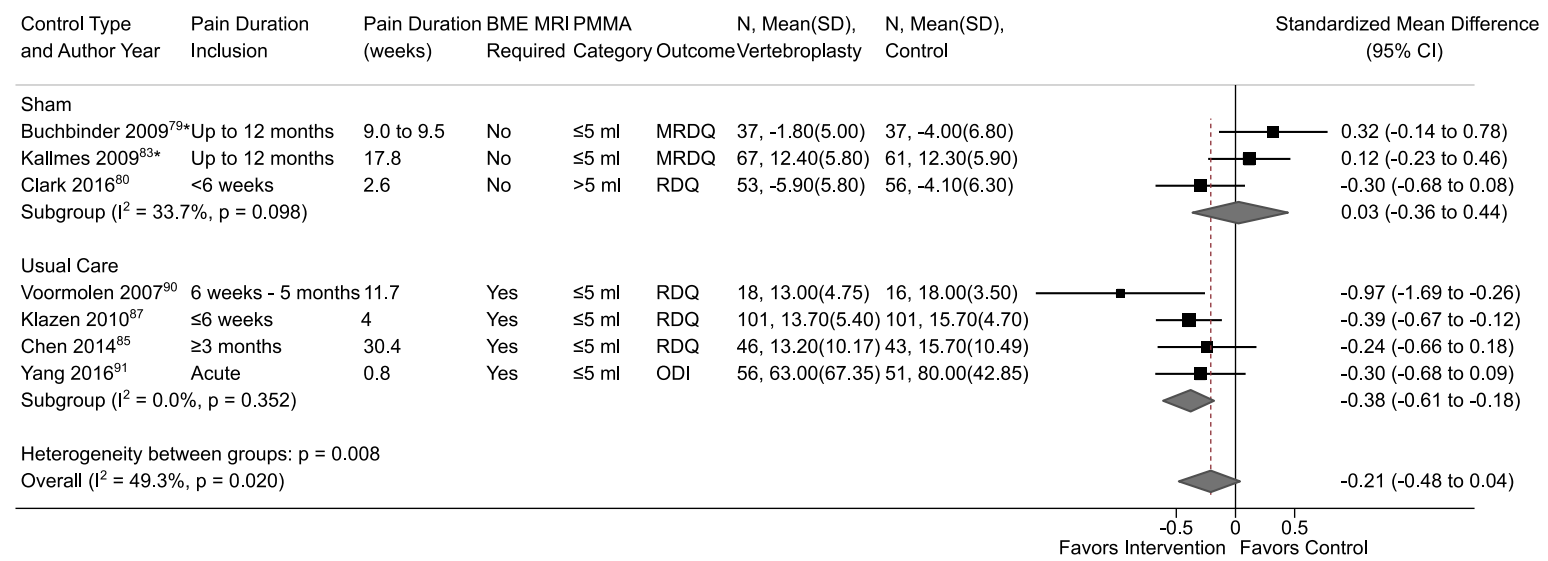

Abbreviations: $\mathrm{BME}=$ bone marrow edema; $\mathrm{CI}=$ confidence interval; $\mathrm{MRI}=$ magnetic resonance imaging; $\mathrm{PMMA}=$ polymethyl methacrylate; $\mathrm{SD}=$ standard deviation

*Adjusted mean difference from a regression model was used 
Figure 9. Vertebroplasty versus sham or usual care, function (continuous) at 2 to 4 weeks

\begin{tabular}{|c|c|c|c|c|c|c|c|c|}
\hline $\begin{array}{l}\text { Control Type } \\
\text { and Author Year }\end{array}$ & $\begin{array}{l}\text { Pain Duration } \\
\text { Inclusion }\end{array}$ & $\begin{array}{l}\text { Pain Duration } \\
\text { (weeks) }\end{array}$ & $\begin{array}{l}\text { BME MRI } \\
\text { Required }\end{array}$ & $\begin{array}{l}\text { PMMA } \\
\text { Category }\end{array}$ & Outcome & $\begin{array}{l}\mathrm{N}, \text { Mean }(\mathrm{SD}) \\
\text { Vertebroplasty }\end{array}$ & $\begin{array}{l}\mathrm{N}, \text { Mean(SD), } \\
\text { Control }\end{array}$ & $\begin{array}{l}\text { Standardized Mean Difference } \\
\qquad(95 \% \mathrm{Cl})\end{array}$ \\
\hline \multicolumn{9}{|l|}{ Sham } \\
\hline Buchbinder $2009^{79 *}$ & * Up to 12 months & 9.0 to 9.5 & No & $\leq 5 \mathrm{ml}$ & MRDQ & $35,-4.40(6.60)$ & $38,-3.10(6.80)$ & $-0.23(-0.69$ to 0.23$)$ \\
\hline Kallmes $2009^{83 *}$ & Up to 12 months & 17.8 & No & $\leq 5 \mathrm{ml}$ & MRDQ & $67,12.00(6.30)$ & $61,13.00(6.40)$ & $-0.12(-0.47$ to 0.23$)$ \\
\hline Clark $2016^{80}$ & $<6$ weeks & 2.6 & No & $>5 \mathrm{ml}$ & $\mathrm{RDQ}$ & $55,-6.90(6.00)$ & $54,-4.30(5.60)$ & $-0.45(-0.83$ to -0.07$)$ \\
\hline Subgroup $\left(I^{2}=0.0 \%\right.$ & $\%, p=0.450)$ & & & & & & & $-0.26(-0.53$ to 0.00$)$ \\
\hline \multicolumn{9}{|l|}{ Usual Care } \\
\hline Klazen $2010^{87}$ & $\leq 6$ weeks & 4 & Yes & $\leq 5 \mathrm{ml}$ & $\mathrm{RDQ}$ & $101,12.50(6.30)$ & $101,14.00(5.70)$ & $-0.25(-0.53$ to 0.03$)$ \\
\hline Chen $2014^{85}$ & $\geq 3$ months & 30.4 & Yes & $\leq 5 \mathrm{ml}$ & $\mathrm{RDQ}$ & $46,11.70(6.78)$ & $43,13.80(9.84)$ & $-0.25(-0.67$ to 0.17$)$ \\
\hline Yang $2016^{91}$ & Acute & 0.8 & Yes & $\leq 5 \mathrm{ml}$ & ODI & $56,47.00(74.83)$ & $51,71.00(57.13)$ & $-0.36(-0.74$ to 0.03$)$ \\
\hline Subgroup $\left(I^{2}=0.0 \%\right.$ & $\%, p=0.895)$ & & & & & & & $-0.28(-0.49$ to -0.07$)$ \\
\hline \multicolumn{9}{|c|}{ Heterogeneity between groups: $p=0.907$} \\
\hline Overall $\left(\mathrm{I}^{2}=0.0 \%, \mathrm{f}\right.$ & $p=0.872)$ & & & & & & & $-0.27(-0.42$ to -0.12$)$ \\
\hline
\end{tabular}

Abbreviations: $\mathrm{BME}=$ bone marrow edema; $\mathrm{CI}=$ confidence interval; $\mathrm{MRI}=$ magnetic resonance imaging; $\mathrm{PMMA}=$ polymethyl methacrylate; $\mathrm{SD}=$ standard deviation

*Adjusted mean difference from a regression model was used

Figure 10. Vertebroplasty versus sham or usual care, function (continuous) at 1 to $\mathbf{6}$ months

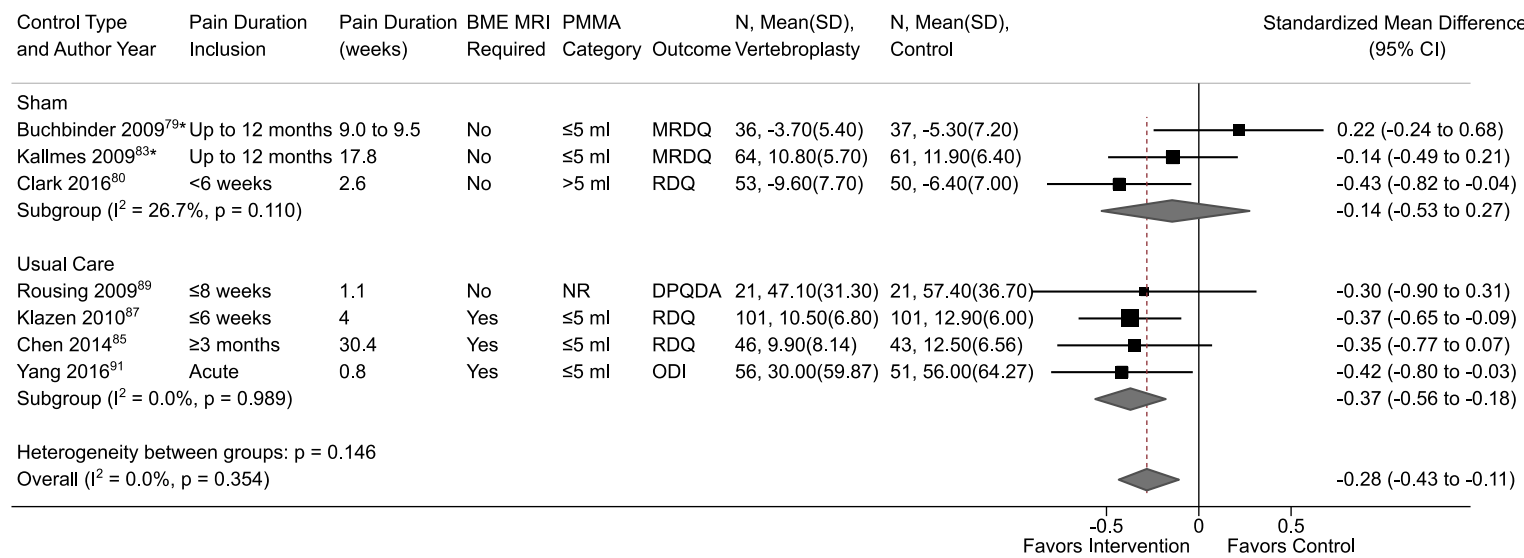

Abbreviations: $\mathrm{BME}=$ bone marrow edema; $\mathrm{CI}=$ confidence interval; $\mathrm{MRI}=$ magnetic resonance imaging; $\mathrm{PMMA}=$ polymethyl methacrylate; $\mathrm{SD}=$ standard deviation

*Adjusted mean difference from a regression model was used

Figure 11. Vertebroplasty versus sham or usual care, function (continuous) at 6 to 12 months

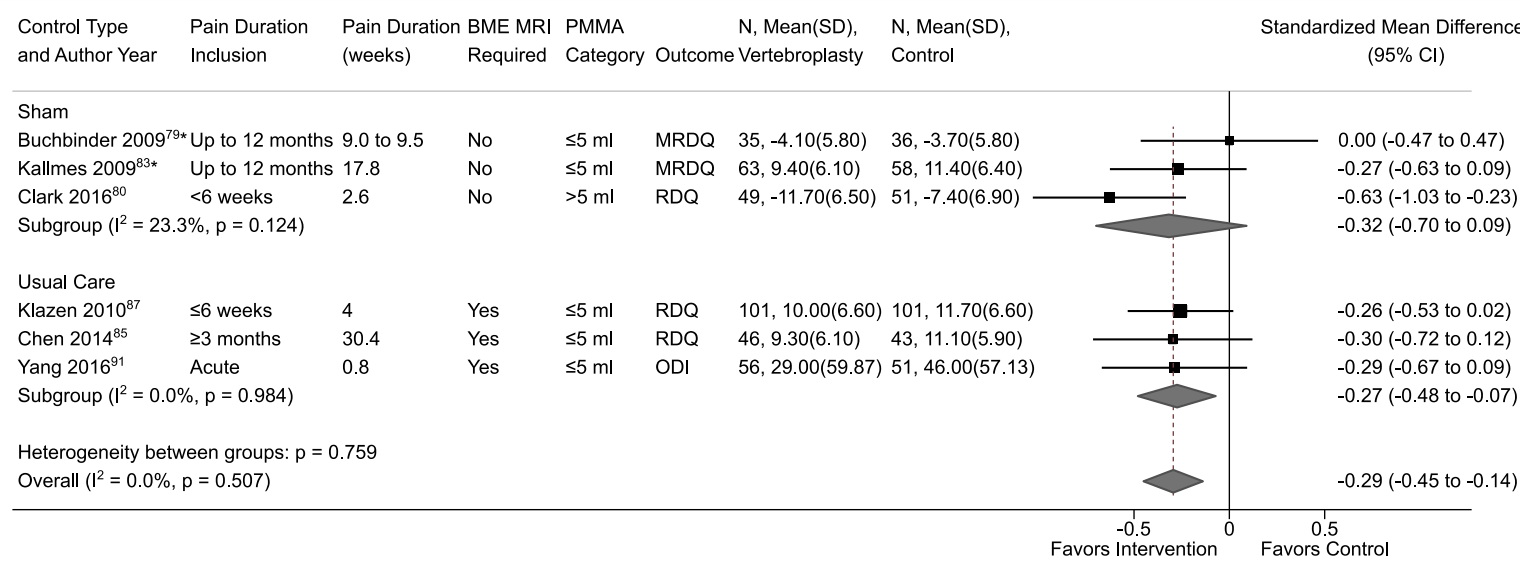


Abbreviations: $\mathrm{BME}=$ bone marrow edema; $\mathrm{CI}=$ confidence interval; $\mathrm{MRI}=$ magnetic resonance imaging; $\mathrm{PMMA}=$ polymethyl methacrylate; $\mathrm{SD}=$ standard deviation

*Adjusted mean difference from a regression model was used

Figure 12. Vertebroplasty versus sham or usual care, function (continuous) at $\mathbf{1 2}$ months and longer

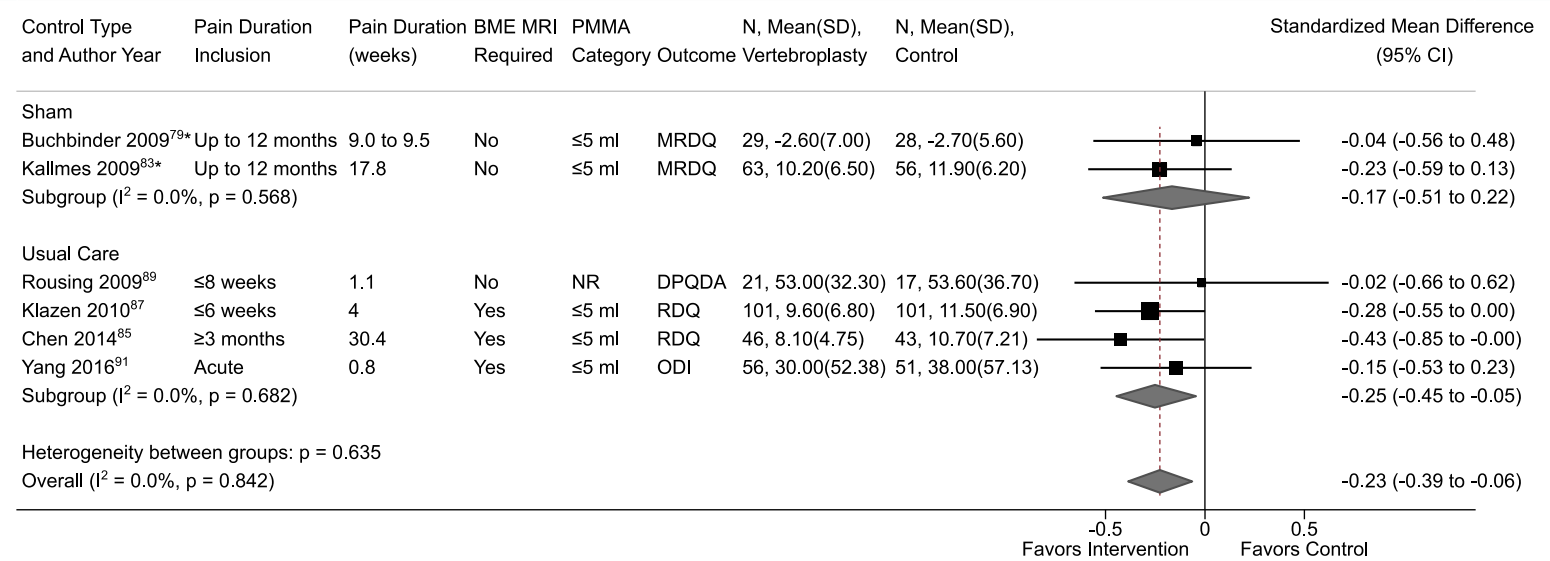

Abbreviations: $\mathrm{BME}=$ bone marrow edema; $\mathrm{CI}=$ confidence interval; $\mathrm{MRI}=$ magnetic resonance imaging; $\mathrm{PMMA}=$ polymethyl methacrylate; $\mathrm{SD}=$ standard deviation

*Adjusted mean difference from a regression model was used

Only one trial (mean pain duration at enrollment 17.8 weeks) evaluated the association between vertebroplasty versus sham or usual care and likelihood of experiencing functional improvement (defined as RDQ improved $\geq 30 \%$ ). ${ }^{83}$ Vertebroplasty was associated with reduced likelihood of functional improvement versus sham at 2 to 4 weeks (relative risk [RR] 0.66, 95\% CI, 0.45 to 0.97 ), but increased likelihood at 12 months and longer (RR $1.56,95 \%$ CI, 1.12 to 2.18).

\section{Other Outcomes}

Vertebroplasty was associated with a small improvement versus sham or usual care in general quality of life as measured by the EuroQOL 5-Dimension Questionnaire (EQ-5D) at 2 to 4 weeks (4 trials, mean difference $0.05,95 \%$ CI, 0.02 to $0.09, \mathrm{I}^{2}=0 \%$, Appendix Figure I3) $)^{79,80,83,87}$ and at 6 to 12 months ( 3 trials, mean difference $0.06,95 \%$ CI, 0.02 to $0.11, \mathrm{I}^{2}=0 \%$, Appendix Figure I-4) ${ }^{79,80,87}$ At other time points there were no differences or the difference was not statistically significant (Appendix Figures I-5 to I-7). Effects of vertebroplasty on the EQ5D did not significantly differ according to study quality, but subgroup analyses were limited by small numbers of trials and estimates were imprecise (Appendix Tables I-6 and I-7).

Vertebroplasty was associated with no difference in Quality of Life Questionnaire of the European Foundation for Osteoporosis (QUALEFFO) scores (a vertebral fracture-specific measure of quality of life) at all time points (Appendix Figures I-8 to I-12). ${ }^{79,80,84,87,90,91}$ Differences on the QUALEFFO were very small (below the threshold for small), ranging from 1.45 to -2.98 points on a 0 to 100 scale. There was no statistically significant difference in effects of vertebroplasty on the QUALEFFO score based on control type or study quality, but subgroup analyses were limited by small numbers of trials and estimates were imprecise (Appendix Tables I-6 and I-7). 
Vertebroplasty was associated with no difference versus sham or usual care in Short-Form 36 Health Survey Physical Component Score (SF-36 PCS) or Short-Form 36 Health Survey Mental Component Score (SF-36 MCS) at any time point (mean differences 1.16 points on a 0 to 100 scale favoring vertebroplasty to -3.08 points favoring controls), but findings were based on one or two trials and most estimates were imprecise (Appendix Figures I-13 and I-14, and Appendix Table I-8). ${ }^{82,83,89}$

Estimates for effects of vertebroplasty versus sham or usual care on likelihood of opioid use (defined as continued opioid use ${ }^{79,81,83,84}$ or major opioid use) were imprecise, based on one to three trials at each time point (Appendix Figure I-15 and Appendix Table I-3). One other trial found similar rates of opioid use with vertebroplasty versus sham at 12 weeks and 12 months, but data were not provided. ${ }^{82}$ Three trials found vertebroplasty associated with decreased likelihood of pain medication use (not restricted to opioids). In one trial, RR estimates ranged from 0.23 to 0.37 at 1 week to 12 months. In the other two trials, results were reported as statistically significant but risk estimates were not provided. ${ }^{87,88}$

\section{Harms}

Vertebroplasty was not associated with increased risk of incident vertebral fracture versus sham or usual care, though some imprecision was present ( 10 trials, RR 1.02, 95\% CI, 0.66 to $1.62, \mathrm{I}^{2}=9.6 \%$, Figure 13). ${ }^{80,81,84-91}$ Results were similar when the analysis was restricted to trials with $\geq 12$ months followup ( 7 trials, RR $0.94,95 \%$ CI, 0.55 to $1.49, \mathrm{I}^{2}=15 \%$ ). ${ }^{81,84-87,89,91}$ There was no interaction between control type, pain duration, requirement for bone marrow edema on MRI for inclusion, PMMA volume, or study quality and risk of incident fracture, but stratified analyses were limited by small numbers of trials and imprecision. Estimates at 1 to 2 weeks and at 6 to 12 months were very imprecise (Appendix Table I-9).

Vertebroplasty was not associated with increased risk of mortality versus sham or usual care ( 7 trials, RR $0.88,95 \%$ CI, 0.50 to $1.53, \mathrm{I}^{2}=0 \%$, Appendix Figure I-16).$^{80,81,84,86-89}$ Findings were similar at 6 to 12 months ( 3 trials, RR $0.76,95 \%$ CI, 0.23 to $\left.2.65, \mathrm{I}^{2}=0 \%\right)^{80,84,88}$ or 12 months and longer ( 5 trials, RR $0.98,95 \%$ CI, 0.51 to $1.87, \mathrm{I}^{2}=0 \%$ ), ${ }^{81,84,86,87,89}$ but estimates were more imprecise (Appendix Table I-9). Estimates for risk of serious adverse events were also imprecise at 6 to 12 months (subgroup analysis of patients with pain $\leq 3$ weeks in the VAPOUR, vertebroplasty for acute painful osteoporotic fractures, trial, ${ }^{80} \mathrm{RR} 0.67,95 \% \mathrm{CI}, 0.12$ to 3.79$)^{94}$ and 12 months and longer ( 1 trial, RR $0.95,95 \%$ CI, 0.06 to 14.90) ${ }^{83}$ based on few events (5 and 2 , respectively). One poor-quality trial found vertebroplasty associated with decreased risk of any adverse event versus usual care ( $16.1 \%$ vs. $35.3 \%$, RR $0.46,95 \% \mathrm{CI}, 0.23$ to 0.92$).{ }^{91}$ 
Figure 13. Vertebroplasty versus sham or usual care and risk of incident vertebral fracture

\begin{tabular}{|c|c|c|c|c|c|c|c|}
\hline $\begin{array}{l}\text { Control Type } \\
\text { and Author Year }\end{array}$ & $\begin{array}{l}\text { Pain Duration } \\
\text { Inclusion }\end{array}$ & $\begin{array}{l}\text { Pain Duration } \\
\text { (weeks) }\end{array}$ & $\begin{array}{l}\text { BME MRI } \\
\text { Required }\end{array}$ & $\begin{array}{l}\text { PMMA } \\
\text { Category }\end{array}$ & $\begin{array}{l}\text { Vertebroplasty } \\
\mathrm{n} / \mathrm{N}\end{array}$ & $\begin{array}{l}\text { Control } \\
\mathrm{n} / \mathrm{N}\end{array}$ & $\begin{array}{l}\text { Risk Ratio } \\
(95 \% \mathrm{Cl})\end{array}$ \\
\hline $\begin{array}{l}\text { Sham } \\
\text { Klazen } 2010^{87} \\
\text { Clark } 2016^{80} \\
\text { Firanescu } 2018^{81} \\
\text { Subgroup } \\
\left(I^{2}=0.0 \%, p=0.786\right)\end{array}$ & $\begin{array}{l}\leq 6 \text { weeks } \\
<6 \text { weeks } \\
\leq 9 \text { weeks }\end{array}$ & $\begin{array}{l}4 \\
2.6 \\
5 \text { to } 8\end{array}$ & $\begin{array}{l}\text { Yes } \\
\text { Yes } \\
\text { Yes }\end{array}$ & $\begin{array}{l}\leq 5 \mathrm{ml} \\
>5 \mathrm{ml} \\
>5 \mathrm{ml}\end{array}$ & $\begin{array}{l}5 / 101 \\
3 / 61 \\
15 / 90 \\
23 / 252\end{array}$ & $\begin{array}{l}6 / 101 \\
2 / 59 \\
19 / 86 \\
27 / 246\end{array}$ & $\begin{array}{l}0.83(0.26 \text { to } 2.64) \\
1.45(0.25 \text { to } 8.37) \\
0.75(0.41 \text { to } 1.39) \\
0.81(0.47 \text { to } 1.57)\end{array}$ \\
\hline $\begin{array}{l}\text { Usual Care } \\
\text { Voormolen } 2007^{90} \\
\text { Rousing } 2009^{89} \\
\text { Farrokhi } 2011^{86} \\
\text { Blasco 2012 } \\
\text { Chen 2014 } 24^{85} \\
\text { Leali 2016 } \\
\text { Yang 2016 } \\
\text { Subgroup } \\
\left(I^{2}=14.2 \%, p=0.162\right)\end{array}$ & $\begin{array}{l}6 \text { weeks }-5 \text { months } \\
\leq 8 \text { weeks } \\
4 \text { weeks }-1 \text { year } \\
\text { Up to } 12 \text { months } \\
\geq 3 \text { months } \\
\text { Acute } \\
\text { Acute }\end{array}$ & $\begin{array}{l}11.7 \\
1.1 \\
27 \text { to } 30 \\
20.4 \\
30.4 \\
\text { NR } \\
0.8\end{array}$ & $\begin{array}{l}\text { Yes } \\
\text { No } \\
\text { Yes } \\
\text { Yes } \\
\text { Yes } \\
\text { Yes } \\
\text { Yes }\end{array}$ & $\begin{array}{l}\leq 5 \mathrm{ml} \\
\mathrm{NR} \\
\leq 5 \mathrm{ml} \\
\mathrm{NR} \\
\leq 5 \mathrm{ml} \\
\leq 5 \mathrm{ml} \\
\leq 5 \mathrm{ml}\end{array}$ & $\begin{array}{l}2 / 18 \\
4 / 26 \\
1 / 38 \\
17 / 64 \\
4 / 46 \\
3 / 200 \\
5 / 56 \\
36 / 448\end{array}$ & $\begin{array}{l}0 / 16 \\
3 / 24 \\
6 / 39 \\
8 / 61 \\
7 / 43 \\
0 / 200 \\
4 / 51 \\
28 / 434\end{array}$ & $\begin{array}{l}4.47(0.23 \text { to } 86.77) \\
1.23(0.31 \text { to } 4.94) \\
0.17(0.02 \text { to } 1.35) \\
2.03(0.94 \text { to } 4.35) \\
0.53(0.17 \text { to } 1.70) \\
-7.00(0.36 \text { to } 134.64) \\
1.14(0.32 \text { to } 4.01) \\
1.20(0.57 \text { to } 2.32)\end{array}$ \\
\hline $\begin{array}{l}\text { Heterogeneity between } \\
\text { Overall } \\
\left(1^{2}=9.6 \%, p=0.271\right)\end{array}$ & groups: $p=0.242$ & & & & $59 / 700$ & $55 / 680$ & 1.02 (0.66 to 1.62$)$ \\
\hline
\end{tabular}

Abbreviations: $\mathrm{BME}=$ bone marrow edema; $\mathrm{CI}=$ confidence interval; $\mathrm{MRI}=$ magnetic resonance imaging; $\mathrm{PMMA}=$ polymethyl methacrylate; $\mathrm{SD}=$ standard deviation

\section{Effects of Demographic, Clinical, and Technical Factors}

Results of study-level stratified analyses based on pain duration are described above. Three trials of vertebroplasty also reported within-study subgroup analyses based on clinical or demographic factors. One trial found no interactions between duration of symptoms ( $<6 \mathrm{vs.} \geq 6$ weeks, or as a continuous measure), sex, or prior vertebral fractures and effects of vertebroplasty on outcomes ( $\mathrm{p}$ for interaction $>0.10$ for all of these factors) ${ }^{79}$ Another study found that vertebroplasty was associated with decreased pain intensity in patients with $<13$ weeks (mean difference -0.8 on a 0 to 10 scale, $95 \%$ CI, -2.5 to 0.8 ) or 14 to 26 weeks of pain (mean difference $-1.3,95 \% \mathrm{CI},-3.4$ to 0.8 ) but not in patients with 27 to 52 weeks of pain (mean difference $0.0,95 \% \mathrm{CI},-1.6$ to 1.7$).{ }^{83}$ However, stratified estimates were imprecise, with overlapping CIs. The third trial also found no statistically significant difference between fracture duration ( 1 to 3 weeks vs. 4 to 6 weeks) and benefits of vertebroplasty, though benefits were larger in the more acute group ( $\mathrm{p}$ for interaction 0.12). ${ }^{94}$

Evidence on how benefits and harms of vertebroplasty varied according to technical factors was very limited. As described above, a stratified analysis found no interaction between PMMA volume and effects on pain related to vertebral fracture.

\section{Kyphoplasty}

\section{Key Points}

- Kyphoplasty for vertebral compression fracture ( 2 trials, $N=434$, mean age 64 and 73 years) was associated with large reductions in pain and moderate to large improvement in function versus usual care at 1 week and 1 month in patients with or without cancer. No trial compared kyphoplasty against sham (SOE: low for function at 1 week; moderate for pain and for function at 1 month).

- In one trial $(\mathrm{N}=300)$ of patients without cancer, effects on pain and function were small to moderate at 3 months to 2 years (SOE: low). 
- Evidence on incident or worsening vertebral fracture was inconsistent and imprecise, based on two trials $(\mathrm{N}=434)$ ( $\mathrm{SOE}$ : insufficient).

\section{Description of Included Studies}

Two trials ( $\mathrm{n}=134$ and 300) compared kyphoplasty versus usual care for vertebral compression fracture (Appendix Table G-1 to G-3 and Table 3) ${ }^{99-102}$ The population differed in the trials: one trial ${ }^{102}$ (FREE, Fracture Reduction Evaluation trial) excluded patients with vertebral fractures related to cancer (mean age 73 years, $77 \%$ female); the other trial (CAFE [Cancer Patient Fracture Evaluation]) restricted inclusion to patients with cancer (mean age 64 years, 58\% female).$^{99}$ Both trials were multinational; neither trial reported what type of provider performed kyphoplasty. In FREE, enrollment was restricted to patients with fracture duration of 3 months or more (mean 6 weeks) with bone marrow edema on MRI; CAFE did not specify fracture duration (median 3.5 months) or require presence of bone marrow edema on imaging ( $67 \%$ had edema). Baseline pain intensity was similar in both trials ( $\sim 7$ on a 0 to 10 scale). Neither trial reported the PMMA volume utilized and both trials described usual care as involving various nonsurgical treatments, but did not otherwise specify usual care. FREE reported followup through 2 years. ${ }^{100,102}$ Although CAFE evaluated outcomes through 6 months, crossover from usual care to kyphoplasty was high (59\%) after 1 month (compared with 8\% in FREE at 1 year); therefore, we focused on 1-month outcomes from CAFE. Both trials were rated fair quality, mainly due to open-label design and differential loss to followup (Appendix Table H-1). 
Table 3. Study characteristics of kyphoplasty trials

\begin{tabular}{|c|c|c|c|c|c|c|c|c|c|}
\hline $\begin{array}{l}\text { Study, Year } \\
\text { Country } \\
\text { Quality }\end{array}$ & $\begin{array}{l}\text { Mean } \\
\text { Age } \\
\text { (Years) }\end{array}$ & $\begin{array}{l}\text { Percent } \\
\text { Female }\end{array}$ & $\begin{array}{l}\text { Number } \\
\text { Randomized }\end{array}$ & $\begin{array}{l}\text { Pain Duration } \\
\text { Inclusion } \\
\text { Criteria }\end{array}$ & $\begin{array}{l}\text { Mean/Median } \\
\text { Pain Duration } \\
\text { (Weeks) }\end{array}$ & $\begin{array}{l}\text { PMMA } \\
\text { Volume } \\
\text { (ml) }\end{array}$ & $\begin{array}{l}\text { Bone } \\
\text { Marrow } \\
\text { Edema on } \\
\text { MRI } \\
\text { Required } \\
\end{array}$ & $\begin{array}{l}\text { Control } \\
\text { Type }\end{array}$ & $\begin{array}{l}\text { Duration } \\
\text { of } \\
\text { Followup } \\
\text { (Months) }\end{array}$ \\
\hline $\begin{array}{l}\text { Berenson, } \\
2011^{99} \\
\text { Australia, } \\
\text { Canada, } \\
\text { Europe, U.S. } \\
\text { Fair }\end{array}$ & 63.9 & 58 & 134 & Not specified & 15.2 & NR & No & Usual care & 1 \\
\hline $\begin{array}{l}\text { Wardlaw, } \\
2009^{100-102} \\
\text { Europe and U.S. } \\
\text { Fair }\end{array}$ & 73.2 & 77 & 300 & $\leq 3$ months & 6 & NR & Yes & Usual care & 24 \\
\hline
\end{tabular}

Abbreviations: $\mathrm{MRI}=$ magnetic resonance imaging; $\mathrm{NR}=$ not reported; PMMA $=$ polymethyl methacrylate 


\section{Detailed Synthesis}

\section{Pain}

Both trials found kyphoplasty associated with reduced pain versus usual care. In FREE, effects were large at 1 week (analysis of variance [ANOVA] mean difference -2.2 on a 0 to 10 scale, $95 \% \mathrm{CI},-2.8$ to -1.6 ), decreasing to small at 1 to 2 years (ANOVA mean difference -0.8 to -0.9). ${ }^{100,102}$ In CAFE, the effects on pain were large at 1 week and 1 month (mean difference in change from baseline -3.5 to -3.3 on a 0 to 10 scale). ${ }^{99}$ Neither trial evaluated pain as a dichotomous outcome.

\section{Function}

Both trials also found kyphoplasty associated with improved function versus usual care. Similar to effects on pain, FREE found that differences between kyphoplasty versus usual care on function were moderate at 1 month (ANOVA mean difference -4.0 on the 0 to $24 \mathrm{RDQ}, 95 \%$ $\mathrm{CI},-5.5$ to -2.6 ) but the benefit was attenuated at 1 year (ANOVA mean difference $-2.6,95 \% \mathrm{CI}$, -4.1 to -2.0 at 1 year); at 2 years the effect was small (ANOVA mean difference $-1.4,95 \%$ CI, $1.4, p=0.05$ [CI not reported]). ${ }^{100,102}$ In CAFE, kyphoplasty was associated with a large improvement in RDQ versus usual care at 1 month (mean difference $-8.4,95 \%$ CI, -7.6 to -9.2$).{ }^{99}$

\section{Other Outcomes}

FREE found kyphoplasty associated with a small improvement in SF-36 PCS score versus placebo at 1 month (ANOVA mean difference 5.2 on a 0 to 100 scale, 95\% CI, 2.9 to 7.4 ); differences were attenuated and below the threshold for small at longer followup and no longer statistically significant at 1 or 2 years. ${ }^{100,102}$ Effects on the EQ-5D also favored kyphoplasty at 1 month (ANOVA mean difference 0.18 on a 0 to 1 scale, $95 \%$ CI, 0.08 to 0.28 ) but were attenuated at 1 or 2 years (ANOVA mean difference 0.12 ). Kyphoplasty was associated with decreased likelihood of any opioid use at 6 months $(29.8 \%$ vs. $42.9 \%, p=0.4)$, with no difference by 1 year $(28.0 \%$ vs. $33.7 \%, p=1.0)$; there was no difference in the likelihood of strong opioid use at 1 month or 1 year.

CAFE found kyphoplasty associated with moderate improvement versus usual care in SF-36 PCS score (mean difference in change from baseline 11.1, 95\% CI, 10.7 to 11.5 ) and small improvement versus usual care in SF-36 MCS score (mean difference in change from baseline $8.4,95 \%$ CI, 7.7 to 9.1 ) at 1 month. ${ }^{99}$ Kyphoplasty was also associated with reduced likelihood of analgesic use at 1 month (52.3\% vs. $82.0 \%$, RR $0.64,95 \%$ CI, 0.49 to 0.83$)$.

\section{Harms}

FREE found no difference between kyphoplasty versus usual care in mortality, serious adverse events, or any adverse event, though estimates were imprecise. ${ }^{101,102}$ The estimate for new of worsening fracture also was imprecise, but the proportion with this outcome was higher in the kyphoplasty arm (33.0\% vs. $25.3 \%$, absolute risk difference $7.7 \%, 95 \%$ CI, -4.5 to 20.0$)$.

In CAFE, kyphoplasty was associated with increased likelihood of mortality $(32.9 \%$, vs. $18.8 \%, 95 \%$ CI, 0.95 to 3.23$)$ and any adverse event (37.1\% vs. $29.7 \%$, RR $1.27,95 \%$ CI, 0.78 to 2.06) that were not statistically significant. ${ }^{99}$ However, there were few adverse events resulting in death $(2.9 \%$ [2/70] vs. $1.6 \%$ [1/64]). There were also few incident symptomatic fractures $(2.9 \%$ [2/70] vs. $7.8 \%$ [5/64]). Injury or procedural complications occurred in 5.7\% (4/70) of patients in the kyphoplasty arm. 


\title{
Alternatives to Conventional Radiofrequency Ablation Cooled Radiofrequency Denervation
}

\author{
Key Points
}

Versus Sham Radiofrequency Denervation for Sacroiliac Pain

- Cooled radiofrequency denervation for sacroiliac pain was associated with a moderate to large reduction in pain and small to large improvement in function versus sham radiofrequency at 1 month ( 2 trials, $\mathrm{N}=79$ ); improvements in pain and function at 3 months were moderate ( 1 trial, $\mathrm{N}=28$ ) ( $\mathrm{SOE}$ : moderate for pain and function at 3 months; low for function at 1 month).

Versus Conventional Radiofrequency Denervation for Presumed Facet Joint Pain

- Cooled radiofrequency denervation for presumed facet joint pain was associated with a small, nonstatistically significant reduction in pain versus conventional radiofrequency at 6 months and no difference in function ( 1 trial, $N=43$ ); there were no differences at earlier (1 or 3 month) followup (SOE: low).

\section{Across Trials of Cooled and Pulsed Radiofrequency Denervation}

- Harms were not well-reported, but when recorded were usually related to temporary increase in pain. No serious complications were reported (SOE: low).

- The mean age of participants ranged from 52 to 59 years.

\section{Cooled Radiofrequency Denervation Versus Sham Radiofrequency Denervation for Sacroiliac Pain}

\section{Description of Included Studies}

Two trials ( $\mathrm{n}=28$ and 51) evaluated cooled radiofrequency denervation versus sham radiofrequency for sacroiliac pain. (Appendix Table G-4 to G-6 and Table 4). ${ }^{103,104}$ Both trials were conducted in the United States. Mean age was 52 and 59 years and the proportion female 61 to 72 percent. Both trials required patients to have pain in the sacroiliac area for at least 6 months and persistent pain despite standard nonoperative therapies. Patients had to have at least 75 percent pain relief with a single ${ }^{103}$ or repeat ${ }^{104}$ diagnostic sacroiliac block. Baseline pain intensity was $\sim 6$ on a 0 to 10 scale in both trials. In both trials, cooled radiofrequency denervation was performed with imaging guidance; details regarding the radiofrequency techniques are shown in Table 4. Sham radiofrequency involved needle placement as for active treatment, without radiofrequency lesioning; in one trial, ${ }^{103}$ lidocaine was administered. Both trials were rated fair quality; methodological shortcomings included unclear randomization methods and high crossover without intent-to-treat analysis (Appendix Table H-1). Crossover was high: in one trial, ${ }^{104} 94$ percent (16/17) of patients randomized to sham treatment crossed over to cooled radiofrequency denervation after 3 months and in the other, ${ }^{103} 64$ percent $(9 / 14)$ crossed over after 1 month. Therefore, results focus on outcomes prior to high crossover ( 3 and 1 months, respectively). 
Table 4. Study characteristics and results for cooled radiofrequency ablation trials

\begin{tabular}{|c|c|c|c|c|c|c|c|c|c|c|}
\hline $\begin{array}{l}\text { Study, } \\
\text { Year } \\
\text { Country } \\
\text { Quality }\end{array}$ & $\begin{array}{l}\text { Mean } \\
\text { Age } \\
\text { (Years) }\end{array}$ & $\begin{array}{l}\text { Percent } \\
\text { Female }\end{array}$ & $\begin{array}{l}\text { Number } \\
\text { Randomized }\end{array}$ & $\begin{array}{l}\text { Duration } \\
\text { of } \\
\text { Symptoms } \\
\text { (Months) }\end{array}$ & $\begin{array}{l}\text { Diagnostic } \\
\text { Testing }\end{array}$ & $\begin{array}{l}\text { Cooled or } \\
\text { Pulsed } \\
\text { Radiofrequency } \\
\text { Parameters }\end{array}$ & $\begin{array}{l}\text { Control } \\
\text { Type }\end{array}$ & $\begin{array}{l}\text { Duration } \\
\text { of } \\
\text { Followup } \\
\text { (Months) }\end{array}$ & Pain & Function \\
\hline $\begin{array}{l}\text { Cohen, } \\
2008^{103} \\
\text { U.S. } \\
\text { Fair }\end{array}$ & 51.8 & 61 & 28 & $\geq 6$ & $\begin{array}{l}\text { Sacroiliac } \\
\text { joint block } \\
\text { (single, } \\
\geq 75 \% \\
\text { relief) }\end{array}$ & $\begin{array}{l}2 \text { minutes at } 60^{\circ} \\
\mathrm{C} \text {, target tissue } \\
\text { heated to } 75^{\circ} \mathrm{C} \\
(\mathrm{L} 4 \text { and } \mathrm{L} 5 \\
\text { dorsal rami } \\
\text { treated with } \\
\text { conventional RF } \\
\text { for } 90 \text { seconds } \\
\text { at } 80^{\circ} \mathrm{C} \text { ) }\end{array}$ & Sham RF & 3 & $\begin{array}{l}\text { Dichotomous } \\
\text { Successful } \\
\text { outcome* } \\
1 \text { month: } 79 \% \text { vs. } \\
14.3 \%, \text { RR } 5.50 \\
(95 \% \text { Cl, } 1.48 \text { to } \\
20.42) \\
3 \text { months: } 64 \% \text { vs. } \\
0 \%, \text { RR } 0.36 \text { (95\% } \\
\text { Cl, } 0.18 \text { to } 0.72) \\
\text { Continuous } \\
\text { NRS } 0 \text { to } 10, \text { mean } \\
\text { (SD) } \\
1 \text { month: } 2.4(2.0) \\
\text { vs. } 6.3(2.4), p<0.05 \\
3 \text { months: } 2.4(2.3) \\
\text { vs. } 6(0), p>0.05\end{array}$ & $\begin{array}{l}\text { ODI } 0 \text { to } 100, \\
\text { mean (SD) } \\
1 \text { month: } \\
20.9(10.9) \\
\text { vs. } 43.6(14), \\
\text { p<0.05 } \\
3 \text { months: } \\
18.5(11.6) \\
\text { vs. } 24(8.5), \\
\text { p>0.05 }\end{array}$ \\
\hline $\begin{array}{l}\text { Patel, } \\
2012^{104} \\
\text { U.S. } \\
\text { Fair }\end{array}$ & 58.7 & 72 & 51 & $>6$ & $\begin{array}{l}\text { S1-S3 } \\
\text { lateral } \\
\text { branch and } \\
\text { L5 dorsal } \\
\text { ramus } \\
\text { block (dual, } \\
\geq 75 \% \\
\text { relief) }\end{array}$ & $\begin{array}{l}150 \text { seconds at } \\
60^{\circ} \mathrm{C}\end{array}$ & Sham RF & 3 & $\begin{array}{l}\text { Dichotomous } \\
\geq 50 \% \text { pain intensity } \\
\text { improvement } \\
3 \text { months: } 53 \% \text { vs. } \\
29 \%, \text { RR } 1.80(95 \% \\
\mathrm{Cl}, 0.80 \text { to } 4.01) \\
\text { Continuous } \\
\text { NRS } 0 \text { to } 10, \text { mean } \\
\text { change (SD) } \\
1 \text { month: }-2.7(2.6) \\
\text { vs. }-1.7(2.0), \\
p=0.16 \\
3 \text { months: }-2.4(2.7) \\
\text { vs. }-0.8(2.4), \\
p=0.04\end{array}$ & $\begin{array}{l}\text { Dichotomous } \\
\geq 10 \% \text { ODI } \\
\text { improved } \\
3 \text { months: } \\
41.2 \% \text { vs. } \\
5.9 \% \text {, RR } \\
7.00 \text { (95\% } \\
\text { Cl, } 1.00 \text { to } \\
48.88) \\
\text { Continuous } \\
\text { ODI } 0 \text { to } 100, \\
\text { mean } \\
\text { change (SD) } \\
1 \text { month: }-12 \\
\text { (14) vs. }-4 \\
\text { (11), } \\
\text { p=0.046 } \\
3 \text { months: - } \\
11 \text { (17) vs. } 2 \\
\text { (6), p=0.01 }\end{array}$ \\
\hline
\end{tabular}




\begin{tabular}{|c|c|c|c|c|c|c|c|c|c|c|}
\hline $\begin{array}{l}\text { Study, } \\
\text { Year } \\
\text { Country } \\
\text { Quality }\end{array}$ & $\begin{array}{l}\text { Mean } \\
\text { Age } \\
\text { (Years) }\end{array}$ & $\begin{array}{l}\text { Percent } \\
\text { Female }\end{array}$ & $\begin{array}{l}\text { Number } \\
\text { Randomized }\end{array}$ & $\begin{array}{l}\text { Duration } \\
\text { of } \\
\text { Symptoms } \\
\text { (Months) }\end{array}$ & $\begin{array}{l}\text { Diagnostic } \\
\text { Testing }\end{array}$ & $\begin{array}{l}\text { Cooled or } \\
\text { Pulsed } \\
\text { Radiofrequency } \\
\text { Parameters }\end{array}$ & $\begin{array}{l}\text { Control } \\
\text { Type }\end{array}$ & $\begin{array}{l}\text { Duration } \\
\text { of } \\
\text { Followup } \\
\text { (Months) }\end{array}$ & Pain & Function \\
\hline $\begin{array}{l}\text { McCormick, } \\
2019^{105} \\
\text { U.S. } \\
\text { Good }\end{array}$ & 55.8 & 59 & 43 & $\geq 6$ & $\begin{array}{l}\text { Medial } \\
\text { branch } \\
\text { block } \\
\text { (single, } \\
>75 \% \\
\text { relief) }\end{array}$ & $\begin{array}{l}165 \text { seconds at } \\
60^{\circ} \mathrm{C} \text {, target } \\
\text { tissue heated to } \\
>80^{\circ} \mathrm{C}\end{array}$ & $\begin{array}{l}\text { Conventional } \\
\text { RF }(90 \\
\text { seconds at } \\
\left.80^{\circ} \mathrm{C}\right)\end{array}$ & 6 & $\begin{array}{l}\text { Dichotomous } \\
\geq 50 \% \text { NRS } \\
\text { improved } \\
6 \text { months: } 52.3 \% \text { vs. } \\
44.4 \% \text {, RR } 1.18 \\
(95 \% \text { Cl, } 0.61 \text { to } \\
2.28) \\
\text { Continuous } \\
\text { NRS } 0 \text { to } 10, \text { mean } \\
\text { change (SD) } \\
6 \text { months: }-3.8(2.5) \\
\text { vs. }-3.0(3.2), \\
\text { p=0.41 }\end{array}$ & $\begin{array}{l}\text { Dichotomous } \\
\geq 30 \% \text { ODI } \\
\text { improved } \\
6 \text { months: } \\
61.9 \% \text { vs. } \\
44.4 \%, \text { RR } \\
1.39 \text { (95\% } \\
\mathrm{Cl}, 0.75 \text { to } \\
2.58) \\
\text { Continuous } \\
\text { ODI } 0 \text { to } 100, \\
\text { mean } \\
\text { change (SD) } \\
6 \text { months: - } \\
11.3(11.2) \\
\text { vs. }-8.1 \\
(12.3), \\
\text { p=0.40 }\end{array}$ \\
\hline
\end{tabular}

Abbreviations: $\mathrm{CI}=$ confidence interval; $\mathrm{NR}=$ not reported; $\mathrm{NRS}=$ numeric rating scale; $\mathrm{ODI}=$ Oswestry Disability Index; PRF $=$ pulsed radiofrequency ablation; $\mathrm{RF}=$

radiofrequency ablation; $\mathrm{RR}=$ relative risk; $\mathrm{SD}=$ standard deviation; $\mathrm{VAS}=$ visual analogue scale

*Successful outcome was defined as $\geq 50 \%$ improvement in pain, positive Global Perceived Effect, and $\geq 10$-point improvement in ODI or $\geq 4$ point improvement in ODI and $>20 \%$

reduction in opioid use or complete cessation of nonopioid analgesic 


\section{Detailed Synthesis}

\section{Pain}

Both trials found cooled radiofrequency associated with reduced pain versus sham at 1 month; effects were moderate to large (mean difference 1.0 to 2.9 points on a 0 to 10 scale). ${ }^{103,104}$ At 3 months, one trial found cooled radiofrequency associated with a persistent moderate reduction in pain (mean change from baseline -2.4 vs. $-0.8, p=0.04$ ).${ }^{103}$ In this trial, cooled radiofrequency was also associated with increased likelihood of pain intensity improvement of at least 50 percent at 3 months, though the difference was not statistically significant (53\% vs. 29\%, RR $0.81,95 \%$ CI, 0.81 to 4.01$).{ }^{103}$

\section{Function}

Both trials found cooled radiofrequency associated with improved function versus sham at 1 month; effects were small in one trial (mean change from baseline -12 vs. -4 on the 0 to 100 Oswestry Disability Index [ODI], $\mathrm{p}=0.046)^{103}$ and large in the other trial (mean 20.9 vs. 43.6 on the ODI, $\mathrm{p}<0.05) .{ }^{104}$ One trial found cooled radiofrequency associated with a moderate improvement versus sham in ODI at 3 months (mean change from baseline -11 vs. 2, $p=001$ ). ${ }^{103}$ In this trial, patients randomized to cooled radiofrequency were also more likely to experience an ODI improvement of at least 10 points (41\% vs. 5.9\%, RR 7.00, 95\% CI, 1.00 to 48.88 ).

\section{Other Outcomes}

One trial found cooled radiofrequency associated with improved SF-36 PCS versus sham at 3 months (mean change from baseline 14 vs. 3 on 0 to 100 scale, $p=0.04$ ); the difference at 1 month was small and not statistically significant. ${ }^{103}$ Cooled radiofrequency was also associated with improvement in Assessment of Quality of Life score at 3 months (mean 0.69 vs. 0.56 on 0 to 1 scale, $p=0.048$ ). The other trial found cooled radiofrequency associated with increased likelihood of a more than 20 percent reduction in opioid use or complete cessation of nonopioid analgesics at 1 month $(77 \%$ vs. $8 \%, \mathrm{p}<0.05) .{ }^{104}$ Both trials found cooled radiofrequency associated with increased likelihood of experiencing a composite outcome of treatment success. In one trial, ${ }^{104}$ treatment success was defined as at least a 50 percent improvement in pain, positive Global Perceived Effect, and at least a 10 point improvement in ODI or at least a 4 point improvement in ODI and reduction in medication use and assessed at 1 month (79\% vs. 14.3\%, RR 5.50, 95\% CI, 1.48 to 20.42); in the other, ${ }^{103}$ it was defined as pain intensity improved at least 50 percent and either 10 point increase in SF-36 bodily pain or 10 point decrease in ODI and assessed at 3 months (47\% vs. 12\%, RR 4.00, 95\% CI, 1.04 to 15.43 ).

\section{Harms}

One trial reported no serious complications, though some patients reported temporary worsening pain typically lasting 5 to 10 days after the procedure; one patient in the cooled radiofrequency arm reported transient nonpainful buttock paresthesias. ${ }^{103}$ Harms were not reported in the other trial. ${ }^{104}$ 


\section{Cooled Versus Conventional Radiofrequency Denervation for Presumed Lumbar Facet Joint Pain}

\section{Description of Included Studies}

One good-quality trial $(\mathrm{n}=43)$ conducted in the United States compared cooled radiofrequency versus conventional radiofrequency for presumed lumbar facet joint pain (Appendix Table G-4 to G-6, Appendix Table H-1, and Table 4). ${ }^{105}$ Patients had to have a positive response ( $\geq 75 \%$ pain relief) to one set of diagnostic medial branch nerve blocks. Mean age was 56 years and 59 percent of participants were female; the mean duration of pain was 86 months. Baseline pain intensity was approximately 7 on a 0 to 10 NRS. Cooled radiofrequency to medial branch nerve targets was performed for 165 seconds at 60 degrees $\mathrm{C}$ (intraregional temperature $>80$ degrees $\mathrm{C}$ ). Conventional radiofrequency was performed for 90 seconds at 80 degrees $\mathrm{C}$.

\section{Detailed Synthesis}

\section{Pain}

Cooled radiofrequency denervation was associated with a small, nonstatistically significant greater reduction in pain versus conventional radiofrequency at 6 months (mean change from baseline -3.8 vs. -3.0 on a 0 to 10 scale, $p=0.41$ ); there were also no statistically significant differences at 1 or 3 months. ${ }^{105}$ There was no difference in likelihood of experiencing at least a 50 percent improvement in pain at 6 months ( $52.3 \%$ vs. $44.4 \%$, RR $1.18,95 \%$ CI, 0.61 to 2.28$)$.

\section{Function}

There was no difference between cooled versus conventional radiofrequency in improvement in ODI at 1,3 , or 6 months. ${ }^{105}$ Cooled radiofrequency was associated with increased likelihood of experiencing at least a 30 percent improvement in ODI that was not statistically significant (61.9\% vs. $44.4 \%$, RR $1.39,95 \%$ CI, 0.75 to 2.58$)$.

\section{Other Outcomes}

There was no difference between cooled versus conventional radiofrequency in Global Impression of Change at 6 months (mean 2 vs. 2 on a 1 to 7 scale, $p=0.51$ ). ${ }^{105}$

\section{Harms}

No serious adverse events were reported with either cooled or conventional radiofrequency. ${ }^{105}$ Self-limited post-procedural pain was reported in two patients.

\section{Pulsed Radiofrequency Denervation}

\section{Key Points}

- Evidence was insufficient to assess pulsed radiofrequency denervation for presumed facet joint pain versus sham denervation ( 1 trial, $\mathrm{N}=40$ ) or continuous radiofrequency denervation (1 trial, $\mathrm{N}=40)$ (SOE: insufficient).

\section{Across Trials of Cooled and Pulsed Radiofrequency Denervation}

- Harms were not well-reported, but when recorded were usually related to temporary increase in pain. No serious complications were reported (SOE: low). 
- The mean age of participants ranged from 52 to 59 years.

\section{Pulsed Versus Sham Radiofrequency Denervation for Presumed Lumbar Facet Joint Pain}

\section{Description of Included Studies}

One fair-quality trial ${ }^{106}$ and one poor-quality trial ${ }^{107}$ compared pulsed versus conventional radiofrequency denervation for presumed lumbar facet joint pain (Appendix Table G-4 to G-6 and Table 5). In both trials, patients had to have a positive response ( $>50 \%$ or complete/near complete pain relief) to one or two diagnostic medial branch blocks. The fair-quality trial $(\mathrm{n}=40)$ evaluated pulsed ( $2 \mathrm{~Hz}$ waves for 4 minutes [ $45 \mathrm{~V}$ ] to 42 degrees $\mathrm{C}$ ) versus electrode placement without radiofrequency current and administration of a local anesthetic. ${ }^{106}$ Mean age was 49 years, 57 percent of participants were female, and the mean duration of pain was 35 months. In the poor-quality trial $(\mathrm{n}=50),{ }^{107}$ mean age was 57 years and the proportion female 65 percent. It compared pulsed radiofrequency ( $2 \mathrm{~Hz}$ waves for 2 minutes at 42 degrees $\mathrm{C}$ ) of the dorsal root ganglia versus electrode placement without radiofrequency current (no local anesthetic). ${ }^{107}$ Methodological limitations in both trials included failure to report allocation concealment methods, unclear masking of care providers, and high or unclear attrition (Appendix Table H1). In addition, the poor quality trial did not report randomization methods or baseline characteristics, did not conduct intent-to-treat analysis, and had discrepancies in reported results. 
Table 5. Study characteristics and results of pulsed radiofrequency ablation trials

\begin{tabular}{|c|c|c|c|c|c|c|c|c|c|c|}
\hline $\begin{array}{l}\text { Study, } \\
\text { Year } \\
\text { Country } \\
\text { Quality }\end{array}$ & $\begin{array}{l}\text { Mean } \\
\text { Age } \\
\text { (Years) }\end{array}$ & $\begin{array}{l}\text { Percent } \\
\text { Female }\end{array}$ & $\begin{array}{l}\text { Number } \\
\text { Randomized }\end{array}$ & $\begin{array}{l}\text { Duration } \\
\text { of } \\
\text { Symptoms } \\
\text { (Months) }\end{array}$ & $\begin{array}{l}\text { Diagnostic } \\
\text { Testing }\end{array}$ & $\begin{array}{l}\text { Cooled or } \\
\text { Pulsed } \\
\text { Radiofrequency } \\
\text { Parameters }\end{array}$ & $\begin{array}{l}\text { Control } \\
\text { Type }\end{array}$ & $\begin{array}{l}\text { Duration } \\
\text { of } \\
\text { Followup } \\
\text { (Months) }\end{array}$ & Pain & Function \\
\hline $\begin{array}{l}\text { Kroll, } \\
2008^{108} \\
\text { U.S. } \\
\text { Poor }\end{array}$ & 58.2 & 54 & 50 & $>1$ & $\begin{array}{l}\text { Medial } \\
\text { branch } \\
\text { block (dual, } \\
>50 \% \\
\text { relief) }\end{array}$ & $\begin{array}{l}120 \text { seconds at } \\
42^{\circ} \mathrm{C} \text {, pulse } \\
\text { duration } 20 \mathrm{~ms} \text {, } \\
\text { pulse rate } 2 \mathrm{~Hz}\end{array}$ & $\begin{array}{l}\text { Conventional } \\
\mathrm{RF}(75 \\
\text { seconds at } \\
\left.80^{\circ} \mathrm{C}\right)\end{array}$ & 3 & $\begin{array}{l}\text { VAS } 0 \text { to } 10, \text { mean (SD) } \\
3 \text { months: } 5.1(2.1) \text { vs. } 5.2(2.7)\end{array}$ & $\begin{array}{l}\text { ODI } 0 \text { to } 100, \\
\text { mean (SD) } \\
3 \text { months: } 42.2 \\
(19.0) \text { vs. } 41.7 \\
(16.9)\end{array}$ \\
\hline $\begin{array}{l}\text { Moussa, } \\
2020^{107} \\
\text { Egypt } \\
\text { Poor }\end{array}$ & 57 & 65 & 150 & $\geq 12$ & $\begin{array}{l}\text { Medial } \\
\text { dorsal } \\
\text { branch } \\
\text { block } \\
\text { (single, } \\
\text { complete } \\
\text { or near } \\
\text { complete } \\
\text { relief) }\end{array}$ & $\begin{array}{l}\text { Four 2-minute } \\
\text { cycles at } \leq 42^{\circ} \mathrm{C} \text {, } \\
\text { pulse rate } 2 \mathrm{~Hz} \text {, } \\
45 \mathrm{~V} \text { unilaterally } \\
\text { or bilaterally }\end{array}$ & $\begin{array}{l}\text { A: } \\
\text { Conventional } \\
\text { RF ( } 90 \\
\text { seconds at } \\
\left.85^{\circ} \mathrm{C}\right) \\
\text { B: Sham RF }\end{array}$ & 36 & 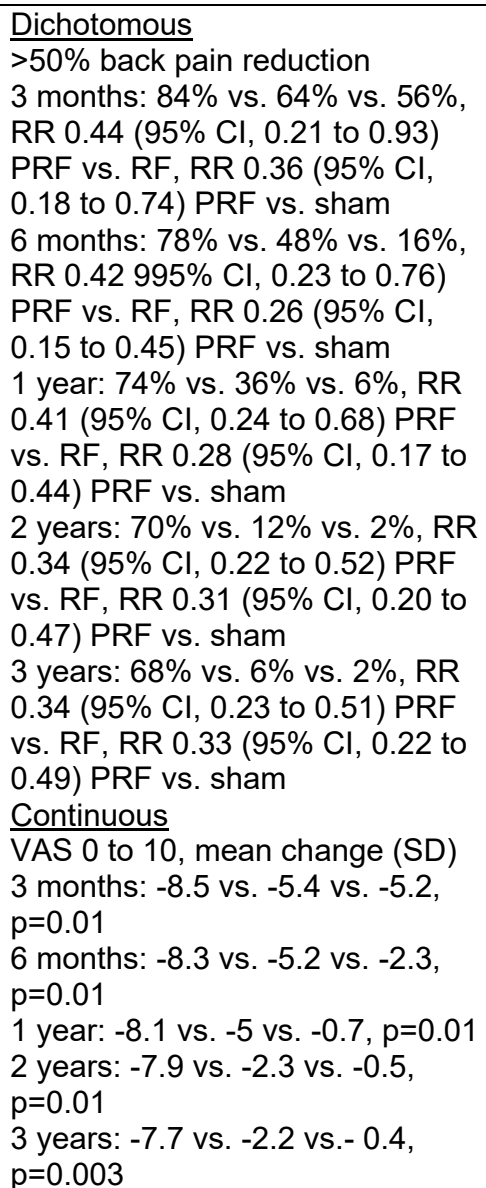 & $\begin{array}{l}\text { ODI } 0 \text { to } 100, \\
\text { mean change } \\
\text { (SD) } \\
3 \text { months: }-50.5 \\
\text { vs. }-34.9 \text { vs. - } \\
33.6, p=0.05 \\
6 \text { months: }-48.1 \\
\text { vs. }-30.3 \text { vs. - } \\
10.8, p=0.03 \\
1 \text { year: }-43.9 \text { vs.- } \\
26.4 \text { vs. }-5.5 \text {, } \\
\text { p=0.01 } \\
2 \text { years: }-39.3 \text { vs. } \\
-15.3 \text { vs. }-3.7, \\
p=0.01 \\
3 \text { years: }-39.2 \text { vs. } \\
-6.3 \text { vs. }-2, \\
\text { p=0.004 }\end{array}$ \\
\hline
\end{tabular}




\begin{tabular}{|c|c|c|c|c|c|c|c|c|c|c|}
\hline $\begin{array}{l}\text { Study, } \\
\text { Year } \\
\text { Country } \\
\text { Quality }\end{array}$ & $\begin{array}{l}\text { Mean } \\
\text { Age } \\
\text { (Years) }\end{array}$ & $\begin{array}{l}\text { Percent } \\
\text { Female }\end{array}$ & $\begin{array}{l}\text { Number } \\
\text { Randomized }\end{array}$ & $\begin{array}{l}\text { Duration } \\
\text { of } \\
\text { Symptoms } \\
\text { (Months) }\end{array}$ & $\begin{array}{l}\text { Diagnostic } \\
\text { Testing }\end{array}$ & $\begin{array}{l}\text { Cooled or } \\
\text { Pulsed } \\
\text { Radiofrequency } \\
\text { Parameters }\end{array}$ & $\begin{array}{l}\text { Control } \\
\text { Type }\end{array}$ & $\begin{array}{l}\text { Duration } \\
\text { of } \\
\text { Followup } \\
\text { (Months) }\end{array}$ & Pain & Function \\
\hline $\begin{array}{l}\text { Tekin, } \\
2007^{106} \\
\text { Turkey } \\
\text { Fair }\end{array}$ & 59.3 & 57 & 60 & $>6$ & $\begin{array}{l}\text { Medial } \\
\text { branch } \\
\text { block } \\
\text { (single, } \\
>50 \% \\
\text { relief) }\end{array}$ & $\begin{array}{l}4 \text { minutes at } 42^{\circ} \\
\mathrm{C} \text {, pulse rate } 2 \\
\mathrm{~Hz}, 45 \mathrm{~V}\end{array}$ & $\begin{array}{l}\text { A: } \\
\text { Conventional } \\
\text { RF }(90 \\
\text { seconds at } \\
\left.80^{\circ} \mathrm{C}\right) \\
\text { B: Sham RF }\end{array}$ & 12 & $\begin{array}{l}\text { VAS } 0 \text { to } 10, \text { mean (SD) } \\
6 \text { months: } 2.9(1.6) \text { vs. } 2.3(1.3) \text { vs. } \\
3.1(0.8), p=0.19 \text { PRF vs. RF and } \\
p=0.62 \text { PRF vs. sham } \\
1 \text { year: } 3.5(1.3) \text { vs. } 2.4(1.1) \text { vs. } \\
3.9(1.2), p=0.004 \text { for PRF vs. RF } \\
\text { and } p=0.31 \text { PRF vs. sham }\end{array}$ & $\begin{array}{l}\text { ODI } 0 \text { to } 100, \\
\text { mean (SD) } \\
6 \text { months: } 25.3 \\
(6.9) \text { vs. } 25.1 \\
(6.4) \text { vs. } 28.9 \\
\text { (5.7), p=0.92 } \\
\text { PRF vs. RF, } \\
\text { p=0.07 PRF vs. } \\
\text { sham } \\
-1 \text { year: } 28.5 \\
(6.1) \text { vs. } 28.0 \\
(7.1) \text { vs. } 33.6 \\
(5.7), p=0.81 \\
\text { PRF vs. RF and } \\
\text { p=0.006 PRF vs. } \\
\text { sham }\end{array}$ \\
\hline
\end{tabular}

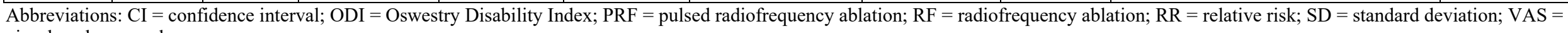
visual analogue scale 


\section{Detailed Synthesis}

\section{Pain}

The fair-quality trial found no difference between pulsed versus radiofrequency denervation versus sham (with local anesthetic) at 6 months (2.9 vs. 3.1 on a 0 to 10 visual analogue scale [VAS], $\mathrm{p}=0.62)$ or 1 year $(3.5$ vs. $3.9, \mathrm{p}=0.31) .{ }^{106}$

The poor-quality trial found pulsed radiofrequency of the dorsal root ganglia associated with a large reduction in pain versus sham (without local anesthetic) at 3 months to 3 years (differences ranged from 3.3 to 7.3 points on a 0 to $10 \mathrm{VAS}$ ). ${ }^{107}$ Pulsed radiofrequency was also associated with an increased likelihood of experiencing greater than a 50 percent reduction in back pain (absolute differences ranged from $28 \%$ to $68 \%$ ).

\section{Function}

The fair-quality trial found pulsed radiofrequency of the medial branches and sham (with local anesthetic) associated with similar function at 6 months (mean 25.4 vs. 28.9 on the 0 to 100 ODI, $\mathrm{p}=0.07$ ), though the difference was slightly larger and favored sham at 1 year (mean 28.5 vs. 33.6, $\mathrm{p}=0.006){ }^{106}$

The poor-quality trial found pulsed radiofrequency of the dorsal root ganglia associated with moderate to large improvement in function versus sham (without local anesthetic) at 3 months to 3 years (differences ranged from 16.9 to 38.4 points on the 0 to $100 \mathrm{ODI}$ ). ${ }^{107}$

\section{Other Outcomes}

The fair-quality trial found both pulsed radiofrequency of the medial branches and sham (with local anesthetic) associated with high likelihood of analgesic use at 1 year (75\% vs. 95\%) and patient satisfaction reported as good or excellent ( $85 \%$ vs. $70 \%)$; differences were not statistically significant. ${ }^{106}$

The poor-quality trial found pulsed radiofrequency of the dorsal root ganglia associated with an increased likelihood of a composite outcome of success versus conventional radiofrequency denervation (absolute difference $30 \%$ to $72 \%$ ), and greater decrease in World Health Organization (WHO) analgesic intake score (mean difference in change from baseline on a 0 to 3 scale ranged from 0.4 to 1.9 points) at 3 months to 3 years. ${ }^{107}$

\section{Harms}

Neither trial reported harms. ${ }^{106,107}$

\section{Pulsed Versus Conventional Radiofrequency Denervation for Presumed Lumbar Facet Joint Pain}

\section{Description of Included Studies}

One fair-quality trial ${ }^{106}$ and two poor-quality trials ${ }^{107,108}$ compared pulsed versus conventional radiofrequency denervation for presumed lumbar facet joint pain (Appendix Table G-4 to G-6 and Table 5). In all of the trials, patients had to have a positive response to one or two diagnostic medial branch blocks. The fair-quality trial $(n=40)$ was conducted in Turkey and evaluated pulsed ( $2 \mathrm{~Hz}$ waves for 4 minutes [45 V] to 42 degrees $\mathrm{C}$ ) versus conventional (90 seconds to 80 degrees $\mathrm{C}$ ) radiofrequency denervation of the medial branches. ${ }^{106}$ Mean age was 49 years, 57 percent of participants were female, and the mean duration of pain was 35 months. 
The two poor-quality trials ( $\mathrm{n}=50$ and 100) were conducted in Egypt and the United States. ${ }^{107,108}$ Mean ages were 57 and 59 years and the proportion female 54 percent and 65 percent. Patients had to have chronic pain in both trials, but mean pain duration was not reported. One poorquality trial compared pulsed radiofrequency ( $2 \mathrm{~Hz}$ waves for 2 minutes at 42 degrees $\mathrm{C}$ ) of the dorsal root ganglia versus conventional radiofrequency ( 85 degrees $\mathrm{C}$ for 90 seconds) of the medial branches, potentially complicating interpretation because of different denervation targets. ${ }^{107}$ The other trial compared pulsed radiofrequency $(2 \mathrm{~Hz}$ waves for 2 minutes at 42 degrees $C$ ) versus conventional radiofrequency ( 80 degrees $C$ for 75 seconds) of the medial branches. ${ }^{108}$ Across trials, methodological limitations included failure to report allocation concealment methods, unclear masking of care providers, and high or unclear attrition (Appendix Table H-1). In addition, the poor-quality trials did not report randomization methods, baseline characteristics, did not conduct intent-to-treat analysis, and had discrepancies in reported results.

\section{Detailed Synthesis}

\section{Pain}

The fair-quality trial found a small, nonstatistically significant difference between pulsed versus radiofrequency denervation at 6 months (mean 2.9 vs. 2.3 on a 0 to $10 \mathrm{VAS}, \mathrm{p}=0.19$ ), but pulsed radiofrequency denervation was associated with moderate increased pain at 1 year (mean 3.5 vs. $2.4, p=0.004) .{ }^{106}$

The two poor-quality trials reported inconsistent effects on pain intensity. ${ }^{107,108}$ The trial of pulsed versus conventional radiofrequency denervation of the medial branches found no difference in pain intensity at 3 months, ${ }^{108}$ but the trial of pulsed radiofrequency of the dorsal root ganglia versus conventional radiofrequency denervation of the medial branches found a large reduction in pain with pulsed radiofrequency at 3 months through 3 year (mean differences 3.1 to 5.6 points on a 0 to 10 scale). ${ }^{107}$ In this trial, pulsed radiofrequency was also associated with an increased likelihood of experiencing a greater than 50 percent reduction in back pain (absolute difference ranged from $20 \%$ to $60 \%$ ).

\section{Function}

The fair-quality trial found no difference between pulsed versus radiofrequency denervation of the medial branches at 6 months ( 25.4 vs. 25.1 on the 0 to 100 ODI, $\mathrm{p}=0.92)$ or 1 year $(28.5$ vs. 28.0 on the ODI, $\mathrm{p}=0.81){ }^{106}$

The two poor-quality trials reported inconsistent effects on pain intensity. ${ }^{107,108}$ The trial of pulsed versus conventional radiofrequency denervation of the medial branches found no difference in function (ODI) at 3 months, ${ }^{108}$ but the trial of pulsed radiofrequency of the dorsal root ganglia versus conventional radiofrequency denervation of the medial branches found a moderate to large reduction in pain with pulsed radiofrequency at 3 months through 3 years (differences on the 0 to 100 ODI ranged from 15.6 to 32.9 point). ${ }^{107}$

\section{Other Outcomes}

The fair-quality trial found pulsed radiofrequency of the medial branches associated with increased likelihood of analgesic use versus conventional radiofrequency of the medial branches at 1 year (75\% vs. $40 \%$, RR $1.88,95 \%$ CI, 1.04 to 3.39$).{ }^{106}$ There was no difference in likelihood of patient satisfaction rating of good or excellent ( $85 \%$ vs. $95 \%)$. 
One poor-quality trial found pulsed radiofrequency of the dorsal root ganglia associated with increased likelihood of a composite outcome of success versus conventional radiofrequency denervation (absolute difference $22 \%$ to $58 \%$ ), and greater decrease in WHO analgesic intake score (mean difference in change from baseline on a 0 to 3 scale ranged from 0.3 to 1.4 points) at 3 months to 3 years. ${ }^{107}$

\section{Harms}

One poor-quality trial reported no adverse events. ${ }^{108}$ Harms were not reported in the other two trials. ${ }^{106,107}$

\section{Intradiscal and Facet Joint Platelet-Rich Plasma for Low Back Pain of Presumed Discogenic Origin or Into the Lumbar Facet Joint for Low Back Pain of Presumed Facet Joint Origin}

\section{Key Points}

- Evidence was insufficient to assess intradiscal platelet-rich plasma injection for presumed discogenic back pain (1 trial, $\mathrm{N}=58$ ) (SOE: insufficient).

- There were no differences between stem cell and saline injection in harms, including no serious adverse events, at up to 3 years following treatment (SOE: low).

- The mean age of participants was 42 years.

\section{Description of Included Studies}

One small $(\mathrm{n}=47)$ trial conducted in the United States compared intradiscal platelet-rich plasma (PRP) versus sham (contrast agent) injection for presumed discogenic low back pain (Appendix Table G-7 to G-9 and Table 6). ${ }^{109}$ Pain had to be chronic ( $>6$ months; mean duration not reported) and patients had to have a concordant response on single provocative discography prior to undergoing the injection. The mean age of participants was 42 years; 66 percent were female. At baseline, current pain averaged 4.7 on a 0 to $10 \mathrm{NRS}$; baseline mean best pain was 2.5 and mean worst pain 7.9. Under fluoroscopic guidance, patients received 1 to 2 $\mathrm{ml}$ platelet-rich plasma (3 to $4 \mathrm{ml}$ divided for multiple discs) or 1 to $2 \mathrm{ml}$ contrast agent in the affected disc(s) and outcomes compared through 8 weeks, at which point the trial was unblinded and crossover permitted (88\% [15/17] of those randomized to sham crossed over to PRP). The trial was rated fair quality, due to baseline imbalance in sex, unclear randomization method, and lack of intent-to-treat analysis (Appendix Table H-1)

No trial evaluated facet joint PRP injection versus sham or usual care. 
Table 6. Study characteristics and results of platelet-rich plasma trial

\begin{tabular}{|c|c|c|c|c|c|c|c|c|c|c|}
\hline $\begin{array}{l}\text { Study, } \\
\text { Year } \\
\text { Country } \\
\text { Quality } \\
\end{array}$ & $\begin{array}{l}\text { Mean } \\
\text { Age } \\
\text { (Years) } \\
\end{array}$ & \begin{tabular}{|l} 
Percent \\
Female
\end{tabular} & \begin{tabular}{|l|} 
Number \\
Randomized \\
\end{tabular} & $\begin{array}{l}\text { Duration of } \\
\text { Symptoms } \\
\text { (Months) } \\
\end{array}$ & \begin{tabular}{|l} 
Diagnostic \\
Testing \\
\end{tabular} & $\begin{array}{l}\text { Platelet-Rich } \\
\text { Plasma } \\
\text { Intervention } \\
\end{array}$ & $\begin{array}{l}\text { Control } \\
\text { Type } \\
\end{array}$ & $\begin{array}{l}\text { Duration of } \\
\text { Followup } \\
\text { (Months) } \\
\end{array}$ & Pain & Function \\
\hline $\begin{array}{l}\text { Tuakli- } \\
\text { Wosornu, } \\
2016^{109} \\
\text { U.S. } \\
\text { Fair }\end{array}$ & 42.32 & 66 & 57 & $\geq 6$ & $\begin{array}{l}\text { Disc protrusion } \\
<5 \mathrm{~mm} \text { on } \mathrm{MRI} \\
\text { or } \mathrm{CT}\end{array}$ & $\begin{array}{l}1-2 \mathrm{ml} \text { injected } \\
\text { into target discs }\end{array}$ & $\begin{array}{l}\text { Sham } \\
\text { (contrast } \\
\text { agent) } \\
\text { injection }\end{array}$ & \begin{tabular}{|l|}
2 \\
\\
\end{tabular} & $\begin{array}{l}\text { NRS } 0 \text { to } 10 \text { worst pain, } \\
\text { mean difference }(95 \% \text { Cl }) \\
1 \text { week: }-0.53(-1.67 \text { to } \\
0.61) \\
1 \text { month: }-0.70(-1.82 \text { to } \\
0.42) \\
2 \text { months: }-1.01(-2.38 \text { to } \\
0.36)\end{array}$ & $\begin{array}{l}\text { FRI } 0 \text { to } 100, \text { mean } \\
\text { difference }(95 \% \mathrm{Cl}) \\
1 \text { week: } 3.84(-5.41 \text { to } \\
13.09) \\
1 \text { month: }-0.92(-10.90 \\
\text { to } 9.06) \\
2 \text { months: }-6.46(-17.99 \\
\text { to } 5.07)\end{array}$ \\
\hline
\end{tabular}

Abbreviations: $\mathrm{CI}=$ confidence interval; $\mathrm{CT}=$ computed tomography; FRI = Functional Rating Index; MRI = magnetic resonance imaging; NRS = numeric rating scale 


\section{Detailed Synthesis}

\section{Pain}

Intradiscal PRP was associated with small to moderate decreases in current pain versus sham at 1,4 , and 8 weeks, but differences were not statistically significant (mean differences -0.57 to 1.30 points on a 0 to $10 \mathrm{NRS}$ ). Results were similar for best and worst pain. There was also no difference on the SF-36 bodily pain subscale.

\section{Function}

There were no differences between intradiscal PRP versus sham in function (based on the Functional Rating Index) at 1, 4, or 8 weeks; mean differences ranged from -0.93 to 3.84 points on a 0 to 100 scale. ${ }^{109}$ There were also no difference on the SF-36 physical function subscale.

\section{Other Outcomes}

Intradiscal PRP was associated with increased likelihood versus sham of patient reporting of "satisfied" or "would undergo procedure again" versus sham (55.6\% vs. 17.6\%, RR 3.15, 95\% CI, 1.07 to 9.28). ${ }^{109}$ However, it was unclear if assessment occurred prior to or after unblinding.

\section{Harms}

No cases of disc space infection, neurologic injury, or progressive herniation were reported. $^{109}$

\section{Intradiscal Stem Cells for Low Back Pain of Presumed Discogenic Origin}

\section{Key Points}

- Evidence was insufficient to assess intradiscal stem cell injection for presumed discogenic back pain (1 trial, $\mathrm{N}=100)$ ( $\mathrm{SOE}$ : insufficient).

- Mean age was 42 years.

\section{Description of Included Studies}

One trial $(n=100)$ compared intradiscal injection of allogenic mesenchymal stem cells in hyaluronic acid delivery versus intradiscal hyaluronic acid alone or saline for chronic low back pain of presumed discogenic origin (Appendix Table G-10 and G-11, and Table 7). ${ }^{110}$ The study was conducted at 13 sites in the United States and Australia. Study participants had chronic low back pain for at least 6 months that was refractory to at least 3 months of conservative treatment. Patients were not required to undergo provocative discography, but among those who did, only those with a concordant pain response at one level were enrolled. Mean age of participants was 42 years and 47 percent were female. The mean duration of discogenic disease was 5.8 years and mean pain score was 7 on a 0 to $10 \mathrm{VAS}$. Patients were randomized to 6 million (1.0 ml at 30 million $/ 5 \mathrm{ml})$ or 18 million $(1.0 \mathrm{ml}$ at 90 million $/ 5 \mathrm{ml})$ allogenic mesenchymal stem cells (each mixed with $1 \%$ hyaluronic acid) versus $2 \mathrm{ml}$ of 1 percent hyaluronic acid alone, or $2 \mathrm{ml}$ saline. Although saline and hyaluronic acid injections were both considered inactive controls, hyaluronic acid could have potential therapeutic effects; therefore, results described here primarily focus on findings against saline injection. Outcomes were 
assessed from 1 month to 3 years after treatment. The study was rated fair quality due to presence of baseline differences (Appendix Table H-1). Specifically, the 18 million stem cell group included a higher proportion of male participants ( $70 \%$ versus $50 \%)$, was younger (38 years versus 44 years) and had a shorter duration of disease (3.7 years versus 5.9 years) than the saline control group. 
Table 7. Study characteristics and results of intradiscal stem cell trial

\begin{tabular}{|c|c|c|c|c|c|c|c|c|c|}
\hline $\begin{array}{l}\text { Study, Year } \\
\text { Country } \\
\text { Quality }\end{array}$ & $\begin{array}{l}\text { Mean } \\
\text { Age } \\
\text { (Years) }\end{array}$ & $\begin{array}{l}\text { Percent } \\
\text { Female }\end{array}$ & $\begin{array}{l}\text { Number } \\
\text { Randomized }\end{array}$ & $\begin{array}{l}\text { Duration of } \\
\text { Symptoms } \\
\text { (Months) }\end{array}$ & $\begin{array}{l}\text { Diagnostic } \\
\text { Testing }\end{array}$ & $\begin{array}{l}\text { Control } \\
\text { Type }\end{array}$ & $\begin{array}{l}\text { Duration } \\
\text { of } \\
\text { Followup } \\
\text { (Months) }\end{array}$ & Pain & Function \\
\hline $\begin{array}{l}\text { Amirdelfan } \\
2020^{110} \\
\text { Australia and } \\
\text { U.S. } \\
\text { Fair }\end{array}$ & 41.9 & 47 & 100 & Mean 69.7 & $\begin{array}{l}\text { Degenerative } \\
\text { disc disease } \\
\text { at one level } \\
\text { from L1 to S1 }\end{array}$ & Saline & 36 & 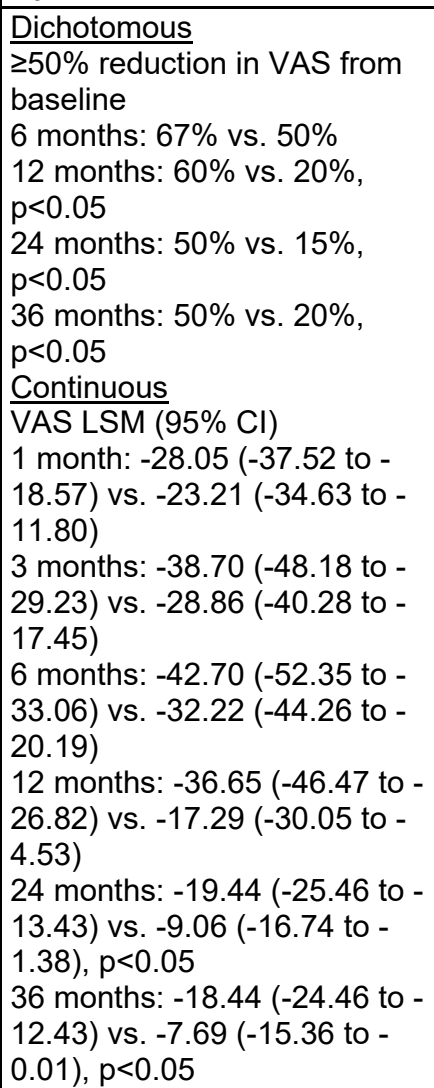 & $\begin{array}{l}\text { Dichotomous } \\
\geq 15 \text { point reduction on ODI from } \\
\text { baseline } \\
6 \text { months: } 63 \% \text { vs. } 25 \% \\
12 \text { months: } 50 \% \text { vs. } 20 \%, p<0.05 \\
24 \text { months: } 47 \% \text { vs. } 15 \%, p<0.05 \\
36 \text { months: } 47 \% \text { vs. } 15 \%, p<0.05 \\
\text { Continuous } \\
\text { ODI LSM ( } 95 \% \text { Cl) } \\
1 \text { month: }-13.07(-18.77 \text { to }-7.37) \text { vs. } \\
-10.80(-17.67 \text { to }-3.93) \\
3 \text { months: }-17.31(-23.01 \text { to }-11.61) \\
\text { vs. }-14.00(-20.87 \text { to }-7.13) \\
6 \text { months: }-18.02(-23.63 \text { to }-12.42) \\
\text { vs. }-12.64(-19.88 \text { to }-5.39) \\
12 \text { months: }-17.54(-23.44 \text { to }-11.64) \\
\text { vs. }-9.31(-16.99 \text { to }-1.63) \\
24 \text { months: }-19.44(-25.46 \text { to }-13.43) \\
\text { vs. }-9.06(-16.74 \text { to }-1.38), p<0.05 \\
36 \text { months: }-18.44(-24.46 \text { to }-12.43) \\
\text { vs. }-7.69(-15.36 \text { to }-0.01), p<0.05\end{array}$ \\
\hline
\end{tabular}

Abbreviations: CI = confidence interval; LSM = least square mean; ODI = Oswestry Disability Index; VAS = visual analogue scale 


\section{Detailed Synthesis}

\section{Pain}

Intradiscal injection of 6 or 18 million stem cells was associated with a small improvement in pain versus saline injection that was not statistically significant at 1, 3, and 6 months (least squares mean differences adjusted for posttreatment interventions ranged from 0.38 to 1.05 points on a 0 to $10 \mathrm{VAS}) .{ }^{110}$ At 1 to 3 years, stem cell injections were associated with moderate to large, statistically significant reduction in pain (differences ranged from 1.61 to 2.62 points). Both stem cell doses were associated with increased likelihood of at least a 50 percent reduction in pain at 1 year $(60.0 \%$ vs. $20.0 \%$ for 6 million stem cell dose, RR 3.00, 95\% CI, 1.19 to 7.56 and $53.3 \%$ vs. $20.0 \%$, for 18 million stem cell dose, RR 2.67, 95\% CI, 1.04 to 6.81 ) and the 6 million stem cell dose was associated with increased likelihood of at least 50 percent pain reduction at 2 years $(50.0 \%$ vs. $20.0 \%$, RR 3.33, 95\% CI, 1.11 to 10.04). Although results also favored stem cell injections at 6 months and 3 years, the differences were smaller and not statistically significant. Results for stem cell injections versus hyaluronic acid alone injection also favored stem cells, but at most time points differences were smaller relative to comparisons against usual care, and few differences were statistically significant. There was no pattern to indicate that the higher stem cell dose was associated with greater effects on pain than the lower dose.

\section{Function}

Intradiscal injection of 6 or 18 million stem cells was associated with no differences in ODI versus saline injection at 1,3, and 6 months. ${ }^{110}$ At 1, 2, and 3 years, stem cell injections were associated with small to moderate reductions in function that were statistically significant (differences ranged from 8.23 to 18.15 points on the 0 to $100 \mathrm{ODI}$ ). Stem cell injections were also associated with increased likelihood of at least a 15-point improvement in the ODI at 2 or 3 years (at 3 years, $46.7 \%$ vs. $25.0 \%$ for 6 million stem cell dose, RR 3.11, 95\% CI, 1.02 to 9.45 and $50.0 \%$ vs. $15.0 \%$ for 18 million stem cell injection, RR 3.33, 95\% CI, 1.11 to 10.04). The 6 million stem cell dose was also associated at increased likelihood of ODI response at 6 months (63.3\% vs. $25.0 \%$, RR 2.53, 95\% CI, 1.13 to 5.67); although the point estimate was similar at 1 year the difference was not statistically significant. Results for stem cell injections versus hyaluronic acid alone were similar to results versus saline at 1 to 6 months and indicated slightly reduced differences at 1 to 3 years. There was no pattern to indicate that the higher stem cell dose was associated with greater effects on function than the lower dose.

\section{Other Outcomes}

Stem cell injections were associated with increased likelihood of experiencing a composite measure of treatment response ( $\geq 30 \%$ pain reduction and $\geq 10$-point ODI improvement) versus saline injection at 6 months to 3 years, but the differences were only statistically significant for the 18 million stem cell dose at 1 year $(56.7 \%$ vs. $20.0 \%)$ and the 6 million stem cell injection at 2 years $(46.7 \%$ vs. $15.0 \%) .{ }^{110}$

The 18 million stem cell injection was associated with greater improvement in SF-36 PCS versus saline $(p=0.025)$ or hyaluronic acid $(p=0.04)$ at 3 years (mean differences not reported). There were no statistically significant differences between injections versus controls in SF-36 MCS and PCS at earlier time points. 


\section{Harms}

There were no deaths reported in the study, and no statistically significant differences between groups in the risk of serious adverse events, any adverse event, or withdrawals due to adverse events. ${ }^{110}$

\section{Effects of Dose}

As described above, there was no pattern to indicate that a higher dose (18 million) of intradiscal stem cells was associated with superior outcomes compared with a lower dose (6 million). ${ }^{109}$

\section{Intradiscal Methylene Blue for Low Back Pain of Presumed Discogenic Origin}

\section{Key Points}

- Intradiscal methylene blue for presumed discogenic back pain ( 1 trial, $\mathrm{N}=81)$ was associated with no difference versus sham at 6 weeks and 3 months. Evidence was insufficient to determine effects of intradiscal methylene blue at 6 months ( 2 trials, $\mathrm{N}=153$, with conflicting results) and 12 months or longer (1 trial, $\mathrm{N}=72$ ) (SOE: low for no difference at 6 weeks and 3 months; insufficient for 6,12 and 24 months).

- Both trials of intradiscal methylene blue excluded patients older than 66 years of age (mean 41 years).

\section{Description of Included Studies}

Two trials ( $\mathrm{n}=84$ and 72$)$ compared intradiscal methylene blue versus sham intradiscal therapy in patients with presumed discogenic back pain (Appendix Table G-12 to G-14 and Table 8). ${ }^{111,112}$ The trials were conducted in the Netherlands (the IMBI Study ${ }^{111}$ ) and China. ${ }^{112}$ Methods of the Dutch trial were intentionally similar to the earlier Chinese trial, in an effort to determine whether its results could be duplicated. The mean age was 41 years in both trials, and both trials excluded patients older than 66 years. The proportion of female patients was 72 percent in one trial ${ }^{111}$ and 43 percent in the other. ${ }^{112}$ Baseline pain intensity was similar (mean 6.6 and 7.0, on a 0 to 10 scale). Although both trials enrolled patients with chronic pain, the duration of pain symptoms was longer in the Dutch trial (9 years) $)^{111}$ than the Chinese trial. ${ }^{112}$ In both trials, the diagnosis of discogenic back pain was based on a positive response to provocative discography, with negative control discs. In addition, the Dutch trial excluded patients with multilevel discogenic pain or facet pain based on confirmatory facet block. ${ }^{111}$ Both trials compared an intradiscal injection of methylene blue $(1 \mathrm{ml} ; 10 \mathrm{mg} / \mathrm{ml})$ or saline $(1 \mathrm{ml})$; both groups received 2 percent lidocaine $(0.5 \mathrm{ml})$ injection. Duration of followup was 6 months in the Dutch trial ${ }^{111}$ and 2 years in the Chinese trial. ${ }^{12}$ The Dutch trial was rated good quality ${ }^{111}$ and the Chinese trial fair quality, ${ }^{112}$ mainly for unclear allocation concealment (Appendix Table H1). 
Table 8. Study characteristics and results of intradiscal methylene blue trials

\begin{tabular}{|c|c|c|c|c|c|c|c|c|c|c|}
\hline $\begin{array}{l}\text { Study, Year } \\
\text { Country } \\
\text { Quality }\end{array}$ & $\begin{array}{l}\text { Mean } \\
\text { Age } \\
\text { (Years) }\end{array}$ & $\begin{array}{l}\text { Percent } \\
\text { Female }\end{array}$ & $\begin{array}{l}\text { Number } \\
\text { Randomized }\end{array}$ & $\begin{array}{l}\text { Duration of } \\
\text { Symptoms } \\
\text { (Months) }\end{array}$ & $\begin{array}{l}\text { Diagnostic } \\
\text { Testing }\end{array}$ & $\begin{array}{l}\text { Methylene } \\
\text { Blue } \\
\text { Intervention }\end{array}$ & $\begin{array}{l}\text { Control } \\
\text { Type }\end{array}$ & $\begin{array}{l}\text { Duration of } \\
\text { Followup } \\
\text { (Months) }\end{array}$ & Pain & Function \\
\hline $\begin{array}{l}\text { Kallewaard, } \\
2019^{111} \\
\text { the } \\
\text { Netherlands } \\
\text { Good }\end{array}$ & 41.1 & 72 & 81 & $\geq 6$ & \begin{tabular}{|l|} 
Positive \\
provocative \\
discography \\
at pressure \\
$<50$ PSI \\
above \\
opening \\
pressure
\end{tabular} & $\begin{array}{l}\text { Intradiscal } 1 \mathrm{ml} \\
(10 \mathrm{mg} / \mathrm{ml}) \\
\text { methylene blue } \\
+0.5 \mathrm{ml} \\
\text { lidocaine } \\
\text { hydrochloride } \\
2 \%+0.5 \mathrm{ml} \\
\text { contrast dye }\end{array}$ & $\begin{array}{l}\text { Sham } \\
\text { injection(lid } \\
\text { ocaine, } \\
\text { saline, and } \\
\text { contrast) }\end{array}$ & 6 & $\begin{array}{l}\text { Dichotomous } \\
30 \% \text { improvement } \\
6 \text { weeks: } 15 \% \text { vs. } 17 \% \text {, } \\
\text { RR } 1.02 \text { ( } 95 \% \mathrm{Cl}, 0.85 \text { to } \\
1.24) \\
3 \text { months: } 25 \% \text { vs. } 24 \% \text {, } \\
\text { RR } 0.99 \text { ( } 95 \% \mathrm{Cl}, 0.77 \text { to } \\
1.27) \\
6 \text { months: } 35 \% \text { vs. } 27 \% \text {, } \\
\text { RR } 0.89 \text { ( } 95 \% \mathrm{Cl}, 0.66 \text { to } \\
1.19) \\
\text { Continuous } \\
\text { NRS } 0 \text { to } 10, \text { mean } \\
\text { difference in mean } \\
\text { change ( } 95 \% \mathrm{Cl}) \\
6 \text { weeks: }-0.4(-1.2 \text { to } 0.3) \\
3 \text { months: }-0.5(-1.3 \text { to } \\
0.4) \\
6 \text { months: }-0.2(-1.2 \text { to } \\
0.80)\end{array}$ & $\begin{array}{l}\text { ODI } 0 \text { to } 100, \text { mean } \\
\text { change (SD) } \\
6 \text { weeks: }-8.0(17.1) \text { vs. } \\
-1.7(9.8), p=0.046 \\
-3 \text { months: }-8.8(18.4) \\
\text { vs. }-3.6(9.9), p=0.12 \\
-6 \text { months: }-7.8(16.9) \\
\text { vs. }-5.5(10.5), p=0.46\end{array}$ \\
\hline $\begin{array}{l}\text { Peng, } \\
2010^{112} \\
\text { China } \\
\text { Fair }\end{array}$ & 41.7 & 43 & 72 & $\begin{array}{l}\text { Mean of } \\
40.8\end{array}$ & $\begin{array}{l}\text { Positive } \\
\text { discography } \\
\text {, pressure } \\
\text { and volume } \\
\text { parameters } \\
\mathrm{NR} \text {, with at } \\
\text { least one } \\
\text { negative } \\
\text { adjacent } \\
\text { control disc }\end{array}$ & \begin{tabular}{|l|} 
Intradiscal 1 \\
$(10 \mathrm{mg} / \mathrm{ml})$ \\
methylene blue \\
$+1 \mathrm{ml}$ \\
lidocaine \\
hydrochloride \\
$2 \%$
\end{tabular} & $\begin{array}{l}\text { Sham } \\
\text { injection } \\
\text { (lidocaine } \\
\text { and saline) }\end{array}$ & 24 & $\begin{array}{l}\text { NRS } 0 \text { to } 10, \text { mean } \\
\text { difference }(95 \% \mathrm{Cl}) \\
6 \text { months: } 3.86(3.15 \text { to } \\
4.56) \\
12 \text { months: } 4.08 \text { (3.36 to } \\
4.81) \\
24 \text { months: } 4.05 \text { (3.34 to } \\
4.77)\end{array}$ & $\begin{array}{l}\text { ODI } 0 \text { to } 100, \text { mean } \\
\text { difference }(95 \% \mathrm{Cl}) \\
6 \text { months: } 32.40(27.62 \\
\text { to } 37.18) \\
12 \text { months: } 34.70 \\
\text { (29.19 to } 40.20) \\
24 \text { months: } 34.80 \\
(29.37 \text { to } 40.22)\end{array}$ \\
\hline
\end{tabular}

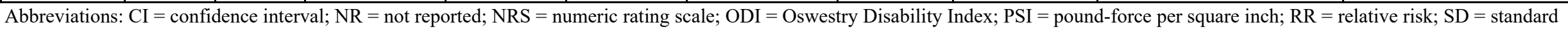
deviation 


\section{Detailed Synthesis}

\section{Pain}

The two trials reported discordant effects of intradiscal methylene blue on pain. In the Chinese trial, intradiscal methylene blue was associated with large reduction in pain versus sham at 6,12 , and 24 months (mean differences 3.86 to 4.08 points on a 0 to $11 \mathrm{NRS}$ ). ${ }^{112}$ However, the Dutch trial found no differences between intradiscal methylene blue versus sham in pain at 6 weeks, 3 months, or 6 months (mean differences 0.4 to 0.5 points on a 0 to $11 \mathrm{NRS}$ ). ${ }^{111}$ The Dutch trial also found methylene blue and sham associated with similar likelihood of at least a 30 percent reduction in NRS (at 6 months, 35.0\% [14/40] vs. 26.8\% [11/41], p=0.43). The Chinese trial did not evaluate the likelihood of experiencing a pain response.

\section{Function}

Results of the two trials were also discordant regarding function. In the Chinese trial, intradiscal methylene blue was associated with large improvement in function versus sham (mean differences 32.4 to 34.8 points on the 0 to 100 ODI at 6,12 , and 24 months). ${ }^{112}$ In the Dutch trial, methylene blue was associated with a small improvement in function at 6 weeks (mean difference $-6.3,95 \% \mathrm{CI},-12.4$ to -0.17 on the ODI), but differences were reduced and no longer statistically significant at 3 or 6 months (mean differences -5.2 to -2.3 points). ${ }^{111}$

\section{Other Outcomes}

As with pain and function, effects of methylene blue on medication use was also discordant. At 6 months, the Chinese trial ${ }^{112}$ found methylene blue associated with marked reduction in likelihood of regular nonsteroidal anti-inflammatory drug (NSAID) or opioid use $(8.3 \%$ vs. $42.9 \%, \mathrm{p}=0.002$ ) but the Dutch trial ${ }^{111}$ found no difference in likelihood of strong opioid use (7.5\% vs. 9.8\%, $\mathrm{p}=1.0)$. The Dutch trial also found no differences between methylene blue versus sham in EQ-5D, SF-36 PCS, SF-36 MCS, or patient global impression of change "much improved" or "improved" at 6 weeks, 3 months, or 6 months; these outcomes were not evaluated in the Chinese trial.

\section{Harms}

Reporting of harms was limited. The Chinese trial reported no cases of nerve injury or disc space infection with methylene blue or sham, and no cases of back pain aggravation with methylene blue. ${ }^{12}$ The Dutch trial found no difference in risk of any adverse event (data not reported); two serious adverse events that did not appear due to the methylene blue procedure were reported (unrelated elective surgery and hospitalization for laryngitis). ${ }^{111}$

\section{Intradiscal Ozone Injection for Radicular Low Back Pain or Nonradicular Low Back Pain of Presumed Discogenic Origin}

\section{Key Points}

- Evidence was insufficient to assess intradiscal oxygen-ozone for radicular low back pain (1 trial, $\mathrm{N}=159$ ) (SOE: insufficient).

- No trial evaluated intradiscal oxygen-ozone injection without corticosteroid or oxygenozone injection for presumed (nonradicular) discogenic low back pain. 
- Mean age ranged from 40 to 51 years.

\section{Description of Included Studies}

No trial evaluated intradiscal ozone injection alone for radicular or nonradicular low back pain. Three trials ( $\mathrm{n}=80$ to 159 , total $\mathrm{N}=339$ ) evaluated intradiscal ozone (mixed with oxygen) plus corticosteroid injection for radicular back pain (Appendix Table G-15 to G-17 and Table 9). ${ }^{113-115}$ The studies were conducted in Italy, ${ }^{113}$ Egypt, ${ }^{114}$ and India. ${ }^{115}$ Mean age of study participants ranged from 40 to 51 years and 45 to 62 percent were female. The mean duration of pain was 8 and 15 weeks in two trials ${ }^{113,114}$ and 9 months in one trial. ${ }^{115}$ Baseline ODI ranged from 31 to 72 ; only one trial ${ }^{115}$ reported baseline pain (mean 7.1 on a 0 to $10 \mathrm{VAS}$ ). In all trials, patients had radicular pain with concordant herniated disc on MRI and injections were performed with CT or fluoroscopic guidance. The amount of intradiscal oxygen-ozone (concentration 28 or $40 \mu \mathrm{g} / \mathrm{ml}$ ) administered ranged from 5 to $10 \mathrm{ml}$; in one trial, patients also received transforaminal epidural oxygen-ozone (volume 5 to $7 \mathrm{ml}$ ). Oxygen-ozone was administered with a corticosteroid (triamcinolone or methylprednisolone) in all trials, two ${ }^{113,114}$ of which also administered ropivacaine. The corticosteroid was intradiscal and epidural in two trials ${ }^{113,114}$ and epidural only in one trial. ${ }^{115}$ All three trials compared oxygen-ozone plus corticosteroid versus corticosteroid without oxygen-ozone; one trial ${ }^{114}$ also evaluated a local anesthetic only (without corticosteroid) control injection (site not specified). The duration of followup was 6 months.

One trial ${ }^{113}$ was rated fair quality and two trials ${ }^{114,115}$ poor quality, including the trial that compared an oxygen-ozone versus local anesthetic alone injection (Appendix Table H-1). Methodological limitations in all trials included unclear randomization and allocation methods and failure to report attrition. The poor-quality trials also did not clearly blind patients, had poor reporting of outcomes, data discrepancies, and potential selective outcomes reporting.

No trial evaluated intradiscal ozone injection for presumed (nonradicular) discogenic back pain. 
Table 9. Study characteristics and results of intradiscal ozone trials

\begin{tabular}{|c|c|c|c|c|c|c|c|c|c|c|}
\hline $\begin{array}{l}\text { Study, } \\
\text { Year } \\
\text { Country } \\
\text { Quality }\end{array}$ & $\begin{array}{l}\text { Mean Age } \\
\text { (Years) }\end{array}$ & $\begin{array}{l}\text { Percent } \\
\text { Female }\end{array}$ & $\begin{array}{l}\text { Number } \\
\text { Randomized }\end{array}$ & $\begin{array}{l}\text { Duration of } \\
\text { Symptoms } \\
\text { (Months) }\end{array}$ & $\begin{array}{l}\text { Diagnostic } \\
\text { Testing }\end{array}$ & $\begin{array}{l}\text { Ozone } \\
\text { Intervention }\end{array}$ & \begin{tabular}{|l} 
Control \\
Type
\end{tabular} & $\begin{array}{l}\text { Duration } \\
\text { of } \\
\text { Followup } \\
\text { (Months) }\end{array}$ & Pain & Function \\
\hline $\begin{array}{l}\text { Gallucci, } \\
2007^{113} \\
\text { Italy } \\
\text { Fair }\end{array}$ & 40.48 & 45 & 159 & Mean 3.75 & $\begin{array}{l}\text { MRI- or CT- } \\
\text { confirmed disc } \\
\text { herniation }\end{array}$ & \begin{tabular}{|l|} 
Oxygen-ozone \\
intradiscal 5-7 ml \\
(concentration 28 \\
$\mu \mathrm{g} / \mathrm{ml}$ ) \\
Triamcinolone \\
acetonide $2 \mathrm{ml}(1$ \\
$\mathrm{ml}$ intradiscal and 1 \\
ml epidural) \\
Ropivacaine $2 \% 2-4$ \\
$\mathrm{ml}(1 \mathrm{ml}$ intradiscal \\
and 2 ml epidural) \\
\end{tabular} & Steroid & 6 & NR & $\begin{array}{l}\text { ODI }<20 \% \\
2 \text { weeks: } 88 \% \text { vs. } 90 \% \text {, } \\
\text { p=0.72 } \\
3 \text { months: } 78 \% \text { vs. } \\
67 \%, p=0.14 \\
6 \text { months: } 745 \text { vs. } 47 \% \text {, } \\
\text { p }<0.001\end{array}$ \\
\hline $\begin{array}{l}\text { Haseeb, } \\
2019^{114} \\
\text { Egypt } \\
\text { Poor }\end{array}$ & 42.44 & 58 & 80 & Mean 2 & $\begin{array}{l}\text { MRI-confirmed } \\
\text { disc herniation }\end{array}$ & $\begin{array}{l}\text { Oxygen-ozone } \\
\text { intradiscal 5-7 } \mathrm{ml} \\
\text { and intraforaminal } \\
\text { mean } 6.5 \mathrm{ml} \\
\text { (concentration } 28 \\
\mu \mathrm{g} / \mathrm{ml} \text { ) } \\
\text { Triamcinolone } \\
\text { acetonide } 2 \mathrm{ml} 40 \\
\mathrm{mg} / \mathrm{ml}(1 \mathrm{ml} \\
\text { intradiscal and } 1 \mathrm{ml} \\
\text { intraforaminal) } \\
\text { Ropivacaine } 2 \% 2-4 \\
\text { ml intradiscal and } \\
\text { intraforaminal }\end{array}$ & Steroid & 6 & NR & $\begin{array}{l}\text { ODI } 0 \text { to } 100, \text { mean } \\
\text { change (SD) } \\
2 \text { weeks: }-20.40 \text { (9.66) } \\
\text { vs. }-16.60 \text { ( } 7.33) \text {, mean } \\
\text { difference }-3.80 \text { (-7.56 } \\
\text { to }-0.04) \\
3 \text { months: }-18.95 \text { (8.55) } \\
\text { vs. }-13.30 \text { (5.66), mean } \\
\text { difference }-5.65(-8.83 \\
\text { to }-2.47) \\
6 \text { months: }-14.73(9.60) \\
\text { vs. }-9.88(5.79), \text { mean } \\
\text { difference }-4.85(-8.32 \\
\text { to }-1.38)\end{array}$ \\
\hline $\begin{array}{l}\text { Haseeb, } \\
2019^{114} \\
\text { Egypt } \\
\text { Poor }\end{array}$ & 42.44 & 58 & 60 & Mean 2 & $\begin{array}{l}\text { MRI-confirmed } \\
\text { disc herniation }\end{array}$ & $\begin{array}{l}\text { Oxygen-ozone } \\
\text { intradiscal 5-7 } \mathrm{ml} \\
\text { and intraforaminal } \\
\text { mean } 6.5 \mathrm{ml} \\
\text { (concentration } 28 \\
\mu \mathrm{g} / \mathrm{ml} \text { ) } \\
\text { Triamcinolone } \\
\text { acetonide } 2 \mathrm{ml} 40 \\
\mathrm{mg} / \mathrm{ml}(1 \mathrm{ml} \\
\text { intradiscal and } 1 \mathrm{ml} \\
\text { intraforaminal) } \\
\text { Ropivacaine } 2 \% 2-4 \\
\text { ml intradiscal and } \\
\text { intraforaminal }\end{array}$ & Sham & 6 & NR & $\begin{array}{l}\text { ODI } 0 \text { to } 100, \text { mean } \\
\text { change (SD) } \\
2 \text { weeks: }-20.40(9.66) \\
\text { vs. }-3.10(3.72), \text { mean } \\
\text { difference }-17.30(95 \% \\
\mathrm{Cl},-20.71 \text { to }-13.89) \\
3 \text { months: }-18.95(8.55) \\
\text { vs. }-2.10(3.81) \text {, mean } \\
\text { difference }-16.85(95 \% \\
\mathrm{Cl},-19.98 \text { to }-13.72)\end{array}$ \\
\hline
\end{tabular}




\begin{tabular}{|c|c|c|c|c|c|c|c|c|c|c|}
\hline $\begin{array}{l}\text { Study, } \\
\text { Year } \\
\text { Country } \\
\text { Quality }\end{array}$ & $\begin{array}{l}\text { Mean Age } \\
\text { (Years) }\end{array}$ & $\begin{array}{l}\text { Percent } \\
\text { Female }\end{array}$ & $\begin{array}{l}\text { Number } \\
\text { Randomized }\end{array}$ & $\begin{array}{l}\text { Duration of } \\
\text { Symptoms } \\
\text { (Months) }\end{array}$ & $\begin{array}{l}\text { Diagnostic } \\
\text { Testing }\end{array}$ & $\begin{array}{l}\text { Ozone } \\
\text { Intervention }\end{array}$ & $\begin{array}{l}\text { Control } \\
\text { Type }\end{array}$ & $\begin{array}{l}\text { Duration } \\
\text { of } \\
\text { Followup } \\
\text { (Months) }\end{array}$ & Pain & Function \\
\hline $\begin{array}{l}\text { Nilachandr } \\
\text { a, 2016 } 115 \\
\text { India } \\
\text { Poor }\end{array}$ & 51.3 & 62 & 80 & Mean: 9.45 & $\begin{array}{l}\text { MRI-confirmed } \\
\text { disc herniation }\end{array}$ & $\begin{array}{l}\text { Oxygen-ozone } 10 \\
\text { ml intradiscal } \\
\text { (concentration } 40 \\
\mu \mathrm{g} / \mathrm{ml} \text { ) }\end{array}$ & Steroid & 6 & $\begin{array}{l}\text { VAS } 0 \text { to } 10 \text {, } \\
\text { mean (SD) } \\
1 \text { week: } 3.50 \\
(1.16) \text { vs. } 3.25 \\
(1.03) \text {, mean } \\
\text { difference } 0.25 \\
(95 \% \text { Cl, }-0.23 \text { to } \\
0.73) \\
2 \text { weeks: } 2.54 \\
(0.89) \text { vs. } 2.75 \\
(0.74) \text {, mean } \\
\text { difference }-0.21 \\
(95 \% \text { Cl, }-0.57 \text { to } \\
0.15) \\
3 \text { months: } 1.54 \\
(1.15) \text { vs. } 2.84 \\
(0.64), \text { mean } \\
\text { difference }-1.30 \\
(95 \% \mathrm{Cl},-1.72 \text { to } \\
-0.88) \\
6 \text { months: } 0.86 \\
(0.69 \text { vs. } 2.24 \\
(0.93), \text { mean } \\
\text { difference }-1.38 \\
(95 \% \mathrm{Cl},-1.75 \text { to } \\
-1.01)\end{array}$ & $\begin{array}{l}\text { ODI } 0 \text { to } 100, \text { mean } \\
\text { (SD) } \\
1 \text { week: } 38.98(7.61) \\
\text { vs. } 42.45(9.97), \text { mean } \\
\text { difference }-3.47(95 \% \\
\text { Cl, }-7.36 \text { to } 0.42) \\
2 \text { weeks: } 34.13(7.94) \\
\text { vs. } 36.20(4.27), \text { mean } \\
\text { difference }-2.07(95 \% \\
\text { Cl, }-4.89 \text { to } 0.75) \\
3 \text { months: } 25.14(7.92) \\
\text { vs. } 36.21(4.67), \text { mean } \\
\text { difference }-12.06(95 \% \\
\text { Cl, }-15.01 \text { to }-9.11) \\
6 \text { months: } 18.28(8.77) \\
\text { vs. } 29.00(6.78), \text { mean } \\
\text { difference }-10.7295 \% \\
\text { Cl, }(-14.32 \text { to }-7.12)\end{array}$ \\
\hline
\end{tabular}

Abbreviations: $\mathrm{CI}$ = confidence interval; $\mathrm{CT}$ = computed tomography; MRI = magnetic resonance imaging; $\mathrm{ODI}=$ Oswestry Disability Index; $\mathrm{SD}=$ standard deviation 


\section{Detailed Synthesis}

\section{Pain}

Only one poor-quality trial reported effects on pain. ${ }^{115}$ It found no difference between intradiscal oxygen-ozone plus epidural methylprednisolone injection versus methylprednisolone alone at 1 (mean difference 0.25 on a 0 to 10 scale, $95 \%$ CI, -0.23 to 0.73 ) or 2 weeks (mean differences $-0.21,95 \% \mathrm{CI},-0.57$ to 0.15 ). However, oxygen-ozone was associated with a moderate decrease in pain versus corticosteroid alone at 3 (mean difference $-1.30,95 \% \mathrm{CI},-1.72$ to -0.88 ) and 6 months (mean difference $-1.38,95 \% \mathrm{CI},-1.75$ to -1.01 ).

\section{Function}

The fair-quality trial found no differences between oxygen-ozone, corticosteroid, and local anesthetic versus corticosteroid plus local anesthetic without oxygen-ozone in likelihood of ODI score less than 20 ( 0 to 100 scale) at 2 or 3 weeks. ${ }^{113}$ Oxygen-ozone was associated with an increased likelihood of achieving an ODI score less than 20 at 6 months ( $74 \%$ vs. $47 \%$, RR 1.59 , $95 \% \mathrm{CI}, 1.21$ to 2.08 )

The two poor-quality trials found little difference between oxygen-ozone and corticosteroid (with or without local anesthetic) versus corticosteroid without oxygen-ozone in the ODI at 1 or 2 weeks. ${ }^{14,115}$ Differences on the ODI were larger and statistically significant at 3 and 6 months (mean differences -10.7 to -4.8 points). One poor-quality trial found oxygen-ozone, corticosteroid and local anesthetic injection associated with moderate improvement in the ODI versus local anesthetic alone (without steroid) at 2 weeks and 3 months (mean differences 17 points). ${ }^{114}$

\section{Other Outcomes}

The trials did not evaluate outcomes other than pain or function.

\section{Harms}

No serious adverse events were reported in any trial. The risk of any adverse event was higher in the oxygen-ozone group when compared with lidocaine alone (RR 3.17, 95\% CI, 1.06 to 9.45 ) in one poor-quality trial. ${ }^{114}$

\section{Sphenopalatine Block for Trigeminal Neuralgia and Headache}

\section{Key Points}

- Evidence was insufficient to assess sphenopalatine block versus sham for headache (1 trial, $\mathrm{N}=41$ ) (SOE: insufficient).

- The mean age of patients in the trial of sphenopalatine block was 41 years.

\section{Description of Included Studies}

One trial $(n=41)$ reported in two publications compared 0.5 percent intranasal bupivacaine versus saline sphenopalatine block via the intranasal approach using a flexible device (Tx360, Tian Medical Inc., Lombard, IL) in patients with chronic migraine headache (Appendix Table G-18 and G-19, and Table 10). ${ }^{116,117}$ Blocks were administered 12 times over a 6-week period (12 total treatments). Study participants had a mean age of 41 years and were predominately 
female (76\%). Study inclusion criteria required at least a 3-month history of migraine; mean duration since migraine diagnosis was 8.6 years duration. Patients using schedule II opioids for migraine were excluded. On average, patients reported 15 days of migraine days per month, 22 headache days per month, and had a baseline mean pain score (0 to 10 NRS) of 3.37 . The study was rated poor quality; limitations included high overall $(27 \%)$ and differential attrition $(43 \%$ in sham arm) at 1 month post-treatment followup, as well as lack of intent-to-treat analysis (Appendix Table H-1). In addition, the trial did not report the scales used to assess a number of outcomes (quality of life [general activity, work, and mood], analgesic use, and global impression of change).

No trial or controlled observational study evaluated sphenopalatine block for trigeminal neuralgia. 
Table 10. Study characteristics and results of sphenopalatine block trial

\begin{tabular}{|c|c|c|c|c|c|c|c|c|c|c|}
\hline $\begin{array}{l}\text { Study, } \\
\text { Year } \\
\text { Country } \\
\text { Quality }\end{array}$ & $\begin{array}{l}\text { Mean } \\
\text { Age } \\
\text { (Years) }\end{array}$ & $\begin{array}{l}\text { Percent } \\
\text { Female }\end{array}$ & $\begin{array}{l}\text { Number } \\
\text { Randomized }\end{array}$ & $\begin{array}{l}\text { Duration of } \\
\text { Symptoms } \\
\text { (Months) }\end{array}$ & $\begin{array}{l}\text { Headache } \\
\text { Type }\end{array}$ & Approach & $\begin{array}{l}\text { Control } \\
\text { Type }\end{array}$ & $\begin{array}{l}\text { Duration of } \\
\text { Followup } \\
\text { (Months) }\end{array}$ & Pain & Function \\
\hline $\begin{array}{l}\text { Cady, } \\
2015^{116,117} \\
\text { U.S. } \\
\text { Poor }\end{array}$ & 41.3 & 76 & 41 & Mean 103.2 & $\begin{array}{l}\text { Chronic } \\
\text { migraine (IHS } \\
\text { criteria) }\end{array}$ & $\begin{array}{l}\text { Transnasal, } \\
\text { using Tx360 } \\
\text { device }\end{array}$ & Placebo & 1 & $\begin{array}{l}\text { NRS } 0 \text { to } 10, \text { mean } \\
\text { difference }(95 \% \mathrm{Cl}) \\
1 \text { day: }-1.35(-3.17 \text { to } 0.47) \\
1 \text { month: }-0.55(-2.54 \text { to } \\
1.44) \\
6 \text { months: }-1.14(-3.06 \text { to } \\
0.78)\end{array}$ & $\begin{array}{l}\text { HIT-6 } 36 \text { to } 78 \text { (higher } \\
\text { score=greater impact), } \\
\text { mean difference }(95 \% \\
\mathrm{CI}) \\
1 \text { month: }-2.69(-7.32 \text { to } \\
1.94) \\
6 \text { months: }-2.84(-7.71 \text { to } \\
2.03)\end{array}$ \\
\hline
\end{tabular}

Abbreviations: CI = confidence interval; HIT-6 = Headache Impact TestIHS = International Headache Society; NRS = numerical rating scale 


\section{Detailed Synthesis}

\section{Pain}

At 24 hours following treatments (data pooled for all 12 treatment sessions), sphenopalatine block was associated with moderate decrease in pain intensity versus sham (mean 2.85 vs. 4.20 on a 0 to 10 NRS, ANOVA p<0.001). ${ }^{116,117}$ However, differences were small and not statistically significant 1 and 6 months after completing the course of treatments (3.36 vs. 3.91 at 1 month and 2.86 vs. 4.00 at 6 months), though sphenopalatine block was associated with fewer number of headaches days per month at 1 month (17.44 vs. 22.82, ANOVA p>0.05).

\section{Function}

Effects of sphenopalatine block versus sham on the Headache Impact Test (HIT-6) were small and not statistically significant at 24 hours following treatments or at 1 to 6 months after completing the course of treatment (differences $\sim 3$ points on a 36 to 78 scale). There were also no differences in general activity or normal work at 1 or 6 months, but the scales used to measure these outcomes were not reported.

\section{Other Outcomes}

There were no differences between sphenopalatine block versus sham in acute medication use at 6 weeks, mood at 1 or 6 months, or patient global impression of change at 24 hours following treatments. ${ }^{116,117}$ However, the scales used to report these outcomes were not reported.

\section{Harms}

There was no difference in any adverse events (mean 7.52 vs. 5.00, $\mathrm{p}=0.30$ ); only one serious adverse event following sphenopalatine block that was probably not related to the intervention was reported (pulmonary embolus resulting in death 81 days after treatment). ${ }^{116,117}$

\section{Occipital Nerve Stimulation for Headache}

\section{Key Points}

- Evidence was insufficient to assess occipital nerve stimulation versus sham stimulation for headache (1 trial, $\mathrm{N}=157$ ) (SOE: insufficient).

- For headache, occipital nerve stimulation with adjustable parameters versus usual care at 3 months was associated with a small, nonstatistically significant reduction in pain intensity, moderate decrease in headache related disability, and decrease in headache days ( 1 trial, $\mathrm{N}=67$ ) (SOE: low for headache related disability and headache days; insufficient for pain).

- Lead migration occurred in 14 to 24 percent of patients ( 2 trials, $\mathrm{N}=224$ ), serious devicerelated complications requiring hospitalization occurred in 5.9 percent of patients (1 trial, $\mathrm{N}=67$ ), and persistent pain/numbness at implantation site in 13 percent of patients ( 1 trial, $\mathrm{N}=157)$ (SOE: low).

- One trial $(\mathrm{N}=67)$ found occipital nerve stimulation with adjustable parameters associated with superior outcomes compared with stimulation using preset parameters.

- The mean age of patients ranged from 43 to 46 years. 


\section{Description of Included Studies}

Three trials (number randomized 30,67, and 157, total $=254$ ) evaluated occipital nerve stimulation for chronic headache (Appendix Table G-20 to G-22 and Table 11). ${ }^{18-120}$ Two trials ${ }^{118,120}$ were multicenter studies; one additional publication ${ }^{121}$ reported results from a single participating center $(n=20)$ in one ${ }^{120}$ of the trials. The trials were conducted in the United States, Italy, and Europe. The mean age ranged from 43 to 46 years and the proportion female ranged from 76 to 80 percent. Two trials ${ }^{118,120}$ restricted inclusion to patients who met criteria for chronic migraine headaches and one trial ${ }^{119}$ included patients with chronic migraine or medication overuse headache; all trials required patients to have unsuccessfully tried at least two prior treatments. Two trials ${ }^{119,120}$ required patients to experience at least 50 percent pain relief with trial stimulation and one trial ${ }^{118}$ required at least 50 percent response to a diagnostic occipital nerve block. Electrodes were placed subcutaneously and occipital nerve stimulation was compared against sham stimulation (electrodes placed but no current applied) (two trials) $)^{119,120}$ or usual care (one trial). ${ }^{118}$ One trial permitted some adjustment of stimulation parameters, ${ }^{119}$ one trial randomized patients to adjustable or preset stimulation parameters, ${ }^{118}$ and one trial ${ }^{120}$ did not report stimulation parameters (Table 11). One crossover trial was rated poor quality due to failure to report randomization or allocation concealment methods, unclear blinding, and potential selective outcomes reporting; in addition, the analysis did not account for use of crossover design (Appendix Table H-1). ${ }^{119}$ The other two trials were rated fair quality. 
Table 11. Study characteristics and results of occipital nerve stimulation trials

\begin{tabular}{|c|c|c|c|c|c|c|c|c|c|c|}
\hline $\begin{array}{l}\text { Study, } \\
\text { Year } \\
\text { Country } \\
\text { Quality }\end{array}$ & $\begin{array}{l}\text { Mean } \\
\text { Age } \\
\text { (Years) }\end{array}$ & $\begin{array}{l}\text { Percent } \\
\text { Female }\end{array}$ & $\begin{array}{l}\text { Number } \\
\text { Randomized }\end{array}$ & $\begin{array}{l}\text { Duration of } \\
\text { Symptoms } \\
\text { (Months) }\end{array}$ & Diagnosis Eligibility & $\begin{array}{l}\text { Stimulation } \\
\text { Intervention }\end{array}$ & $\begin{array}{l}\text { Control } \\
\text { Type }\end{array}$ & $\begin{array}{l}\text { Duration } \\
\text { of } \\
\text { Followup } \\
\text { (Months) }\end{array}$ & Pain & Function \\
\hline $\begin{array}{l}\text { Serra, } \\
2012^{119} \\
\text { Italy } \\
\text { Poor }\end{array}$ & 46 & 76 & 30 & Mean NR & $\begin{array}{l}\text { Unsuccessfully tried } \\
\geq 2 \text { prior treatments } \\
\text { and } \geq 50 \% \text { response } \\
\text { to temporary ONS }\end{array}$ & \begin{tabular}{|l|} 
Pulse frequency \\
$50 \mathrm{~Hz}$, pulse \\
width 330 to 450 \\
Hs, maximum \\
stimulation \\
amplitude $10.5 \mathrm{~V}$
\end{tabular} & Sham & 1 & $\begin{array}{l}\text { Scale } 0 \text { to } 10, \text { median } \\
\text { (IQR), first crossover period: } \\
5(5 \text { to } 6) \text { vs. } 7.5 \text { ( } 7.8), \\
p<0.001 \\
\text { Headache days/week, } \\
\text { median (IQR), first } \\
\text { crossover period: } 2.1 \text { (1.2 to } \\
\text { 3.3) vs. } 6.3 \text { (3.6 to } 7 \text { ), } \\
p<0.001\end{array}$ & NR \\
\hline $\begin{array}{l}\text { Silberstein, } \\
2012^{120} \\
\text { U.S. } \\
\text { Fair }\end{array}$ & 44.9 & 79 & 157 & Mean 23.3 & $\begin{array}{l}\text { Unsuccessfully tried } \\
\geq 2 \text { prior treatments } \\
\text { and } \geq 50 \% \text { response } \\
\text { to temporary ONS }\end{array}$ & $\begin{array}{l}\text { Stimulation } \\
\text { parameters not } \\
\text { reported } \\
\text { ("programmed } \\
\text { for appropriate } \\
\text { stimulation") }\end{array}$ & Sham & 3 & \begin{tabular}{|l} 
Dichotomous \\
$\geq 50 \%$ reduction in \\
headache pain intensity: \\
$17.1 \%$ vs. $13.5 \%, \mathrm{RR} 1.27$ \\
$(95 \% \mathrm{Cl}, 0.57$ to 2.86$)$ \\
"Good" or "excellent" \\
headache relief: $50 \%$ vs. \\
$18 \%$, RR 2.86 ( $95 \% \mathrm{Cl}$, \\
1.53 to 5.34$)$ \\
Continuous \\
Headache days, mean \\
change (SD NR): $-27.2 \%$ \\
vs. $-14.9 \%$, p<0.05
\end{tabular} & $\begin{array}{l}\text { MIDAS score } \\
\text { ( }>20=\text { severe } \\
\text { disability), mean } \\
\text { (SD NR) at } 12 \\
\text { weeks: }-64.6 \text { vs. } \\
-20.4 \text { mean } \\
\text { difference }(95 \% \\
\text { Cl): }-44.2(-65.3 \\
\text { to }-22.8)\end{array}$ \\
\hline $\begin{array}{l}\text { Mekhail, } \\
2017^{121} \\
\text { (single } \\
\text { center from } \\
\text { Silberstein } \\
\text { 2012) } \\
\text { U.S. } \\
\text { Fair }\end{array}$ & 44.6 & 75 & 20 & Mean NR & $\begin{array}{l}\text { Unsuccessfully tried } \\
\geq 2 \text { prior treatments } \\
\text { and } \geq 50 \% \text { response } \\
\text { to temporary ONS }\end{array}$ & $\begin{array}{l}\text { Stimulation } \\
\text { parameters not } \\
\text { reported } \\
\text { ("programmed } \\
\text { for appropriate } \\
\text { stimulation") }\end{array}$ & Sham & 3 & $\begin{array}{l}\frac{\text { Dichotomous }}{\geq 50 \% \text { reduction in }} \\
\text { headache pain intensity: } \\
17.1 \% \text { vs. } 0 \%, \mathrm{RR} 0.71 \\
(95 \% \mathrm{Cl}, 0.51 \text { to } 0.99) \\
\text { Continuous } \\
\text { VAS } 0 \text { to } 10, \text { average daily } \\
\text { pain intensity, mean change } \\
(\mathrm{SD}) \\
-4 \text { weeks: }-2.16(1.02) \mathrm{vs.} \\
0.34(0.99), \mathrm{p}<0.001 \\
-12 \text { weeks: }-2.30(1.15) \mathrm{vs} . \\
0.79(1.06), \mathrm{p}<0.001\end{array}$ & $\begin{array}{l}\text { MIDAS score } \\
(>20=\text { severe } \\
\text { disability), mean } \\
\text { change (SD) at } \\
12 \text { weeks: }-85.21 \\
(40.63) \text { vs. }- \\
12.17(60.43) \\
p=0.008\end{array}$ \\
\hline
\end{tabular}




\begin{tabular}{|c|c|c|c|c|c|c|c|c|c|c|}
\hline $\begin{array}{l}\text { Study, } \\
\text { Year } \\
\text { Country } \\
\text { Quality }\end{array}$ & $\begin{array}{l}\text { Mean } \\
\text { Age } \\
\text { (Years) }\end{array}$ & \begin{tabular}{|l} 
Percent \\
Female
\end{tabular} & $\begin{array}{l}\text { Number } \\
\text { Randomized }\end{array}$ & $\begin{array}{l}\text { Duration of } \\
\text { Symptoms } \\
\text { (Months) }\end{array}$ & Diagnosis Eligibility & $\begin{array}{l}\text { Stimulation } \\
\text { Intervention }\end{array}$ & $\begin{array}{l}\text { Control } \\
\text { Type }\end{array}$ & $\begin{array}{l}\text { Duration } \\
\text { of } \\
\text { Followup } \\
\text { (Months) }\end{array}$ & Pain & Function \\
\hline $\begin{array}{l}\text { Saper, } \\
2011^{118} \\
\text { Canada, } \\
\text { U.S., and } \\
\text { U.K. } \\
\text { Fair }\end{array}$ & 43 & 80 & 67 & Mean 22 & $\begin{array}{l}\text { Unsuccessfully tried } \\
\geq 2 \text { prior treatments } \\
\text { and } \geq 50 \% \text { response } \\
\text { to diagnostic ONS }\end{array}$ & $\begin{array}{l}\text { A: Adjustable: } \\
\text { Pulse frequency } \\
3 \text { to } 130 \mathrm{~Hz}, \\
\text { pulse width } 60 \text { to } \\
450 \mu \mathrm{s}, \text { pulse } \\
\text { amplitude } 0 \text { to } \\
10.5 \mathrm{~V} ; \\
\text { adjustable by } \\
\text { patient for pain } \\
\text { B: Preset: } 1 \\
\text { minute per day; } \\
\text { other parameters } \\
\text { not described }\end{array}$ & Usual care & 3 & \begin{tabular}{|l|} 
Dichotomous \\
Response*: $39.3 \%$ vs. $0 \%$, \\
RR $14.3(95 \% \mathrm{Cl}, 0.9$ to \\
$227.8)$ \\
Continuous \\
Scale 0 to 10, mean change \\
(SD): $-1.5(1.6)$ vs. -0.6 \\
$(1.0) ; p>0.05$ for all \\
comparison
\end{tabular} & $\begin{array}{l}\text { Functional } \\
\text { disability (scale } \\
\text { NR), mean } \\
\text { change (SD): } 0.3 \\
(0.5) \text { vs. } 0.0(0.3) \\
\end{array}$ \\
\hline
\end{tabular}

Abbreviations: $\mathrm{CI}=$ confidence interval; IQR $=$ interquartile range; $\mathrm{NR}=$ not reported; $\mathrm{ONS}=$ occipital nerve stimulation; $\mathrm{RR}=$ relative risk; $\mathrm{SD}=$ standard deviation; $\mathrm{VAS}=$ visual analogue scale

$* \geq 50 \%$ reduction in headache days per month or $\geq 3$-point reduction in overall pain intensity from baseline 


\section{Detailed Synthesis}

\section{Pain}

One fair-quality trial found occipital nerve stimulation associated with similar likelihood of the primary study outcome of at least a 50 percent reduction in headache pain intensity versus sham stimulation at 12 weeks ( $17.1 \%$ vs. $13.5 \%$, RR $1.27,95 \%$ CI, 0.57 to 2.86$).{ }^{120}$ However, occipital nerve stimulation was associated with increased likelihood of at least a 30 percent reduction in headache pain intensity that just met the threshold for statistical significance $33.3 \%$ vs. $17.3 \%$, RR $1.93,95 \% \mathrm{CI}, 1.00$ to 3.70 ). Average effects on pain intensity were not reported in the main publication reporting full multicenter results, but a report from a single center $(\mathrm{n}=20)$ participating in the trial found occipital nerve stimulation associated with a large decrease in pain intensity at 4 weeks (mean change from baseline -2.16 vs. 0.34 on a 0 to 10 scale, $p<0.001$ ) and 12 weeks (mean change from baseline -2.30 vs. $0.79, \mathrm{p}<0.001$ ). The poor-quality crossover trial also found occipital nerve stimulation associated with a large decrease in pain intensity versus sham stimulation at the end of the initial 1-month (prior to crossover) period (median 5 vs. 7.5, $\mathrm{p}<0.001) .{ }^{119}$

The other fair-quality trial found occipital nerve stimulation with adjustable parameters associated with greater reduction in pain versus usual care at 3 months, but the difference was small and not statistically significant (mean change from baseline -1.5 vs. -0.6 on a 0 to 10 scale). ${ }^{118}$ There was no difference between stimulation using preset parameters versus usual care in pain.

\section{Function}

One fair-quality trial found occipital nerve stimulation associated with greater improvement in headache related disability versus sham stimulation at 12 weeks (mean change from baseline 64.6 vs. -20.4 on the Migraine Disability Test (MIDAS) score [ $>20=$ severe disability], mean difference $-44.2,95 \% \mathrm{CI},-65.3$ to -22.8$).{ }^{120}$ The poor-quality crossover trial of occipital nerve stimulation versus sham did not report effects on headache related disability by treatment group. ${ }^{119}$

The other fair-quality trial found occipital nerve stimulation with adjustable parameters associated with larger decrease in headache disability category versus usual care at 3 months (mean change in MIDAS severity category $-1.3,95 \% \mathrm{CI},-2.25$ to -0.35 ); one category level refers to the MIDAS score decreasing from the "severe" to "moderate" or "moderate" to "mild" category. ${ }^{118}$ There was no difference between stimulation using preset parameters versus usual care in headache related disability.

\section{Other Outcomes}

One fair-quality trial found occipital nerve stimulation associated with greater percent decrease in headache days (mean change from baseline $-27.2 \%$ vs. $-14.9 \%, \mathrm{p}<0.05$ ) and increased likelihood of reporting "good" or "excellent" headache relief versus sham stimulation $(50 \%$ vs. $18 \%$, RR $2.86,95 \%$ CI, 1.53 to 5.34$)$ at 12 weeks. ${ }^{120}$ The other fair-quality trial found occipital nerve stimulation with adjustable parameters associated with greater decrease in headaches days/month versus usual care at 3 months (mean difference -5.7 days, $95 \% \mathrm{CI},-10.9$ to -0.54). Stimulation was also associated with greater improvement from baseline in Profile of Mood States score (mean difference -8.3 on a 0 to 168 scale, $95 \%$ CI, -15.2 to -1.4 ) and SF-36 
MCS (mean difference 7.0 on a 0 to 100 scale, $95 \%$ CI, 1.7 to 12.3 ). ${ }^{118}$ There were no differences between occipital nerve stimulation with present parameters versus usual care in headache days or measures of psychological well-being.

\section{Harms}

The most common device-related adverse event was lead migration, which occurred in 14 to 24 percent of patients in two trials. One trial reported three cases of serious device-related adverse events requiring hospitalization $(5.9 \%[3 / 51]) .{ }^{118}$ The events were implant site infection, lead migration, and postoperative nausea. In the other trial, persistent pain or numbness at the implant or lead site was reported in 13.1 percent of patients, skin erosion in 3.7 percent, and wound site complications in 2.8 percent. $^{120}$

\section{Effects of Technical Factors}

As described above, one trial found occipital nerve stimulation with patient-adjustable parameters associated with superior outcomes compared with stimulation using preset (nonadjusted) parameters. ${ }^{118}$

\section{Piriformis Injection for Piriformis Syndrome}

\section{Key Points}

- One trial $(\mathrm{N}=50)$ found piriformis injection with corticosteroid and local anesthetic for piriformis syndrome associated with no difference versus local anesthetic alone in pain at rest at 1 week; piriformis injection was associated with a moderate reduction in pain at rest versus local anesthetic at 1 month (SOE: low for no difference at 1 week and for benefit at 1 month).

- Evidence was insufficient to assess piriformis injection with botulinum toxin.

- The mean age of participants ranged from 42 to 57 years.

\section{Description of Included Studies}

Four RCTs assessed the effectiveness of piriformis injection for piriformis syndrome (Appendix Table G-23 to G-25 and Table 12). ${ }^{122-125}$ Ten participants were randomized in one small pilot trial ${ }^{122}$ and the sample sizes in the other trials ranged from 50 to 87 . In three trials, diagnosis of piriformis syndrome required a positive flexion, adduction and internal rotation (FAIR) test. The fourth trial ${ }^{122}$ based diagnosis of piriformis syndrome on history and physical examination. In three trials, mean age ranged from 42 to 57 and symptom duration ranged from 2 to 3 years. ${ }^{122,123,125}$ One trial did not report demographic or clinical characteristics. ${ }^{124}$ The comparisons varied: three trials compared botulinum toxin A (dose 100 to 300 units) versus placebo (saline) injection, ${ }^{122-124}$ one of which also evaluated a corticosteroid (triamcinolone acetonide $20 \mathrm{mg}$ ) plus local anesthetic (lidocaine) control injection. ${ }^{123}$ The fourth trial compared a corticosteroid (betamethasone) plus lidocaine injection versus lidocaine alone. ${ }^{125}$ Imaging or electromyographic guidance was used in all trials (Table 12). 
Table 12. Study characteristics and results of piriformis injection trials

\begin{tabular}{|c|c|c|c|c|c|c|c|c|c|c|}
\hline $\begin{array}{l}\text { Study, } \\
\text { Year } \\
\text { Country } \\
\text { Quality }\end{array}$ & $\begin{array}{l}\text { Mean } \\
\text { Age } \\
\text { (Years) }\end{array}$ & $\begin{array}{l}\text { Percent } \\
\text { Female }\end{array}$ & $\begin{array}{l}\text { Number } \\
\text { Randomized }\end{array}$ & $\begin{array}{l}\text { Duration } \\
\text { of } \\
\text { Symptoms } \\
\text { (Months) }\end{array}$ & $\begin{array}{l}\text { Diagnostic } \\
\text { Criteria }\end{array}$ & $\begin{array}{l}\text { Piriformis } \\
\text { Injection }\end{array}$ & $\begin{array}{l}\text { Control } \\
\text { Type }\end{array}$ & $\begin{array}{l}\text { Duration } \\
\text { of } \\
\text { Followup } \\
\text { (Months) }\end{array}$ & Pain & Function \\
\hline $\begin{array}{l}\text { Childers, } \\
2002^{122} \\
\text { U.S } \\
\text { Poor }\end{array}$ & 42.1 & 100 & 10 & $\geq 3$ & $\begin{array}{l}\text { H-reflex } \\
\text { testing not } \\
\text { used for } \\
\text { inclusion }\end{array}$ & $\begin{array}{l}\text { Botulinum toxin } \\
\text { type A } 100 \text { units } \\
\text { (fluoroscopic } \\
\text { guidance) }\end{array}$ & Placebo & 2.5 & $\begin{array}{l}\text { Mean difference } \\
(95 \% \mathrm{CI}), \mathrm{VAS} 0 \text { to } \\
10 \\
1 \text { week: }-2.2(-4.4 \text { to } \\
0.02) \\
4 \text { weeks: }-1.5(-4.6 \text { to } \\
1.6) \\
9 \text { weeks: }-1.0(-3.4 \text { to } \\
1.4)\end{array}$ & $\begin{array}{l}\text { Mean difference } \\
(95 \% \mathrm{Cl}) \text { in } \\
\text { interference with } \\
\text { activities, VAS } 0 \\
\text { to } 10 \\
1 \text { week: }-2.1 \text { (- } \\
4.9 \text { to } 0.7) \\
4 \text { weeks: }-2.4 \text { (- } \\
5.2 \text { to } 0.4) \\
9 \text { weeks: }-3.2 \text { (- } \\
6.0 \text { to }-0.4)\end{array}$ \\
\hline $\begin{array}{l}\text { Fishman, } \\
2002^{123} \\
\text { U.S } \\
\text { Poor }\end{array}$ & 57.4 & 67 & 87 & Mean 38.4 & $\begin{array}{l}\text { Positive } \\
\text { FAIR test } \\
\text { (posterior } \\
\text { tibial nerve } \\
\text { H-reflex } \\
>1.86 \mathrm{~ms} \text { ) }\end{array}$ & $\begin{array}{l}\text { A. Botulinum toxin } \\
\text { type A } 200 \text { units } \\
\text { (electromyographic } \\
\text { guidance) } \\
\text { B. Triamcinolone } \\
\text { acetonide } 20 \mathrm{mg}+ \\
1.5 \mathrm{ml} 2 \% \\
\text { lidocaine } \\
\text { (electromyographic } \\
\text { guidance) }\end{array}$ & Placebo & 3 & $\begin{array}{l}\text { RR }(95 \% \mathrm{Cl}) \text { of } \\
\geq 50 \% \text { improvement: } \\
9.29(1.36 \text { to } 63.53)\end{array}$ & NR \\
\hline $\begin{array}{l}\text { Fishman, } \\
2017^{124} \\
\text { U.S } \\
\text { Poor }\end{array}$ & NR & NR & 56 & NR & $\begin{array}{l}\text { Positive } \\
\text { FAIR test } \\
\text { (posterior } \\
\text { tibial or } \\
\text { fibular } \\
\text { nerve H- } \\
\text { reflex } \\
>1.86 \mathrm{~ms} \text { ) }\end{array}$ & $\begin{array}{l}\text { Botulinum toxin } \\
\text { type } A 300 \text { units } \\
\text { (electromyographic } \\
\text { guidance) }\end{array}$ & Placebo & 3 & $\begin{array}{l}\text { Mean (SD) change } \\
\text { from baseline, scale } \\
\text { unclear } \\
4 \text { weeks: }-0.39(0.31) \\
\text { vs. }-0.05(0.12), \\
\text { p<0.0001 } \\
12 \text { weeks: }-0.65 \\
(0.24) \text { vs. }-0.008 \\
(0.02), p<0.0001\end{array}$ & NR \\
\hline
\end{tabular}




\begin{tabular}{|c|c|c|c|c|c|c|c|c|c|c|}
\hline $\begin{array}{l}\text { Study, } \\
\text { Year } \\
\text { Country } \\
\text { Quality }\end{array}$ & $\begin{array}{l}\text { Mean } \\
\text { Age } \\
\text { (Years) }\end{array}$ & $\begin{array}{l}\text { Percent } \\
\text { Female }\end{array}$ & $\begin{array}{l}\text { Number } \\
\text { Randomized }\end{array}$ & $\begin{array}{l}\text { Duration } \\
\text { of } \\
\text { Symptoms } \\
\text { (Months) }\end{array}$ & $\begin{array}{l}\text { Diagnostic } \\
\text { Criteria }\end{array}$ & $\begin{array}{l}\text { Piriformis } \\
\text { Injection }\end{array}$ & $\begin{array}{l}\text { Control } \\
\text { Type }\end{array}$ & $\begin{array}{l}\text { Duration } \\
\text { of } \\
\text { Followup } \\
\text { (Months) }\end{array}$ & Pain & Function \\
\hline $\begin{array}{l}\text { Misirlioglu, } \\
2015^{125} \\
\text { Turkey } \\
\text { Fair }\end{array}$ & 46.3 & 84 & 50 & Mean 20.3 & $\begin{array}{l}\text { Positive } \\
\text { FAIR test } \\
\text { (threshold } \\
\text { not } \\
\text { reported) }\end{array}$ & $\begin{array}{l}\text { Betamethasone } 1 \\
\mathrm{ml}+4 \mathrm{ml} 2 \% \\
\text { lidocaine } \\
\text { (ultrasound } \\
\text { guidance) }\end{array}$ & Sham & 3 & $\begin{array}{l}\text { Mean difference } \\
(95 \% \mathrm{Cl}) \text { at rest, VAS } \\
0 \text { to } 10 \\
1 \text { week: } 0.40 \text { (-0.97 } \\
\text { to } 1.77) \\
1 \text { month: } 1.20 \text { (-0.03 } \\
\text { to } 2.43) \\
3 \text { months: } 1.20 \text { ( } 0.26 \\
\text { to } 2.14) \\
\text { Mean difference } \\
\text { ( } 95 \% \mathrm{Cl}) \text { with } \\
\text { activity, VAS } 0 \text { to } 10 \\
1 \text { week: } 1.10 \text { ( }-0.50 \\
\text { to } 2.70) \\
1 \text { month: } 2.00 \text { ( } 0.70 \\
\text { to } 3.30) \\
3 \text { months: } 1.30 \text { ( }-0.13 \\
\text { to } 2.73) \\
\text { Mean difference } \\
\text { (95\% Cl) during } \\
\text { sleep, VAS } 0 \text { to } 10 \\
1 \text { week: } 0.80 \text { (-0.68 } \\
\text { to } 2.28) \\
1 \text { month: } 0.40 \text { (-0.57 } \\
\text { to } 1.37) \\
3 \text { months: } 0.60 \text { ( }-0.29 \\
\text { to } 1.49)\end{array}$ & NR \\
\hline
\end{tabular}

Abbreviations: $\mathrm{CI}$ = confidence interval; FAIR = flexion, adduction, and internal rotation; $\mathrm{NR}=$ not reported; $\mathrm{RR}=$ relative risk; $\mathrm{SD}=$ standard deviation; $\mathrm{VAS}=$ visual analogue scale 
The trial of a corticosteroid plus lidocaine versus lidocaine was rated fair quality and the other three trials were rated poor quality (Appendix Table H-1). Methodological limitations in the poor-quality trials included unclear randomization and allocation concealment, unreported baseline characteristics, unclear blinding of outcome assessors and care providers, high attrition, lack of intent-to-treat analysis, and use of unreported (potentially unvalidated) scales to measure outcomes, including pain. In addition to a very small sample size, the pilot trial did not account for crossover design in the analysis. ${ }^{122}$

\section{Detailed Synthesis}

\section{Pain}

The fair-quality trial $(\mathrm{n}=50)$ found no difference between piriformis injection with corticosteroid plus lidocaine versus lidocaine alone in pain at rest at 1 week (mean difference 0.40 on 0 to $10 \mathrm{VAS}, 95 \% \mathrm{CI},-0.97$ to 1.77 ). ${ }^{125}$ Differences were larger (mean difference 1.20 ) at 1 and 3 months, but only statistically significant at 1 month. A corticosteroid plus lidocaine was associated with a large reduction in pain with activity at 1 month (mean difference -2.00 , 95\% CI, -3.30 to -0.70 ); differences were smaller at 1 week and 3 months (mean differences 1.10 and -1.30 points) and not statistically significant. For pain at sleep, mean differences were less than 1 point and not statistically significant.

Three poor-quality trials $(\mathrm{n}=10,50 \text {, and } 56)^{122-124}$ found piriformis injection with botulinum toxin A associated with reduced pain versus placebo (saline) injection at 2 to 12 week followup and one poor-quality trial $(\mathrm{n}=61)^{123}$ found piriformis injection with corticosteroid plus lidocaine associated with reduced pain versus placebo, but results are difficult to interpret due to serious methodological limitations.

\section{Function}

One poor-quality trial found piriformis injection with botulinum toxin A associated with improvement in interference with daily activities versus placebo (saline) at 1 and 4 weeks, but enrolled a small sample $(\mathrm{n}=10)$ and did not report the instrument used to measure this outcome. ${ }^{122}$ The other trials did not report function.

\section{Other Outcomes}

One small $(\mathrm{n}=10)$ poor-quality trial found piriformis injection with botulinum toxin A associated with decreased distress versus placebo (saline) injection at 1 week, using an unreported instrument. ${ }^{122}$

\section{Harms}

The fair-quality trial reported similar rates of transient sciatic nerve block with piriformis injections with corticosteroid plus lidocaine and lidocaine alone (24.0\% vs. $27.3 \%) .{ }^{125}$ Reporting of harms in the poor-quality trials was limited. The small crossover trial reported no serious adverse events ${ }^{122}$ and one trial reported similar rates of any adverse event between piriformis injection with botulinum toxin versus saline (RR $0.96,95 \% \mathrm{CI}, 0.32$ to 2.94 ). ${ }^{124}$ 


\section{Peripheral Nerve Stimulation for Ulnar, Median, and Radial Neuropathy}

\section{Key Points}

- Evidence was insufficient to assess peripheral nerve stimulation for upper extremity peripheral neuropathic pain (SOE: insufficient).

\section{Description of Included Studies}

No RCT or controlled observational study compared peripheral nerve stimulation versus usual care, no stimulation, or sham for upper extremity (ulnar, median, or radial nerve) neuropathy. One RCT ( $\mathrm{n}=94)$ compared peripheral nerve stimulation versus sham (current not applied) for patients with chronic (>3 months) upper extremity, lower extremity, or trunk peripheral neuropathic pain; some results were reported in the subgroup of patients with upper extremity pain ( $\mathrm{n}=26)$ (Appendix Table G-26 and G-27, and Table 13). ${ }^{126}$ Specific causes of upper extremity pain were not reported, though pain had to be posttraumatic or postsurgical. The mean age of patients was 53 years and 42 percent were female. The mean duration of pain was not reported. Lead placement was performed with imaging (ultrasound or fluoroscopic guidance) and test stimulation for verification. Parameters varied with phase duration 70 to $500 \mu / \mathrm{sec}$, pulse rate 1 to $200 \mathrm{~Hz}$, time on ranging from 10 minutes to 12 hours (mean 6 hours per day). Typical settings were $200 \mu / \mathrm{sec}$ and $100 \mathrm{~Hz}$, with amplitude set for paresthesia. Outcomes were assessed at 3 months. The trial was rated fair quality due to failure to report allocation concealment methods, unclear blinding of outcome assessors and care providers, and failure to report attrition (Appendix Table H-1). 
Table 13. Study characteristics and results of peripheral nerve stimulation trial

\begin{tabular}{|c|c|c|c|c|c|c|c|c|c|}
\hline $\begin{array}{l}\text { Study, } \\
\text { Year } \\
\text { Country } \\
\text { Quality }\end{array}$ & $\begin{array}{l}\text { Mean } \\
\text { Age } \\
\text { (Years) }\end{array}$ & $\begin{array}{l}\text { Percent } \\
\text { Female }\end{array}$ & $\begin{array}{l}\text { Number } \\
\text { Randomized }\end{array}$ & $\begin{array}{l}\text { Duration } \\
\text { of } \\
\text { Symptoms } \\
\text { (Months) }\end{array}$ & Diagnosis Criteria & $\begin{array}{l}\text { Control } \\
\text { Type }\end{array}$ & $\begin{array}{l}\text { Duration } \\
\text { of } \\
\text { Followup } \\
\text { (Months) }\end{array}$ & Pain & Function \\
\hline $\begin{array}{l}\text { Deer, } \\
2016^{126} \\
\text { U.S. } \\
\text { Fair }\end{array}$ & 53 & 41.5 & 94 & $\geq 3$ & $\begin{array}{l}\text { Severe intractable chronic } \\
\text { pain of peripheral nerve } \\
\text { origin associated with } \\
\text { posttraumatic/postsurgical } \\
\text { neuralgia for } \geq 3 \text { months, } \\
\text { worst pain level in the last } \\
24 \text { hours } \geq 5 \text { (NRS } 0 \text { to } \\
10 \text { ), pain is attributable to } \\
\text { a lesion or disease of the } \\
\text { somatosensory nervous } \\
\text { system }\end{array}$ & Sham & 12 & 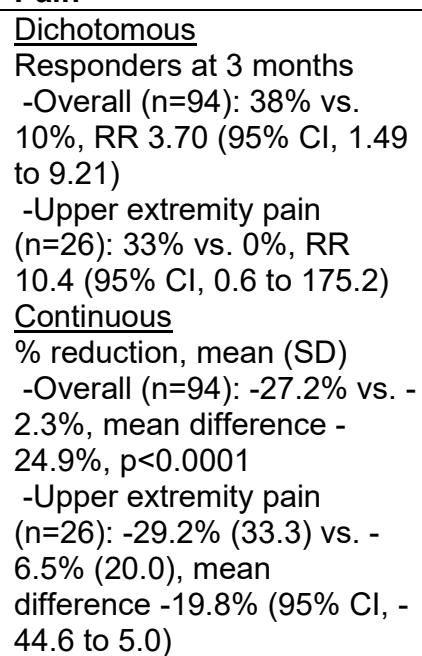 & $\begin{array}{l}\text { SF-12 } 0 \text { to } \\
100, \text { mean } \\
\text { change (SD) } \\
\text { at } 3 \text { months } \\
\text {-Overall: } 1.4 \\
\text { (5.9) vs. }-0.2 \\
(3.4), p=0.04\end{array}$ \\
\hline
\end{tabular}

Abbreviations: $\mathrm{CI}=$ confidence interval; $\mathrm{NRS}=$ numeric rating scale; $\mathrm{RR}=$ relative risk; $\mathrm{SD}=$ standard deviation; $\mathrm{SF}-12=\mathrm{Short} \mathrm{Form} 12$-item

$*$ Responders were defined as those with $\geq 30 \%$ reduction in pain and no increase in pain medication 


\section{Detailed Synthesis}

\section{Pain}

Among the subgroup of patients with upper extremity pain, peripheral nerve stimulation was associated with greater percent change from baseline in pain intensity at 3 months, but the estimate was imprecise and not statistically significant (mean difference $-19.8 \%, 95 \%$ CI, -44.6 to 5.0). ${ }^{126}$ The estimate for treatment response (defined as $\geq 30 \%$ reduction in pain with no increase in pain medication use) also favored peripheral nerve stimulation, but was very imprecise (33\% vs. $0 \%$, RR $10.4,95 \%$ CI, 0.6 to 175.2$)$.

\section{Function and Other Outcomes}

The trial did not report function and other outcomes separately for the subgroup of patients with upper extremity pain. ${ }^{126}$ For all participants, peripheral nerve stimulation was associated with greater improvement in Brief Pain Inventory general activity score (mean change from baseline -2.3 vs. -0.4 on a 0 to 10 scale, $p=0.001$ ). Peripheral nerve stimulation was also associated with greater improvement in Short-Form 12 (SF-12), but the difference was very small (mean change from baseline 1.4 vs. -0.2 on a 0 to 100 scale, $p=0.04$ ).

\section{Harms}

Harms were not reported separately for the subgroup of patients with upper extremity pain. Among all participants, there was no difference between peripheral nerve stimulation versus sham in likelihood of any adverse events, device related adverse events, or nondevice related adverse events. ${ }^{126}$ There were no serious device-related serious adverse events. 


\section{Discussion}

\section{Key Findings and Strength of Evidence}

The key findings of this review are summarized in Table $\mathbf{1 4}$ and the summary of evidence table (Appendix J). Table 14 shows effects of the interventional procedures and comparisons evaluated in this report on pain and function at five predefined followup intervals, including the magnitude of benefit and strength of evidence assessment. The summary of evidence table

provides additional details about the domains used to determine strength of evidence for pain, function, and additional outcomes. 
Table 14. Interventional pain therapies for acute and chronic pain*

\begin{tabular}{|c|c|c|c|c|c|c|c|c|c|c|c|}
\hline Intervention & Condition & $\begin{array}{c}\text { Pain } \\
1 \text { to } 2 \\
\text { weeks } \\
\text { Effect Size } \\
\text { SOE } \\
\end{array}$ & \begin{tabular}{|c|} 
Pain \\
2 to 4 \\
weeks \\
Effect Size \\
SOE \\
\end{tabular} & $\begin{array}{c}\text { Pain } \\
1 \text { to } 6 \\
\text { months } \\
\text { Effect Size } \\
\text { SOE } \\
\end{array}$ & $\begin{array}{c}\text { Pain } \\
6 \text { to } 12 \\
\text { months } \\
\text { Effect Size } \\
\text { SOE } \\
\end{array}$ & \begin{tabular}{|c|} 
Pain \\
$\geq 12$ months \\
Effect Size \\
SOE \\
\end{tabular} & \begin{tabular}{|c|} 
Function \\
1 to 2 \\
weeks \\
Effect Size \\
SOE \\
\end{tabular} & \begin{tabular}{|c|} 
Function \\
2 to 4 \\
weeks \\
Effect Size \\
SOE \\
\end{tabular} & $\begin{array}{c}\text { Function } \\
1 \text { to } 6 \\
\text { months } \\
\text { Effect Size } \\
\text { SOE } \\
\end{array}$ & $\begin{array}{l}\text { Function } \\
6 \text { to } 12 \\
\text { months } \\
\text { Effect Size } \\
\text { SOE } \\
\end{array}$ & $\begin{array}{c}\text { Function } \\
\geq 12 \text { months } \\
\text { Effect Size } \\
\text { SOE } \\
\end{array}$ \\
\hline $\begin{array}{l}\text { Vertebroplasty vs. } \\
\text { sham or usual care }\end{array}$ & $\begin{array}{l}\text { Vertebral } \\
\text { compression } \\
\text { fractures } \\
\end{array}$ & $\begin{array}{c}\text { Small }^{\dagger} \\
+\end{array}$ & $\begin{array}{c}\text { Moderate }^{\ddagger} \\
++\end{array}$ & $\begin{array}{c}\text { Small } \\
++\end{array}$ & $\begin{array}{c}\text { Small } \\
++\end{array}$ & $\begin{array}{c}\text { Small } \\
++\end{array}$ & Insufficient§ & $\begin{array}{c}\text { Small } \\
+++\end{array}$ & $\begin{array}{c}\text { Small } \\
++\end{array}$ & $\begin{array}{c}\text { Small } \\
+++\end{array}$ & $\begin{array}{c}\text { Small } \\
++\end{array}$ \\
\hline $\begin{array}{l}\text { Kyphoplasty vs. } \\
\text { usual care }\end{array}$ & $\begin{array}{l}\text { Vertebral } \\
\text { compression } \\
\text { fractures } \\
\end{array}$ & $\begin{array}{l}\text { Large } \\
++\end{array}$ & $\begin{array}{l}\text { Large } \\
++\end{array}$ & $\begin{array}{c}\text { Moderate } \\
+\end{array}$ & $\begin{array}{c}\text { Moderate } \\
+\end{array}$ & $\begin{array}{l}\text { Small } \\
+\end{array}$ & $\begin{array}{c}\text { Moderate } \\
+\end{array}$ & $\begin{array}{c}\text { Moderate to } \\
\text { large } \\
\mathbf{+ +}\end{array}$ & $\begin{array}{l}\text { Moderate } \\
+\end{array}$ & $\begin{array}{c}\text { Moderate } \\
+\end{array}$ & $\begin{array}{l}\text { Small } \\
+\end{array}$ \\
\hline $\begin{array}{l}\text { Cooled } \\
\text { radiofrequency } \\
\text { ablation vs. sham }\end{array}$ & $\begin{array}{l}\text { Sacroiliac } \\
\text { pain }\end{array}$ & $\begin{array}{c}\text { No } \\
\text { evidence }\end{array}$ & \begin{tabular}{|c|} 
Moderate to \\
large \\
++
\end{tabular} & $\begin{array}{c}\text { Moderate } \\
++\end{array}$ & $\begin{array}{c}\text { No } \\
\text { evidence }\end{array}$ & $\begin{array}{c}\text { No } \\
\text { evidence }\end{array}$ & $\begin{array}{c}\text { No } \\
\text { evidence }\end{array}$ & $\begin{array}{c}\text { Small to } \\
\text { large } \\
+\end{array}$ & $\begin{array}{c}\text { Moderate } \\
+++\end{array}$ & $\begin{array}{c}\text { No } \\
\text { evidence }\end{array}$ & No evidence \\
\hline $\begin{array}{l}\text { Cooled vs. } \\
\text { conventional } \\
\text { radiofrequency } \\
\text { denervation } \\
\end{array}$ & $\begin{array}{l}\text { Presumed } \\
\text { facet joint } \\
\text { pain }\end{array}$ & $\begin{array}{c}\text { No } \\
\text { evidence }\end{array}$ & $\begin{array}{c}\text { None } \\
+\end{array}$ & $\begin{array}{c}\text { None } \\
+\end{array}$ & $\begin{array}{l}\text { Small } \\
+\end{array}$ & $\begin{array}{c}\text { No } \\
\text { evidence }\end{array}$ & $\begin{array}{c}\text { No } \\
\text { evidence }\end{array}$ & $\begin{array}{c}\text { None } \\
+\end{array}$ & $\begin{array}{c}\text { None } \\
+\end{array}$ & $\begin{array}{c}\text { None } \\
+\end{array}$ & No evidence \\
\hline $\begin{array}{l}\text { Pulsed } \\
\text { radiofrequency } \\
\text { denervation vs. } \\
\text { sham" }\end{array}$ & $\begin{array}{l}\text { Presumed } \\
\text { facet joint } \\
\text { pain }\end{array}$ & $\begin{array}{c}\text { No } \\
\text { evidence }\end{array}$ & $\begin{array}{c}\text { No } \\
\text { evidence }\end{array}$ & $\begin{array}{c}\text { No } \\
\text { evidence }\end{array}$ & Insufficient & Insufficient & $\begin{array}{c}\text { No } \\
\text { evidence }\end{array}$ & $\begin{array}{c}\text { No } \\
\text { evidence }\end{array}$ & $\begin{array}{c}\text { No } \\
\text { evidence }\end{array}$ & Insufficient & Insufficient \\
\hline $\begin{array}{l}\text { Pulsed vs. } \\
\text { Conventional } \\
\text { radiofrequency } \\
\text { denervation" }\end{array}$ & $\begin{array}{l}\text { Presumed } \\
\text { facet joint } \\
\text { pain }\end{array}$ & $\begin{array}{c}\text { No } \\
\text { evidence }\end{array}$ & $\begin{array}{c}\text { No } \\
\text { evidence }\end{array}$ & $\begin{array}{c}\text { No } \\
\text { evidence }\end{array}$ & Insufficient & Insufficient & $\begin{array}{c}\text { No } \\
\text { evidence }\end{array}$ & $\begin{array}{c}\text { No } \\
\text { evidence }\end{array}$ & $\begin{array}{c}\text { No } \\
\text { evidence }\end{array}$ & Insufficient & Insufficient \\
\hline \begin{tabular}{|l|} 
Cooled or pulsed \\
radiofrequency \\
denervation vs. \\
sham, usual care, or \\
conventional \\
radiofrequency \\
denervation \\
\end{tabular} & $\begin{array}{l}\text { Degenerative } \\
\text { hip pain }\end{array}$ & $\begin{array}{c}\text { No } \\
\text { evidence }\end{array}$ & $\begin{array}{c}\text { No } \\
\text { evidence }\end{array}$ & $\begin{array}{c}\text { No } \\
\text { evidence }\end{array}$ & $\begin{array}{c}\text { No } \\
\text { evidence }\end{array}$ & $\begin{array}{c}\text { No } \\
\text { evidence }\end{array}$ & $\begin{array}{c}\text { No } \\
\text { evidence }\end{array}$ & $\begin{array}{c}\text { No } \\
\text { evidence }\end{array}$ & $\begin{array}{c}\text { No } \\
\text { evidence }\end{array}$ & $\begin{array}{c}\text { No } \\
\text { evidence }\end{array}$ & No evidence \\
\hline \begin{tabular}{|l|} 
Facet joint platelet- \\
rich plasma vs. sham \\
or usual care
\end{tabular} & $\begin{array}{l}\text { Presumed } \\
\text { facet joint } \\
\text { pain } \\
\end{array}$ & $\begin{array}{c}\text { No } \\
\text { evidence }\end{array}$ & $\begin{array}{c}\text { No } \\
\text { evidence }\end{array}$ & $\begin{array}{c}\text { No } \\
\text { evidence }\end{array}$ & $\begin{array}{c}\text { No } \\
\text { evidence }\end{array}$ & $\begin{array}{c}\text { No } \\
\text { evidence }\end{array}$ & $\begin{array}{c}\text { No } \\
\text { evidence }\end{array}$ & $\begin{array}{c}\text { No } \\
\text { evidence }\end{array}$ & $\begin{array}{c}\text { No } \\
\text { evidence }\end{array}$ & $\begin{array}{c}\text { No } \\
\text { evidence }\end{array}$ & No evidence \\
\hline
\end{tabular}




\begin{tabular}{|c|c|c|c|c|c|c|c|c|c|c|c|}
\hline Intervention & Condition & \begin{tabular}{|c|} 
Pain \\
1 to 2 \\
weeks \\
Effect Size \\
SOE \\
\end{tabular} & \begin{tabular}{|c|} 
Pain \\
2 to 4 \\
weeks \\
Effect Size \\
SOE \\
\end{tabular} & \begin{tabular}{|c|} 
Pain \\
1 to 6 \\
months \\
Effect Size \\
SOE \\
\end{tabular} & $\begin{array}{c}\text { Pain } \\
6 \text { to } 12 \\
\text { months } \\
\text { Effect Size } \\
\text { SOE }\end{array}$ & $\begin{array}{c}\text { Pain } \\
\geq 12 \text { months } \\
\text { Effect Size } \\
\text { SOE }\end{array}$ & \begin{tabular}{|} 
Function \\
1 to 2 \\
weeks \\
Effect Size \\
SOE
\end{tabular} & $\begin{array}{l}\text { Function } \\
2 \text { to } 4 \\
\text { weeks } \\
\text { Effect Size } \\
\text { SOE } \\
\end{array}$ & \begin{tabular}{|c|} 
Function \\
1 to 6 \\
months \\
Effect Size \\
SOE \\
\end{tabular} & \begin{tabular}{|c|} 
Function \\
6 to 12 \\
months \\
Effect Size \\
SOE
\end{tabular} & $\begin{array}{c}\text { Function } \\
\geq 12 \text { months } \\
\text { Effect Size } \\
\text { SOE }\end{array}$ \\
\hline \begin{tabular}{|l|} 
Intradiscal platelet- \\
rich plasma vs. sham
\end{tabular} & $\begin{array}{l}\text { Discogenic } \\
\text { back pain }\end{array}$ & Insufficient & \begin{tabular}{|l|} 
Insufficient \\
\end{tabular} & Insufficient & $\begin{array}{c}\text { No } \\
\text { evidence }\end{array}$ & \begin{tabular}{|c|} 
No \\
evidence
\end{tabular} & Insufficient & Insufficient & \begin{tabular}{|l|} 
Insufficient \\
\end{tabular} & \begin{tabular}{|c|} 
No \\
evidence
\end{tabular} & No evidence \\
\hline $\begin{array}{l}\text { Intradiscal stem cells } \\
\text { vs. control* }\end{array}$ & $\begin{array}{l}\text { Discogenic } \\
\text { back pain }\end{array}$ & $\begin{array}{c}\text { No } \\
\text { evidence }\end{array}$ & Insufficient & Insufficient & Insufficient & Insufficient & $\begin{array}{c}\text { No } \\
\text { evidence }\end{array}$ & Insufficient & Insufficient & Insufficient & Insufficient \\
\hline $\begin{array}{l}\text { Intradiscal } \\
\text { methylene blue vs. } \\
\text { sham }\end{array}$ & $\begin{array}{l}\text { Discogenic } \\
\text { back pain }\end{array}$ & $\begin{array}{c}\text { No } \\
\text { evidence }\end{array}$ & $\begin{array}{c}\text { No } \\
\text { evidence }\end{array}$ & $\begin{array}{c}\text { None } \\
+\end{array}$ & $\begin{array}{c}\text { None } \\
+\end{array}$ & Insufficient & $\begin{array}{c}\text { No } \\
\text { evidence }\end{array}$ & $\begin{array}{c}\text { No } \\
\text { evidence }\end{array}$ & $\begin{array}{l}\text { Small } \\
+\end{array}$ & $\begin{array}{c}\text { None } \\
+\end{array}$ & Insufficient \\
\hline $\begin{array}{l}\text { Intradiscal ozone + } \\
\text { corticosteroid vs. } \\
\text { corticosteroid }\end{array}$ & $\begin{array}{l}\text { Discogenic } \\
\text { back pain }\end{array}$ & Insufficient & $\begin{array}{c}\text { No } \\
\text { evidence }\end{array}$ & Insufficient & Insufficient & $\begin{array}{c}\text { No } \\
\text { evidence }\end{array}$ & Insufficient & Insufficient & $\begin{array}{c}\text { No } \\
\text { evidence }\end{array}$ & Insufficient & Insufficient \\
\hline $\begin{array}{l}\text { Sphenopalatine } \\
\text { block vs. control }\end{array}$ & $\begin{array}{l}\text { Trigeminal } \\
\text { neuralgia }\end{array}$ & $\begin{array}{c}\text { No } \\
\text { evidence } \\
\end{array}$ & $\begin{array}{c}\text { No } \\
\text { evidence }\end{array}$ & $\begin{array}{c}\text { No } \\
\text { evidence } \\
\end{array}$ & $\begin{array}{c}\text { No } \\
\text { evidence } \\
\end{array}$ & $\begin{array}{c}\text { No } \\
\text { evidence } \\
\end{array}$ & $\begin{array}{c}\text { No } \\
\text { evidence } \\
\end{array}$ & $\begin{array}{c}\text { No } \\
\text { evidence }\end{array}$ & $\begin{array}{c}\text { No } \\
\text { evidence } \\
\end{array}$ & $\begin{array}{c}\text { No } \\
\text { evidence } \\
\end{array}$ & No evidence \\
\hline \begin{tabular}{|l} 
Sphenopalatine \\
block vs. control"
\end{tabular} & $\begin{array}{l}\text { Chronic } \\
\text { migraine }\end{array}$ & $\begin{array}{c}\text { No } \\
\text { evidence }\end{array}$ & Insufficient & $\begin{array}{c}\text { No } \\
\text { evidence }\end{array}$ & Insufficient & $\begin{array}{c}\text { No } \\
\text { evidence }\end{array}$ & $\begin{array}{c}\text { No } \\
\text { evidence }\end{array}$ & Insufficient & $\begin{array}{c}\text { No } \\
\text { evidence }\end{array}$ & Insufficient & No evidence \\
\hline \begin{tabular}{|l|} 
Occipital nerve \\
stimulation vs. sham"
\end{tabular} & $\begin{array}{l}\text { Chronic } \\
\text { migraine }\end{array}$ & $\begin{array}{c}\text { No } \\
\text { evidence }\end{array}$ & $\begin{array}{c}\text { No } \\
\text { evidence }\end{array}$ & Insufficient & $\begin{array}{c}\text { No } \\
\text { evidence }\end{array}$ & $\begin{array}{c}\text { No } \\
\text { evidence }\end{array}$ & $\begin{array}{c}\text { No } \\
\text { evidence }\end{array}$ & $\begin{array}{c}\text { No } \\
\text { evidence }\end{array}$ & Insufficient & $\begin{array}{c}\text { No } \\
\text { evidence }\end{array}$ & No evidence \\
\hline $\begin{array}{l}\text { Occipital nerve } \\
\text { stimulation vs. usual } \\
\text { care }\end{array}$ & $\begin{array}{l}\text { Chronic } \\
\text { migraine }\end{array}$ & $\begin{array}{c}\text { No } \\
\text { evidence }\end{array}$ & $\begin{array}{c}\text { No } \\
\text { evidence }\end{array}$ & Insufficient & $\begin{array}{c}\text { No } \\
\text { evidence }\end{array}$ & $\begin{array}{c}\text { No } \\
\text { evidence }\end{array}$ & $\begin{array}{c}\text { No } \\
\text { evidence }\end{array}$ & $\begin{array}{c}\text { No } \\
\text { evidence }\end{array}$ & Insufficient & $\begin{array}{c}\text { No } \\
\text { evidence }\end{array}$ & No evidence \\
\hline \begin{tabular}{|l|} 
Piriformis injection \\
with corticosteroid \\
plus local anesthetic \\
vs. corticosteroid \\
plus local anesthetic, \\
or sham"
\end{tabular} & $\begin{array}{l}\text { Piriformis } \\
\text { syndrome }\end{array}$ & $\begin{array}{c}\text { None } \\
+\end{array}$ & $\begin{array}{c}\text { Moderate } \\
+\end{array}$ & Insufficient & $\begin{array}{c}\text { No } \\
\text { evidence }\end{array}$ & $\begin{array}{c}\text { No } \\
\text { evidence }\end{array}$ & $\begin{array}{c}\text { No } \\
\text { evidence }\end{array}$ & $\begin{array}{c}\text { No } \\
\text { evidence }\end{array}$ & $\begin{array}{c}\text { No } \\
\text { evidence }\end{array}$ & $\begin{array}{c}\text { No } \\
\text { evidence }\end{array}$ & No evidence \\
\hline $\begin{array}{l}\text { Peripheral nerve } \\
\text { stimulation vs. sham }\end{array}$ & $\begin{array}{l}\text { Ulnar, median } \\
\text { or radial } \\
\text { neuropathy } \\
\text { pain }\end{array}$ & $\begin{array}{c}\text { No } \\
\text { evidence }\end{array}$ & $\begin{array}{c}\text { No } \\
\text { evidence }\end{array}$ & Insufficient & $\begin{array}{c}\text { No } \\
\text { evidence }\end{array}$ & $\begin{array}{c}\text { No } \\
\text { evidence }\end{array}$ & $\begin{array}{c}\text { No } \\
\text { evidence }\end{array}$ & $\begin{array}{c}\text { No } \\
\text { evidence }\end{array}$ & Insufficient & $\begin{array}{c}\text { No } \\
\text { evidence }\end{array}$ & No evidence \\
\hline
\end{tabular}

Abbreviations: $\mathrm{SOE}=$ strength of evidence

Effect size: none (i.e., no effect/no statistically significant effect), small, moderate, or large increased risk; SOE: $+=$ low, $++=$ moderate, $+++=$ high.

* Grey shading indicates insufficient or no evidence

tThere was no difference in trials with sham control and moderate difference in trials with usual care control, but no statistically significant interaction between control type and effects on pain ( $\mathrm{p}$ for interaction $=0.14$ )

¥There was a small difference in trials with sham control and large difference in trials with usual care control, with a statistically significant interaction between control type and effect on pain ( $p$ for interaction $<0.01$ )

$\S$ There was no difference in trials with sham control and small difference in trials with usual care control, but no statistically significant interaction between control type and effects on pain ( $\mathrm{p}$ for interaction $=0.19$ )

"Poor-quality trials excluded 
Vertebroplasty was the only intervention evaluated in a sufficient number of trials to permit meta-analysis. The evidence on vertebroplasty was of high applicability to Medicare populations due to enrollment of older ( $>65$ years of age) patients in all of the trials, consistent with the epidemiology of osteoporotic compression fractures, which predominantly impacts older patients. Based on pooled estimates, vertebroplasty was associated with small improvements in pain and function versus controls (sham or usual care) at most time points evaluated (ranging from 1 to 2 weeks to 12 months and longer). Mean differences for pain ranged from 0.53 to 1.05 points on a 0 to 10 scale and were less than 2 points on the 0 to 24 Roland-Morris Disability Questionnaire (RDQ). Although these differences were below proposed minimally important differences (1.5 points for pain ${ }^{72,127,128}$ and 2 to 3 points or higher for the RDQ), ${ }^{72,129,130}$ they are comparable to the benefits observed for other treatments used for pain, including nonsteroidal anti-inflammatory drugs ${ }^{75}$ or antidepressants ${ }^{74}$ for low back pain, epidural corticosteroid injection for lumbar radiculopathy, ${ }^{44}$ and opioids for chronic pain, ${ }^{76}$ which are also below proposed minimum clinically important differences. Because average differences may obscure larger benefits that occur in some patients, evaluating effects on pain or function based on the likelihood of achieving a clinical response (e.g., $\geq 30 \%$ or at least moderate improvement) can provide complementary information. However, few trials reported the likelihood of achieving a pain or function response. Results were imprecise with nonstatistically significant differences, though the likelihood of achieving a pain response favored vertebroplasty at 2 to 4 weeks, 1 to 6 months, and 6 to 12 months.

Although statistical heterogeneity was present in some pooled estimates on effects of vertebroplasty, the overall findings were consistent with a small benefit. Sources of heterogeneity could include the type of control (sham versus usual care), the type of sham (with or without periosteal local anesthetic), or the duration of pain. Benefits of vertebroplasty were generally larger in trials with usual care rather than sham controls. This is consistent with increased susceptibility of usual care trials to placebo effects, due to their open-label design, leading to overestimation of effectiveness due to expectations regarding benefits. However, differences between control type and effects on pain or function were only statistically significant for pain at 2 to 4 weeks (at this time point, the effect was small in sham-controlled trials and large in trials with usual care control). However, our ability to identify statistically significant interactions was limited by the relatively small number of trials in subgroup analyses, resulting in imprecise estimates.

Other potential sources of heterogeneity include fracture duration (more acute fractures potentially more responsive to treatment), ${ }^{94}$ whether the trials restricted enrollment to patients with imaging findings indicating bone marrow edema at fracture sites (a marker of fracture acuity), ${ }^{131}$ or the volume of cement used in the vertebroplasty procedure (polymethyl methacrylate [PMMA] volume). ${ }^{132}$ Although trials of acute fractures (based on either inclusion criterion of $<4$ weeks or average pain duration at enrollment of $<4$ weeks) generally reported larger estimates of benefit that trials of patients with longer duration of fracture, few trials evaluated patients with acute fractures (only 1 trial $^{91}$ was restricted to patients with acute fractures and the average duration $<4$ weeks in only 3 trials), ${ }^{80,89,91}$ subgroup estimates were imprecise, and analyses indicated no statistically significant subgroup effects. In addition, only one sham-controlled trial ${ }^{80}$ focused on patients with acute pain (mean duration $<3$ weeks), potentially confounding analyses on control type and pain duration. Further, among the shamcontrolled trials, this trial reported the largest (moderate) benefits of vertebroplasty on pain intensity at 2 to 4 weeks. ${ }^{80}$ Although three trials that performed within-study subgroup analyses 
found no statistically significant interaction between fracture duration and effects of vertebroplasty, acute fractures were defined differently in each trial $(<3,<6 \text {, or }<13 \text { weeks })^{79,80,83}$ and two of the trials ${ }^{80,83}$ reported larger benefit were in patients with more acute fractures. Requiring bone marrow imaging on magnetic resonance imaging (MRI) (a marker of fracture acuity) for trial enrollment was not associated with differential effects on pain and results did not indicate a difference in effects of vertebroplasty based on larger average PMMA volume used.

Another factor that could partially explain decreased effects of vertebroplasty in shamcontrolled trials is related to use of local anesthetic infiltration in patients randomized to sham. ${ }^{81}$ In four sham-controlled trials that found no benefit of vertebroplasty, patients underwent periosteal or vertebral body local anesthetic infiltration. ${ }^{79,81-83}$ In the fifth trial, which found vertebroplasty associated with moderate benefits, patients randomized to sham underwent subcutaneous but not periosteal local anesthetic infiltration. ${ }^{80}$ If infiltration of local anesthetic into periosteum or bone is associated with therapeutic benefits for fracture beyond subcutaneous infiltration, it is possible that its use in sham could attenuate benefits of vertebroplasty. However, this would require that infiltration of cement not have a therapeutic effect beyond local anesthetic - even though stabilization of the fracture with cement is the proposed mechanism of action of vertebroplasty. Furthermore, effects of local anesthetic would need to persist long beyond their expected duration (generally 1 to 8 hours), as differences between sham and usual care controlled trials are observed at long term (months to beyond a year) followup (Table 4). It was not possible to isolate the effects of local anesthetic bone infiltration from the shamcontrolled trials, because the trial ${ }^{80}$ that only utilized subcutaneous local anesthetic infiltration differed from the others in several other ways that might impact effectiveness, including use of the largest PMMA volume $(7.5 \mathrm{ml}$ vs. 2 to $5.1 \mathrm{ml})$ and enrolment of the most acute patients $(<6$ weeks, with mean duration of 2.6 weeks vs. mean of up to 17.8 weeks in the other sham trials).

Evidence on other outcomes of vertebroplasty was more limited, but indicated small effects on general quality of life (EuroQOL 5-Dimension Questionnaire [EQ-5D]) at some time points, no differences in condition-specific quality of life (Quality of Life Questionnaire of the European Foundation for Osteoporosis [QUALEFFO]), and no difference in Short-Form 36 Health Survey Physical Component Score (SF-36 PCS) or Short-Form 36 Health Survey Mental Component Score (SF-36 MCS) status. There was no increased risk of incident vertebral fractures or mortality, though some imprecision in estimates was present; evidence on serious harms was very imprecise but also did not indicate increased risk.

Like vertebroplasty, kyphoplasty is a vertebral augmentation procedure, but involves restoration of vertebral body height before injecting cement. Evidence was limited to two openlabel trials, one of which focused on patients with fracture and cancer. ${ }^{99,102}$ Kyphoplasty was associated with large improvement in pain and moderate improvement in function at 1 week and 1 month, moderate benefits through 1 year, and small improvements at 2 years. These findings may be an overestimate, due to potential placebo effects in open-label, usual care trials. There was no increased risk of serious adverse events, but evidence on incident vertebral fracture and mortality was inconsistent and imprecise.

Cooled and pulsed radiofrequency denervation are alternatives to conventional radiofrequency involving use of a cooler probe or decreased current in shorter bursts. Based on two trials, cooled radiofrequency was associated with moderate to large improvement in pain at 1 month and moderate improvement at 3 month compared with sham in patients with sacroiliac pain. ${ }^{103,104}$ For function, benefits were small to large at 1 month and moderate at 3 months. However, there were no statistically significant differences between cooled versus conventional 
radiofrequency denervation for presumed facet joint pain in pain or function. ${ }^{105}$ Evidence on pulsed radiofrequency versus sham or conventional radiofrequency denervation for presumed facet joint pain was insufficient, based on a single fair-quality trial with imprecise estimates. ${ }^{106}$ Based on limited evidence, occipital nerve stimulation for headache may be more effective than usual care for improving headache-related disability and reducing headache days (lead migration was common and other device-related complications have been reported) and piriformis corticosteroid injection for piriformis syndrome may be similarly effective versus sham for pain at 1 week, but more effective for reducing pain at 1 month.

Interpretation of the results of two trials of intradiscal methylene blue trials for presumed discogenic back pain is challenging. Intradiscal methylene blue was associated with large benefits versus sham at 6 months in pain and function in an initial trial. ${ }^{112}$ However, a subsequent trial $^{111}$ found no differences between methylene blue versus sham in pain or function at 6 months, despite mimicking the study design of the earlier trial. The earlier trial also found large benefits at 12 and 24 months; the subsequent trial did not evaluate outcomes beyond 6 months, but found no differences in pain and small improvements in function at 6 weeks and 3 months. It is unclear why 6 month results of the trials were discordant, though the earlier trial ${ }^{112}$ was assessed as lower (fair) quality, reported a higher participation rate (58\% of screened participants enrolled compared with $6 \%$ in the subsequent trial), did not exclude patients with multilevel disease, and did not exclude patients with positive response to a facet joint block, it is not clear why these differences would result in greater benefits of intradiscal methylene blue.

For the other interventions addressed in this report, evidence was generally insufficient to determine benefits and harms, based on single fair-quality trials with methodological limitations, often with imprecise estimates. No study evaluated cooled radiofrequency denervation versus sham or usual care for degenerative hip conditions, intradiscal ozone for nonradicular, presumed discogenic back pain, piriformis injection with botulinum toxin for piriformis syndrome, or sphenopalatine block for trigeminal neuralgia.

\section{Findings in Relation to What Is Already Known}

Our findings regarding vertebroplasty are generally consistent with a recent systematic review of randomized controlled trials (RCTs) that also found vertebroplasty associated with small effects on pain and function versus sham treatments that were below prespecified minimum clinically important thresholds, with larger effects in trials of vertebroplasty versus usual care. ${ }^{22}$ Our review differs from this prior review by performing analyses on additional potential modifiers of treatment effect (PMMA volume, presence of bone marrow edema on MRI), including overall as well as stratified estimates from sham- and usual care-controlled trials, evaluating pain duration based on inclusion criteria as well as mean duration of symptoms, and incorporating additional recently studies and publications ${ }^{81,82,94,95}$ from a more recent literature search. We showed that PMMA volume and requiring presence of bone marrow edema on MRI had little impact on estimates. We also showed that sham and usual care trials reported similar effects on pain and function at some time points and that pain duration appeared to affect treatment estimates, suggesting that differences are multifactorial and not solely related to the type of control used. Unlike another recent review of vertebroplasty in older adults that included RCTs and non-RCTs, we restricted inclusion to RCTs, strengthening the certainty in findings, though overall conclusions were similar. ${ }^{133}$ We also identified additional data on mortality, serious adverse events, and incident fractures to provide more robust estimates and confidence that vertebroplasty does not increase risk of these outcomes (though some imprecision persists). 
Two recent meta-analyses ${ }^{134,135}$ that included observational studies, which may be a useful supplement to RCTs for evaluating harms, were consistent with our review in finding no association between vertebroplasty versus nonsurgical management and increased risk of subsequent incident fractures or mortality. In one of the reviews, vertebroplasty was associated with a protective effect on mortality (hazard ratio $0.78,95 \%$ confidence interval, 0.69 to 0.71 ). ${ }^{134}$ We found no indication of a protective effect of vertebroplasty on mortality, suggesting that the findings based on observational studies should be interpreted with caution and could be related to confounding by indication, if patients are selected for vertebroplasty based in part on being healthier and at lower risk of mortality.

Our findings regarding kyphoplasty are consistent with a recent systematic review that also found no sham-controlled trials and greater reduction in pain and improvement in function versus usual care. ${ }^{136}$ Our findings are also consistent with a recent systematic review ${ }^{137}$ of cooled radiofrequency denervation and association with benefit for sacroiliac pain that included RCTs as well as observational studies. Although a recent systematic review evaluated radiofrequency denervation for chronic back pain, it did not focus on effects of pulsed or cooled radiofrequency specifically. ${ }^{24}$ Regarding the other interventional procedures addressed in this report, we found systematic reviews to be lacking, likely reflecting the paucity of evidence. Therefore, our review adds to what is known by providing a systematic synthesis of the available evidence. Our review of reference lists from nonsystematic reviews verified the absence of additional RCTs.

\section{Applicability}

As previously noted, evidence on vertebroplasty and kyphoplasty is highly relevant for Medicare-eligible patients. These procedures are performed for vertebral compression fractures, most commonly due to osteoporosis, a condition which increases in prevalence with age. All trials of vertebroplasty and kyphoplasty enrolled patients with a mean age of 65 years of older, with the exception of one trial ${ }^{99}$ of kyphoplasty for vertebral compression fractures related to cancer in which the mean age was 64 years. Trials of vertebroplasty and kyphoplasty generally appeared to use techniques consistent with current practice and most were conducted in very high human development index countries, likely increasing applicability to clinical practice in the United States. The majority of participants in the trials were women, consistent with the sex distribution of this condition, but one trial found no association between sex and effects of vertebroplasty. ${ }^{79}$

The evidence on the other interventional procedures evaluated in this report may be less directly applicable to Medicare-eligible patients. The mean age of trial participants for these procedures ranged from 40 to 59 years and some trials (e.g., the trials of intradiscal methylene blue for presumed discogenic back pain $)^{111,112}$ specifically excluded older ( $>66$ years) patients. No trial reported results stratified by older age or other factors relevant for determining Medicare eligibility, such as disability status or presence of end-stage renal disease. The lack of direct evidence in Medicare-eligible patients is unsurprising, given the overall lack of evidence on these procedures.

\section{Implications for Clinical and Policy Decision Making}

Our review has implications for clinical and policy decision making. Findings of this review may inform use of vertebroplasty in Medicare-eligible patients. Although benefits of vertebroplasty were classified as small, they are comparable with the benefits observed with other therapies for pain, including nonsteroidal anti-inflammatory drugs ${ }^{75}$ and antidepressants ${ }^{74}$ 
for chronic low back pain, opioids for chronic pain, ${ }^{76}$ epidural corticosteroid injections for lumbar radiculopathy, ${ }^{44}$ and psychological therapies for chronic pain. ${ }^{138}$ For all of these therapies, pain reduction averaged 0.5 to less than 1.0 point on a 0 to 10 scale. For vertebroplasty, interpretation of small benefits is complicated by inability to completely disentangle effects of study design (sham vs. usual care) from other factors (pain duration, potential therapeutic effects of sham, and others) that may impact estimates of benefit.

Use of vertebroplasty for treatment of vertebral compression fractures remains controversial. Decisions regarding use of vertebroplasty should take into consideration the severity of pain and response to analgesics and other medical management. In patients with more severe pain who are not responding to medical management, factors that may inform decisions to use vertebroplasty include the relatively small benefit, uncertainty regarding potential benefits (including magnitude of placebo effects) and harms (including risk of incident vertebral fracture), costs, and variability in patient preferences or how they value small average benefits. This approach is consistent with a proposed (not finalized) Medicare Local Coverage Determination document. ${ }^{139}$ In the proposed Local Coverage Determination, presence of bone marrow edema on imaging is required. Based on the evidence reviewed in this report, there is insufficient evidence to identify subgroups more likely to benefit from vertebroplasty based on pain duration or presence of bone marrow edema, or technical factors associated with greater benefit, such as optimal PMMA volume.

Although our report found that kyphoplasty was associated with larger benefits than vertebroplasty, these estimates are likely an overestimate, given that results are derived from open-label, usual care-controlled trials. Systematic reviews that included trials that directly compared kyphoplasty versus vertebroplasty (not eligible for our report) found no differences between the procedures, supporting similarity in benefits. ${ }^{22}$ Therefore, considerations like those described for vertebroplasty are also likely to be relevant for decisions regarding kyphoplasty. Of note, kyphoplasty is considered a more technically complex procedure and more costly, but is usually preferred when there is more compression of the vertebral body, and there is more uncertainty with regard to benefits as well as harms.

Cooled radiofrequency denervation appears to have potential for treatment of sacroiliac pain. Selection of patients for this procedure should take into account that in both trials in which cooled radiofrequency denervation was found to be effective, patients were selected on the basis of a positive response to a sacroiliac diagnostic block and lack of response to conventional (medical) therapy. A factor complicating use of cooled radiofrequency was that the trials utilized different techniques, with insufficient evidence to determine the optimal method: in one trial, ${ }^{103}$ cooled radiofrequency denervation was performed to the S1 to S3 lateral branches and conventional radiofrequency denervation to the L4 and L5 dorsal rami, whereas in the other trial $^{104}$ cooled radiofrequency was performed at the L5 dorsal ramus and the S1 to S3 sites. The trials required patients to have at least a 75 percent reduction in pain with diagnostic block, which should inform considerations regarding patient selection for this procedure.

For the other interventional procedures and conditions evaluated in this report, current evidence was too limited to guide clinical and policy decision making. For some interventions and comparisons, current evidence suggested no benefit, though the strength of evidence was low (methylene blue vs. sham for presumed discogenic back pain and cooled vs. conventional radiofrequency denervation for presumed facet joint pain). 


\section{Limitations of the Systematic Review Process}

We focused on randomized trials, because observational and other non-randomized studies are more susceptible to bias and confounding, especially when assessing more subjective outcomes such as pain and function. ${ }^{48}$ Furthermore, non-randomized studies have been shown to overestimate benefits of interventional pain treatments. For example, non-randomized studies of vertebroplasty reported complete and sustained pain relief in 78 percent to 90 percent of patients and non-randomized studies of intradiscal electrothermal therapy ${ }^{55}$ and transforaminal epidural steroid injection ${ }^{53}$ reported reductions in pain intensity of 2 to 4.5 points on a 10 point pain scale versus usual care or sham, compared with less than 1 point in RCTs of these therapies.. ${ }^{43,57}$ Although cohort studies assessing benefits would have been included if no RCTs were available, there was at least 1 RCT for all interventions addressed in this report. We also planned to include large $(n>500)$ case series on rare and serious harms, but did not identify such eligible studies.

We excluded non-English language articles and did not search for or include non-peer reviewed studies or studies published only as abstracts. This resulted in the exclusion of one completed sham-controlled trial $(n=80)$ of patients with chronic ( $>3$ months) vertebral compression fractures published as a non-peer-reviewed preprint; ${ }^{140}$ results were consistent with our analyses in finding vertebroplasty associated with small to moderate benefits in pain intensity and quality of life. Meta-analyses were not possible for interventions other than vertebroplasty, due to small numbers of studies and methodological limitations. In the metaanalyses of vertebroplasty, assessment for small sample effects (a potential marker of publication bias) using statistical and graphical methods was limited to analyses on pain intensity at two time points with 10 trials (neither indicated small sample effects); the other analyses included fewer than 10 trials, a proposed threshold for informative analyses of small sample effects. ${ }^{141}$ Analyses of subgroup effects in the vertebroplasty meta-analyses were limited by small numbers of trials in subgroups, with imprecise estimates. In addition, subgroup analyses were based on study level data, which are limited in their ability to evaluate factors that vary on an individual level (e.g., pain duration or severity). We did not have access to individual patient data, which would have enabled more robust evaluations of demographic, clinical, and technical characteristics and impacts on vertebroplasty outcomes. Some pooled estimates were associated with high statistical heterogeneity; because of anticipated heterogeneity, a random effects model was used to perform meta-analysis. We excluded active-controlled trials, focusing on outcomes compared with sham or usual care controls, with the exception of trials of cooled or pulsed radiofrequency denervation versus conventional radiofrequency denervation, which were included because these techniques have been proposed as alternatives to conventional radiofrequency denervation. We excluded trials that combined multiple therapies in order to focus on the effects of the specific interventional procedures of interest, with the exception of intradiscal ozone plus epidural corticosteroid versus epidural corticosteroid for lumbar radiculopathy with herniated disc, which was included because no trial evaluated intradiscal ozone therapy alone and epidural corticosteroids are considered a standard treatment for this condition. We did not address outcomes prior to 1 week; therefore, our review does not address immediate and very early outcomes of interventional procedures. Such very early outcomes are likely more relevant for patients with acute pain than for the chronic pain conditions addressed by most of the interventions in this report. For parallel group trials in which high crossover rates occurred (usually from sham or usual care to the intervention), we focused on results reported prior to high crossover, to preserve randomization and the intent-to-treat approach. 


\section{Limitations of Evidence Base}

The evidence base had important limitations. For vertebroplasty, trials varied with regard to patient selection criteria (e.g., duration of pain), technical factors (e.g., volume of PMMA), and sham interventions (e.g., sites of local anesthetic infiltration); in addition, the usual care interventions were not well standardized or defined. Some factors were correlated (e.g., only 1 sham-controlled trial enrolled patients with pain $<4$ weeks and did not utilize periosteal local anesthetic injection like the other trials) and evidence was insufficient to fully disentangle the effects of these factors. Pain and function were the most commonly reported outcomes, with limited evidence on quality of life, health status (e.g., SF-36), mood, analgesic (including opioid) use, and other outcomes. Most results were based on mean differences in outcomes, with few trials reporting the likelihood of achieving a clinically relevant response. Data on harms were relatively sparse and inconsistently reported. The trials were not designed to evaluate how benefits and harms varied in populations defined by demographic, clinical, or technical factors. Data on long-term ( $\geq 1$ year) outcomes was relatively limited.

For the other interventional procedures evaluated in this report, the major limitation was the small numbers of trials, with important methodological shortcomings in almost all available trials. There was also variability with regard to use of sham or usual care comparators, as well as among sham and usual care treatments, representing a potential source of heterogeneity. Usual care was often not well described, making it difficult to determine applicability to clinical practice. For kyphoplasty, a major limitation is the absence of sham-controlled trials.

\section{Research Recommendations}

For vertebroplasty, the need for additional RCTs has been questioned, given moderate to high certainty that benefits are likely to be no greater than small. ${ }^{142}$ However, a number of outstanding questions regarding vertebroplasty remain, including whether some sham interventions have therapeutic effects and whether benefits are greater in patients with hyperacute (e.g., $<3$ weeks pain). If conducted, future RCTs should be sham-controlled to reduce potential placebo effects and be designed to address effects of pain duration on effects of vertebroplasty (e.g., via sufficiently powered subgroup analyses of patients with $<3$ weeks and of patients with $<3$ weeks and 3 to 6 weeks pain), whether periosteal infiltration with local anesthetic without administration of PMMA is associated with an independent, persistent therapeutic effect (e.g., via inclusion of control arms using different sham with and without periosteal local anesthetic), and long-term outcomes, including harms. Alternatively, an individual patient data meta-analysis of existing trials could more robustly evaluate how factors such as pain duration, baseline pain severity, PMMA volume, MRI findings, and other factors impact outcomes of vertebroplasty. Comparator treatments, including the components of usual care, should be described with sufficient detail to determine applicability to practice.

For the other procedures addressed in this report, there is a need for rigorous RCTs to clarify benefits and harms. As illustrated by the example of intradiscal methylene blue, promising results of future RCTs will require confirmatory trials. Ideally, future RCTs should attempt to minimize placebo effects by utilizing appropriate sham interventions and include rigorous assessment of harms and longer-term outcomes. For cooled radiofrequency for sacroiliac pain, additional research would be helpful to clarify optimal techniques, given the variability in methods between the two available trials. ${ }^{103,104}$ Prospective clinical registries designed to 
evaluate uncommon and serious harms would be a useful supplement to RCTs, given likely sample size limitations.

\section{Conclusions}

Vertebroplasty is probably effective at reducing pain and improving function in older patients with vertebral compression fractures; benefits are small but similar to other therapies recommended for pain. Evidence was too limited to separate effects of control type and symptom acuity on effectiveness of vertebroplasty. Kyphoplasty has not been compared against sham, but is probably more effective than usual care for vertebral compression fractures in older patients. In younger populations, cooled radiofrequency denervation is probably more effective than sham for sacroiliac pain. Research is needed to determine the benefits and harms of the other interventional procedures and conditions addressed in this review. 


\section{References}

1. Institute of Medicine. Relieving Pain in America: A Blueprint for Transforming Prevention, Care, Education, and Research. Washington, DC: The National Academies Press; 2011.

2. Treede RD, Rief W, Barke A, et al. Chronic pain as a symptom or a disease: the IASP Classification of Chronic Pain for the International Classification of Diseases (ICD-11). Pain. 2019 Jan;160(1):19-27. doi: 10.1097/j.pain.0000000000001384. PMID: 30586067.

3. Gaskin DJ, Richard P. The Economic Costs of Pain in the United States. J. Pain. 2012;13(8):715-24. doi:

10.1016/j.jpain.2012.03.009. PMID: 22607834

4. Dahlhamer J, Lucas J, Zelaya C, et al. Prevalence of Chronic Pain and HighImpact Chronic Pain Among Adults - United States, 2016. 0149-2195 (Print) 0149-2195. Sep 14 2018. doi:

10.15585/mmwr.mm6736a2. PMID: 30212442 .

5. Morden NE, Munson JC, Colla CH, et al. Prescription opioid use among disabled Medicare beneficiaries: intensity, trends, and regional variation. Med Care. 2014 Sep;52(9):852-9. doi: 10.1097/mlr.0000000000000183. PMID: 25119955 .

6. Makris UE, Abrams RC, Gurland B, et al. Management of persistent pain in the older patient: a clinical review. JAMA.

2014;312(8):825-36. doi: 10.1001/jama.2014.9405. PMID: 25157726.

7. Cavalieri TA. Managing pain in geriatric patients. J Am Osteopath Assoc. 2007;107(suppl_4):ES10-ES6.

8. Kuo YF, Raji MA, Chen NW, et al. Trends in opioid prescriptions among Part D medicare recipients from 2007 to 2012 . Am J Med. 2016 Feb;129(2):221.e21-30. doi: 10.1016/j.amjmed.2015.10.002. PMID: 26522794 .
9.

Olfson M, Wang S, Wall MM, et al. Trends in opioid prescribing and self-reported pain among US adults. Health Aff (Millwood). 2020 Jan;39(1):146-54. doi: 10.1377/hlthaff.2019.00783. PMID: 31905067.

10. Hargan ED, Department of Health and Human Services. Determination that a public health emergency exists (https://www.cms.gov/About-CMS/AgencyInformation/Emergency/Downloads/October 262017 Public Health_Declaration for Opioids_Crisis.pdf). 2017 Oct.

11. Weiss AJ, Heslin KC, Barrett ML, et al. Opioid-related Inpatient Stays and Emergency Department Visits Among Patients aged 65 Years and Older, 2010 and 2015: Statistical brief \#244 Agency for Healthcare Research and Quality (US). Rockville (MD): 2006. PMID: 30475561.

12. Huhn AS, Strain EC, Tompkins DA, et al. A hidden aspect of the U.S. opioid crisis: Rise in first-time treatment admissions for older adults with opioid use disorder. Drug Alcohol Depend. 2018 Dec 1;193:142-7. doi: 10.1016/j.drugalcdep.2018.10.002. PMID: 30384321.

13. Centers for Disease Control and Prevention. 2018 Annual Surveillance Report of DrugRelated Risks and Outcomes - United States. Surveillance Special Report. U.S. Department of Health and Human Services; August 31, 2018.

https://www.cdc.gov/drugoverdose/pdf/pubs /2018-cdc-drug-surveillance-report.pdf. Accessed July 7, 2020.

14. Schieber LZ, Guy GP, Jr., Seth P, et al. Variation in Adult Outpatient Opioid Prescription Dispensing by Age and Sex United States, 2008-2018. MMWR Morb Mortal Wkly Rep. 2020 Mar 20;69(11):298302. doi: 10.15585/mmwr.mm6911a5. PMID: 32191686.

15. Dowell D, Haegerich TM, Chou R. CDC Guideline for Prescribing Opioids for Chronic Pain--United States, 2016. Jama. 2016 Apr 19;315(15):1624-45. doi: 10.1001/jama.2016.1464. PMID: 26977696. 
16. Dowell D, Haegerich TM, Chou R. CDC Guideline for Prescribing Opioids for Chronic Pain - United States, 2016. 10575987. Mar 18 2016. doi:

10.15585/mmwr.rr6501e1. PMID: 26987082.

17. Reisner L. Pharmacological management of persistent pain in older persons. J Pain. 2011 Mar;12(3 Suppl 1):S21-9. doi:

10.1016/j.jpain.2011.01.001. PMID: 21396598.

18. Pain Management Best Practices InterAgency Task Force Report: Updates, Apps, Inconsistencies, and Recommendations. Final Report. U.S. Department of Health and Human Services; May 9, 2019. Available at: https://www.hhs.gov/ash/advisorycommittees/pain/reports/index.html. Accessed July 2, 2020.

19. Manchikanti L, Singh V, Hirsch JA. Facility payments for interventional pain management procedures: Impact of proposed rules. Pain physician. 2016 SepOct;19(7):E957-84. PMID: 27676688.

20. Gazelka HM, Leal JC, Lapid MI, et al. Opioids in older adults: indications, prescribing, complications, and alternative therapies for primary care. Mayo Clin Proc. 2020 Apr;95(4):793-800. doi: 10.1016/j.mayocp.2020.02.002. PMID: 32247352 .

21. Skelly A. Integrated Pain Management Programs. 2020.

22. Buchbinder R, Johnston RV, Rischin KJ, et al. Percutaneous vertebroplasty for osteoporotic vertebral compression fracture. Cochrane Database Syst Rev. 2018 Nov 06;11:CD006349. doi: 10.1002/14651858.CD006349.pub4. PMID: 30399208 .

23. Davies E. No more vetebroplasty for acute vertebral compression fractures? Bmj. 2018 May 9;361:k1756. doi: 10.1136/bmj.k1756. PMID: 29743282.

24. Chappell ME, Lakshman R, Trotter P, et al. Radiofrequency denervation for chronic back pain: a systematic review and metaanalysis. BMJ Open. $2020 \mathrm{Jul}$ 21;10(7):e035540. doi: 10.1136/bmjopen2019-035540. PMID: 32699129.
25. Bhatia A, Hoydonckx Y, Peng P, et al. Radiofrequency procedures to relieve chronic hip pain: an evidence-based narrative review. Reg Anesth Pain Med. 2018 Jan;43(1):72-83. doi: 10.1097/aap.0000000000000694. PMID: 29140960.

26. Kapural L, Jolly S, Mantoan J, et al. Cooled Radiofrequency Neurotomy of the Articular Sensory Branches of the Obturator and Femoral Nerves - Combined Approach Using Fluoroscopy and Ultrasound Guidance: Technical Report, and Observational Study on Safety and Efficacy. Pain physician. 2018 May;21(3):279-84. PMID: 29871372.

27. Hintz A. Non-inferiority of Cooled vs Traditional Radiofrequency Ablation of the Lumbar Medial Branch Nerves in the Treatment of Axial Low Back Pain. The Spine Journal. 2017;17(10):S120. doi: 10.1016/j.spinee.2017.07.105.

28. Contreras Lopez WO, Navarro PA, Vargas $\mathrm{MD}$, et al. Pulsed radiofrequency versus continuous radiofrequency for facet joint low back pain: a systematic review. World Neurosurg. 2019 Feb;122:390-6. doi: 10.1016/j.wneu.2018.10.191. PMID: 30404055 .

29. Levi D, Horn S, Tyszko S, et al. Intradiscal Platelet-Rich Plasma Injection for Chronic Discogenic Low Back Pain: Preliminary Results from a Prospective Trial. Pain Med. 2016 Jun;17(6):1010-22. doi: 10.1093/pm/pnv053. PMID: 26814283.

30. Wu J, Du Z, Lv Y, et al. A new technique for the treatment of lumbar facet joint syndrome using intra-articular injection with autologous platelet rich plasma. Pain physician. 2016 Nov-Dec;19(8):617-25. PMID: 27906940.

31. Meisel HJ, Agarwal N, Hsieh PC, et al. Cell therapy for treatment of intervertebral disc degeneration: a systematic review. Global spine j. 2019 May;9(1 Suppl):39s-52s. doi: 10.1177/2192568219829024. PMID: 31157145 . 
32. Kim SH, Ahn SH, Cho YW, et al. Effect of Intradiscal Methylene Blue Injection for the Chronic Discogenic Low Back Pain: One Year Prospective Follow-up Study. Ann Rehabil Med. 2012 Oct;36(5):657-64. doi: 10.5535/arm.2012.36.5.657. PMID: 23185730

33. Ezeldin M, Leonardi M, Princiotta C, et al. Percutaneous ozone nucleolysis for lumbar disc herniation. Neuroradiology. 2018;60(11):1231-41. doi: 10.1007/s00234018-2083-4. PMID: 132699262. Language: English. Entry Date: 20181102. Revision Date: 20191101. Publication Type: Article.

34. Ho KWD, Przkora R, Kumar S. Sphenopalatine ganglion: block, radiofrequency ablation and neurostimulation - a systematic review. J Headache Pain. 2017 Dec 28;18(1):118. doi: 10.1186/s10194-017-0826-y. PMID: 29285576.

35. Lambru G, Matharu MS. Occipital nerve stimulation in primary headache syndromes. Ther Adv Neurol Disord. 2012 Jan;5(1):5767. doi: 10.1177/1756285611420903. PMID: 22276076.

36. Boyajian-O'Neill LA, McClain RL, Coleman MK, et al. Diagnosis and management of piriformis syndrome: an osteopathic approach. J Am Osteopath Assoc. 2008 Nov;108(11):657-64. doi: 10.7556/jaoa.2008.108.11.657. PMID: 19011229 .

37. Hopayian K, Song F, Riera R, et al. The clinical features of the piriformis syndrome: a systematic review. Eur Spine J. 2010 Dec;19(12):2095-109. doi: 10.1007/s00586010-1504-9. PMID: 20596735.

38. Kozak J, Kobesova A, Vrba I, et al. Peripheral nerve stimulation in intractable neuropathic pain. Neuro Endocrinol Lett. 2011;32(3):226-33. PMID: 21712779.

39. Duarte RV, Nevitt S, McNicol E, et al. Systematic review and meta-analysis of placebo/sham controlled randomised trials of spinal cord stimulation for neuropathic pain. Pain. 2020 Jan;161(1):24-35. doi: 10.1097/j.pain.0000000000001689. PMID: 31453983 .
40. Weinstein EJ, Levene JL, Cohen MS, et al. Local anaesthetics and regional anaesthesia versus conventional analgesia for preventing persistent postoperative pain in adults and children. Cochrane Database Syst Rev. 2018 Apr 25;4(4):Cd007105. doi: 10.1002/14651858.CD007105.pub3. PMID: 29694674.

41. Practice guidelines for acute pain management in the perioperative setting: an updated report by the American Society of Anesthesiologists Task Force on Acute Pain Management. Anesthesiology. 2012 Feb;116(2):248-73. doi: 10.1097/ALN.0b013e31823c1030. PMID: 22227789.

42. Chou R, Gordon DB, de Leon-Casasola OA, et al. Management of Postoperative Pain: A Clinical Practice Guideline From the American Pain Society, the American Society of Regional Anesthesia and Pain Medicine, and the American Society of Anesthesiologists' Committee on Regional Anesthesia, Executive Committee, and Administrative Council. J Pain. 2016 Feb;17(2):131-57. doi: 10.1016/j.jpain.2015.12.008. PMID: 26827847.

43. Oliveira CB, Maher CG, Ferreira ML, et al. Epidural corticosteroid injections for lumbosacral radicular pain. Cochrane Database Syst Rev. 2020 Apr 9;4(4):Cd013577. doi: 10.1002/14651858.Cd013577. PMID: 32271952 .

44. Chou R, Hashimoto R, Friedly J, et al. Epidural Corticosteroid Injections for Radiculopathy and Spinal Stenosis: A Systematic Review and Meta-analysis. Ann Intern Med. 2015 Sep 1;163(5):373-81. doi: 10.7326/m15-0934. PMID: 26302454.

45. Methods Guide for Effectiveness and Comparative Effectiveness Reviews. Rockville, MD: Agency for Healthcare Research and Quality. https://effectivehealthcare.ahrq.gov/topics/ce r-methods-guide/overview. Accessed September 21, 2020.

46. Gamerman V, Cai T, Elsäßer A. Pragmatic randomized clinical trials: best practices and statistical guidance. Health Serv Outcomes Res Methodol. 2019;19(1):23-35. doi: 10.1007/s10742-018-0192-5. 
47. Guyatt GH, Oxman AD, Kunz R, et al. What is "quality of evidence" and why is it important to clinicians? Bmj. 2008 May 3;336(7651):995-8. doi:

10.1136/bmj.39490.551019.BE. PMID: 18456631 .

48. Cohen SP, Wallace M, Rauck RL, et al. Unique aspects of clinical trials of invasive therapies for chronic pain. Pain Rep. 2019 May-Jun;4(3):e687. doi: 10.1097/pr9.0000000000000687. PMID: 31583336.

49. Carragee EJ. The vertebroplasty affair: the mysterious case of the disappearing effect size. Spine J. 2010 Mar;10(3):191-2. doi: 10.1016/j.spinee.2010.01.002. PMID: 20207329.

50. Cyteval C, Fescquet N, Thomas E, et al. Predictive factors of efficacy of periradicular corticosteroid injections for lumbar radiculopathy. AJNR Am J Neuroradiol. 2006 May;27(5):978-82. PMID: 16687527.

51. Weiner BK, Fraser RD. Foraminal injection for lateral lumbar disc herniation. J Bone Joint Surg Br. 1997 Sep;79(5):804-7. doi: 10.1302/0301-620x.79b5.7636. PMID: 9331040 .

52. Wang JC, Lin E, Brodke DS, et al. Epidural injections for the treatment of symptomatic lumbar herniated discs. J Spinal Disord Tech. 2002 Aug;15(4):269-72. doi: 10.1097/00024720-200208000-00001. PMID: 12177540.

53. Vad VB, Bhat AL, Lutz GE, et al. Transforaminal epidural steroid injections in lumbosacral radiculopathy: a prospective randomized study. Spine (Phila Pa 1976). 2002 Jan 1;27(1):11-6. doi: 10.1097/00007632-200201010-00005. PMID: 11805628.

54. Karasek M, Bogduk N. Twelve-month follow-up of a controlled trial of intradiscal thermal anuloplasty for back pain due to internal disc disruption. Spine (Phila $\mathrm{Pa}$ 1976). 2000 Oct 15;25(20):2601-7. doi: 10.1097/00007632-200010150-00010. PMID: 11034644.
55. Bogduk N, Karasek M. Two-year follow-up of a controlled trial of intradiscal electrothermal anuloplasty for chronic low back pain resulting from internal disc disruption. Spine J. 2002 Sep-Oct;2(5):34350. doi: 10.1016/s1529-9430(02)00409-6. PMID: 14589465.

56. Saal JA, Saal JS. Intradiscal electrothermal treatment for chronic discogenic low back pain: a prospective outcome study with minimum 1-year follow-up. Spine (Phila $\mathrm{Pa}$ 1976). 2000 Oct 15;25(20):2622-7. doi: 10.1097/00007632-200010150-00013. PMID: 11034647.

57. Henschke N, Kuijpers T, Rubinstein SM, et al. Injection therapy and denervation procedures for chronic low-back pain: a systematic review. Eur Spine J. 2010 Sep;19(9):1425-49. doi: 10.1007/s00586010-1411-0. PMID: 20424870.

58. Chou R, Aronson N, Atkins D, et al. AHRQ series paper 4: assessing harms when comparing medical interventions: AHRQ and the effective health-care program. Journal of clinical epidemiology. 2010 May;63(5):502-12. doi: 10.1016/j.jclinepi.2008.06.007. PMID: 18823754.

59. 7.7.3.2 Obtaining standard deviations from standard errors and confidence intervals for group means. https://handbook-51.cochrane.org/chapter 7/7 $7 \quad 3 \quad 2$ obtainin $\mathrm{g}$ standard deviations from standard error s and.htm. Accessed February 26, 2021.

60. MedCalc. Relative risk calculator. https://www.medcalc.org/calc/relative_risk. php. Accessed February 26, 2021.

61. MedCalc. Comparison means calculator. https://www.medcalc.org/calc/comparison_o f_means.php. Accessed February 26, 2021.

62. Viswanathan M, Patnode CD, Berkman ND, et al. Chapter 9: Assessing the Risk of Bias of Individual Studies in Systematic Reviews of Health Care Interventions. In: Methods Guide for Effectiveness and Comparative Effectiveness Reviews. AHRQ Publication No. 10(14)-EHC063-EF. Rockville, MD: Agency for Healthcare Research and Quality; Jan 2014. Chapters available at: www.effectivehealthcare.ahrq.gov. 
63. Higgins J, Green S. Cochrane Handbook for Systematic Reviews of Interventions.

Version 5.1. 0. The Cochrane Collaboration; March 2011. http://handbook-5-

1.cochrane.org/. Accessed September 21, 2020.

64. U.S. Preventive Services Task Force Procedure Manual. https://www.uspreventiveservicestaskforce.o rg/uspstf/procedure-manual. Accessed September 21, 2020.

65. Morton SC, Murad MH, O'Connor E, et al. Quantitative Synthesis-An Update.

Methods Guide for Comparative Effectiveness Reviews. (Prepared by the Scientific Resource Center under Contract No. 290-2012-0004-C). AHRQ Publication No. 18-EHC007-EF. Rockville, MD: Agency for Healthcare Research and Quality; February 2018. Posted final reports are located on the Effective Health Care Program search page (https://effectivehealthcare.ahrq.gov/). https://doi.org/10.23970/AHRQEPCMETH GUIDE3.

66. Systematic Review Update: Noninvasive Nonpharmacologic Treatments for Chronic Pain. Agency for Healthcare Research and Quality. https://effectivehealthcare.ahrq.gov/topics/n oninvasive-nonpharm-pain-update/protocol. Accessed August 8, 2019.

67. Nonopioid Pharmacologic Treatments for Chronic Pain. Agency for Healthcare Research and Quality. https:/effectivehealthcare.ahrq.gov/topics/n onopioid-chronic-pain/protocol. Accessed August 8, 2019.

68. Opioid Treatments for Chronic Pain. Agency for Healthcare Research and Quality.

https://effectivehealthcare.ahrq.gov/topics/o pioids-chronic-pain/protocol. Accessed August 8, 2019.

69. Chou R, Deyo R, Friedly J, et al.

Noninvasive Treatments for Low Back Pain. Comparative Effectiveness Review No. 169. (Prepared by the Pacific Northwest Evidence-based Practice Center under Contract No. 290-2012-00014-I.) AHRQ Publication No. 16-EHC004-EF. Rockville, MD: Agency for Healthcare Research and Quality; February 2016.
70. Skelly AC, Chou R, Dettori JR, et al. Noninvasive Nonpharmacological Treatment for Chronic Pain: A Systematic Review. Comparative Effectiveness Review No. 209. (Prepared by the Pacific Northwest Evidence-based Practice Center under Contract No. 290-2015-00009-I.) AHRQ Publication No 18-EHC013-EF. : . Rockville, MD: Agency for Healthcare Research and Quality; June 2018. https://effectivehealthcare.ahrq.gov/topics/n onpharma-treatment-pain/research-2018 PMID: 30179389.

71. Escobar A, Quintana JM, Bilbao A, et al. Responsiveness and clinically important differences for the WOMAC and SF-36 after total knee replacement. Osteoarthritis Cartilage. 2007 Mar;15(3):273-80. doi: 10.1016/j.joca.2006.09.001. PMID: 17052924.

72. Ostelo RW, Deyo RA, Stratford P, et al. Interpreting change scores for pain and functional status in low back pain: towards international consensus regarding minimal important change. Spine (Phila Pa 1976). 2008 Jan 1;33(1):90-4. doi: 10.1097/BRS.0b013e31815e3a10. PMID: 18165753.

73. Skelly AC, Chou R, Dettori JR, et al. AHRQ Comparative Effectiveness Reviews.

Noninvasive Nonpharmacological Treatment for Chronic Pain: A Systematic Review Update. Rockville (MD): Agency for Healthcare Research and Quality (US); 2020.

74. Ferreira GE, McLachlan AJ, Lin CC, et al. Efficacy and safety of antidepressants for the treatment of back pain and osteoarthritis: systematic review and meta-analysis. Bmj. 2021 Jan 20;372:m4825. doi: 10.1136/bmj.m4825. PMID: 33472813.

75. Machado GC, Maher CG, Ferreira PH, et al. Non-steroidal anti-inflammatory drugs for spinal pain: a systematic review and metaanalysis. Ann Rheum Dis. 2017

Jul;76(7):1269-78. doi:

10.1136/annrheumdis-2016-210597. PMID: 28153830 . 
76. Busse JW, Wang L, Kamaleldin M, et al. Opioids for Chronic Noncancer Pain: A Systematic Review and Meta-analysis. Jama. 2018 Dec 18;320(23):2448-60. doi: 10.1001/jama.2018.18472. PMID: 30561481 .

77. Jayadevappa R, Cook R, Chhatre S. Minimal important difference to infer changes in health-related quality of life-a systematic review. Journal of clinical epidemiology. 2017 Sep;89:188-98. doi: 10.1016/j.jclinepi.2017.06.009. PMID: 28676426.

78. Keurentjes JC, Van Tol FR, Fiocco M, et al. Minimal clinically important differences in health-related quality of life after total hip or knee replacement: A systematic review. Bone Joint Res. 2012 May;1(5):71-7. doi: 10.1302/2046-3758.15.2000065. PMID: 23610674.

79. Buchbinder R, Osborne RH, Ebeling PR, et al. A randomized trial of vertebroplasty for painful osteoporotic vertebral fractures. N Engl J Med. 2009 Aug 06;361(6):557-68. doi: 10.1056/NEJMoa0900429. PMID: 19657121.

80. Clark W, Bird P, Gonski P, et al. Safety and efficacy of vertebroplasty for acute painful osteoporotic fractures (VAPOUR): a multicentre, randomised, double-blind, placebo-controlled trial. Lancet. 2016 Oct 01;388(10052):1408-16. doi: 10.1016/S0140-6736(16)31341-1. PMID: 27544377.

81. Firanescu CE, de Vries J, Lodder P, et al. Vertebroplasty versus sham procedure for painful acute osteoporotic vertebral compression fractures (VERTOS IV): randomised sham controlled clinical trial. Bmj. 2018 May 09;361:k1551. doi: 10.1136/bmj.k1551. PMID: 29743284.

82. Hansen E, Simony A, Carreon L, et al. Vertebroplasty vs. SHAM for Treating Osteoporotic Vertebral Compression Fractures: A Double Blind RCT. Integr J Orthop Traumatol. 2019;2(4):1-6. doi: 10.31038/IJOT.2019244.
83. Kallmes DF, Comstock BA, Heagerty PJ, et al. A randomized trial of vertebroplasty for osteoporotic spinal fractures. N Engl J Med. 2009 Aug 06;361(6):569-79. doi: 10.1056/NEJMoa0900563. PMID: 19657122.

84. Blasco J, Martinez-Ferrer A, Macho J, et al. Effect of vertebroplasty on pain relief, quality of life, and the incidence of new vertebral fractures: a 12-month randomized follow-up, controlled trial. J Bone Miner Res. 2012 May;27(5):1159-66. doi: 10.1002/jbmr.1564. PMID: 22513649.

85. Chen D, An ZQ, Song S, et al. Percutaneous vertebroplasty compared with conservative treatment in patients with chronic painful osteoporotic spinal fractures. J Clin Neurosci. 2014 Mar;21(3):473-7. doi: 10.1016/j.jocn.2013.05.017. PMID: 24315046.

86. Farrokhi MR, Alibai E, Maghami Z. Randomized controlled trial of percutaneous vertebroplasty versus optimal medical management for the relief of pain and disability in acute osteoporotic vertebral compression fractures. J Neurosurg Spine. 2011 May;14(5):561-9. doi: 10.3171/2010.12.SPINE10286. PMID: 21375382.

87. Klazen CA, Lohle PN, de Vries J, et al. Vertebroplasty versus conservative treatment in acute osteoporotic vertebral compression fractures (Vertos II): an openlabel randomised trial. Lancet. $2010 \mathrm{Sep}$ 25;376(9746):1085-92. doi: 10.1016/S01406736(10)60954-3. PMID: 20701962.

88. Leali PT, Solla F, Maestretti G, et al. Safety and efficacy of vertebroplasty in the treatment of osteoporotic vertebral compression fractures: A prospective multicenter international randomized controlled study. Clin. 2016 SepDec;13(3):234-6. doi: 10.11138/ccmbm/2016.13.3.234. PMID: 28228788. 
89. Rousing R, Andersen MO, Jespersen SM, et al. Percutaneous vertebroplasty compared to conservative treatment in patients with painful acute or subacute osteoporotic vertebral fractures: three-months follow-up in a clinical randomized study. Spine. 2009 Jun 01;34(13):1349-54. doi: 10.1097/BRS.0b013e3181a4e628. PMID: 19478654.

90. Voormolen MH, Mali WP, Lohle PN, et al. Percutaneous vertebroplasty compared with optimal pain medication treatment: shortterm clinical outcome of patients with subacute or chronic painful osteoporotic vertebral compression fractures. The VERTOS study. AJNR Am J Neuroradiol. 2007 Mar;28(3):555-60. PMID: 17353335.

91. Yang EZ, Xu JG, Huang GZ, et al. Percutaneous vertebroplasty versus conservative treatment in aged patients with acute osteoporotic vertebral compression fractures: a prospective randomized controlled clinical study. Spine. 2016 Apr;41(8):653-60. doi: 10.1097/BRS.0000000000001298. PMID: 26630417.

92. Kroon F, Staples M, Ebeling PR, et al. Twoyear results of a randomized placebocontrolled trial of vertebroplasty for acute osteoporotic vertebral fractures. J Bone Miner Res. 2014 Jun;29(6):1346-55. doi: 10.1002/jbmr.2157. PMID: 24967454.

93. Staples MP, Howe BM, Ringler MD, et al. New vertebral fractures after vertebroplasty: 2-year results from a randomised controlled trial. Arch Osteoporos. 2015;10:229. doi: 10.1007/s11657-015-0229-0. PMID: 26272712 .

94. Diamond T, Clark W, Bird P, et al. Early vertebroplasty within 3 weeks of fracture for acute painful vertebral osteoporotic fractures: subgroup analysis of the VAPOUR trial and review of the literature. Eur Spine J. 2020 Jul;29(7):1606-13. doi: 10.1007/s00586-020-06362-2. PMID: 32170438 .

95. Firanescu CE, de Vries J, Lodder P, et al. Percutaneous vertebroplasty is no risk factor for new vertebral fractures and protects against further height loss(VERTOS IV). Cardiovasc Intervent Radiol. 2019 Jul;42(7):991-1000. doi: 10.1007/s00270019-02205-w. PMID: 30941490.
96. Comstock BA, Sitlani CM, Jarvik JG, et al. Investigational vertebroplasty safety and efficacy trial (INVEST): patient-reported outcomes through 1 year. Radiology. 2013 Oct;269(1):224-31. doi: 10.1148/radiol.13120821. PMID: 23696683.

97. Venmans A, Klazen CA, van Rooij WJ, et al. Postprocedural CT for perivertebral cement leakage in percutaneous vertebroplasty is not necessary--results from VERTOS II. Neuroradiology. 2011 Jan;53(1):19-22. doi: 10.1007/s00234-0100705-6. PMID: 20442991.

98. Rousing R, Hansen KL, Andersen MO, et al. Twelve-months follow-up in forty-nine patients with acute/semiacute osteoporotic vertebral fractures treated conservatively or with percutaneous vertebroplasty: a clinical randomized study. Spine. 2010 Mar 01;35(5):478-82. doi: 10.1097/BRS.0b013e3181b71bd1. PMID: 20190623.

99. Berenson J, Pflugmacher R, Jarzem P, et al. Balloon kyphoplasty versus non-surgical fracture management for treatment of painful vertebral body compression fractures in patients with cancer: a multicentre, randomised controlled trial. The lancet. 2011; Oncology. 12(3):225-35. PMID: CN00787315.

100. Boonen S, Van Meirhaeghe J, Bastian L, et al. Balloon kyphoplasty for the treatment of acute vertebral compression fractures: 2year results from a randomized trial. J Bone Miner Res. 2011 Jul;26(7):1627-37. doi: 10.1002/jbmr.364. PMID: 21337428.

101. Van Meirhaeghe J, Bastian L, Boonen S, et al. A randomized trial of balloon kyphoplasty and nonsurgical management for treating acute vertebral compression fractures: vertebral body kyphosis correction and surgical parameters. Spine. 2013 May 20;38(12):971-83. doi: 10.1097/BRS.0b013e31828e8e22. PMID: 23446769.

102. Wardlaw D, Cummings SR, Van Meirhaeghe J, et al. Efficacy and safety of balloon kyphoplasty compared with nonsurgical care for vertebral compression fracture (FREE): a randomised controlled trial. Lancet. 2009 Mar 21;373(9668):101624. doi: 10.1016/S0140-6736(09)60010-6. PMID: 19246088. 
103. Cohen SP, Hurley RW, Buckenmaier CC, 3rd, et al. Randomized placebo-controlled study evaluating lateral branch

radiofrequency denervation for sacroiliac joint pain. Anesthesiology. 2008

Aug;109(2):279-88. doi: 10.1097/ALN.0b013e31817f4c7c. PMID: 18648237.

104. Patel N, Gross A, Brown L, et al. A randomized, placebo-controlled study to assess the efficacy of lateral branch neurotomy for chronic sacroiliac joint pain. Pain Med. 2012 Mar;13(3):383-98. doi: 10.1111/j.1526-4637.2012.01328.x. PMID: 22299761 .

105. McCormick ZL, Choi H, Reddy R, et al. Randomized prospective trial of cooled versus traditional radiofrequency ablation of the medial branch nerves for the treatment of lumbar facet joint pain. Reg Anesth Pain Med. 2019 Mar;44(3):389-97. doi: 10.1136/rapm-2018-000035. PMID: 30777903.

106. Tekin I, Mirzai H, Ok G, et al. A comparison of conventional and pulsed radiofrequency denervation in the treatment of chronic facet joint pain. Clin J Pain. 2007 Jul-Aug;23(6):524-9. PMID: 17575493.

107. Moussa WM, Khedr W, Elsawy M. Percutaneous pulsed radiofrequency treatment of dorsal root ganglion for treatment of lumbar facet syndrome. Clin Neurol Neurosurg. 2020 Dec;199:106253. doi: 10.1016/j.clineuro.2020.106253. PMID: 33045627 .

108. Kroll HR, Kim D, Danic MJ, et al. A randomized, double-blind, prospective study comparing the efficacy of continuous versus pulsed radiofrequency in the treatment of lumbar facet syndrome. J Clin Anesth. 2008 Nov;20(7):534-7. doi:

10.1016/j.jclinane.2008.05.021. PMID: 19041042.

109. Tuakli-Wosornu YA, Terry A, BoachieAdjei K, et al. Lumbar intradiskal plateletrich plasma (PRP) injections: A prospective, double-blind, randomized controlled study.

Pm R. 2016 Jan;8(1):1-10; quiz doi: 10.1016/j.pmrj.2015.08.010. PMID: 26314234.
110. Amirdelfan K, Bae H, McJunkin T, et al. Allogeneic mesenchymal precursor cells treatment for chronic low back pain associated with degenerative disc disease: a prospective randomized, placebo-controlled 36-month study of safety and efficacy. Spine J. 2020 Oct 09;09:212-30. doi: 10.1016/j.spinee.2020.10.004. PMID: 33045417.

111. Kallewaard JW, Wintraecken VM, Geurts JW, et al. A multicenter randomized controlled trial on the efficacy of intradiscal methylene blue injection for chronic discogenic low back pain: the IMBI study. Pain. 2019 Apr;160(4):945-53. doi: 10.1097/j.pain.0000000000001475. PMID: 30730862.

112. Peng B, Pang X, Wu Y, et al. A randomized placebo-controlled trial of intradiscal methylene blue injection for the treatment of chronic discogenic low back pain. Pain. 2010 Apr;149(1):124-9. doi: 10.1016/j.pain.2010.01.021. PMID: 20167430.

113. Gallucci M, Limbucci N, Zugaro L, et al. Sciatica: treatment with intradiscal and intraforaminal injections of steroid and oxygen-ozone versus steroid only. Radiology. 2007 Mar;242(3):907-13. PMID: 17209164.

114. Haseeb AESA, Abd El Hares AEH, Abd El Moez KM, et al. Comparative Study between Treatment of Lumbar Disc Herniation with Intra Discal Ozone and Transforaminal Steroid Injection versus Steroid Injection only. The Egyptian Journal of Hospital Medicine. 2019;74(4):705-20. doi: 10.12816/ejhm.2019.24068.

115. Nilachandra L, Darendrajit L, Joy Singh A, et al. Ozone nucleolysis in the management of prolapsed lumbar intervertebral disc in reducing pain and disability: a randomized controlled study. PARIPEX-Indian Journal of Research. 2016 Nov;5(11):51-4.

116. Cady RK, Saper J, Dexter K, et al. Longterm efficacy of a double-blind, placebocontrolled, randomized study for repetitive sphenopalatine blockade with bupivacaine vs. saline with the Tx360 device for treatment of chronic migraine. Headache. 2015 Apr;55(4):529-42. doi:

10.1111/head.12546. PMID: 25828648. 
117. Cady R, Saper J, Dexter K, et al. A doubleblind, placebo-controlled study of repetitive transnasal sphenopalatine ganglion blockade with tx360( R) as acute treatment for chronic migraine. Headache. 2015 Jan;55(1):101-16. doi: 10.1111/head.12458. PMID: 25338927.

118. Saper JR, Dodick DW, Silberstein SD, et al. Occipital nerve stimulation for the treatment of intractable chronic migraine headache: ONSTIM feasibility study. Cephalalgia. 2011 Feb;31(3):271-85. doi: 10.1177/0333102410381142. PMID: 20861241.

119. Serra G, Marchioretto F. Occipital nerve stimulation for chronic migraine: a randomized trial. Pain physician. 2012 MayJun;15(3):245-53. PMID: 22622909.

120. Silberstein SD, Dodick DW, Saper J, et al. Safety and efficacy of peripheral nerve stimulation of the occipital nerves for the management of chronic migraine: results from a randomized, multicenter, doubleblinded, controlled study. Cephalalgia. 2012 Dec;32(16):1165-79. doi: 10.1177/0333102412462642. PMID: 23034698.

121. Mekhail NA, Estemalik E, Azer G, et al. Safety and efficacy of occipital nerves stimulation for the treatment of chronic migraines: randomized, double-blind, controlled single-center experience. Pain pract. 2017 Jun;17(5):669-77. doi: 10.1111/papr.12504. PMID: 27779368.

122. Childers MK, Wilson DJ, Gnatz SM, et al. Botulinum toxin type A use in piriformis muscle syndrome: a pilot study. Am J Phys Med Rehabil. 2002 Oct;81(10):751-9. PMID: 12362115.

123. Fishman LM, Anderson C, Rosner B. BOTOX and physical therapy in the treatment of piriformis syndrome. Am J Phys Med Rehabil. 2002 Dec;81(12):93642. doi: 10.1097/00002060-20021200000009. PMID: 12447093.

124. Fishman LM, Wilkins AN, Rosner B. Electrophysiologically identified piriformis syndrome is successfully treated with incobotulinum toxin a and physical therapy. Muscle Nerve. 2017 Aug;56(2):258-63. doi: 10.1002/mus.25504. PMID: 27935076.
125. Misirlioglu TO, Akgun K, Palamar D, et al. Piriformis syndrome: comparison of the effectiveness of local anesthetic and corticosteroid injections: a double-blinded, randomized controlled study. Pain physician. 2015 Mar-Apr;18(2):163-71. PMID: 25794202.

126. Deer T, Pope J, Benyamin R, et al. Prospective, multicenter, randomized, double-blinded, partial crossover study to assess the safety and efficacy of the novel neuromodulation system in the treatment of patients with chronic pain of peripheral nerve origin. Neuromodulation. 2016 Jan;19(1):91-100. doi: 10.1111/ner.12381. PMID: 26799373.

127. Huskisson EC. Measurement of pain. J Rheumatol. 1982 Sep-Oct;9(5):768-9. PMID: 6184474.

128. Grotle M, Brox JI, Vøllestad NK. Concurrent comparison of responsiveness in pain and functional status measurements used for patients with low back pain. Spine (Phila Pa 1976). 2004 Nov 1;29(21):E492501. doi: 10.1097/01.brs.0000143664.02702.0b. PMID: 15507789.

129. Trout AT, Kallmes DF, Gray LA, et al. Evaluation of vertebroplasty with a validated outcome measure: the RolandMorris Disability Questionnaire. AJNR Am J Neuroradiol. 2005 Nov-Dec;26(10):26527. PMID: 16286418.

130. Bombardier C, Hayden J, Beaton DE. Minimal clinically important difference. Low back pain: outcome measures. J Rheumatol. 2001 Feb;28(2):431-8. PMID: 11246692.

131. Elnoamany HA. Influence of Vertebral Bone Marrow Edema on Outcome in Non-Acute Osteoporotic Patients Treated with Percutaneous Vertebroplasty. Asian spine j. 2016 Jun;10(3):436-42. doi: 10.4184/asj.2016.10.3.436. PMID: 27340521.

132. Boszczyk B. Volume matters: a review of procedural details of two randomised controlled vertebroplasty trials of 2009. Eur Spine J. 2010 Nov;19(11):1837-40. doi: 10.1007/s00586-010-1525-4. PMID: 20686793. 
133. Sanli I, van Kuijk SMJ, de Bie RA, et al. Percutaneous cement augmentation in the treatment of osteoporotic vertebral fractures (OVFs) in the elderly: a systematic review. Eur Spine J. 2020 Jul;29(7):1553-72. doi: 10.1007/s00586-020-06391-x. PMID: 32240375 .

134. Hinde K, Maingard J, Hirsch JA, et al. Mortality outcomes of vertebral augmentation (vertebroplasty and/or balloon kyphoplasty) for osteoporotic vertebral compression fractures: a systematic review and meta-analysis. Radiology. 2020 Apr;295(1):96-103. doi: 10.1148/radiol.2020191294. PMID: 32068503 .

135. Zhang H, Xu C, Zhang T, et al. Does percutaneous vertebroplasty or balloon kyphoplasty for osteoporotic vertebral compression fractures increase the incidence of new vertebral fractures? A meta-analysis. Pain physician. 2017 Jan-Feb;20(1):13-28. PMID: 28072794.

136. Rodriguez AJ, Fink HA, Mirigian L, et al. Pain, quality of life, and safety outcomes of kyphoplasty for vertebral compression fractures: report of a task force of the American society for bone and mineral research. J Bone Miner Res. 2017 Sep;32(9):1935-44. doi: 10.1002/jbmr.3170. PMID: 28513888.

137. Sun HH, Zhuang SY, Hong X, et al. The efficacy and safety of using cooled radiofrequency in treating chronic sacroiliac joint pain: A PRISMA-compliant metaanalysis. Medicine (Baltimore). 2018 Feb;97(6):9809. doi: 10.1097/MD.0000000000009809. PMID: 29419679.
138. Williams ACC, Fisher E, Hearn L, et al. Psychological therapies for the management of chronic pain (excluding headache) in adults. Cochrane Database Syst Rev. 2020 Aug 12;8(8):Cd007407. doi: 10.1002/14651858.CD007407.pub4. PMID: 32794606.

139. Proposed Local Coverage Determination (LCD): Percutaneous Vertebral Augmentation (PVA) for Vertebral Compression Fracture (VCF) (DL35130). https://www.cms.gov/medicare-coveragedatabase/details/led$\underline{\text { details.aspx } \text {.LCDId }=38876 \& \text { ver }=\& \text { NCAId }=}$ $\underline{143 \& \mathrm{MCDId}=5 \& \text { SearchType }=\text { Advanced } \&}$ CoverageSelection $=$ Both $\& N C S e l e c t i o n=N C$ A\%257CCAL\%257CNCD\%257CMEDCA

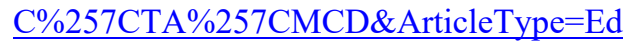
\%257CKey\%257CSAD\%257CFAQ\&Polic yType $=$ Final\&s $=5 \% 257 \mathrm{C} 6 \% 257 \mathrm{C} 66 \% 257 \mathrm{C}$ 67\%257C9\%257C $38 \% 257 \mathrm{C} 63 \% 257 \mathrm{C} 41 \% 2$ 57C64\%257C65\%257C44\&KeyWord=whe elchairs\&KeyWordLookUp=Doc\&KeyWor $\underline{\mathrm{d} \text { SearchType }}=$ Exact $\& \mathrm{kq}=$ true $\& \mathrm{bc}=\mathrm{IAAAA}$ CgAIAAA\&. Accessed February 26, 2021.

140. Carli D, Venmans A, Lodder P, et al. Vertebroplasty Versus Sham Intervention for Painful Chronic Osteoporotic Vertebral Compression Fractures (VERTOS 5): Randomised Sham Controlled Clinical Trial. SSRN Electronic Journal. 2020 Oct 27 doi: 10.2139/ssrn.3712918.

141. Sterne JA, Sutton AJ, Ioannidis JP, et al. Recommendations for examining and interpreting funnel plot asymmetry in metaanalyses of randomised controlled trials. Bmj. 2011 Jul 22;343:d4002. doi: 10.1136/bmj.d4002. PMID: 21784880.

142. Ebeling PR, Akesson K, Bauer DC, et al. The efficacy and safety of vertebral augmentation: a second ASBMR task force report. J Bone Miner Res. 2019 Jan;34(1):321. doi: 10.1002/jbmr.3653. PMID: 30677181 . 


\section{Abbreviations and Acronyms}

\begin{tabular}{|c|c|}
\hline ANOVA & analysis of variance \\
\hline ARD & absolute risk difference \\
\hline $\mathrm{BMD}$ & bone mineral density \\
\hline BME & bone marrow edema \\
\hline BMI & body mass index \\
\hline BPI & Brief Pain Inventory \\
\hline BTX-A & botulinum toxin type-A \\
\hline CAFE & Cancer Patient Fracture Evaluation \\
\hline $\mathrm{CI}$ & confidence interval \\
\hline CT & computed tomography \\
\hline EMG & electromyographic \\
\hline EQ-5D & EuroQOL 5-Dimension Questionnaire \\
\hline FAIR & flexion, adduction, internal rotation \\
\hline FREE & Fracture Reduction Evaluation \\
\hline HIT-6 & Headache Impact Test-6 \\
\hline HR & hazard ratio \\
\hline ICHD-II & International Classification of Headache Disorders, second edition \\
\hline IHS & International Headache Society \\
\hline IMBI & intradiscal methylene blue injection \\
\hline INVEST & Investigational Vertebroplasty Safety and Efficacy Trial \\
\hline IPG & implantable pulse generator \\
\hline IQR & interquartile range \\
\hline IU & International Unit \\
\hline LBP & low-back pain \\
\hline LSM & least squares mean \\
\hline MCS & Mental Component Summary \\
\hline MIDAS & migraine disability assessment \\
\hline MMSE & Mini-Mental State Exam \\
\hline MPC & mesenchymal precursor cell \\
\hline MR & magnetic resonance \\
\hline MRI & magnetic resonance imaging \\
\hline MRI-STIR & magnetic resonance imaging short tau inversion recovery \\
\hline NR & not reported \\
\hline NRS & numerical rating scale \\
\hline NS & not significant \\
\hline NSAID & nonsteroidal anti-inflammatory drug \\
\hline ODI & Oswestry Disability Index \\
\hline ONSTIM & $\begin{array}{l}\text { occipital nerve stimulation for the treatment of intractable chronic migraine } \\
\text { headache }\end{array}$ \\
\hline OR & odds ratio \\
\hline PCS & Physical Component Summary \\
\hline $\mathrm{PE}$ & pulmonary embolism \\
\hline PGIC & Patient's Global Impression of Change \\
\hline PMMA & polymethyl methacrylate \\
\hline
\end{tabular}




\begin{tabular}{|c|c|}
\hline PSI & pounds per square inch \\
\hline PVP & percutaneous vertebroplasty \\
\hline QALY & quality-adjusted life-year \\
\hline QUALEFFO & Quality of Life Questionnaire of the European Foundation for Osteoporosis \\
\hline $\mathrm{RCT}$ & randomized controlled trial \\
\hline RDQ & Roland-Morris Disability Questionnaire \\
\hline RFA & Radio frequency denervation/ablation \\
\hline RR & relative risk \\
\hline SAE & serious adverse event \\
\hline SD & standard deviation \\
\hline SF-12 & Short-Form 12 \\
\hline SF-36 & Short-Form 36 Health Survey \\
\hline $\mathrm{SF}-36 \mathrm{MCS}$ & Short-Form 36 Health Survey Mental Component Score \\
\hline SF-36 PCS & Short-Form 36 Health Survey Physical Component Score \\
\hline SMD & standard mean deviation \\
\hline SOF-ADL & Study of Osteoporotic Fractures-Activities of Daily Living \\
\hline TL & thoracolumbar junction \\
\hline VAPOUR & vertebroplasty for acute painful osteoporotic fractures \\
\hline VAS & visual analogue scale \\
\hline VB & vertebral body \\
\hline $\mathrm{VCF}$ & vertebral compression fracture \\
\hline VERTOS & $\begin{array}{l}\text { percutaneous vertebroplasty compared with optimal pain medication treatment: } \\
\text { short-term clinical outcome of patients with subacute or chronic painful } \\
\text { osteoporotic vertebral compression fractures }\end{array}$ \\
\hline VERTOS II & $\begin{array}{l}\text { vertebroplasty versus conservative treatments in acute osteoporotic vertebral } \\
\text { compression fractures }\end{array}$ \\
\hline VERTOS IV & $\begin{array}{l}\text { vertebroplasty versus sham procedure for painful acute osteoporotic vertebral } \\
\text { compression fractures }\end{array}$ \\
\hline VOPE & $\begin{array}{l}\text { vertebroplasty vs. sham for treating osteoporotic vertebral compression fractures: } \\
\text { a double blind RCT }\end{array}$ \\
\hline WHO & World Health Organization \\
\hline WPAI & Work Productivity and Activity Index \\
\hline
\end{tabular}




\section{Appendix A. Search Strategies}

Database: Ovid MEDLINE(R) ALL 1946 to December 08, 2020

1 Chronic Pain/

2 exp arthralgia/ or exp back pain/ or exp headache/ or exp musculoskeletal pain/ or neck pain/ or exp neuralgia/ or exp nociceptive pain/ or pain, intractable/ or fibromyalgia/ or myalgia/

3 Pain/

4 (acute or chronic).ti,ab,kw.

$5 \quad 3$ and 4

6 ((acute or chronic or persistent or intractable or refractory) adj3 pain).ti,ab,kw.

7 (((back or spine or spinal or discogenic or leg or hip or musculoskeletal or neuropathic or nociceptive or radicular or "non-radicular") adj1 pain) or headache or arthritis or fibromyalgia or osteoarthritis or neuralgia or neuropathy).ti,ab,kw.

81 or 2 or 5 or 6 or 7

9 Medicare/

10 medicare.ti,ab,kf.

119 or 10

12 exp Vertebroplasty/

13 (vertebroplasty or kyphoplasty).ti,ab,kf.

14 Piriformis Muscle Syndrome/

15 inject*.ti,ab,kf.

$16 \quad 14$ and 15

17 (piriformis adj3 inject*).ti,ab,kf.

18 Sphenopalatine Ganglion Block/

19 (sphenopalatine adj3 block*).ti,ab,kf.

20 Electric Stimulation Therapy/

21 Occipital Lobe/

$22 \quad 20$ and 21

23 (occipital adj3 stimulation).ti,ab,kf.

24 ((cool* or puls*) adj3 radiofrequency).ti,ab,kf.

25 Platelet-Rich Plasma/

26 ("platelet rich plasma" or "stem cell*").ti,ab,kf.

27 Stem Cells/

28 (intradisc* or "intra disc*" or facet or joint).ti,ab,kf,sh.

29 (25 or 26 or 27$)$ and 28

30 Methylene Blue/

31 "methylene blue".ti,ab,kf.

32 (30 or 31$)$ and 28

33 Ozone/

34 ozone.ti,ab,kf.

35 (33 or 34$)$ and 28

36 (peripheral nerve adj2 stimulat*).ti,ab,kf.

3718 or 19 or 22 or 23 or 24 or 29 or 32 or 35 or 36

38 Fractures, Compression/

39 ((vertebra* or compression) adj2 fracture*).ti,ab,kf.

$40 \quad 8$ and 37

$41 \quad 11$ and (12 or 13 or 16 or 17 or 37$)$ 
42 (12 or 13$)$ and (38 or 39$)$

$43 \quad 16$ or 17

4440 or 41 or 42 or 43

4544 not (cancer or malignan* or child* or adolescen*).ti.

46 (Animals/ or Models, Animal/ or Disease Models, Animal/) not Humans/

47 ((animal or animals or avian or bird or birds or bovine or canine or cow* or dog or dogs or cat or cats or feline or hamster* or horse* or lamb or lamb* or mouse or mice or monkey or monkeys or murine or pig or piglet* or pigs or porcine or primate* or rabbit* or rat or rats or rodent* or songbird* or veterinar*) not (human* or patient*)).ti,kf,jw.

48 or $/ 46-47$

$49 \quad 45$ not 48

50 (random* or control* or trial or systematic or "meta analysis" or metaanalysis or cohort or prospective or retrospective or observational or "case series").ti,ab,kf,sh,pt.

5149 and 50

52 limit 51 to english language

53 limit 52 to $\mathrm{yr}=$ "1990 -Current"

Database: EBM Reviews - Cochrane Central Register of Controlled Trials November 2020

1 Chronic Pain/

2 exp arthralgia/ or exp back pain/ or exp headache/ or exp musculoskeletal pain/ or neck pain/ or exp neuralgia/ or exp nociceptive pain/ or pain, intractable/ or fibromyalgia/ or myalgia/

3 Pain/

4 (acute or chronic).ti,ab,kw.

$5 \quad 3$ and 4

6 ((acute or chronic or persistent or intractable or refractory) adj3 pain).ti,ab,kw.

7 (((back or spine or spinal or discogenic or leg or hip or musculoskeletal or neuropathic or nociceptive or radicular or "non-radicular") adj1 pain) or headache or arthritis or fibromyalgia or osteoarthritis or neuralgia or neuropathy).ti,ab,kw.

81 or 2 or 5 or 6 or 7

9 Medicare/

10 medicare.ti,ab,kw.

119 or 10

12 exp Vertebroplasty/

13 (vertebroplasty or kyphoplasty).ti,ab,kw.

14 Piriformis Muscle Syndrome/

15 inject*.ti,ab,kw.

$16 \quad 14$ and 15

17 (piriformis adj3 inject*).ti,ab,kw.

18 Sphenopalatine Ganglion Block/

19 (sphenopalatine adj3 block*).ti,ab,kw.

20 Electric Stimulation Therapy/

21 Occipital Lobe/

$22 \quad 20$ and 21

23 (occipital adj3 stimulation).ti,ab,kw.

24 ((cool* or puls*) adj3 radiofrequency).ti,ab,kw.

25 Platelet-Rich Plasma/ 
26 ("platelet rich plasma" or "stem cell*").ti,ab,kw.

27 Stem Cells/

28 (intradisc* or "intra disc*" or facet or joint).ti,ab,kw.

29 (25 or 26 or 27 ) and 28

30 Methylene Blue/

31 "methylene blue".ti,ab,kw.

32 (30 or 31$)$ and 28

33 Ozone/

34 ozone.ti,ab,kw.

35 (33 or 34$)$ and 28

36 (peripheral nerve adj2 stimulat*).ti,ab,kw.

3718 or 19 or 22 or 23 or 24 or 29 or 32 or 35 or 36

38 Fractures, Compression/

39 ((vertebra* or compression) adj2 fracture*).ti,ab,kw.

$40 \quad 8$ and 37

$41 \quad 11$ and (12 or 13 or 16 or 17 or 37$)$

42 (12 or 13$)$ and (38 or 39$)$

$43 \quad 16$ or 17

4440 or 41 or 42 or 43

45 conference abstract.pt.

46 "journal: conference abstract".pt.

47 "journal: conference review".pt.

48 "http://.www.who.int/trialsearch*".so.

49 "https://clinicaltrials.gov*".so.

5045 or 46 or 47 or 48 or 49

5144 not 50

52 limit 51 to english language

53 limit 52 to $\mathrm{yr}=$ "1990 -Current"

Database: EBM Reviews - Cochrane Database of Systematic Reviews 2005 to December 03, 2020

1 (vertebroplasty or kyphoplasty).ti,ab.

2 (piriformis and inject*).ti,ab.

3 (sphenopalatine and block*).ti,ab.

4 (occipital and stimulation).ti,ab.

5 ((cool* or puls*) and radiofrequency).ti,ab.

6 "platelet rich plasma".ti,ab.

7 stem cell*.ti,ab.

8 (intradisc* or "intra disc*" or facet or joint).ti,ab.

9 "methylene blue".ti,ab.

10 ozone.ti,ab.

11 (peripheral nerve and stimulat*).ti,ab.

126 or 7 or 9 or 10

$13 \quad 8$ and 12

141 or 2 or 3 or 4 or 5 or 11 or 13 
Database: APA PsycInfo 1806 to November Week 52020

1 Chronic Pain/

2 exp arthralgia/ or exp back pain/ or exp headache/ or exp musculoskeletal pain/ or neck pain/ or exp neuralgia/ or exp nociceptive pain/ or pain, intractable/ or fibromyalgia/ or myalgia/

3 Pain/

4 (acute or chronic).ti,ab.

$5 \quad 3$ and 4

6 ((acute or chronic or persistent or intractable or refractory) adj3 pain).ti,ab.

7 (((back or spine or spinal or discogenic or leg or hip or musculoskeletal or neuropathic or nociceptive or radicular or "non-radicular") adj1 pain) or headache or arthritis or fibromyalgia or osteoarthritis or neuralgia or neuropathy).ti,ab.

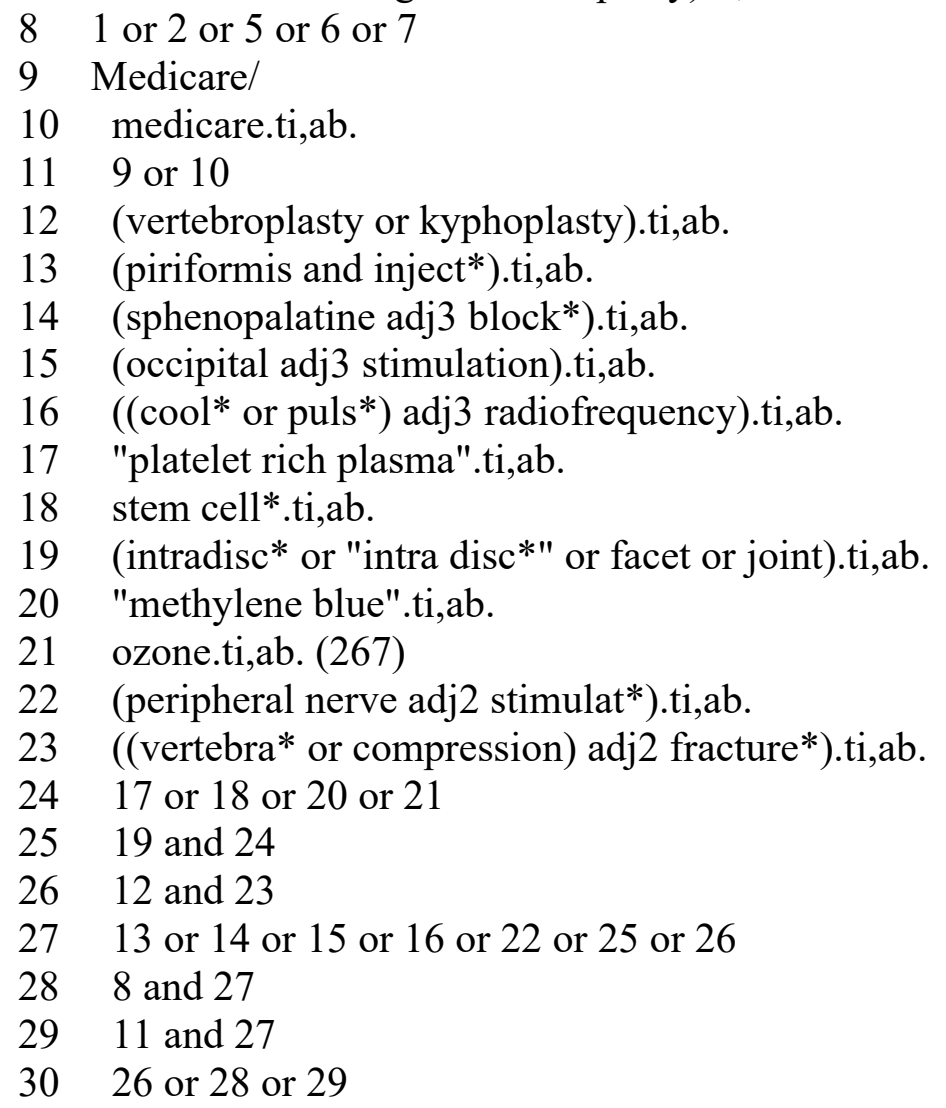

31 ((animal or animals or avian or bird or birds or bovine or canine or cow* or dog or dogs or cat or cats or feline or hamster* or horse* or lamb or lamb* or mouse or mice or monkey or monkeys or murine or pig or piglet* or pigs or porcine or primate* or rabbit* or rat or rats or rodent* or songbird* or veterinar*) not (human* or patient*)).ti,jw.

3230 not 31

33 limit 32 to english language

34 limit 33 to $\mathrm{yr}=$ "1990 -Current"

Database: EBSCOHost CINAHL Plus through December 9, 2020

S1 vertebroplasty OR kyphoplasty

S2 compression fracture

S3 vertebral fracture 


\section{S4 S2 OR S3}

S5 S1 AND S4

S6 piriformis AND injection

S7 sphenopalatine AND ( neuralgia OR headache )

S8 occipital AND stimulation AND headache

S9 ( cooled OR pulsed) AND radiofrequency

S10 pain

S11 S9 AND S10

S12 platelet rich plasma AND ( intradiscal OR facet ) AND pain

S13 methylene blue AND pain

S14 ozone AND pain

S15 peripheral nerve stimulation AND ( pain OR neuropathic OR neuropathy )

S16 S5 OR S6 OR S7 OR S8 OR S11 OR S12 OR S13 OR S14 OR S15

S17 S5 OR S6 OR S7 OR S8 OR S11 OR S12 OR S13 OR S14 OR S15; Limiters - Published Date: 19900101-20201231; English Language; Exclude MEDLINE records 


\section{Appendix B. List of Excluded Studies}

$2=$ Ineligible population

$\mathbf{3}=$ Ineligible intervention

$4=$ Ineligible comparison

5 = Ineligible outcome

$\mathbf{6}=$ Ineligible study design

$7=$ Not a study

$8=$ Not in English language

9 = Outdated or unusable systematic review

$10=$ Background paper

1. Erratum...Erdine S, Bilir A, Cosman ER, Cosman ER Jr. Ultrastructural changes in axons following exposure to pulsed radiofrequency fields. Pain Pract. 2009;9:407-417. Pain pract. 2010;10(3):264. doi: 10.1111/j.1533-2500.2010.00379.x. PMID: 105196084. Language: English. Entry Date: 20100702. Revision Date: 20200708. Publication Type: Journal Article. Exclusion: 7.

2. Erratum...Van Boxem K, Van Eerd M, Brinkhuize T, Patijn J, Van Kleef M, Van Zundert J. Radiofrequency and pulsed radiofrequency treatment of chronic pain syndromes: the available evidence. Pain Pract 2008;5:385-393. Pain pract. 2010;10(2):164-. doi: 10.1111/j.15332500.2010.00368.x. PMID: 105131187. Language: English. Entry Date: 20100409. Revision Date: 20200708. Publication Type: Journal Article. Exclusion: 7.

3. Sun Peng-Fei, Jia Yu-Hua, and Sibel Eyigor Pulsed radiofrequency versus conventional transcutaneous electrical nerve stimulation in painful shoulder: a prospective, randomized study - can you really have the conclusion?...Pulsed radiofrequency versus conventional transcutaneous electrical nerve stimulation in painful shoulder: a prospective, randomized study. Thousand Oaks, California: Sage Publications Inc.; 2011. p. 856-7. Exclusion: 7.

4. Pulmonary embolism caused by cement leakage during percutaneous vertebroplasty: a case report of successful conservative management. 2012;25:481-5. doi: 10.1177/197140091202500411. Exclusion: 6.

5. Increased Nuclear T2 Signal Intensity and Improved Function and Pain in a Patient One Year After an Intradiscal Platelet-Rich Plasma Injection. 2017;18:1197-9. doi: 10.1093/pm/pnw299. Exclusion: 7.

6. Sphenopalatine Ganglion Block for Postdural Puncture Headache. 2020;21:2615-6. doi: 10.1093/pm/pnz351. Exclusion: 7.

7. Abejon D, Garcia-del-Valle S, Fuentes ML, et al. Pulsed radiofrequency in lumbar radicular pain: clinical effects in various etiological groups. Pain pract. 2007 Mar;7(1):21-6. PMID: 17305674. Exclusion: 6.

8. Abhinav K, Park ND, Prakash SK, et al. Novel use of narrow paddle electrodes for occipital nerve stimulation--technical note. Neuromodulation. 2013 NovDec;16(6):607-9. doi: 10.1111/j.15251403.2012.00524.x. PMID: 23106950. Exclusion: 6.

9. Aebi M. Vertebroplasty: about sense and nonsense of uncontrolled "controlled randomized prospective trials". Eur Spine J. 2009 Sep;18(9):1247-8. doi: 10.1007/s00586-009-1164-9. PMID: 19756780. Exclusion: 7.

10. Aebi M. Editorial: vertebroplasty: about sense and nonsense of uncontrolled "controlled randomized prospective trials". Eur Spine J. 2009;18(9):1247-8. PMID: CN01783404 NEW. Exclusion: 7.

11. Ahn DK, Lee S, Kim DG, et al. Percutaneous vertebroplasty using fresh frozen allogeneic bone chips as filler. Clin. 2014 Mar;6(1):49-55. doi: 10.4055/cios.2014.6.1.49. PMID: 24605189. Exclusion: 6. 
12. Ahn Y, Lee JH, Lee HY, et al. Predictive factors for subsequent vertebral fracture after percutaneous vertebroplasty. $\mathrm{J}$ Neurosurg Spine. 2008 Aug;9(2):129-36. doi: 10.3171/SPI/2008/9/8/129. PMID: 18764744. Exclusion: 6.

13. Ahn Y, Lee SH. Vertebroplasty for adjacent vertebral fracture following lumbar interbody fusion. Br J Neurosurg. 2011 Feb;25(1):104-8. doi: 10.3109/02688697.2010.508848. PMID: 20825286. Exclusion: 6.

14. Aibar-Duran JA, Alvarez Holzapfel MJ, Rodriguez Rodriguez R, et al. Occipital nerve stimulation and deep brain stimulation for refractory cluster headache: a prospective analysis of efficacy over time. $\mathrm{J}$ Neurosurg. 2020 Jan 17:1-8. doi: 10.3171/2019.11.JNS192042. PMID: 31952039. Exclusion: 4.

15. Aiyer R, Noori S, Schirripa F, et al. Treatment of knee osteoarthritic pain with platelet-rich plasma: a systematic review of clinical studies. Pain manag. 2021

Apr;11(4):419-31. doi: https://dx.doi.org/10.2217/pmt-2020-0052. PMID: 33764185. Exclusion: 2.

16. Akeda K, Ohishi K, Masuda K, et al. Intradiscal Injection of Autologous PlateletRich Plasma Releasate to Treat Discogenic Low Back Pain: A Preliminary Clinical Trial. Asian spine j. 2017 Jun;11(3):380-9. doi: 10.4184/asj.2017.11.3.380. PMID: 28670405. Exclusion: 4.

17. Akeda K, Yamada J, Linn ET, et al. Plateletrich plasma in the management of chronic low back pain: A critical review. J Pain Res. 2019;12:753-67. doi: 10.2147/JPR.S153085. PMID: 30881089. Exclusion: 9.

18. Al-Ali F, Barrow T, Luke K. Vertebroplasty: what is important and what is not. AJNR Am J Neuroradiol. 2009

Nov;30(10):1835-9. doi: 10.3174/ajnr.A1732. PMID: 19713320. Exclusion: 6.

19. Albayrak A, Ozcafer R, Balioglu MB, et al. Piriformis syndrome: treatment of a rare cause of posterior hip pain with fluoroscopic-guided injection. Hip int. 2015 Mar-Apr;25(2):172-5. doi: 10.5301/hipint.5000219. PMID: 25837782. Exclusion: 4.
20. Albers CE, Schott PM, Ahmad SS, et al. Vertebral body lavage Reduces hemodynamic response to vertebral body wugmentation with PMMA. Global spine $\mathrm{j}$. 2019 Aug;9(5):499-504. doi: 10.1177/2192568218803106. PMID: 31431872. Exclusion: 3.

21. Alhashash M, Shousha M, Barakat AS, et al. Effects of polymethylmethacrylate cement viscosity and bone porosity on cement leakage and new vertebral fractures after percutaneous vertebroplasty: A prospective study. Global spine j. 2019 Oct;9(7):754-60. doi: $10.1177 / 2192568219830327$. PMID: 31552157. Exclusion: 3.

22. Alsalmi S, Capel C, Chenin L, et al. Robotassisted intravertebral augmentation corrects local kyphosis more effectively than a conventional fluoroscopy-guided technique. J Neurosurg Spine. 2018 Nov 30;30(2):28995. doi: 10.3171/2018.8.SPINE18197. PMID: 30544363. Exclusion: 3.

23. Alvarez L, Alcaraz M, Perez-Higueras A, et al. Percutaneous vertebroplasty: functional improvement in patients with osteoporotic compression fractures. Spine. 2006 May 01;31(10):1113-8. PMID: 16648745. Exclusion: 6.

24. Amar AP, Larsen DW, Teitelbaum GP. Use of a screw-syringe injector for cement delivery during kyphoplasty: technical report. Neurosurgery. 2003 Aug;53(2):3802; discussion 3. PMID: 12925255.

Exclusion: 3.

25. Amoretti N, Guinebert S, Kastler A, et al. Symptomatic Schmorl's nodes: role of percutaneous vertebroplasty. Open study on 52 patients. Neuroradiology. 2019 Apr;61(4):405-10. doi: 10.1007/s00234-01902171-7. PMID: 30778620. Exclusion: 6.

26. Anderson PA, Froyshteter AB, Tontz WL, Jr. Meta-analysis of vertebral augmentation compared with conservative treatment for osteoporotic spinal fractures. J Bone Miner Res. 2013 Feb;28(2):372-82. doi: 10.1002/jbmr.1762. PMID: 22991246. Exclusion: 9. 
27. Anjana Reddy VS, Sharma C, Chang KY, et al. 'Simplicity' radiofrequency neurotomy of sacroiliac joint: a real life 1-year follow-up UK data. Br J Pain. 2016 May;10(2):90-9. doi: 10.1177/2049463715627287. PMID: 27551419. Exclusion: 6.

28. Anonymous. Vertebroplasty versus sham procedure for painful acute osteoporotic vertebral compression fractures (VERTOS IV): randomised sham controlled clinical trial. Bmj. 2018 Jul 04;362:k2937. doi: 10.1136/bmj.k2937. PMID: 29973351. Exclusion: 7.

29. Anselmetti GC, Manca A, Montemurro F, et al. Percutaneous vertebroplasty in multiple myeloma: prospective long-term follow-up in 106 consecutive patients. Cardiovasc Intervent Radiol. 2012 Feb;35(1):139-45. doi: 10.1007/s00270-011-0111-4. PMID: 21305282. Exclusion: 6.

30. Anselmetti GC, Manca A, Tutton S, et al. Percutaneous vertebral augmentation assisted by PEEK implant in painful osteolytic vertebral metastasis involving the vertebral wall: experience on 40 patients. Pain physician. 2013 Jul-Aug;16(4):397404. PMID: 23877463. Exclusion: 6.

31. Anselmetti GC, Zoarski G, Manca A, et al. Percutaneous vertebroplasty and bone cement leakage: clinical experience with a new high-viscosity bone cement and delivery system for vertebral augmentation in benign and malignant compression fractures. Cardiovasc Intervent Radiol. 2008 Sep-Oct;31(5):937-47. doi: 10.1007/s00270008-9324-6. PMID: 18389186. Exclusion: 4.

32. Aquino-Jose VM, Blinder V, Johnson J, et al. Ultrasound-guided trigger point injection for piriformis syndrome in the emergency department. J Am Coll Emerg Physicians Open. 2020 Oct;1(5):876-9. doi: 10.1002/emp2.12153. PMID: 33145535. Exclusion: 6.

33. Arabmotlagh M, Rickert M, Lukas A, et al. Small cavity creation in the vertebral body reduces the rate of cement leakage during vertebroplasty. J Orthop Res. 2017

Jan;35(1):154-9. doi: 10.1002/jor.23215. PMID: 26919407. Exclusion: 6.
34. Astur N, Avanzi O. Balloon kyphoplasty in the treatment of neoplastic spine lesions: A systematic review. Global spine j. 2019

May;9(3):348-56. doi: 10.1177/2192568218768774. PMID: 31192104. Exclusion: 9.

35. Aurora SK, Dodick DW, Turkel CC, et al. OnabotulinumtoxinA for treatment of chronic migraine: results from the doubleblind, randomized, placebo-controlled phase of the PREEMPT 1 trial. Cephalalgia. 2010 Jul;30(7):793-803. doi: 10.1177/0333102410364676. PMID: 20647170. Exclusion: 2.

36. Bae H, Shen M, Maurer P, et al. Clinical experience using Cortoss for treating vertebral compression fractures with vertebroplasty and kyphoplasty: twenty four-month follow-up. Spine (Phila Pa 1976). 2010 Sep 15;35(20):E1030-6. doi: 10.1097/BRS.0b013e3181dcda75. PMID: 20844420. Exclusion: 4.

37. Bastian L, Schils F, Tillman JB, et al. A randomized trial comparing 2 techniques of balloon kyphoplasty and curette use for obtaining vertebral body height restoration and angular-deformity correction in vertebral compression fractures due to osteoporosis. AJNR Am J Neuroradiol. 2013 Mar;34(3):666-75. doi: 10.3174/ajnr.A3363. PMID: 23179647. Exclusion: 4.

38. Bonetti M, Fontana A, Cotticelli B, et al. Intraforaminal $\mathrm{O}(2)-\mathrm{O}(3)$ versus periradicular steroidal infiltrations in lower back pain: randomized controlled study. AJNR Am J Neuroradiol. 2005 May;26(5):996-1000. PMID: 15891150. Exclusion: 4.

39. Bono F, Salvino D, Mazza MR, et al. The influence of ictal cutaneous allodynia on the response to occipital transcutaneous electrical stimulation in chronic migraine and chronic tension-type headache: a randomized, sham-controlled study. Cephalalgia. 2015 Apr;35(5):389-98. doi: 10.1177/0333102414544909. PMID: 25078717. Exclusion: 3. 
40. Buchbinder R, Osborne RH, Ebeling PR, et al. Vertebroplasty was not effective for painful osteoporotic vertebral fractures. Journal of bone and joint surgery. 2010;American volume. 92(5):1263-. doi: 10.2106/JBJS.9205.ebo443. PMID: 20439677. Exclusion: 7.

41. Buchbinder R, Osborne RH, Ebeling PR, et al. Efficacy and safety of vertebroplasty for treatment of painful osteoporotic vertebral fractures: a randomised controlled trial [ACTRN012605000079640]. BMC Musculoskelet Disord. 2008 Nov 25;9:156. doi: 10.1186/1471-2474-9-156. PMID: 19025665. Exclusion: 7.

42. Cadalso RT, Jr., Daugherty J, Holmes C, et al. Efficacy of electrical stimulation of the occipital nerve in intractable primary headache disorders: a systematic review with meta-analyses. J Oral Facial Pain Headache. 2018 2018;32(1):40-52. doi: 10.11607/ofph.1784. PMID: 29161336. Exclusion: 10.

43. Cánovas Martínez L, Orduña Valls J, Paramés Mosquera E, et al. Sacroiliac joint pain: Prospective, randomised, experimental and comparative study of thermal radiofrequency with sacroiliac joint block. Rev Esp Anestesiol Reanim. 2016 May;63(5):267-72. doi: 10.1016/j.redar.2015.08.003. PMID: 26642949. Exclusion: 3.

44. Cao Z, Li Y, Gao F, et al. Mesenchymal Stem Cells: A New Choice for Nonsurgical Treatment of OA? Results from a Bayesian Network Meta-Analysis. Biomed Res Int. 2021;2021:6663003. doi: https://dx.doi.org/10.1155/2021/6663003. PMID: 33614784. Exclusion: 2.

45. Carrondo Cottin S, Gallani N, Cantin L, et al. Occipital nerve stimulation for nonmigrainous chronic headaches: a systematic review protocol. Syst. 2019 July 22;8(1):181. doi: 10.1186/s13643-019-1101x. PMID: 31331392. Exclusion: 10.
46. Cetin A, Yektas A. Evaluation of the shortand long-term effectiveness of pulsed radiofrequency and conventional radiofrequency performed for medial branch block in patients with lumbar facet joint pain. Pain Research \& Management Vol 2018 2018, ArtID 7492753. 2018 Nov;2018 doi:

http://dx.doi.org/10.1155/2018/7492753. PMID: 2018-64001-001. Exclusion: 6.

47. Chang MC, Cho YW, Ahn SH. Comparison between bipolar pulsed radiofrequency and monopolar pulsed radiofrequency in chronic lumbosacral radicular pain: A randomized controlled trial. Medicine (Baltimore). 2017 Mar;96(9):e6236. doi: 10.1097/MD.0000000000006236. PMID: 28248888. Exclusion: 4.

48. Chang MC, Park D. The Effect of Intradiscal Platelet-Rich Plasma Injection for Management of Discogenic Lower Back Pain: A Meta-Analysis. J Pain Res. 2021;14:505-12. doi: https://dx.doi.org/10.2147/JPR.S292335. PMID: 33642874. Exclusion: 9.

49. Chen W, Xie W, Xiao Z, et al. Incidence of cement leakage between unilateral and bilateral percutaneous vertebral augmentation for osteoporotic vertebral compression fractures: a meta-analysis of randomized controlled trials. World Neurosurg. 2019 Feb;122:342-8. doi: 10.1016/j.wneu.2018.10.143. PMID: 30391616. Exclusion: 10.

50. Chen WC, Tsai SHL, Goyal A, et al. Comparison between vertebroplasty with high or low viscosity cement augmentation or kyphoplasty in cement leakage rate for patients with vertebral compression fracture: a systematic review and network metaanalysis. Eur Spine J. 2020 Nov 13;13 doi: 10.1007/s00586-020-06636-9. PMID: 33185740. Exclusion: 10.

51. Chen X, Guo W, Li Q, et al. Is unilateral percutaneous kyphoplasty superior to bilateral percutaneous kyphoplasty for osteoporotic vertebral compression fractures? evidence from a systematic review of discordant meta-analyses. Pain physician. 2018 Jul;21(4):327-36. PMID: 30045590. Exclusion: 10. 
52. Chen X, Ren J, Zhang J, et al. Impact of cement placement and leakage in osteoporotic vertebral compression fractures followed by percutaneous vertebroplasty. Clin Spine Surg. 2016 Aug;29(7):365-70. doi: 10.1097/BSD.0b013e3182aa28d6. PMID: 24005031. Exclusion: 6.

53. Chen YC, Zhang L, Li EN, et al. Unilateral versus bilateral percutaneous vertebroplasty for osteoporotic vertebral compression fractures in elderly patients: A metaanalysis. Medicine (Baltimore). 2019 Feb;98(8):e14317. doi: 10.1097/MD.0000000000014317. PMID: 30813133. Exclusion: 10.

54. Chen YF, Bramley G, Unwin G, et al. Occipital nerve stimulation for chronic migraine--a systematic review and metaanalysis. PLoS ONE. 2015 Mar 20;10(3):e0116786. doi: 10.1371/journal.pone.0116786. PMID: 25793740. Exclusion: 10.

55. Cheng X, Long HQ, Xu JH, et al. Comparison of unilateral versus bilateral percutaneous kyphoplasty for the treatment of patients with osteoporosis vertebral compression fracture (OVCF): a systematic review and meta-analysis. Eur Spine J. 2016 Nov;25(11):3439-49. doi: 10.1007/s00586016-4395-6. PMID: 26814475. Exclusion: 10.

56. Cheng Y, Liu Y. Percutaneous curved vertebroplasty in the treatment of thoracolumbar osteoporotic vertebral compression fractures. J Int Med Res. 2019 Jun;47(6):2424-33. doi: 10.1177/0300060519836917. PMID: 31007103. Exclusion: 4.

57. Cheung G, Chow E, Holden L, et al. Percutaneous vertebroplasty in patients with intractable pain from osteoporotic or metastatic fractures: A prospective study using quality-of-life assessment. Can Assoc Radiol J. 2006 Feb;57(1):13-21. PMID: 16719207. Exclusion: 4.

58. Chitale A, Prasad S. An evidence-based analysis of vertebroplasty and kyphoplasty. $\mathrm{J}$ Neurosurg Sci. 2013 Jun;57(2):129-37. PMID: 23676862. Exclusion: 10.
59. Chua NH, Vissers KC, Sluijter ME. Pulsed radiofrequency treatment in interventional pain management: mechanisms and potential indications-a review. Acta Neurochir (Wien). 2011 Apr;153(4):763-71. doi: 10.1007/s00701-010-0881-5. PMID: 21116663. Exclusion: 10.

60. Cohen S, Levin D, Mellender S, et al. Topical sphenopalatine ganglion block compared with epidural blood patch for postdural puncture headache management in postpartum patients: a retrospective review. Reg Anesth Pain Med. 2018 Nov;43(8):8804. doi: 10.1097/AAP.0000000000000840. PMID: 30063655. Exclusion: 6.

61. Cohen SP, Peterlin BL, Fulton L, et al. Randomized, double-blind, comparativeeffectiveness study comparing pulsed radiofrequency to steroid injections for occipital neuralgia or migraine with occipital nerve tenderness. Pain. 2015 Dec;156(12):2585-94. doi: 10.1097/j.pain.0000000000000373. PMID: 26447705. Exclusion: 2.

62. Contreras Lopez WO, Navarro PA, Vargas $\mathrm{MD}$, et al. Pulsed radiofrequency versus continuous radiofrequency for facet joint low back pain: a systematic review. World Neurosurg. 2019 Feb;122:390-6. doi: 10.1016/j.wneu.2018.10.191. PMID: 30404055. Exclusion: 10.

63. Cornelis FH, Joly Q, Nouri-Neuville M, et al. Innovative spine implants for improved augmentation and stability in neoplastic vertebral compression fracture. Medicina (Kaunas). 2019 Jul 31;55(8):31. doi: 10.3390/medicina55080426. PMID: 31370309. Exclusion: 10.

64. Crockett MT, Moynagh M, Long N, et al. Ozone-augmented percutaneous discectomy: a novel treatment option for refractory discogenic sciatica. Clin Radiol. 2014 Dec;69(12):1280-6. doi: 10.1016/j.crad.2014.08.008. PMID: 25240564. Exclusion: 6.

65. De Leacy R, Chandra RV, Barr JD, et al. The evidentiary basis of vertebral augmentation: a 2019 update. J Neurointerv Surg. 2020 May;12(5):442-7. doi: 10.1136/neurintsurg-2019-015026. PMID: 31974279. Exclusion: 10. 
66. De M, Mohan VK, Bhoi D, et al. Transforaminal epidural injection of local anesthetic and dorsal root ganglion pulsed radiofrequency treatment in lumbar radicular pain: a randomized, triple-blind, activecontrol trial. Pain pract. 2020 Feb;20(2):154-67. doi: 10.1111/papr.12840. PMID: 31538405. Exclusion: 2.

67. Deer TR, Gilmore CA, Desai MJ, et al. Percutaneous Peripheral Nerve Stimulation of the Medial Branch Nerves for the Treatment of Chronic Axial Back Pain in Patients After Radiofrequency Ablation. Pain Med. 2021 Mar 18;22(3):548-60. doi: https://dx.doi.org/10.1093/pm/pnaa432. PMID: 33616178. Exclusion: 4.

68. Dere K, Akbas M, Sen H, et al. Comparing the effectiveness of thiocolchicoside and triamcinolone in piriformis syndrome treatment. Turkiye Klinikleri Journal of Medical Sciences. 2009;29(5):1267-72. PMID: 105265429. Language: English. Entry Date: 20100122. Revision Date: 20150711. Publication Type: Journal Article. Exclusion: 3.

69. Desai MJ, Mansfield JT, Robinson DM, et al. Regenerative Medicine for Axial and Radicular Spine-Related Pain: A Narrative Review. Pain pract. 2020;20(4):437-53. doi: 10.1111/papr.12868. PMID: 142690387. Language: English. Entry Date: 20200415. Revision Date: 20200504. Publication Type: Article. Exclusion: 10.

70. Diamond T, Clark W, Bird P, et al. Percutaneous vertebroplasty for acute painful osteoporotic vertebral fracturesbenefits shown in VAPOUR trial masked when pooled with other clinical trials. J Bone Miner Res. 2019 Jun;34(6):1182-4. doi: 10.1002/jbmr.3725. PMID: 31136012. Exclusion: 7.

71. Diamond TH, Bryant C, Browne L, et al. Clinical outcomes after acute osteoporotic vertebral fractures: a 2-year non-randomised trial comparing percutaneous vertebroplasty with conservative therapy. Med J Aust. 2006 Feb 06;184(3):113-7. PMID: 16460295. Exclusion: 6 .
72. Diamond TH, Champion B, Clark WA. Management of acute osteoporotic vertebral fractures: a nonrandomized trial comparing percutaneous vertebroplasty with conservative therapy. Am J Med. 2003 Mar;114(4):257-65. PMID: 12681451. Exclusion: 6.

73. Diener HC, Dodick DW, Aurora SK, et al. OnabotulinumtoxinA for treatment of chronic migraine: results from the doubleblind, randomized, placebo-controlled phase of the PREEMPT 2 trial. Cephalalgia. 2010 Jul;30(7):804-14. doi: 10.1177/0333102410364677. PMID: 20647171. Exclusion: 2.

74. Ding W, Yang S, Guo X, et al. Intradiscal Methylene Blue Injection for Discogenic Low Back Pain: A Meta-Analysis. Pain pract. 2019;19(1):118-29. doi: 10.1111/papr.12725. PMID: 134021908. Language: English. Entry Date: 20190111. Revision Date: 20200101. Publication Type: Article. Exclusion: 10.

75. Ding Y, Li H, Yao P, et al. Clinical observation of CT-guided intra-articular conventional radiofrequency and pulsed radiofrequency in the treatment of chronic sacroiliac joint pain. J Pain Res.

2018;11:2359-66. doi: 10.2147/JPR.S179712. PMID: 30410388. Exclusion: 6.

76. Do KH, Ahn SH, Cho YW, et al. Comparison of intra-articular lumbar facet joint pulsed radiofrequency and intraarticular lumbar facet joint corticosteroid injection for management of lumbar facet joint pain: A randomized controlled trial. Medicine (Baltimore). 2017 Mar;96(13):e6524. doi: 10.1097/MD.0000000000006524. PMID: 28353611. Exclusion: 4.

77. Dobrogowski J, Wrzosek A, Wordliczek J. Radiofrequency denervation with or without addition of pentoxifylline or methylprednisolone for chronic lumbar zygapophysial joint pain. Pharmacol Rep. 2005 Jul-Aug;57(4):475-80. PMID: 16129914. Exclusion: 3. 
78. Dodick DW, Silberstein SD, Reed KL, et al. Safety and efficacy of peripheral nerve stimulation of the occipital nerves for the management of chronic migraine: long-term results from a randomized, multicenter, double-blinded, controlled study. Cephalalgia. 2015 Apr;35(4):344-58. doi: 10.1177/0333102414543331. PMID: 25078718. Exclusion: 6.

79. Dohm M, Black CM, Dacre A, et al. A randomized trial comparing balloon kyphoplasty and vertebroplasty for vertebral compression fractures due to osteoporosis.

AJNR Am J Neuroradiol. 2014

Dec;35(12):2227-36. doi:

10.3174/ajnr.A4127. PMID: 25300981.

Exclusion: 4.

80. Dondas A, Luca A, Alexa T, et al. Repeated methylene blue administration produces analgesia in experimental pain. J Headache Pain. 2013;14:1-. doi: 10.1186/1129-237714-S1-P86. PMID: 104100557. Language: English. Entry Date: 20140718. Revision Date: 20200708. Publication Type: Journal Article. Exclusion: 2.

81. Du J, Li X, Lin X. Kyphoplasty versus vertebroplasty in the treatment of painful osteoporotic vertebral compression fractures: two-year follow-up in a prospective controlled study. Acta Orthop Belg. 2014 Dec;80(4):477-86. PMID: 26280719. Exclusion: 4.

82. Du JP, Fan Y, Liu JJ, et al. The analysis of MSTMOVCF (Multi-segment thoracolumbar mild osteoporotic fractures surgery or conservative treatment) based on ASTLOF (the assessment system of thoracolumbar osteoporotic fracture). Sci. 2018 May 29;8(1):8185. doi: 10.1038/s41598-018-26562-7. PMID: 29844542. Exclusion: 6.

83. Ducic I, Felder JM, 3rd, Fantus SA. A systematic review of peripheral nerve interventional treatments for chronic headaches. Ann Plast Surg. 2014 Apr;72(4):439-45. doi: 10.1097/SAP.000000000000063. PMID: 24374395. Exclusion: 10.

84. Duger C, Kol IO, Kaygusuz K, et al. Effects of facet joint nerve block addition to radiofrequency in the treatment of low back pain. Healthmed. 2012;6(6):2052-6. PMID: CN-00902974. Exclusion: 3.
85. Dutta K, Dey S, Bhattacharyya P, et al. Comparison of efficacy of lateral branch pulsed radiofrequency denervation and intraarticular depot methylprednisolone injection for sacroiliac joint pain. Pain physician. 2018 Sep;21(5):489-96. PMID: 30282393. Exclusion: 4.

86. Dworkin RH, Turk DC, Wyrwich KW, et al. Interpreting the clinical importance of treatment outcomes in chronic pain clinical trials: IMMPACT recommendations. J Pain. 2008 Feb;9(2):105-21. doi: 10.1016/j.jpain.2007.09.005. PMID: 18055266. Exclusion: 7.

87. Eck JC, Nachtigall D, Humphreys SC, et al. Comparison of vertebroplasty and balloon kyphoplasty for treatment of vertebral compression fractures: a meta-analysis of the literature. Spine J. 2008 MayJun;8(3):488-97. PMID: 17588820. Exclusion: 10.

88. Eisenberg E, Waisbrod H, Gerbershagen HU. Long-term peripheral nerve stimulation for painful nerve injuries. Clin J Pain. 2004 May-Jun;20(3):143-6. PMID: 15100589. Exclusion: 6.

89. Elawamy A, Kamel EZ, Hassanien M, et al. Implication of two different doses of intradiscal ozone-oxygen injection upon the pain alleviation in patients with low back pain: a randomized, single-blind study. Pain physician. 2018 Jan;21(1):25-31. PMID: 29357333. Exclusion: 4.

90. Eldabe SS, Taylor RS, Goossens S, et al. A randomized controlled trial of subcutaneous nerve stimulation for back pain due to failed back surgery syndrome: The subQStim study. Neuromodulation. 2019 Jul;22(5):519-28. doi: 10.1111/ner.12784. PMID: 29704437. Exclusion: 2.

91. En X, Hao DJ. Percutaneous kyphoplasty versus conservative treatment in acute and subacute osteoporotic vertebral compression fractures (OVCF): a double-blinded, randomized controlled clinical trial (RCT) in the population of Western China. Spine journal. 2013;13(9):90S-1S. doi: 10.1016/j.spinee.2013.07.247. PMID: CN01006814. Exclusion: 7. 
92. Ercalik T, Kilic M. Efficacy of intradiscal ozone therapy with or without periforaminal steroid injection on lumbar disc herniation: A double-blinded controlled study. Pain physician. 2020 09;23(5):477-84. PMID: 32967390. Exclusion: 3.

93. Evans AJ, Kip KE, Brinjikji W, et al. Randomized controlled trial of vertebroplasty versus kyphoplasty in the treatment of vertebral compression fractures. J Neurointerv Surg. 2016 Jul;8(7):756-63. doi: 10.1136/neurintsurg-2015-011811. PMID: 26109687. Exclusion: 4.

94. Facchini G, Spinnato P, Guglielmi G, et al. A comprehensive review of pulsed radiofrequency in the treatment of pain associated with different spinal conditions. Br J Radiol. 2017 May;90(1073):20150406. doi: 10.1259/bjr.20150406. PMID: 28186832. Exclusion: 10.

95. Fanous SN, Saleh EG, Abd Elghafar EM, et al. Randomized controlled trials between dorsal root ganglion thermal radiofrequency, pulsed radiofrequency and steroids for the management of intractable metastatic back pain in thoracic vertebral body. British journal of pain. 2020 PMID: CN-02161430 NEW. Exclusion: 2.

96. Farrokhi MR, Lotfi M, Masoudi MS, et al. Effects of methylene blue on postoperative low-back pain and functional outcomes after lumbar open discectomy: a triple-blind, randomized placebo-controlled trial. J Neurosurg Spine. 2016 Jan;24(1):7-15. doi: 10.3171/2015.3.SPINE141172. PMID: 26360148. Exclusion: 2.

97. Feng H, Huang P, Zhang X, et al. Unilateral versus bilateral percutaneous kyphoplasty for osteoporotic vertebral compression fractures: A systematic review and metaanalysis of RCTs. J Orthop Res. 2015

Nov;33(11):1713-23. doi:

10.1002/jor.22957. PMID: 26123667. Exclusion: 10.

98. Feng L, Shen JM, Feng C, et al. Comparison of radiofrequency kyphoplasty (RFK) and balloon kyphoplasty (BKP) in the treatment of vertebral compression fractures: A metaanalysis. Medicine (Baltimore). 2017 Jun;96(25):e7150. doi: 10.1097/MD.0000000000007150. PMID: 28640091. Exclusion: 10.
99. Fernández Sanromán J, Fernández Ferro M, Costas López A, et al. Does injection of plasma rich in growth factors after temporomandibular joint arthroscopy improve outcomes in patients with Wilkes stage IV internal derangement? A randomized prospective clinical study. Int J Oral Maxillofac Surg. 2016 Jul;45(7):82835. doi: 10.1016/j.ijom.2016.01.018. PMID: 26922496. Exclusion: 2.

100. Fernández-Ferro M, Fernández-Sanromán J, Blanco-Carrión A, et al. Comparison of intra-articular injection of plasma rich in growth factors versus hyaluronic acid following arthroscopy in the treatment of temporomandibular dysfunction: A randomised prospective study. $\mathrm{J}$ Craniomaxillofac Surg. 2017 Apr;45(4):44954. doi: 10.1016/j.jcms.2017.01.010. PMID: 28237253. Exclusion: 2.

101. Filardo G, Kon E, Roffi A, et al. Plateletrich plasma: why intra-articular? A systematic review of preclinical studies and clinical evidence on PRP for joint degeneration. Knee Surg Sports Traumatol Arthrosc. 2015 Sep;23(9):2459-74. doi: 10.1007/s00167-013-2743-1. PMID: 24275957. Exclusion: 10.

102. Firanescu C, Lohle PN, de Vries J, et al. A randomised sham controlled trial of vertebroplasty for painful acute osteoporotic vertebral fractures (VERTOS IV). Trials. 2011 Apr 05;12:93. doi: 10.1186/17456215-12-93. PMID: 21466679. Exclusion: 7.

103. Foster L, Clapp L, Erickson M, et al. Botulinum toxin A and chronic low back pain: a randomized, double-blind study. Neurology. 2001 May 22;56(10):1290-3. doi: 10.1212/wnl.56.10.1290. PMID: 11376175. Exclusion: 2.

104. Fowler IM, Tucker AA, Weimerskirch BP, et al. A randomized comparison of the efficacy of 2 techniques for piriformis muscle injection: ultrasound-guided versus nerve stimulator with fluoroscopic guidance. Reg Anesth Pain Med. 2014 Mar-

Apr;39(2):126-32. doi: 10.1097/AAP.0000000000000056. PMID: 24509422. Exclusion: 3. 
105. Frankel BM, Krishna V. Meta-analysis: vertebroplasty for vertebral compression fracture ineffective in improving pain and function. Evid Based Med. 2012 Oct;17(5):142-3. doi: 10.1136/ebmed-2011100215. PMID: 22044795. Exclusion: 10.

106. Freitas TDS, Fonoff ET, Marquez Neto OR, et al. Peripheral nerve stimulation for painful mononeuropathy secondary to leprosy: a 12-month follow-up study. Neuromodulation. 2018 Apr;21(3):310-6. doi: 10.1111/ner.12714. PMID: 29082637. Exclusion: 6.

107. Freund B, Kotchetkov IS, Rao A. The Efficacy of Botulinum Toxin in Cluster Headache: A Systematic Review. Journal of Oral \& Facial Pain \& Headache. 2020 Spring2020;34(2):129-34. doi: 10.11607/ofph.2444. PMID: 143591374. Language: English. Entry Date: 20200608. Revision Date: 20200613. Publication Type: Article. Exclusion: 9.

108. Fritzell P, Ohlin A, Borgstrom F. Costeffectiveness of balloon kyphoplasty versus standard medical treatment in patients with osteoporotic vertebral compression fracture: a Swedish multicenter randomized controlled trial with 2-year follow-up. Spine. 2011 Dec 15;36(26):2243-51. doi: 10.1097/BRS.0b013e3182322d0f. PMID: 21912321. Exclusion: 5.

109. Fukui S, Nitta K, Iwashita N, et al. Intradiscal pulsed radiofrequency for chronic lumbar discogenic low back pain: a one year prospective outcome study using discoblock for diagnosis. Pain physician. 2013 Jul-Aug;16(4):435-42. PMID: 23877468. Exclusion: 6.

110. Gabrhelik T, Michalek P, Adamus M. Pulsed radiofrequency therapy versus greater occipital nerve block in the management of refractory cervicogenic headache - a pilot study. Prague Med Rep. 2011;112(4):279-87. PMID: 22142523. Exclusion: 2.

111. Gao Y, Huo M, Fan X, et al. Effect of PVP with a mesh-hold bone-filling mesh bag and different viscosities of bone cement in the treatment of osteoporotic vertebral compression fractures. Int J Clin Exp Med. 2020;13(7):5006-12. PMID: CN-02161078 NEW. Exclusion: 4.
112. Gautam S, Rastogi V, Jain A, et al. Comparative evaluation of oxygen-ozone therapy and combined use of oxygen-ozone therapy with percutaneous intradiscal radiofrequency thermocoagulation for the treatment of lumbar disc herniation. Pain pract. 2011 Mar-Apr;11(2):160-6. doi: 10.1111/j.1533-2500.2010.00409.x. PMID: 20642485. Exclusion: 4.

113. Genev IK, Tobin MK, Zaidi SP, et al. Spinal compression fracture management: A review of current treatment strategies and possible future avenues. Global spine j. 2017 Feb;7(1):71-82. doi: 10.1055/s-00361583288. PMID: 28451512. Exclusion: 10.

114. Gill JB, Kuper M, Chin PC, et al. Comparing pain reduction following kyphoplasty and vertebroplasty for osteoporotic vertebral compression fractures. Pain physician. 2007 Jul;10(4):583-90. PMID: 17660858. Exclusion: 10.

115. Gilula L, Persenaire M. Subsequent fractures post-vertebral augmentation: analysis of a prospective randomized trial in osteoporotic vertebral compression fractures. AJNR Am J Neuroradiol. 2013 Jan;34(1):221-7. doi: 10.3174/ajnr.A3156. PMID: 22743641. Exclusion: 3.

116. Goadsby PJ, Sahai-Srivastava S, Kezirian EJ, et al. Safety and efficacy of sphenopalatine ganglion stimulation for chronic cluster headache: a double-blind, randomised controlled trial. The lancet. 2019; Neurology. 18(12):1081-90. PMID: CN-02006591. Exclusion: 3.

117. Grafe IA, Da Fonseca K, Hillmeier J, et al. Reduction of pain and fracture incidence after kyphoplasty: 1-year outcomes of a prospective controlled trial of patients with primary osteoporosis. Osteoporos Int. 2005 Dec;16(12):2005-12. PMID: 16078092. Exclusion: 6 .

118. Gray LA, Jarvik JG, Heagerty PJ, et al. INvestigational Vertebroplasty Efficacy and Safety Trial (INVEST): a randomized controlled trial of percutaneous vertebroplasty. BMC Musculoskelet Disord. 2007 Dec 20;8:126. PMID: 18096050. Exclusion: 7. 
119. Griffoni C, Lukassen JNM, Babbi L, et al. Percutaneous vertebroplasty and balloon kyphoplasty in the treatment of osteoporotic vertebral fractures: a prospective randomized comparison. Eur Spine J. 2020 Jul;29(7):1614-20. doi: 10.1007/s00586020-06434-3. PMID: 32361843. Exclusion: 4.

120. Gu CN, Brinjikji W, Evans AJ, et al. Outcomes of vertebroplasty compared with kyphoplasty: a systematic review and metaanalysis. J Neurointerv Surg. 2016 Jun;8(6):636-42. doi: 10.1136/neurintsurg2015-011714. PMID: 25964376. Exclusion: 9.

121. Guo X, Ding W, Liu L, et al. Intradiscal methylene blue injection for discogenic low back pain: a meta-analysis. Pain pract. 2019 Jan;19(1):118-29. doi: 10.1111/papr.12725. PMID: 30039642. Exclusion: 10.

122. Guo Z, Wang W, Gao WS, et al. Comparison the clinical outcomes and complications of high-viscosity versus lowviscosity in osteoporotic vertebral compression fractures. Medicine (Baltimore). 2017 Dec;96(48):e8936. doi: 10.1097/MD.0000000000008936. PMID: 29310386. Exclusion: 4.

123. Haigler MC, Abdulrehman E, Siddappa S, et al. Use of platelet-rich plasma, platelet-rich growth factor with arthrocentesis or arthroscopy to treat temporomandibular joint osteoarthritis: Systematic review with metaanalyses. J Am Dent Assoc. 2018 Nov;149(11):940-52. doi: 10.1016/j.adaj.2018.07.025. PMID: 30724168. Exclusion: 9.

124. Han S, Wan S, Ning L, et al. Percutaneous vertebroplasty versus balloon kyphoplasty for treatment of osteoporotic vertebral compression fracture: a meta-analysis of randomised and non-randomised controlled trials. Int Orthop. 2011 Sep;35(9):1349-58. doi: 10.1007/s00264-011-1283-x. PMID: 21637959. Exclusion: 10.

125. Han SL, Wan SL, Li QT, et al. Is vertebroplasty a risk factor for subsequent vertebral fracture, meta-analysis of published evidence? Osteoporos Int. 2015 Jan;26(1):113-22. doi: 10.1007/s00198-0142848-5. PMID: 25149856. Exclusion: 10.
126. Hansen EJ, Simony A, Rousing R, et al. Double Blind Placebo-controlled Trial of Percutaneous Vertebroplasty (VOPE). Global spine j. 2016;6(1_suppl):s-00361582763-s-0036-. doi: 10.1055/s-00361582763. Exclusion: 7.

127. Hashemi M, Hashemian M, Mohajerani SA, et al. Effect of pulsed radiofrequency in treatment of facet-joint origin back pain in patients with degenerative spondylolisthesis. Eur Spine J. 2014 Sep;23(9):1927-32. doi: 10.1007/s00586-014-3412-x. PMID: 24997616. Exclusion: 2.

128. Hazzard MA, Huang KT, Toche UN, et al. Comparison of vertebroplasty, kyphoplasty, and nonsurgical management of vertebral compression fractures and impact on US healthcare resource utilization. Asian spine j. 2014 Oct;8(5):605-14. doi: 10.4184/asj.2014.8.5.605. PMID: 25346813. Exclusion: 6.

129. Hegab AF, Ali HE, Elmasry M, et al. Platelet-rich plasma injection as an effective treatment for temporomandibular joint osteoarthritis. J Oral Maxillofac Surg. 2015 Sep;73(9):1706-13. doi: 10.1016/j.joms.2015.03.045. PMID: 25882438. Exclusion: 2.

130. Hernigou P, Dubory A, Homma Y, et al. Cell therapy versus simultaneous contralateral decompression in symptomatic corticosteroid osteonecrosis: a thirty year follow-up prospective randomized study of one hundred and twenty five adult patients. Int Orthop. 2018 Jul;42(7):1639-49. doi: 10.1007/s00264-018-3941-8. PMID: 29744647. Exclusion: 3.

131. Hinde K, Maingard J, Hirsch JA, et al. Mortality outcomes of vertebral augmentation (vertebroplasty and/or balloon kyphoplasty) for osteoporotic vertebral compression fractures: a systematic review and meta-analysis. Radiology. 2020 Apr;295(1):96-103. doi: 10.1148/radiol.2020191294. PMID: 32068503. Exclusion: 9. 
132. Hintz A. 84 - Non-inferiority of Cooled vs Traditional Radiofrequency Ablation of the Lumbar Medial Branch Nerves in the Treatment of Axial Low Back Pain. Spine Journal. 2017;17:S120-S. doi: 10.1016/j.spinee.2017.07.105. PMID: 125611602. Language: English. Entry Date: In Process. Revision Date: 20171017. Publication Type: Article. Supplement Title: Oct2017 Supplement. Journal Subset: Biomedical. Exclusion: 7.

133. Ho KY, Hadi MA, Pasutharnchat K, et al. Cooled radiofrequency denervation for treatment of sacroiliac joint pain: two-year results from 20 cases. J Pain Res.

2013;6:505-11. doi: 10.2147/jpr.S46827. PMID: 23869175. Exclusion: 6.

134. Hoffmeister E. Researchers find vertebroplasty not superior to placebo for recent-onset fracture or severe back pain. Lippincott's Bone \& Joint Newsletter. 2011;17(10):109-13. PMID: 108213033. Language: English. Entry Date: 20120106. Revision Date: 20150712. Publication Type: Journal Article. Exclusion: 10.

135. Hofmeister M, Memedovich A, Brown S, et al. Effectiveness of neurostimulation technologies for the management of chronic pain: a systematic review. Neuromodulation. 2020 Feb;23(2):150-7. doi:

10.1111/ner.13020. PMID: 31310417. Exclusion: 10.

136. Hong T, Wang H, Li G, et al. Systematic review and meta-analysis of 12 randomized controlled trials evaluating the efficacy of invasive radiofrequency treatment for knee pain and function. Biomed Res Int. 2019 Jun 26;2019:9037510. doi: 10.1155/2019/9037510. PMID: 31346525. Exclusion: 10.

137. Hoshino M, Takahashi S, Yasuda H, et al. Balloon kyphoplasty versus conservative treatment for acute osteoporotic vertebral fractures with poor prognostic factors: propensity score matched analysis using data from two prospective multicenter studies. Spine. 2019 Jan 15;44(2):110-7. doi: 10.1097/BRS.0000000000002769. PMID: 29958202. Exclusion: 6.
138. Huang CH, Wang WH, Kor CT, et al. Risk of venous thromboembolism in elderly patients with vertebral compression fracture: A population-based case-control study. Medicine (Baltimore). 2020

May;99(18):e20072. doi: 10.1097/MD.0000000000020072. PMID: 32358388. Exclusion: 6.

139. Huang Z, Zhang L. Treatment of osteoporotic vertebral compressive fractures with percutaneous kyphoplasty and oral Zishengukang. J Tradit Chin Med. 2012 Dec;32(4):561-4. doi: 10.1016/s02546272(13)60071-0. PMID: 23427389. Exclusion: 3.

140. Hulme PA, Krebs J, Ferguson SJ, et al. Vertebroplasty and kyphoplasty: a systematic review of 69 clinical studies. Spine. 2006 Aug 01;31(17):1983-2001. PMID: 16924218. Exclusion: 10.

141. Hung KC, Chen JY, Ho CN, et al. Use of sphenopalatine ganglion block in patients with postdural puncture headache: a pilot meta-analysis. $\mathrm{Br} \mathrm{J}$ Anaesth. 2020 Oct 29;29:25-7. doi: 10.1016/j.bja.2020.10.005. PMID: 33131755. Exclusion: 10.

142. Iida K, Harimaya K, Tarukado K, et al. Kyphosis progression after balloon kyphoplasty compared with conservative treatment. Asian spine j. 2019 Jul 09:92835. doi: 10.31616/asj.2018.0329. PMID: 31281176. Exclusion: 6.

143. Ishiguro S, Kasai Y, Sudo A, et al. Percutaneous vertebroplasty for osteoporotic compression fractures using calcium phosphate cement. J. 2010 Dec;18(3):34651. doi: 10.1177/230949901001800318. PMID: 21187549. Exclusion: 6.

144. Jain D, Goyal T, Verma N, et al. Intradiscal platelet-rich plasma injection for discogenic low back pain and correlation with platelet concentration: a prospective clinical trial. Pain Med. 2020 Aug 31;31:2719-25. doi: 10.1093/pm/pnaa254. PMID: 32869064. Exclusion: 6.

145. Janzen VD, Scudds R. Sphenopalatine blocks in the treatment of pain in fibromyalgia and myofascial pain syndrome. Laryngoscope. 1997 Oct;107(10):1420-2. PMID: 9331324. Exclusion: 2. 
146. Jena BR, Paswan A, Singh Y, et al. A comparative study of continuous versus pulsed radiofrequency discectomy for management of low backache: Prospective randomized, double-blind study. Anesthesia Essays and Researches. 2016 SepDec;10(3):602-6. doi: 10.4103/02591162.186616. PMID: 27746559. Exclusion: 2.

147. Jiang P, Mao L, Qiao L, et al. Efficacy and safety of mesenchymal stem cell injections for patients with osteoarthritis: a metaanalysis and review of RCTs. Arch Orthop Trauma Surg. 2021 Jan 28;28:28. doi: https://dx.doi.org/10.1007/s00402-02003703-0. PMID: 33507375. Exclusion: 9.

148. Jones JC, Miller JA, Sudarshana DM, et al. Predictors of favorable quality of life outcome following kyphoplasty and vertebroplasty. J Neurosurg Spine. 2019 May 24;31(3):389-96. doi: 10.3171/2019.3.SPINE18419. PMID: 31125962. Exclusion: 6.

149. Ju DG, Kanim LE, Bae HW. Is there clinical improvement associated with intradiscal therapies? a comparison across randomized controlled studies. Global spine j. 2020 Oct 13:2192568220963058. doi: 10.1177/2192568220963058. PMID: 33047622. Exclusion: 10.

150. Juch JNS, Maas ET, Ostelo R, et al. Effect of Radiofrequency Denervation on Pain Intensity Among Patients With Chronic Low Back Pain: The Mint Randomized Clinical Trials. Jama. 2017 Jul 4;318(1):68-81. doi: 10.1001/jama.2017.7918. PMID: 28672319. Exclusion: 3.

151. Jürgens $\mathrm{T}$, Jensen R, Kaube $H$, et al. EHMTI-0227. Therapeutic effectiveness of sphenopalatine ganglion (SPG) stimulation for cluster headache - pathway registry study interim results at 6 months. J Headache Pain. 2014;15:1-. doi: 10.1186/1129-237715-S1-C26. PMID: 103899322. Language: English. Entry Date: 20141001. Revision Date: 20150710. Publication Type: Journal Article. Supplement Title: Sep2014 Supplement. Journal Subset: Biomedical. Exclusion: 3.
152. Kallewaard JW, Geurts JW, Kessels A, et al. Efficacy, safety, and predictors of intradiscal methylene blue injection for discogenic low back pain: results of a multicenter prospective clinical series. Pain pract. 2016 Apr;16(4):405-12. doi: 10.1111/papr.12283. PMID: 25753429. Exclusion: 4.

153. Kapural L, Nageeb F, Kapural M, et al. Cooled radiofrequency system for the treatment of chronic pain from sacroiliitis: the first case-series. Pain pract. 2008 SepOct;8(5):348-54. doi: 10.1111/j.15332500.2008.00231.x. PMID: 18844853. Exclusion: 6.

154. Kasperk C, Grafe IA, Schmitt S, et al. Three-year outcomes after kyphoplasty in patients with osteoporosis with painful vertebral fractures. J Vasc Interv Radiol. 2010 May;21(5):701-9. doi: 10.1016/j.jvir.2010.01.003. PMID: 20304677. Exclusion: 6.

155. Kasperk C, Hillmeier J, Noldge G, et al. Treatment of painful vertebral fractures by kyphoplasty in patients with primary osteoporosis: a prospective nonrandomized controlled study. J Bone Miner Res. 2005 Apr;20(4):604-12. PMID: 15765179. Exclusion: 6.

156. Ke M, Yinghui F, Yi J, et al. Efficacy of pulsed radiofrequency in the treatment of thoracic postherpetic neuralgia from the angulus costae: a randomized, doubleblinded, controlled trial. Pain physician. 2013 Jan;16(1):15-25. PMID: 23340530. Exclusion: 2.

157. Klazen CA, Verhaar HJ, Lampmann LE, et al. VERTOS II: percutaneous vertebroplasty versus conservative therapy in patients with painful osteoporotic vertebral compression fractures; rationale, objectives and design of a multicenter randomized controlled trial. Trials. 2007 Oct 31;8:33. doi: 10.1186/17456215-8-33. PMID: 17973983. Exclusion: 7.

158. Kloimstein H, Likar R, Kern M, et al. Peripheral nerve field stimulation (PNFS) in chronic low back pain: a prospective multicenter study. Neuromodulation. 2014 Feb;17(2):180-7. doi: 10.1111/ner.12139. PMID: 24320718. Exclusion: 4. 
159. Koh W, Choi SS, Karm MH, et al. Treatment of chronic lumbosacral radicular pain using adjuvant pulsed radiofrequency: a randomized controlled study. Pain Med. 2015 Mar;16(3):432-41. doi: 10.1111/pme.12624. PMID: 25530347. Exclusion: 3 .

160. Komp M, Ruetten S, Godolias G. Minimally invasive therapy for functionally unstable osteoporotic vertebral fracture by means of kyphoplasty: prospective comparative study of 19 surgically and 17 conservatively treated patients. J Miner Stoffwechs. 2004;11(Suppl 1):13-5. Exclusion: 8.

161. Korovessis P, Vardakastanis K, Repantis T, et al. Balloon kyphoplasty versus KIVA vertebral augmentation--comparison of 2 techniques for osteoporotic vertebral body fractures: a prospective randomized study. Spine. 2013 Feb 15;38(4):292-9. doi: 10.1097/BRS.0b013e31826b3aef. PMID: 23407406. Exclusion: 4.

162. Korovessis P, Vardakastanis K, Vitsas V, et al. Is Kiva implant advantageous to balloon kyphoplasty in treating osteolytic metastasis to the spine? Comparison of 2 percutaneous minimal invasive spine techniques: a prospective randomized controlled shortterm study. Spine. 2014 Feb 15;39(4):231-9. doi: 10.1097/BRS.0000000000000112. PMID: 24253785. Exclusion: 4.

163. Ku B, Jun M, Lee JH, et al. Short-term efficacy of pulsed radiofrequency thermal stimulation on acupoints for chronic low back pain: A preliminary study of a randomized, single-blinded, placebocontrolled trial. Evid Based Complement Alternat Med. 2018;2018:4510909. doi: 10.1155/2018/4510909. PMID: 30158995. Exclusion: 3 .

164. Kwak SG, Lee DG, Chang MC. Effectiveness of pulsed radiofrequency treatment on cervical radicular pain: A metaanalysis. Medicine (Baltimore). 2018 Aug;97(31):e11761. doi: 10.1097/MD.000000000011761. PMID: 30075599. Exclusion: 10.
165. Lee DG, Ahn SH, Lee J. Comparative effectivenesses of pulsed radiofrequency and transforaminal steroid injection for radicular pain due to disc herniation: a prospective randomized trial. J Korean Med Sci. 2016 Aug;31(8):1324-30. doi: 10.3346/jkms.2016.31.8.1324. PMID: 27478346. Exclusion: 4.

166. Lee HM, Park SY, Lee SH, et al. Comparative analysis of clinical outcomes in patients with osteoporotic vertebral compression fractures (OVCFs): conservative treatment versus balloon kyphoplasty. Spine J. 2012 Nov;12(11):9981005. doi: 10.1016/j.spinee.2012.08.024. PMID: 23026068. Exclusion: 6.

167. Levi D, Horn S, Tyszko S, et al. Intradiscal platelet-rich plasma injection for chronic discogenic low back pain: preliminary results from a prospective trial. Pain Med. 2016 Jun;17(6):1010-22. doi: 10.1093/pm/pnv053. PMID: 26814283. Exclusion: 6.

168. Levy H, Seydafkan S, Rice JD, et al. Comparative efficacy of vertebroplasty, kyphoplasty, and medical therapy for vertebral fractures on survival and prevention of recurrent fractures. Endocr Pract. 2012 Jul-Aug;18(4):499-507. doi: 10.4158/EP11349.OR. PMID: 22440996. Exclusion: 6.

169. Li D, Sun G, Sun H, et al. Combined therapy of pulsed radiofrequency and nerve block in postherpetic neuralgia patients: a randomized clinical trial. Peerj. 2018;6:e4852. doi: 10.7717/peerj.4852. PMID: 29888123. Exclusion: 2.

170. Li HM, Zhang RJ, Gao H, et al. New vertebral fractures after osteoporotic vertebral compression fracture between balloon kyphoplasty and nonsurgical treatment PRISMA. Medicine (Baltimore). 2018 Oct;97(40):e12666. doi: 10.1097/MD.0000000000012666. PMID: 30290650. Exclusion: 10.

171. Li WS, Cai YF, Cong L. The Effect of Vertebral Augmentation Procedure on Painful OVCFs: A Meta-Analysis of Randomized Controlled Trials. Global spine j. 2021 Mar 11:2192568221999369. doi: https://dx.doi.org/10.1177/21925682219993 69. PMID: 33706568. Exclusion: 9. 
172. Li Y, Hai Y, Li L, et al. Early effects of vertebroplasty or kyphoplasty versus conservative treatment of vertebral compression fractures in elderly polytrauma patients. Arch Orthop Trauma Surg. 2015 Dec;135(12):1633-6. doi: 10.1007/s00402015-2311-x. PMID: 26559063. Exclusion: 6.

173. Lin J, Hsieh Y-C, Chien L-N, et al. P27 Vertebroplasty Associated with a Lower Risk of Mortality and Morbidity of Aged Patients with Painful Vertebral Compression Fractures: A Population-Based Propensity Score Matching Cohort Study in Taiwan. Spine Journal. 2016;16:S262-S. doi: 10.1016/j.spinee.2016.07.352. PMID: 118698909. Language: English. Entry Date: In Process. Revision Date: 20161014. Publication Type: Article. Supplement Title: Oct2016 Supplement. Journal Subset: Biomedical. Exclusion: 7.

174. Lipton RB. PRISM study: occipital nerve stimulation for treatment-refractory migraine. Abstract PO47. 2009 doi: 10.1111/J.1468-2982.2009.01960.X. Exclusion: 7.

175. Liu J, Li X, Tang D, et al. Comparing pain reduction following vertebroplasty and conservative treatment for osteoporotic vertebral compression fractures: a metaanalysis of randomized controlled trials. Pain physician. 2013 Sep-Oct;16(5):455-64. PMID: 24077192. Exclusion: 10.

176. Liu JT, Liao WJ, Tan WC, et al. Balloon kyphoplasty versus vertebroplasty for treatment of osteoporotic vertebral compression fracture: a prospective, comparative, and randomized clinical study. Osteoporos Int. $2010 \mathrm{Feb}$;21(2):359-64. doi: 10.1007/s00198-009-0952-8. PMID: 19513578. Exclusion: 4.

177. Liu Q, Cao J, Kong JJ. Clinical effect of balloon kyphoplasty in elderly patients with multiple osteoporotic vertebral fracture. Niger J Clin Pract. 2019 Mar;22(3):289-92. doi: 10.4103/njcp.njcp_8_18. PMID: 30837413. Exclusion: $\overline{6}$.
178. Ma K, Yiqun M, Wu T, et al. Efficacy of diclofenac sodium in pain relief after conventional radiofrequency denervation for chronic facet joint pain: a double-blind randomized controlled trial. Pain Med. 2011 Jan;12(1):27-35. doi: 10.1111/j.15264637.2010.00978.x. PMID: 21040436. Exclusion: 3.

179. Ma Y, Wang T, Liao J, et al. Efficacy of autologous bone marrow buffy coat grafting combined with core decompression in patients with avascular necrosis of femoral head: a prospective, double-blinded, randomized, controlled study. Stem Cell Res Ther. 2014 Oct 14;5(5):115. doi: 10.1186/scrt505. PMID: 25315149. Exclusion: 3 .

180. Macias-Hernandez SI, Chavez-Arias DD, Miranda-Duarte A, et al. Percutaneous vertebroplasty versus conservative treatment and rehabilitation in women with vertebral fractures due to osteoporosis: a prospective comparative study. Rev Invest Clin. 2015 Mar-Apr;67(2):98-103. PMID: 25938842. Exclusion: 6.

181. Magalhaes FN, Dotta L, Sasse A, et al. Ozone therapy as a treatment for low back pain secondary to herniated disc: a systematic review and meta-analysis of randomized controlled trials. Pain physician. 2012 Mar-Apr;15(2):115-29. PMID: 22430658. Exclusion: 10.

182. Mahapatra AK. Peer review report 1 on "Percutaneous Vertebroplasty Versus Conservative Treatment for Osteoporotic Vertebral Compression Fractures: An Updated Meta-analysis of Prospective Randomized Controlled Trials". Int J Surg. 2017;37:593-. doi: 10.1016/j.ijsu.2017.10.009. PMID: 127136384. Language: English. Entry Date: In Process. Revision Date: 20180108. Publication Type: Article. Supplement Title: Jan2017 Supplement 1. Journal Subset: Biomedical. Exclusion: 10.

183. Makharita MY, El Bendary HM, Sonbul $\mathrm{ZM}$, et al. Ultrasound-guided pulsed radiofrequency in the management of thoracic postherpetic neuralgia: a randomized, double-blinded, controlled trial. Clin J Pain. 2018 Nov;34(11):1017-24. doi: 10.1097/AJP.0000000000000629. PMID: 29757758. Exclusion: 2. 
184. Mao Q, Wang W, Xu T, et al. Combination treatment of biomechanical support and targeted intra-arterial infusion of peripheral blood stem cells mobilized by granulocytecolony stimulating factor for the osteonecrosis of the femoral head: a randomized controlled clinical trial. J Bone Miner Res. 2015 Apr;30(4):647-56. doi: 10.1002/jbmr.2390. PMID: 25349059. Exclusion: 3.

185. Martinez-Ferrer A, Blasco J, Carrasco JL, et al. Risk factors for the development of vertebral fractures after percutaneous vertebroplasty. J Bone Miner Res. 2013 Aug;28(8):1821-9. doi: 10.1002/jbmr.1899. PMID: 23427068. Exclusion: 3.

186. Masala S, Crusco S, Meschini A, et al. Piriformis syndrome: long-term follow-up in patients treated with percutaneous injection of anesthetic and corticosteroid under CT guidance. Cardiovasc Intervent Radiol. 2012 Apr;35(2):375-82. doi: 10.1007/s00270-0110185-z. PMID: 21607823. Exclusion: 6.

187. Mazzantini M, Carpeggiani P, d'Ascanio A, et al. Long-term prospective study of osteoporotic patients treated with percutaneous vertebroplasty after fragility fractures. Osteoporos Int. 2011 May;22(5):1599-607. doi: 10.1007/s00198010-1341-z. PMID: 20661546. Exclusion: 6.

188. Mehta V, Poply K, Husband M, et al. The Effects of Radiofrequency Neurotomy Using a Strip-Lesioning Device on Patients with Sacroiliac Joint Pain: Results from a SingleCenter, Randomized, Sham-Controlled Trial. Pain physician. 2018 Nov;21(6):60718. PMID: 30508988 . Exclusion: 3.

189. Monfett M, Harrison J, Boachie-Adjei K, et al. Intradiscal platelet-rich plasma (PRP) injections for discogenic low back pain: an update. Int Orthop. 2016 Jun;40(6):1321-8. doi: 10.1007/s00264-016-3178-3. PMID: 27073034. Exclusion: 7.
190. Muzumdar D. Peer review report 3 on "Percutaneous Vertebroplasty Versus Conservative Treatment for Osteoporotic Vertebral Compression Fractures: An Updated Meta-analysis of Prospective Randomized Controlled Trials". Int J Surg. 2017;37:565-. doi: 10.1016/j.ijsu.2017.10.011. PMID: 127136348. Language: English. Entry Date: In Process. Revision Date: 20180108. Publication Type: Article. Supplement Title: Jan2017 Supplement 1. Journal Subset: Biomedical. Exclusion: 10.

191. Nebreda C, Vallejo R, Salvador E, et al. Comparative study of the thermal or conventional radiofrequency and pulsed radiofrequency in the treatment of pain in the lumbar facet origin arthropathy. Revista de la sociedad espanola del dolor. 2016;23(4):170-4. PMID: CN-01176960. Exclusion: 8 .

192. Omar AS, Ibrahim ME, Ahmed AS, et al. Local injection of autologous platelet rich plasma and corticosteroid in treatment of lateral epicondylitis and plantar fasciitis: randomized clinical trial. Egyptian rheumatologist. 2012;34(2):43-9. PMID: CN-00896010. Exclusion: 2.

193. Orhurhu V, Khan F, Quispe RC, et al. Use of radiofrequency ablation for the management of facial pain: A systematic review. Pain physician. 2020 11;23(6):E559E80. PMID: 33185371. Exclusion: 2.

194. Oswald J, Shahi V, Chakravarthy KV. Prospective case series on the use of peripheral nerve stimulation for focal mononeuropathy treatment. Pain manag. 2019 Nov;9(6):551-8. doi: 10.2217/pmt2019-0028. PMID: 31686589. Exclusion: 6.

195. Ozcan S, Muz A, Yildiz Altun A, et al. Intradiscal ozone therapy for lumbar disc herniation. Cell Mol Biol (Noisy-le-grand). 2018 Apr 30;64(5):52-5. PMID: 29729693. Exclusion: 6.

196. Paoloni M, Di Sante L, Cacchio A, et al. Intramuscular oxygen-ozone therapy in the treatment of acute back pain with lumbar disc herniation: a multicenter, randomized, double-blind, clinical trial of active and simulated lumbar paravertebral injection. Spine. 2009 Jun 01;34(13):1337-44. doi: 10.1097/BRS.0b013e3181a3c18d. PMID: 19478653. Exclusion: 3. 
197. Papanastassiou ID, Phillips FM, Van Meirhaeghe J, et al. Comparing effects of kyphoplasty, vertebroplasty, and nonsurgical management in a systematic review of randomized and non-randomized controlled studies. Eur Spine J. 2012 Sep;21(9):1826-43. doi: 10.1007/s00586012-2314-z. PMID: 22543412. Exclusion: 9.

198. Patel N. Twelve-month follow-up of a randomized trial assessing cooled radiofrequency denervation as a treatment for sacroiliac region pain. Pain pract. 2016 Feb;16(2):154-67. doi: 10.1111/papr.12269. PMID: 25565322. Exclusion: 6.

199. Paterson KL, Nicholls M, Bennell KL, et al. Intra-articular injection of photo-activated platelet-rich plasma in patients with knee osteoarthritis: a double-blind, randomized controlled pilot study. BMC Musculoskelet Disord. 2016;17(67) PMID: CN-01260047. Exclusion: 3 .

200. Peeters CM, Leijs MJ, Reijman M, et al. Safety of intra-articular cell-therapy with culture-expanded stem cells in humans: a systematic literature review. Osteoarthritis Cartilage. 2013 Oct;21(10):1465-73. doi: 10.1016/j.joca.2013.06.025. PMID: 23831631. Exclusion: 9.

201. Peng B, Zhang Y, Hou S, et al. Intradiscal methylene blue injection for the treatment of chronic discogenic low back pain. Eur Spine J. 2007 Jan;16(1):33-8. PMID: 16496191. Exclusion: 4.

202. peng-fei S, yu-hua J. Pulsed radiofrequency versus conventional transcutaneous electrical nerve stimulation in painful shoulder: a prospective, randomized study can you really have the conclusion? Clin Rehabil. 2011 Sep;25(9):856-7. doi: 10.1177/0269215511400270. PMID: 21865447. Exclusion: 7.

203. Pepke W, Kasten P, Beckmann NA, et al. Core Decompression and Autologous Bone Marrow Concentrate for Treatment of Femoral Head Osteonecrosis: A Randomized Prospective Study. Orthop Rev (Pavia). 2016 Mar 21;8(1):6162. doi: 10.4081/or.2016.6162. PMID: 27114808. Exclusion: 3.
204. Pernientakis SS, Masouros PT, Margiannis $\mathrm{CP}$, et al. Radiofrequency kyphoplasty for the treatment of osteoporotic vertebral fractures: A review of the literature. Journal of Research \& Practice on the Musculoskeletal System (JRPMS). 2018;2(3):85-8. doi: 10.22540/JRPMS-02085. Exclusion: 9.

205. Piazzolla A, Bizzoca D, Solarino G, et al. Vertebral fragility fractures: clinical and radiological results of augmentation and fixation-a systematic review of randomized controlled clinical trials. Aging Clin Exp Res. 2020 Jul;32(7):1219-32. doi: 10.1007/s40520-019-01289-1. PMID: 31471888. Exclusion: 9.

206. Plazier M, Dekelver I, Vanneste S, et al. Occipital nerve stimulation in fibromyalgia: a double-blind placebo-controlled pilot study with a six-month follow-up. Neuromodulation. 2014 Apr;17(3):256-63. doi: 10.1111/ner.12121. PMID: 24118206. Exclusion: 2.

207. Plazier M, Ost J, Stassijns G, et al. C2 nerve field stimulation for the treatment of fibromyalgia: a prospective, double-blind, randomized, controlled cross-over study. Brain Stimul. 2015 Jul-Aug;8(4):751-7. doi: 10.1016/j.brs.2015.03.002. PMID: 25910427. Exclusion: 2.

208. Popeney CA, Alo KM. Peripheral neurostimulation for the treatment of chronic, disabling transformed migraine. Headache. 2003 Apr;43(4):369-75. PMID: 12656708. Exclusion: 6.

209. Pourtaheri S, Luo W, Cui C, et al. Vertebral augmentation is superior to nonoperative care at reducing lower back pain for symptomatic osteoporotic compression fractures: A meta-analysis. Clin Spine Surg. 2018 Oct;31(8):339-44. doi: 10.1097/BSD.0000000000000670. PMID: 29901504. Exclusion: 9.

210. Rayegani SM, Raeissadat SA, Taheri MS, et al. Does intra articular platelet rich plasma injection improve function, pain and quality of life in patients with osteoarthritis of the knee? A randomized clinical trial. Orthopedic reviews. 2014;6(3):112-7. PMID: CN-01013946. Exclusion: 2. 
211. Rodrigo D, Acin P, Bermejo P. Occipital nerve stimulation for refractory chronic migraine: results of a long-term prospective study. Pain physician. 2017 Jan-

Feb;20(1):151-9. PMID: 28072807.

Exclusion: 4.

212. RodríGuez-PiÑEro M, Vargas VV, Sarmiento ASJ. Long-Term Efficacy of Ultrasound-Guided Injection of IncobotulinumtoxinA in Piriformis Syndrome. Oxford University Press / USA; 2018. p. 408-11. Exclusion: 7.

213. Romero FR, Vital RB, Zanini MA, et al. Long-term follow-up in sacroiliac joint pain patients treated with radiofrequency ablative therapy. Arq Neuropsiquiatr. 2015 Jun;73(6):476-9. doi: 10.1590/0004282x20150049. PMID: 26083881. Exclusion: 3 .

214. Sanapati J, Manchikanti L, Atluri S, et al. Do regenerative medicine therapies provide long-term relief in chronic low back pain: A systematic review and metaanalysis. Pain physician. 2018 Nov;21(6):515-40. PMID: 30508983. Exclusion: 9.

215. Santana-Pineda MM, Vanlinthout LE, Santana-Ramirez S, et al. A randomized controlled trial to compare analgesia and functional improvement after continuous neuroablative and pulsed neuromodulative radiofrequency treatment of the genicular nerves in patients with knee osteoarthritis up to one year after the intervention. Pain Med. 2021 Mar 18;12:637-52. doi:

10.1093/pm/pnaa309. PMID: 33179073. Exclusion: 2.

216. Saxena AK, Lakshman K, Sharma T, et al. Modulation of serum BDNF levels in postherpetic neuralgia following pulsed radiofrequency of intercostal nerve and pregabalin. Pain manag. 2016;6(3):217-27. doi: 10.2217/pmt.16.3. PMID: 27094801.

Exclusion: 2 .

217. Schoenen J, Jensen RH, Lantéri-Minet M, et al. Stimulation of the sphenopalatine ganglion (SPG) for cluster headache treatment. Pathway CH-1: a randomized, sham-controlled study. Cephalalgia. 2013 Jul;33(10):816-30. doi: 10.1177/0333102412473667. PMID: 23314784. Exclusion: 3.
218. Sen RK, Tripathy SK, Aggarwal S, et al. Early results of core decompression and autologous bone marrow mononuclear cells instillation in femoral head osteonecrosis: a randomized control study. J Arthroplasty. 2012 May;27(5):679-86. doi: 10.1016/j.arth.2011.08.008. PMID: 22000577. Exclusion: 3.

219. Shanthanna H, Chan P, McChesney J, et al. Pulsed radiofrequency treatment of the lumbar dorsal root ganglion in patients with chronic lumbar radicular pain: a randomized, placebo-controlled pilot study. J Pain Res. 2014 Jan 10;7:47-55. doi: 10.2147/JPR.S55749. PMID: 24453500. Exclusion: 2.

220. Sharan A, Huh B, Narouze S, et al. Analysis of adverse events in the management of chronic migraine by peripheral nerve stimulation. Neuromodulation. 2015 Jun;18(4):305-12. doi: 10.1111/ner.12243. PMID: 25313847. Exclusion: 6.

221. Shi MM, Cai XZ, Lin T, et al. Is there really no benefit of vertebroplasty for osteoporotic vertebral fractures? A meta-analysis. Clin Orthop. 2012 Oct;470(10):2785-99. doi: 10.1007/s11999-012-2404-6. PMID: 22729693. Exclusion: 9.

222. Shi-Ming G, Wen-Juan L, Yun-Mei H, et al. Percutaneous vertebroplasty and percutaneous balloon kyphoplasty for osteoporotic vertebral compression fracture: A metaanalysis. Indian j. 2015 JulAug;49(4):377-87. doi: 10.4103/00195413.154892. PMID: 26229156. Exclusion: 9.

223. Shih CL, Shen PC, Lu CC, et al. A comparison of efficacy among different radiofrequency ablation techniques for the treatment of lumbar facet joint and sacroiliac joint pain: A systematic review and metaanalysis. Clin Neurol Neurosurg. 2020 Aug; 195:105854. doi: 10.1016/j.clineuro.2020.105854. Exclusion: 10. 
224. Shin SM, Kwak SG, Lee DG, et al. Clinical effectiveness of intra-articular pulsed radiofrequency compared to intra-articular corticosteroid injection for management of atlanto-occipital joint pain: A prospective randomized controlled pilot study. Spine. 2018 Jun 01;43(11):741-6. doi: 10.1097/BRS.0000000000002414. PMID: 28902105. Exclusion: 2.

225. Silberstein S. Efficacy of Occipital Stimulation for the Management of Intractable, Chronic Migraine: Results from a Prospective, Multicenter, Double-Blinded, Controlled Study. 2012 doi: 10.1111/j.15264610.2012.02174.x. Exclusion: 7.

226. Silberstein SD, Dodick DW, Saper J, et al. "Safety and efficacy of peripheral nerve stimulation of the occipital nerves for the management of chronic migraine: Results from a randomized, multicenter, doubleblinded, controlled study": Corrigendum. Cephalalgia. 2014 Oct;34(11):944. doi: http://dx.doi.org/10.1177/033310241454441 9. PMID: 2014-42746-015. Exclusion: 7.

227. Simopoulos TT, Kraemer J, Nagda JV, et al. Response to pulsed and continuous radiofrequency lesioning of the dorsal root ganglion and segmental nerves in patients with chronic lumbar radicular pain. Pain physician. 2008 Mar-Apr;11(2):137-44. PMID: 18354708. Exclusion: 3.

228. Singla V, Batra YK, Bharti N, et al. Steroid vs. platelet-rich plasma in ultrasound-guided sacroiliac joint injection for chronic low back pain. Pain pract. 2017 Jul;17(6):78291. doi: 10.1111/papr.12526. PMID: 27677100. Exclusion: 4.

229. Slavin KV. Peripheral nerve stimulation for neuropathic pain. Neurother. 2008

Jan;5(1):100-6. doi: http://dx.doi.org/10.1016/j.nurt.2007.11.005. PMID: 2008-09761-011. Exclusion: 6.

230. Slotty P, Bara G, Kowatz L, et al. Occipital nerve stimulation for chronic migraine: A randomized trial on subthreshold stimulation. Cephalalgia. 2015 Jan;35(1):738. doi: http://dx.doi.org/10.1177/033310241453408 2. PMID: 2014-55163-008. Exclusion: 2.
231. Spakova T, Rosocha J, Lacko M, et al. Treatment of knee joint osteoarthritis with autologous platelet-rich plasma in comparison with hyaluronic acid. Am J Phys Med Rehabil. 2012 May;91(5):411-7. doi: 10.1097/PHM.0b013e3182aab72. PMID: 22513879. Exclusion: 2.

232. Staples MP, Kallmes DF, Comstock BA, et al. Effectiveness of vertebroplasty using individual patient data from two randomised placebo controlled trials: meta-analysis. Bmj. 2011 Jul 12;343:3952. doi: 10.1136/bmj.d3952. PMID: 21750078. Exclusion: 9 .

233. Stelzer W, Aiglesberger M, Stelzer D, et al. Use of cooled radiofrequency lateral branch neurotomy for the treatment of sacroiliac joint-mediated low back pain: a large case series. Pain Med. 2013 Jan;14(1):29-35. doi: 10.1111/pme.12014. PMID: 23279364. Exclusion: 6.

234. Stelzer W, Stelzer V, Stelzer D, et al. Influence of BMI, gender, and sports on pain decrease and medication usage after facet-medial branch neurotomy or SI joint lateral branch cooled RF-neurotomy in case of low back pain: original research in the Austrian population. J Pain Res. 2017;10:183-90. doi: 10.2147/jpr.S121897. PMID: 28144161. Exclusion: 6.

235. Stevenson M, Gomersall T, Lloyd Jones M, et al. Percutaneous vertebroplasty and percutaneous balloon kyphoplasty for the treatment of osteoporotic vertebral fractures: a systematic review and cost-effectiveness analysis. Health Technol Assess. 2014 Mar;18(17):1-290. doi: 10.3310/hta18170. PMID: 24650687. Exclusion: 9.

236. Sun H, Li C. Comparison of unilateral and bilateral percutaneous vertebroplasty for osteoporotic vertebral compression fractures: a systematic review and metaanalysis. J. 2016 Dec 01;11(1):156. doi: 10.1186/s13018-016-0479-6. PMID: 27908277. Exclusion: 3.

237. Sun H, Lu PP, Liu YJ, et al. Can unilateral kyphoplasty replace bilateral kyphoplasty in treatment of osteoporotic vertebral compression fractures? A systematic review and meta-analysis. Pain physician. 2016 Nov-Dec;19(8):551-63. PMID: 27906934. Exclusion: 3. 
238. Sun HH, Zhuang SY, Hong X, et al. The efficacy and safety of using cooled radiofrequency in treating chronic sacroiliac joint pain: A PRISMA-compliant metaanalysis. Medicine (Baltimore). 2018 Feb;97(6):9809. doi: 10.1097/MD.000000000009809. PMID: 29419679. Exclusion: 9.

239. Tabatabaee RM, Saberi S, Parvizi J, et al. Combining Concentrated Autologous Bone Marrow Stem Cells Injection With Core Decompression Improves Outcome for Patients with Early-Stage Osteonecrosis of the Femoral Head: A Comparative Study. J Arthroplasty. 2015 Sep;30(9 Suppl):11-5. doi: 10.1016/j.arth.2015.06.022. PMID: 26143238. Exclusion: 2.

240. Taylor RS, Fritzell P, Taylor RJ. Balloon kyphoplasty in the management of vertebral compression fractures: an updated systematic review and meta-analysis. Eur Spine J. 2007 Aug;16(8):1085-100. PMID: 17277923. Exclusion: 9.

241. Taylor RS, Taylor RJ, Fritzell P. Balloon kyphoplasty and vertebroplasty for vertebral compression fractures: a comparative systematic review of efficacy and safety. Spine. 2006 Nov 01;31(23):2747-55. PMID: 17077747. Exclusion: 3.

242. Tian J, Xiang L, Zhou D, et al. The clinical efficacy of vertebroplasty on osteoporotic vertebral compression fracture: a metaanalysis. Int J Surg. 2014 Dec;12(12):124953. doi: 10.1016/j.ijsu.2014.10.027. PMID: 25448642. Exclusion: 9.

243. Tietze DC, Geissler K, Borchers J. The effects of platelet-rich plasma in the treatment of large-joint osteoarthritis: a systematic review. Phys Sportsmed. 2014 May;42(2):27-37. doi:

10.3810/psm.2014.05.2055. PMID: 24875970. Exclusion: 9.

244. Trams E, Kulinski K, Kozar-Kaminska K, et al. The clinical use of platelet-rich plasma in knee disorders and surgery-A systematic review and meta-analysis. Life (Basel). 2020 Jun 25;10(6):25. doi: 10.3390/life10060094. PMID: 32630404. Exclusion: 2.
245. Urits I, Viswanath O, Galasso AC, et al. Platelet-rich plasma for the treatment of low back pain: a comprehensive review. Curr Pain Headache Rep. 2019 Jul 03;23(7):52. doi: 10.1007/s11916-019-0797-6. PMID: 31270622. Exclusion: 9.

246. van Tilburg CW, Schuurmans FA, Stronks DL, et al. Randomized Sham-controlled Double-Blind Multicenter Clinical Trial to Ascertain the Effect of Percutaneous Radiofrequency Treatment for Sacroiliac Joint Pain: Three-month Results. Clin J Pain. 2016 Nov;32(11):921-6. doi: 10.1097/ajp.0000000000000351. PMID: 26889616. Exclusion: 3.

247. Van Zundert J, Patijn J, Kessels A, et al. Pulsed radiofrequency adjacent to the cervical dorsal root ganglion in chronic cervical radicular pain: a double blind sham controlled randomized clinical trial. Pain. 2007 Jan;127(1-2):173-82. PMID: 17055165. Exclusion: 2.

248. Vangsness CT, Farr J, Boyd J, et al. Adult human mesenchymal stem cells delivered via intra-articular injection to the knee following partial medial meniscectomy: a randomized, double-blind, controlled study. Journal of bone and joint surgery. 2014;American volume. 96(2):90-8. PMID: CN-00985400. Exclusion: 2.

249. Vanni D, Pantalone A, Bigossi F, et al. New perspective for third generation percutaneous vertebral augmentation procedures: Preliminary results at 12 months. J Craniovertebr Junction Spine. 2012 Jul;3(2):47-51. doi: 10.4103/09748237.116537. PMID: 24082683. Exclusion: 4.

250. Vigneri S, Sindaco G, La Grua M, et al. Electrocatheter-mediated high-voltage pulsed radiofrequency of the dorsal root ganglion in the treatment of chronic lumbosacral neuropathic pain: a randomized controlled study. Clin J Pain. 2020 Jan;36(1):25-33. doi: 10.1097/AJP.0000000000000766. PMID: 31577546. Exclusion: 2. 
251. Vuka I, Dosenovic S, Marcius T, et al. Efficacy and safety of pulsed radiofrequency as a method of dorsal root ganglia stimulation for treatment of non-neuropathic pain: a systematic review. BMC anesthesiol. 2020 May 04;20(1):105. doi: 10.1186/s12871-020-01023-9. PMID: 32366286. Exclusion: 2.

252. Vuka I, Marcius T, Dosenovic S, et al. Efficacy and safety of pulsed radiofrequency as a method of dorsal root ganglia stimulation in patients with neuropathic pain: A systematic review. Pain Med. 2020 Jun 03;03:3320-43. doi: 10.1093/pm/pnaa141. PMID: 32488240. Exclusion: 9.

253. Wan C, Dong DS, Song T. High-voltage, long-duration pulsed radiofrequency on Gasserian ganglion improves acute/subacute zoster-related trigeminal neuralgia: A randomized, double-blinded, controlled trial. Pain physician. 2019 Jul;22(4):361-8. PMID: 31337167. Exclusion: 2.

254. Wang B, Guo H, Yuan L, et al. A prospective randomized controlled study comparing the pain relief in patients with osteoporotic vertebral compression fractures with the use of vertebroplasty or facet blocking. Eur Spine J. 2016 Nov;25(11):3486-94. doi: 10.1007/s00586016-4425-4. PMID: 26850264. Exclusion: 4.

255. Wang D, Zhang K, Han S, et al. PainVision $\mathrm{R}$ apparatus for assessment of efficacy of pulsed radiofrequency combined with pharmacological therapy in the treatment of postherpetic neuralgia and correlations with measurements. Biomed Res Int. 2017 Mar 5;2017:5670219. doi:

10.1155/2017/5670219. PMID: 28357404. Exclusion: 2.

256. Wang F, Zhou Q, Xiao L, et al. A randomized comparative study of pulsed radiofrequency treatment with or without selective nerve root block for chronic cervical radicular pain. Pain pract. 2017 Jun;17(5):589-95. doi: 10.1111/papr.12493. PMID: 27739217. Exclusion: 2.
257. Wang H, Sribastav SS, Ye F, et al. Comparison of percutaneous vertebroplasty and balloon kyphoplasty for the treatment of single level vertebral compression fractures: a meta-analysis of the literature. Pain physician. 2015 May-Jun;18(3):209-22. PMID: 26000665. Exclusion: 3.

258. Wang HK, Lu K, Liang CL, et al. Comparing clinical outcomes following percutaneous vertebroplasty with conservative therapy for acute osteoporotic vertebral compression fractures. Pain Med. 2010 Nov;11(11):1659-65. doi: 10.1111/j.1526-4637.2010.00959.x. PMID: 21044255. Exclusion: 6.

259. Wang L, Huang S, Li S, et al. Efficacy and safety of umbilical cord mesenchymal stem cell therapy for Rheumatoid Arthritis patients: a prospective phase I/II study. Drug Des Devel Ther. 2019;13:4331-40. doi: 10.2147/DDDT.S225613. PMID: 31908418. Exclusion: 2.

260. Waseem Z, Boulias C, Gordon A, et al. Botulinum toxin injections for low-back pain and sciatica. Cochrane Database Syst Rev. 2011 Jan 19(1):CD008257. doi: 10.1002/14651858.CD008257.pub2. PMID: 21249702. Exclusion: 9.

261. Werner CM, Osterhoff G, Schlickeiser J, et al. Vertebral body stenting versus kyphoplasty for the treatment of osteoporotic vertebral compression fractures: a randomized trial. J Bone Joint Surg Am. 2013 Apr 03;95(7):577-84. doi: 10.2106/JBJS.L.00024. PMID: 23553291. Exclusion: 4.

262. Wu CY, Lin HC, Chen SF, et al. Efficacy of pulsed radiofrequency in herpetic neuralgia: A meta-analysis of randomized controlled trials. Clin J Pain. 2020 Nov;36(11):887-95. doi: 10.1097/AJP.0000000000000867. PMID: 32701526. Exclusion: 9.

263. Wu H, Zhou J, Chen J, et al. Therapeutic efficacy and safety of radiofrequency ablation for the treatment of trigeminal neuralgia: a systematic review and metaanalysis. J Pain Res. 2019;12:423-41. doi: 10.2147/JPR.S176960. PMID: 30697063. Exclusion: 2. 
264. Wu J, Zhou J, Liu C, et al. A prospective study comparing platelet-rich plasma and local anesthetic (LA)/corticosteroid in intraarticular injection for the treatment of lumbar facet joint syndrome. Pain pract. 2017 Sep;17(7):914-24. doi:

10.1111/papr.12544. PMID: 27989008. Exclusion: 3 .

265. Xiang GH, Tong MJ, Lou C, et al. The role of unilateral balloon kyphoplasty for the treatment of patients with OVCFS: A systematic review and meta-analysis. Pain physician. 2018 May;21(3):209-18. PMID: 29871365. Exclusion: 3.

266. Xu J, Sun Z, Wu J, et al. Peripheral Nerve Stimulation in Pain Management: A Systematic Review. Pain physician. 2021 Mar;24(2):E131-E52. PMID: 33740342. Exclusion: 9.

267. Yang H, Liu T, Zhou J, et al. Kyphoplasty versus vertebroplasty for painful osteoporotic vertebral compression fractures-which one is better? A systematic review and meta-analysis. Int J Spine Surg. 2013;7:e45-57. doi: 10.1016/j.ijsp.2013.03.001. PMID: 25694904. Exclusion: 3.

268. Yang LY, Wang XL, Zhou L, et al. A systematic review and meta-analysis of randomized controlled trials of unilateral versus bilateral kyphoplasty for osteoporotic vertebral compression fractures. Pain physician. 2013 Jul-Aug;16(4):277-90. PMID: 23877445. Exclusion: 3.

269. Yang S, Chen C, Wang H, et al. A systematic review of unilateral versus bilateral percutaneous vertebroplasty/percutaneous kyphoplasty for osteoporotic vertebral compression fractures. Acta Orthop Traumatol Turc. 2017 Jul;51(4):290-7. doi: 10.1016/j.aott.2017.05.006. PMID: 28647158. Exclusion: 3.

270. Yang Y, Song M, Fan Y, et al. Occipital nerve stimulation for migraine: A systematic review. Pain pract. 2016 Apr;16(4):509-17. doi: 10.1111/papr.12303. PMID: 25865962. Exclusion: 9.
271. Yi X, Lu H, Tian F, et al. Recompression in new levels after percutaneous vertebroplasty and kyphoplasty compared with conservative treatment. Arch Orthop Trauma Surg. 2014 Jan;134(1):21-30. doi: 10.1007/s00402-013-1886-3. PMID: 24287674. Exclusion: 3.

272. Yin P, Li Z, Zhu S, et al. The treatment of osteoporotic thoraco-lumbar burst fractures by unilateral percutaneous kyphoplasty: A prospective observation study. Eur J Pain. 2020 March;24(3):659-64. doi: 10.1002/ejp.1516. PMID: 31782863. Exclusion: 6.

273. Yokoyama K, Kawanishi M, Yamada M, et al. Comparative study of percutaneous vertebral body perforation and vertebroplasty for the treatment of painful vertebral compression fractures. AJNR Am J Neuroradiol. 2012 Apr;33(4):685-9. doi: 10.3174/ajnr.A2847. PMID: 22194379. Exclusion: 6.

274. Yoon YM, Han SR, Lee SJ, et al. The efficacy of pulsed radiofrequency treatment of cervical radicular pain patients. Korean J. 2014 Sep;11(3):109-12. doi: 10.14245/kjs.2014.11.3.109. PMID: 25346754. Exclusion: 4.

275. $\mathrm{Yu} \mathrm{W}, \mathrm{Xu} \mathrm{W}$, Jiang X, et al. Risk factors for recollapse of the augmented vertebrae after percutaneous vertebral augmentation: a systematic review and meta-analysis. World Neurosurg. 2018 Mar;111:119-29. doi: 10.1016/j.wneu.2017.12.019. PMID: 29253703. Exclusion: 9.

276. Zambello A, Fara B, Tabaracci G, et al. Epidural steroid injection vs paravertebral $\mathrm{O} 2 \mathrm{O} 3$ infiltration for symptomatic herniated disc refractory to conventional treatment: A prospective randomized study. Rivista Italiana di Ossigeno-Ozonoterapia. 2006 10/01;5:123-7. Exclusion: 4.

277. Zhan Y, Jiang J, Liao H, et al. Risk factors for cement leakage after vertebroplasty or kyphoplasty: a meta-analysis of published evidence. World Neurosurg. 2017

May;101:633-42. doi: 10.1016/j.wneu.2017.01.124. PMID: 28192270. Exclusion: 9. 
278. Zhang C, Fang X, Huang Z, et al. Addition

of bone marrow stem cells therapy achieves better clinical outcomes and lower rates of disease progression compared with core decompression alone for early stage osteonecrosis of the femoral head: a systematic review and meta-analysis. J Am Acad Orthop Surg. 2020 Dec 1;28:973-9. doi: 10.5435/JAAOS-D-19-00816. PMID: 32118614. Exclusion: 9.

279. Zhang L, Wang J, Feng X, et al. A comparison of high viscosity bone cement and low viscosity bone cement vertebroplasty for severe osteoporotic vertebral compression fractures. Clin Neurol Neurosurg. 2015 Feb;129:10-6. doi: 10.1016/j.clineuro.2014.11.018. PMID: 25524481. Exclusion: 4.

280. Zhang L, Zhai P. A comparison of percutaneous vertebroplasty versus conservative treatment in terms of treatment effect for osteoporotic vertebral compression fractures: a meta-analysis. Surg Innov. 2020 Feb;27(1):19-25. doi: 10.1177/1553350619869535. PMID: 31423902. Exclusion: 9.

281. Zhang T, Wang Y, Zhang P, et al. What are the risk factors for adjacent vertebral fracture after vertebral augmentation? A meta-analysis of published studies. Global spine j. 2020 Dec 04:2192568220978223. doi: 10.1177/2192568220978223. PMID: 33272041. Exclusion: 9.

282. Zhang Y, Ma Y, Jiang J, et al. Treatment of the lumbar disc herniation with intradiscal and intraforaminal injection of oxygenozone. J Back Musculoskeletal Rehabil. 2013;26(3):317-22. doi: 10.3233/BMR130386. PMID: 23893147. Exclusion: 6.
283. Zhang Y, Song J, Hou Y, et al. Clinical research about the improved PVP method in treatment of acute osteoporotic vertebral compression fractures. J. 2019 SepDec;27(3):2309499019864667. doi: 10.1177/2309499019864667. PMID: 31382815. Exclusion: 5.

284. Zhao D, Cui D, Wang B, et al. Treatment of early stage osteonecrosis of the femoral head with autologous implantation of bone marrow-derived and cultured mesenchymal stem cells. Bone. 2012 Jan;50(1):325-30. doi: 10.1016/j.bone.2011.11.002. PMID: 22094904. Exclusion: 2.

285. Zhao G, Liu X, Li F. Balloon kyphoplasty versus percutaneous vertebroplasty for treatment of osteoporotic vertebral compression fractures (OVCFs). Osteoporos Int. 2016 Sep;27(9):2823-34. doi: 10.1007/s00198-016-3610-y. PMID: 27121344. Exclusion: 4.

286. Zheng Y, Gu M, Shi D, et al. Tomographyguided palisade sacroiliac joint radiofrequency neurotomy versus celecoxib for ankylosing spondylitis: a open-label, randomized, and controlled trial. Rheumatol Int. 2014 Sep;34(9):1195-202. doi: 10.1007/s00296-014-2959-5. PMID: 24518967. Exclusion: 3.

287. Zhiyong C, Yun T, Hui F, et al. Unilateral versus bilateral balloon kyphoplasty for osteoporotic vertebral compression fractures: a systematic review of overlapping meta-analyses. Pain physician. 2019 Jan;22(1):15-28. PMID: 30700065. Exclusion: 3.

288. Zhu Y, Cheng J, Yin J, et al. Therapeutic effect of kyphoplasty and balloon vertebroplasty on osteoporotic vertebral compression fracture: A systematic review and meta-analysis of randomized controlled trials. Medicine (Baltimore). 2019 Nov;98(45):e17810. doi: 10.1097/MD.0000000000017810. PMID: 31702634. Exclusion: 3. 


\section{Appendix C. Quality Rating Criteria}

\section{Randomized Controlled Trials}

\section{Selection Bias}

- Randomization Sequence Generation: Is the method used to generate the allocation sequence described in sufficient detail to allow an assessment of whether it should produce comparable groups?

- Allocation Concealment: Is the method used to conceal the allocation sequence described in sufficient detail to determine whether intervention allocations could have been foreseen in advance of, or during, enrollment?

\section{Performance Bias}

- Blinding of Participants and Personnel: Are the measures used to blind study participants and personnel from knowledge of which intervention a participant received adequate to ensure blinding was effective?

\section{Detection Bias}

- Blinding of Outcome Assessments: Are measures used to blind outcome assessors from knowledge of which intervention a participant received adequate to ensure the intended blinding was effective.

\section{Attrition Bias}

- Incomplete Outcome Data: To what degree do missing data and attrition likely affect outcomes ( $20 \%$ overall or differential between groups is considered high risk)?

\section{Reporting Bias}

- Selective Reporting: Do authors pre-specify outcomes and report findings for all outcomes?

\section{Other Sources of Bias}

- State any important concerns about bias not addressed in other domains. Primarily assessed on concerns of contamination, confounding, and baseline differences.

Selections for each criteria included: Yes, No, and Unclear.

\section{Definition of Ratings Based on Above Criteria}

\section{Good}

- Least risk of bias, results generally considered valid

- Employ valid methods for selection, inclusion, and allocation of patients to treatment; report similar baseline characteristics in different treatment groups; clearly describe attrition and have low attrition; use appropriate means for preventing bias (e.g., blinding 
of patients, care providers, and outcomes assessors); and use appropriate analytic methods (e.g., intention-to-treat analysis)

\section{Fair}

- Susceptible to some bias but not enough to necessarily invalidate results

- May not meet all criteria for good quality, but no flaw is likely to cause major bias; the study may be missing information making it difficult to assess limitations and potential problems

- Category is broad; studies with this rating will vary in strengths and weaknesses; some fair-quality studies are likely to be valid, while others may be only possibly valid

\section{Poor}

- Significant flaws that imply biases of various kinds that may invalidate results; "fatal flaws" in design, analysis or reporting; large amounts of missing information; discrepancies in reporting; or serious problems with intervention delivery

- Studies are at least as likely to reflect flaws in the study design or execution as the true difference between the compared interventions

- Considered to be less reliable than higher quality studies when synthesizing the evidence, particularly if discrepancies between studies are present

Source: Higgins JPT, Green S (editors). Cochrane Handbook for Systematic Reviews of Interventions Version 6.2. The Cochrane Collaboration, 2021. http://handbook.cochrane.org. Used with permission. 


\section{Appendix D. Detailed Statistical Methods}

Random effects meta-analysis using the profile likelihood method was performed to combine randomized trials of vertebroplasty versus sham vertebroplasty or usual care. Because of the potential impact of the type of control group on treatment effects, the primary analysis was stratified according to whether the control group received a sham intervention or usual care. Separate analyses were performed for the prespecified followup duration categories (1 to 2 weeks, 2 to 4 weeks, 1 to 6 months, 6 to 12 months, and 12 months and longer). For studies that reported outcomes at more than one time point within a duration category, we used data for the longest duration within the category.

For continuous outcomes, mean differences was the effect measure for pain, health status, quality of life, and mental health outcomes, and pain scales were converted to a common 0 to 10 scale. For function, standard mean difference (SMD) was the effect measure due to differences in the scales used (most commonly, RDQ and ODI). We also pooled data separately for RDQ and ODI, using the original scales, to aid in interpretation of results. For health status, we pooled SF36 Physical Component Summary (PCS) and Mental Component Summary (MCS) scores. For quality of life, we pooled the EQ-5D (a generic measure of quality of life) separately from the QUALEFFO score (an osteoporosis-specific measure of quality of life). For both mean difference and SMD, adjusted or unadjusted mean difference from the analysis of covariance or other appropriate regression models was used if available, followed by difference in followup score and change score. There were no missing SDs for followup or change scores that needed imputation. When reported SDs were implausibly small, we re-calculated SDs based on the assumption that they were actually standard errors and misreported as SDs (a conservative [i.e., resulting in less precise estimates] assumption); sensitivity analysis was conducted using SDs as reported. Estimates were slightly larger in the sensitivity analysis but did not change overall conclusions and are not described further.

Pooled relative risks (RR) were estimated for binary outcomes including pain response, function improvement, mortality, medication use, and incident vertebral fracture. When a study reported dichotomized pain or function response using multiple thresholds, data were selected for inclusion in the meta-analysis in the following descending order: 30 percent or more improvement, an alternative numerical threshold closest to 30 percent or more improvement, and "moderate" or "good" (or similar categories, for pain relief) on a categorical scale.

Statistical heterogeneity was assessed using the $I^{2}$ statistic ${ }^{51}$ and the Cochran's $\chi^{2}$ test. All meta-analyses were conducted using Stata/SE 16.1 (StataCorp, College Station, TX). For pain intensity, which was the most commonly evaluated outcome, a stratified analysis was performed based on the trials' pain duration inclusion criteria (acute [ $<4$ weeks], acute or subacute [up to 6 to 10 weeks], acute through chronic [up to 12 months], or subacute or chronic only [acute excluded]); because pain inclusion criteria were overlapping and studies using the same inclusion criterion (e.g. up to 12 months) could enroll populations with substantially different average pain duration, we also analyzed pain duration according to the mean/median at enrollment ( $<4$ weeks, 4 to 8 weeks, or $\geq 8$ weeks). Stratified analyses were also performed on PMMA volume ( $<5 \mathrm{ml}$ or $\geq 5 \mathrm{ml}$ ), MRI findings of bone marrow edema required for inclusion (yes or no), and quality (good, fair, or poor). For function, which was evaluated in four to seven trials (depending on time point), stratified analysis was limited to mean/median pain duration and study quality. For other outcomes, due to small numbers of trials, analyses were only stratified by control type. Differences in treatment effects among subgroups were evaluated using meta-regression. For analyses with at least 10 trials, small sample effects were evaluated using funnel plots and the Egger test. 


\section{Appendix E. Grading the Strength of Evidence}

\section{Criteria:}

- Study limitations (low, medium, or high level of study limitations)

- Rated according to the degree to which studies for a given outcome are likely to reduce bias based on study design and conduct across individual studies. Evidence was rated down for study limitations when higher-quality studies were not available or if there were few higher-quality trials and estimates differed in analyses stratified by study quality.

- Consistency (consistent, inconsistent, or unknown/not applicable)

- Rated by degree to which studies find similar magnitude of effect (i.e., range sizes are similar) or same direction of effect (i.e., effect sizes have the same sign). When pooled estimates were available, evidence was rated inconsistent if the $\mathrm{I}^{2}$ was greater than 40 percent, unless findings were consistent in subgroup analyses and there were sufficient trials $(>20)$ for subgroup analyses to be informative.

- Directness (direct or indirect)

- Rated by degree to which the outcome is directly or indirectly related to health outcomes of interest. Patient centered outcomes are considered direct

- Precision (precise or imprecise)

- Describes the level of certainty of the estimate of effect for a particular outcome with a precise estimate being on that allows a clinically useful conclusion. This may be based on sufficiency of sample size and number of events, and if these are adequate, the interpretation of the confidence interval. Evidence was rated imprecise if the pooled estimate confidence interval $(\mathrm{CI})$ crossed the null and the threshold for small magnitude of effect.

- Reporting bias (suspected or undetected)

- Publication bias, selective outcome reporting, and selective analysis reporting are types of reporting bias. Reporting bias is difficult to assess as systematic identification of unpublished evidence is challenging. If sufficient numbers of RCTs $(>10)$ are available, quantitative funnel plot analysis may be done.

An overall SOE grade of high, moderate, low, or insufficient was assigned, based on a fourlevel scale by evaluating and weighing the combined results of the above domains. Bodies of evidence consisting of RCTs are initially considered as high strength. The strength of the evidence may be downgraded based on limitations identified in the domains described above. The SOE levels were defined as:

- High - High confidence that the estimate of effect lies close to the true effect for this outcome. The body of evidence has few or no deficiencies. We believe that the findings are stable, i.e., another study would not change the conclusions.

- Moderate-Moderate confidence that the estimate of effect lies close to the true effect for this outcome. The body of evidence has some deficiencies. We believe that the findings are likely to be stable, but some doubt remains.

- Low-Limited confidence that the estimate of effect lies close to the true effect for this outcome. The body of evidence has major or numerous deficiencies (or both). We believe that additional evidence is needed before concluding either that the findings are stable or that the estimate of effect is close to the true effect. 
- Insufficient-No evidence, unable to estimate an effect, ore no confidence in the estimate of effect for this outcome. No evidence is available or the body of evidence has unacceptable deficiencies, precluding reaching a conclusion. 


\section{Appendix F. List of Included Studies}

1. Amirdelfan K, Bae H, McJunkin T, et al. Allogeneic Mesenchymal Precursor Cells Treatment for Chronic Low Back Pain Associated with Degenerative Disc Disease: A Prospective Randomized, Placebo-Controlled 36-Month Study of Safety and Efficacy. Spine J. 2020 Oct 09;09:09. doi:

https://dx.doi.org/10.1016/j.spinee.2020.10.004 . PMID: 33045417.

2. Berenson J, Pflugmacher R, Jarzem P, et al. Balloon kyphoplasty versus non-surgical fracture management for treatment of painful vertebral body compression fractures in patients with cancer: a multicentre, randomised controlled trial. The lancet. 2011; Oncology. 12(3):225-35. PMID: CN-00787315.

3. Blasco J, Martinez-Ferrer A, Macho J, et al. Effect of vertebroplasty on pain relief, quality of life, and the incidence of new vertebral fractures: a 12-month randomized follow-up, controlled trial. J Bone Miner Res. 2012 May;27(5):1159-66. doi: https://dx.doi.org/10.1002/jbmr.1564. PMID: 22513649 .

4. Boonen S, Van Meirhaeghe J, Bastian L, et al. Balloon kyphoplasty for the treatment of acute vertebral compression fractures: 2-year results from a randomized trial. J Bone Miner Res. 2011 Jul;26(7):1627-37. doi: https://dx.doi.org/10.1002/jbmr.364. PMID: 21337428 .

5. Buchbinder R, Osborne RH, Ebeling PR, et al. A randomized trial of vertebroplasty for painful osteoporotic vertebral fractures. N Engl J Med. 2009 Aug 06;361(6):557-68. doi: https://dx.doi.org/10.1056/NEJMoa0900429. PMID: 19657121.

6. Cady R, Saper J, Dexter K, et al. A doubleblind, placebo-controlled study of repetitive transnasal sphenopalatine ganglion blockade with tx360( R) as acute treatment for chronic migraine. Headache. 2015 Jan;55(1):101-16. doi: https://dx.doi.org/10.1111/head.12458. PMID: 25338927.
7. Cady RK, Saper J, Dexter K, et al. Long-term efficacy of a double-blind, placebo-controlled, randomized study for repetitive sphenopalatine blockade with bupivacaine vs. saline with the Tx360 device for treatment of chronic migraine. Headache. 2015 Apr;55(4):529-42. doi: https://dx.doi.org/10.1111/head.12546. PMID: 25828648.

8. Chen D, An ZQ, Song S, et al. Percutaneous vertebroplasty compared with conservative treatment in patients with chronic painful osteoporotic spinal fractures. J Clin Neurosci. 2014 Mar;21(3):473-7. doi:

https://dx.doi.org/10.1016/j.jocn.2013.05.017. PMID: 24315046.

9. Childers MK, Wilson DJ, Gnatz SM, et al. Botulinum toxin type A use in piriformis muscle syndrome: a pilot study. Am J Phys Med Rehabil. 2002 Oct;81(10):751-9. PMID: 12362115.

10. Clark W, Bird P, Gonski P, et al. Safety and efficacy of vertebroplasty for acute painful osteoporotic fractures (VAPOUR): a multicentre, randomised, double-blind, placebo-controlled trial. Lancet. 2016 Oct 01;388(10052):1408-16. doi: https://dx.doi.org/10.1016/S01406736(16)31341-1. PMID: 27544377.

11. Cohen SP, Hurley RW, Buckenmaier CC, 3rd, et al. Randomized placebo-controlled study evaluating lateral branch radiofrequency denervation for sacroiliac joint pain. Anesthesiology. 2008 Aug;109(2):279-88. doi: https://dx.doi.org/10.1097/ALN.0b013e31817f 4c7c. PMID: 18648237.

12. Comstock BA, Sitlani CM, Jarvik JG, et al. Investigational vertebroplasty safety and efficacy trial (INVEST): patient-reported outcomes through 1 year. Radiology. 2013 Oct;269(1):224-31. doi: https://dx.doi.org/10.1148/radiol.13120821. PMID: 23696683. 
13. Deer T, Pope J, Benyamin R, et al. Prospective, Multicenter, Randomized, Double-Blinded, Partial Crossover Study to Assess the Safety and Efficacy of the Novel Neuromodulation System in the Treatment of Patients With Chronic Pain of Peripheral Nerve Origin. Neuromodulation. 2016 Jan;19(1):91-100. doi: https://dx.doi.org/10.1111/ner.12381. PMID: 26799373.

14. Diamond T, Clark W, Bird P, et al. Early vertebroplasty within 3 weeks of fracture for acute painful vertebral osteoporotic fractures: subgroup analysis of the VAPOUR trial and review of the literature. Eur Spine J. 2020 Jul;29(7):1606-13. doi: https://dx.doi.org/10.1007/s00586-020-063622. PMID: 32170438.

15. Farrokhi MR, Alibai E, Maghami Z. Randomized controlled trial of percutaneous vertebroplasty versus optimal medical management for the relief of pain and disability in acute osteoporotic vertebral compression fractures. J Neurosurg Spine. 2011

May;14(5):561-9. doi: https://dx.doi.org/10.3171/2010.12.SPINE1028 6. PMID: 21375382.

16. Firanescu CE, de Vries J, Lodder P, et al. Percutaneous Vertebroplasty is no Risk Factor for New Vertebral Fractures and Protects Against Further Height Loss (VERTOS IV). Cardiovasc Intervent Radiol. 2019 Jul;42(7):991-1000. doi: https://dx.doi.org/10.1007/s00270-019-02205w. PMID: 30941490.

17. Firanescu CE, de Vries J, Lodder P, et al. Vertebroplasty versus sham procedure for painful acute osteoporotic vertebral compression fractures (VERTOS IV): randomised sham controlled clinical trial. Bmj. 2018 05 09;361:k1551. doi: https://dx.doi.org/10.1136/bmj.k1551. PMID: 29743284.

18. Fishman LM, Anderson C, Rosner B. BOTOX and physical therapy in the treatment of piriformis syndrome. Am J Phys Med Rehabil. 2002 Dec;81(12):936-42. doi: 10.1097/00002060-200212000-00009. PMID: 12447093.
19. Fishman LM, Wilkins AN, Rosner B. Electrophysiologically identified piriformis syndrome is successfully treated with incobotulinum toxin a and physical therapy. Muscle Nerve. 2017 08;56(2):258-63. doi: https://dx.doi.org/10.1002/mus.25504. PMID: 27935076.

20. Gallucci M, Limbucci N, Zugaro L, et al. Sciatica: treatment with intradiscal and intraforaminal injections of steroid and oxygen-ozone versus steroid only. Radiology. 2007 Mar;242(3):907-13. PMID: 17209164.

21. Hansen E, Simony A, Carreon L, et al. Vertebroplasty vs. SHAM for Treating Osteoporotic Vertebral Compression Fractures: A Double Blind RCT. Integr J Orthop Traumatol. 2019;2(4):1-6. doi: 10.31038/IJOT.2019244.

22. Haseeb AESA, Abd El Hares AEH, Abd El Moez KM, et al. Comparative Study between Treatment of Lumbar Disc Herniation with Intra Discal Ozone and Transforaminal Steroid Injection versus Steroid Injection only. The Egyptian Journal of Hospital Medicine. 2019;74(4):705-20. doi: 10.12816/ejhm.2019.24068.

23. Kallewaard JW, Wintraecken VM, Geurts JW, et al. A multicenter randomized controlled trial on the efficacy of intradiscal methylene blue injection for chronic discogenic low back pain: the IMBI study. Pain. 2019 Apr;160(4):945-53. doi:

https://dx.doi.org/10.1097/j.pain.00000000000 01475. PMID: 30730862.

24. Kallmes DF, Comstock BA, Heagerty PJ, et al. A randomized trial of vertebroplasty for osteoporotic spinal fractures. N Engl J Med. 2009 Aug 06;361(6):569-79. doi: https://dx.doi.org/10.1056/NEJMoa0900563. PMID: 19657122.

25. Klazen CA, Lohle PN, de Vries J, et al. Vertebroplasty versus conservative treatment in acute osteoporotic vertebral compression fractures (Vertos II): an open-label randomised trial. Lancet. 2010 Sep 25;376(9746):1085-92. doi: https://dx.doi.org/10.1016/S01406736(10)60954-3. PMID: 20701962. 
26. Kroll HR, Kim D, Danic MJ, et al. A randomized, double-blind, prospective study comparing the efficacy of continuous versus pulsed radiofrequency in the treatment of lumbar facet syndrome. J Clin Anesth. 2008 Nov;20(7):534-7. doi: https://dx.doi.org/10.1016/j.jclinane.2008.05.0 21. PMID: 19041042.

27. Kroon F, Staples M, Ebeling PR, et al. Twoyear results of a randomized placebo-controlled trial of vertebroplasty for acute osteoporotic vertebral fractures. J Bone Miner Res. 2014 Jun;29(6):1346-55. PMID: 24967454.

28. Leali PT, Solla F, Maestretti G, et al. Safety and efficacy of vertebroplasty in the treatment of osteoporotic vertebral compression fractures: a prospective multicenter international randomized controlled study. Clin. 2016 Sep-Dec;13(3):234-6. doi: https://dx.doi.org/10.11138/ccmbm/2016.13.3. 234. PMID: 28228788.

29. McCormick ZL, Choi H, Reddy R, et al. Randomized prospective trial of cooled versus traditional radiofrequency ablation of the medial branch nerves for the treatment of lumbar facet joint pain. Reg Anesth Pain Med. 2019 03;44(3):389-97. doi: https://dx.doi.org/10.1136/rapm-2018-000035. PMID: 30777903.

30. Mekhail NA, Estemalik E, Azer G, et al. Safety and Efficacy of Occipital Nerves Stimulation for the Treatment of Chronic Migraines: Randomized, Double-blind, Controlled Singlecenter Experience. Pain pract. 2017

06;17(5):669-77. doi: https://dx.doi.org/10.1111/papr.12504. PMID: 27779368.

31. Misirlioglu TO, Akgun K, Palamar D, et al. Piriformis syndrome: comparison of the effectiveness of local anesthetic and corticosteroid injections: a double-blinded, randomized controlled study. Pain physician. 2015 Mar-Apr;18(2):163-71. PMID: 25794202.

32. Moussa WM, Khedr W, Elsawy M. Percutaneous pulsed radiofrequency treatment of dorsal root ganglion for treatment of lumbar facet syndrome. Clin Neurol Neurosurg. 2020 Dec;199:106253. doi: https://dx.doi.org/10.1016/j.clineuro.2020.1062 53. PMID: 33045627.
33. Nilachandra L, Darendrajit L, Joy Singh A, et al. Ozone nucleolysis in the management of prolapsed lumbar intervertebral disc in reducing pain and disability: a randomized controlled study. PARIPEX-Indian Journal of Research. 2016 Nov;5(11):51-4.

34. Patel N, Gross A, Brown L, et al. A randomized, placebo-controlled study to assess the efficacy of lateral branch neurotomy for chronic sacroiliac joint pain. Pain Med. 2012 Mar;13(3):383-98. doi: https://dx.doi.org/10.1111/j.15264637.2012.01328.x. PMID: 22299761.

35. Peng B, Pang X, Wu Y, et al. A randomized placebo-controlled trial of intradiscal methylene blue injection for the treatment of chronic discogenic low back pain. Pain. 2010 Apr;149(1):124-9. doi: https://dx.doi.org/10.1016/j.pain.2010.01.021. PMID: 20167430.

36. Rousing R, Andersen MO, Jespersen SM, et al. Percutaneous vertebroplasty compared to conservative treatment in patients with painful acute or subacute osteoporotic vertebral fractures: three-months follow-up in a clinical randomized study. Spine. 2009 Jun 01;34(13):1349-54. doi: https://dx.doi.org/10.1097/BRS.0b013e3181a4 e628. PMID: 19478654.

37. Rousing R, Hansen KL, Andersen MO, et al. Twelve-months follow-up in forty-nine patients with acute/semiacute osteoporotic vertebral fractures treated conservatively or with percutaneous vertebroplasty: a clinical randomized study. Spine. 2010 Mar 01;35(5):478-82. doi: https://dx.doi.org/10.1097/BRS.0b013e3181b7 1bd1. PMID: 20190623.

38. Saper JR, Dodick DW, Silberstein SD, et al. Occipital nerve stimulation for the treatment of intractable chronic migraine headache: ONSTIM feasibility study. Cephalalgia. 2011 Feb;31(3):271-85. doi: https://dx.doi.org/10.1177/0333102410381142. PMID: 20861241.

39. Serra G, Marchioretto F. Occipital nerve stimulation for chronic migraine: a randomized trial. Pain physician. 2012 May-Jun;15(3):24553. PMID: 22622909. 
40. Silberstein SD, Dodick DW, Saper J, et al. Safety and efficacy of peripheral nerve stimulation of the occipital nerves for the management of chronic migraine: results from a randomized, multicenter, double-blinded, controlled study. Cephalalgia. 2012

Dec;32(16):1165-79. doi:

https://dx.doi.org/10.1177/0333102412462642. PMID: 23034698.

41. Staples MP, Howe BM, Ringler MD, et al. New vertebral fractures after vertebroplasty: 2year results from a randomised controlled trial. Arch Osteoporos. 2015;10:229. doi: https://dx.doi.org/10.1007/s11657-015-0229-0. PMID: 26272712.

42. Tekin I, Mirzai H, Ok G, et al. A comparison of conventional and pulsed radiofrequency denervation in the treatment of chronic facet joint pain. Clin J Pain. 2007 JulAug;23(6):524-9. PMID: 17575493.

43. Tuakli-Wosornu YA, Terry A, Boachie-Adjei $\mathrm{K}$, et al. Lumbar Intradiskal Platelet-Rich Plasma (PRP) Injections: A Prospective, Double-Blind, Randomized Controlled Study. Pm R. 2016 Jan;8(1):1-10; quiz doi: https://dx.doi.org/10.1016/j.pmrj.2015.08.010. PMID: 26314234.

44. Van Meirhaeghe J, Bastian L, Boonen S, et al. A randomized trial of balloon kyphoplasty and nonsurgical management for treating acute vertebral compression fractures: vertebral body kyphosis correction and surgical parameters. Spine. 2013 May 20;38(12):971-83. doi: https://dx.doi.org/10.1097/BRS.0b013e31828e 8e22. PMID: 23446769.

45. Venmans A, Klazen CA, van Rooij WJ, et al. Postprocedural CT for perivertebral cement leakage in percutaneous vertebroplasty is not necessary--results from VERTOS II.

Neuroradiology. 2011 Jan;53(1):19-22. doi: https://dx.doi.org/10.1007/s00234-010-0705-6. PMID: 20442991.

46. Voormolen MH, Mali WP, Lohle PN, et al. Percutaneous vertebroplasty compared with optimal pain medication treatment: short-term clinical outcome of patients with subacute or chronic painful osteoporotic vertebral compression fractures. The VERTOS study. AJNR Am J Neuroradiol. 2007 Mar;28(3):55560. PMID: 17353335.
47. Wardlaw D, Cummings SR, Van Meirhaeghe $\mathrm{J}$, et al. Efficacy and safety of balloon kyphoplasty compared with non-surgical care for vertebral compression fracture (FREE): a randomised controlled trial. Lancet. 2009 Mar 21;373(9668):1016-24. doi: https://dx.doi.org/10.1016/S01406736(09)60010-6. PMID: 19246088.

48. Yang EZ, Xu JG, Huang GZ, et al. Percutaneous Vertebroplasty Versus Conservative Treatment in Aged Patients With Acute Osteoporotic Vertebral Compression Fractures: A Prospective Randomized Controlled Clinical Study. Spine. 2016 Apr;41(8):653-60. doi: https://dx.doi.org/10.1097/BRS.000000000000 1298. PMID: 26630417. 


\section{Appendix G. Data Abstraction Tables}

Table G-1. Trials of vertebral augmentation procedures to treat vertebral compression fractures - study characteristics

\begin{tabular}{|c|c|c|c|c|c|}
\hline $\begin{array}{c}\text { Vertebral } \\
\text { Augmentation } \\
\text { Procedure }\end{array}$ & $\begin{array}{l}\text { Author, } \\
\text { Year } \\
\text { Trial } \\
\end{array}$ & $\begin{array}{c}\text { Study } \\
\text { Design } \\
\text { Duration }\end{array}$ & $\begin{array}{c}\text { Setting/Provider } \\
\text { Type } \\
\text { Country } \\
\end{array}$ & $\begin{array}{c}\text { Eligibility Criteria } \\
\end{array}$ & $\begin{array}{c}\text { Interventions } \\
\end{array}$ \\
\hline Vertebroplasty & \begin{tabular}{|l|} 
Blasco, \\
2012
\end{tabular} & $\begin{array}{l}\mathrm{RCT} \\
12 \text { months }\end{array}$ & $\begin{array}{l}1 \text { center, } \\
\text { interventional } \\
\text { radiology } \\
\text { Spain }\end{array}$ & $\begin{array}{l}\text { Osteoporotic VCF from T4 to L5 with clinical onset } \\
<12 \text { months, confirmed by spine radiograph and by } \\
\text { the presence of edema on MRI or activity on bone } \\
\text { scan, and pain VAS (0 to } 10) \geq 4 \\
\text { Excluded: untreatable coagulopathy, active local or } \\
\text { systemic infection, current malignancy, vertebral canal } \\
\text { occupation by a fragment of the vertebral body or } \\
\text { nonosteoporotic VCF, active associated disorders } \\
\text { (i.e., fibromyalgia or spondyloarthropathies) or other } \\
\text { disorders (i.e., dementia) potentially interfering with } \\
\text { assessment of quality of life and pain }\end{array}$ & $\begin{array}{l}\text { A: Vertebroplasty: Most procedure performed with } \\
\text { bilateral transpedicular 10-gauge or 13-gauge } \\
\text { needle injection of PMMA cement (Exolent Spine, } \\
\text { Elmdown, London, UK, mean volume not } \\
\text { reported). CT immediately or } 24 \text { hours after the } \\
\text { procedure } \\
\text { B: Usual care: Analgesics and nasal calcitonin } \\
\text { (doses not reported); intrathecal infusion ( } 25 \mu \mathrm{g} \\
\text { fentanyl and } 1.5 \mathrm{mg} \text { bupivacaine) for breakthrough } \\
\text { pain or if medications ineffective }\end{array}$ \\
\hline Vertebroplasty & $\begin{array}{l}\text { Buchbinder, } \\
2009 \\
\\
\text { Additional } \\
\text { publications: } \\
\text { Kroon, 2014 } \\
\text { and Staples } \\
2015\end{array}$ & \begin{tabular}{|l|} 
RCT \\
24 months \\
(see \\
Kroon \\
2014 for \\
12 and 24 \\
month \\
results)
\end{tabular} & \begin{tabular}{|l}
4 centers, \\
interventional \\
radiology \\
Australia
\end{tabular} & $\begin{array}{l}\text { Back pain } \leq 12 \text { months duration, } 1 \text { or } 2 \text { recent } \\
\text { vertebral fractures (defined as vertebral collapse of } \\
\text { grade } 1 \text { or higher [scale } 0 \text { to } 3 \text {, higher numbers } \\
\text { indicating greater vertebral collapse], and edema, a } \\
\text { fracture line, or both within the vertebral body on MRI } \\
\text { Excluded: }>2 \text { recent vertebral fractures, spinal cancer, } \\
\text { neurologic complications, osteoporotic vertebral } \\
\text { collapse }>90 \% \text {, fracture through or } \\
\text { destruction of the posterior wall, retro pulsed bony } \\
\text { fragment or bony fragments impinging on the spinal } \\
\text { cord, medical conditions that would make the patient } \\
\text { ineligible for emergency decompressive surgery if } \\
\text { needed, previous vertebroplasty }\end{array}$ & $\begin{array}{l}\text { A: Vertebroplasty: Periosteum of the posterior } \\
\text { lamina infiltrated with local anesthetic, } 13 \text {-gauge } \\
\text { needle was placed posterolaterally relative to the } \\
\text { eye of the pedicle and guided into the anterior two- } \\
\text { thirds of the fractured vertebral body and } \\
\text { approximately } 3 \mathrm{ml} \text { prepared PMMA slowly } \\
\text { injected into the vertebral body (mean } 2.8 \mathrm{ml} \text { [SD } \\
\text { 1.2]); satisfactory infiltration of the vertebral body } \\
\text { confirmed radiographically } \\
\text { B: Sham vertebroplasty: Periosteum of the } \\
\text { posterior lamina infiltrated with local anesthetic, } \\
\text { 13-gauge needle inserted as for vertebroplasty, } \\
\text { then the central sharp stylet was replaced with a } \\
\text { blunt stylet; to simulate vertebroplasty, the } \\
\text { vertebral body was gently tapped; PMMA was } \\
\text { prepared so that its smell permeated the room }\end{array}$ \\
\hline Vertebroplasty & $\begin{array}{l}\text { Staples, } \\
2015 \\
\\
\text { Secondary } \\
\text { publication } \\
\text { of } \\
\text { Buchbinder } \\
2009 \\
\end{array}$ & $\begin{array}{l}\mathrm{RCT} \\
\text { additional } \\
\text { followup } \\
2 \text { years }\end{array}$ & $\begin{array}{l}\text { see Buchbinder, } \\
2009\end{array}$ & see Buchbinder, 2009 & see Buchbinder, 2009 \\
\hline Vertebroplasty & $\begin{array}{l}\text { Kroon, } 2014 \\
\text { Secondary } \\
\text { publication } \\
\text { of } \\
\text { Buchbinder, } \\
2009\end{array}$ & \begin{tabular}{|l|}
$\mathrm{RCT}$ \\
2 years
\end{tabular} & $\begin{array}{l}\text { see Buchbinder, } \\
2009\end{array}$ & see Buchbinder, 2009 & see Buchbinder, 2009 \\
\hline
\end{tabular}




\begin{tabular}{|c|c|c|c|c|c|}
\hline $\begin{array}{c}\text { Vertebral } \\
\text { Augmentation } \\
\text { Procedure }\end{array}$ & $\begin{array}{l}\text { Author, } \\
\text { Year } \\
\text { Trial }\end{array}$ & $\begin{array}{c}\text { Study } \\
\text { Design } \\
\text { Duration }\end{array}$ & $\begin{array}{c}\text { Setting/Provider } \\
\text { Type } \\
\text { Country }\end{array}$ & Eligibility Criteria & Interventions \\
\hline Vertebroplasty & Chen, 2014 & $\begin{array}{l}\mathrm{RCT} \\
12 \text { months }\end{array}$ & $\begin{array}{l}1 \text { center, } \\
\text { orthopedic } \\
\text { surgery } \\
\text { China }\end{array}$ & $\begin{array}{l}\text { Chronic osteoporotic compression spinal fractures on } \\
\text { MRI (low signal on T1-weighted and high signal on } \\
\text { T2-weighted scans) and persistent back pain for } \geq 3 \\
\text { months } \\
\text { Excluded: NR }\end{array}$ & $\begin{array}{l}\text { A: Vertebroplasty: Bone puncture needle (13 G, } \\
\text { Cook Medical, Bloomington, IN, USA) was placed } \\
\text { transpedicularly in the fractured vertebra. After } \\
\text { removal of the inner needle, commercially } \\
\text { available PMMA (Osteo-Firm, Cook Medical) was } \\
\text { injected into the fractured vertebra under } \\
\text { continuous fluoroscopic monitoring (mean } 3.6 \mathrm{ml} \\
\text { [range } 3 \text { to } 6 \mathrm{~mL} \text { ). } \\
\text { B: Usual care: Offered brace treatment, analgesia, } \\
\text { general mobilizing physiotherapy, and } \\
\text { osteoporotic medication treatment, including } \\
\text { vitamin D and bisphosphonate }\end{array}$ \\
\hline Vertebroplasty & $\begin{array}{l}\text { Clark, } 2016 \\
\text { VAPOUR }\end{array}$ & $\begin{array}{l}\text { RCT } \\
6 \text { months }\end{array}$ & $\begin{array}{l}4 \text { centers, } \\
\text { interventional } \\
\text { radiology } \\
\text { Australia }\end{array}$ & $\begin{array}{l}\geq 60 \text { years with back pain of }<6 \text { weeks, NRS score } \geq 7 \text {, } \\
\text { MRI confirming } 1 \text { or } 2 \text { recent fractures. } \\
\text { Excluded: chronic back pain requiring opiate use, } \\
\text { substantial fracture retropulsion, acute infection, } \\
\text { spinal malignancy, neurological complications, and }>2 \\
\text { vertebral fractures. }\end{array}$ & $\begin{array}{l}\text { A: Vertebroplasty: 11-guage or 13-gauge } \\
\text { vertebroplasty needle introduced into the vertebral } \\
\text { body with unipedicular or bipedicular technique } \\
\text { with fluoroscopic guidance, using an AVAMAX kit } \\
\text { (CareFusion Corporation). Aimed to fill vertebral } \\
\text { body with PMMA from superior to inferior } \\
\text { endplate, mid-pedicle to mid-pedicle in frontal } \\
\text { projection, and from anterior cortex to posterior } \\
\text { third of vertebral body (mean } 7.5 \text { ml [SD 2.8]) } \\
\text { B: Sham vertebroplasty: Subcutaneous lidocaine } \\
\text { but not periosteal numbing. Manual skin pressure } \\
\text { and regular tapping on the needle was done, } \\
\text { mimicking vertebroplasty needle advanced, with } \\
\text { conversation about PMMA mixing and injection to } \\
\text { suggest vertebroplasty was being done. }\end{array}$ \\
\hline Vertebroplasty & $\begin{array}{l}\text { Diamond, } \\
2020 \\
\text { VAPOUR }\end{array}$ & $\begin{array}{l}\text { RCT } \\
6 \text { months }\end{array}$ & $\begin{array}{l}4 \text { centers, } \\
\text { interventional } \\
\text { radiology } \\
\text { Australia }\end{array}$ & $\begin{array}{l}\text { Patients included in the VAPOUR (Clark, 2016) trial } \\
\text { with fractures } \leq 3 \text { weeks in duration. }\end{array}$ & See Clark, 2016 \\
\hline Vertebroplasty & $\begin{array}{l}\text { Farrokhi, } \\
2011\end{array}$ & $\begin{array}{l}\text { RCT } \\
36 \text { months }\end{array}$ & $\begin{array}{l}1 \text { center, } \\
\text { neurosurgery } \\
\text { Iran }\end{array}$ & $\begin{array}{l}\text { VCF with } 10 \text { to } 70 \% \text { loss of vertebral body height; } \\
\text { severe back pain related to VCF refractory to } \\
\text { medications for } \geq 4 \text { weeks and } \leq 1 \text { year; focal } \\
\text { tenderness on examination related to level of fracture; } \\
\text { T-score <- } 2.5 \text { on bone densitometry; vacuum } \\
\text { phenomenon or bone marrow edema of vertebral } \\
\text { fracture on MR imaging; unresponsive to medical } \\
\text { therapy } \\
\text { Excluded: uncorrected coagulopathy; local or } \\
\text { systemic infection; secondary osteoporosis; impaired } \\
\text { cardiopulmonary function; dementia; posterior wall } \\
\text { defect of the VB on CT studies; painless VCF; spinal } \\
\text { cancer; traumatic fracture; and neurological } \\
\text { complications }\end{array}$ & $\begin{array}{l}\text { A: Vertebroplasty: 11-gauge needle inserted into } \\
\text { the vertebral body via a unilateral parapedicular } \\
\text { approach in } 35 \text { patients }(87.5 \%) \text { and via a bilateral } \\
\text { transpedicular approach in } 5 \text { patients (12.5\%). A } \\
\text { bilateral transpedicular approach was used only if } \\
\text { there was inadequate instillation of cement with } \\
\text { the unilateral approach under fluoroscopy. A } \\
\text { PMMA mixture was injected into the vertebral } \\
\text { body (mean } 3.5 \mathrm{ml} \text { for } 1 \text { level fracture and } 5 \mathrm{ml} \text { for } \\
\text { multilevel fractures) } \\
\text { B: Usual care: Acetaminophen } 250 \mathrm{mg} \text { with } \\
\text { codeine twice daily, ibuprofen } 400 \mathrm{mg} \text { twice daily, } \\
\text { calcium } 1000 \mathrm{mg} \text { daily, vitamin D } 400 \mathrm{IU} \text { daily, } \\
\text { alendronate } 70 \mathrm{mg} \text { orally once weekly, and } \\
\text { calcitonin } 200 \mathrm{IU} \text { daily }\end{array}$ \\
\hline
\end{tabular}




\begin{tabular}{|c|c|c|c|c|c|}
\hline $\begin{array}{c}\text { Vertebral } \\
\text { Augmentation } \\
\text { Procedure }\end{array}$ & $\begin{array}{l}\text { Author, } \\
\text { Year } \\
\text { Trial } \\
\end{array}$ & $\begin{array}{c}\text { Study } \\
\text { Design } \\
\text { Duration }\end{array}$ & \begin{tabular}{|c|} 
Setting/Provider \\
Type \\
Country
\end{tabular} & Eligibility Criteria & Interventions \\
\hline Vertebroplasty & $\begin{array}{l}\text { Firanescu, } \\
2018 \text { \& } 2019 \\
\text { VERTOS IV }\end{array}$ & $\begin{array}{l}\mathrm{RCT} \\
12 \text { months }\end{array}$ & $\begin{array}{l}4 \text { centers, } \\
\text { interventional } \\
\text { radiology } \\
\text { the Netherlands }\end{array}$ & $\begin{array}{l}\geq 50 \text { years, T5 to L5 focal back pain of } \leq 9 \text { weeks } \\
\text { duration, bone density T score } \leq-1, \geq 15 \% \text { loss } \\
\text { vertebral height, bone edema on MRI } \\
\text { Excluded: severe cardiopulmonary morbidity, } \\
\text { untreatable coagulopathy, systemic or local spine } \\
\text { infection, suspected malignancy, neurological } \\
\text { symptoms, or inability to undergo MRI }\end{array}$ & $\begin{array}{l}\text { A: Vertebroplasty: Bone biopsy needles at } \\
\text { vertebral body positioned bilaterally, using } \\
\text { standard transpedicular placements with local } \\
\text { anesthetic ( } 1 \% \text { lidocaine into each pedicle } \\
\text { followed by } 0.25 \% \text { ropivacaine) unless conscious } \\
\text { sedation required (50 } \mu \text { g fentanyl in } 22 \% \text { of } \\
\text { patients), PMMA injection stopped when cement } \\
\text { leakage was noticed via CT (mean PMMA volume } \\
5.1 \mathrm{ml}[\mathrm{SD} 1.8] \text { ). In participants with multiple } \\
\text { fractures, all were treated. } \\
\text { B: Sham vertebroplasty: Stab incisions at level of } \\
\text { the vertebral body, local anesthetic as above, } \\
\text { PMMA prepared in close proximity to the } \\
\text { participants to duplicate mixing sound and smell; } \\
\text { simulated procedure using verbal and physical } \\
\text { cues. }\end{array}$ \\
\hline Vertebroplasty & $\begin{array}{l}\text { Hansen, } \\
2019 \\
\text { VOPE }\end{array}$ & \begin{tabular}{|l|}
$\mathrm{RCT}$ \\
12 months
\end{tabular} & $\begin{array}{l}1 \text { center, surgery } \\
\text { Denmark }\end{array}$ & $\begin{array}{l}\text { Osteoporotic VCF from T5 to L5, VAS }>7.0 \text { (0 to } 10 \\
\text { scale), } \leq 8 \text { weeks of back pain and a MRI-STIR } \\
\text { sequence showing edema. } \\
\text { Excluded: history of malignancy, age }<50 \text { years, } \\
\text { known allergy towards vertebroplasty components, } \\
\text { dementia (based on MMSE), long bone osteoporotic } \\
\text { fracture }\end{array}$ & $\begin{array}{l}\text { A: Vertebroplasty: } 11 \text {-gauge needles inserted into } \\
\text { the fractured vertebral body via the pedicles under } \\
\text { fluoroscopic guidance and a biopsy specimen was } \\
\text { taken, then } 2 \text { to } 4 \mathrm{ml} \text { of bone cement was injected } \\
\text { into fracture vertebral body. } \\
\text { B: Sham vertebroplasty: Same procedure, with } \\
\text { bone cement mixed to create the odor similar to a } \\
\text { PVP-procedure; lidocaine } 2 \mathrm{ml}(10 \mathrm{mg} / \mathrm{ml}) \text { injected } \\
\text { into fractured vertebral body. }\end{array}$ \\
\hline Vertebroplasty & $\begin{array}{l}\text { Kallmes, } \\
2009 \text { and } \\
\text { Comstock, } \\
2013 \\
\text { INVEST }\end{array}$ & \begin{tabular}{|l|}
$\mathrm{RCT}$ \\
12 months
\end{tabular} & $\begin{array}{l}11 \text { centers, } \\
\text { provider type not } \\
\text { described } \\
\text { U.K., Australia, } \\
\text { and U.S. }\end{array}$ & $\begin{array}{l}\geq 50 \text { years, } 1 \text { to } 3 \text { painful osteoporotic VCFs between } \\
\text { T4 and L5, duration }<1 \text { year, inadequate relief with } \\
\text { standard medical therapy, pain } \geq 3 \text { ( } 0 \text { to } 10 \text { scale) } \\
\text { Excluded: evidence or suspicion of neoplasm in the } \\
\text { target vertebral body, substantial retropulsion of bony } \\
\text { fragments, concomitant hip fracture, active infection, } \\
\text { uncorrectable bleeding diatheses, surgery within the } \\
\text { previous } 60 \text { days, lack of access to a telephone, } \\
\text { inability to communicate in English, and dementia. }\end{array}$ & $\begin{array}{l}\text { A: Vertebroplasty: Subcutaneous tissues overlying } \\
\text { pedicle infiltrated with } 1 \% \text { lidocaine and } \\
\text { periosteum of pedicles infiltrated with } 0.25 \% \\
\text { bupivacaine. } 11-\text { or } 13-\text { gauge needles passed into } \\
\text { the central aspect of the target vertebra or } \\
\text { vertebrae. Barium opacified PMMA was prepared } \\
\text { on the bench and infused under constant lateral } \\
\text { fluoroscopy into the vertebral body. Infusion } \\
\text { stopped when the PMMA reached to the posterior } \\
\text { aspect of the vertebral body or entered an extra } \\
\text { osseous space (mean PMMA volume } 2.6 \text { ml). } \\
\text { B: Sham vertebroplasty: Subcutaneous tissues } \\
\text { overlying pedicle infiltrated with } 1 \% \text { lidocaine and } \\
\text { periosteum of pedicles infiltrated with } 0.25 \% \\
\text { bupivacaine. Verbal and physical cues, such as } \\
\text { pressure on the patient's back, then methacrylate } \\
\text { monomer opened to simulate the odor associated } \\
\text { with mixing of PMMA, but needle not placed and } \\
\text { PMMA not infused }\end{array}$ \\
\hline
\end{tabular}




\begin{tabular}{|c|c|c|c|c|c|}
\hline $\begin{array}{c}\text { Vertebral } \\
\text { Augmentation } \\
\text { Procedure }\end{array}$ & \begin{tabular}{|l|} 
Author, \\
Year \\
Trial \\
\end{tabular} & $\begin{array}{c}\text { Study } \\
\text { Design } \\
\text { Duration } \\
\end{array}$ & \begin{tabular}{|c} 
Setting/Provider \\
Type \\
Country
\end{tabular} & Eligibility Criteria & Interventions \\
\hline Vertebroplasty & $\begin{array}{l}\text { Klazen, } \\
2010 \text { and } \\
\text { Venmans, } \\
2011 \\
\text { VERTOS II }\end{array}$ & $\begin{array}{l}\text { RCT } \\
12 \text { months }\end{array}$ & $\begin{array}{l}6 \text { centers, } \\
\text { interventional } \\
\text { radiology } \\
\text { the Netherlands } \\
\text { and Belgium }\end{array}$ & $\begin{array}{l}\geq 50 \text { years, } \geq 15 \% \text { height loss, fracture at thoracic } 5 \text { or } \\
\text { lower (meaning toward lumbar region), bone edema } \\
\text { on MRI, back pain } \leq 6 \text { weeks, } \geq 5 \text { VAS ( } 0 \text { to } 10 \text { scale) } \\
\text { Excluded: severe cardiopulmonary comorbidity; } \\
\text { untreatable coagulopathy; systemic or local spine } \\
\text { infection; suspected underlying malignant disease; } \\
\text { radicular syndrome; spinal-cord compression } \\
\text { syndrome; and contraindication } \\
\text { for MRI }\end{array}$ & $\begin{array}{l}\text { A: Vertebroplasty: Two 11- or 13- gauge bone- } \\
\text { biopsy needles placed transpedicularly in the } \\
\text { fractured vertebral body. PMMA bone cement } \\
\text { (Osteo-Firm, COOK Medical, Bloomington, IN, } \\
\text { USA) injected through bone-biopsy needles under } \\
\text { continuous fluoroscopic monitoring (mean PMMA } \\
\text { volume } 4.1 \mathrm{ml} \text { [SD 1.5]). } \\
\text { B: Usual care: Not defined }\end{array}$ \\
\hline Vertebroplasty & Leali, 2016 & \begin{tabular}{|l|}
$\mathrm{RCT}$ \\
6 months
\end{tabular} & $\begin{array}{l}\text { Multicenter } \\
\text { (number of } \\
\text { centers not } \\
\text { reported), } \\
\text { provider type not } \\
\text { described } \\
\text { Italy, France, } \\
\text { Switzerland }\end{array}$ & $\begin{array}{l}\text { Postmenopausal women with } 1 \text { thoracic or lumbar } \\
\text { VCF caused by primary or secondary osteoporosis } \\
\text { with severe acute (not defined) pain, VCF height of } \\
\text { the visible loss of vertebral body in radiography and } \\
\text { standard evidence of osteoporosis on bone } \\
\text { densitometry, bone marrow edema of the affected } \\
\text { VCF on spine MRI, and the presence of evidence of } \\
\text { an acute fracture. } \\
\text { Excluded: pathological fracture due to } \\
\text { myeloma/metastasis, retropulsion mass of bone } \\
\text { fragments in the spinal canal, unstable } \\
\text { cardiopulmonary conditions, coagulopathy incurable, } \\
\text { systemic infection in progress, or local infection spine, } \\
\text { radicular syndrome or spinal cord compression. }\end{array}$ & $\begin{array}{l}\text { A: Vertebroplasty: Transpedicular approach under } \\
\text { local anesthesia with (mepivacaine } 2 \% \text { and } \\
\text { ropivacaine } 10 \%) \text {. PMMA (mean } 4 \mathrm{ml} \text { ) was } \\
\text { injected into each fractured vertebral body under } \\
\text { fluoroscopy } \\
\text { B: Usual care: Pain medication, osteoporosis } \\
\text { medication, physiotherapy or bracing }\end{array}$ \\
\hline Vertebroplasty & $\begin{array}{l}\text { Rousing, } \\
2009 \& 2010\end{array}$ & $\begin{array}{l}\text { RCT } \\
12 \text { months }\end{array}$ & $\begin{array}{l}1 \text { center, } \\
\text { orthopedic } \\
\text { surgery } \\
\text { Denmark }\end{array}$ & $\begin{array}{l}\text { Intractable pain due to acute ( }<2 \text { weeks, } 40 \text { patients) } \\
\text { or subacute (between } 2 \text { and } 8 \text { weeks, } 10 \text { patients) } \\
\text { osteoporotic fractures preventing the patient in taking } \\
\text { care of oneself, and sufficient cognitive function to } \\
\text { complete the study } \\
\text { Excluded: }<65 \text { years, uncorrected therapeutic } \\
\text { anticoagulation, senile dementia, impaired cognitive } \\
\text { function or other cerebral disease, infection in the } \\
\text { spine or the overlying skin, malignant disease, bone } \\
\text { metabolic disease, fracture of tubular bone, or allergy } \\
\text { to radiopaque agents. }\end{array}$ & $\begin{array}{l}\text { A: Vertebroplasty: 11- to 13-gauge needles were } \\
\text { placed using a uni or bilateral transpedicular } \\
\text { approach. Bone cement (PMMA) injected under } \\
\text { continuous fluoroscopy (PMMA volume not } \\
\text { reported). } \\
\text { B: Usual care: Not described }\end{array}$ \\
\hline
\end{tabular}




\begin{tabular}{|c|c|c|c|c|c|}
\hline $\begin{array}{c}\text { Vertebral } \\
\text { Augmentation } \\
\text { Procedure }\end{array}$ & \begin{tabular}{|l|} 
Author, \\
Year \\
Trial \\
\end{tabular} & $\begin{array}{c}\text { Study } \\
\text { Design } \\
\text { Duration }\end{array}$ & \begin{tabular}{|c|} 
Setting/Provider \\
Type \\
Country
\end{tabular} & Eligibility Criteria & Interventions \\
\hline Vertebroplasty & $\begin{array}{l}\text { Voormolen, } \\
2007 \\
\text { VERTOS }\end{array}$ & $\begin{array}{l}\text { RCT } \\
12 \text { months }\end{array}$ & $\begin{array}{l}3 \text { centers, } \\
\text { orthopedic } \\
\text { surgery and } \\
\text { radiology } \\
\text { the Netherlands }\end{array}$ & $\begin{array}{l}\geq 50 \text { years with VCF with } \geq 15 \% \text { height loss of the } \\
\text { vertebral body on X-ray of the spine, invalidating back } \\
\text { pain related to the VCF refractive to medical therapy } \\
\text { for } 6 \text { weeks to } 6 \text { months, focal tenderness on physical } \\
\text { examination related to the level of the VCF, bone } \\
\text { mineral density T-score <- } 2.0 \text {, bone marrow edema of } \\
\text { the affected } \\
\text { VCF on MR imaging scan of the spine. } \\
\text { Excluded: poor cardiopulmonary condition, } \\
\text { untreatable coagulopathy, ongoing systemic infection } \\
\text { or local infection of the spine (osteomyelitis, } \\
\text { spondylodiscitis), radiculopathy or myelopathy, } \\
\text { indication of other underlying disease than } \\
\text { osteoporosis }\end{array}$ & $\begin{array}{l}\text { A: Vertebroplasty: Performed under local } \\
\text { anesthesia, bilateral transpedicular approach used } \\
\text { with continuous fluoroscopy. PMMA injected using } \\
\text { 11- or 13-gauge needle (mean PMMA volume } 3.2 \\
\text { ml). } \\
\text { B: Usual care: Stepped analgesics with } \\
\text { acetaminophen, NSAIDs, or opiate derivatives. }\end{array}$ \\
\hline Vertebroplasty & Yang, 2016 & $\begin{array}{l}\text { RCT } \\
1 \text { year }\end{array}$ & $\begin{array}{l}1 \text { center, surgery } \\
\text { China }\end{array}$ & $\begin{array}{l}\text { >70 years with acute (not defined) osteoporotic } \\
\text { vertebral compression fracture, back pain VAS } \geq 5 \text { ( } 0 \\
\text { to } 10 \text { scale), BMD T-score }-1 \text { or worse, low signal on } \\
\text { T1-weighted and high signal on T2-weighted MRI, } \\
\text { fracture at T5 level or lower, no wheelchair use prior } \\
\text { to trauma } \\
\text { Excluded: chronic back pain; suspected } \\
\text { underlying malignant disease; spine infection } \\
\text { retropulsion of bony fragments; spinal cord } \\
\text { compression syndrome; concomitant hip fracture; } \\
\text { severe cardiopulmonary comorbidity; } \\
\text { major coagulopathy }\end{array}$ & $\begin{array}{l}\text { A. Vertebroplasty: Bone puncture needle placed } \\
\text { transpedicularly in the fractured vertebral body } \\
\text { under fluoroscopic monitoring; PMMA injected into } \\
\text { the fractured vertebra with the fluoroscopic control } \\
\text { (mean } 4.5 \text { [SD 1.2] ml per vertebral body); CT } \\
\text { scan performed to identity cement distribution and } \\
\text { leakage. } \\
\text { B. Usual care: Bed rest for } 2 \text { weeks, then patients } \\
\text { encouraged to stand and walk with brace and } \\
\text { assistance. NSAIDs with additional analgesics } \\
\text { (e.g. tramadol and morphine) added if needed. } \\
\text { Physical therapy initiated } 2 \text { weeks after diagnosis. } \\
\text { Both groups received bisphosphonates, calcium } \\
\text { supplementation, and vitamin D. }\end{array}$ \\
\hline Kyphoplasty & $\begin{array}{l}\text { Berenson, } \\
2011 \\
\text { CAFE Trial }\end{array}$ & $\begin{array}{l}\text { RCT } \\
1 \text { month } \\
\text { (prior to } \\
\text { allowed } \\
\text { crossover) }\end{array}$ & $\begin{array}{l}22 \text { centers, } \\
\text { provider type not } \\
\text { described } \\
\text { Australia, } \\
\text { Canada, Europe, } \\
\text { and U.S. }\end{array}$ & $\begin{array}{l}\geq 21 \text { years with cancer and } 1 \text { to } 3 \text { painful VCFs (T5 to } \\
\text { L5) clinically diagnosed in conjunction with either plain } \\
\text { radiographs or MRI; NRS } \geq 4 \text { and RDQ } \geq 10 \\
\text { Excluded: presence of osteoblastic tumors, primary } \\
\text { bone tumors, plasmacytoma at the index VCF, } \\
\text { substantial clinical morbidities, VCF morphology } \\
\text { deemed unsuitable for kyphoplasty, needed additional } \\
\text { surgical treatment for the index fracture, needed } \\
\text { treatment with high dose steroids, IV pain medication, } \\
\text { nerve blocks. }\end{array}$ & $\begin{array}{l}\text { A: Kyphoplasty: Balloon kyphoplasty performed } \\
\text { with introducer tools, inflatable bone tamps, and } \\
\text { PMMA bone cement and delivery devices } \\
\text { (Medtronic Spine, Sunnyvale, CA, USA), by a } \\
\text { percutaneous bilateral, transpedicular, or } \\
\text { extrapedicular method (PMMA volume not } \\
\text { reported). } \\
\text { B: Usual care: Continued on non-surgical } \\
\text { management, including analgesics, bed rest, } \\
\text { bracing, physiotherapy, rehabilitation programs, } \\
\text { walking aids, radiation treatment, other antitumor } \\
\text { therapy; medications were calcium, vitamin D } \\
\text { supplements, and antiresorptive or anabolic } \\
\text { agents as necessary }\end{array}$ \\
\hline
\end{tabular}




\begin{tabular}{|c|c|c|c|c|c|}
\hline $\begin{array}{c}\text { Vertebral } \\
\text { Augmentation } \\
\text { Procedure }\end{array}$ & $\begin{array}{l}\text { Author, } \\
\text { Year } \\
\text { Trial }\end{array}$ & $\begin{array}{l}\text { Study } \\
\text { Design } \\
\text { Duration }\end{array}$ & $\begin{array}{c}\text { Setting/Provider } \\
\text { Type } \\
\text { Country }\end{array}$ & Eligibility Criteria & Interventions \\
\hline Kyphoplasty & $\begin{array}{l}\text { Wardlaw, } \\
2009 \\
\text { FREE Trial } \\
\text { Additional } \\
\text { publications: } \\
\text { Boonen, } \\
2013 \text { and } \\
\text { Van } \\
\text { Meirhaege, } \\
2013\end{array}$ & $\begin{array}{l}\text { RCT } \\
1 \text { year }\end{array}$ & $\begin{array}{l}21 \text { sites, provider } \\
\text { type not } \\
\text { described } \\
\text { Europe and U.S. }\end{array}$ & $\begin{array}{l}\geq 21 \text { years with } 1 \text { to } 3 \text { vertebral fractures from T5 } \\
\text { through L5; duration } \leq 3 \text { months, } \geq 1 \text { fracture with } \\
\text { edema by MRI and } \geq 1 \text { with } \geq 15 \% \text { height loss (single } \\
\text { fractures met both criteria). } \\
\text { Excluded: chronic fracture; pedicle fracture; previous } \\
\text { vertebroplasty; neurological deficit; radicular pain; } \\
\text { spinal cord compression or canal narrowing; taking } \\
\text { uninterruptible anticoagulation therapy; allergies to } \\
\text { kyphoplasty materials or contraindications to MRI; } \\
\text { dementia or unable to walk before fracture; vertebral } \\
\text { fractures from primary bone tumors, osteoblastic } \\
\text { metastases, or high energy trauma. }\end{array}$ & $\begin{array}{l}\text { A. Kyphoplasty: Use of introducer instruments, } \\
\text { inflatable bone tamps, and PMMA by a } \\
\text { percutaneous, bilateral, transpedicular, or } \\
\text { extrapedicular approach (mean PMMA volume not } \\
\text { reported). } \\
\text { B. Usual care: Analgesics, bed rest, back braces, } \\
\text { physiotherapy, rehabilitation programs, and } \\
\text { walking aids according to standard practices of } \\
\text { participating hospitals. }\end{array}$ \\
\hline Kyphoplasty & $\begin{array}{l}\text { Boonen, } \\
2011 \\
\text { FREE Trial } \\
\text { Secondary } \\
\text { publication } \\
\text { of Wardlaw } \\
2009\end{array}$ & $\begin{array}{l}\mathrm{RCT} \\
\text { additional } \\
\text { followup } \\
2 \text { years }\end{array}$ & $\begin{array}{l}\text { see Wardlaw } \\
2009\end{array}$ & see Wardlaw, 2009 & see Wardlaw, 2009 \\
\hline Kyphoplasty & $\begin{array}{l}\text { Van } \\
\text { Meirhaeghe, } \\
2013 \\
\text { FREE Trial } \\
\text { Secondary } \\
\text { publication } \\
\text { of Wardlaw, } \\
2009\end{array}$ & \begin{tabular}{|l|}
$\mathrm{RCT}$ \\
2 years
\end{tabular} & $\begin{array}{l}\text { see Wardlaw } \\
2009\end{array}$ & see Wardlaw, 2009 & see Wardlaw, 2009 \\
\hline
\end{tabular}

Abbreviations: ANCOVA = analysis of covariance; $\mathrm{ANOVA}=$ analysis of variance; $\mathrm{ARD}=$ absolute risk difference; $\mathrm{BMD}=$ bone mineral density; $\mathrm{CAFE}=\mathrm{Cancer}$ Patient Fracture

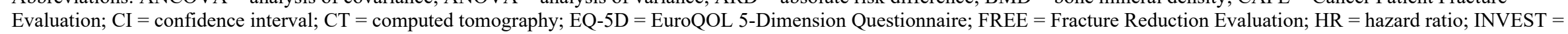
Investigational Vertebroplasty Safety and Efficacy Trial; IQR = interquartile range; IU = International Unit; LBP = low-back pain; MCS = Mental Component Summary; MMSE = Mini-

Mental State Exam; MR = magnetic resonance; MRI = magnetic resonance imaging; MRI-STIR = magnetic resonance imaging short tau inversion recovery; NR = not reported; NRS = numeric rating scale; NS = not significant; ODI = Oswestry Disability Index; OR = odds ratio; PCS = Physical Component Summary; PMMA = polymethylmethacrylate; PVP =

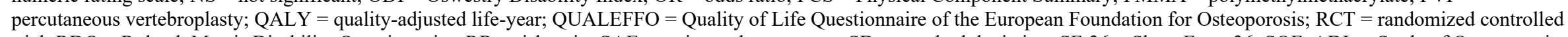

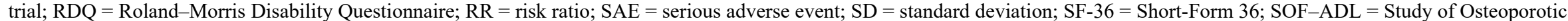

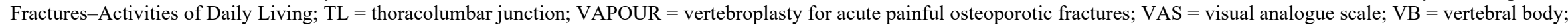

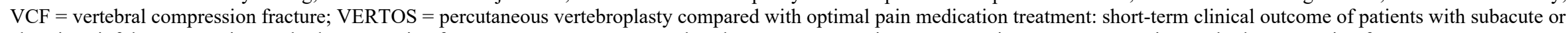

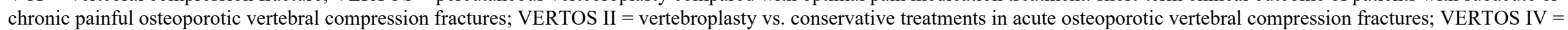

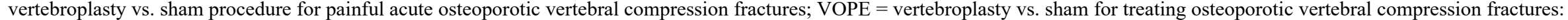
a double blind RCT

\section{See Appendix F, List of Included Studies, for full citations}


Table G-2. Trials of vertebral augmentation procedures to treat vertebral compression fractures - additional study characteristics

\begin{tabular}{|c|c|c|c|c|c|}
\hline $\begin{array}{l}\text { Vertebral } \\
\text { Augmentation } \\
\text { Procedure }\end{array}$ & $\begin{array}{l}\text { Author, Year } \\
\text { Trial }\end{array}$ & Sample Characteristics & \begin{tabular}{|l|} 
Screened \\
Eligible \\
Randomized \\
Analyzed \\
Crossover \\
\end{tabular} & Sponsor & Quality \\
\hline Vertebroplasty & Blasco, 2012 & $\begin{array}{l}\text { Mean (SD) age, years: } 73.2(9.3) \\
\text { Female: } 78 \% \\
\text { Race: NR } \\
\text { Symptom duration (mean [SD], months): } 4.7 \text { (3.8) } \\
\text { Symptom onset <6 weeks: } 4.8 \% \\
\text { Symptom onset <4 months: } 51 \% \\
\text { Number of vertebral fractures at baseline (mean [SD]: } 3.29 \\
\text { (2.51) } \\
2 \text { initial fractures: } 25 \% \\
>2 \text { initial fractures: } 49 \% \\
\text { A vs. B } \\
\text { Baseline pain (mean [SD], } 0 \text { to } 10 \text { VAS): } 7.21 \text { (2.8) vs. } 6.31 \\
\text { (2.7) } \\
\text { Baseline QUALEFFO-41 (mean [SD], } 0 \text { to } 100 \text { scale): } 65.2 \\
\text { (16) vs. } 59.2 \text { (16) }\end{array}$ & $\begin{array}{l}\text { Screened: } 219 \\
\text { Eligible: } 139 \\
\text { Randomized: } 125 \text { ( } 64 \text { vs. } \\
61) \\
\text { Completed followup: } 110 \\
\text { (54 vs. } 56 \text { ) at } 2 \text { months, } \\
104 \text { (50 vs. } 54 \text { ) at } 6 \\
\text { months, } 95 \text { (47 vs. } 48 \text { ) at } \\
12 \text { months } \\
\text { Analyzed: Appears to be } \\
125 \text { (64 vs. } 61) \text { for } \\
\text { continuous variables }\end{array}$ & $\begin{array}{l}\text { Fundació La Marató de TV3, } \\
\text { the Spanish Society of } \\
\text { Medical Radiology, Catalan } \\
\text { Society of Rheumatology }\end{array}$ & Fair \\
\hline Vertebroplasty & $\begin{array}{l}\text { Buchbinder, } \\
2009 \\
\\
\text { Additional } \\
\text { publications: } \\
\text { Kroon, 2014 } \\
\text { and Staples, } \\
2015\end{array}$ & $\begin{array}{l}\text { Mean (SD) age, years: } 77 \text { (11.91) } \\
\text { Female: } 79 \% \\
\text { Race: NR } \\
\text { Duration of back pain (median [IQR], weeks): } 9.0 \text { (3.7 to 13.0) } \\
\text { vs. } 9.5 \text { (3.0 to } 17.0 \text { ) } \\
\text { Number of vertebral bodies treated: } \\
-1: 82 \% \\
-2: 18 \% \\
\text { Previous vertebral fracture: } 50 \% \\
\text { Opioid use for pain: } 82 \% \\
\text { Medication use for osteoporosis: } 92 \% \\
\text { A vs. B } \\
\text { Baseline overall pain (mean [SD], } 0 \text { to } 10 \text { VAS): } 7.4(2.1) \text { vs. } \\
7.1(2.3) \\
\text { Baseline QUALEFFO total score: } 56.9 \text { (13.4) vs. } 59.6(17.1) \\
\text { Baseline Assessment of Quality of Life (AQoL) score (mean } \\
\text { [SD], }-0.04 \text { to } 1.0 \text { scale): } 0.33 \text { (0.25) vs. } 0.27(0.26) \\
\text { Baseline modified RDQ (mean [SD], } 0 \text { to } 23 \text { scale): } 17.3(2.8) \\
\text { vs. } 17.3 \text { (2.9) } \\
\text { Baseline EQ-5D (mean [SD], } 0 \text { to } 1 \text { scale): } 0.30 \text { (0.32) vs. } \\
0.28 \text { (0.33) }\end{array}$ & $\begin{array}{l}\text { Screened: } 468 \\
\text { Eligible: } 220 \\
\text { Randomized: } 78 \text { (38 vs. } \\
40) \\
\text { Completed followup: } 73 \\
\text { (36 vs. } 37 \text { ) at } 3 \text { months, } \\
71 \text { (35 vs. } 36 \text { ) at } 6 \\
\text { months } \\
\text { Analyzed: } 73 \text { (36 vs. } 37) \\
\text { at } 3 \text { months, } 71 \text { (35 vs. } \\
36 \text { ) at } 6 \text { months }\end{array}$ & $\begin{array}{l}\text { National Health and Medical } \\
\text { Research Council of } \\
\text { Australia, Arthritis Australia, } \\
\text { the } \\
\text { Cabrini Education and } \\
\text { Research Institute, Cook } \\
\text { Australia. }\end{array}$ & Good \\
\hline
\end{tabular}




\begin{tabular}{|c|c|c|c|c|c|}
\hline $\begin{array}{l}\text { Vertebral } \\
\text { Augmentation } \\
\text { Procedure }\end{array}$ & $\begin{array}{l}\text { Author, Year } \\
\text { Trial }\end{array}$ & Sample Characteristics & $\begin{array}{l}\text { Screened } \\
\text { Eligible } \\
\text { Randomized } \\
\text { Analyzed } \\
\text { Crossover }\end{array}$ & Sponsor & Quality \\
\hline Vertebroplasty & $\begin{array}{l}\text { Staples, } 2015 \\
\text { Secondary } \\
\text { publication of } \\
\text { Buchbinder, } \\
2009\end{array}$ & see Buchbinder, 2009 & $\begin{array}{l}\text { Screened: } 468 \\
\text { Eligible: } 220 \\
\text { Randomized: } 78 \text { (38 vs. } \\
40) \\
\text { Analyzed: } 70 \text { (34 vs. } 36 \text { ) } \\
\text { at } 1 \text { year, } 64 \text { (32 vs. } 32 \text { ) } \\
\text { at } 2 \text { years }\end{array}$ & see Buchbinder, 2009 & $\begin{array}{l}\text { see } \\
\text { Buchbinder, } \\
2009\end{array}$ \\
\hline Vertebroplasty & $\begin{array}{l}\text { Kroon, } 2014 \\
\text { Secondary } \\
\text { publication of } \\
\text { Buchbinder, } \\
2009\end{array}$ & see Buchbinder, 2009 & $\begin{array}{l}\text { Screened: } 468 \\
\text { Eligible: } 220 \\
\text { Randomized: } 78 \text { (38 vs. } \\
40) \\
\text { Analyzed: } 57 \text { ( } 29 \text { vs. } 28 \text { ) } \\
\text { at } 24 \text { months }\end{array}$ & see Buchbinder, 2009 & $\begin{array}{l}\text { see } \\
\text { Buchbinder, } \\
2009\end{array}$ \\
\hline Vertebroplasty & Chen, 2014 & $\begin{array}{l}\text { Mean (SD) age, years: } 65.5(9.1) \\
\text { Female: } 70 \% \\
\text { Race: NR } \\
\text { Duration of pain (mean [SD], months): } 6.98(2.77) \\
\text { Number of VCF (mean [SD]): } 2.14(0.72) \\
\text { Use of osteoporosis drugs: } 34 \% \\
\\
\text { A vs. B } \\
\text { Baseline pain (mean [SD], } 0 \text { to } 10 \text { VAS): } 6.5(0.9) \text { vs. } 6.4(0.9) \\
\text { Baseline ODI (mean [SD], } 0 \text { to } 100 \text { scale): } 59.9(2.2) \text { vs. } 57.9 \\
\text { (1.9) } \\
\text { Baseline RDQ (mean [SD], } 0 \text { to } 24 \text { scale): } 18.6(1.8) \text { vs. } 16.7 \\
\text { (1.3) }\end{array}$ & $\begin{array}{l}\text { Screened: NR } \\
\text { Eligible: NR } \\
\text { Randomized: } 96 \text { (46 vs. } \\
50 \text { ) } \\
\text { Completed followup: } 89 \\
\text { (46 vs. } 43 \text { ) } \\
\text { Analyzed: } 89 \text { (46 vs. } 43 \text { ) }\end{array}$ & None & Fair \\
\hline
\end{tabular}




\begin{tabular}{|c|c|c|c|c|c|}
\hline $\begin{array}{l}\text { Vertebral } \\
\text { Augmentation } \\
\text { Procedure }\end{array}$ & $\begin{array}{l}\text { Author, Year } \\
\text { Trial }\end{array}$ & Sample Characteristics & \begin{tabular}{|l} 
Screened \\
Eligible \\
Randomized \\
Analyzed \\
Crossover \\
\end{tabular} & Sponsor & Quality \\
\hline Vertebroplasty & \begin{tabular}{|l|} 
Clark, 2016 \\
VAPOUR
\end{tabular} & $\begin{array}{l}\text { Mean (SD) age, years: } 80(7) \\
\text { Female: } 73 \% \\
\text { Race: NR } \\
\text { Fracture duration (mean [SD], weeks): } 2.6 \text { (1.5) } \\
\text { Fracture duration } 1 \text { to } 3 \text { weeks: } 79 \% \\
\text { Fracture duration } 4 \text { to } 6 \text { weeks: } 21 \% \\
\text { Location of fracture } \\
\text { - Lumbar: } 14 \% \\
\text { - Thoracic: } 29 \% \\
\text { - Thoracolumbar: } 61 \% \\
\text { Taking opioids for pain: } 88 \% \\
\text { Inpatient: } 57 \% \\
\text { Previous osteoporotic fractures: } 57 \% \\
\text { A vs. B } \\
\text { Baseline pain intensity, last } 24 \text { hours (mean [SD], } 0 \text { to } 100 \\
\text { VAS converted to } 0 \text { to } 10 \text { scale): } 8.1(1.8) \text { vs. } 8.2 \text { (1.5) } \\
\text { Baseline pain intensity, last } 24 \text { hours (mean [SD], } 0 \text { to } 10 \\
\text { NRS): } 8.6 \text { (1.3) vs. } 8.6 \text { (1.2) } \\
\text { Baseline RDQ (mean [SD], } 0 \text { to } 24 \text { ): } 19.5 \text { (3.5) vs. } 19.8 \text { (3.7) } \\
\text { Baseline EQ-5D (mean [SD, } 0 \text { to 1): } 0.60 \text { (0.07) vs. } 0.59 \\
\text { (0.06) } \\
\text { Baseline QUALEFFO score (mean [SD, } 0 \text { to 100): } 65.4 \text { (11.4) } \\
\text { vs. } 67.7 \text { (11.2) }\end{array}$ & $\begin{array}{l}\text { Screened: } 302 \\
\text { Eligible: } 154 \\
\text { Randomized: } 120 \text { ( } 61 \text { vs. } \\
59) \\
\text { Complete followup: } 105 \\
\text { (53 vs. } 52) \text { at } 3 \text { months, } \\
102 \text { (51 vs. } 51) \text { at } 6 \\
\text { months } \\
\text { Analyzed: } 112 \text { (55 vs. } \\
57) \text { at } 14 \text { days, } 105 \text { (53 } \\
\text { vs. } 52) \text { at } 3 \text { months, } 102 \\
\text { (51 vs. } 51) \text { at } 6 \text { months }\end{array}$ & CareFusion Corporation & Good \\
\hline Vertebroplasty & $\begin{array}{l}\text { Diamond, } \\
2020 \\
\text { VAPOUR }\end{array}$ & $\begin{array}{l}\text { Mean (SD) age, years: } 81 \text { (NR) } \\
\text { Female: } 73 \% \\
\text { Race: NR } \\
\text { Mean lumbar spine T-score: }-4.3 \\
\text { Receiving anti-osteoporotic therapies: } 75 \% \\
\text { Genant grade } 3 \text { vertebral deformities: } 71 \% \\
\text { Inpatient: } 63 \% \\
\text { Mean (SD) duration of fracture, weeks: } 2.6(1.5) \\
\text { A vs. B } \\
\text { Pain intensity (mean [SD], } 0 \text { to } 10 \text { NRS): } 8.7(1.3) \text { vs. } 8.6 \\
(1.2) \\
\text { RDQ (mean [SD], } 0 \text { to } 24 \text { scale): } 19.7(2.8) \text { vs. } 19.9(4.1) \\
\text { QUALEFFO score (mean [SD], } 0 \text { to } 100 \text { scale): } 67.0(11.0) \\
\text { vs. } 68.8(11.7) \\
\text { EQ-5D score (mean [SD], } 0 \text { to } 1 \text { scale): } 0.59(0.06) \text { vs. } 0.59 \\
(0.06)\end{array}$ & $\begin{array}{l}\text { Screened: } 120 \\
\text { Eligible: NR } \\
\text { Randomized: } 93 \text { (46 vs. } \\
47 \text { ) } \\
\text { Analyzed for primary } \\
\text { outcome: } 86 \text { (43 vs. } 43 \text { ) }\end{array}$ & CareFusion Corporation & Good \\
\hline
\end{tabular}




\begin{tabular}{|c|c|c|c|c|c|}
\hline $\begin{array}{l}\text { Vertebral } \\
\text { Augmentation } \\
\text { Procedure }\end{array}$ & $\begin{array}{l}\text { Author, Year } \\
\text { Trial }\end{array}$ & Sample Characteristics & $\begin{array}{l}\text { Screened } \\
\text { Eligible } \\
\text { Randomized } \\
\text { Analyzed } \\
\text { Crossover } \\
\end{array}$ & Sponsor & Quality \\
\hline Vertebroplasty & Farrokhi, 2011 & $\begin{array}{l}\text { Mean age: } 72 \text { vs. } 74 \text { (range } 55-90 \text { ) } \\
\text { Female: } 73 \% \\
\text { Race: NR } \\
\text { Mean duration of LBP, weeks: } 27 \text { vs. } 30 \text { (range } 4 \text { to } 54 \text { ) } \\
\text { Total number of VCFs: } 190 \\
\text { Grade of treated VCF } \\
\text { - Mild: } 61 \% \\
\text { - Moderate: } 29 \% \\
\text { - Severe: } 6 \% \\
\text { Shape of treated VCF } \\
\text { - Wedge: } 84 \% \\
\text { - Biconcave: } 16 \% \\
\text { Taking acetaminophen with codeine: } 73 \% \\
\text { Taking NSAIDs: } 63 \% \\
\text { A vs. B } \\
\text { Baseline pain intensity (mean [SD], } 0 \text { to } 10 \text { VAS): } 8.4 \text { (1.6) vs. } \\
7.2 \text { (1.7) } \\
\text { Baseline ODI (mean [SD, } 0 \text { to } 100 \text { scale): } 51.2 \text { (2.2) vs. } 47.1 \\
(2.8)\end{array}$ & $\begin{array}{l}\text { Screened: } 105 \\
\text { Eligible: } 84 \\
\text { Randomized: } 82 \text { ( } 40 \text { vs. } \\
42 \text { ) } \\
\text { Completed followup: } 77 \\
\text { (38 vs. } 39 \text { ) at } 12 \text { months, } \\
76 \text { (37 vs. } 39 \text { ) at } 36 \\
\text { months } \\
\text { Analyzed: } 82 \text { ( } 40 \text { vs. } 42 \text { ) } \\
\text { at } 2 \text { and } 6 \text { months, } 76 \text { ( } 37 \\
\text { vs. } 39 \text { ) at } 3 \text { years } \\
\text { Crossover: } 0 \text { vs. } 10 \text { ( } 3 \text { at } \\
<6 \text { months, } 7 \text { from } 1 \text { to } 3 \\
\text { years) }\end{array}$ & $\begin{array}{l}\text { Vice chancellor for research } \\
\text { affairs Shiraz University of } \\
\text { Medical Sciences and } \\
\text { Apadana Tajhizgostar Co. } \\
\text { provided grant support. }\end{array}$ & Poor \\
\hline Vertebroplasty & $\begin{array}{l}\text { Firanescu, } \\
2018 \text { \& } 2019 \\
\text { VERTOS IV }\end{array}$ & $\begin{array}{l}\text { Mean (SD) age, years: } 75.8(9.5) \\
\text { Female: } 75 \% \\
\text { Race: NR } \\
\text { Duration of back pain (median [IQR], days): } 43 \text { (29 to } 52 \text { ) vs. } \\
36 \text { (24 to } 51 \text { ) } \\
\text { Duration from radiographic diagnosis (median [IQR], days): } \\
13 \text { (7 to } 18 \text { ) vs. } 11 \text { (7 to } 17 \text { ) } \\
\text { Type of fracture (Genant classification) } \\
\text { - Mild: } 38 \% \\
\text { - Moderate: } 57 \% \\
\text { - Severe: } 32 \% \\
\text { - Wedge: } 69 \% \\
\text { - Biconcave: } 58 \% \\
\text { Number of VCF: } 223 \\
\text { Mean (SD) RDQ: } 17.9 \text { (4.6) } \\
\text { On drugs for osteoporosis: } 52 \% \\
\text { Weak opioids: } 17 \% \\
\text { Strong opioids: } 38 \% \\
\text { A vs. B } \\
\text { Baseline pain intensity (mean [SD], } 0 \text { to } 10 \text { VAS): } 7.7 \text { (1.4) vs. } \\
7.9 \text { (1.6) } \\
\text { Baseline RDQ (mean [SD], } 0 \text { to } 24): 18.0 \text { (4.5) vs. } 17.8 \text { (4.7) } \\
\text { Baseline QUALEFFO score (mean [SD], } 0 \text { to 100): } 68.4 \\
\text { (17.1) vs. } 69.7 \text { (17.9) }\end{array}$ & $\begin{array}{l}\text { Screened: } 1280 \\
\text { Eligible: } 336 \\
\text { Randomized: } 180 \text { (91 vs. } \\
89) \\
\text { Completed followup: } 171 \\
\text { (87 vs. } 84 \text { ) at } 3 \text { months, } \\
152 \text { (76 vs. } 76 \text { at } 1 \text { year } \\
\text { Analyzed: } 176 \text { (90 vs. } 86) \\
\text { at } 1 \text { year }\end{array}$ & Stryker (grant No S-1-013) & Good \\
\hline
\end{tabular}




\begin{tabular}{|c|c|c|c|c|c|}
\hline $\begin{array}{l}\text { Vertebral } \\
\text { Augmentation } \\
\text { Procedure }\end{array}$ & $\begin{array}{l}\text { Author, Year } \\
\text { Trial }\end{array}$ & Sample Characteristics & \begin{tabular}{|l|} 
Screened \\
Eligible \\
Randomized \\
Analyzed \\
Crossover \\
\end{tabular} & Sponsor & Quality \\
\hline Vertebroplasty & $\begin{array}{l}\text { Hansen, } 2019 \\
\text { VOPE }\end{array}$ & $\begin{array}{l}\text { Mean (SD NR) age, years: } 69.9 \\
\text { Female: } 87 \% \\
\text { Race: NR } \\
\text { BMD T-score: }-2.44 \\
\text { A vs. B } \\
\text { Baseline pain intensity at rest (mean [SD, } 0 \text { to } 100 \text { VAS } \\
\text { converted to } 0 \text { to } 10 \text { scale): } 4.1(2.1) \text { vs. } 5.3(2.1) \\
\text { Baseline SF-36 Physical Component Summary (mean [SD, } 0 \\
\text { to } 100 \text { scale): } 25.1 \text { (6.9) vs. } 25.5 \text { (4.6) } \\
\text { Baseline SF-36 Mental Component Summary (mean [SD], } 0 \\
\text { to } 100 \text { scale): } 42.0 \text { (9.8) vs. } 44.3 \text { (13.1) } \\
\text { Baseline EQ-5D (mean [SD NR], } 0 \text { to } 1 \text { scale): } 0.44 \text { vs. } 0.49\end{array}$ & $\begin{array}{l}\text { Screened: } 342 \\
\text { Eligible: NR } \\
\text { Randomized: } 52 \text { (26 vs. } \\
26 \text { ) } \\
\text { Completed followup: } 46 \\
\text { (22 vs. } 24 \text { ) } \\
\text { Analyzed: } 46 \text { (22 vs. } 24 \text { ) }\end{array}$ & $\begin{array}{l}\text { Danish Rheumatism } \\
\text { Association }\end{array}$ & Fair \\
\hline Vertebroplasty & $\begin{array}{l}\text { Kallmes, } 2009 \\
\text { and } \\
\text { Comstock, } \\
2013 \\
\text { INVEST }\end{array}$ & $\begin{array}{l}\text { Mean (SD) age, years: } 73.8(9.5) \\
\text { Female: } 76 \% \\
\text { White: } 97 \% \\
\text { Mean (SD) pain duration, weeks: } 17.9 \text { (57.7) } \\
\text { Reported use of opioids: } 59 \% \\
\text { A vs. B } \\
\text { Baseline modified RDQ (mean [SD], } 0 \text { to } 23 \text { scale): } 16.6 \text { (3.8) } \\
\text { vs. } 17.5 \text { (4.1) } \\
\text { Baseline average pain intensity in last } 24 \text { hours (mean [SD], } 0 \\
\text { to } 10 \text { VAS): } 6.9 \text { (2.0) vs. } 7.2 \text { (1.8) } \\
\text { Baseline SF-36 PCS (mean [SD], } 0 \text { to } 100 \text { scale): } 25.3 \text { (7.8) } \\
\text { vs. } 25.3 \text { (7.3) } \\
\text { Baseline SF-36 MCS (mean [SD], } 0 \text { to } 100 \text { scale): } 44.8(11.8) \\
\text { vs. } 41.5 \text { (14.1) } \\
\text { Baseline EQ-5D (mean [SD], } 0 \text { to } 1 \text { scale): } 0.57 \text { (0.18) vs. } \\
0.54 \text { (0.23) } \\
\text { Baseline Study of Osteoporotic Fractures-Activities of Daily } \\
\text { Living (SOF-ADL) scale (mean [SD], } 0 \text { to } 18 \text { scale): } 10.0 \text { (3.6) } \\
\text { vs. } 10.3 \text { (2.8) }\end{array}$ & $\begin{array}{l}\text { Screened: } 1813 \\
\text { Eligible: } 431 \\
\text { Randomized: } 131 \text { ( } 68 \text { vs. } \\
63 \text { ) } \\
\text { Completed followup: } 125 \\
\text { (64 vs. } 61) \text { at } 3 \text { months, } \\
119 \text { (63 vs. } 56 \text { at } 1 \text { year) } \\
\text { Analyzed: } 125 \text { ( } 64 \text { vs. } 61) \\
\text { at } 3 \text { months; } 119 \text { (63 vs. } \\
56) \text { at } 1 \text { year } \\
\text { Crossover: } 35 \text { (8 vs. } 27) \\
\text { at } 3 \text { months; } 49 \text { (38 vs. } \\
11) \text { at } 1 \text { year }\end{array}$ & $\begin{array}{l}\text { National Institute of Arthritis } \\
\text { and Muscular-Skeletal and } \\
\text { Skin Diseases }\end{array}$ & Good \\
\hline
\end{tabular}




\begin{tabular}{|c|c|c|c|c|c|}
\hline $\begin{array}{l}\text { Vertebral } \\
\text { Augmentation } \\
\text { Procedure }\end{array}$ & $\begin{array}{l}\text { Author, Year } \\
\text { Trial }\end{array}$ & Sample Characteristics & $\begin{array}{l}\text { Screened } \\
\text { Eligible } \\
\text { Randomized } \\
\text { Analyzed } \\
\text { Crossover } \\
\end{array}$ & Sponsor & Quality \\
\hline Vertebroplasty & $\begin{array}{l}\text { Klazen, } 2010 \\
\text { and Venmans, } \\
2011 \\
\text { VERTOS II }\end{array}$ & $\begin{array}{l}\text { Mean (SD) age, years: } 75.3(9.1) \\
\text { Female: } 69 \% \\
\text { Race: NR } \\
\text { Mean (SD) duration of pain, days: } 28.0 \text { (16.6) } \\
\text { Use of osteoporosis drugs: } 25 \% \\
\text { Mean (SD) number of vertebral compression fractures: } 2.3 \\
(1.7) \\
\text { A vs. B } \\
\text { Baseline pain intensity (mean [SD], } 0 \text { to } 10 \text { VAS): } 7.8 \text { (1.5) vs. } \\
7.5(1.6) \\
\text { Baseline RDQ (mean [SD], } 0 \text { to } 24 \text { scale): } 18.6(3.6) \text { vs. } 17.2 \\
(4.2) \\
\text { Baseline QUALEFFO score (mean [SD], } 0 \text { to } 100 \text { scale): } 58.7 \\
(13.5) \text { vs. } 54.7 \text { (14.4) } \\
\text { Baseline EQ-5D (mean [SD], } 0 \text { to } 1 \text { scale): } 0.27 \text { (0.03) vs. } \\
0.38 \text { (0.03) }\end{array}$ & $\begin{array}{l}\text { Screened: } 934 \\
\text { Eligible: } 434 \\
\text { Randomized: } 202 \text { (101 } \\
\text { vs. } 101) \\
\text { Completed followup: } 178 \\
\text { (92 vs. } 86) \text { at } 3 \text { months, } \\
163 \text { (86 vs. } 77) \text { at } 1 \text { year } \\
\text { Analyzed: } 202 \text { (101 vs. } \\
101) \\
\text { Crossover: } 16 \text { (6 vs. } 10) \\
\text { at } 1 \text { year }\end{array}$ & $\begin{array}{l}\text { ZonMw (Dutch organization } \\
\text { for health care research and } \\
\text { innovation of care); } \\
\text { Unrestricted grant COOK } \\
\text { Medical }\end{array}$ & Fair \\
\hline Vertebroplasty & Leali, 2016 & $\begin{array}{l}\text { Mean age: NR (range } 56 \text { to } 82 \text { years) } \\
\text { Female: } 100 \% \\
\text { Race: NR } \\
\text { Fracture duration: NR } \\
\text { Fracture site (among vertebroplasty patients) } \\
\text { - Lumbar: } 47.5 \% \\
\text { - Thoracic vertebrae: } 52.5 \% \\
\text { Opioid analgesic use: Not reported } \\
\text { A vs. B } \\
\text { Baseline pain (mean [SD NR], } 0 \text { to } 10 \text { VAS): } 4.8 \text { vs. NR } \\
\text { Baseline ODI (mean [SD NR], } 0 \text { to } 100 \text { scale): } 53.6\end{array}$ & $\begin{array}{l}\text { Screened: NR } \\
\text { Eligible: NR } \\
\text { Randomized: } 400 \text { (200 } \\
\text { vs. 200) } \\
\text { Completed followup: Not } \\
\text { reported } \\
\text { Analyzed: Not reported }\end{array}$ & NR & Poor \\
\hline
\end{tabular}




\begin{tabular}{|c|c|c|c|c|c|}
\hline $\begin{array}{l}\text { Vertebral } \\
\text { Augmentation } \\
\text { Procedure }\end{array}$ & $\begin{array}{l}\text { Author, Year } \\
\text { Trial }\end{array}$ & Sample Characteristics & $\begin{array}{l}\text { Screened } \\
\text { Eligible } \\
\text { Randomized } \\
\text { Analyzed } \\
\text { Crossover } \\
\end{array}$ & Sponsor & Quality \\
\hline Vertebroplasty & $\begin{array}{l}\text { Rousing, } 2009 \\
\& 2010\end{array}$ & $\begin{array}{l}\text { Mean age, years: } 80 \text { (range } 65 \text { to } 96) \\
\text { Female: } 82 \% \\
\text { Race: NR } \\
\text { Mean (SD) duration of fracture, days: } 7.6 \text { (11.7) } \\
\text { A vs. B } \\
\text { Baseline pain (mean [SD], } 0 \text { to } 10 \text { VAS: } 7.5(1.9) \text { vs. } 8.8(1.1) \\
\text { Baseline SF-36 PCS (mean [SD], } 0 \text { to } 100 \text { scale): } 36.7 \text { (13.0) } \\
\text { vs. } 33.4 \text { (14.1) } \\
\text { Baseline SF-36 MCS (mean [SD], } 0 \text { to } 100 \text { scale): } 49.7(11.9) \\
\text { vs. } 49.6 \text { (15.0) } \\
\text { Baseline Dallas Pain Questionnaire, daily activities (mean } \\
\text { [SD], } 0 \text { to } 100 \text { scale): } 47.8(47.5) \text { vs. } 68.5(44.7) \\
\text { Baseline Dallas Pain Questionnaire, anxiety and depression } \\
\text { (mean [SD], } 0 \text { to } 100 \text { scale): } 31.5 \text { (26.4) vs. } 43.0 \text { (46.2) } \\
\text { EQ-5D (mean [SD], } 0 \text { to } 100 \text { scale): } 0.36 \text { (0.31) vs. } 0.08 \\
(0.44)\end{array}$ & $\begin{array}{l}\text { Screened: NR } \\
\text { Eligible: NR } \\
\text { Randomized: } 50 \text { (26 vs. } \\
24) \\
\text { Completed followup: } 46 \\
\text { (23 vs. } 23) \text { at } 3 \text { months, } \\
45 \text { ( } 23 \text { vs. } 22) \text { at } 12 \\
\text { months } \\
\text { Analyzed: } 47 \text { (24 vs. } 23) \\
\text { at } 3 \text { months, } 45 \text { ( } 23 \text { vs. } \\
22) \text { at } 12 \text { months }\end{array}$ & $\begin{array}{l}\text { Foundation and Danish } \\
\text { government funds }\end{array}$ & Poor \\
\hline Vertebroplasty & $\begin{array}{l}\text { Voormolen, } \\
2007 \\
\text { VERTOS }\end{array}$ & $\begin{array}{l}\text { Mean age, years: } 73 \text { (range } 55 \text { to } 88 \text { ) } \\
\text { Female: } 82 \% \\
\text { Race: NR } \\
\text { Mean duration of back pain, days: } 81 \text { (range } 46 \text { to 141) } \\
\text { Total number of VCFs: } 108 \\
\text { Grade of VCF } \\
\text { - Mild: } 12 \% \\
\text { - Moderate: } 22 \% \\
\text { - Severe: } 65 \% \\
\text { Shape of VCF } \\
\text { - Wedge: } 78 \% \\
\text { - Bio concave: } 22 \% \\
\text { On opiate derivative: } 32 \% \\
\text { On NSAIDs: } 27 \% \\
\text { On paracetamol: } 32 \% \\
\text { A vs. B } \\
\text { Baseline pain (mean [range], } 0 \text { to } 10 \text { VAS): } 7.1 \text { (5 to } 9 \text { ) vs. } 7.6 \\
\text { (5 to } 10) \\
\text { Baseline RDQ (mean [range], } 0 \text { to } 24 \text { scale): } 15.7 \text { (8 to } 22 \text { ) } \\
\text { vs. } 17.8 \text { ( } 9 \text { to } 24 \text { ) } \\
\text { Baseline QUALEFFO (mean [range], } 0 \text { to } 100 \text { scale): } 60 \text { (37 } \\
\text { to } 86 \text { ) vs. } 67 \text { (38 to } 86 \text { ) } \\
\text { Baseline analgesic use (mean [range], } 0 \text { to } 3 \text { scale): } 1.9 \text { (0 to } \\
3 \text { ) vs. } 1.7 \text { (0 to } 3 \text { ) }\end{array}$ & $\begin{array}{l}\text { Screened: NR } \\
\text { Eligible: NR } \\
\text { Randomized: } 34 \\
\text { Completed followup: } 34 \\
\text { (18 vs. 16) at } 2 \text { weeks } \\
\text { Analyzed: } 34 \text { (18 vs. } 16 \text { ) } \\
\text { Crossover: None prior to } \\
2 \text { weeks (14 patients in } \\
\text { usual care arm crossed } \\
\text { over after } 2 \text { week } \\
\text { assessment) }\end{array}$ & NR & Fair \\
\hline
\end{tabular}




\begin{tabular}{|c|c|c|c|c|c|}
\hline $\begin{array}{l}\text { Vertebral } \\
\text { Augmentation } \\
\text { Procedure }\end{array}$ & $\begin{array}{l}\text { Author, Year } \\
\text { Trial }\end{array}$ & Sample Characteristics & \begin{tabular}{|l|} 
Screened \\
Eligible \\
Randomized \\
Analyzed \\
Crossover \\
\end{tabular} & Sponsor & Quality \\
\hline Vertebroplasty & Yang, 2016 & $\begin{array}{l}\text { Mean (SD) age, years: } 76.7 \text { (5.81) } \\
\text { Female: } 64 \% \\
\text { Race: NR } \\
\text { Mean (SD) time since onset of pain, days: } 5.55(3.85) \\
\text { Fracture location (based on } 123 \text { total fractures) } \\
\text {-Thoracic spine ( T10): } 4.9 \%(6 / 123) \\
\text {-TL junction (T11 to L2): } 71.5 \%(88 / 123) \\
\text {-Lumbar spine (L3 to L5): } 23.6 \%(29 / 123) \\
\\
\text { A vs. B } \\
\text { Baseline pain (mean [SD], } 0 \text { to } 10 \text { VAS): } 7.5(1.1) \text { vs. } 7.7(1.1) \\
\text { Baseline ODI (mean [SD], } 0 \text { to } 100 \text { scale): } 80.2(9.9) \text { vs. } 81.5 \\
\text { (9.7) } \\
\text { Baseline QUALEFFO score (mean [SD], } 0 \text { to } 100 \text { scale): } 78.1 \\
\text { (8.1) vs. } 77.5 \text { (8.6) }\end{array}$ & $\begin{array}{l}\text { Screened: NR } \\
\text { Eligible: } 158 \\
\text { Randomized: } 135 \text { (66 vs. } \\
69) \\
\text { Completed followup: } 107 \\
\text { (56 vs. } 51 \text { ) at } 1 \text { year } \\
\text { Analyzed: } 107 \text { (56 vs. 51) } \\
\text { at } 1 \text { year } \\
\text { Crossover: } 8 \text { (0 vs. } 8 ; 2 \\
\text { additional patients in } \\
\text { usual care group } \\
\text { underwent open surgery) } \\
\text { at } 1 \text { year }\end{array}$ & No external funding & Poor \\
\hline Kyphoplasty & $\begin{array}{l}\text { Berenson, } \\
2011 \\
\text { CAFE Trial }\end{array}$ & $\begin{array}{l}\text { Mean (SD) age, years: } 63.9 \text { (11.1) } \\
\text { Female: } 58 \% \\
\text { Race: } 88 \% \text { White, } 7.0 \% \text { Black, } 1.6 \% \text { Asian, } 0.8 \% \text { Hispanic, } \\
2.3 \% \text { other } \\
\text { Symptomatic fracture duration (median [IQR], months): } 3.5 \\
(1.2 \text { to } 6.8) \\
\text { Edema on MRI: } 67 \% \\
\text { Prior radiation treatment: } 49 \% \\
\text { - Spinal irradiation: } 21 \% \\
\text { Prior chemotherapy or hormonal treatments: } 83 \% \\
\text { A vs. B } \\
\text { Baseline pain (mean [SD], } 0 \text { to } 10 \text { NRS): } 7.3 \text { (1.4) vs. } 7.3 \\
\text { (1.4) } \\
\text { Baseline RDQ (mean [SD NR], } 0 \text { to } 24 \text { ): } 17.6 \text { vs. } 18.2\end{array}$ & $\begin{array}{l}\text { Screened: } 477 \\
\text { Eligible: } 223 \\
\text { Randomized: } 134 \text { (70 vs. } \\
64) \\
\text { Completed followup: } 117 \\
\text { (65 vs. } 52) \text { at } 1 \text { month } \\
\text { Analyzed: } 117 \text { (65 vs. } 52 \text { ) } \\
\text { at } 1 \text { month } \\
\text { Crossover in usual care } \\
\text { arm after } 1 \text { month: } 59 \% \\
(38 / 64)\end{array}$ & Medtronic Spine LLC. & Fair \\
\hline
\end{tabular}




\begin{tabular}{|c|c|c|c|c|c|}
\hline $\begin{array}{l}\text { Vertebral } \\
\text { Augmentation } \\
\text { Procedure }\end{array}$ & $\begin{array}{l}\text { Author, Year } \\
\text { Trial }\end{array}$ & Sample Characteristics & $\begin{array}{l}\text { Screened } \\
\text { Eligible } \\
\text { Randomized } \\
\text { Analyzed } \\
\text { Crossover }\end{array}$ & Sponsor & Quality \\
\hline Kyphoplasty & $\begin{array}{l}\text { Wardlaw, } \\
2009 \\
\text { FREE Trial } \\
\text { Additional } \\
\text { publications: } \\
\text { Boonen, 2013 } \\
\text { and Van } \\
\text { Meirhaege, } \\
2013\end{array}$ & $\begin{array}{l}\text { Mean (SD) age, years: } 73.16 \text { (9.35) } \\
\text { Female: } 77 \% \\
\text { Race: NR } \\
\text { Mean (SD) duration of fracture, weeks: } 6.0 \text { (4.82) } \\
\text { Number of fractures } \\
\text {-One: } 72 \% \\
\text {-Two: } 21 \% \\
\text {-Three: } 7.7 \% \\
\text { Fracture location } \\
\text {-Thoracic (T5-T9): } 22.0 \% \\
\text {-Thoracolumbar junction (T10-L2): } 62.8 \% \\
\text {-Lumbar (L3-L5): } 15.2 \% \\
\text { Glucocorticoid use: } 17 \% \\
\text { Strong opioid use: } 14 \% \\
\text { Opioid + nonopioid: } 57 \% \\
\text { A vs. B } \\
\text { Baseline pain (mean [SD], } 0 \text { to } 10 \text { VAS): } 6.9 \text { (2.2) vs. } 7.0 \text { (2.2) } \\
\text { Baseline RDQ (mean [SD], } 0 \text { to } 24 \text { scale): } 17 \text { (6.2) vs. } 17 \\
(6.2 \text { ) } \\
\text { SF-36 PCS (mean [SD], } 0 \text { to } 100 \text { scale): } 26 \text { (12.2) vs. } 26 \\
(12.5) \\
\text { Baseline EQ-5D (mean [SD], } 0 \text { to } 24 \text { scale): } 1.7 \text { (0.31) vs. } 1.7 \\
(0.31)\end{array}$ & $\begin{array}{l}\text { Screened: } 1279 \\
\text { Eligible: } 624 \\
\text { Randomized: } 300 \text { (149 } \\
\text { vs. 151) } \\
\text { Completed followup: } 251 \\
\text { (134 vs. 117) at } 3 \\
\text { months, } 235 \text { (124 vs. } 111 \\
\text { at } 1 \text { year) } \\
\text { Analyzed: } 300 \text { (149 vs. } \\
\text { 151) } \\
\text { Crossover: } 24 \text { (10 vs.14) } \\
\end{array}$ & Medtronic Spine LLC & Fair \\
\hline Kyphoplasty & $\begin{array}{l}\text { Boonen, } 2011 \\
\text { FREE Trial } \\
\text { Secondary } \\
\text { publication of } \\
\text { Wardlaw } 2009\end{array}$ & see Wardlaw, 2009 & $\begin{array}{l}\text { Screened: } 1279 \\
\text { Eligible: } 624 \\
\text { Randomized: } 300 \text { (149 } \\
\text { vs. } 151) \\
\text { Completed followup: } 232 \\
\text { (120 vs. } 112) \text { at } 2 \text { years } \\
\text { Analyzed: } 300 \text { (149 vs. } \\
\text { 151) at } 2 \text { years }\end{array}$ & see Wardlaw, 2009 & $\begin{array}{l}\text { see } \\
\text { Wardlaw, } \\
2009\end{array}$ \\
\hline Kyphoplasty & $\begin{array}{l}\text { Van } \\
\text { Meirhaeghe, } \\
2013 \\
\text { FREE Trial } \\
\text { Secondary } \\
\text { publication of } \\
\text { Wardlaw } 2009\end{array}$ & see Wardlaw, 2009 & see Wardlaw 2009 & see Wardlaw, 2009 & $\begin{array}{l}\text { see } \\
\text { Wardlaw, } \\
2009\end{array}$ \\
\hline
\end{tabular}

Abbreviations: ANCOVA = analysis of covariance; ANOVA = analysis of variance; ARD = absolute risk difference; BMD = bone mineral density; CAFE = Cancer Patient Fracture

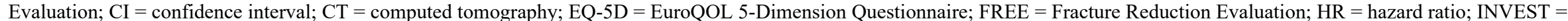
Investigational Vertebroplasty Safety and Efficacy Trial; IQR = interquartile range; IU = International Unit; LBP = low-back pain; MCS = Mental Component Summary; MMSE = MiniMental State Exam; MR = magnetic resonance; MRI = magnetic resonance imaging; MRI-STIR = magnetic resonance imaging short tau inversion recovery; NR = not reported; NRS = numeric rating scale; NS = not significant; ODI = Oswestry Disability Index; OR = odds ratio; PCS = Physical Component Summary; PMMA = polymethylmethacrylate; PVP = 


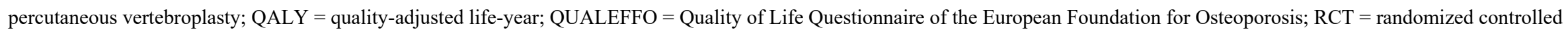

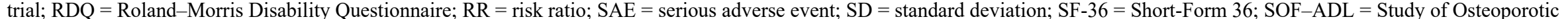

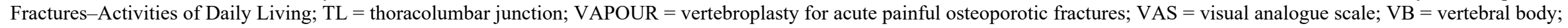

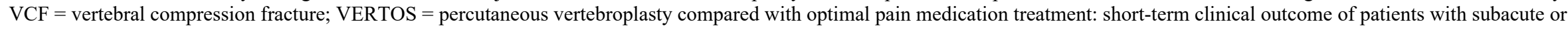

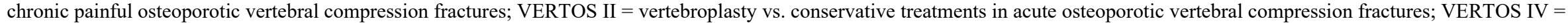

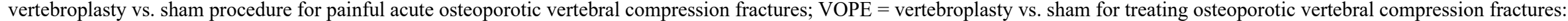
a double blind RCT

\section{See Appendix F, List of Included Studies, for full citations}


Table G-3. Trials of vertebral augmentation procedures to treat vertebral compression fractures - results

\begin{tabular}{|c|c|c|c|}
\hline $\begin{array}{l}\text { Vertebral } \\
\text { Augmentation } \\
\text { Procedure }\end{array}$ & $\begin{array}{l}\text { Author, Year } \\
\text { Trial }\end{array}$ & Results & $\begin{array}{l}\text { Adverse Events and Withdrawals } \\
\text { Due to Adverse Events }\end{array}$ \\
\hline Vertebroplasty & Blasco, 2012 & 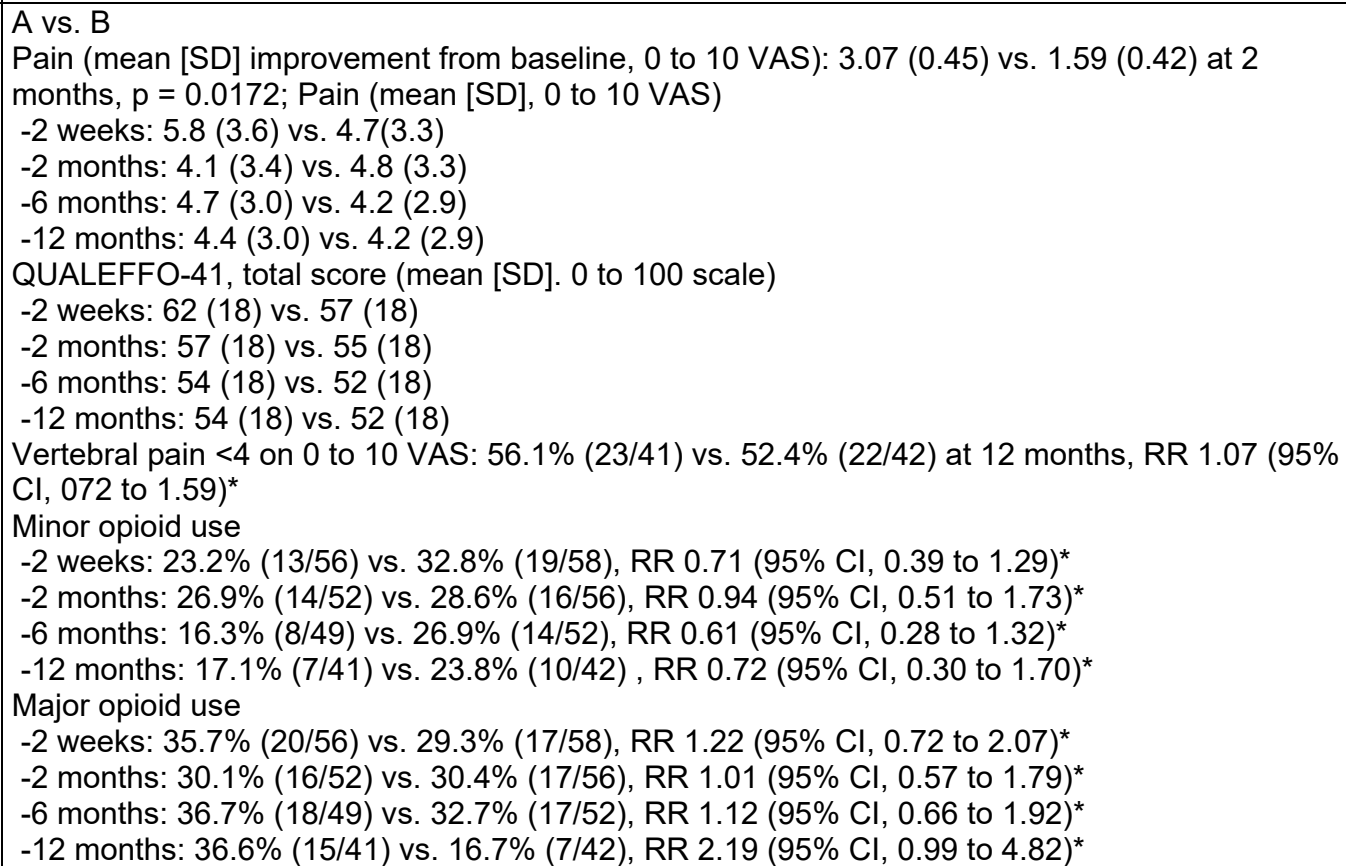 & $\begin{array}{l}\text { A vs. B } \\
\text { Mortality: } 4.7 \%(3 / 64) \text { vs. } 9.8 \%(6 / 61) \\
\text { at } 12 \text { months, RR } 0.48(95 \% \mathrm{Cl}, 0.12 \\
\text { to } 1.82)^{*} \\
\text { New radiological vertebral fracture: } \\
26 \%(17 / 64) \text { vs. } 13 \%(8 / 61) \text { at } 12 \\
\text { months; OR } 2.78(95 \% \mathrm{Cl}, 1.02 \text { to } \\
7.62)\end{array}$ \\
\hline
\end{tabular}




\begin{tabular}{|c|c|c|c|}
\hline $\begin{array}{l}\text { Vertebral } \\
\text { Augmentation } \\
\text { Procedure }\end{array}$ & $\begin{array}{l}\text { Author, Year } \\
\text { Trial }\end{array}$ & Results & $\begin{array}{l}\text { Adverse Events and Withdrawals } \\
\text { Due to Adverse Events }\end{array}$ \\
\hline Vertebroplasty & $\begin{array}{l}\text { Buchbinder, } \\
2009 \\
\text { Additional } \\
\text { publications: } \\
\text { Kroon, 2014 } \\
\text { and Staples, } \\
2015\end{array}$ & 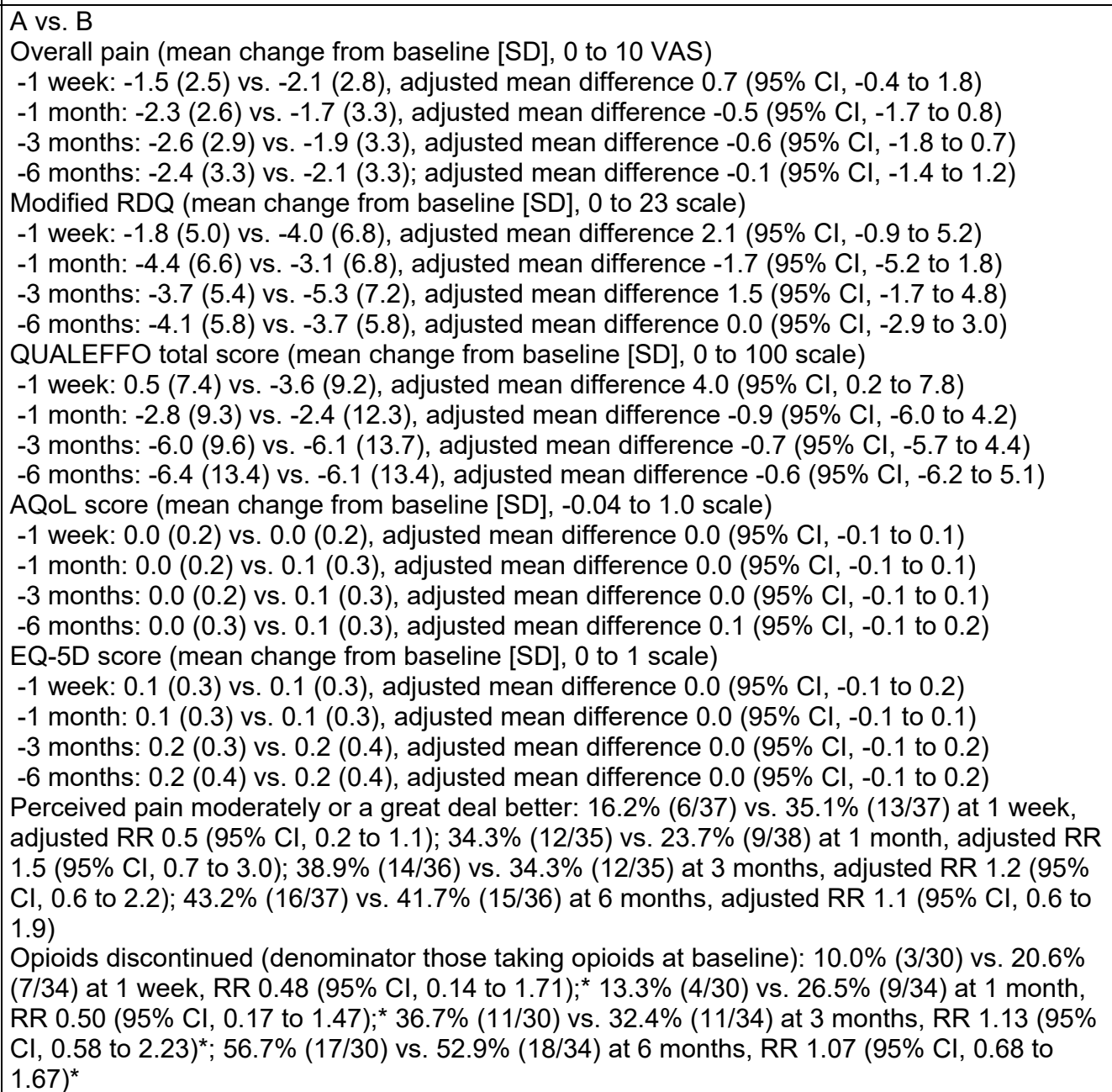 & $\begin{array}{l}\text { A vs. B } \\
\text { Mortality: } 5.3 \%(2 / 38) \text { vs. } 2.5 \%(1 / 40) \\
\text { at } 6 \text { months, RR } 2.11(95 \% \mathrm{Cl}, 0.20 \text { to } \\
22.28) \\
\text { Incident clinical vertebral fracture: } \\
7.9 \%(3 / 38) \text { vs. } 5.0 \%(2 / 40) \text { at } 6 \\
\text { months, RR } 1.58(95 \% \mathrm{Cl}, 0.28 \text { to } \\
8.94) \\
\text { Osteomyelitis: } 2.6 \%(1 / 38) \text { vs. } 0 \% \\
(0 / 40), \text { RR } 3.15(95 \% \mathrm{Cl}, 0.13 \text { to } \\
75.12)^{*}\end{array}$ \\
\hline
\end{tabular}




\begin{tabular}{|c|c|c|c|}
\hline $\begin{array}{l}\text { Vertebral } \\
\text { Augmentation } \\
\text { Procedure }\end{array}$ & $\begin{array}{l}\text { Author, Year } \\
\text { Trial }\end{array}$ & Results & $\begin{array}{l}\text { Adverse Events and Withdrawals } \\
\text { Due to Adverse Events }\end{array}$ \\
\hline Vertebroplasty & $\begin{array}{l}\text { Staples, } 2015 \\
\text { Secondary } \\
\text { publication of } \\
\text { Buchbinder, } \\
2009\end{array}$ & Not reported & $\begin{array}{l}\text { A vs. B } \\
\text { New fracture, any level, } \mathrm{HR}(95 \% \mathrm{Cl}) \text { : } \\
1.80 \text { (0.83 to } 3.94) \\
\text {-Adjacent level: } 2.30(0.57 \text { to } 9.29) \\
\text {-Non-adjacent level: } 1.45(0.55 \text { to } \\
\text { 3.81) } \\
\text {-Treated level: Not calculable (no } \\
\text { fracture in placebo group) } \\
\text {-Untreated level: } 1.69(0.77 \text { to } 3.74) \\
\text { New or progressed fracture, any level, } \\
\text { HR (95\% Cl): } 1.29(0.80 \text { to } 2.08) \\
\text {-Adjacent level: } 2.18(0.74 \text { to } 6.42) \\
\text {-Non-adjacent level: } 1.18(0.58 \text { to } \\
\text { 2.43) } \\
\text {-Treated level: } 1.05(0.47 \text { to } 2.34) \\
\text {-Untreated level: } 1.69(0.77 \text { to } 3.74)\end{array}$ \\
\hline Vertebroplasty & $\begin{array}{l}\text { Kroon, } 2014 \\
\text { Secondary } \\
\text { publication of } \\
\text { Buchbinder, } \\
2009\end{array}$ & 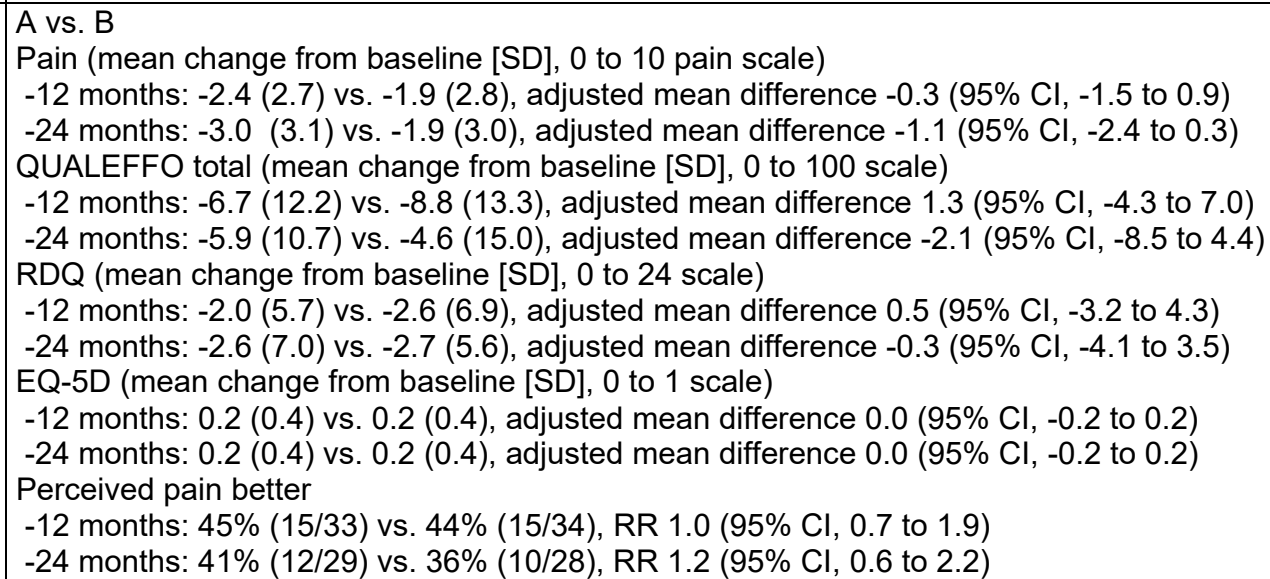 & $\begin{array}{l}\text { A vs. B } \\
\text { Mortality: } 13 \%(5 / 37) \text { vs. } 19 \%(7 / 37) \text { at } \\
24 \text { months, all deaths unrelated to trial, } \\
\text { RR } 0.71(95 \% \mathrm{Cl}, 0.25 \text { to } 2.05)^{*} \\
\text { New fractures at } 2 \text { years: } 14 \text { vs. } 13\end{array}$ \\
\hline
\end{tabular}




\begin{tabular}{|c|c|c|c|}
\hline $\begin{array}{l}\text { Vertebral } \\
\text { Augmentation } \\
\text { Procedure }\end{array}$ & $\begin{array}{l}\text { Author, Year } \\
\text { Trial }\end{array}$ & Results & $\begin{array}{l}\text { Adverse Events and Withdrawals } \\
\text { Due to Adverse Events }\end{array}$ \\
\hline Vertebroplasty & Chen, 2014 & $\begin{array}{l}\text { A vs. B } \\
\text { Pain (mean [SD], } 0 \text { to } 10 \text { VAS), all p<0.001 } \\
\text { - } 1 \text { week: } 3.4(0.5) \text { vs. } 5.0(0.7) \\
\text { - } 1 \text { month: } 2.8(0.4) \text { vs. } 4.0(0.6) \\
\text { - } 3 \text { months: } 2.5(0.5) \text { vs. } 3.9(0.7) \\
\text { - } 6 \text { months: } 2.5(0.6) \text { vs. } 4.0(0.8) \\
\text { - } 12 \text { months: } 2.5(0.5) \text { vs. } 4.1(0.8) \\
\text { RDQ (mean [SD], } 0 \text { to } 24 \text { scale), all p<0.001 } \\
\text { - } 1 \text { week: } 13.2(1.5) \text { vs. } 15.7(1.6) \\
\text { - } 1 \text { month: } 11.7(1.0) \text { vs. } 13.8(1.5) \\
\text { - } 3 \text { months: } 9.9(1.2) \text { vs. } 12.5(1.0) \\
\text { - } 6 \text { months: } 9.3(0.9) \text { vs. } 11.1(0.9) \\
\text { - } 12 \text { months: } 8.1(0.7) \text { vs. } 10.7(1.1) \\
\text { ODI (mean }[S D], 0 \text { to } 100 \text { scale), all p<0.001 } \\
\text { - } 1 \text { week: } 30.3(3.2) \text { vs. } 44.5(3.9) \\
\text { - } 1 \text { month: } 20.4(3.1) \text { vs. } 35.4(2.9) \\
\text { - } 3 \text { months: } 16.6(1.6) \text { vs. } 30.0(2.4) \\
\text { - } 6 \text { months: } 15.5(1.1) \text { vs. } 31.3(3.5) \\
\text { - } 12 \text { months: } 15.0(1.3) \text { vs. } 32.1(4.5) \\
\text { Pain medication use, all p<0.001 } \\
\text { - } 1 \text { week: } 37 \%(17 / 46) \text { vs. } 100 \%(43 / 43), \text { RR } 0.37(95 \% \mathrm{Cl}, 0.25 \text { to } 0.54)^{*} \\
\text { - } 1 \text { month: } 28 \%(13 / 46) \text { vs. } 77 \%(33 / 34), \text { RR } 0.29(95 \% \mathrm{Cl}, 0.18 \text { to } 0.46)^{*} \\
\text { - } 3 \text { months: } 15 \%(7 / 46) \text { vs. } 60 \%(26 / 43), \text { RR } 0.25(95 \% \mathrm{Cl}, 0.12 \text { to } 0.52)^{*} \\
\text { - } 6 \text { months: } 13 \%(6 / 46) \text { vs. } 56 \%(24 / 43), \text { RR } 0.23(95 \% \mathrm{Cl}, 0.10 \text { to } 0.52)^{*} \\
-12 \text { months: } 15 \%(7 / 46) \text { vs. } 65 \%(23 / 43), \text { RR } 0.28(95 \% \mathrm{Cl}, 0.14 \text { to } 0.59)^{*}\end{array}$ & $\begin{array}{l}\text { A vs. B } \\
\text { Mortality: No cases reported } \\
\text { Incident vertebral compression } \\
\text { fractures: } 8.7 \%(4 / 46) \text { vs. } 16.3 \%(7 / 43) \\
\text { at } 12 \text { months, RR } 0.60(95 \% \mathrm{Cl}, 0.19 \\
\text { to } 1.90)\end{array}$ \\
\hline
\end{tabular}




\begin{tabular}{|c|c|c|c|}
\hline $\begin{array}{l}\text { Vertebral } \\
\text { Augmentation } \\
\text { Procedure }\end{array}$ & $\begin{array}{l}\text { Author, Year } \\
\text { Trial }\end{array}$ & Results & $\begin{array}{l}\text { Adverse Events and Withdrawals } \\
\text { Due to Adverse Events }\end{array}$ \\
\hline Vertebroplasty & $\begin{array}{l}\text { Clark, } 2016 \\
\text { VAPOUR }\end{array}$ & 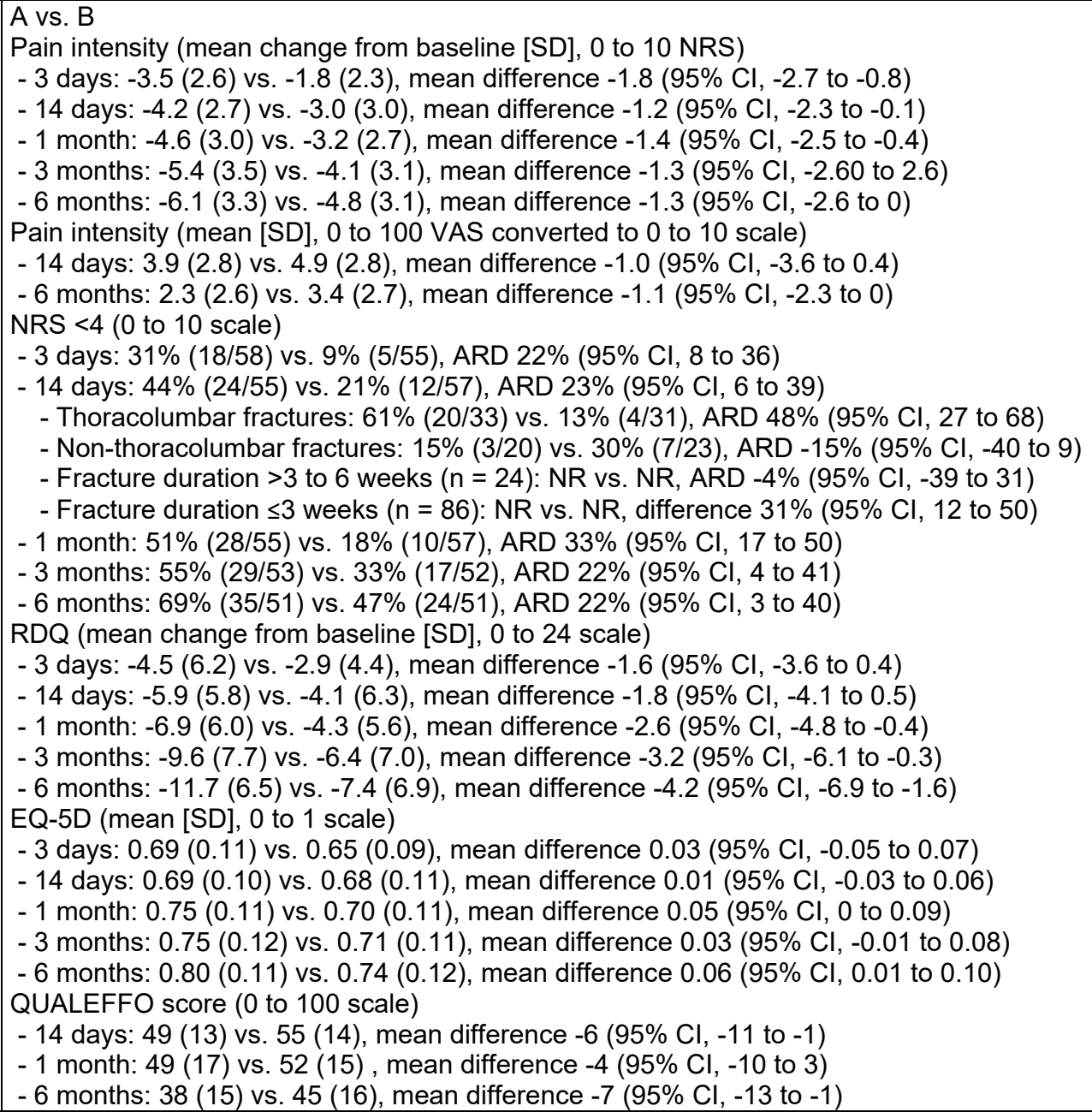 & $\begin{array}{l}\text { A vs. B } \\
\text { Mortality: } 4.9 \%(3 / 61) \text { vs. } 6.8 \%(4 / 59) \\
\text { at } 6 \text { months, RR } 0.72(95 \% \mathrm{Cl}, 0.17 \text { to } \\
3.10)^{*} \\
\text { SAEs related to procedure: } 3.3 \% \\
(2 / 61 \text {; respiratory arrest or humerus } \\
\text { fracture during transfer) vs. NR } \\
\text { SAEs related to fracture: NR vs. } 3.4 \% \\
(2 / 59 ; \text { spinal cord compression with } \\
\text { resolution [n = 1] or paraplegia [n = } 1 \text { ]) } \\
\text { Incident vertebral compression } \\
\text { fracture: } 4.9 \%(3 / 61) \text { vs. } 3.4 \%(2 / 59) \text { at } \\
6 \text { months, RR } 1.45(95 \% \mathrm{Cl}, 0.25 \text { to } \\
8.37)^{*}\end{array}$ \\
\hline Vertebroplasty & $\begin{array}{l}\text { Clark, } 2016 \\
\text { VAPOUR } \\
\text { (Cont.) }\end{array}$ & $\begin{array}{l}\text { Analgesic use } \\
\text { - } 3 \text { days: } 97 \%(57 / 59) \text { vs. } 98 \%(56 / 57), \text { ARD }-2 \%(95 \% \mathrm{Cl},-7 \text { to } 4) \\
\text { - } 14 \text { days: } 88 \%(49 / 56) \text { vs. } 91 \%(52 / 57), \text { ARD }-4 \%(95 \% \mathrm{Cl},-15 \text { to } 8) \\
\text { - } 1 \text { month: } 75 \%(41 / 55) \text { vs. } 88 \%(50 / 57), \text { ARD }-13 \%(95 \% \mathrm{Cl},-28 \text { to } 1) \\
\text { - } 3 \text { months: } 64 \%(34 / 53) \text { vs. } 83 \%(44 / 53), \text { ARD }-19 \%(95 \% \mathrm{Cl},-35 \text { to }-2) \\
\text { - } 6 \text { months: } 58 \%(29 / 50) \text { vs. } 76 \%(39 / 51), \text { ARD }-18 \%(95 \% \mathrm{Cl},-36 \text { to } 1) \\
\text { Opiate use: no difference between groups, data not provided }\end{array}$ & \\
\hline
\end{tabular}




\begin{tabular}{|c|c|c|c|}
\hline $\begin{array}{l}\text { Vertebral } \\
\text { Augmentation } \\
\text { Procedure }\end{array}$ & $\begin{array}{l}\text { Author, Year } \\
\text { Trial }\end{array}$ & Results & $\begin{array}{l}\text { Adverse Events and Withdrawals } \\
\text { Due to Adverse Events }\end{array}$ \\
\hline Vertebroplasty & $\begin{array}{l}\text { Diamond, } \\
2020 \\
\text { VAPOUR }\end{array}$ & 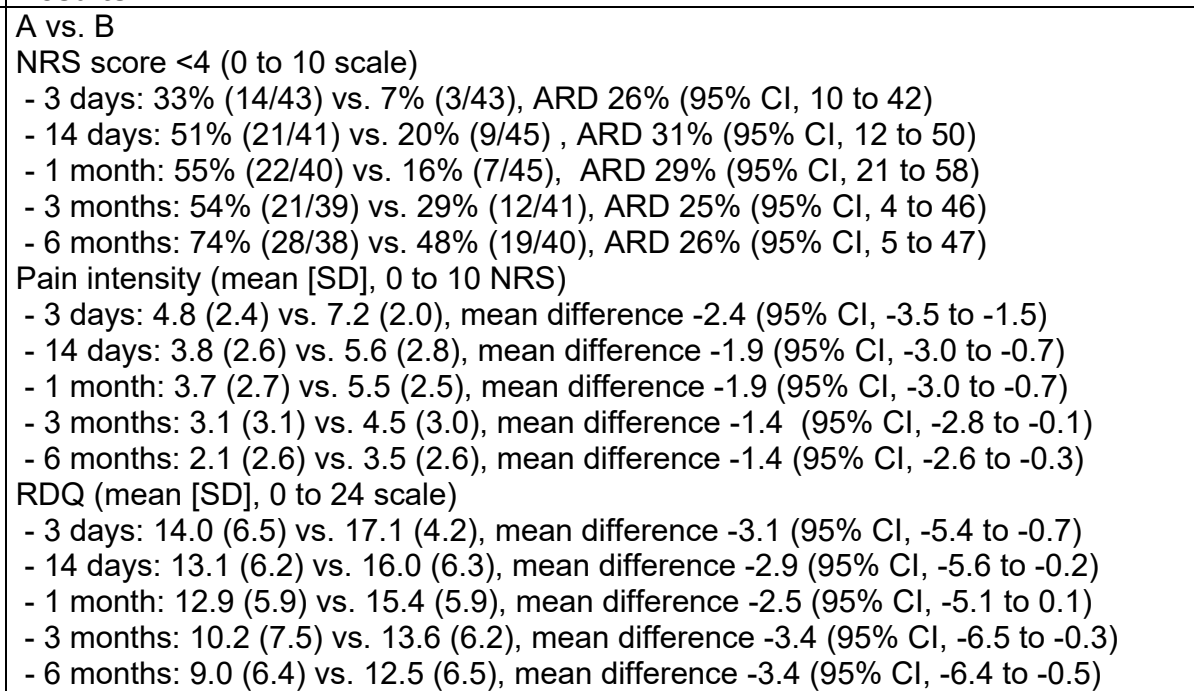 & $\begin{array}{l}\text { A vs. B } \\
\text { SAEs: } 4.6 \%(2 / 43 \text {; hypoventilation and } \\
\text { humeral fracture) vs. } 4.6 \%(2 / 43 ; \\
\text { spinal cord compression, } 1 \text { with } \\
\text { paraplegia), RR } 1.00(95 \% \mathrm{Cl}, 0.15 \text { to } \\
6.78)^{\star}\end{array}$ \\
\hline Vertebroplasty & $\begin{array}{l}\text { Farrokhi, } \\
2011\end{array}$ & $\begin{array}{l}\text { A vs. B } \\
\text { Pain intensity (mean [SD], } 0 \text { to } 10 \text { VAS) } \\
\text { - } 1 \text { week: } 3.3(1.5) \text { vs. } 6.4(2.1) \text {, mean difference }-3.1(95 \% \mathrm{Cl},-3.72 \text { to }-2.28) \\
\text { - } 2 \text { months: } 3.2(2.2) \text { vs. } 6.1(2.1) \text {, mean difference }-2.9(95 \% \mathrm{Cl},-4.9 \text { to }-0.81) \\
\text { - } 6 \text { months: } 2.2(2.1) \text { vs. } 4.1(1.5) \text {, mean difference }-1.9(95 \% \mathrm{Cl},-3.25 \text { to }-0.55) \\
\text { - } 12 \text { months: } 2.2(2.1) \text { vs. } 4.1(1.8) \text {, mean difference }-1.9(95 \% \mathrm{Cl},-2.9 \text { to } 0.90) \\
\text { - } 24 \text { months: } 2.8(2.0) \text { vs. } 3.7(2.0) \text {, mean difference }-0.5(-95 \% \mathrm{Cl}, 1.39 \text { to } 0.5) \\
\text { - } 36 \text { months: } 1.8(1.7) \text { vs. } 3.7(2.5) \text {, mean difference }-1.5(95 \% \mathrm{Cl},-9.85 \text { to } 6.85) \\
\text { ODI (mean [SD], 0 to } 100 \text { scale) } \\
\text { - } 1 \text { week: } 30.1(3.0) \text { vs. } 44.0(2.5) \text {, mean difference }-14(95 \% \mathrm{Cl},-15 \text { to }-12.82) \\
\text { - } 2 \text { months: } 15.0(2.2) \text { vs. } 30.0(3.1) \text {, mean difference }-15(95 \% \mathrm{Cl},-16.76 \text { to }-13.24) \\
\text { - } 6 \text { months: } 10.0(2.0) \text { vs. } 21.0(2.5) \text {, mean difference }-11(95 \% \mathrm{Cl},-12.17 \text { to }-7.83) \\
\text { - } 12 \text { months: } 8.0(3.2) \text { vs. } 20.0(1.7) \text {, mean difference }-12(95 \% \mathrm{Cl},-13.5 \text { to }-11.5) \\
\text { - } 24 \text { months: } 8.0(2.2) \text { vs. } 20.0(2.0), \text { mean difference }-12(95 \% \mathrm{Cl},-13.32 \text { to }-10.68) \\
-36 \text { months: } 8.0(1.7) \text { vs. } 22.0(1.2), \text { mean difference }-14(95 \% \mathrm{Cl},-14.91 \text { to }-13.09)\end{array}$ & $\begin{array}{l}\text { A vs. B } \\
\text { Mortality: } 5 \%(2 / 40) \text { vs. } 2.4 \%(1 / 42) \text { at } \\
12 \text { months (no deaths reported from } \\
12 \text { to } 36 \text { months), RR } 2.10(95 \% \mathrm{Cl} \text {, } \\
0.20 \text { to } 22.26)^{*} \\
\text { New fracture: } 2.6 \%(1 / 38) \text { vs. } 15.4 \% \\
(6 / 39) \text { at } 2 \text { years, RR } 0.17(95 \% \mathrm{Cl}, \\
0.02 \text { to } 1.35)^{*} \\
\text { Epidural cement leakage with lower } \\
\text { extremity pain and weakness: } 2.5 \% \\
\text { (1/40) vs. NR } \\
\text { Venous emboli or infection: No cases }\end{array}$ \\
\hline
\end{tabular}




\begin{tabular}{|c|c|c|c|}
\hline $\begin{array}{l}\text { Vertebral } \\
\text { Augmentation } \\
\text { Procedure }\end{array}$ & $\begin{array}{l}\text { Author, Year } \\
\text { Trial }\end{array}$ & Results & $\begin{array}{l}\text { Adverse Events and Withdrawals } \\
\text { Due to Adverse Events }\end{array}$ \\
\hline Vertebroplasty & $\begin{array}{l}\text { Firanescu, } \\
2018 \text { \& } 2019 \\
\text { VERTOS IV }\end{array}$ & $\begin{array}{l}\text { A vs. B } \\
\text { Pain intensity (mean [SD], } 0 \text { to } 10 \text { VAS) } \\
\text { - } 1 \text { day: } 5.24(2.49) \text { vs. } 4.82(2.48) \text {, adjusted mean difference } 0.43(95 \% \mathrm{Cl},-0.31 \text { to } 1.17) \\
\text { - } 1 \text { week: } 4.38(2.52) \text { vs. } 4.27(2.48) \text {, adjusted mean difference } 0.11(95 \% \mathrm{Cl},-0.63 \text { to } 0.85) \\
\text { - } 1 \text { month: } 3.32(2.52) \text { vs. } 3.73(2.51) \text {, adjusted mean difference }-0.41(95 \% \mathrm{Cl},-1.15 \text { to } 0.33) \\
\text { - } 3 \text { months: } 2.69(2.54) \text { vs. } 2.90(2.58) \text {, adjusted mean difference }-0.21(95 \% \mathrm{Cl},-0.96 \text { to } 0.54) \\
\text { - } 6 \text { months: } 3.02(2.59) \text { vs. } 3.41(2.60) \text {, adjusted mean difference }-0.39(95 \% \mathrm{Cl},-1.15 \text { to } 0.37) \\
\text { - } 12 \text { months: } 2.72(2.61) \text { vs. } 3.17(2.72) \text {, adjusted mean difference }-0.45(95 \% \mathrm{Cl},-1.24 \text { to } 0.37) \\
\text { On weak opioids at } 1 \text { month: } 6.7 \%(6 / 90) \text { vs. } 4.7 \%(4 / 86), \mathrm{RR} 1.43(95 \% \mathrm{Cl}, 0.42 \text { to } 4.90)^{*} \\
\text { On strong opioids at } 1 \text { month: } 20.0 \%(18 / 90) \text { vs. } 22.1 \%(19 / 86), \mathrm{RR} 0.90(95 \% \mathrm{Cl}, 0.51 \text { to } 1.60)^{\star}\end{array}$ & $\begin{array}{l}\text { A vs. B } \\
\text { Mortality: } 8.8 \%(8 / 91) \text { vs. } 5.6 \%(5 / 89) \\
\text { at } 1 \text { year, RR } 1.56(95 \% \mathrm{Cl}, 0.53 \text { to } \\
4.60)^{*} \\
\text { Incident vertebral compression } \\
\text { fracture: } 16.7 \%(15 / 90) \text { vs. } 22.1 \% \\
\text { (19/86) at } 1 \text { year; number of fractures } \\
31 \text { vs. } 28 \text { OR } 0.71(95 \% \mathrm{Cl}, 0.33 \text { to } \\
1.50) \\
\text { Underwent re-treatment for new } \\
\text { fracture: } 7 \%(6 / 90) \text { vs. } 7 \%(6 / 86), \mathrm{RR} \\
0.95(95 \% \mathrm{Cl}, 0.32 \text { to } 2.85)^{*} \\
\text { Location of new fractures, all } \mathrm{p}=\mathrm{NS} \\
- \text { Adjacent above: } 52 \%(16 / 31) \text { vs. } \\
50 \%(14 / 28), \text { OR } 1.07(95 \% \mathrm{Cl}, 0.38 \text { to } \\
2.96) \\
- \text { Between (sandwich): } 3 \%(1 / 31) \text { vs. } \\
4 \%(1 / 28), \text { OR } 0.90(955 \mathrm{Cl}, 0.05 \text { to } \\
15.10) \\
\text { - Distant: } 45 \% \text { (14/31) vs. } 46 \% \\
(13 / 28), \text { OR } 0.95 \text { (95\% Cl, } 0.34 \text { to } \\
2.65) \\
\text { Procedure related adverse reactions: } \\
2.2 \%(2 / 90,1 \text { respiratory insufficiency } \\
\text { and } 1 \text { vasovagal reaction) vs. NR }\end{array}$ \\
\hline Vertebroplasty & $\begin{array}{l}\text { Hansen, } 2019 \\
\text { VOPE }\end{array}$ & $\begin{array}{l}\text { A vs. B } \\
\text { Pain at rest (mean [SD], } 0 \text { to } 10 \text { VAS) } \\
\text { - } 1 \text { week: } 2.5(2.2) \text { vs. } 2.1(2.1) \text {, mean difference } 0.4(95 \% \mathrm{Cl},-0.9 \text { to } 1.7) \\
\text { - } 4 \text { weeks: } 1.3(2.2) \text { vs. } 1.0(2.1) \text {. mean difference } 0.3(95 \% \mathrm{Cl},-1.0 \text { to } 1.6) \\
\text { - } 12 \text { weeks: } 0.8(2.1) \text { vs. } 0.7(2.1) \text {, mean difference } 0.1(95 \% \mathrm{Cl},-1.1 \text { to } 1.3) \\
\text { - } 52 \text { weeks: } 1.6(2.4) \text { vs. } 1.6(2.1) \text {, mean difference } 0.0(95 \% \mathrm{Cl},-1.3 \text { to } 1.3) \\
\text { SF-36 PCS (mean [SD], } 0 \text { to } 100 \text { scale) } \\
\text { - } 3 \text { months: } 31.4(10.0) \text { vs. } 33.9(10.6) \text {, mean difference }-2.5(95 \% \mathrm{Cl},-8.6 \text { to } 3.6) \\
\text { - } 12 \text { months: } 31.9(9.2) \text { vs. } 35.2(11.9) \text {, mean difference }-3.3(95 \% \mathrm{Cl},-9.7 \text { to } 3.1) \\
\text { SF-36 MCS (mean [SD], } 0 \text { to } 100 \text { scale) } \\
\text { - } 3 \text { months: } 49.7(12.0) \text { vs. } 51.4(11.0) \text {, mean difference }-1.7(95 \% \mathrm{Cl},-8.5 \text { to } 5.1) \\
\text { - } 12 \text { months: } 48.6(10.8) \text { vs. } 53.6(10.3) \text {, mean difference }-5.0(95 \% \mathrm{Cl},-11.3 \text { to } 1.3) \\
\text { EQ-5D (mean [SD] } 0 \text { to } 100 \text { scale) } \\
\text { - } 3 \text { months: } 0.68(0.23) \text { vs. } 0.71(0.23), \text { mean difference }-0.03(95 \% \mathrm{Cl},-0.17 \text { to } 0.11) \\
\text { - } 12 \text { months: } 0.67(0.27) \text { vs. } 0.74(0.22) \text {, mean difference }-0.07(95 \% \mathrm{Cl},-0.22 \text { to } 0.08) \\
\text { Opioid use: Similar in two groups at } 0 \text { to } 12 \text { weeks and } 12 \text { months, data not provided }\end{array}$ & NR \\
\hline
\end{tabular}




\begin{tabular}{|c|c|c|c|}
\hline $\begin{array}{l}\text { Vertebral } \\
\text { Augmentation } \\
\text { Procedure }\end{array}$ & $\begin{array}{l}\text { Author, Year } \\
\text { Trial }\end{array}$ & Results & $\begin{array}{l}\text { Adverse Events and Withdrawals } \\
\text { Due to Adverse Events }\end{array}$ \\
\hline Vertebroplasty & $\begin{array}{l}\text { Kallmes, } 2009 \\
\text { and } \\
\text { Comstock, } \\
2013 \\
\text { INVEST }\end{array}$ & 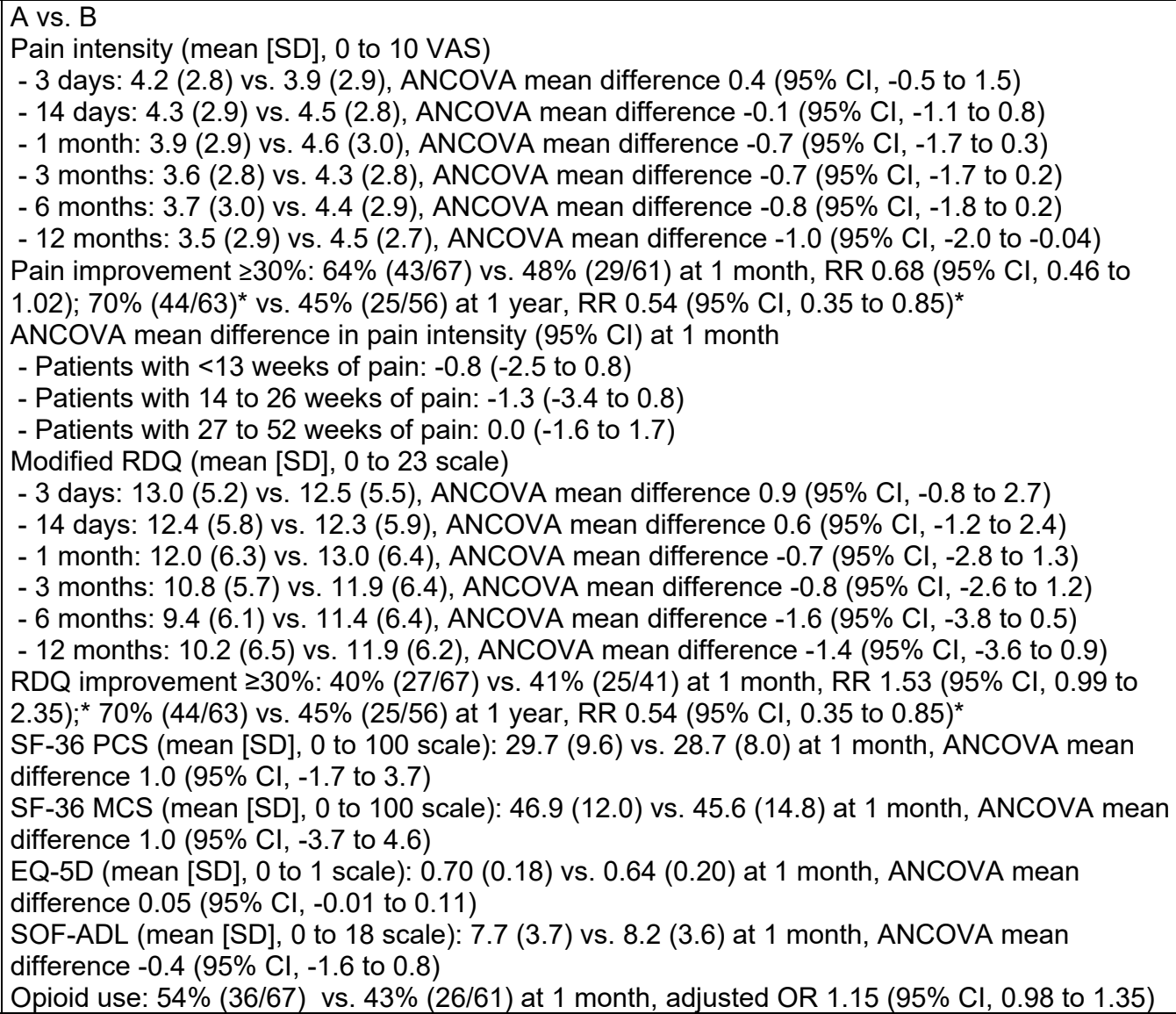 & $\begin{array}{l}\text { A vs. B } \\
\text { Mortality: None reported } \\
\text { SAEs: } 1.6 \%(1 / 64), \text { injury to thecal } \\
\text { sac) vs. } 1.6 \%(1 / 61) \text {, tachycardia and } \\
\text { rigors), RR } 0.95(95 \% \mathrm{Cl}, 0.06 \text { to } \\
14.90)^{*}\end{array}$ \\
\hline
\end{tabular}




\begin{tabular}{|c|c|c|c|}
\hline $\begin{array}{l}\text { Vertebral } \\
\text { Augmentation } \\
\text { Procedure }\end{array}$ & $\begin{array}{l}\text { Author, Year } \\
\text { Trial }\end{array}$ & Results & $\begin{array}{l}\text { Adverse Events and Withdrawals } \\
\text { Due to Adverse Events }\end{array}$ \\
\hline Vertebroplasty & \begin{tabular}{|l|} 
Klazen, 2010 \\
and \\
Venmans, \\
2011 \\
VERTOS II
\end{tabular} & 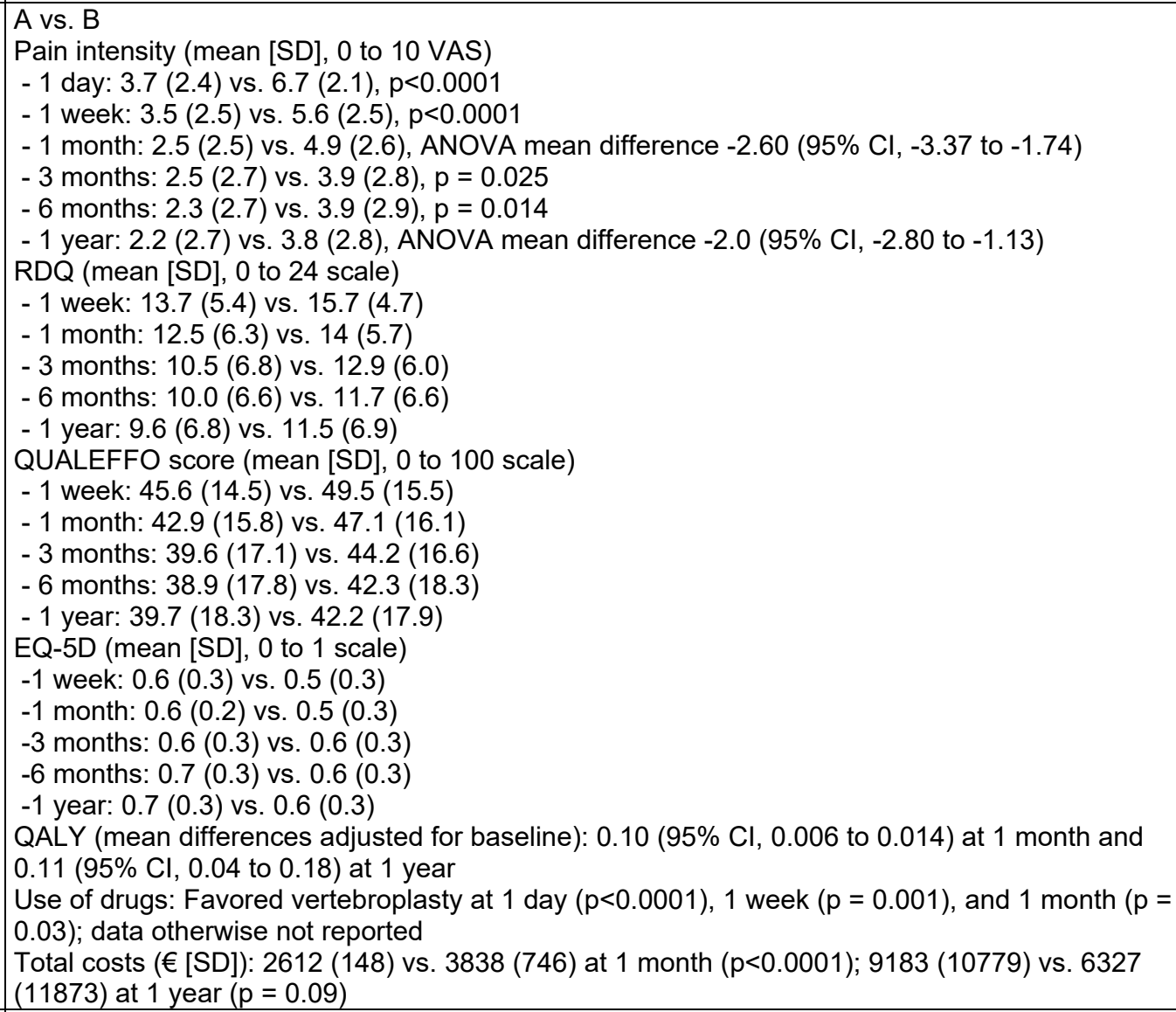 & $\begin{array}{l}\text { A vs. B } \\
\text { Mortality: } 5.0 \%(5 / 101) \text { vs. } 5.9 \% \\
(6 / 101) \text { at } 1 \text { year, RR } 0.83(95 \% \mathrm{Cl} \\
0.26 \text { to } 2.64)^{*} \\
\text { Incident vertebral facture: } 16.5 \% \\
(15 / 91) \text { vs. } 24.7 \%(21 / 85) \text { at } 1 \text { year, } \\
\text { RR } 0.67(95 \% \mathrm{Cl}, 0.37 \text { to } 1.21)^{*}\end{array}$ \\
\hline Vertebroplasty & Leali, 2016 & $\begin{array}{l}\text { A vs. B } \\
\text { Pain intensity (mean [SD NR], } 0 \text { to } 10 \text { VAS): } 2.3 \text { vs. NR at } 1 \text { day } \\
\text { ODI (mean [SD NR], } 0 \text { to } 100 \text { scale): } 31.7 \text { vs. NR at } 1 \text { day } \\
\text { Discontinued analgesics: } 65 \%(120 / 200) \text { vs. NR at } 2 \text { days } \\
\text { - Reports patients in usual care group had no change in pain or disability, but data not provided } \\
\text { - Reports results at } 6 \text { weeks, } 3 \text { months, and } 6 \text { months similar in both groups, but data not } \\
\text { provided }\end{array}$ & $\begin{array}{l}\text { A vs. B } \\
\text { Mortality: } 0.5 \%(1 / 200) \text { vs. } 1.5 \% \\
(3 / 200) \text { at } 6 \text { months, RR } 0.33(95 \% \mathrm{Cl} \text {, } \\
0.03 \text { to } 3.18)^{*} \\
\text { Minor complications: } 1.0 \%(2 / 200) \text { vs. } \\
\text { NR } \\
\text { New vertebral fracture above treated } \\
\text { fracture: } 1.5 \%(3 / 200) \text { vs. } 0 \%(0 / 200) \\
\text { at } 6 \text { weeks, RR } 7.00(95 \% \mathrm{Cl}, 0.36 \text { to } \\
134.65)^{\star}\end{array}$ \\
\hline
\end{tabular}




\begin{tabular}{|c|c|c|c|}
\hline $\begin{array}{l}\text { Vertebral } \\
\text { Augmentation } \\
\text { Procedure }\end{array}$ & $\begin{array}{l}\text { Author, Year } \\
\text { Trial }\end{array}$ & Results & $\begin{array}{l}\text { Adverse Events and Withdrawals } \\
\text { Due to Adverse Events }\end{array}$ \\
\hline Vertebroplasty & $\begin{array}{l}\text { Rousing, } \\
2009 \& 2010\end{array}$ & $\begin{array}{l}\text { A vs. B } \\
\text { Pain intensity (mean [SD], } 0 \text { to } 10 \text { VAS) } \\
\text { - } 3 \text { months: } 1.8(2.3) \text { vs. } 2.6(3.2), p=0.32 \\
\text { - } 1 \text { year: } 2.0(2.1) \text { vs. } 2.9(2.8), p=0.29 \\
\text { SF-36 PCS (mean [SD], } 0 \text { to } 100 \text { scale) } \\
\text { - } 3 \text { months: } 34.0(9.0) \text { vs. } 29.3(10.3), p=0.12 \\
-1 \text { year: } 32.1(9.1) \text { vs. } 30.5(11.5), p=0.63 \\
\text { SF-36 MCS (mean [SD], } 0 \text { to } 100 \text { scale) } \\
\text { - } 3 \text { months: } 48.9(11.8) \text { vs. } 46.2(15.0), p=0.51 \\
\text { - } 12 \text { months: } 48.7(12.7) \text { vs. } 49.0(11.2), p=0.93 \\
\text { EQ-5D (mean [SD], } 0 \text { to } 1 \text { scale) } \\
\text { - } 3 \text { months: } 0.73(0.14) \text { vs. } 0.54(0.30), p=0.04 \\
\text { - } 12 \text { months: } 0.68(0.17) \text { vs. } 0.57(0.25), p=0.19 \\
\text { Dallas Pain Questionnaire, daily activities (mean [SD], } 0 \text { to } 100 \text { scale) } \\
\text { - } 3 \text { months: } 47.1(31.3) \text { vs. } 57.4(36.7), p=0.33 \\
\text { - } 12 \text { months: } 53.0(32.3) \text { vs. } 53.6(36.7), p=0.95 \\
\text { Dallas Pain Questionnaire, anxiety and depression (mean [SD], } 0 \text { to } 100 \text { scale) } \\
\text { - } 3 \text { months: } 28.7(28.2) \text { vs. } 40.0(38.4), p=0.30 \\
\text { - } 12 \text { months: } 31.3(26.8) \text { vs. } 35.3(30.0), p=0.70\end{array}$ & $\begin{array}{l}\text { A vs. B } \\
\text { Mortality: } 3.8 \%(1 / 26) \text { vs. } 4.2 \%(1 / 26) \\
\text { at } 3 \text { months, RR } 1.00(95 \% \mathrm{Cl}, 0.07 \text { to } \\
15.15){ }^{*} 7.7 \%(2 / 26) \text { vs. } 8.3 \%(2 / 24) \text { at } \\
1 \text { year, RR } 0.92(95 \% \mathrm{Cl}, 0.14 \text { to } \\
6.05)^{*} \\
\text { Any incident vertebral fracture: } 11.5 \% \\
(3 / 26) \text { vs. } 4.2 \%(1 / 24) \text { at } 3 \text { months, RR } \\
2.77(95 \% \mathrm{Cl}, 0.31 \text { to } 24.85))^{*} 15.4 \% \\
(4 / 26) \text { vs. } 12.5 \%(3 / 24) \text { at } 12 \text { months, } \\
\text { RR } 1.23(95 \% \mathrm{Cl}, 0.31 \text { to } 4.94)^{*} \\
\text { Adjacent incident vertebral fracture: } \\
3.8 \%(1 / 26) \text { vs. } 0 \%(0 / 24) \text { at } 3 \text { months, } \\
\text { RR } 2.78(95 \% \mathrm{Cl}, 0.12 \text { to } 65.09)^{*} 3.8 \% \\
(1 / 26) \text { vs. } 0 \%(0 / 24) \text { at } 12 \text { months, RR } \\
2.78(95 \% \mathrm{Cl}, 0.12 \text { to } 65.09) \\
\text { Symptomatic incident vertebral } \\
\text { fracture: } 0 \%(0 / 26) \text { vs. } 12.5 \%(3 / 24) \text { at } \\
12 \text { months, RR } 0.13(95 \% \mathrm{Cl}, 0.01 \text { to } \\
2.43)^{*}\end{array}$ \\
\hline Vertebroplasty & $\begin{array}{l}\text { Voormolen, } \\
2007 \\
\text { VERTOS }\end{array}$ & $\begin{array}{l}\text { A vs. B } \\
\text { Pain intensity (mean [range], } 0 \text { to } 10 \text { VAS) } \\
-1 \text { day: } 4.7 \text { ( } 1 \text { to } 8) \text { vs. } 7.1 \text { ( } 5 \text { to } 10) \text {, mean difference }-2.4(95 \% \mathrm{Cl},-3.7 \text { to }-1.0) \\
-2 \text { weeks: } 4.9 \text { (0 to } 10) \text { vs. } 6.4 \text { ( } 3 \text { to } 9) \text {, mean difference }-1.5(95 \% \mathrm{Cl},-3.2 \text { to } 0.2) \\
\text { Analgesic use (mean [range], } 0 \text { to } 3 \text { scale) } \\
-1 \text { day: } 1.1 \text { ( } 0 \text { to } 3) \text { vs. } 2.5(1 \text { to } 3) \text {, mean difference }-1.4(95 \% \mathrm{Cl},-2.1 \text { to }-0.8) \\
-2 \text { weeks: } 1.2 \text { (0 to } 3) \text { vs. } 2.6 \text { ( } 2 \text { to } 3) \text {, mean difference }-1.4(95 \% \mathrm{Cl},-2.0 \text { to }-0.8) \\
\text { RDQ (mean [range], } 0 \text { to } 24 \text { scale) } \\
-2 \text { weeks: } 13 \text { ( } 3 \text { to } 22) \text { vs. } 18 \text { ( } 9 \text { to } 23) \text {, mean difference }-5(95 \% \mathrm{Cl},-8.4 \text { to }-1.2) \\
\text { QUALEFFO (mean [range, } 0 \text { to } 100 \text { scale) } \\
-2 \text { weeks: } 53 \text { ( } 28 \text { to } 79) \text { vs. } 67(40 \text { to } 88) \text {, mean difference }-14(95 \% \mathrm{Cl},-24.7 \text { to }-3.4)\end{array}$ & $\begin{array}{l}\text { A vs. B } \\
\text { Mortality: None reported } \\
\text { Incident vertebral compression } \\
\text { fracture: } 11.1 \%(2 / 18) \text { vs. } 0 \%(0 / 16) \text { at } \\
2 \text { weeks, RR } 4.47(95 \% \mathrm{Cl}, 0.23 \text { to } \\
86.77)^{*}\end{array}$ \\
\hline
\end{tabular}




\begin{tabular}{|c|c|c|c|}
\hline $\begin{array}{l}\text { Vertebral } \\
\text { Augmentation } \\
\text { Procedure }\end{array}$ & $\begin{array}{l}\text { Author, Year } \\
\text { Trial }\end{array}$ & Results & $\begin{array}{l}\text { Adverse Events and Withdrawals } \\
\text { Due to Adverse Events }\end{array}$ \\
\hline Vertebroplasty & Yang, 2016 & 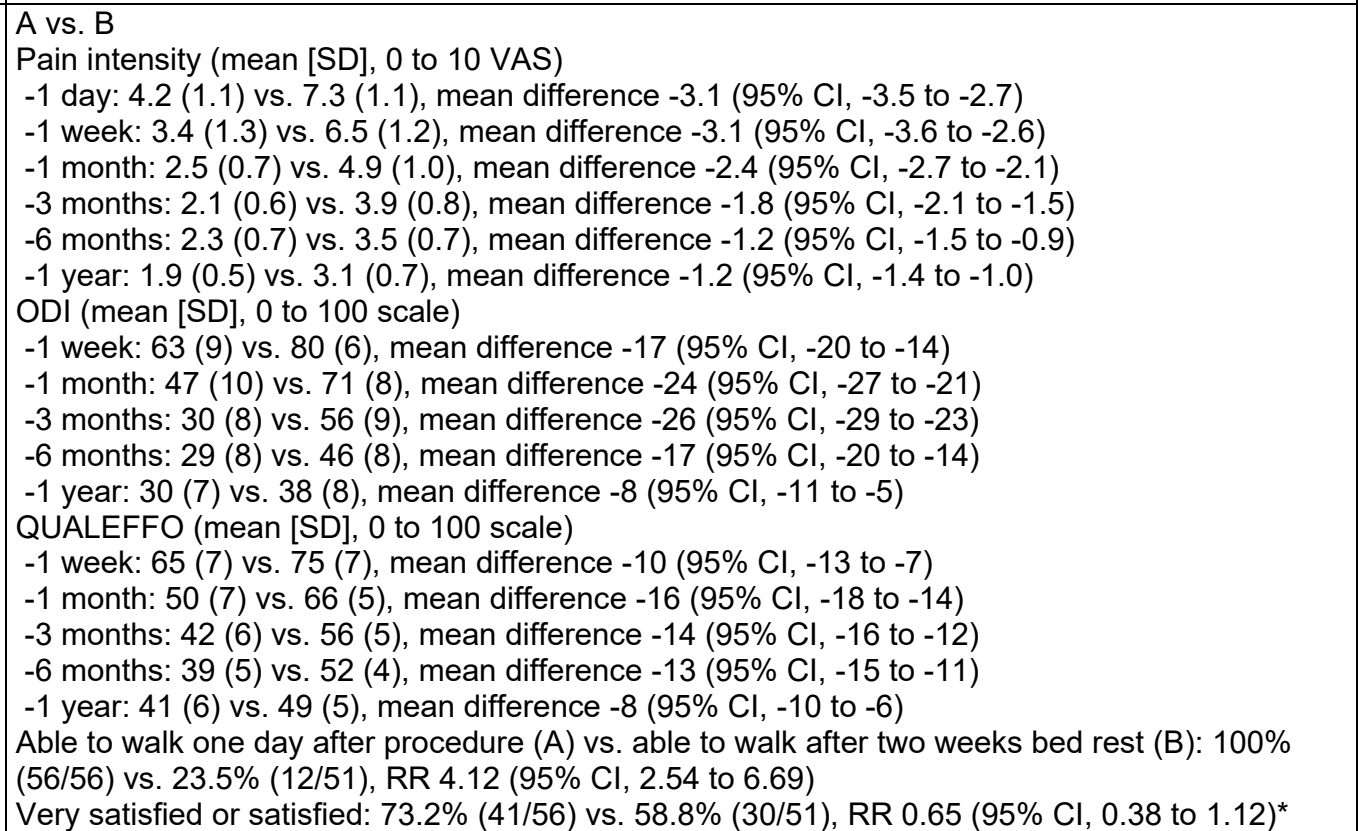 & $\begin{array}{l}\text { A vs. B } \\
\text { Mortality: None reported } \\
\text { Any adverse event: } 16.1 \%(9 / 56) \text { vs. } \\
35.3 \%(18 / 51) \text {, RR } 0.46(95 \% \mathrm{Cl}, 0.23 \\
\text { to } 0.92) \\
\text { Incident vertebral fracture: } 8.9 \%(5 / 56) \\
\text { vs. } 7.8 \%(4 / 51) \text { at } 1 \text { year, RR } 1.14 \\
(95 \% \mathrm{Cl}, 0.32 \text { to } 4.01)\end{array}$ \\
\hline Kyphoplasty & $\begin{array}{l}\text { Berenson, } \\
2011 \\
\text { CAFE Trial }\end{array}$ & $\begin{array}{l}\text { A vs. B } \\
\text { Pain (mean, } 0 \text { to } 10 \mathrm{NRS}): 3.5(2.2) \text { vs. } 7.0(1.5) \text { at } 7 \text { days, mean difference in change from } \\
\text { baseline }-3.5(95 \% \mathrm{Cl}-3.8 \text { to }-3.2) ; 3.3(2.6) \text { vs. } 6.9(1.1) \text { at } 1 \text { month, mean difference in change } \\
\text { from baseline }-3.3(95 \% \mathrm{Cl},-3.6 \text { to }-3.0) \\
\text { RDQ (mean, } 0 \text { to } 24): 9.1 \text { vs. } 18.0 \text { at } 1 \text { month, mean difference }-8.4(95 \% \mathrm{Cl}-7.6 \text { to }-9.2) \\
\text { SF-36 Mental Component Summary (mean difference in change from baseline, } 0 \text { to } 100): 8.4 \\
(95 \% \mathrm{Cl}, 7.7 \text { to } 9.1) \text { at } 1 \text { month } \\
\text { SF-36 Physical Component Summary (mean difference in change from baseline, } 0 \text { to } 100): 11.1 \\
(95 \% \mathrm{Cl}, 10.7 \text { to } 11.5) \text { at } 1 \text { month } \\
\text { Karnofsky Performance Status (mean difference in change from baseline, } 0 \text { to } 100) 15.3(95 \% \\
\mathrm{Cl}, 13.5 \text { to } 17.1) \text { at } 1 \text { month } \\
\text { Karnofsky Performance Status score improved }>10 \text { points: } 65.1 \%(41 / 63) \text { vs. } 26.5 \%(13 / 49) \text { at } 1 \\
\text { month, RR } 2.45(95 \% \mathrm{Cl}, 1.49 \text { to } 4.04)^{*} \\
\text { Karnofsky Performance Status score } \geq 70: 74.6 \%(47 / 63) \text { vs. } 38.8 \%(19 / 49) \text { at } 1 \text { month, RR } 1.92 \\
(95 \% \mathrm{Cl}, 1.32 \text { to } 2.81)^{*} \\
\text { Analgesic use: } 52.3 \%(34 / 65) \text { vs. } 82.0 \%(41 / 50) \text { at } 1 \text { month, RR } 0.64(95 \% \mathrm{Cl}, 0.49 \text { to } 0.83)^{*}\end{array}$ & $\begin{array}{l}\text { A vs. B vs. C } \\
\text { Mortality: } 32.9 \%(23 / 70) \text { vs. } 18.8 \% \\
(12 / 64), \mathrm{RR} 1.75(95 \% \mathrm{Cl}, 0.95 \text { to } \\
3.22)^{*} \\
\text { Any adverse event: } 37.1 \%(26 / 70) \text { vs. } \\
29.7 \%(19 / 64), \mathrm{RR} 1.25(95 \% \mathrm{Cl}, 0.77 \\
\text { to } 2.03)^{*} \\
\text { Adverse events resulting in death: } \\
2.9 \%(2 / 70) \text { vs. } 1.6 \%(1 / 64), \mathrm{RR} 1.83 \\
(95 \% \mathrm{Cl}, 0.17 \text { to } 19.69)^{*} \\
\text { Back pain: } 5.7 \%(4 / 70) \text { vs. } 7.8 \% \\
(5 / 64), \mathrm{RR} 0.73(95 \% \mathrm{Cl}, 0.20 \text { to } 2.60)^{*} \\
\text { Incident symptomatic fracture: } 2.9 \% \\
(2 / 70) \text { vs. } 7.8 \%(5 / 64), \mathrm{RR} 0.36(95 \% \\
\text { Cl, } 0.07 \text { to } 1.82)^{*} \\
\text { Injury or procedural complications: } \\
5.7 \%(4 / 70) \text { vs. } 0 \%(0 / 64), \text { RR } 8.24 \\
(95 \% \text { Cl, } 0.45 \text { to } 150.10)^{*}\end{array}$ \\
\hline
\end{tabular}




\begin{tabular}{|c|c|c|c|}
\hline $\begin{array}{l}\text { Vertebral } \\
\text { Augmentation } \\
\text { Procedure }\end{array}$ & $\begin{array}{l}\text { Author, Year } \\
\text { Trial }\end{array}$ & Results & $\begin{array}{l}\text { Adverse Events and Withdrawals } \\
\text { Due to Adverse Events }\end{array}$ \\
\hline Kyphoplasty & $\begin{array}{l}\text { Wardlaw, } \\
2009 \\
\text { FREE Trial } \\
\text { Additional } \\
\text { publications: } \\
\text { Boonen, } 2013 \\
\text { and Van } \\
\text { Meirhaege, } \\
2013\end{array}$ & 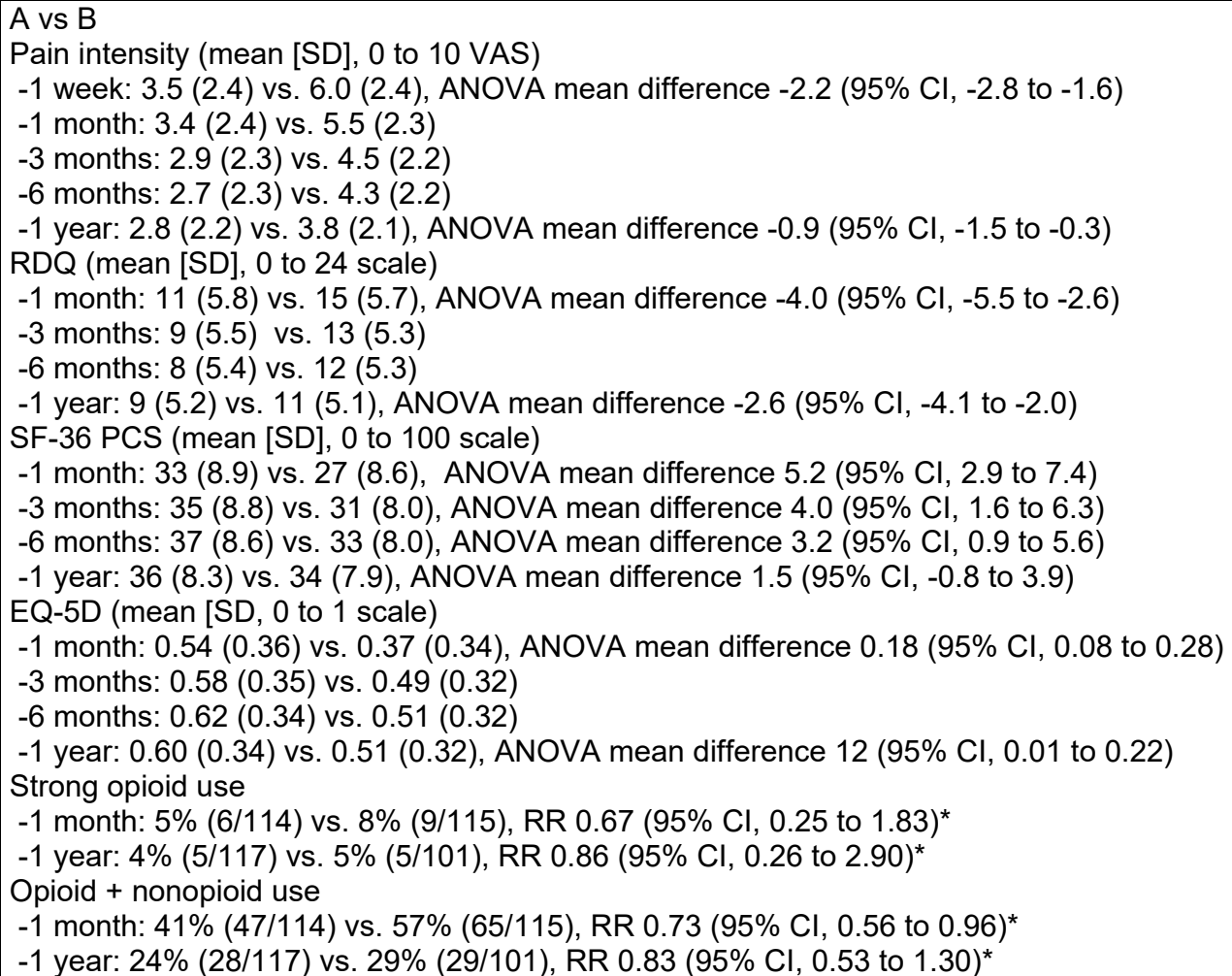 & $\begin{array}{l}\text { A vs B } \\
\text { Mortality: } 6.0 \% \text { (9/149) vs. } 4.6 \% \\
\text { (7/151) at } 12 \text { months, RR } 1.30 \text { ( } 95 \% \\
\mathrm{Cl}, 0.50 \text { to } 3.41) \\
\text { Serious adverse events (death, life- } \\
\text { threatening injury, or permanent } \\
\text { impairment; or required extended } \\
\text { hospital stay or intervention to prevent } \\
\text { impairment): } 38.9 \%(58 / 149) \text { vs. } \\
35.8 \%(54 / 151), \mathrm{RR} 1.09(95 \% \mathrm{Cl} \text {, } \\
0.81 \text { to } 1.46) \\
\text { Any adverse event: } 87.2 \%(130 / 149) \\
\text { vs. } 80.1 \%(122 / 151), \mathrm{RR} 1.08(95 \% \\
\mathrm{Cl}, 0.98 \text { to } 1.19) \\
\text { Withdrawal due to adverse events: } \\
0.7 \%(1 / 149) \text { vs. } 0.7 \%(1 / 151), \mathrm{RR} \\
1.01(95 \% \mathrm{Cl}, 0.06 \text { to } 16.05) \\
\text { New or worsening fracture: } 33.0 \% \\
\text { (38/115) vs. } 25.3 \% \text { (24/95) at } 1 \text { year; } \\
\text { ARD } 7.7 \%(95 \% \mathrm{Cl},-4.5 \% \text { to } 20.0 \%)\end{array}$ \\
\hline
\end{tabular}




\begin{tabular}{|c|c|c|c|}
\hline $\begin{array}{l}\text { Vertebral } \\
\text { Augmentation } \\
\text { Procedure }\end{array}$ & $\begin{array}{l}\text { Author, Year } \\
\text { Trial }\end{array}$ & Results & $\begin{array}{l}\text { Adverse Events and Withdrawals } \\
\text { Due to Adverse Events }\end{array}$ \\
\hline Kyphoplasty & $\begin{array}{l}\text { Boonen, } 2011 \\
\text { FREE Trial } \\
\text { Secondary } \\
\text { publication of } \\
\text { Wardlaw, } \\
2009\end{array}$ & $\begin{array}{l}\text { A vs. B } \\
\text { Pain (mean [SD], } 0 \text { to } 10 \text { VAS) } \\
-2 \text { years: } 2.8(2.8) \text { vs. } 3.7 \text { (2.8), ANOVA mean difference }-0.80(95 \% \mathrm{Cl},-1.39 \text { to }-0.20) \\
\text { RDQ (mean [SD], } 0 \text { to } 24 \text { scale) } \\
-2 \text { years: } 9(6.2) \text { vs. } 10 \text { (6.3), ANOVA mean difference }-1.43(95 \% \mathrm{Cl} \mathrm{NR}) ; \mathrm{p}=0.051 \\
\text { SF-36 PCS (mean [SD], } 0 \text { to } 100 \text { scale) } \\
-2 \text { years: } 36(12.5) \text { vs. } 34 \text { (12.5), ANOVA mean difference } 1.68(95 \% \mathrm{Cl},-0.63 \text { to } 3.99) \\
\text { EQ-5D (mean [SD], } 0 \text { to } 1 \text { scale) } \\
2 \text { years: } 0.61(0.37) \text { vs. } 0.53(0.38), \text { ANOVA mean difference } 0.12(95 \% \mathrm{Cl}, 0.06 \text { to } 0.18) \\
\text { Satisfaction (mean difference [95\% Cl] on } 0 \text { to } 20 \text { scale): } 2.31(1.19 \text { to } 3.43) \text { at } 24 \text { months } \\
\text { Opioid use } \\
-6 \text { months: } 29.8 \%(37 / 124) \text { vs. } 42.9 \%(48 / 112), \mathrm{RR} 0.69(95 \% \mathrm{Cl}, 0.49 \text { to } 0.98)^{*} \\
-1 \text { year: } 28.0 \%(33 / 118) \text { vs. } 33.7 \%(34 / 101), \mathrm{RR} 0.83(95 \% \mathrm{Cl}, 0.56 \text { to } 1.24)^{*} \\
-2 \text { years: } 8.8 \%(10 / 114) \text { vs. } 9.5 \%(10 / 105), \mathrm{RR} 0.92(95 \% \mathrm{Cl}, 0.40 \text { to } 2.12)^{*}\end{array}$ & 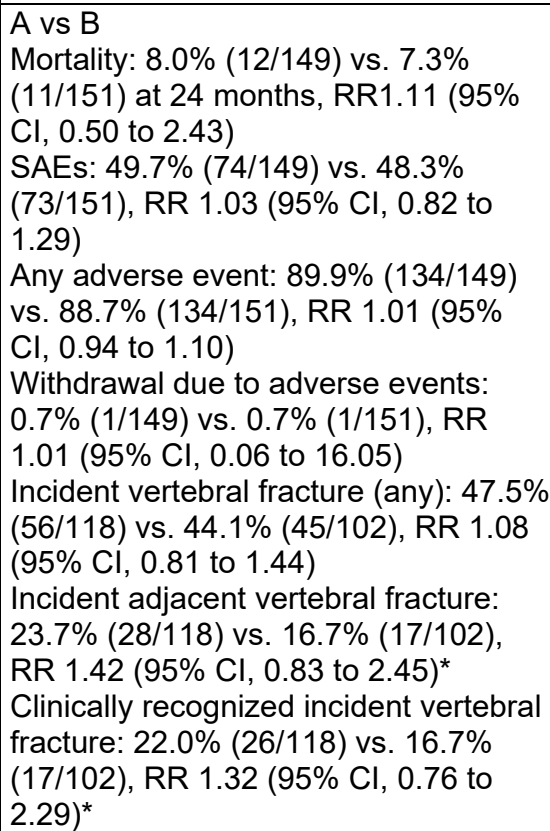 \\
\hline Kyphoplasty & $\begin{array}{l}\text { Van } \\
\text { Meirhaeghe, } \\
2013 \\
\text { FREE Trial } \\
\text { Secondary } \\
\text { publication of } \\
\text { Wardlaw, } \\
2009\end{array}$ & see Wardlaw 2009 and Boonen 2011 & $\begin{array}{l}\text { A vs B } \\
\text { Serious adverse events: } 16.1 \% \\
(24 / 149) \text { vs. } 11.2 \%(17 / 151) \text { at } 30 \\
\text { days, RR } 1.43(95 \% \mathrm{Cl}, 0.80 \text { to } 2.55) \\
\text { Any adverse event: } 63.1 \%(94 / 149) \text { vs. } \\
36.4 \%(55 / 151) \text { at } 30 \text { days, RR } 1.73 \\
(95 \% \mathrm{Cl}, 1.36 \text { to } 2.21) \\
\text { Infection: } 11.4 \%(17 / 149) \text { vs. } 5.3 \% \\
(8 / 151), \mathrm{RR} 2.15(95 \% \mathrm{Cl}, 0.96 \text { to } \\
4.84)\end{array}$ \\
\hline
\end{tabular}

Abbreviations: ANCOVA = analysis of covariance; ANOVA = analysis of variance; ARD = absolute risk difference; BMD = bone mineral density; CAFE = Cancer Patient Fracture

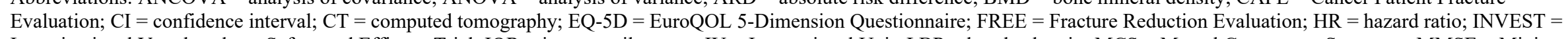
Investigational Vertebroplasty Safety and Efficacy Trial; IQR = interquartile range; IU = International Unit; LBP = low-back pain; MCS = Mental Component Summary; MMSE = MiniMental State Exam; MR = magnetic resonance; MRI = magnetic resonance imaging; MRI-STIR = magnetic resonance imaging short tau inversion recovery; NR = not reported; NRS = numeric rating scale; NS = not significant; ODI = Oswestry Disability Index; OR = odds ratio; PCS = Physical Component Summary; PMMA = polymethylmethacrylate; PVP =

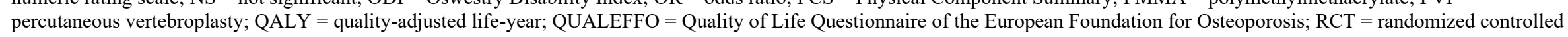

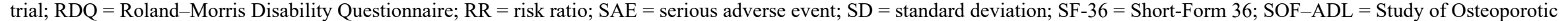

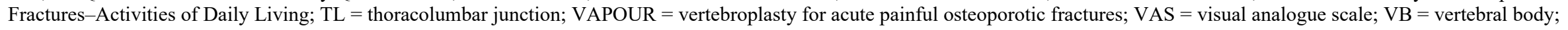

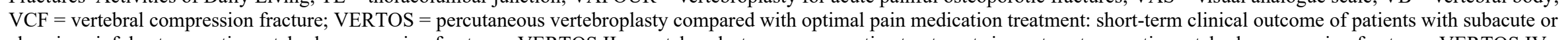

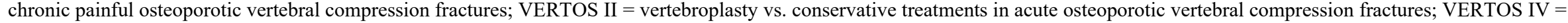

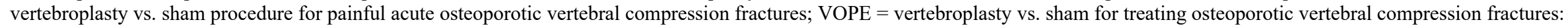
a double blind RCT 
See Appendix F, List of Included Studies, for full citations 
Table G-4. Trials of cooled and pulsed radiofrequency denervation - study characteristics

\begin{tabular}{|c|c|c|c|c|c|}
\hline $\begin{array}{c}\text { Type of } \\
\text { Denervation }\end{array}$ & $\begin{array}{l}\text { Author, } \\
\text { Year } \\
\text { Trial } \\
\end{array}$ & $\begin{array}{c}\text { Study } \\
\text { Design } \\
\text { Duration }\end{array}$ & \begin{tabular}{|c|} 
Number of \\
Centers/Provider \\
Type \\
Country \\
\end{tabular} & Eligibility Criteria & Interventions \\
\hline $\begin{array}{l}\text { Cooled } \\
\text { radiofrequency }\end{array}$ & $\begin{array}{l}\text { Cohen, } \\
2008\end{array}$ & $\begin{array}{l}\text { RCT } \\
3 \text { months } \\
\text { (prior to } \\
\text { crossover) }\end{array}$ & \begin{tabular}{|l|}
1 center, \\
anesthesia pain \\
medicine \\
U.S. \\
\\
\\
\\
\end{tabular} & $\begin{array}{l}\geq 18 \text { years with sacroiliac pain (axial low } \\
\text { back or buttock pain } \geq 6 \text { months, } \\
\text { tenderness overlying the sacroiliac } \\
\text { joint[s]), failure to respond to } \\
\text { conservative therapy (including }>2 \\
\text { months pain relief with sacroiliac joint } \\
\text { corticosteroid injection), pain relief } \\
\geq 75 \% \text { following single diagnostic } \\
\text { sacroiliac joint injection } \\
\text { Excluded: focal neurologic signs or } \\
\text { symptoms, radiologic evidence of a } \\
\text { symptomatic herniated disc, } \\
\text { spondyloarthropathy, untreated } \\
\text { coagulopathy, and unstable medical or } \\
\text { psychiatric illness }\end{array}$ & $\begin{array}{l}\text { A: Cooled radiofrequency denervation: For S1 to S3 lateral branches, } 17- \\
\text { gauge, } 75 \text {-mm cooled electrodes with } 4 \mathrm{~mm} \text { active tips (Baylis Medical, } \\
\text { Montreal, Quebec, Canada) placed between } 3 \text { and } 5 \mathrm{~mm} \text { from the lateral } \\
\text { border of the sacral foramina at predesignated positions. Placement } \\
\text { confirmed with electrostimulation (concordant sensation at } 0.5 \mathrm{~V} \text { or less). } \\
\text { Administered } 0.5 \mathrm{ml} 2 \% \text { lidocaine, followed by water-cooled } \\
\text { radiofrequency heating system (Pain Management Slnergy System; } \\
\text { Baylis Medical) and generator (PMG-115-TD, V2.0A; Baylis Medical) } \\
\text { applied for } 2 \text { minutes at } 60^{\circ} \mathrm{C} \text {, with target tissue heated to } 75^{\circ} \mathrm{C} \text { (resulting } \\
\text { lesion diameter } 8 \text { to } 10 \mathrm{~mm} \text { ). } \\
\text {-For L4 and } \mathrm{L} 5 \text { dorsal rami, conventional radiofrequency with } 22 \text {-gauge } \\
\text { SMK-C10 cannula with } 5 \text {-mm active tips inserted parallel to the course of } \\
\text { the nerve until bone contacted. Placement confirmed with } \\
\text { electrostimulation at } 50 \mathrm{~Hz} \text {, with concordant sensation achieved at } \leq 0.5 \mathrm{~V} \text {; } \\
\text { absence of leg contractions verified with stimulation at } 2 \mathrm{~Hz} \text { up to } \leq 2 \mathrm{~V} \text {. } \\
\text { Administered } 0.5 \mathrm{ml} 2 \% \text { lidocaine followed by } 90 \text { second, } 80^{\circ} \mathrm{C} \\
\text { radiofrequency lesion } \\
\text { B: Sham radiofrequency: Electrodes positioned similarly and } \\
\text { electrostimulation performed in identical manner. Administered } 0.52 \% \\
\text { lidocaine but no current administered (procedure time similar to active } \\
\text { treatment). Offered crossover to conventional (non-cooled) } \\
\text { radiofrequency denervation as described above. }\end{array}$ \\
\hline $\begin{array}{l}\text { Cooled } \\
\text { radiofrequency }\end{array}$ & $\begin{array}{l}\text { McCormick, } \\
2019\end{array}$ & $\begin{array}{l}\text { RCT } \\
6 \text { months }\end{array}$ & $\begin{array}{l}1 \text { center, } \\
\text { anesthesia pain } \\
\text { medicine } \\
\text { U.S. }\end{array}$ & $\begin{array}{l}\text { Low back pain } \geq 6 \text { months, NRS } \geq 4 \text { on } 0 \\
\text { to } 10 \text { scale, no response to } \\
\text { conventional therapy, pain diagram } \\
\text { suggesting possibility of facet-mediated } \\
\text { pain, referred pain not beyond the knee } \\
\text { (if present), positive response to one } \\
\text { set of diagnostic medial branch nerve } \\
\text { blocks defined as }>75 \% \text { reduction in } \\
\text { pain following diagnostic blocks with } \\
\text { local anesthetic ( } 0.5 \mathrm{~mL} \text { of } 0.5 \% \\
\text { bupivacaine or } 2 \% \text { lidocaine) } \\
\text { Excluded: focal neurologic signs or } \\
\text { symptoms, radiologic evidence of } \\
\text { symptomatic herniated disc or nerve } \\
\text { root impingement related to spinal } \\
\text { stenosis, previous radiofrequency } \\
\text { ablation for similar symptoms, active } \\
\text { systemic or local infection, } \\
\text { coagulopathy or other bleeding } \\
\text { disorder, current anticoagulants or } \\
\text { antiplatelet medications }\end{array}$ & $\begin{array}{l}\text { A: Cooled radiofrequency denervation: } 17-\text { gauge cooled radiofrequency } \\
\text { ablation introducer needle placed at medial branch nerve targets, } 18- \\
\text { gauge cooled radiofrequency ablation probe with a } 4 \mathrm{~mm} \text { active tip } \\
\text { (Coolief Cooled Radiofrequency Kit, Halyard Health, Alpharetta, Georgia) } \\
\text { with } 2 \mathrm{~mm} \text { gap between the electrode tip and the base of the superior } \\
\text { articular process. Motor testing }(2.0 \mathrm{~V}, 2 \mathrm{~Hz} \text { ) performed at each target } \\
\text { site. Administered } 1 \mathrm{ml} \text { of } 2 \% \text { lidocaine through the introducer needle, } \\
\text { followed by cooled radiofrequency ablation lesioning for } 165 \text { seconds at } \\
\text { each site, generator temperature set to } 60^{\circ} \mathrm{C} \text { (intralesional temperature } \\
\left.>80^{\circ} \mathrm{C}\right) \text {. Administered } 0.5 \mathrm{ml} 0.5 \% \text { bupivacaine following procedure } \\
\mathrm{B}: \text { Conventional radiofrequency denervation: } 20 \text {-gauge traditional } \\
\text { radiofrequency ablation probes with } 10 \mathrm{~mm} \text { active tips (Baylis Medical, } \\
\text { Montreal, Canada) placed at medial branch nerve targets using parallel } \\
\text { technique. Motor testing and local anesthetic as described for cooled } \\
\text { radiofrequency. Radiofrequency lesioning performed for } 90 \text { seconds at } \\
80^{\circ} \mathrm{C} \text { at each target site. }\end{array}$ \\
\hline
\end{tabular}




\begin{tabular}{|c|c|c|c|c|c|}
\hline $\begin{array}{c}\text { Type of } \\
\text { Denervation }\end{array}$ & $\begin{array}{l}\text { Author, } \\
\text { Year } \\
\text { Trial }\end{array}$ & $\begin{array}{l}\text { Study } \\
\text { Design } \\
\text { Duration }\end{array}$ & \begin{tabular}{|c|} 
Number of \\
Centers/Provider \\
Type \\
Country \\
\end{tabular} & Eligibility Criteria & Interventions \\
\hline $\begin{array}{l}\text { Cooled } \\
\text { radiofrequency }\end{array}$ & Patel, 2012 & $\begin{array}{l}\mathrm{RCT} \\
3 \text { months } \\
\text { (prior to } \\
\text { crossover) }\end{array}$ & $\begin{array}{l}1 \text { center, } \\
\text { anesthesia pain } \\
\text { medicine. } \\
\text { U.S. }\end{array}$ & $\begin{array}{l}>18 \text { years, predominantly axial pain } \\
\text { below the L5 vertebrae }>6 \text { months; } 3- \\
\text { day average NRS between } 4 \text { and } 8 \text { ( } 0 \\
\text { to } 10 \text { scale); failure to achieve } \\
\text { adequate improvement with } \\
\text { comprehensive non-operative } \\
\text { treatment, other sources of LBP } \\
\text { excluded; } \geq 75 \% \text { dual relief between } 4 \\
\text { hours and } 7 \text { days following S1-S3 } \\
\text { lateral branch and L5 dorsal ramus } \\
\text { diagnostic block } \\
\text { Excluded: history of potentially } \\
\text { confounding intervertebral disc disease } \\
\text { or facet joint pain; Beck Depression } \\
\text { Inventory score >20; irreversible } \\
\text { psychological barries to recovery; } \\
\text { spinal pathology that may impede } \\
\text { recovery such as spondylolisthesis at } \\
\text { L5/S1, or scoliosis; symptomatic } \\
\text { moderate or severe foraminal or central } \\
\text { canal stenosis; systemic infection or } \\
\text { localized infection at anticipated } \\
\text { introducer entry site; concomitant } \\
\text { cervical or thoracic pain; uncontrolled or } \\
\text { acute illness; chronic severe conditions; } \\
\text { active radicular pain; } \\
\text { immunosuppression; worker's } \\
\text { compensation, injury litigation, or } \\
\text { disability remuneration; >30 mg } \\
\text { morphine daily or equivalent use; active } \\
\text { smokers }\end{array}$ & $\begin{array}{l}\text { A: Cooled radiofrequency denervation: For L5 dorsal ramus, introducer } \\
\text { needle placed under fluoroscopy to junction of } S 1 \text { superior articular } \\
\text { process and sacral ala; stylet replaced with SInergy Probe (Kimberly } \\
\text { Clark Health Care). Accurate electrode placement confirmed and } 0.5 \mathrm{cc} \\
2 \% \text { lidocaine and } 0.75 \% \text { bupivacaine injected, then radiofrequency } \\
\text { energy delivered for } 150 \text { seconds at } 60^{\circ} \mathrm{C} \text {. For } \mathrm{S} 1 \text { to } \mathrm{S} 3 \text { lateral branch } \\
\text { sites, } 27 \text {-gauge needle placed under fluoroscopy } 7 \mathrm{~mm} \text { lateral to } \mathrm{S} 1 \\
\text { posterior sacral foramen for localization. Introducer advanced and } 17- \\
\text { gauge, } 75-\mathrm{mm} \text { cooled electrode with } 4 \mathrm{~mm} \text { active tip (Kimberly Clark } \\
\text { Health Care) inserted } 2 \mathrm{~mm} \text { from surface of the sacrum. Impedance } \\
\text { confirmed at } 100 \text { to } 500 \mathrm{~W} \text {. Radiofrequency lesioning performed as } \\
\text { described for } \mathrm{L} 5 \text { dorsal ramus. To form an arc-shaped treated area lateral } \\
\text { to the } \mathrm{S} 1 \text { posterior sacral foramen, } 2 \text { additional lesions were created at } \\
\text { that level. Similar technique used for } \mathrm{S} 2 \text { and } \mathrm{S} 3 \text { sites }(2 \text { lesions at } \mathrm{S} 3 \text { ). } \\
\text { Post-lesioning, } 1 \mathrm{cc} \text { of a } 1: 1 \text { mixture of } 2 \% \text { lidocaine and } 0.75 \% \\
\text { bupivacaine administered. } \\
\text { B: Sham radiofrequency: Needle placement as described for } \mathrm{A} \text {, but no } \\
\text { cooled radiofrequency lesioning performed }\end{array}$ \\
\hline
\end{tabular}




\begin{tabular}{|c|c|c|c|c|c|}
\hline $\begin{array}{c}\text { Type of } \\
\text { Denervation }\end{array}$ & $\begin{array}{l}\text { Author, } \\
\text { Year } \\
\text { Trial }\end{array}$ & $\begin{array}{l}\text { Study } \\
\text { Design } \\
\text { Duration }\end{array}$ & $\begin{array}{c}\text { Number of } \\
\text { Centers/Provider } \\
\text { Type } \\
\text { Country }\end{array}$ & Eligibility Criteria & Interventions \\
\hline $\begin{array}{l}\text { Pulsed } \\
\text { radiofrequency }\end{array}$ & Kroll, 2008 & $\begin{array}{l}\mathrm{RCT} \\
3 \text { months }\end{array}$ & $\begin{array}{l}1 \text { center, } \\
\text { anesthesia pain } \\
\text { medicine } \\
\text { U.S. }\end{array}$ & \begin{tabular}{|l|}
$\geq 18$ years, unilateral or bilateral lumbar \\
back pain $>1$ month, ASA physical \\
status I to III with no radiating \\
symptoms below the knee, \\
radiographically ruled out disc \\
herniation and spinal stenosis, \\
symptoms reproduced by extension- \\
rotation of the lumbar spine and \\
palpation of the paraspinal region, \\
$>50 \%$ pain reduction based on subjects' \\
mean VAS pain assessment for $\geq 3$ \\
hours after two separate diagnostic \\
medial branch blocks \\
Excluded: history of previous back \\
surgery, neurological deficits, \\
claudication, active psychiatric disorder, \\
bleeding disorder, active infection, \\
involved in current litigation
\end{tabular} & $\begin{array}{l}\text { A: Pulsed radiofrequency denervation: Radiofrequency cannula was } \\
\text { either } 21 \text {-gauge, } 100-\mathrm{mm} \text { (Model PMC21-100-5; Baylis Medical Co., } \\
\text { Montreal, QC, Canada) or } 20 \text {-gauge, } 145-\mathrm{mm} \text { length (Model PMC20-145- } \\
5 \text {, Baylis Medical Co) with } 5 \mathrm{~mm} \text { active tip. Under fluoroscopy, positioned } \\
\text { cannula for the L1 to L4 medial branches at the superior, medial edges of } \\
\text { the posterior surfaces of the transverse processes at the junction with the } \\
\text { articular pillars and for the L5 medial branch at the junction of the medial } \\
\text { end of the ala of the sacrum with the articular pillar. Baylis Pain } \\
\text { Management Generator (Model PMG-115) with } 100-\mathrm{mm} \text { (Model PMP21- } \\
\text { 100) or } 145-\mathrm{mm} \text { (Model PMP-20-145) radiofrequency probe used. Placed } \\
\text { radiofrequency probes through the cannulae and confirmed placement by } \\
\text { provocative sensory testing at a frequency of } 50 \mathrm{~Hz} \text { at }<1 \text { volt and } \\
\text { absence of motor stimulation in the lower extremity at a frequency of } 2 \mathrm{~Hz} \\
\text { and up to } 2.5 \text { volts. Pulsed radiofrequency lesioning was delivered at } 42^{\circ} \\
\mathrm{C} \text { with a pulse duration of } 20 \text { ms and pulse rate of two Hz for } 120 \\
\text { seconds. } \\
\text { B: Continuous radiofrequency denervation: As above, with radiofrequency } \\
\text { lesioning was at } 80^{\circ} \mathrm{C} \text { for } 75 \text { seconds. }\end{array}$ \\
\hline
\end{tabular}




\begin{tabular}{|c|c|c|c|c|c|}
\hline $\begin{array}{c}\text { Type of } \\
\text { Denervation }\end{array}$ & $\begin{array}{l}\text { Author, } \\
\text { Year } \\
\text { Trial }\end{array}$ & $\begin{array}{l}\text { Study } \\
\text { Design } \\
\text { Duration }\end{array}$ & \begin{tabular}{|c|} 
Number of \\
Centers/Provider \\
Type \\
Country \\
\end{tabular} & Eligibility Criteria & Interventions \\
\hline $\begin{array}{l}\text { Pulsed } \\
\text { radiofrequency }\end{array}$ & $\begin{array}{l}\text { Moussa, } \\
2020\end{array}$ & \begin{tabular}{|l|}
$\mathrm{RCT}$ \\
3 years
\end{tabular} & \begin{tabular}{|l|}
1 center, \\
neurosurgery \\
Egypt
\end{tabular} & $\begin{array}{l}\geq 18 \text { years with continuous chronic LBP } \\
\text { with or without pain radiating into the } \\
\text { upper leg for } \geq 1 \text { year with } \\
\text { unsatisfactory improvement in response } \\
\text { to } \geq 3 \text { months of conservative treatment, } \\
\text { clinical manifestations suggesting facet } \\
\text { joint pain (e.g., paraspinal tenderness } \\
\text { and increasing pain on spinal } \\
\text { extension), pain VAS } \geq 7 \text { ( } 0 \text { to } 10 \text { scale) } \\
\text { on } 2 \text { different occasions separated by } \\
\text { at least } 2 \text { weeks, complete or near } \\
\text { complete reduction of VAS score } 30 \\
\text { minutes after fluoroscopically-guided } \\
0.5 \% \text { bupivacaine diagnostic block of } \\
\text { medial dorsal branch of segmental L3, } \\
\text { L4, and L5 nerve roots } \\
\text { Excluded: surgical causes of low back } \\
\text { pain (e.g., spondylolisthesis and } \\
\text { fracture spine, prior lumbar surgery, } \\
\text { major comorbidities (e.g., uncontrolled } \\
\text { diabetes mellitus, uncontrolled } \\
\text { hypertension, cardiac diseases, } \\
\text { malignancy and bleeding diathesis), } \\
\text { prior radiofrequency treatment for LBP, } \\
\text { presence of radicular syndromes, } \\
\text { infection at the injection site, } \\
\text { pregnancy, possible work } \\
\text { compensation litigation, score } \geq 50 \text { on } \\
\text { the Zung Self Rating Depression Scale }\end{array}$ & $\begin{array}{l}\text { A: Pulsed radiofrequency denervation of dorsal root ganglia: } \\
\text { Thermocouple electrode (CSK, } 20 \mathrm{~cm} \text { length with } 10 \mathrm{~mm} \text { active tip) } \\
\text { placed perpendicular to the dorsal root ganglion under fluoroscopy. Motor } \\
\text { and sensory stimulation at } 2 \text { and } 50 \mathrm{~Hz} \text { to confirmed electrode tip } \\
\text { proximity to dorsal root ganglia with presence of ipsilateral lower limb } \\
\text { muscle contractions and paraesthesia at }<0.5 \mathrm{~V} \text {. Pulsed radiofrequency } \\
\text { (NeuroTherm NT1100, St. Jude Medical, Inc., Saint Paul, MN, United } \\
\text { States) of the dorsal root ganglia L4, L5, and S1 administered with } 42 \\
\text { minute cycles using } 2 \mathrm{~Hz} \text { stimulation at } 45 \mathrm{~V} \text { unilaterally or bilaterally, with } \\
\text { the cannulae tip temperature not exceeding } 42^{\circ} \mathrm{C} \text {. } \\
\text { B: Continuous radiofrequency denervation of medial branch: As for pulsed } \\
\text { radiofrequency, except electrode was placed parallel to the medial dorsal } \\
\text { branch (junction of the superior articular process and the transverse } \\
\text { process where the medial dorsal branch is, without the electrode tip } \\
\text { projecting past the ventral border of the facet column); absence of } \\
\text { ipsilateral lower limb muscle contractions and paresthesia on stimulation; } \\
\text { and continuous radiofrequency performed at L3 to } 4 \text {, L4 to } 5 \text { and L5-S1 } \\
\text { levels at } 85^{\circ} \mathrm{C} \text { for } 90 \text { seconds with } 3 \text { lesions at each level (2 mm intervals } \\
\text { between lesions) } \\
\text { C: Sham radiofrequency denervation: As above, except radiofrequency } \\
\text { generator switched on but did not delivering current to the thermocouple } \\
\text { electrode. } \\
\text { All patients received } 1 \mathrm{ml} \text { of a mixture of equal volume of bupivacaine } 0.5 \\
\% \text { and methylprednisolone acetate } 40 \mathrm{mg} / \mathrm{mL} \text { at the conclusion of the } \\
\text { procedure through the electrode needle. }\end{array}$ \\
\hline
\end{tabular}




\begin{tabular}{|c|c|c|c|c|c|}
\hline $\begin{array}{c}\text { Type of } \\
\text { Denervation }\end{array}$ & $\begin{array}{l}\text { Author, } \\
\text { Year } \\
\text { Trial }\end{array}$ & $\begin{array}{c}\text { Study } \\
\text { Design } \\
\text { Duration }\end{array}$ & $\begin{array}{c}\text { Number of } \\
\text { Centers/Provider } \\
\text { Type } \\
\text { Country }\end{array}$ & Eligibility Criteria & Interventions \\
\hline $\begin{array}{l}\text { Pulsed } \\
\text { radiofrequency }\end{array}$ & Tekin, 2007 & $\begin{array}{l}\mathrm{RCT} \\
1 \text { years }\end{array}$ & $\begin{array}{l}1 \text { center, } \\
\text { anesthesia pain } \\
\text { medicine } \\
\text { Turkey }\end{array}$ & $\begin{array}{l}>17 \text { years with }>6 \text { months of continuous } \\
\text { LBP with or without radiation into the } \\
\text { upper leg, focal tenderness over the } \\
\text { facet joints, pain on hyperextension, no } \\
\text { finding of obvious neurologic defect, no } \\
\text { indication for low back surgery, no } \\
\text { radicular syndrome, unresponsiveness } \\
\text { to traditional conservative treatments, } \\
\text { positive ( }>50 \% \text { improvement in pain, } \\
\text { duration consistent with expected } \\
\text { duration of local anesthetic used) } \\
\text { response to single diagnostic medial } \\
\text { branch block using } 0.3 \text { ml } 2 \% \text { lidocaine } \\
\text { Excluded: prior radiofrequency } \\
\text { treatment, coagulation disturbances, } \\
\text { allergies to radiopaque contrast media } \\
\text { or local anesthetics, } \\
\text { malignancy }\end{array}$ & $\begin{array}{l}\text { A. Pulsed radiofrequency denervation: } 22 \text {-gauge } 10 \mathrm{~cm} \text { SMK-C10 } \\
\text { electrode, } 2 \text {-mm active tip placed at angle between the superior articular } \\
\text { process and transverse process for the segmental medial branches of } \\
\text { lumbar nerve roots. Impedance verified at } 300 \text { to } 700 \text { Ohms and sensory } \\
\text { stimulation }(50 \mathrm{~Hz} \text { ) reproduced pain at }<0.5 \mathrm{~V} \text { and did not result in leg } \\
\text { contractions at } 1 \mathrm{~V} \text {; contractions of the multifidus muscle observed } \\
\text { between } 0.3 \text { and } 0.5 \mathrm{~V} \mathrm{~L} 1 \text { to } \mathrm{L} 3 \text { or } \mathrm{L} 3 \text { to } \mathrm{L} 5 \text { treated; } 0.5 \mathrm{ml} 2 \% \text { prilocaine } \\
\text { followed with } 2 \mathrm{~Hz} \text { pulsed radiofrequency waves for } 4 \text { minutes ( } 45 \mathrm{~V}) \text { to a } \\
\text { temperature of } 42 \text { degrees } \mathrm{C} \text {. } \\
\mathrm{B} \text {. Continuous radiofrequency denervation: As above, except used an } \\
\text { electrode with } 10 \text {-mm active tip and treated continuously for } 90 \text { seconds } \\
\text { to } 80 \text { degrees } \mathrm{C} \\
\text { C. Sham radiofrequency denervation: Electrodes and thermocouple } \\
\text { probes positioned similarly without switching on radiofrequency current, } \\
\text { only } 0.3 \text { ml } 0.5 \% \text { bupivacaine injected }\end{array}$ \\
\hline
\end{tabular}

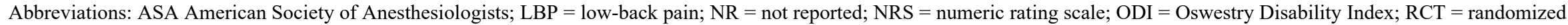
controlled trial; VAS = visual analogue scale; WHO World Health Organization

See Appendix F, List of Included Studies, for full citations 
Table G-5. Trials of cooled and pulsed radiofrequency denervation - additional study characteristics

\begin{tabular}{|c|c|c|c|c|c|}
\hline $\begin{array}{c}\text { Type of } \\
\text { Denervation }\end{array}$ & $\begin{array}{l}\text { Author, Year } \\
\text { Trial }\end{array}$ & Sample Characteristics & $\begin{array}{l}\text { Screened } \\
\text { Eligible } \\
\text { Randomized } \\
\text { Analyzed } \\
\end{array}$ & Sponsor & Quality \\
\hline $\begin{array}{l}\text { Cooled } \\
\text { radiofrequency }\end{array}$ & Cohen, 2008 & $\begin{array}{l}\text { Mean (SD) age, years: } 51.85(13.35) \\
\text { Female: } 61 \% \\
\text { Race: NR } \\
\text { Mean duration of back pain: NR } \\
\text { Failed back surgery syndrome: } 21 \% \\
\text { Opioid use: } 46 \% \\
\text { Mean (SD) opioid dosage, morphine equivalents per } \\
\text { day: } 52.68 \text { (46.41) } \\
\text { A vs. B } \\
\text { Baseline pain intensity (mean [SD], } 0 \text { to } 10 \text { NRS): } 6.1 \\
\text { (1.8) vs. } 6.5 \text { (1.9) } \\
\text { Baseline ODI (mean [SD], } 0 \text { to } 100 \text { scale): } 37.1 \text { (10.6) } \\
\text { vs. } 47.9(9.3)\end{array}$ & $\begin{array}{l}\text { Screened: } 90 \\
\text { Eligible: NR } \\
\text { Lost to followup: } 0 \\
\text { Randomized: } 28 \text { ( } 14 \text { vs. } 14) \\
\text { Lost to followup: None reported } \\
\text { Analyzed: } 28 \text { ( } 14 \text { vs. } 14) \\
\text { Crossover: } 9(0 \text { vs. } 9 \text { ) at } 1 \text { month and } \\
11 \text { (0 vs. } 11) \text { at } 3 \text { months }\end{array}$ & $\begin{array}{l}\text { John P. Murtha } \\
\text { Neuroscience and } \\
\text { Pain Institute, Army } \\
\text { Regional } \\
\text { Anesthesia and } \\
\text { Pain Medicine } \\
\text { Initiative, National } \\
\text { Institutes of Health }\end{array}$ & Fair \\
\hline $\begin{array}{l}\text { Cooled } \\
\text { radiofrequency }\end{array}$ & $\begin{array}{l}\text { McCormick, } \\
2019\end{array}$ & $\begin{array}{l}\text { Mean (SD) age, years: } 55.82 \text { (13.61) } \\
\text { Female: } 59 \% \\
\text { Race: NR } \\
\text { Mean (SD) duration of pain, months: } 86.15(90.39) \\
\% \text { (SD) relief from diagnostic block: } 85.38 \%(15.44) \\
\text { Mean (SD) morphine equivalents: } 11.02(21.46) \\
\text { A vs. B } \\
\text { Baseline pain intensity (mean [SD], } 0 \text { to } 10 \text { NRS): } 7.4 \\
\text { vs. } 6.9(1.5) \\
\text { Baseline ODI (mean [SD, } 0 \text { to } 100 \text { scale): } 29.1 \text { (7.0) vs. } \\
26.7(8.7)\end{array}$ & $\begin{array}{l}\text { Screened: } 48 \\
\text { Eligible and enrolled: } 48 \\
\text { Randomized: } 43 \text { (22 vs. } 21) \\
\text { Completed followup: } 40 \text { (21 vs. } 19) \\
\text { Analyzed: } 39 \text { (21 vs. } 19)\end{array}$ & $\begin{array}{l}\text { Midwest Pain } \\
\text { Society }\end{array}$ & Good \\
\hline $\begin{array}{l}\text { Cooled } \\
\text { radiofrequency }\end{array}$ & Patel, 2012 & $\begin{array}{l}\text { Mean (SD) age, years: } 58.7 \text { (14.7) } \\
\text { Female: } 72 \% \\
\text { Race: NR } \\
\text { Duration of pain } 6 \text { to } 12 \text { months: } 13.7 \% \\
\text { Duration of pain } 12 \text { to } 24 \text { months: } 15.7 \% \\
\text { Duration of pain > } 24 \text { months: } 68.6 \% \\
\text { Prior treatment with opioids: } 45.1 \% \\
\text { Prior treatment with antiinflammatory drugs: } 66.7 \% \\
\text { Prior treatment with injections: } 41.2 \% \\
\text { A vs. B } \\
\text { Baseline pain intensity (mean [SD], } 0 \text { to } 10 \text { NRS): } 6.1 \\
\text { (1.3) vs. } 5.8 \text { (1.3) } \\
\text { Baseline SF-36 physical functioning (mean [SD], } 0 \text { to } \\
100 \text { scale): } 50 \text { (20) vs. } 47(24) \\
\text { Baseline ODI (mean [SD], } 0 \text { to } 100 \text { scale): } 37 \text { (14) vs. } \\
35 \text { (10) } \\
\text { Baseline Assessment of Quality of Life (AQoL) score } \\
\text { (mean [SD], } 0 \text { to } 1 \text { scale): } 0.60 \text { (0.19) vs. } 0.54 \text { (0.16) }\end{array}$ & $\begin{array}{l}\text { Screened: } 304 \\
\text { Eligible: } 151 \\
\text { Randomized: } 51 \text { ( } 34 \text { vs. } 17) \\
\text { Completed followup: } 51 \text { ( } 34 \text { vs. 17) at } \\
3 \text { months, } 44 \text { ( } 27 \text { vs. } 17) \text { at } 6 \text { months } \\
\text { Analyzed: } 51 \text { ( } 34 \text { vs. } 17) \text { at } 3 \text { months } \\
\text { Crossover: } 16 \text { (0 vs. } 16)\end{array}$ & Baylis Medical & Fair \\
\hline
\end{tabular}




\begin{tabular}{|c|c|c|c|c|c|}
\hline $\begin{array}{c}\text { Type of } \\
\text { Denervation }\end{array}$ & $\begin{array}{l}\text { Author, Year } \\
\text { Trial }\end{array}$ & Sample Characteristics & $\begin{array}{l}\text { Screened } \\
\text { Eligible } \\
\text { Randomized } \\
\text { Analyzed } \\
\end{array}$ & Sponsor & Quality \\
\hline $\begin{array}{l}\text { Pulsed } \\
\text { radiofrequency }\end{array}$ & Kroll, 2008 & $\begin{array}{l}\text { Mean (SD) age, years: } 58.25(10.13) \\
\text { Female: } 54 \% \\
\text { Race: NR } \\
\text { Pain duration: NR } \\
\text { A vs. B } \\
\text { Baseline pain intensity (mean [SD], } 0 \text { to } 100 \text { VAS } \\
\text { transformed to } 0 \text { to } 10 \text { scale): } 6.4(1.8) \text { vs. } 7.6(1.6) \\
\text { ODI (mean [SD], } 0 \text { to } 100 \text { scale): } 44.9(10.4) \text { vs. } 52.0 \\
(17.3)\end{array}$ & $\begin{array}{l}\text { Screened: NR } \\
\text { Eligible: NR } \\
\text { Randomized: } 50 \text { (25 vs. } 25) \\
\text { Completed followup: } 26 \text { (13 vs. 13) } \\
\text { Analyzed: } 26 \text { (13 vs. } 13 \text { ) }\end{array}$ & $\begin{array}{l}\text { Anesthesia } \\
\text { Research Fund, } \\
\text { Henry Ford Hospital }\end{array}$ & Poor \\
\hline $\begin{array}{l}\text { Pulsed } \\
\text { radiofrequency }\end{array}$ & Moussa, 2020 & $\begin{array}{l}\text { Mean, (SD) age, years: } 56.97(\mathrm{NR}) \\
\text { Female: } 65.3 \% \\
\text { Race: NR } \\
\text { Duration of low back pain: NR } \\
\text { Baseline pain medication use: NR } \\
\text { Baseline pain intensity: NR } \\
\text { Baseline ODI: NR }\end{array}$ & $\begin{array}{l}\text { Screened: NR } \\
\text { Eligible: } 241 \\
\text { Randomized: } 150 \text { ( } 50 \text { vs. } 50 \text { vs. } 50 \text { ) } \\
\text { Completed followup: } 0 \text { at } 6 \text { months; } 8 \\
\text { at } 12 \text { months; } 27 \text { at } 3 \text { years (not } \\
\text { reported by group) } \\
\text { Analyzed: } 150 \text { (50 vs. } 50 \text { vs. } 50 \text { ) }\end{array}$ & No funding & Poor \\
\hline $\begin{array}{l}\text { Pulsed } \\
\text { radiofrequency }\end{array}$ & Tekin, 2007 & $\begin{array}{l}\text { Mean (SD) age, years: } 59.33(8.33) \\
\text { Female: } 57 \% \\
\text { Race: NR } \\
\text { Mean (SD) duration of pain, months: } 35.13 \text { (11.88) } \\
\text { A vs. B vs. C } \\
\text { Baseline pain intensity (mean [SD, } 0 \text { to } 10 \text { VAS): } 6.6 \\
\text { (1.6) vs. } 6.5(1.5) \text { vs. } 6.8(1.6) \\
\text { Baseline ODI (mean [SD, } 0 \text { to } 100 \text { scale): } 39.4(5.0) \text { vs. } \\
39.2(3.5) \text { vs. } 40.1(2.8)\end{array}$ & $\begin{array}{l}\text { Screened: NR } \\
\text { Eligible: } 60 \\
\text { Randomized: } 60 \text { (20 vs. } 20 \text { vs. } 20) \\
\text { Completed followup: NR } \\
\text { Analyzed: } 60\end{array}$ & NR & Fair \\
\hline
\end{tabular}
analogue scale; WHO World Health Organization

See Appendix F, List of Included Studies, for full citations 


\begin{tabular}{|c|c|c|c|}
\hline $\begin{array}{l}\text { Type of } \\
\text { Denervation }\end{array}$ & $\begin{array}{l}\text { Author, Year } \\
\text { Trial }\end{array}$ & Results & $\begin{array}{l}\text { Adverse Events and Withdrawals } \\
\text { Due to Adverse Events }\end{array}$ \\
\hline $\begin{array}{l}\text { Cooled } \\
\text { radiofrequency }\end{array}$ & Cohen, 2008 & 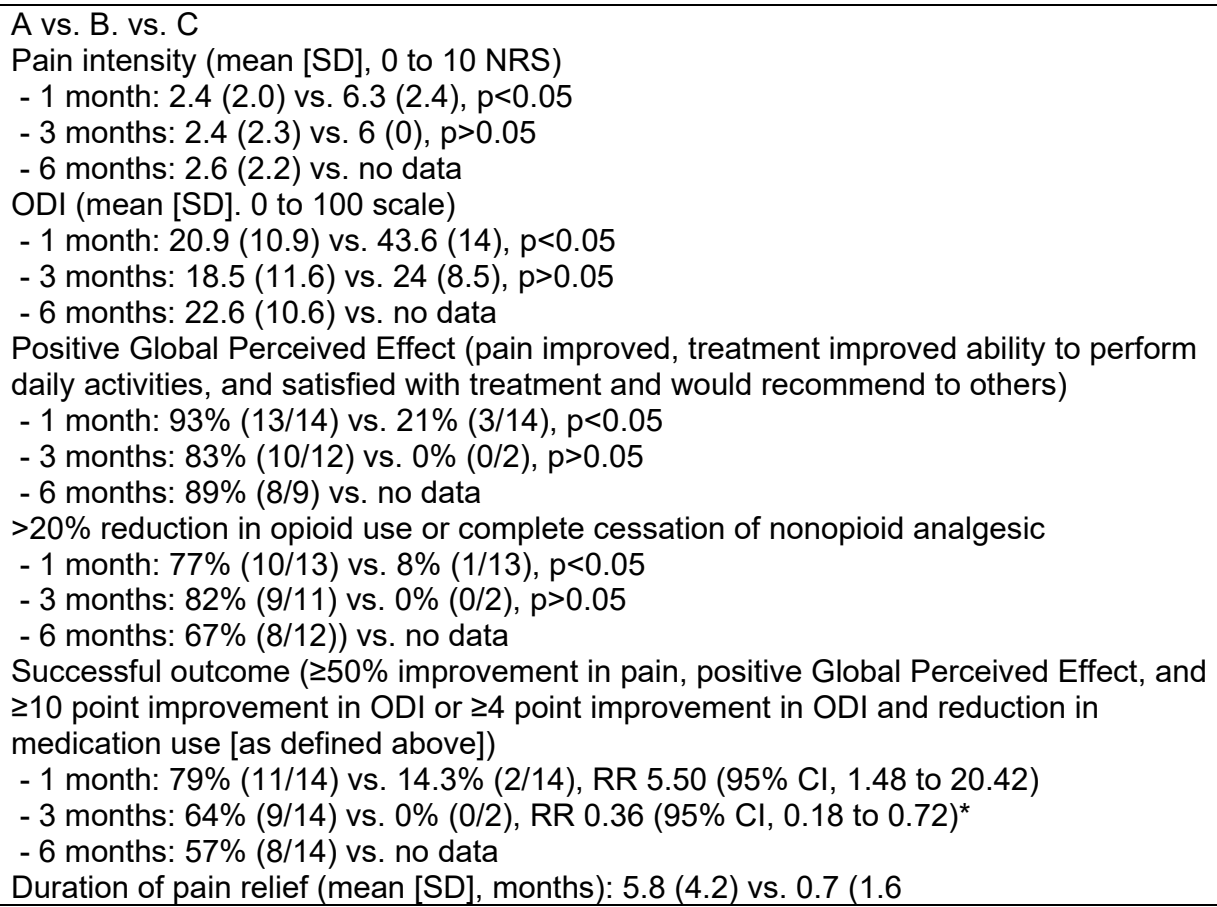 & $\begin{array}{l}\text { Serious complications: None reported } \\
\text { Temporary worsening pain typically } \\
\text { lasting between } 5 \text { and } 10 \text { days after } \\
\text { the procedure reported; } 1 \text { patient } \\
\text { reported transient nonpainful buttock } \\
\text { paresthesias that resolved without } \\
\text { therapy in the radiofrequency } \\
\text { treatment group }\end{array}$ \\
\hline $\begin{array}{l}\text { Cooled } \\
\text { radiofrequency }\end{array}$ & $\begin{array}{l}\text { McCormick, } \\
2019\end{array}$ & $\begin{array}{l}\text { A vs. B } \\
\text { Pain intensity (mean change from baseline [SD], } 0 \text { to } 10 \mathrm{NRS}) \\
-6 \text { months: }-3.8(2.5) \text { vs. }-3.0(3.2), p=0.41 \text { (no differences at } 1 \text { or } 3 \text { months) } \\
\text { NRS improved } \geq 50 \% \\
-6 \text { months: } 52.3 \%(11 / 21) \text { vs. } 44.4 \%(8 / 18) \text {, RR } 1.18(95 \% \mathrm{Cl}, 0.61 \text { to } 2.28) \\
\text { ODI (mean change from baseline [SD], } 0 \text { to } 100 \text { scale) } \\
-6 \text { months: }-11.3(11.2) \text { vs. }-8.1(12.3), p=0.40 \text { (no difference at } 1 \text { or } 3 \text { months) } \\
\text { ODI improved } \geq 30 \% \\
-6 \text { months: } 61.9 \%(13 / 21) \text { vs. } 44.4 \%(8 / 18), \text { RR } 1.39(95 \% \mathrm{Cl}, 0.75 \text { to } 2.58) \\
\text { Global Impression of Change (median [IQR], } 1 \text { to } 7 \text { scale) } \\
-6 \text { months: } 2(3) \text { vs. } 2(3), p=0.51\end{array}$ & $\begin{array}{l}\text { Serious adverse events: None } \\
\text { reported } \\
\text { Self-limited post-procedure pain } \\
\text { reported in } 2 \text { patients }\end{array}$ \\
\hline
\end{tabular}




\begin{tabular}{|c|c|c|c|}
\hline $\begin{array}{l}\text { Type of } \\
\text { Denervation }\end{array}$ & $\begin{array}{l}\text { Author, Year } \\
\text { Trial }\end{array}$ & Results & $\begin{array}{l}\text { Adverse Events and Withdrawals } \\
\text { Due to Adverse Events }\end{array}$ \\
\hline $\begin{array}{l}\text { Cooled } \\
\text { radiofrequency }\end{array}$ & Patel, 2012 & $\begin{array}{l}\text { A vs. B } \\
\text { Pain intensity (mean change from baseline [SD], } 0 \text { to } 10 \mathrm{NRS}) \\
-1 \text { month: }-2.7(2.6) \text { vs. }-1.7(2.0), p=0.16 \\
-3 \text { months: }-2.4(2.7) \text { vs. }-0.8(2.4), p=0.04 \\
\text { SF-36 physical functioning (mean change from baseline [SD], } 0 \text { to } 100 \text { scale) } \\
-1 \text { month: } 10 \text { (17) vs. } 5(12), p=0.24 \\
-3 \text { months: } 14(19) \text { vs. } 3(12), p=0.04 \\
\text { ODI (mean change from baseline [SD], } 0 \text { to } 100 \text { scale) } \\
-1 \text { month: }-12(14) \text { vs. }-4(11), p=0.046 \\
-3 \text { months: }-11(17) \text { vs. } 2(6), p=0.01 \\
\text { AQoL (mean [SD], } 0 \text { to } 1 \text { scale) } \\
-3 \text { months: } 0.69(0.21) \text { vs. } 0.56(0.21), p=0.048 \\
\text { Pain intensity improved } \geq 50 \%: 53 \%(18 / 34) \text { vs. } 29 \%(5 / 17) \text { at } 3 \text { months, RR } 1.80(95 \% \\
\text { Cl, } 0.80 \text { to } 4.01) \\
\text { Treatment success (pain intensity improved } \geq 50 \% \text { and either } 10 \text { point increase in SF-36 } \\
\text { bodily pain or } 10 \text { point decrease in ODI): } 47 \%(16 / 34) \text { vs. } 12 \%(2 / 17) \text { at } 3 \text { months, RR } \\
4.00 \text { ( } 95 \% \text { Cl, } 1.04 \text { to } 15.43) \\
\text { Global Perceived Effect pain "decreased a lot" or "completely gone") } \\
-3 \text { months: } 47 \%(6 / 34) \text { vs. } 8 \% \text { ( }(\mathrm{N} \text { unclear) at } 3 \text { months, } p<0.05 \\
\text { ODI improved } \geq 10 \text { points: } 41.2 \% \text { (14/34) vs. } 5.9 \%(1 / 17) \text { at } 3 \text { months, RR } 7.00(95 \% \mathrm{Cl} \text {, } \\
1.00 \text { to } 48.88)\end{array}$ & NR \\
\hline $\begin{array}{l}\text { Pulsed } \\
\text { radiofrequency }\end{array}$ & Kroll, 2008 & $\begin{array}{l}\text { A vs. B } \\
\text { Pain intensity (mean [SD], } 0 \text { to } 100 \text { VAS transformed to } 0 \text { to } 10 \text { scale) } \\
-3 \text { months: } 5.1(2.1) \text { vs. } 5.2(2.7) \text {; mean improvement (SD) }-1.1 \%(4.5) \text { vs. }-2.5 \%(5.0), p \\
=0.46 \\
\text { ODI (mean [SD], } 0 \text { to } 100 \text { scale): } \\
-3 \text { months: } 42.2(19.0) \text { vs. } 41.7(16.9) \text {; mean improvement (SD) }-4.1 \%(44.3) \text { vs. }-18.3 \% \\
\text { (30.7), } p=0.35\end{array}$ & $\begin{array}{l}\text { No adverse events during procedure } \\
\text { and no complications at } 3 \text { months }\end{array}$ \\
\hline
\end{tabular}




\begin{tabular}{|c|c|c|c|}
\hline $\begin{array}{l}\text { Type of } \\
\text { Denervation }\end{array}$ & $\begin{array}{l}\text { Author, Year } \\
\text { Trial }\end{array}$ & Results & $\begin{array}{l}\text { Adverse Events and Withdrawals } \\
\text { Due to Adverse Events }\end{array}$ \\
\hline $\begin{array}{l}\text { Cooled } \\
\text { radiofrequency }\end{array}$ & Moussa, 2020 & 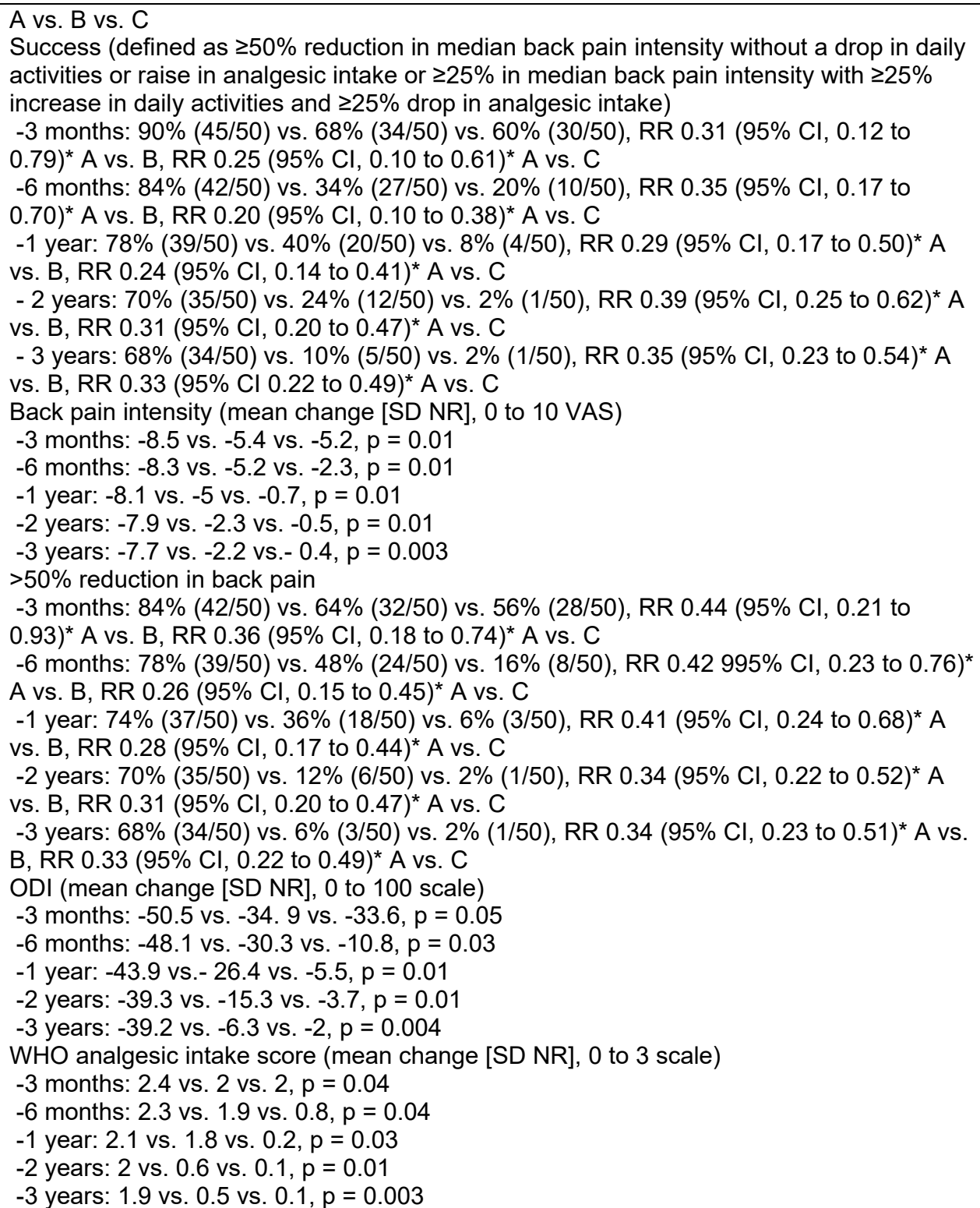 & NR \\
\hline
\end{tabular}




\begin{tabular}{|c|c|c|c|}
\hline $\begin{array}{l}\text { Type of } \\
\text { Denervation }\end{array}$ & $\begin{array}{l}\text { Author, Year } \\
\text { Trial }\end{array}$ & Results & $\begin{array}{l}\text { Adverse Events and Withdrawals } \\
\text { Due to Adverse Events }\end{array}$ \\
\hline $\begin{array}{l}\text { Cooled } \\
\text { radiofrequency }\end{array}$ & Tekin, 2007 & $\begin{array}{l}\text { A vs. B vs. C } \\
\text { Pain (mean [SD], } 0 \text { to } 10 \text { VAS) } \\
-6 \text { months: } 2.9(1.6) \text { vs. } 2.3(1.3) \text { vs. } 3.1(0.8), p=0.19 \text { for } A \text { vs. } B \text { and } p=0.62 \text { for A vs. } \\
\text { C } \\
-1 \text { year: } 3.5(1.3) \text { vs. } 2.4(1.1) \text { vs. } 3.9(1.2), p=0.004 \text { for } A \text { vs. B and } p=0.31 \text { for } A \text { vs. } C \\
\text { ODI (mean [SD], } 0 \text { to } 100 \text { scale) } \\
-6 \text { months: } 25.3(6.9) \text { vs. } 25.1(6.4) \text { vs. } 28.9(5.7), p=0.92 \text { for } A \text { vs. } B \text { and } p=0.07 \text { for } A \\
\text { vs. C } \\
-1 \text { year: } 28.5(6.1) \text { vs. } 28.0(7.1) \text { vs. } 33.6(5.7), p=0.81 \text { for } A \text { vs. B and } p=0.006 \text { for } A \\
\text { vs. C } \\
\text { Analgesic use: } 75 \%(15 / 20) \text { vs. } 40 \%(8 / 20) \text { vs. } 95 \%(19 / 20) \text { at } 1 \text { year, RR } 1.88(95 \% \mathrm{Cl} \text {, } \\
\text { 1.04 to } 3.39) \text { for A vs. B } \\
\text { Patient satisfaction good or excellent: } 85 \%(17 / 20) \text { vs. } 95 \%(19 / 20) \text { vs. } 70 \%(14 / 20) \text { at } 1 \\
\text { year }\end{array}$ & NR \\
\hline
\end{tabular}

Abbreviations: $\mathrm{CI}=$ confidence interval; $\mathrm{IQR}=$ interquartile range; $\mathrm{LBP}=$ low-back pain;
$\mathrm{SD}=$ standard deviation; $\mathrm{VAS}=$ visual analogue scale; $\mathrm{WHO}$ World Health Organization

See Appendix F, List of Included Studies, for full citations 
Table G-7. Trials of intradiscal and facet joint platelet rich plasma for presumed discogenic back pain - study characteristics

\begin{tabular}{|c|c|c|c|c|}
\hline $\begin{array}{l}\text { Author, } \\
\text { Year } \\
\text { Trial }\end{array}$ & $\begin{array}{l}\text { Study } \\
\text { Design } \\
\text { Duration }\end{array}$ & $\begin{array}{c}\text { Setting/Provider } \\
\text { Type } \\
\text { Country }\end{array}$ & Eliqibility Criteria & Interventions \\
\hline $\begin{array}{l}\text { Tuakli- } \\
\text { Wosornu, } \\
2016\end{array}$ & $\begin{array}{l}\mathrm{RCT} \\
8 \text { weeks }\end{array}$ & $\begin{array}{l}1 \text { center, } \\
\text { physical medical } \\
\text { and rehabilitation } \\
\text { U.S. }\end{array}$ & $\begin{array}{l}\text { Refractory LBP } \geq 6 \text { months, failure of conservative treatment measures (oral } \\
\text { medications, rehabilitation therapy, and/or injection therapy), maintained } \\
\text { intervertebral disc height } \geq 50 \% \text {, disc protrusion }<5 \mathrm{~mm} \text { on MRI or } \mathrm{CT} \text {, concordant } \\
\text { pain on provocative discography ( } 1 \text { to } 2 \mathrm{ml} \text { ) with presence of a grade } 3 \text { or } 4 \\
\text { annular fissure } \\
\text { Excluded: presence of a known bleeding disorder, current anticoagulation therapy, } \\
\text { pregnancy, systemic infection or skin infection over the puncture site, allergy to } \\
\text { contrast agent, presence of a psychiatric condition (e.g., posttraumatic stress } \\
\text { disorder, schizophrenia), solid bone fusion preventing access to the disc, severe } \\
\text { spinal canal compromise at the levels to be investigated, extrusions or } \\
\text { sequestered disc fragments, previous spinal surgery, spondylolysis, } \\
\text { spondylolisthesis, discordant pain on discography, presence of a grade } 5 \text { annular } \\
\text { fissure with demonstrated extravasation of }\end{array}$ & $\begin{array}{l}\text { A: Platelet-rich plasma injection: } 1 \text { to } 2 \\
\text { ml of platelet-rich plasma injected mid- } \\
\text { portion of discs that elicited concordant } \\
\text { pain on discography with fluoroscopic } \\
\text { guidance (for multiple discs, a total of } 3 \\
\text { to } 4 \mathrm{ml} \text { was split among the discs) } \\
\text { B: Sham: } 1 \text { to } 2 \mathrm{ml} \text { contrast agent, as } \\
\text { above }\end{array}$ \\
\hline
\end{tabular}

Abbreviations: $\mathrm{CT}$ = computed tomography; $\mathrm{LBP}=$ low-back pain; $\mathrm{MRI}=$ magnetic resonance imaging; $\mathrm{RCT}=$ randomized controlled trial; U.S. $=$ United States

See Appendix F, List of Included Studies, for full citations

Table G-8. Trials of intradiscal and facet joint platelet rich plasma for presumed discogenic back pain - additional study characteristics

\begin{tabular}{|c|c|c|c|c|}
\hline $\begin{array}{l}\text { Author, } \\
\text { Year } \\
\text { Trial }\end{array}$ & Sample Characteristics & $\begin{array}{l}\text { Screened } \\
\text { Eligible } \\
\text { Randomized } \\
\text { Complete Followup } \\
\text { Analyzed }\end{array}$ & Sponsor & Quality \\
\hline $\begin{array}{l}\text { Tuakli- } \\
\text { Wosornu, } \\
2016\end{array}$ & $\begin{array}{l}\text { Mean (SD) age, years: } 42.32 \text { (8.41) } \\
\text { Female: } 66 \% \\
\text { Race: NR } \\
\text { Pain duration: NR } \\
\text { A vs. B } \\
\text { Baseline current pain (mean [SD], } 0 \text { to } 10 \mathrm{NRS} \text { ): } 4.74(2.21) \text { vs. } 4.61(2.21) \\
\text { Baseline best pain (mean [SD] } 0 \text { to } 10 \text { NRS): } 2.81(1.78) \text { vs. } 2.08(1.74) \\
\text { Baseline worst pain (mean [SD], } 0 \text { to } 10 \mathrm{NRS}): 7.98(1.56) \text { vs. } 7.72(1.53) \\
\text { Baseline Functional Rating Index (mean [SD], } 0 \text { to } 100): 51.47(15.62) \text { vs. } 45.37(15.61) \\
\text { Baseline SF-36 bodily pain (mean [SD], 0 to 100): } 43.28(21.11) \text { vs. } 47.92(21.13) \\
\text { Baseline SF-36 physical function (mean [SD], } 0 \text { to } 100): 56.40 \text { (18.52) vs. } 56.11(18.54)\end{array}$ & $\begin{array}{l}\text { Screened: } 109 \\
\text { Eligible: } 84 \\
\text { Randomized: } 58 \text { ( } 36 \text { vs. } \\
\text { 22) } \\
\text { Completed followup: } 57 \\
\text { (35 vs. } 22 \text { ) at } 8 \text { weeks } \\
\text { Analyzed: } 47 \text { (29 vs. } 18 \text { ) at } \\
8 \text { weeks }\end{array}$ & $\begin{array}{l}\text { Hospital for Special } \\
\text { Surgery Physiatry } \\
\text { Research \& Education } \\
\text { Fund, Harvest } \\
\text { Technologies } \\
\text { Corporation }\end{array}$ & Fair \\
\hline
\end{tabular}

Abbreviations: $\mathrm{NR}=$ not reported; $\mathrm{NRS}=$ numeric rating scale; $\mathrm{SD}=$ standard deviation

See Appendix F, List of Included Studies, for full citations 


\begin{tabular}{|c|c|c|}
\hline $\begin{array}{l}\text { Author, } \\
\text { Year } \\
\text { Trial }\end{array}$ & Results & $\begin{array}{l}\text { Adverse Events and Withdrawals } \\
\text { Due to Adverse Events }\end{array}$ \\
\hline $\begin{array}{l}\text { Tuakli- } \\
\text { Wosornu, } \\
2016\end{array}$ & 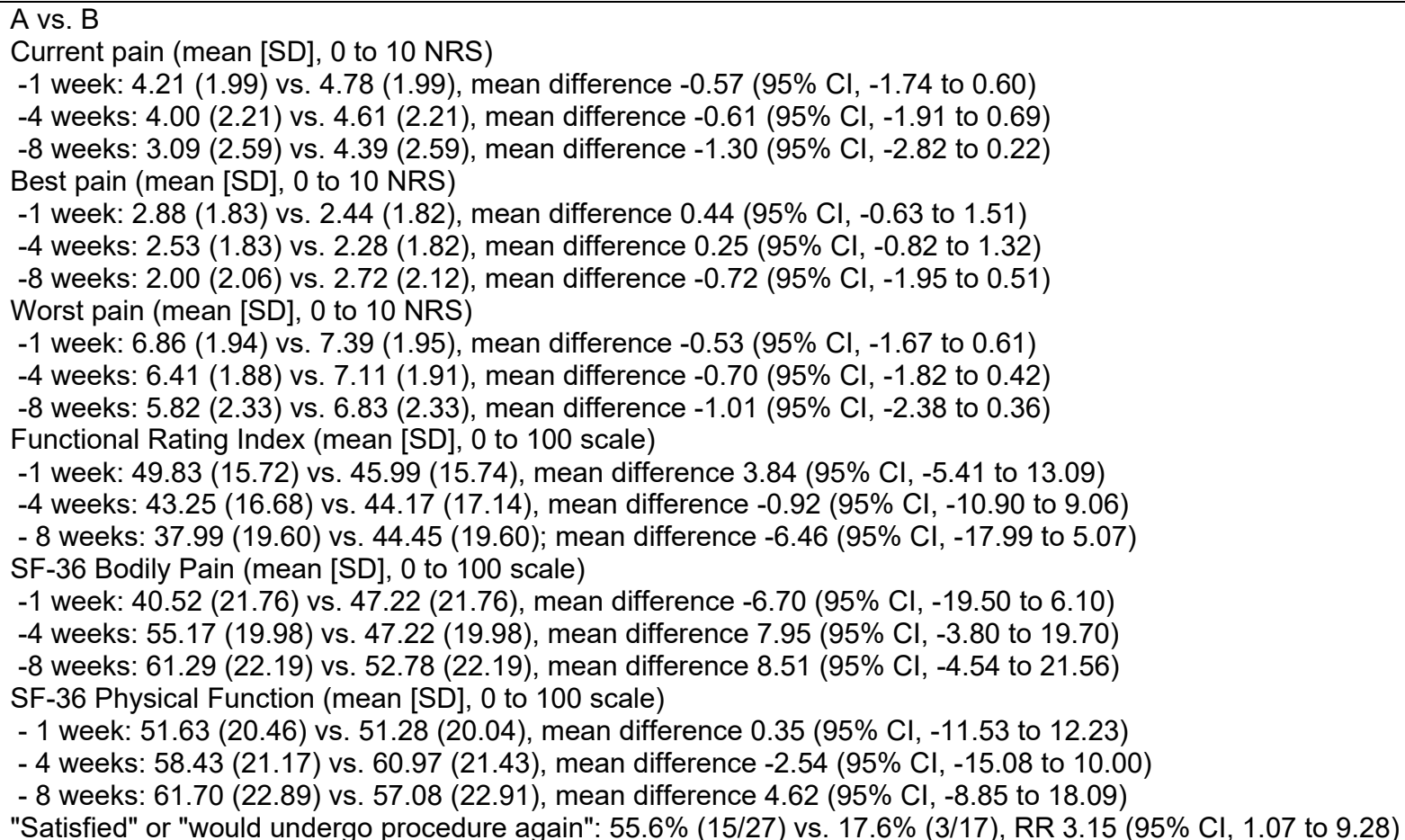 & $\begin{array}{l}\text { No adverse events of disk space } \\
\text { infection, neurologic injury, or } \\
\text { progressive herniation }\end{array}$ \\
\hline
\end{tabular}

Abbreviations: $\mathrm{CI}=$ confidence interval; $\mathrm{NR}=$ not reported; NRS = numeric rating scale; RR = risk ratio; $\mathrm{SD}=$ standard deviation; SF-36 = Short-Form 36

\section{See Appendix F, List of Included Studies, for full citations}


Table G-10. Trial of stem cells for presumed discogenic back pain -study characteristics

\begin{tabular}{|c|c|c|c|c|c|c|c|c|}
\hline $\begin{array}{l}\text { Author, } \\
\text { Year }\end{array}$ & $\begin{array}{c}\text { Study } \\
\text { Design } \\
\text { Duration }\end{array}$ & $\begin{array}{c}\text { Setting/Provider } \\
\text { Type } \\
\text { Country }\end{array}$ & $\begin{array}{c}\text { Eligibility } \\
\text { Criteria }\end{array}$ & Interventions & Sample Characteristics & $\begin{array}{c}\text { Screened } \\
\text { Eligible } \\
\text { Randomized } \\
\text { Analyzed }\end{array}$ & Sponsor & Quality \\
\hline $\begin{array}{l}\text { Amirdelfan, } \\
2020\end{array}$ & $\begin{array}{l}\mathrm{RCT} \\
3 \text { years }\end{array}$ & $\begin{array}{l}13 \text { centers; } \\
\text { provider type not } \\
\text { reported } \\
\text { Australia and } \\
\text { U.S. }\end{array}$ & $\begin{array}{l}\geq 18 \text { years with } \\
\text { documented } \\
\text { diagnosis of } \\
\text { degenerative } \\
\text { disc disease at } \\
\text { one level from } \\
\text { L1 to } S 1 \text {, chronic } \\
\text { LBP for } \geq 6 \\
\text { months, prior } \\
\text { failed } 3 \text { months } \\
\text { conservative } \\
\text { treatment; } \\
\text { provocative } \\
\text { discography } \\
\text { optional but if } \\
\text { performed, only } \\
\text { patients with } \\
\text { concordant pain } \\
\text { at } 1 \text { level eligible } \\
\text { Excluded: } \\
\text { comorbidities } \\
\text { that could } \\
\text { confound the } \\
\text { safety or efficacy } \\
\text { of mesenchymal } \\
\text { precursor cells }\end{array}$ & $\begin{array}{l}\text { A. Intradiscal } \\
\text { allogenic } \\
\text { mesenchymal } \\
\text { precursor cells: } 6 \\
\text { million cells ( } 1.0 \mathrm{~mL} \text { of } \\
\text { the } 30 \text { million } / 5 \mathrm{~mL} \\
\text { MPC product) mixed } \\
\text { with } 1.0 \mathrm{~mL} \text { of } 1 \% \\
\text { hyaluronic acid } \\
\text { B. Intradiscal } \\
\text { allogenic } \\
\text { mesenchymal } \\
\text { precursor cells: } 18 \\
\text { million cells (1.0 } \mathrm{mL} \text { of } \\
\text { the } 90 \text { million } / 5 \mathrm{~mL} \\
\text { MPC product) mixed } \\
\text { with } 1.0 \mathrm{~mL} \text { of } 1 \% \\
\text { hyaluronic acid } \\
\text { C. Intradiscal } \\
\text { hyaluronic acid: } 2 \mathrm{ml} \\
\text { of } 1 \% \text { hyaluronic acid } \\
\text { D. Intradiscal saline: } 2 \\
\text { ml sterile saline } \\
\text { Use of imaging } \\
\text { guidance not reported }\end{array}$ & $\begin{array}{l}\text { Mean age, years: } 41.9 \\
\text { Female: } 47 \% \\
\text { Race/ethnicity: } 86 \% \text { white, } 4 \% \\
\text { Black, } 2 \% \text { Asian, } 1 \% \text { other, } 7 \% \\
\text { Hispanic } \\
\text { Mean duration of degenerative } \\
\text { disc disease, years: } 5.81 \\
\text { Mean VAS (scale } 0 \text { to } 100): \\
70.12 \\
\text { Mean ODI: } 49.06 \\
\text { A vs. B vs. C vs. D } \\
\text { Male sex: } 40 \% \text { vs. } 70 \% \text { vs. } 50 \% \\
\text { vs. } 50 \% \text {; B vs. C or D: } p \leq 0.50 \\
\text { Mean age, years: } 45.1 \text { vs. } 37.9 \\
\text { vs. } 40.3 \text { vs. } 44.5 ; \text { B vs. D: } p \leq 0.50 \\
\text { Mean duration of degenerative } \\
\text { disc disease, years: } 8.4 \text { vs. } 3.7 \\
\text { vs. } 5.0 \text { vs. } 5.9 ; \text { B vs. D: } \leq 0.50 \\
\text { Baseline pain (mean [SD], } 0 \text { to } \\
100 \text { VAS transformed to } 0 \text { to } 10 \\
\text { scale): } 6.97 \text { (2.46) vs. } 7.15(2.46) \\
\text { vs. } 7.18 \text { (2.40) vs. } 6.69 \text { (2.40) } \\
\text { Baseline ODI (mean [SD NR]): } \\
52.07 \text { (16.34) vs. } 50.67 \text { (16.34) } \\
\text { vs. } 46.80 \text { (15.96) vs. } 44.40 \\
\text { (15.96) }\end{array}$ & $\begin{array}{l}\text { Screened: } \\
148 \\
\text { Eligible: } 100 \\
\text { Enrolled: } 100 \\
\text { Analyzed: } \\
100 \text { (data } \\
\text { imputed) }\end{array}$ & Mesoblast & Fair \\
\hline
\end{tabular}

Abbreviations: $\mathrm{LBP}=$ low-back pain; $\mathrm{MPC}=$ mesenchymal precursor cell; $\mathrm{NR}=$ not reported; ODI $=$ Oswestry Disability Index; RCT $=$ randomized controlled trial; $\mathrm{SD}=$ standard deviation; U.S. = United States; VAS = visual analogue scale

See Appendix F, List of Included Studies, for full citations 


\begin{tabular}{|c|c|c|}
\hline $\begin{array}{l}\text { Author, } \\
\text { Year } \\
\text { Trial } \\
\end{array}$ & Results & $\begin{array}{l}\text { Adverse Events and Withdrawals Due to } \\
\text { Adverse Events }\end{array}$ \\
\hline $\begin{array}{l}\text { Amirdelfan, } \\
2020\end{array}$ & 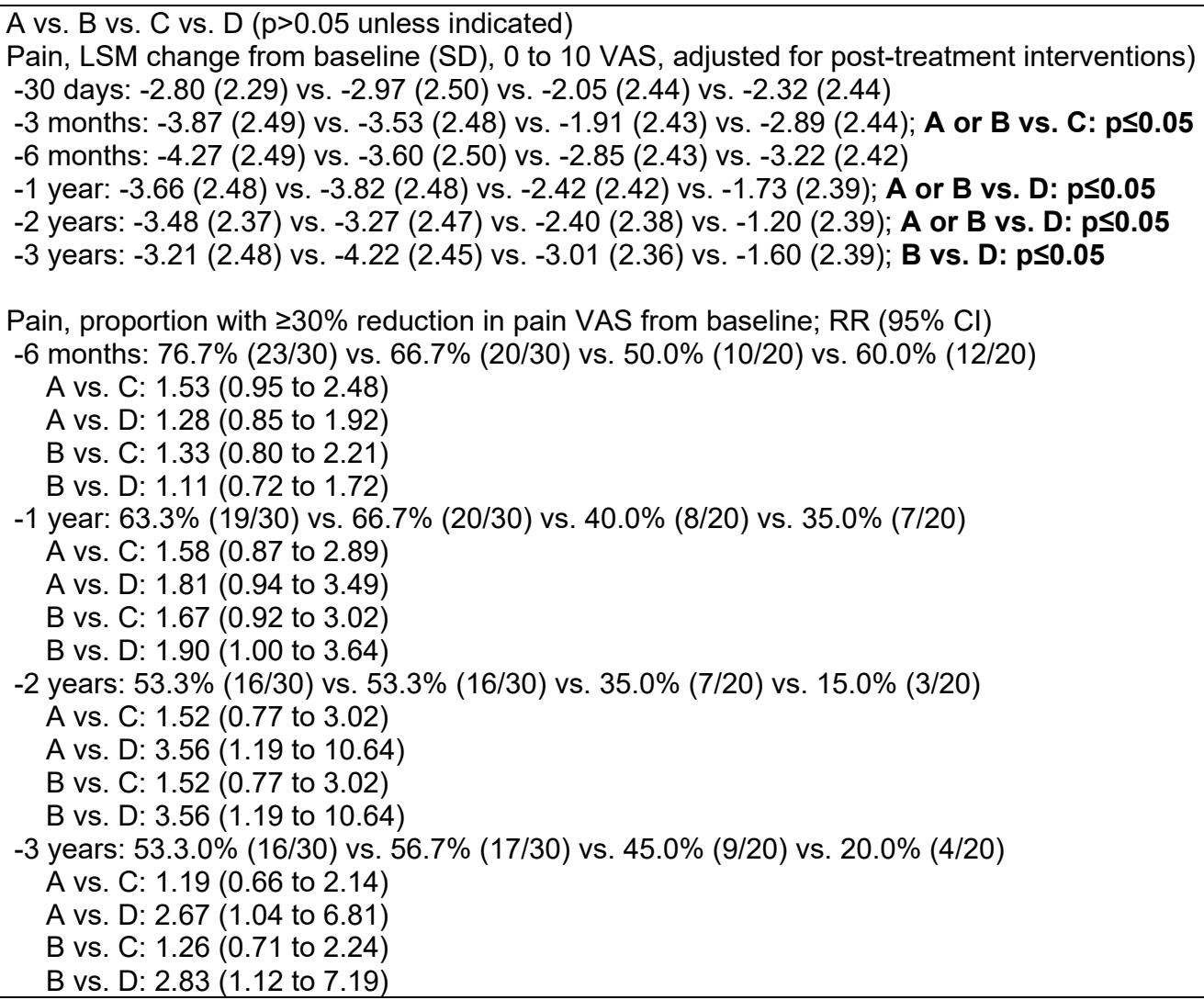 & $\begin{array}{l}\text { A vs. B vs. C vs. D } \\
\text { Mortality: no deaths in any group } \\
\text { Serious adverse events: } 16.7 \%(5 / 30) \text { vs. } \\
\text { 10.0\% (3/30) vs. } 5.0 \%(1 / 20) \text { vs. } 15.0 \%(3 / 20) \\
\text { A vs. C: RR } 3.33(95 \% \mathrm{Cl}, 0.42 \text { to } 26.45) \\
\text { A vs. D: RR } 1.11(95 \% \mathrm{Cl}, 0.30 \text { to } 4.14) \\
\text { B vs. C: RR } 2.00(95 \% \mathrm{Cl}, 0.22 \text { to } 17.89) \\
\text { B vs. D: RR } 0.67(95 \% \mathrm{Cl}, 0.15 \text { to } 2.98) \\
\text { Any adverse event: } 16.7 \%(5 / 30) \text { vs. } 10.0 \% \\
\text { (3/30) vs. } 5.0 \%(1 / 20) \text { vs. } 15.0 \%(3 / 20) \\
\text { A vs. C: RR } 3.33(95 \% \mathrm{Cl}, 0.42 \text { to } 26.45) \\
\text { A vs. D: RR } 1.11(95 \% \mathrm{Cl}, 0.30 \text { to } 4.14) \\
\text { B vs. C: RR } 2.00(95 \% \mathrm{Cl}, 0.22 \text { to } 17.89) \\
\text { B vs. D: RR } 0.67(95 \% \mathrm{Cl}, 0.15 \text { to } 2.98) \\
\text { Withdrawal due to adverse events: } 6.7 \%(2 / 30) \\
\text { vs. 6.7\% (2/30) vs. } 0 \% \text { vs. } 0 \% \\
\text { A vs. C: RR } 3.39(95 \% \mathrm{Cl}, 0.17 \text { to } 67.05) \\
\text { A vs. D: RR } 3.39(95 \% \mathrm{Cl}, 0.17 \text { to } 67.05) \\
\text { B vs. C: RR } 3.39(95 \% \mathrm{Cl}, 0.17 \text { to } 67.05) \\
\text { B vs. D: RR } 3.39(95 \% \mathrm{Cl}, 0.17 \text { to } 67.05)\end{array}$ \\
\hline
\end{tabular}




\begin{tabular}{|c|c|c|}
\hline $\begin{array}{l}\text { Author, } \\
\text { Year } \\
\text { Trial }\end{array}$ & Results & $\begin{array}{l}\text { Adverse Events and Withdrawals Due to } \\
\text { Adverse Events }\end{array}$ \\
\hline $\begin{array}{l}\text { Amirdelfan, } \\
2020, \\
\text { continued }\end{array}$ & 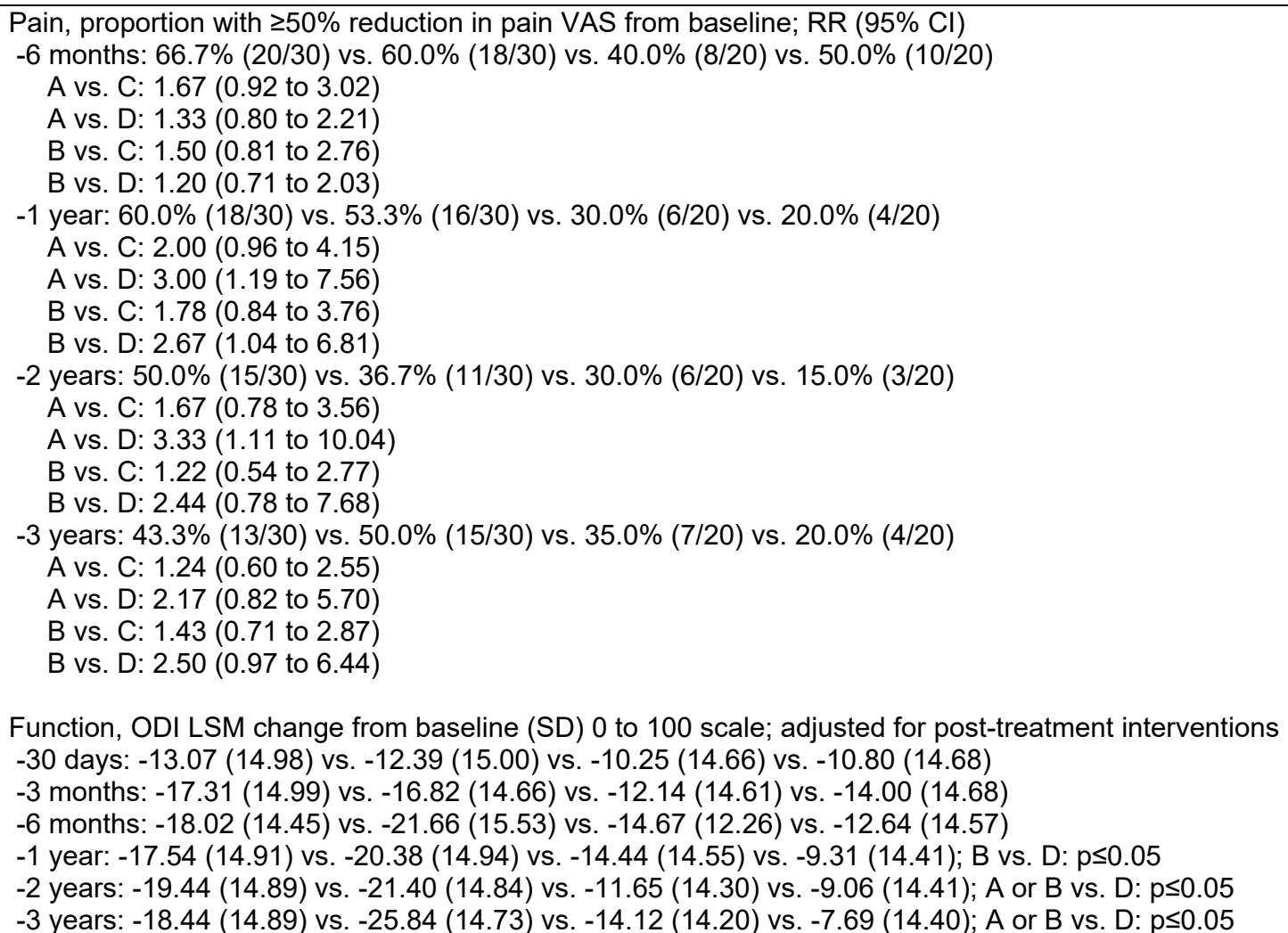 & \\
\hline
\end{tabular}




\begin{tabular}{|c|c|c|}
\hline $\begin{array}{l}\text { Author, } \\
\text { Year } \\
\text { Trial } \\
\end{array}$ & Results & $\begin{array}{l}\text { Adverse Events and Withdrawals Due to } \\
\text { Adverse Events }\end{array}$ \\
\hline $\begin{array}{l}\text { Amirdelfan, } \\
2020, \\
\text { continued }\end{array}$ & 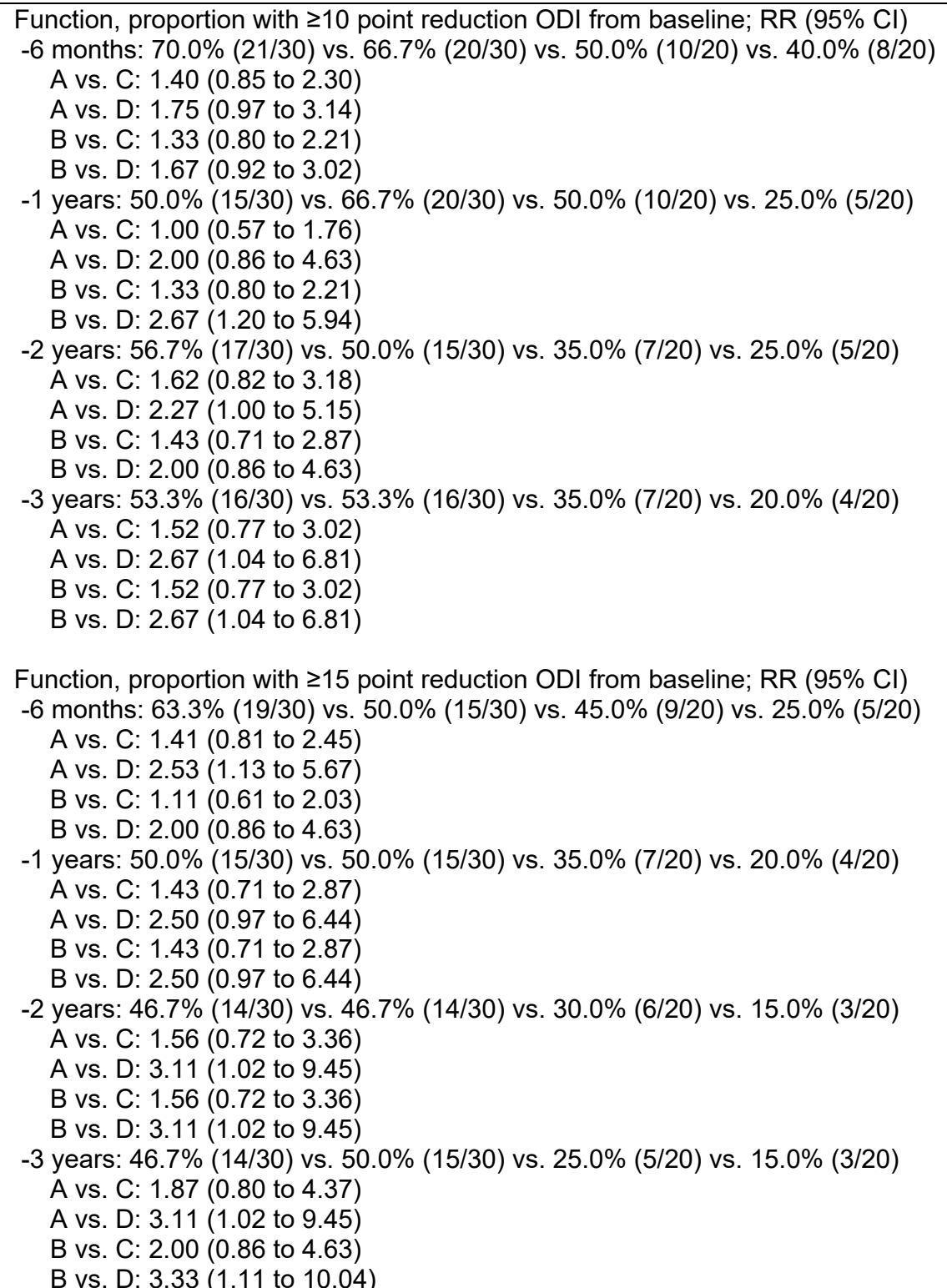 & \\
\hline
\end{tabular}




\begin{tabular}{|c|c|c|}
\hline $\begin{array}{l}\text { Author, } \\
\text { Year } \\
\text { Trial }\end{array}$ & Results & $\begin{array}{l}\text { Adverse Events and Withdrawals Due to } \\
\text { Adverse Events }\end{array}$ \\
\hline $\begin{array}{l}\text { Amirdelfan, } \\
2020, \\
\text { continued }\end{array}$ & $\begin{array}{l}\text { Function, WPAI score, change from baseline } \\
-3 \text { years: B vs. D: } p=0.05 \\
\text { Pain and function composite outcome, proportion with } \geq 30 \% \text { reduction in pain VAS and } \geq 10 \text { point reduction } \\
\text { ODI from baseline; RR }(95 \% \mathrm{Cl}) \\
-6 \text { months: } 63.3 \%(19 / 30) \text { vs. } 50.0 \%(15 / 30) \text { vs. } 35.0 \%(7 / 20) \text { vs. } 40.0 \%(8 / 20) \\
\text { A vs. C: } 1.81 \text { (0.94 to } 3.49) \\
\text { A vs. D: } 1.58(0.87 \text { to } 2.89) \\
\text { B vs. C: } 1.43(0.71 \text { to } 2.87) \\
\text { B vs. D: } 1.25(0.66 \text { to } 2.38) \\
-1 \text { years: } 46.7 \%(14 / 30) \text { vs. } 56.7 \%(17 / 30) \text { vs. } 40.0 \%(8 / 20) \text { vs. } 20.0 \%(4 / 20) \\
\text { A vs. C: } 1.17(0.60 \text { to } 2.26) \\
\text { A vs. D: } 2.33(0.90 \text { to } 6.07) \\
\text { B vs. C: } 1.42(0.76 \text { to } 2.64) \\
\text { B vs. D: } 2.83(1.12 \text { to } 7.19) \\
-2 \text { years: } 46.7 \%(14 / 30) \text { vs. } 43.3 \%(13 / 30) \text { vs. } 25.0 \%(5 / 20) \text { vs. } 15.0 \%(3 / 20) \\
\text { A vs. C: } 1.87(0.80 \text { to } 4.37) \\
\text { A vs. D: } 3.11(1.02 \text { to } 9.45) \\
\text { B vs. C: } 1.73(0.73 \text { to } 4.11) \\
\text { B vs. D: } 2.89(0.94 \text { to } 8.86) \\
-3 \text { years: } 46.7 \%(14 / 30) \text { vs. } 46.7 \%(14 / 30) \text { vs. } 35.0 \%(7 / 20) \text { vs. } 20.0 \%(4 / 20) \\
\text { A vs. C: } 1.33(0.66 \text { to } 2.71) \\
\text { A vs. D: } 2.33(0.90 \text { to } 6.07) \\
\text { B vs. C: } 1.33(0.66 \text { to } 2.71) \\
\text { B vs. D: } 2.33(0.90 \text { to } 6.07) \\
\text { Quality of life, SF-36, physical component score, change from baseline } \\
-3 \text { years: B vs. C: } p=0.04 ; B \text { vs. D: } p=0.025\end{array}$ & \\
\hline
\end{tabular}

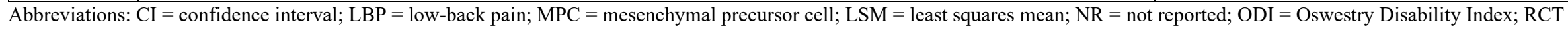

$=$ randomized controlled trial; $\mathrm{RR}=$ risk ratio; $\mathrm{SD}=$ standard deviation; SF-36 = Short-Form 36; VAS = visual analogue scale; WPAI $=$ Work Productivity and Activity Index

\section{See Appendix F, List of Included Studies, for full citations}


Table G-12. Trials of methylene blue for presumed discogenic back pain - study characteristics

\begin{tabular}{|c|c|c|c|c|}
\hline $\begin{array}{l}\text { Author, } \\
\text { Year } \\
\text { Trial }\end{array}$ & $\begin{array}{c}\text { Study } \\
\text { Design } \\
\text { Duration }\end{array}$ & $\begin{array}{c}\text { Setting/Provider } \\
\text { Type } \\
\text { Country }\end{array}$ & Eligibility Criteria & Interventions \\
\hline $\begin{array}{l}\text { Kallewaard, } \\
2019 \\
\text { IMBI Study }\end{array}$ & $\begin{array}{l}\mathrm{RCT} \\
6 \text { months }\end{array}$ & $\begin{array}{l}4 \text { centers, } \\
\text { anesthesia pain } \\
\text { medicine } \\
\text { the Netherlands }\end{array}$ & $\begin{array}{l}18 \text { to } 66 \text { years with a history consistent with lumbar discogenic pain, LBP duration } \\
\geq 6 \text { months, poor response to } \geq 6 \text { weeks conservative treatment, no motor deficit } \\
\text { on neurological examination, pain intensity } \geq 5 \text { ( } 0 \text { to } 10 \text { NRS) in seated position, } \\
\text { MRI in the past } 12 \text { months to rule out severe disk degeneration ( }>50 \% \text { height } \\
\text { loss), negative facet joint blockade, positive provocative discography (at pressure } \\
<50 \text { PSI above opening pressure), pain severity } \geq 7 \text { ( } 0 \text { to } 10 \text { NRS) or } \geq 70 \% \\
\text { reproduction of worst spontaneous pain; } \geq 1 \text { adjacent control level tested) } \\
\text { Excluded: discogenic pain confirmed on more than } 2 \text { levels, extruded or } \\
\text { sequestered herniated nucleus pulposus, previous lumbar surgery or invasive } \\
\text { intradiscal procedures on suspected levels, had grade } 1 \text { to } 5 \text { spondylolisthesis, } \\
\text { had a BMI of } 35 \text { or more, pregnant, received coagulopathy or oral anticoagulant } \\
\text { therapy, infection. }\end{array}$ & $\begin{array}{l}\text { A. Intradiscal methylene blue: } 1 \mathrm{ml}(10 \\
\text { mg/ml) methylene blue }+0.5 \mathrm{ml} \\
\text { lidocaine hydrochloride } 2 \% \text {, and } 0.5 \mathrm{ml} \\
\text { contrast dye injected at } 0.02 \mathrm{ml} / \mathrm{sec} \text { in } \\
\text { symptomatic disc(s) and } \geq 1 \text { adjacent } \\
\text { control disc } \\
\text { B. Sham intradiscal therapy: } 1 \mathrm{ml} \\
\text { saline }+0.5 \mathrm{ml} \text { lidocaine hydrochloride } \\
2 \% \text {, and } 0.5 \mathrm{ml} \text { contrast dye injected } \\
\text { as above }\end{array}$ \\
\hline Peng, 2010 & $\begin{array}{l}\mathrm{RCT} \\
2 \text { years }\end{array}$ & $\begin{array}{l}1 \text { center, provider } \\
\text { type not reported } \\
\text { China }\end{array}$ & $\begin{array}{l}20 \text { to } 65 \text { years, chronic LBP without radiculopathy but with evidence of lumbar } \\
\text { disc degeneration on MRI, preliminary diagnosis of discogenic low back pain, } \\
\text { positive discography (pressure and volume parameters not reported; exact } \\
\text { reproduction of usual pain response pattern, and posterior annular disruption } \\
\text { extending into the outer annulus or beyond the confines of the outer annulus by } \\
\text { the contrast medium; at least one negative adjacent control disc) } \\
\text { Excluded: lumbar disc herniation, spinal instability, lumbar canal stenosis, } \\
\text { spondylolysis, spondylolisthesis, disc degeneration with endplate Modic changes, } \\
\text { neurologic disease, inflammatory arthritis, tumor, infection }\end{array}$ & $\begin{array}{l}\text { A. Intradiscal methylene blue: } 1 \mathrm{~mL} \\
(1 \% ; 10 \mathrm{mg} / \mathrm{mL} \text { ) methylene blue }+1 \mathrm{ml} \\
\text { lidocaine hydrochloride } 2 \% \\
\text { B. Sham intradiscal injection: } 1 \mathrm{ml} \\
\text { saline }+1 \mathrm{ml} \text { lidocaine hydrochloride } \\
2 \%\end{array}$ \\
\hline
\end{tabular}

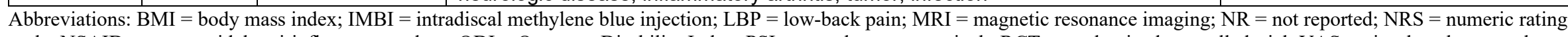
scale; NSAID = nonsteroidal anti-inflammatory drug; ODI = Oswestry Disability Index; PSI = pounds per square inch; RCT = randomized controlled trial; VAS = visual analogue scale

See Appendix F, List of Included Studies, for full citations 
Table G-13. Trials of methylene blue for presumed discogenic back pain - additional study characteristics

\begin{tabular}{|c|c|c|c|c|}
\hline $\begin{array}{l}\text { Author, } \\
\text { Year } \\
\text { Trial }\end{array}$ & Sample Characteristics & $\begin{array}{l}\text { Screened } \\
\text { Eligible } \\
\text { Randomized } \\
\text { Completed Followup } \\
\text { Analyzed }\end{array}$ & Sponsor & Quality \\
\hline $\begin{array}{l}\text { Kallewaard, } \\
2019 \\
\text { IMBI Study }\end{array}$ & $\begin{array}{l}\text { Mean (SD) age, years: } 41.1 \text { (9.91) } \\
\text { Female: } 72 \% \\
\text { Race: NR } \\
\text { Mean (SD) duration of pain, years: } 9.34 \text { (7.98) } \\
\text { Strong opioid use: } 11 \% \\
\text { Weak opioid or antineuropathic medication use: } 25 \% \\
\text { A vs. B } \\
\text { Baseline pain intensity (mean [SD], } 0 \text { to } 10 \mathrm{NRS} \text { ): } 6.6(1.4) \text { vs. } 6.6(1.6) \\
\text { Baseline SF-36 PCS (mean [SD], } 0 \text { to } 100 \text { scale): } 49.8(17.3) \text { vs. } 46.9(19.0) \\
\text { Baseline SF-36 MCS (mean [SD], } 0 \text { to } 100 \text { scale): } 66.1(16.5) \text { vs. } 63.9(23.0) \\
\text { Baseline ODI (mean [SD], } 0 \text { to } 100 \text { scale): } 44.5(14.1) \text { vs. } 42.8(15.9) \\
\text { Baseline EQ-5D health status (mean [SD], } 0 \text { to } 100 \text { VAS): } 52.9(16.5) \text { vs. } 51.8 \\
\text { (18.8) }\end{array}$ & $\begin{array}{l}\text { Screened: } 1364 \\
\text { Eligible: } 432 \\
\text { Randomized: } 81 \text { ( } 40 \text { vs. } 41 \\
\text { excluding } 3 \text { post-randomization } \\
\text { exclusions) } \\
\text { Complete followup: } 81 \text { ( } 40 \text { vs. } \\
41 \text { ) } \\
\text { Analyzed: } 81 \text { ( } 40 \text { vs. } 41 \text { ) }\end{array}$ & $\begin{array}{l}\text { The Netherlands } \\
\text { Organization for } \\
\text { Health Research and } \\
\text { Development }\end{array}$ & Good \\
\hline Peng, 2010 & $\begin{array}{l}\text { Mean (SD) age, years: } 41.7 \text { (13.3) } \\
\text { Female: } 43 \% \\
\text { Race: NR } \\
\text { Mean (SD) duration of low back pain, years: } 3.4(1.7) \\
\text { A vs. B } \\
\text { Baseline pain (mean [SD], } 0 \text { to } 100 \text { NRS converted to } 0 \text { to } 10 \text { scale): } 7.2(12.4) \\
\text { vs. } 6.7 \text { (11.6) } \\
\text { Baseline ODI (mean [SD], } 0 \text { to } 100 \text { scale): } 48.5(5.1) \text { vs. } 49.5(6.7)\end{array}$ & $\begin{array}{l}\text { Screened: } 136 \\
\text { Eligible: } 72 \\
\text { Randomized: } 72 \text { (36 vs. } 36 \text { ) } \\
\text { Completed followup: } 71 \text { (36 vs. } \\
\text { 35) } \\
\text { Analyzed: } 71 \text { (36 vs. } 35 \text { ) }\end{array}$ & $\begin{array}{l}\text { Foundation of Capital } \\
\text { Medical } \\
\text { Development, Beijing, } \\
\text { China; 304th Hospital } \\
\text { grant }\end{array}$ & Fair \\
\hline
\end{tabular}

Abbreviations: EQ-5D = EuroQOL 5-Dimension Questionnaire; MCS = Mental Component SummaryNR = not reported; NRS = numeric rating scale; ODI = Oswestry Disability Index; PCS = Physical Component Summary; SD = standard deviation; SF-36 = Short-Form 36; VAS = visual analogue scale

\section{See Appendix F, List of Included Studies, for full citations}




\begin{tabular}{|c|c|c|}
\hline $\begin{array}{l}\text { Author, } \\
\text { Year } \\
\text { Trial }\end{array}$ & Results & $\begin{array}{l}\text { Adverse Events and Withdrawals Due to } \\
\text { Adverse Events }\end{array}$ \\
\hline $\begin{array}{l}\text { Kallewaard, } \\
2019 \\
\text { IMBI Study }\end{array}$ & 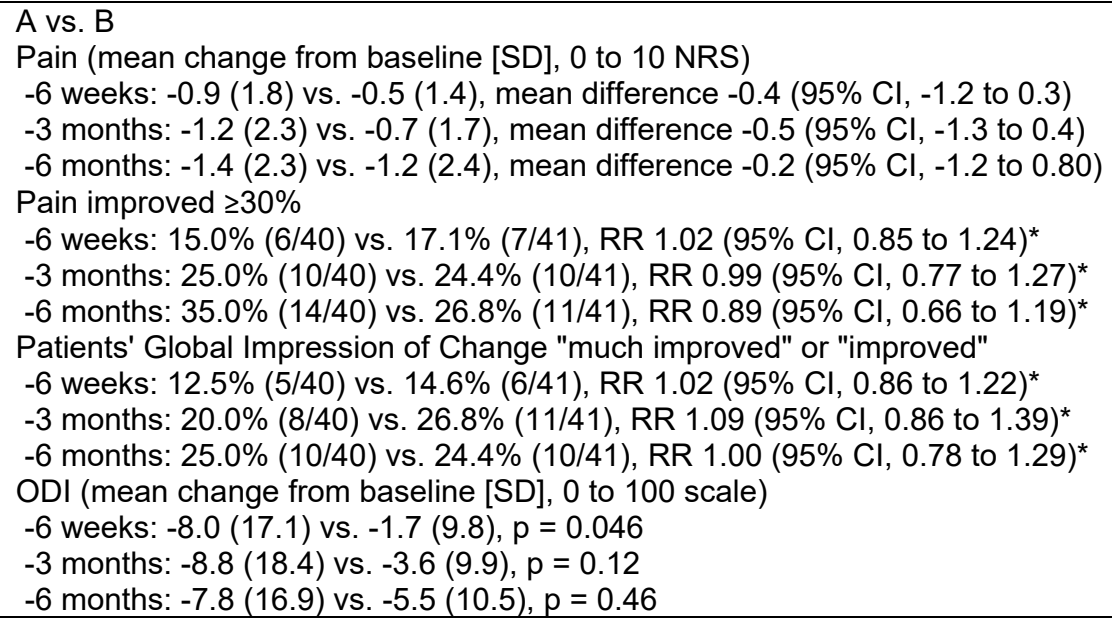 & $\begin{array}{l}\text { A vs. B } \\
\text { SAEs: } 5.0 \%(2 / 40, \text { unrelated elective surgery and } \\
\text { hospitalization due to laryngitis) vs. } 0 \%(0 / 41), \mathrm{RR} \\
5.12(95 \% \mathrm{Cl}, 0.25 \text { to } 103.47)^{*} \\
\text { Any adverse event (n/N NR) } \\
-6 \text { weeks: } p=0.20 \\
-3 \text { months: } p=0.46 \\
-6 \text { months: } p=0.36\end{array}$ \\
\hline $\begin{array}{l}\text { Kallewaard, } \\
2019 \\
\text { IMBI Study } \\
\text { (continued) }\end{array}$ & 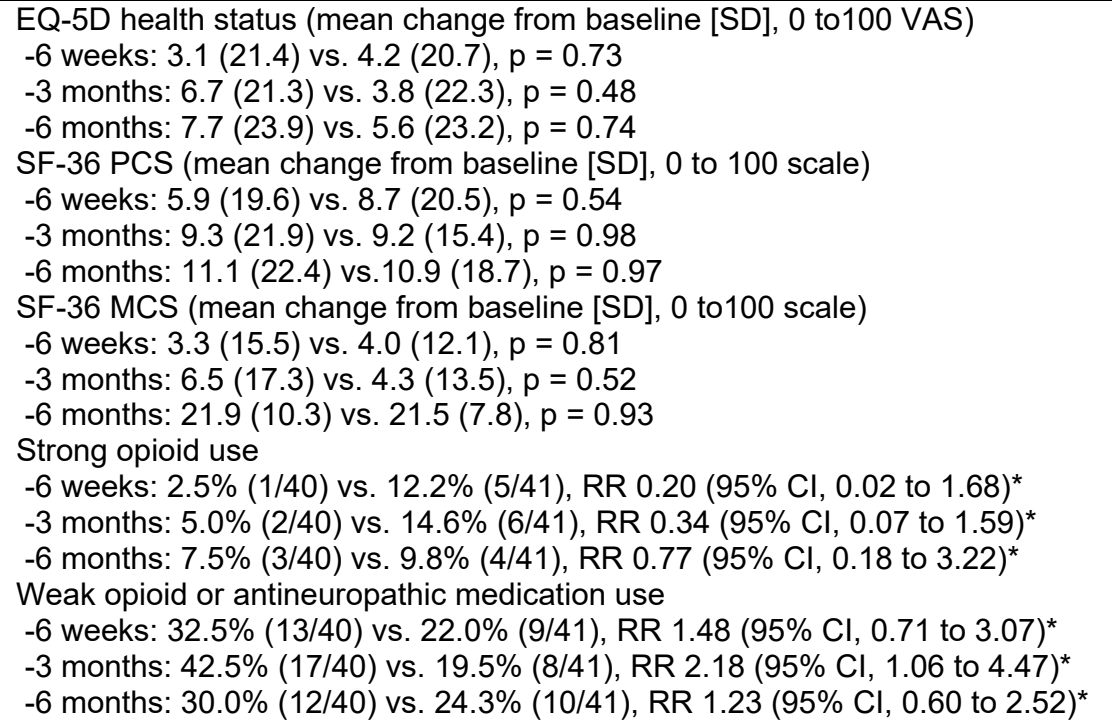 & \\
\hline
\end{tabular}




\begin{tabular}{|c|c|c|}
\hline $\begin{array}{l}\text { Author, } \\
\text { Year } \\
\text { Trial }\end{array}$ & Results & $\begin{array}{l}\text { Adverse Events and Withdrawals Due to } \\
\text { Adverse Events }\end{array}$ \\
\hline Peng, 2010 & $\begin{array}{l}\text { A vs. B } \\
\text { Pain (mean [SD], } 0 \text { to } 100 \text { NRS converted to } 0 \text { to } 10 \text { scale) } \\
\text {-6 months: } 2.49(1.74) \text { vs. } 6.35(1.17) \text {, mean difference } 3.86(95 \% \mathrm{Cl}, 3.15 \text { to } 4.56) \\
-12 \text { months: } 2.16(1.79) \text { vs. } 6.24(1.20) \text {, mean difference } 4.08(95 \% \mathrm{Cl}, 3.36 \text { to } 4.81) \\
-24 \text { months: } 1.98(1.60) \text { vs. } 6.04(1.41) \text {, mean difference } 4.05(95 \% \mathrm{Cl}, 3.34 \text { to } 4.77) \\
\text { ODI (mean [SD], } 0 \text { to } 100 \text { scale) } \\
-6 \text { months: } 16.00(11.91) \text { vs. } 48.40(7.77) \text {, mean difference } 32.40(95 \% \mathrm{Cl}, 27.62 \text { to } 37.18) \\
-12 \text { months: } 14.39(12.87) \text { vs. } 49.09(10.20) \text {, mean difference } 34.70(95 \% \mathrm{Cl}, 29.19 \text { to } 40.20) \\
-24 \text { months: } 12.89(11.95) \text { vs. } 47.69(10.92) \text {, mean difference } 34.80(95 \% \mathrm{Cl}, 29.37 \text { to } 40.22) \\
\text { Regular NSAID or opioid use: } 8.3 \%(3 / 36) \text { vs. } 42.9 \%(15 / 35), \mathrm{RR} 0.19(95 \% \mathrm{Cl}, 0.06 \text { to } 0.61)^{*} \\
\text { Completely satisfied or satisfied: } 91.6 \%(33 / 36) \text { vs. } 14.3 \%(5 / 35), \mathrm{RR} 0.10(95 \% \mathrm{Cl}, 0.03 \text { to } 0.29)^{*}\end{array}$ & $\begin{array}{l}\text { Narrative report of no disc space infection or } \\
\text { nerve root stab injury in either group; no nerve } \\
\text { root injury or back pain aggravation in methylene } \\
\text { blue group }\end{array}$ \\
\hline
\end{tabular}

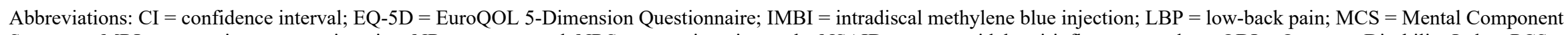
Summary; MRI = magnetic resonance imaging; NR = not reported; NRS = numeric rating scale; NSAID = nonsteroidal anti-inflammatory drug; ODI = Oswestry Disability Index; PCS =

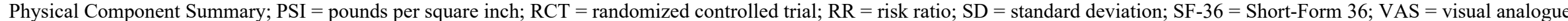
scale

\section{See Appendix F, List of Included Studies, for full citations}


Table G-15. Trials of intradiscal ozone injection for radicular low back pain or nonradicular low back pain of presumed discogenic origin study characteristics

\begin{tabular}{|c|c|c|c|c|}
\hline $\begin{array}{l}\text { Author, } \\
\text { Year } \\
\text { Trial } \\
\end{array}$ & $\begin{array}{c}\text { Study } \\
\text { Design } \\
\text { Duration } \\
\end{array}$ & $\begin{array}{c}\text { Setting/Provider } \\
\text { Type } \\
\text { Country } \\
\end{array}$ & Eligibility Criteria & $\begin{array}{c}\text { Interventions } \\
\end{array}$ \\
\hline $\begin{array}{l}\text { Gallucci, } \\
2007\end{array}$ & $\begin{array}{l}\text { RCT } \\
6 \text { months }\end{array}$ & $\begin{array}{l}1 \text { center, } \\
\text { neuroradiology } \\
\text { Italy }\end{array}$ & $\begin{array}{l}\text { Unilateral radicular pain, herniation site } \\
\text { concordant with the neurologic level, ODI }>30 \\
\text { ( } 0 \text { to } 100 \text { scale), duration of pain } \geq 8 \text { weeks, } \\
\text { conservative therapy for } 2 \text { to } 4 \text { weeks with no or } \\
\text { poor clinical improvement; discography } \\
\text { performed in a few patients initially but } \\
\text { discontinued } \\
\text { Excluded: facet pain syndrome, sacroileitis, } \\
\text { bone lesions, or previous spine surgery }\end{array}$ & $\begin{array}{l}\text { A. Oxygen-ozone, corticosteroid, and local anesthetic injection: } \\
\text { Under CT guidance via paravertebral }(92.4 \%) \text { or interlaminar }(7.6 \%) \\
\text { approach, intradiscal injection of } 5 \text { to } 7 \mathrm{ml} \mathrm{O}_{2} \text { to } \mathrm{O}_{3} \text { (ozone } \\
\text { concentration } 28 \mu \mathrm{g} / \mathrm{ml}), 2 \mathrm{ml} \text { triamcinolone acetonide }(1 \mathrm{ml} \text { in } \\
\text { epidural space and } 1 \mathrm{ml} \text { intradiscal) and } 2 \text { to } 4 \mathrm{ml} 2 \% \text { ropivacaine } \\
(\sim 2 \mathrm{ml} \text { in epidural space and } 1 \mathrm{ml} \text { intradiscal); mean total volume } 6.8 \\
\mathrm{ml} \text { intradiscal and } 9.5 \mathrm{ml} \text { intraforaminal }(12.3 \mathrm{ml} \text { oxygen-ozone) } \\
\mathrm{B} \text {. Corticosteroid and local anesthetic injection: Corticosteroid and } \\
\text { local anesthetic as above, without oxygen-ozone; mean total volume } \\
3 \mathrm{ml} \text { intradiscal and } 2 \mathrm{ml} \text { intraforaminal }\end{array}$ \\
\hline $\begin{array}{l}\text { Haseeb, } \\
2019\end{array}$ & $\begin{array}{l}\text { RCT } \\
6 \text { months }\end{array}$ & $\begin{array}{l}1 \text { center, physical } \\
\text { medicine and } \\
\text { rehabilitation } \\
\text { Egypt }\end{array}$ & $\begin{array}{l}\text { Unilateral radicular pain for } \geq 8 \text { weeks with MRI- } \\
\text { confirmed disc herniation, ODI }>30 \text { (0 to } 100 \\
\text { scale), conservative therapy for } 2 \text { to } 4 \text { weeks } \\
\text { with no or poor clinical improvement. } \\
\text { Excluded: facet syndrome, sacroileitis, previous } \\
\text { spine surgery, absence of disc herniation, major } \\
\text { neurologica deficits, radiculitis secondary to } \\
\text { spinal stenosis, radiculitis without disc } \\
\text { herniation, sequestrated disc contents, multiple } \\
\text { discs involved, suspected spondylodiscitis }\end{array}$ & $\begin{array}{l}\text { A. Oxygen-ozone, corticosteroid, and local anesthetic injection: } \\
\text { Under fluoroscopic guidance via posterolateral extrapedicular } \\
\text { approach, } 5 \text { to } 7 \mathrm{ml} \mathrm{O}_{2} \text { to } \mathrm{O}_{3} \text { (ozone concentration } 28 \mu \mathrm{g} / \mathrm{ml} \text { ) } \\
\text { intradiscal (mean } 5.8 \mathrm{ml} \text { ) and } 5 \text { to } 7 \mathrm{ml} \mathrm{O} 2 \text { to } \mathrm{O} 3 \text { intraforaminal } \\
\text { (mean } 6.5 \mathrm{ml})+2 \mathrm{ml} 40 \mathrm{mg} / \mathrm{ml} \text { triamcinolone acetonide }(1 \mathrm{ml} \\
\text { intradiscal and } 1 \mathrm{ml} \text { intraforaminal) }+2 \text { to } 4 \mathrm{ml} 2 \% \text { ropivacaine } \\
\text { intraforaminal and intradiscal injection } \\
\text { B. Corticosteroid and local anesthetic injection: As above, without } \mathrm{O}_{2} \\
\text { to } \mathrm{O}_{3} \\
\text { C. Sham injection: } 1.5 \mathrm{ml} 1 \% \text { lidocaine alone }\end{array}$ \\
\hline $\begin{array}{l}\text { Nilachandra, } \\
2016\end{array}$ & $\begin{array}{l}\mathrm{RCT} \\
6 \text { months }\end{array}$ & $\begin{array}{l}1 \text { center, physical } \\
\text { medicine and } \\
\text { rehabilitation } \\
\text { India }\end{array}$ & $\begin{array}{l}20 \text { to } 55 \text { years with radicular back pain and } \\
\text { prolapsed intervertebral disc confirmed with } \\
\text { MRI, VAS } \geq 5, \text { ODI }>40 \text { ( } 0 \text { to } 100 \text { scale) } \\
\text { Excluded: cauda equina syndrome, prior } \\
\text { lumbar surgery, multilevel disc prolapse }\end{array}$ & $\begin{array}{l}\text { A. Oxygen-ozone and corticosteroid injection: Under fluoroscopic } \\
\text { guidance, intradiscal } 10 \mathrm{ml} \mathrm{O}_{2} \text { to } \mathrm{O}_{3} \text { (ozone concentration } 40 \mu \mathrm{g} / \mathrm{ml} \text { ) } \\
\text { (target just lateral to the superior articular process) + } \\
\text { methylprednisolone } 80 \mathrm{mg} \text { via transforaminal approach } \\
\text { B. Corticosteroid injection: Methylprednisolone } 80 \mathrm{mg} \text {, epidural via } \\
\text { transforaminal approach }\end{array}$ \\
\hline
\end{tabular}

Abbreviations: $\mathrm{CI}=$ confidence interval; $\mathrm{CT}$ computed tomography; $\mathrm{MRI}=$ magnetic resonance imaging; $\mathrm{NR}=$ not reported; ODI = Oswestry Disability Index; RCT = randomized

controlled trial; $\mathrm{RR}=$ risk ratio; $\mathrm{SD}=$ standard deviation; $\mathrm{VAS}=$ visual analogue scale

\section{See Appendix F, List of Included Studies, for full citations}


Table G-16. Trials of intradiscal ozone injection for radicular low back pain or nonradicular low back pain of presumed discogenic origin additional study characteristics

\begin{tabular}{|c|c|c|c|c|}
\hline $\begin{array}{l}\text { Author, } \\
\text { Year }\end{array}$ & Sample Characteristics & $\begin{array}{l}\text { Screened } \\
\text { Eligible } \\
\text { Randomized } \\
\text { Completed Followup } \\
\text { Analyzed } \\
\end{array}$ & Sponsor & Quality \\
\hline $\begin{array}{l}\text { Gallucci, } \\
2007\end{array}$ & $\begin{array}{l}\text { Mean age, years: } 40.48 \\
\text { Female: } 45 \% \\
\text { Race: NR } \\
\text { Mean duration radicular pain, weeks: } 15 \\
\text { L3 to L4 disc herniation: } 14.5 \% \\
\text { L4 to L5 disc herniation: } 38.4 \% \\
\text { L5 to S1 disc herniation: } 47.2 \% \\
\text { A vs. B } \\
\text { Baseline ODI (mean [SD NR], } 0 \text { to } 100 \text { scale): } 58.4 \text { vs. } 57.5\end{array}$ & $\begin{array}{l}\text { Screened: NR } \\
\text { Eligible: NR } \\
\text { Randomized: } 159 \text { (82 vs. 77) } \\
\text { Complete followup: NR } \\
\text { Analyzed: } 159 \text { (82 vs. } 77 \text { ) }\end{array}$ & NR & Fair \\
\hline $\begin{array}{l}\text { Haseeb, } \\
2019\end{array}$ & $\begin{array}{l}\text { Mean (SD) age, years: } 42.44(7.7) \\
\text { Female: } 58 \% \\
\text { Race: NR } \\
\text { Mean duration of radicular pain, weeks: } 8 \\
\text { A vs. B vs. C } \\
\text { Baseline ODI (mean [SD], } 0 \text { to } 100 \text { scale): } 34.38(12.24) \text { vs. } 29.38(7.18) \\
\text { vs. } 29.20(9.54)\end{array}$ & $\begin{array}{l}\text { Screened: NR } \\
\text { Eligible: NR } \\
\text { Randomized: } 100 \text { (40 vs. } 40 \\
\text { vs. 20) } \\
\text { Completed followup: NR } \\
\text { Analyzed: NR }\end{array}$ & NR & Poor \\
\hline $\begin{array}{l}\text { Nilachandra, } \\
2016\end{array}$ & $\begin{array}{l}\text { Mean (SD) age, years: } 51.3(8.64) \\
\text { Female: } 62 \% \\
\text { Race: NR } \\
\text { Mean (SD) duration of radicular pain, months: } 9.45(3.02) \\
\text { L3 to L4 prolapse: } 22.5 \% \\
\text { L4 to L5 prolapse: } 66.2 \% \\
\text { L5 to S1 prolapse: } 22.5 \% \\
\text { A vs. B } \\
\text { Baseline pain (mean [SD], } 0 \text { to } 10 \text { VAS): } 7.13(1.04) \text { vs. } 7.25(1.10) \\
\text { Baseline ODI (mean [SD], } 0 \text { to } 100 \text { scale): } 70.90(7.55) \text { vs. } 73.05(7.51)\end{array}$ & $\begin{array}{l}\text { Screened: NR } \\
\text { Eligible: NR } \\
\text { Randomized: } 80 \text { (40 vs. } 40) \\
\text { Completed followup: NR } \\
\text { Analyzed: } 75 \text { ( } 37 \text { vs. } 38 \text { ) at } 3 \\
\text { months, } 73 \text { (36 vs. } 37) \text { at } 6 \\
\text { months }\end{array}$ & NR & Poor \\
\hline
\end{tabular}

Abbreviations: $\mathrm{CI}=$ confidence interval; $\mathrm{CT}$ computed tomography; $\mathrm{MRI}=$ magnetic resonance imaging; $\mathrm{NR}=$ not reported; ODI $=$ Oswestry Disability Index; RCT = randomized controlled trial; $\mathrm{RR}=$ risk ratio; $\mathrm{SD}=$ standard deviation; $\mathrm{VAS}=$ visual analogue scale

See Appendix F, List of Included Studies, for full citations 
Table G-17. Trials of intradiscal ozone injection for radicular low back pain or nonradicular low back pain of presumed discogenic origin results

\begin{tabular}{|c|c|c|}
\hline Author, Year & Results & $\begin{array}{l}\text { Adverse Events and Withdrawals Due to Adverse } \\
\text { Events }\end{array}$ \\
\hline $\begin{array}{l}\text { Gallucci, } \\
2007\end{array}$ & $\begin{array}{l}\text { A vs. } \mathrm{B} \\
\text { ODI <20 on } 0 \text { to } 100 \text { scale } \\
-2 \text { weeks: } 88 \%(72 / 82) \text { vs. } 90 \%(69 / 77) \text {, RR } 0.98(95 \% \mathrm{Cl}, 0.88 \text { to } 1.09) \\
-3 \text { months: } 78 \%(64 / 82) \text { vs. } 67 \%(52 / 77) \text {, RR } 1.16(95 \% \mathrm{Cl}, 0.95 \text { to } 1.40) \\
-6 \text { months: } 74 \%(61 / 82) \text { vs. } 47 \%(36 / 77), \text { RR } 1.59(95 \% \mathrm{Cl}, 1.21 \text { to } 2.08)\end{array}$ & $\begin{array}{l}\text { A vs. B } \\
\text { Narrative report of no major or minor complications in } \\
\text { either group }\end{array}$ \\
\hline Haseeb, 2019 & $\begin{array}{l}\text { A vs. B } \\
\text { ODI (mean change from baseline [SD], } 0 \text { to } 100 \text { scale) } \\
-2 \text { weeks: }-20.40(9.66) \text { vs. }-16.60(7.33) \text {, mean difference }-3.80(95 \% \mathrm{Cl},-7.56 \text { to }-0.04) \\
-3 \text { months: }-18.95(8.55) \text { vs. }-13.30(5.66) \text {, mean difference }-5.65(95 \% \mathrm{Cl},-8.83 \text { to }-2.47) \\
-6 \text { months: }-14.73(9.60) \text { vs. }-9.88(5.79) \text {, mean difference }-4.85(95 \% \mathrm{Cl},-8.32 \text { to }-1.38) \\
\text { A vs. C } \\
\text { ODI (mean change from baseline [SD], } 0 \text { to } 100 \text { scale) } \\
-2 \text { weeks: }-20.40 \text { (9.66) vs. }-3.10(3.72) \text {, mean difference }-17.30(95 \% \mathrm{Cl},-20.71 \text { to }-13.89) \\
-3 \text { months: }-18.95 \text { (8.55) vs. }-2.10(3.81) \text {, mean difference }-16.85(95 \% \mathrm{Cl},-19.98 \text { to }-13.72) \\
-6 \text { months: Data not reported for group } \mathrm{C} \text { at } 6 \text { months }\end{array}$ & $\begin{array}{l}\text { A vs. B } \\
\text { Any adverse event: } 47.5 \%(19 / 40) \text { vs. } 27.5 \%(11 / 40) \text {, } \\
\text { RR } 1.73(95 \% \mathrm{Cl}, 0.95 \text { to } 3.15) \\
\text { A vs. C } \\
\text { Any adverse event: } 47.5 \%(19 / 40) \text { vs. } 15.0 \%(3 / 20), \text { RR } \\
3.17(95 \% \mathrm{Cl}, 1.06 \text { to } 9.45)\end{array}$ \\
\hline $\begin{array}{l}\text { Nilachandra, } \\
2016\end{array}$ & $\begin{array}{l}\text { A vs. B } \\
\text { Pain (mean [SD], } 0 \text { to } 10 \text { VAS) } \\
-1 \text { week: } 3.50(1.16) \text { vs. } 3.25(1.03) \text {, mean difference } 0.25(95 \% \mathrm{Cl},-0.23 \text { to } 0.73) \\
-2 \text { weeks: } 2.54(0.89) \text { vs. } 2.75(0.74) \text {, mean difference }-0.21(95 \% \mathrm{Cl},-0.57 \text { to } 0.15) \\
-3 \text { months: } 1.54(1.15) \text { vs. } 2.84(0.64) \text {, mean difference }-1.30(95 \% \mathrm{Cl},-1.72 \text { to }-0.88) \\
-6 \text { months: } 0.86(0.69 \text { vs. } 2.24(0.93) \text {, mean difference }-1.38(95 \% \mathrm{Cl},-1.75 \text { to }-1.01) \\
\text { ODI (mean [SD], } 0 \text { to } 100 \text { scale) } \\
-1 \text { week: } 38.98(7.61) \text { vs. } 42.45(9.97), \text { mean difference }-3.47(95 \% \mathrm{Cl},-7.36 \text { to } 0.42) \\
-2 \text { weeks: } 34.13(7.94) \text { vs. } 36.20(4.27) \text {, mean difference }-2.07(95 \% \mathrm{Cl},-4.89 \text { to } 0.75) \\
-3 \text { months: } 25.14(7.92) \text { vs. } 36.21(4.67) \text {, mean difference }-12.06(95 \% \mathrm{Cl},-15.01 \text { to }-9.11) \\
-6 \text { months: } 18.28(8.77) \text { vs. } 29.00(6.78) \text {, mean difference }-10.72(95 \% \mathrm{Cl},-14.32 \text { to }-7.12)\end{array}$ & No serious adverse events in either group \\
\hline
\end{tabular}

Abbreviations: $\mathrm{CI}=$ confidence interval; $\mathrm{CT}$ computed tomography; $\mathrm{MRI}=$ magnetic resonance imaging; $\mathrm{NR}=$ not reported; ODI = Oswestry Disability Index; RCT = randomized controlled trial; $\mathrm{RR}=$ risk ratio; $\mathrm{SD}=$ standard deviation; $\mathrm{VAS}=$ visual analogue scale

See Appendix F, List of Included Studies, for full citations 
Table G-18. Trial of sphenopalatine block for trigeminal neuralgia or headaches - study characteristics

\begin{tabular}{|c|c|c|c|c|c|c|c|c|}
\hline $\begin{array}{l}\text { Author, } \\
\text { Year }\end{array}$ & $\begin{array}{c}\text { Study } \\
\text { Design } \\
\text { Duration }\end{array}$ & $\begin{array}{c}\text { Setting/Interventionist } \\
\text { Country }\end{array}$ & Eligibility Criteria & Interventions & $\begin{array}{c}\text { Sample } \\
\text { Characteristics }\end{array}$ & $\begin{array}{c}\text { Screened } \\
\text { Eligible } \\
\text { Randomized } \\
\text { Analyzed } \\
\end{array}$ & Sponsor & Quality \\
\hline $\begin{array}{l}\text { Cady, } \\
2015 a \& \\
\text { b }\end{array}$ & $\begin{array}{l}\text { RCT } \\
1 \text { month }\end{array}$ & $\begin{array}{l}\text { Headache specialty } \\
\text { clinics } \\
\text { U.S. }\end{array}$ & $\begin{array}{l}18 \text { to } 80 \text { years with history of } \\
\text { chronic migraines defined by } \\
\text { the Headache Classification } \\
\text { Committee of the } \\
\text { International Headache } \\
\text { Society ICHD-II appendix } \\
\text { definition } 2006 \text { and by history } \\
\text { for } \geq 3 \text { months, if on migraine } \\
\text { medications (preventive or } \\
\text { abortive) must be stable for } \\
30 \text { days prior to enrollment. } \\
\text { Excluded: nasal problems } \\
\text { that would interfere with the } \\
\text { procedure, neoplasm, nasal } \\
\text { medications that would } \\
\text { confound results, current } \\
\text { cocaine user, treating } \\
\text { migraines with Schedule II } \\
\text { narcotics, allergy to } \\
\text { bupivacaine, pregnant or } \\
\text { breastfeeding, concurrent } \\
\text { cervicogenic headache or } \\
\text { occipital neuralgia, severe } \\
\text { clinical depression or anxiety. }\end{array}$ & $\begin{array}{l}\text { A: Sphenopalatine } \\
\text { block: } 0.5 \% \\
\text { bupivacaine } \\
\text { B: Placebo: saline } \\
\text { sphenopalatine } \\
\text { block }\end{array}$ & $\begin{array}{l}\text { Mean (SD) age, } \\
\text { years: } 41.3(12.6) \\
\text { Female: } 76 \% \\
\text { White: } 83 \% \\
\text { Black: } 10 \% \\
\text { Other race/ethnicity: } \\
7 \% \\
\text { Mean duration of } \\
\text { chronic migraine } \\
\text { diagnosis, years: } \\
8.58 \\
\text { Mean number of } \\
\text { migraine days in a } \\
\text { month: } 15.2 \\
\text { Mean number of } \\
\text { headache days in a } \\
\text { month: } 23.6 \\
\text { Mean (SD) NRS } \\
\text { score (scale } 0 \text { to } 10 \\
\text { scale): } 3.37 \text { (2.7) }\end{array}$ & $\begin{array}{l}\text { Screened: } 55 \\
\text { Eligible: } 43 \\
\text { Randomized: } \\
41 \text { (27 vs. } 14) \\
\text { Analyzed for } \\
\text { primary } \\
\text { outcome: } 38 \\
\text { (26 vs. } 12)\end{array}$ & $\begin{array}{l}\text { Tian } \\
\text { Medical } \\
\text { Inc. }\end{array}$ & Poor \\
\hline
\end{tabular}

Abbreviations: ICHD-II = International Classification of Headache Disorders, second edition; NR = not reported; NRS $=$ numeric rating scale; RCT $=$ randomized controlled trial; SD = standard deviation

\section{See Appendix F, List of Included Studies, for full citations}




\begin{tabular}{|c|c|c|}
\hline $\begin{array}{l}\text { Author, } \\
\text { Year } \\
\text { Trial }\end{array}$ & Results & $\begin{array}{l}\text { Adverse Events and Withdrawals Due to } \\
\text { Adverse Events }\end{array}$ \\
\hline $\begin{array}{l}\text { Cady, } \\
2015 a \\
\& \text { b }\end{array}$ & 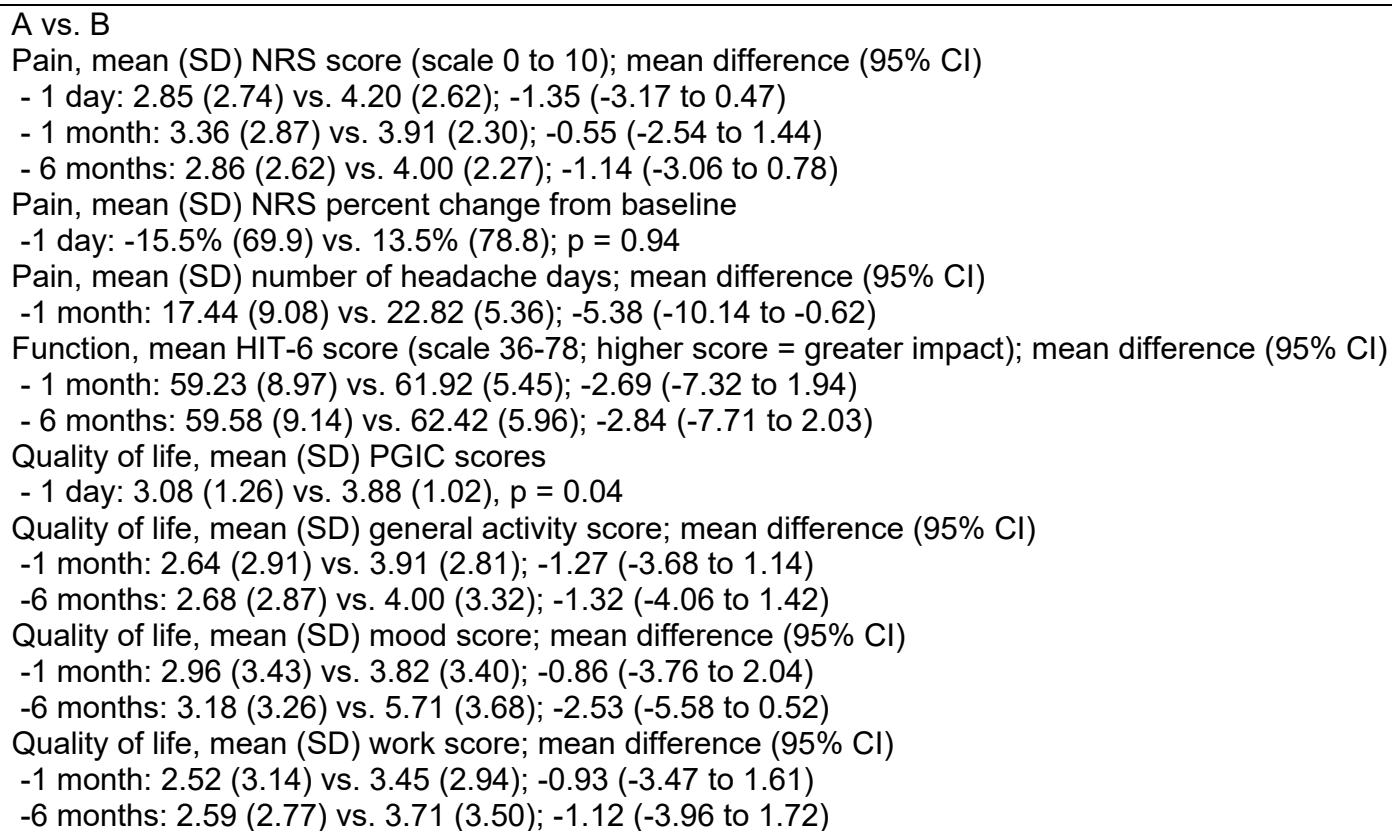 & $\begin{array}{l}\text { A vs. B } \\
\text { Any adverse event, mean (SD): } 7.52 \text { (8.16) vs. } \\
5.00(7.06) ; p=0.30 \\
\text { Serious adverse events: } 0 \%(0 / 27) \text { vs. } 7 \%(1 / 14 ; \\
\text { PE resulting in death } 81 \text { days posttreatment); RR } \\
0.18(95 \% \mathrm{Cl}, 0.01 \text { to } 4.12)\end{array}$ \\
\hline
\end{tabular}

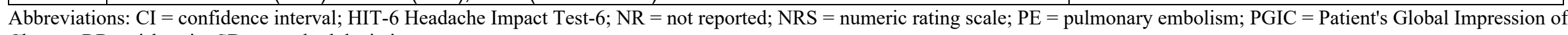
Change; $\mathrm{RR}=$ risk ratio; $\mathrm{SD}=$ standard deviation

See Appendix F, List of Included Studies, for full citations 
Table G-20. Trials of occipital nerve stimulator for various headache disorders - study characteristics

\begin{tabular}{|c|c|c|c|c|}
\hline $\begin{array}{l}\text { Author, Year } \\
\text { Trial }\end{array}$ & $\begin{array}{l}\text { Study } \\
\text { Design } \\
\text { Duration }\end{array}$ & $\begin{array}{c}\text { Setting/Provider } \\
\text { Type } \\
\text { Country }\end{array}$ & Eligibility Criteria & Interventions \\
\hline $\begin{array}{l}\text { Saper, } 2011 \\
\text { ONSTIM }\end{array}$ & $\begin{array}{l}\text { RCT } \\
3 \text { months }\end{array}$ & $\begin{array}{l}9 \text { centers, usually } \\
\text { anesthesiologist } \\
\text { Canada, U.K., and } \\
\text { U.S. }\end{array}$ & $\begin{array}{l}\geq 18 \text { year olds with diagnosis of chronic migraine ( } \geq 15 \text { days/month for } \\
>3 \text { months) refractory to prophylactic treatment from } \geq 2 \text { drug classes } \\
\text { with response to a temporary, short-acting local anesthetic occipital } \\
\text { nerve block ( } \geq 50 \% \text { reduction in migraine pain within } 24 \text { hours) } \\
\text { Excluded: previous destructive ganglionectomy, rhizotomy section or } \\
\text { neurectomy procedure affecting C2/C3/occipital distribution, recent } \\
\text { (within last } 3 \text { years) clinical trial participation, neurostimulation } \\
\text { (implanted or external) for headache or other head or neck pain within } \\
\text { last year }\end{array}$ & $\begin{array}{l}\text { A. Occipital nerve stimulation, adjustable: } 1 \text { or } \\
2 \text { leads implanted subcutaneously superficial } \\
\text { to the fascia and muscle layer at } C 1 \text { level; } \\
\text { pulse frequency } 3 \text { to } 130 \mathrm{~Hz} \text {, pulse width } 60 \\
\text { to } 450 \mu \mathrm{s} \text {, pulse amplitude } 0 \text { to } 10.5 \mathrm{~V} \text {; } \\
\text { parameters adjustable by patient to minimize } \\
\text { pain } \\
\text { B. Occipital nerve stimulation, preset: As } \\
\text { above, but stimulator preset to } 1 \text { minute per } \\
\text { day stimulation } \\
\text { C. Usual care }\end{array}$ \\
\hline Serra, 2012 & $\begin{array}{l}\text { RCT } \\
\text { (crossover) } \\
1 \text { month } \\
\text { (per } \\
\text { crossover } \\
\text { period) }\end{array}$ & $\begin{array}{l}1 \text { center, surgeon } \\
\text { Italy }\end{array}$ & $\begin{array}{l}\geq 18 \text { year old outpatients with chronic migraine or medication overuse } \\
\text { headache refractory to } \geq 2 \text { prophylactic treatments or with intolerable } \\
\text { side effects to treatment, }>50 \% \text { reduction in number or severity of } \\
\text { attacks within } 15 \text { to } 30 \text { days of temporary occipital nerve stimulation } \\
\text { implantation } \\
\text { Excluded: previous occipital surgery, destructive ganglionectomy, } \\
\text { local drug injection, or nerve-blocks in the last } 90 \text { days }\end{array}$ & $\begin{array}{l}\text { A. Occipital nerve stimulation: Percutaneous } \\
\text { quadripolar lead implanted under local } \\
\text { anesthetic and mild sedation. Permanent } \\
\text { neurostimulator implanted; stimulation at } \\
\text { frequency of } 50 \mathrm{~Hz} \text {, pulse width } 330 \text { to } 450 \\
\text { us, maximum stimulation amplitude } 10.5 \mathrm{~V} \text {. } \\
\text { B. Sham occipital nerve stimulation: As } \\
\text { above, but internal neurostimulator was } \\
\text { inactive (turned off) }\end{array}$ \\
\hline $\begin{array}{l}\text { Silberstein, } \\
2012\end{array}$ & $\begin{array}{l}\mathrm{RCT} \\
12 \text { weeks }\end{array}$ & $\begin{array}{l}15 \text { centers, surgery } \\
\text { U.S. }\end{array}$ & $\begin{array}{l}\text { Diagnosed with chronic migraine headache with the following criteria: } \\
\text { headaches on } \geq 15 \text { days per month for }>3 \text { months, average headache } \\
\text { duration of }>4 \text { hours/day, met IHS criteria for migraine without aura } \\
\text { (1.1), migraine with aura (1.2) or probable migraine (1.6) on }>50 \% \text { of } \\
\text { headache days, headache not attributable to another disorder; } \\
\text { previously tried } \geq 2 \text { migraine specific acute medications; refractory to } \\
\geq 2 \text { different classes of prophylactic medications; pain } \geq 6 \text { on } 0 \text { to } 10 \\
\text { VAS; headache location posterior head or cervical region; } \geq 50 \% \\
\text { reduction in pain or adequate paresthesia coverage in painful areas } \\
\text { with trial stimulation } \\
\text { Excluded: medication overuse headaches; prior destructive procedure } \\
\text { affecting C } 2 / C 3 / \text { occipital distribution; started new medications or } \\
\text { therapy to treat headaches within } 8 \text { weeks; received neurotoxin } \\
\text { therapy within } 6 \text { months; met IHS criteria for chronic tension-type } \\
\text { headache, hypnic headache, hemicrania continua, or new daily } \\
\text { persistent headache }\end{array}$ & $\begin{array}{l}\text { A: Occipital nerve stimulation: Leads placed } \\
\text { on either side of midline caudally along the } \\
\text { nerve or, more commonly, perpendicular to } \\
\text { the course of the occipital nerves at the level } \\
\text { of the craniocervical junction. Stimulation } \\
\text { parameters not reported ("programmed for } \\
\text { appropriate stimulation"). } \\
\text { B: Sham occipital nerve stimulation: Leads } \\
\text { placed as above, but no stimulation } \\
\text { administered. }\end{array}$ \\
\hline $\begin{array}{l}\text { Mekhail, } 2017 \\
\text { (single center } \\
\text { from Silberstein } \\
\text { 2012) }\end{array}$ & $\begin{array}{l}\text { RCT } \\
12 \text { weeks }\end{array}$ & $\begin{array}{l}\text { Single center from } \\
\text { the Silberstein, } 2012 \\
\text { study }\end{array}$ & See Silberstein, 2012 & See Silberstein, 2012 \\
\hline
\end{tabular}

Abbreviations: IHS = International Headache Society; ONSTIM = occipital nerve stimulation for the treatment of intractable chronic migraine headache; RCT = randomized controlled trial;

U.K. $=$ United Kingdom; U.S. $=$ United States; VAS = visual analogue scale

See Appendix F, List of Included Studies, for full citations 
Table G-21. Trials of occipital nerve stimulator for various headache disorders - additional study characteristics

\begin{tabular}{|c|c|c|c|c|}
\hline $\begin{array}{l}\text { Author, } \\
\text { Year } \\
\text { Trial } \\
\end{array}$ & Sample Characteristics & \begin{tabular}{|l|} 
Screened \\
Eligible \\
Randomized \\
Complete Followup \\
Analyzed \\
\end{tabular} & Sponsor & Quality \\
\hline $\begin{array}{l}\text { Saper, } 2011 \\
\text { ONSTIM }\end{array}$ & $\begin{array}{l}\text { Mean (SD) age, years: } 43(10.6) \\
\text { Female: } 80 \% \\
\text { Race: NR } \\
\text { Mean (SD) duration of migraine, years: } 22(12.3) \\
\text { Mean (SD) number of headache days/month: } 23.2(5.4) \\
\text { A vs. B vs. C } \\
\text { Baseline pain: NR } \\
\text { Baseline disability score (mean [SD], scale NR): } 4.0(0.2) \text { vs. } 3.9(0.3) \text { vs. } 4.0(0.0)\end{array}$ & $\begin{array}{l}\text { Screened: } 110 \\
\text { Eligible: NR } \\
\text { Randomized: } 67 \text { (33 vs. } \\
17 \text { vs. } 17) \\
\text { Completed followup: } 61 \\
\text { (28 vs. } 16 \text { vs. } 17) \\
\text { Analyzed: } 61(28 \text { vs. } 16 \\
\text { vs. } 17) \text { at } 3 \text { months }\end{array}$ & $\begin{array}{l}\text { Medtronic } \\
\text { Neuromodulation }\end{array}$ & Fair \\
\hline Serra, 2012 & $\begin{array}{l}\text { Mean (SD) age, years: } 46(11) \\
\text { Female: } 76 \% \\
\text { Race: NR } \\
\text { Duration of migraine diagnosis: NR } \\
\text { Baseline headache severity (median [IQR], } 0 \text { to } 10 \mathrm{NRS}): 8(7-8) \\
\text { Baseline headache days/week (mean [SD]): } 5.8(1.6) \\
\text { Baseline MIDAS score (median [IQR], >20 = severe disability): } 79(30-135)\end{array}$ & $\begin{array}{l}\text { Screened: NR } \\
\text { Eligible: } 34 \\
\text { Randomized: } 30 \\
\text { Completed followup: } 29 \\
\text { Analyzed: } 29\end{array}$ & $\begin{array}{l}\text { No external } \\
\text { funding }\end{array}$ & Poor \\
\hline $\begin{array}{l}\text { Silberstein, } \\
2012\end{array}$ & $\begin{array}{l}\text { Mean (SD) age, years: } 44.9(11.0) \\
\text { Female: } 79 \% \\
\text { Duration of headaches, mean (SD) years: } 23.3(14.4) \\
\text { Mean (SD) number of headache days: } 21.3(7.0) \\
\text { Unilateral headaches: } 31.8 \% \\
\text { Bilateral headaches: } 68.2 \% \\
\text { A vs. B } \\
\text { Baseline pain (mean [SD], } 0 \text { to } 100 \text { VAS transformed to } 0 \text { to } 10 \text { scale): } 5.99(1.68) \text { vs. } 5.60 \text { (1.70) } \\
\text { Baseline MIDAS score (mean [SD], >20 = severe disability): } 158.4(76.8) \text { vs. } 152.7(77.1)\end{array}$ & $\begin{array}{l}\text { Screened: } 268 \\
\text { Eligible: } 187 \\
\text { Randomized: } 157 \text { (105 } \\
\text { vs. } 52 \text { ) } \\
\text { Completed followup } 157 \\
\text { (105 vs. } 52) \\
\text { Analyzed: } 157 \text { (105 vs. } \\
52)\end{array}$ & $\begin{array}{l}\text { St. Jude Medical } \\
\text { Neuromodulation } \\
\text { Division }\end{array}$ & Fair \\
\hline $\begin{array}{l}\text { Mekhail, } \\
2017 \text { (single } \\
\text { center from } \\
\text { Silberstein } \\
\text { 2012) }\end{array}$ & $\begin{array}{l}\text { Mean (SD) age, years: } 44.6(12.6) \\
\text { Female: } 75 \% \\
\text { Mean (SD) headache duration, hours: } 18.5(15.1) \\
\text { Cause of headaches } \\
\text { - Unknown: } 70 \% \\
\text { - Trauma: } 15 \% \\
\text { - Other: } 15 \% \\
\text { Bilateral headaches: } 65 \% \\
\text { Unilateral headaches: } 35 \% \\
\text { A vs. B } \\
\text { Baseline pain (mean [SD], } 0 \text { to } 100 \text { VAS transformed to } 0 \text { to } 10 \text { scale): } 5.09 \text { (1.80) vs. } 5.99(2.34) \\
\text { Baseline MIDAS score (mean [SD], >20 = severe disability): } 168.00(55.36) \text { vs. } 183.33(60.43)\end{array}$ & $\begin{array}{l}\text { Screened: NR } \\
\text { Eligible: NR } \\
\text { Randomized: } 20 \text { (14 vs. } \\
6 \text { ) } \\
\text { Analyzed: } 20 \text { (14 vs. } 6 \text { ) }\end{array}$ & $\begin{array}{l}\text { See Silberstein, } \\
2012\end{array}$ & Fair \\
\hline
\end{tabular}

Abbreviations: IQR = interquartile range; MIDAS = migraine disability assessment; NR = not reported; ONSTIM = occipital nerve stimulation for the treatment of intractable chronic migraine headache; $\mathrm{SD}=$ standard deviation; $\mathrm{VAS}=$ visual analogue scale

See Appendix F, List of Included Studies, for full citations 


\begin{tabular}{|c|c|c|}
\hline $\begin{array}{l}\text { Author, } \\
\text { Year } \\
\text { Trial }\end{array}$ & Results & $\begin{array}{l}\text { Adverse Events and Withdrawals Due to Adverse } \\
\text { Events }\end{array}$ \\
\hline $\begin{array}{l}\text { Saper, } \\
2011 \\
\text { ONSTIM }\end{array}$ & 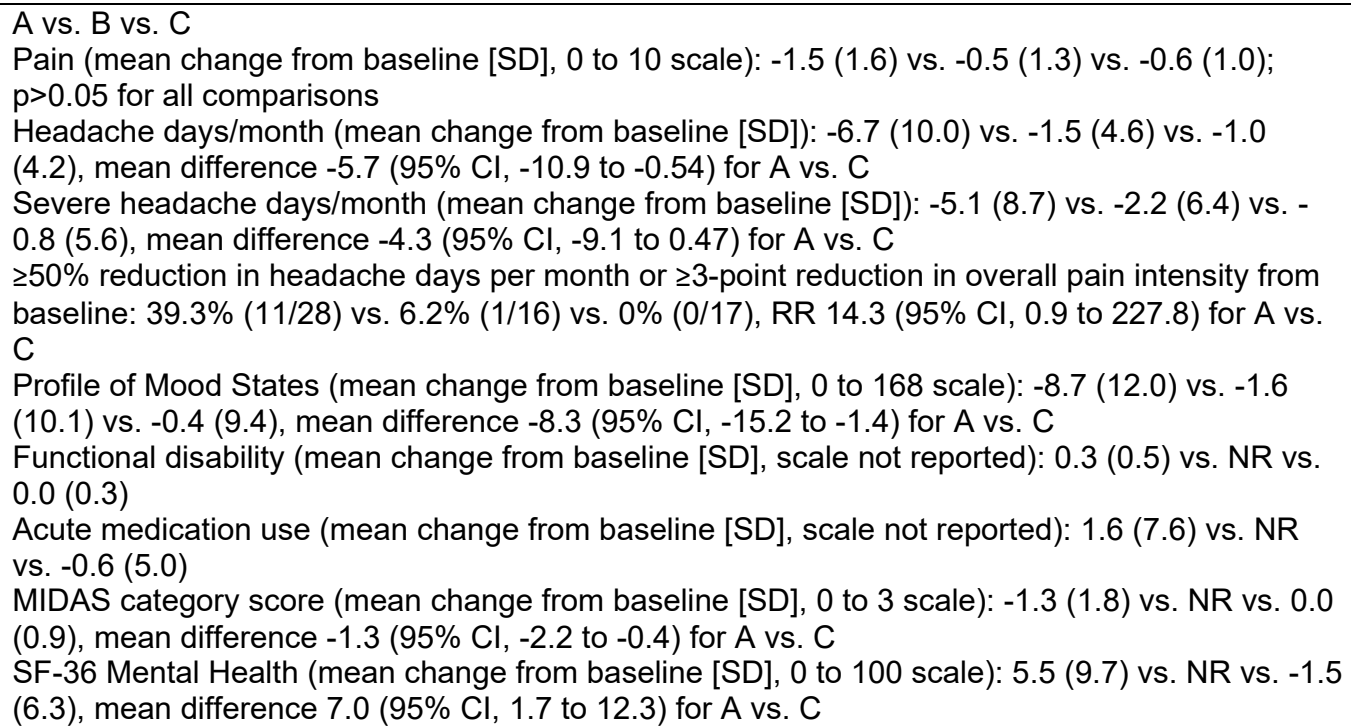 & $\begin{array}{l}\text { A vs. B vs. C vs. D } \\
\text { Any non-device-related adverse event: } 52 \%(17 / 33) \text { vs. } \\
76 \%(13 / 17) \text { vs. } 53 \%(9 / 17) \text { vs. } 75 \%(6 / 8) ; p>0.05 \text { for all } \\
\text { comparisons } \\
\text { Overall } \\
\text { Intraoperative failure: } 3.8 \%(2 / 53) \\
\text { Serious device-related adverse event requiring } \\
\text { hospitalization: } 5.9 \%(3 / 51) \text { (implant site infection, lead } \\
\text { migration, postoperative nausea) } \\
\text { Lead migration: } 24 \%(12 / 51) \\
\text { Long-term complications or nerve damage: None }\end{array}$ \\
\hline $\begin{array}{l}\text { Serra, } \\
2012\end{array}$ & $\begin{array}{l}\text { A vs. B } \\
\text { Pain (median [IQR], } 0 \text { to } 10 \text { scale), first crossover period: } 5 \text { ( } 5 \text { to } 6) \text { vs. } 7.5(7.8), p<0.001 \\
\text { Headache days/week (median [IQR]), first crossover period: } 2.1 \text { (1.2 to } 3.3) \text { vs. } 6.3(3.6 \text { to } 7) \text {, } \\
p<0.001\end{array}$ & $\begin{array}{l}\text { Overall: } 5 \text { adverse events ( } 2 \text { severe infections, } 3 \text { lead } \\
\text { migration) }\end{array}$ \\
\hline $\begin{array}{l}\text { Silberstein, } \\
2012\end{array}$ & $\begin{array}{l}\text { A vs. B } \\
\geq 50 \% \text { reduction in headache pain intensity: } 17.1 \%(18 / 105) \text { vs. } 13.5 \%(7 / 52), \mathrm{RR} 1.27(95 \% \mathrm{Cl} \text {, } \\
0.57 \text { to } 2.86) \\
\geq 30 \% \text { reduction in headache pain intensity: } 33.3 \%(35 / 105) \text { vs. } 17.3 \%(9 / 52), \mathrm{RR} 1.93(95 \% \mathrm{Cl} \text {, } \\
1.00 \text { to } 3.70) \\
\text { Headache days (mean change from baseline [SD NR]): }-27.2 \% \text { vs. }-14.9 \%, \mathrm{p}<0.05 \\
\text { "Good" or "excellent" headache relief: } 50 \%(52 / 105) \text { vs. } 18 \%(9 / 52), \mathrm{RR} 2.86(95 \% \mathrm{Cl}, 1.53 \text { to } \\
5.34) \\
\text { MIDAS score (mean [SD NR], >20 severe disability) at } 12 \text { weeks: }-64.6 \text { vs. }-20.4 \text {, mean } \\
\text { difference }-44.2(95 \% \mathrm{Cl},-65.3 \text { to }-22.8)\end{array}$ & $\begin{array}{l}\text { A vs. B } \\
\text { Total adverse events: } 73 \text { vs. } 34 \\
\text { Lead migration: } 14.0 \% \text { vs. } 4.7 \%, p=0.41 \\
\text { Lead breakage/fracture: } 1.9 \% \text { vs. } 0 \%, p>0.05 \\
\text { Persistent pain and/or numbness at IPG/lead site: } \\
13.1 \% \text { vs. } 8.4 \%, p=0.63 \\
\text { Skin erosion: } 3.7 \% \text { vs. } 2.8 \%, p=1.0 \\
\text { Wound site complications: } 2.8 \% \text { vs. } 0.9 \%, p=1.0 \\
\text { Non-device/procedure-related adverse events: } 7.5 \% \text { vs. } \\
1.9 \%, p=0.50\end{array}$ \\
\hline
\end{tabular}




\begin{tabular}{|c|c|c|}
\hline $\begin{array}{l}\text { Author, } \\
\text { Year } \\
\text { Trial } \\
\end{array}$ & Results & $\begin{array}{l}\text { Adverse Events and Withdrawals Due to Adverse } \\
\text { Events }\end{array}$ \\
\hline $\begin{array}{l}\text { Mekhail, } \\
2017 \\
\text { (single } \\
\text { center } \\
\text { from } \\
\text { Silberstein, } \\
2012 \text { ) }\end{array}$ & $\begin{array}{l}\text { A vs. B } \\
\geq 50 \% \text { reduction in headache pain intensity: } 17.1 \%(4 / 14) \text { vs. } 0 \%(0 / 6), \mathrm{RR} 0.71(95 \% \mathrm{Cl}, 0.51 \text { to } \\
0.99)^{*} \\
\geq 30 \% \text { reduction in headache pain intensity: } 85.7 \%(12 / 14) \text { vs. } 66.7 \%(4 / 6), \mathrm{RR} 0.43(95 \% \mathrm{Cl} \text {, } \\
0.08 \text { to } 2.37)^{*} \\
\text { Patients who achieved } \% \text { average daily VAS reduction and no increase in headache duration or } \\
\text { frequency } \\
-30 \% \text { at } 12 \text { weeks: } 86 \%(12 / 14) \text { vs. } 66 \%(4 / 6), p=0.373 \\
-50 \% \text { at } 12 \text { weeks: } 29 \%(4 / 14) \text { vs. } 0 \%, p=0.018 \\
\text { Average daily pain intensity (mean change from baseline [SD], } 0 \text { to } 100 \text { VAS transformed to } 0 \text { to } \\
10 \text { scale) } \\
-4 \text { weeks: }-2.16(1.02) \text { vs. } 0.34(0.99), p<0.001 \\
-12 \text { weeks: }-2.30(1.15) \text { vs. } 0.79(1.06), p<0.001 \\
\text { Headache days (mean change from baseline }[S D]) \\
-4 \text { weeks: }-11.50(6.29) \text { vs. }-0.95(5.93), p<0.05 \\
-12 \text { weeks: }-12.32(8.88) \text { vs. }-0.15(5.27), p=0.02 \\
\text { MIDAS score (mean change from baseline }[S D],>20=\text { severe disability) } \\
-12 \text { weeks: }-85.21(40.63) \text { vs. }-12.17(60.43), p=0.008\end{array}$ & $\begin{array}{l}\text { A vs. B } \\
\text { Any adverse events: } 35.7 \%(5 / 14) \text { vs. } 50 \%(3 / 6) \\
\text { Stimulation related: } 0 \% \text { vs. } 17 \%(1 / 6) \\
\text { - Nausea/vomiting: } 0 \% \text { vs. } 17 \%(1 / 6) \\
\text { Hardware related: } 14 \%(2 / 14) \text { vs. } 33 \%(2 / 6) \\
\text { - Lead migration: } 14 \%(2 / 14) \text { vs. } 17 \%(1 / 6) \\
\text { Persistent pain or numbness: } 7 \%(1 / 14) \text { vs. } 0 \% \\
\text { Wound site complication: } 7 \%(1 / 14) \text { vs. } 0 \%\end{array}$ \\
\hline
\end{tabular}

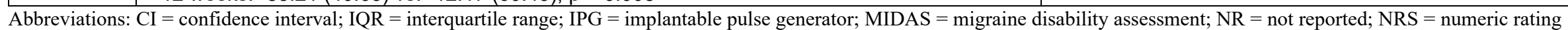
scale; ONSTIM = occipital nerve stimulation for the treatment of intractable chronic migraine headache; RR = risk ratio; $\mathrm{SD}=$ standard deviation; $\mathrm{SF}-36=\mathrm{Short}-\mathrm{Form} 36 ; \mathrm{VAS}=$ visual analogue scale

\section{See Appendix F, List of Included Studies, for full citations}


Table G-23. Trials of piriformis injection for piriformis syndrome - study characteristics

\begin{tabular}{|c|c|c|c|c|}
\hline $\begin{array}{l}\text { Author, } \\
\text { Year } \\
\text { Trial }\end{array}$ & $\begin{array}{c}\text { Study } \\
\text { Design } \\
\text { Duration }\end{array}$ & $\begin{array}{c}\text { Setting/Provider } \\
\text { Type } \\
\text { Country }\end{array}$ & Eligibility Criteria & Interventions \\
\hline $\begin{array}{l}\text { Childers, } \\
2002\end{array}$ & $\begin{array}{l}\text { RCT } \\
\text { (crossover) } \\
10 \text { weeks }\end{array}$ & $\begin{array}{l}1 \text { center, physical } \\
\text { medicine and } \\
\text { rehabilitation clinic } \\
\text { U.S. }\end{array}$ & $\begin{array}{l}>18 \text { years; buttock, hip, and lower limb intermittent } \\
\text { positional pain for } \geq 3 \text { months reproduced by } 2 \text { of } 3 \\
\text { maneuvers: palpation over point midway between the } \\
\text { sacrum and greater trochanter of the femur, active hip } \\
\text { abduction in the lateral recumbent position, and rectal } \\
\text { palpation of the ipsilateral side of the involved limb; } \\
\text { pain aggravated by sitting, stair climbing, and leg } \\
\text { crossing; pain }>5 \text { on } 0 \text { to } 10 \text { VAS } \\
\text { Excluded: imaging studies demonstrated evidence of a } \\
\text { herniated lumbar disk or nerve root impingement, or } \\
\text { electromyographic examination demonstrated } \\
\text { spontaneous discharges in the lumbar paraspinal } \\
\text { muscles suggestive of pathology proximal to the sciatic } \\
\text { notch. }\end{array}$ & $\begin{array}{l}\text { A: Botulinum toxin type A piriformis injection : } 100 \text { units } \\
\text { intramuscular injection under fluoroscopic guidance to piriformis } \\
\text { muscle; placement verified with electromyography and pattern } \\
\text { of radiotracer spread } \\
\text { B: Placebo injection : Intramuscular preservative-free normal } \\
\text { saline injection as above } \\
\text { Crossover occurred after } 10 \text { weeks }\end{array}$ \\
\hline $\begin{array}{l}\text { Fishman, } \\
2002\end{array}$ & $\begin{array}{l}\mathrm{RCT} \\
3 \text { months }\end{array}$ & $\begin{array}{l}1 \text { center, physical } \\
\text { medicine and } \\
\text { rehabilitation } \\
\text { U.S. }\end{array}$ & $\begin{array}{l}\text { Buttock tenderness and sciatica, with positive FAIR } \\
\text { test (defined as prolongation of posterior tibial H-reflex } \\
>1.86 \mathrm{~ms} \text { ) } \\
\text { Excluded: NR }\end{array}$ & $\begin{array}{l}\text { A: Botulinum toxin type A piriformis injection: } 200 \text { units } 2 \mathrm{ml} \\
\text { intramuscular injection under electromyographic guidance } \\
\text { (based on location of points at which } 2 \text { to } 6 \mathrm{~mA} \text { at } 0.05 \mathrm{~ms} \\
\text { stimulus duration stimulated significant motility along the course } \\
\text { of the piriformis muscle) } \\
\text { B: Corticosteroid piriformis injection: Triamcinolone acetonide: } \\
20 \mathrm{mg} \text { in } 0.5 \mathrm{ml} \text { solution }+1.5 \mathrm{ml} \text { of } 2 \% \text { lidocaine ( } 2 \mathrm{ml} \text { total } \\
\text { injection volume) intramuscular injection, as above } \\
\text { C: Placebo injection: } 2 \mathrm{ml} \text { saline intramuscular injection as } \\
\text { above } \\
\text { All groups received physical therapy twice weekly (ultrasound, } \\
\text { hot packs or cold spray, stretching, myofascial release, } \\
\text { McKenzie exercise, lumbosacral corset when in the flexion, } \\
\text { adduction, and internal rotation position) }\end{array}$ \\
\hline $\begin{array}{l}\text { Fishman, } \\
2017\end{array}$ & $\begin{array}{l}\mathrm{RCT} \\
3 \text { months }\end{array}$ & $\begin{array}{l}1 \text { center, physical } \\
\text { medicine and } \\
\text { rehabilitation } \\
\text { U.S. }\end{array}$ & $\begin{array}{l}\geq 18 \text { years; } \geq 2 \text { of the following conditions: buttock pain, } \\
\text { sciatica, tenderness at the intersection of the piriformis } \\
\text { muscle and sciatic nerve; or positive straight-leg raise } \\
\text { of } \leq 60^{\circ} \text {, or } 15^{\circ} \text { deficit on the affected side; functional } \\
\text { prolongation of the posterior tibial or fibular nerve H- } \\
\text { reflex (>1.86 ms, positive FAIR test) } \\
\text { Excluded: positive sharp waves or fibrillation potentials } \\
\text { in the lumbar paraspinal muscles on EMG assessment; } \\
\text { thrombocytopenia; anticoagulation; autoimmune } \\
\text { disease; previous exposure to BTX-A; previous buttock } \\
\text { surgery; neuromuscular disease; weight < }<0 \text { pounds; } \\
\text { vascular anomalies. }\end{array}$ & $\begin{array}{l}\text { A: Botulinum toxin type A piriformis injection: } 300 \text { units } 3 \mathrm{ml} \\
\text { intramuscular injection to } 4 \text { piriformis muscle sites (the most } \\
\text { medial injection was made just lateral to the greater sciatic } \\
\text { foramen along the line linking its midpoint to the greater } \\
\text { trochanter) including the myoneural junctions of the } \mathrm{S} 1 \text { to } \mathrm{S} 2 \\
\text { nerve fibers that innervate the piriformis muscle; placement with } \\
\text { electromyographic guidance } \\
\text { B: Placebo injection: } 3 \text { ml saline injection as above } \\
\text { Both groups received physical therapy weekly (piriformis } \\
\text { muscle stretch and ultrasound) }\end{array}$ \\
\hline
\end{tabular}




\begin{tabular}{|c|c|c|c|c|}
\hline $\begin{array}{l}\text { Author, } \\
\text { Year } \\
\text { Trial }\end{array}$ & $\begin{array}{l}\text { Study } \\
\text { Design } \\
\text { Duration }\end{array}$ & $\begin{array}{c}\text { Setting/Provider } \\
\text { Type } \\
\text { Country }\end{array}$ & Eligibility Criteria & Interventions \\
\hline $\begin{array}{l}\text { Misirlioglu, } \\
2015\end{array}$ & $\begin{array}{l}\text { RCT } \\
3 \text { months }\end{array}$ & $\begin{array}{l}1 \text { center, physical } \\
\text { medicine and } \\
\text { rehabilitation } \\
\text { Turkey }\end{array}$ & $\begin{array}{l}18 \text { to } 70 \text { years; unilateral hip and/or leg pain with } \\
\text { positive FAIR test and tenderness and/or trigger point } \\
\text { at the piriformis muscle. } \\
\text { Excluded: neurological deficit; limited lumbar and/or hip } \\
\text { range of motion; prior surgery at the lumbar and/or hip } \\
\text { region; BMI > } 35 \mathrm{~kg} / \mathrm{m}^{2} \text {; history of inflammatory or } \\
\text { infectious disease; active psychiatric disease; } \\
\text { uncontrolled hypertension; uncontrolled diabetes } \\
\text { mellitus; uncompensated chronic heart/liver/renal } \\
\text { deficiency; vascular/tumoral disease. }\end{array}$ & $\begin{array}{l}\text { A: Corticosteroid piriformis injection: } 1 \mathrm{ml} \text { betametazone }+4 \mathrm{ml} \\
2 \% \text { lidocaine intramuscular injection to piriformis muscle with } \\
\text { ultrasound guidance } \\
\text { B: Sham injection: } 5 \mathrm{ml} 2 \% \text { lidocaine intramuscular injection to } \\
\text { piriformis muscle with ultrasound guidance }\end{array}$ \\
\hline
\end{tabular}

Abbreviations: BMI = body mass index; BTX-A = botulinum toxin type-A; FAIR = flexion, adduction, internal rotation; NR = not reported; RCT = randomized controlled trial; VAS = visual analogue scale

See Appendix F, List of Included Studies, for full citations 
Table G-24. Trials of piriformis injection for piriformis syndrome - additional study characteristics

\begin{tabular}{|c|c|c|c|c|}
\hline $\begin{array}{l}\text { Author, } \\
\text { Year }\end{array}$ & Sample Characteristics & $\begin{array}{l}\text { Screened } \\
\text { Eligible } \\
\text { Randomized } \\
\text { Analyzed } \\
\end{array}$ & Sponsor & Quality \\
\hline $\begin{array}{l}\text { Childers, } \\
2002\end{array}$ & $\begin{array}{l}\text { Mean (SD) age: } 42.1(5.7) \\
\text { Female: } 100 \% \\
\text { Race: NR } \\
\text { Mean (SD) duration of symptoms: } 38.7 \text { (21) months } \\
\text { A vs. B } \\
\text { Baseline pain (mean [SD], } 0 \text { to } 10 \text { VAS): } 7.6(1.9) \text { vs. } 7.4(1.6) \\
\text { Baseline interference with activities (mean [SD], } 0 \text { to } 10 \text { VAS): } 7.8(2.1) \text { vs. } 7.7 \\
\text { (1.7) } \\
\text { Baseline distress (mean [SD], } 0 \text { to } 10 \text { VAS): } 6.8(2.6) \text { vs. } 7.5(1.7)\end{array}$ & $\begin{array}{l}\text { Screened: NR } \\
\text { Eligible: NR } \\
\text { Randomized: } 10 \\
\text { Completed followup: } 9 \\
\text { Analyzed: } 9\end{array}$ & NR & Poor \\
\hline $\begin{array}{l}\text { Fishman, } \\
2002\end{array}$ & $\begin{array}{l}\text { Mean (SD) age, years: } 57.4(13.4) \\
\text { Female: } 67 \% \\
\text { Race: NR } \\
\text { Mean (SD) duration of sciatica, years: } 3.2(3.6) \\
\text { Baseline pain, function: NR }\end{array}$ & $\begin{array}{l}\text { Screened: NR } \\
\text { Eligible: NR } \\
\text { Randomized: } 87 \text { ( } 26 \text { vs. } 37 \text { vs. } 24) \\
\text { Completed followup: } 67 \text { ( } 31 \text { vs. } 21 \\
\text { vs. } 15) \\
\text { Analyzed: } 67 \text { ( } 31 \text { vs. } 21 \text { vs. } 15)\end{array}$ & NR & Poor \\
\hline $\begin{array}{l}\text { Fishman, } \\
2017\end{array}$ & $\begin{array}{l}\text { Mean age: NR } \\
\text { Female: NR } \\
\text { Race: NR } \\
\text { A vs. B } \\
\text { Baseline pain (mean [SD], unclear scale): } 0.71\end{array}$ & $\begin{array}{l}\text { Screened: NR } \\
\text { Eligible: NR } \\
\text { Randomized: } 56(26 \text { vs. } 28) \\
\text { Analyzed: } 29 \text { ( } 25 \text { vs. } 24) \text { at } 4 \text { weeks, } \\
38 \text { (19 vs. } 19) \text { at } 8 \text { weeks, } 15 \text { ( } 9 \text { vs. } \\
6 \text { ) at } 12 \text { weeks }\end{array}$ & NR & Poor \\
\hline $\begin{array}{l}\text { Misirlioglu, } \\
2015\end{array}$ & $\begin{array}{l}\text { Mean (SD) age, years: } 46.3 \text { (13.8) } \\
\text { Female: } 84 \% \\
\text { Race: NR } \\
\text { Mean (SD) symptom duration, months: } 20.3(29.5) \\
\text { Left side pain: } 60 \% \\
\text { Right side pain: } 40 \% \\
\text { Local pain: } 17 \% \\
\text { Radiating pain: } 83 \% \\
\text { History of trauma: } 42 \% \\
\text { A vs. B } \\
\text { Baseline pain at rest (mean [SD], } 0 \text { to } 10 \text { VAS): } 3.6(3.1) \text { vs. } 2.8 .(3.1) \\
\text { Baseline pain with activity (mean [SD], } 0 \text { to } 10 \text { VAS): } 7.4(2.4) \text { vs. } 7.2(2.0) \\
\text { Baseline pain during sleep (mean [SD], } 0 \text { to } 10 \text { VAS): } 3.8(3.9) \text { vs. } 3.3(3.2)\end{array}$ & $\begin{array}{l}\text { Screened: } 57 \\
\text { Eligible: } 50 \\
\text { Randomized: } 50 \text { ( } 25 \text { vs. } 25) \\
\text { Completed followup: } 47 \text { (25 vs. } 22) \\
\text { Analyzed: } 47 \text { (25 vs. } 22)\end{array}$ & None & Fair \\
\hline
\end{tabular}

Abbreviations: $\mathrm{NR}=$ not reported; $\mathrm{SD}$ = standard deviation; VAS = visual analogue scale

See Appendix F, List of Included Studies, for full citations 


\begin{tabular}{|c|c|c|}
\hline $\begin{array}{l}\text { Author, } \\
\text { Year }\end{array}$ & Results & $\begin{array}{l}\text { Adverse Events and Withdrawals Due to } \\
\text { Adverse Events }\end{array}$ \\
\hline $\begin{array}{l}\text { Childers, } \\
2002\end{array}$ & 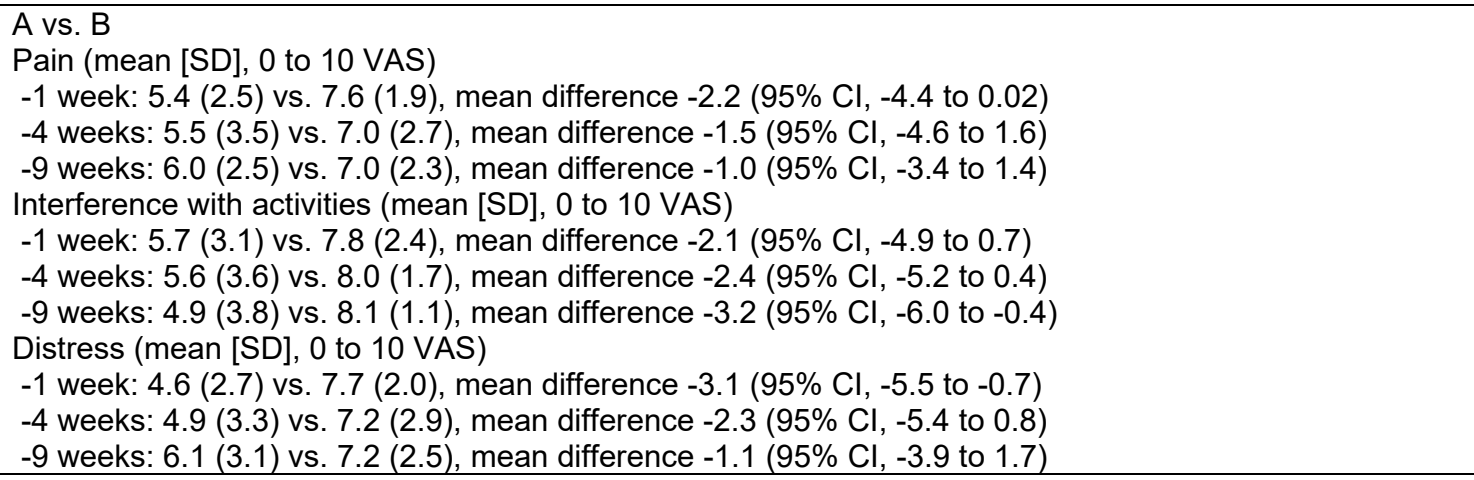 & No serious adverse events \\
\hline $\begin{array}{l}\text { Fishman, } \\
2002\end{array}$ & $\begin{array}{l}\text { A vs. B vs. C } \\
\geq 50 \% \text { improvement in pain VAS at last } 2 \text { visits (through week } 12): 65 \%(13 / 21) \text { vs. } 32 \%(10 / 31) \text { vs. } 6 \% \\
(1 / 15) ; \text { RR } 9.29(95 \% \text { Cl, } 1.36 \text { to } 63.53) \text { for A vs. C, RR } 4.84(95 \% \mathrm{Cl}, 0.68 \text { to } 34.39) \text { for B vs. C, RR } 1.92 \\
(95 \% \mathrm{Cl}, 1.04 \text { to } 3.53) \text { for A vs. B }\end{array}$ & NR \\
\hline $\begin{array}{l}\text { Fishman, } \\
2017\end{array}$ & $\begin{array}{l}\text { A vs. } B \\
\text { Pain intensity (mean change from baseline [SD], unclear scale) } \\
-2 \text { weeks: }-0.36(0.23) \text { vs. }-0.04(0.19), p<0.0001 \\
-4 \text { weeks: }-0.39(0.31) \text { vs. }-0.05(0.12), p<0.0001 \\
-6 \text { weeks: }-0.55(0.29) \text { vs. }-0.04(0.10), p<0.001 \\
-8 \text { weeks: }-0.65(0.16) ; 0.00(0.13), p<0.001 \\
-10 \text { weeks: }-0.55(0.31) \text { vs. }-0.04(0.10), p<0.0001 \\
-12 \text { weeks: }-0.65(0.24) \text { vs. }-0.008(0.02), p<0.0001\end{array}$ & $\begin{array}{l}\text { A vs. B } \\
\text { Any adverse event: } 18.5 \%(5 / 27) \text { vs. } 19.2 \% \\
(5 / 26) \text {, RR } 0.96(95 \% \mathrm{Cl}, 0.32 \text { to } 2.94)\end{array}$ \\
\hline $\begin{array}{l}\text { Misirlioglu, } \\
2015\end{array}$ & $\begin{array}{l}\text { A vs. B } \\
\text { Pain at rest (mean [SD], } 0 \text { to } 10 \text { VAS) } \\
\text { - } 1 \text { week: } 1.4(2.7) \text { vs. } 1.0(2.1) \text {, mean difference } 0.40(95 \% \mathrm{Cl},-0.97 \text { to } 1.77) \\
\text { - } 1 \text { month: } 1.7(2.9) \text { vs. } 0.5(1.1) \text {, mean difference } 1.20(95 \% \mathrm{Cl},-0.03 \text { to } 2.43) \\
\text { - } 3 \text { months: } 1.6(2.1) \text { vs. } 0.4(1.1) \text {, mean difference } 1.20(95 \% \mathrm{Cl}, 0.26 \text { to } 2.14) \\
\text { Pain with activity (mean [SD], } 0 \text { to } 10 \text { VAS) } \\
\text { - } 1 \text { week: } 4.6(3.0) \text { vs. } 3.5(2.6) \text {, mean difference } 1.10(95 \% \mathrm{Cl},-0.50 \text { to } 2.70) \\
\text { - } 1 \text { month: } 3.9(2.9) \text { vs. } 1.9(1.5) \text {, mean difference } 2.00(95 \% \mathrm{Cl}, 0.70 \text { to } 3.30) \\
\text { - } 3 \text { months: } 3.0(2.7) \text { vs. } 1.7(2.3) \text {, mean difference } 1.30(95 \% \mathrm{Cl},-0.13 \text { to } 2.73) \\
\text { Pain during sleep (mean [SD], } 0 \text { to } 10 \text { VAS) } \\
\text { - } 1 \text { week: } 2.1(3.2) \text { vs. } 1.3(1.9), \text { mean difference } 0.80(95 \% \mathrm{Cl},-0.68 \text { to } 2.28) \\
\text { - } 1 \text { month: } 1.0(1.9) \text { vs. } 0.6(1.5), \text { mean difference } 0.40(95 \% \mathrm{Cl},-0.57 \text { to } 1.37) \\
\text { - } 3 \text { months: } 1.0(2.0) \text { vs. } 0.4(1.0) \text {, mean difference } 0.60(95 \% \mathrm{Cl},-0.29 \text { to } 1.49)\end{array}$ & $\begin{array}{l}\text { A vs. B } \\
\text { Sciatic nerve block: } 24.0 \%(6 / 25) \text { vs. } 27.3 \% \\
(6 / 22), \mathrm{RR} 0.88(95 \% \mathrm{Cl}, 0.33 \text { to } 2.33) ;{ }^{*} \text { all } \\
\text { resolved in hours after the procedure } \\
\text { No other complications reported }\end{array}$ \\
\hline
\end{tabular}

Abbreviations: $\mathrm{CI}=$ confidence interval; $\mathrm{NR}=$ not reported; $\mathrm{RR}=$ risk ratio; $\mathrm{SD}=$ standard deviation; $\mathrm{VAS}=$ visual analogue scale

See Appendix F, List of Included Studies, for full citations 
Table G-26. Trial of peripheral nerve stimulation for chronic pain - study characteristics

\begin{tabular}{|c|c|c|c|c|c|c|c|c|}
\hline $\begin{array}{l}\text { Author, } \\
\text { Year } \\
\text { Trial }\end{array}$ & $\begin{array}{c}\text { Study } \\
\text { Design } \\
\text { Duration }\end{array}$ & $\begin{array}{c}\text { Setting/Provider } \\
\text { Type } \\
\text { Country }\end{array}$ & Eligibility Criteria & Interventions & Sample Characteristics & $\begin{array}{c}\text { Screened } \\
\text { Eligible } \\
\text { Randomized } \\
\text { Completed } \\
\text { Followup } \\
\text { Analyzed } \\
\end{array}$ & Sponsor & Quality \\
\hline $\begin{array}{l}\text { Deer, } \\
2016\end{array}$ & $\begin{array}{l}\text { RCT } \\
12 \\
\text { months }\end{array}$ & $\begin{array}{l}13 \text { centers, } \\
\text { provider type not } \\
\text { reported } \\
\text { U.S. }\end{array}$ & $\begin{array}{l}\geq 22 \text { years with severe } \\
\text { intractable chronic pain of } \\
\text { peripheral nerve origin } \\
\text { associated with } \\
\text { posttraumatic/postsurgical } \\
\text { neuralgia for } \geq 3 \text { months, } \\
\text { worst pain level in the last } \\
24 \text { hours } \geq 5 \text { (NRS } 0 \text { to } \\
10 \text { ), pain is attributable to } \\
\text { a lesion or disease of the } \\
\text { somatosensory nervous } \\
\text { system; stable regimen of } \\
\text { pain medications for } \geq 4 \\
\text { weeks and able to } \\
\text { maintain an equivalent } \\
\text { dosage during followup } \\
\text { Excluded: active systemic } \\
\text { infection; } \\
\text { immunocompromised; } \\
\text { may need diathermy or } \\
\text { therapeutic ultrasound at } \\
\text { the implant site; } \\
\text { implanted medical device } \\
\text { within } 15 \text { cm of the } \\
\text { intended placement site } \\
\text { for peripheral nerve } \\
\text { stimulator; bleeding } \\
\text { disorders or active } \\
\text { anticoagulation that } \\
\text { cannot be discontinued } \\
\text { for implantation. }\end{array}$ & $\begin{array}{l}\text { A: Peripheral nerve } \\
\text { stimulation: Lead } \\
\text { placement under } \\
\text { fluoroscopic or } \\
\text { ultrasound } \\
\text { guidance, } \\
\text { placement } \\
\text { confirmed with test } \\
\text { stimulation; } \\
\text { stimulation } \\
\text { parameters phase } \\
\text { duration } 70 \text { to } 500 \\
\text { m/sec, pulse rate } 1 \\
\text { to } 200 \text { Hz, time on } \\
\text { ranged from } 10 \\
\text { minutes to } 12 \\
\text { hours (mean } 6 \\
\text { hours per day at } 3- \\
\text { month study visit). } \\
\text { Typical settings } \\
\text { were } 200 \text { m/sec; } \\
100 \text { Hz; amplitude } \\
\text { set for paresthesia. } \\
\text { B: Sham } \\
\text { stimulation: } \\
\text { Stimulator placed } \\
\text { but no therapeutic } \\
\text { stimulation } \\
\text { provided }\end{array}$ & $\begin{array}{l}\text { Mean (SD) age, years: } 53.0 \\
(11.1) \\
\text { Female: } 41.5 \% \\
\text { White: } 91.5 \% \\
\text { Black/African American: } 3.2 \% \\
\text { Native American: } 1.1 \% \\
\text { Hispanic: } 3.2 \% \\
\text { Other race/ethnicity: } 1.1 \% \\
\text { Pain in lower extremity: } \\
28.7 \% \\
\text { Pain in upper extremity: } \\
27.7 \% \\
\text { Pain in trunk: } 43.6 \% \\
\text { A vs. B } \\
\text { Baseline BPI worst pain } \\
\text { (mean [SD], } 0 \text { to } 10 \text { scale): } \\
8.1 \text { (1.1) vs. } 8.0 \text { (1.1) } \\
\text { Baseline BPI, general activity } \\
\text { (mean [SD], } 0 \text { to } 10 \text { scale): } \\
6.6 \text { (2.2) vs. } 6.5 \text { (1.8) } \\
\text { SF-12 (mean, } 0 \text { to } 100 \text { scale): } \\
35.5 \text { (4.9) vs. } 36.0 \text { (4.3) }\end{array}$ & $\begin{array}{l}\text { Screened: } 147 \\
\text { Eligible: NR } \\
\text { Randomized: } 94 \\
\text { (45 vs. 49) } \\
\text { Complete followup: } \\
\text { Unclear } \\
\text { Analyzed: } 94 \text { (45 } \\
\text { vs. 49) }\end{array}$ & $\begin{array}{l}\text { Bioness, } \\
\text { Inc }\end{array}$ & Fair \\
\hline
\end{tabular}

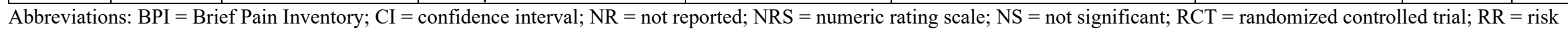
ratio; $\mathrm{SD}=$ standard deviation; $\mathrm{SF}-12=$ Short-Form 12

See Appendix F, List of Included Studies, for full citations 


\begin{tabular}{|c|c|c|}
\hline $\begin{array}{l}\text { Author, } \\
\text { Year } \\
\text { Trial }\end{array}$ & Results & $\begin{array}{l}\text { Adverse Events and Withdrawals Due to Adverse } \\
\text { Events }\end{array}$ \\
\hline $\begin{array}{l}\text { Deer, } \\
2016\end{array}$ & $\begin{array}{l}\text { A vs. B } \\
\text { Pain (mean } \% \text { reduction }[S D]) \text {, overall }(n=94):-27.2 \% \text { vs. }-2.3 \% \text {, mean difference }-24.9 \% \\
(p<0.0001) \\
- \text { Upper extremity pain }(n=26):-29.2 \%(33.3) \text { vs. }-6.5 \%(20.0) \text {, mean difference }-19.8 \%(95 \% \mathrm{Cl},- \\
44.6 \text { to } 5.0) \\
\text { Responders (at least } 30 \% \text { reduction in pain and no increase in pain medication), overall: } 38 \% \\
(17 / 45) \text { vs. } 10 \%(5 / 49) \text { at } 3 \text { months, RR } 3.70(95 \% \mathrm{Cl}, 1.49 \text { to } 9.21) \\
- \text { Upper extremity pain: } 33 \%(4 / 12) \text { vs. } 0 \%(0 / 14) \text { at } 3 \text { months, } \mathrm{RR} 10.4(95 \% \mathrm{Cl} 0.6 \text { to } 175.2) \\
\text { BPI general activity (mean change from baseline [SD], } 0 \text { to } 10 \text { scale), overall: }-2.3(2.7) \text { vs. }-0.4 \\
(2.0) \text { at } 3 \text { months, } p=0.001 \\
\text { SF-12 (mean change from baseline [SD], } 0 \text { to } 100 \text { scale), overall: } 1.4(5.9) \text { vs. }-0.2(3.4) \text { at } 3 \\
\text { months, } p=0.04 \\
\text { Pain medication increased at } 3 \text { months, overall: } 2.2 \%(1 / 45) \text { vs. } 4.1 \%(2 / 49) \text { at } 3 \text { months, } p=\mathrm{NS} \\
\text { Clinical Global Impression (mean [SD], } 0 \text { to } 7 \text { scale), overall: } 4.8(1.5) \text { vs. } 2.5(1.9) \text { at } 3 \text { months, } \\
\text { p<0.0001 }\end{array}$ & $\begin{array}{l}\text { A vs. B (overall sample) } \\
\text { Any adverse events: } 42.2 \%(19 / 45) \text { vs. } 32.6 \%(16 / 49) \\
\text { Device related adverse events: } 31.1 \%(14 / 45) \text { vs. } 26.5 \% \\
(13 / 49) \\
\text { Nondevice-related adverse events: } 11.1 \%(5 / 45) \text { vs. } 6.1 \% \\
(3 / 49) \\
\text { Serious adverse events: } 20 \%(9 / 45) \text { vs. } 22.4 \%(11 / 49) \\
\text { Device related serious adverse events: } 0 \% \text { vs. } 0 \% \\
\text { Nondevice related serious adverse events: } 20 \%(9 / 45) \text { vs. } \\
22.4 \%(11 / 49)\end{array}$ \\
\hline
\end{tabular}

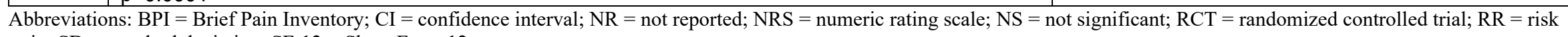
ratio; $\mathrm{SD}=$ standard deviation; SF-12 = Short-Form 12

See Appendix F, List of Included Studies, for full citations 


\section{Appendix H. Quality Table}

Table H-1. Quality assessments of randomized controlled trials

\begin{tabular}{|c|c|c|c|c|c|c|c|c|c|c|c|}
\hline $\begin{array}{l}\text { Author, } \\
\text { Year } \\
\text { Country }\end{array}$ & $\begin{array}{l}\text { Randomization } \\
\text { Adequate? }\end{array}$ & $\begin{array}{l}\text { Allocation } \\
\text { Concealment } \\
\text { Adequate? }\end{array}$ & $\begin{array}{l}\text { Groups } \\
\text { Similar at } \\
\text { Baseline? }\end{array}$ & $\begin{array}{l}\text { Outcome } \\
\text { Assessors } \\
\text { Masked? }\end{array}$ & $\begin{array}{l}\text { Care } \\
\text { Provider } \\
\text { Masked? }\end{array}$ & $\begin{array}{l}\text { Patient } \\
\text { Masked? }\end{array}$ & $\begin{array}{l}\text { Acceptable } \\
\text { Levels of Overall } \\
\text { Attrition and } \\
\text { Between-Group } \\
\text { Differences in } \\
\text { Attrition? }\end{array}$ & $\begin{array}{l}\text { Intention- } \\
\text { to-Treat } \\
\text { (ITT) } \\
\text { Analysis }\end{array}$ & $\begin{array}{l}\text { Avoidance } \\
\text { of } \\
\text { Selective } \\
\text { Outcomes } \\
\text { Reporting }\end{array}$ & $\begin{array}{l}\text { Quality } \\
\text { Rating }\end{array}$ & Comments \\
\hline $\begin{array}{l}\text { Amirdelfan } \\
2020 \\
\text { Australia } \\
\text { and U.S. }\end{array}$ & Unclear & Yes & No & Yes & No & Yes & Yes/Yes & Yes & Yes & Fair & \\
\hline $\begin{array}{l}\text { Berenson, } \\
2011 \\
\text { Australia, } \\
\text { Canada, } \\
\text { Europe, } \\
\text { U.S. }\end{array}$ & Yes & Yes & Yes & $\begin{array}{l}\text { No (except } \\
\text { for safety) }\end{array}$ & No & No & Yes/No & No & Yes & Fair & 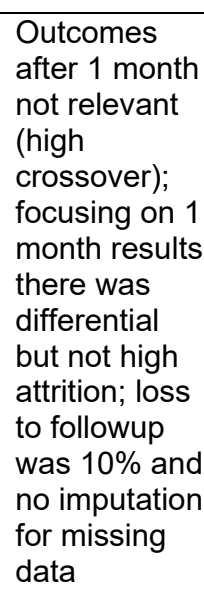 \\
\hline $\begin{array}{l}\text { Blasco, } \\
2012 \\
\text { Spain }\end{array}$ & Yes & Unclear & No (pain) & Unclear & No & No & No $(24 \%) / Y e s$ & Unclear & Yes & Fair & \\
\hline $\begin{array}{l}\text { Buchbinder, } \\
2009 \\
\text { Australia }\end{array}$ & Yes & Yes & Yes & Yes & No & Yes & Yes/Yes & Yes & Yes & Good & \\
\hline $\begin{array}{l}\text { Cady, } 2015 \\
\text { U.S. }\end{array}$ & Yes & Yes & Yes & Yes & Unclear & Yes & $\begin{array}{l}\text { No/No (at } 1 \\
\text { month post- } \\
\text { treatment) }\end{array}$ & No & Yes & Poor & $\begin{array}{l}\text { At } 1 \text { month } \\
\text { attrition was } \\
27 \% \text { and loss } \\
\text { in the sham } \\
\text { group was } \\
43 \% \text {. }\end{array}$ \\
\hline $\begin{array}{l}\text { Chen, } 2014 \\
\text { China }\end{array}$ & Unclear & Unclear & Yes & Unclear & No & No & Yes/Yes & Yes & Yes & Fair & $\begin{array}{l}\text { Attrition was } \\
\text { low so ITT is } \\
\text { OK }\end{array}$ \\
\hline
\end{tabular}




\begin{tabular}{|c|c|c|c|c|c|c|c|c|c|c|c|}
\hline $\begin{array}{l}\text { Author, } \\
\text { Year } \\
\text { Country }\end{array}$ & $\begin{array}{l}\text { Randomization } \\
\text { Adequate? }\end{array}$ & $\begin{array}{l}\text { Allocation } \\
\text { Concealment } \\
\text { Adequate? }\end{array}$ & $\begin{array}{l}\text { Groups } \\
\text { Similar at } \\
\text { Baseline? }\end{array}$ & $\begin{array}{l}\text { Outcome } \\
\text { Assessors } \\
\text { Masked? }\end{array}$ & $\begin{array}{l}\text { Care } \\
\text { Provider } \\
\text { Masked? }\end{array}$ & $\begin{array}{l}\text { Patient } \\
\text { Masked? }\end{array}$ & $\begin{array}{l}\text { Acceptable } \\
\text { Levels of Overall } \\
\text { Attrition and } \\
\text { Between-Group } \\
\text { Differences in } \\
\text { Attrition? }\end{array}$ & $\begin{array}{l}\text { Intention- } \\
\text { to-Treat } \\
\text { (ITT) } \\
\text { Analysis }\end{array}$ & $\begin{array}{l}\text { Avoidance } \\
\text { of } \\
\text { Selective } \\
\text { Outcomes } \\
\text { Reporting }\end{array}$ & $\begin{array}{l}\text { Quality } \\
\text { Rating }\end{array}$ & Comments \\
\hline $\begin{array}{l}\text { Childers, } \\
2002 \\
\text { U.S }\end{array}$ & Unclear & Unclear & Yes & Unclear & Unclear & Yes & Yes/Yes & Yes & Yes & Poor & $\begin{array}{l}\text { Analysis did } \\
\text { not account } \\
\text { for crossover } \\
\text { design; } \\
\text { scales not } \\
\text { reported and } \\
\text { may be } \\
\text { unvalidated }\end{array}$ \\
\hline $\begin{array}{l}\text { Clark, } 2016 \\
\text { Australia }\end{array}$ & Yes & Yes & Yes & Yes & Yes & Yes & Yes/Yes & Yes & Yes & Good & \\
\hline $\begin{array}{l}\text { Cohen, } \\
2008 \\
\text { U.S. }\end{array}$ & Unclear & Yes & No (ODI) & Yes & No & Yes & Yes/Yes & $\begin{array}{l}\text { No (at } 3 \\
\text { months } \\
\text { and } \\
\text { beyond, } \\
\text { due to } \\
\text { high } \\
\text { crossover) }\end{array}$ & Yes & Fair & $\begin{array}{l}\text { High } \\
\text { crossover at } \\
3 \text { months; } \\
\text { crossover } \\
\text { patients } \\
\text { excluded } \\
\text { from analysis }\end{array}$ \\
\hline $\begin{array}{l}\text { Deer, } 2016 \\
\text { U.S. }\end{array}$ & Yes & Unclear & Yes & Unclear & Unclear & Yes & Unclear & Yes & Yes & Fair & \\
\hline $\begin{array}{l}\text { Farrokhi, } \\
2011 \\
\text { Iran }\end{array}$ & Yes & Yes & No (pain) & Yes & No & No & Yes/Yes & Yes & Yes & Poor & $\begin{array}{l}\text { Serious data } \\
\text { discrepancies } \\
\text { (implausible } \\
\text { values for } \\
\text { standard } \\
\text { deviations } \\
\text { and results } \\
\text { inconsistent } \\
\text { with reported } \\
\text { data) }\end{array}$ \\
\hline $\begin{array}{l}\text { Firanescu, } \\
2018 \\
\text { the } \\
\text { Netherlands }\end{array}$ & Yes & Unclear & Yes & Yes & Unclear & Yes & Yes/Yes & Yes & Yes & Good & \\
\hline $\begin{array}{l}\text { Fishman, } \\
2017 \\
\text { U.S }\end{array}$ & Unclear & Unclear & UNclear & Unclear & Unclear & Yes & $\mathrm{No} / \mathrm{No}$ & No & Unclear & Poor & $\begin{array}{l}\text { Scale used to } \\
\text { measure pain } \\
\text { not reported }\end{array}$ \\
\hline $\begin{array}{l}\text { Gallucci, } \\
2007 \\
\text { Italy }\end{array}$ & Unclear & Unclear & Yes & Yes & Unclear & Yes & Unclear & Yes & Yes & Fair & \\
\hline
\end{tabular}




\begin{tabular}{|c|c|c|c|c|c|c|c|c|c|c|c|}
\hline $\begin{array}{l}\text { Author, } \\
\text { Year } \\
\text { Country }\end{array}$ & $\begin{array}{l}\text { Randomization } \\
\text { Adequate? }\end{array}$ & $\begin{array}{l}\text { Allocation } \\
\text { Concealment } \\
\text { Adequate? }\end{array}$ & $\begin{array}{l}\text { Groups } \\
\text { Similar at } \\
\text { Baseline? }\end{array}$ & $\begin{array}{l}\text { Outcome } \\
\text { Assessors } \\
\text { Masked? }\end{array}$ & $\begin{array}{l}\text { Care } \\
\text { Provider } \\
\text { Masked? }\end{array}$ & $\begin{array}{l}\text { Patient } \\
\text { Masked? }\end{array}$ & $\begin{array}{l}\text { Acceptable } \\
\text { Levels of Overall } \\
\text { Attrition and } \\
\text { Between-Group } \\
\text { Differences in } \\
\text { Attrition? }\end{array}$ & $\begin{array}{l}\text { Intention- } \\
\text { to-Treat } \\
\text { (ITT) } \\
\text { Analysis }\end{array}$ & $\begin{array}{l}\text { Avoidance } \\
\text { of } \\
\text { Selective } \\
\text { Outcomes } \\
\text { Reporting }\end{array}$ & $\begin{array}{l}\text { Quality } \\
\text { Rating }\end{array}$ & Comments \\
\hline $\begin{array}{l}\text { Hansen, } \\
2019 \\
\text { Denmark }\end{array}$ & Unclear & Yes & No (pain) & Yes & Unclear & Yes & Yes/Yes & No & Yes & Fair & $\begin{array}{l}\text { Attrition was } \\
>10 \% \text { and } \\
\text { did not do } \\
\text { imputation or } \\
\text { other method } \\
\text { for handling } \\
\text { missing data. } \\
\text { Envelop } \\
\text { probably ok } \\
\text { for allocation } \\
\text { concealment }\end{array}$ \\
\hline $\begin{array}{l}\text { Haseeb, } \\
2019 \\
\text { Egypt }\end{array}$ & Unclear & Unclear & Unclear & Yes & Unclear & Unclear & Unclear & Unclear & No & Poor & \\
\hline $\begin{array}{l}\text { Kallmes, } \\
2009 \\
\text { U.K., } \\
\text { Austraia, } \\
\text { U.S. }\end{array}$ & Yes & Yes & Yes & Yes & Yes & Yes & Yes/Yes & Yes & Yes & Good & \\
\hline $\begin{array}{l}\text { Klazen, } \\
2010 \\
\text { the } \\
\text { Netherlands } \\
\text { and Belgium }\end{array}$ & Yes & Yes & Yes & No & No & No & Yes/Yes & Yes & Yes & Fair & $\begin{array}{l}\text { Open-label is } \\
\text { one of the } \\
\text { major issues } \\
\text { with these } \\
\text { trials }\end{array}$ \\
\hline $\begin{array}{l}\text { Kroll, } 2008 \\
\text { U.S. }\end{array}$ & Yes & Unclear & No (pain) & Unclear & No & Yes & No/Unclear & No & Yes & Poor & \\
\hline $\begin{array}{l}\text { Leali, } 2016 \\
\text { Italy, } \\
\text { France, } \\
\text { Switzerland }\end{array}$ & Unclear & Unclear & Unclear & Unclear & No & No & Unclear & Unclear & Unclear & Poor & \\
\hline $\begin{array}{l}\text { McCormick, } \\
2019 \\
\text { U.S. }\end{array}$ & Yes & Yes & Yes & Yes & No & Yes & Yes/Yes & Yes & Yes & Good & \\
\hline
\end{tabular}




\begin{tabular}{|c|c|c|c|c|c|c|c|c|c|c|c|}
\hline $\begin{array}{l}\text { Author, } \\
\text { Year } \\
\text { Country }\end{array}$ & $\begin{array}{l}\text { Randomization } \\
\text { Adequate? }\end{array}$ & $\begin{array}{l}\text { Allocation } \\
\text { Concealment } \\
\text { Adequate? }\end{array}$ & $\begin{array}{l}\text { Groups } \\
\text { Similar at } \\
\text { Baseline? }\end{array}$ & $\begin{array}{l}\text { Outcome } \\
\text { Assessors } \\
\text { Masked? }\end{array}$ & $\begin{array}{l}\text { Care } \\
\text { Provider } \\
\text { Masked? }\end{array}$ & $\begin{array}{l}\text { Patient } \\
\text { Masked? }\end{array}$ & $\begin{array}{l}\text { Acceptable } \\
\text { Levels of Overall } \\
\text { Attrition and } \\
\text { Between-Group } \\
\text { Differences in } \\
\text { Attrition? }\end{array}$ & $\begin{array}{l}\text { Intention- } \\
\text { to-Treat } \\
\text { (ITT) } \\
\text { Analysis }\end{array}$ & $\begin{array}{l}\text { Avoidance } \\
\text { of } \\
\text { Selective } \\
\text { Outcomes } \\
\text { Reporting }\end{array}$ & $\begin{array}{l}\text { Quality } \\
\text { Rating }\end{array}$ & Comments \\
\hline $\begin{array}{l}\text { Mekhail, } \\
2017 \text { (single } \\
\text { center from } \\
\text { Silberstein } \\
\text { 2012) } \\
\text { U.S. }\end{array}$ & Yes & Yes & Unclear & Unclear & Yes & Yes & Yes/Yes & Yes & Yes & Fair & $\begin{array}{l}\text { Single center } \\
\text { from } \\
\text { Silberstein } \\
2012 \\
\text { multicenter } \\
\text { trial }\end{array}$ \\
\hline $\begin{array}{l}\text { Misirlioglu, } \\
2015 \\
\text { Turkey }\end{array}$ & Unclear & Yes & Yes & Yes & Yes & Yes & Yes/Yes & Yes & Yes & Fair & \\
\hline $\begin{array}{l}\text { Moussa, } \\
2020 \\
\text { Egypt }\end{array}$ & Unclear & Unclear & Unclear & Yes & No & Yes & Unclear & Unclear & Yes & Poor & $\begin{array}{l}\text { Data } \\
\text { discrepancies } \\
\text { present }\end{array}$ \\
\hline $\begin{array}{l}\text { Patel, } 2012 \\
\text { U.S. }\end{array}$ & Unclear & Unclear & Yes & Yes & No & Yes & Yes/Yes & $\begin{array}{l}\text { No (at } 3 \\
\text { months } \\
\text { and } \\
\text { beyond, } \\
\text { due to } \\
\text { high } \\
\text { crossover) }\end{array}$ & Yes & Fair & $\begin{array}{l}\text { High } \\
\text { crossover, } \\
\text { appear to } \\
\text { have been } \\
\text { excluded } \\
\text { from analysis } \\
\text { at } 3 \text { months }\end{array}$ \\
\hline $\begin{array}{l}\text { Peng, } 2010 \\
\text { China }\end{array}$ & Yes & Unclear & Yes & Yes & No & Yes & Yes/Yes & Yes & Yes & Fair & \\
\hline $\begin{array}{l}\text { Rousing, } \\
2009 \\
\text { Denmark }\end{array}$ & Unclear & Yes & $\begin{array}{l}\text { No (pain, } \\
\text { EQ-5D) }\end{array}$ & Unclear & No & No & Yes/Yes & Yes & Yes & Poor & $\begin{array}{l}\text { Missing } \\
\text { baseline data }\end{array}$ \\
\hline $\begin{array}{l}\text { Saper, } 2011 \\
\text { Canada, } \\
\text { U.S., and } \\
\text { U.K. }\end{array}$ & Unclear & Yes & Yes & Yes & Yes & No & Yes/Yes & Yes & Unclear & Fair & \\
\hline $\begin{array}{l}\text { Silberstein, } \\
2012 \\
\text { U.S. }\end{array}$ & Yes & Yes & Yes & Unclear & Yes & Yes & Yes/Yes & Yes & Yes & Fair & $\begin{array}{l}\text { Stimulation } \\
\text { parameters } \\
\text { not reported }\end{array}$ \\
\hline $\begin{array}{l}\text { Tekin, } 2007 \\
\text { Turkey }\end{array}$ & Yes & Unclear & Yes & Yes & No & Yes & Unclear & Unclear & Yes & Fair & \\
\hline
\end{tabular}




\begin{tabular}{|c|c|c|c|c|c|c|c|c|c|c|c|}
\hline $\begin{array}{l}\text { Author, } \\
\text { Year } \\
\text { Country }\end{array}$ & $\begin{array}{l}\text { Randomization } \\
\text { Adequate? }\end{array}$ & $\begin{array}{l}\text { Allocation } \\
\text { Concealment } \\
\text { Adequate? }\end{array}$ & $\begin{array}{l}\text { Groups } \\
\text { Similar at } \\
\text { Baseline? }\end{array}$ & $\begin{array}{l}\text { Outcome } \\
\text { Assessors } \\
\text { Masked? }\end{array}$ & $\begin{array}{l}\text { Care } \\
\text { Provider } \\
\text { Masked? }\end{array}$ & $\begin{array}{l}\text { Patient } \\
\text { Masked? }\end{array}$ & $\begin{array}{l}\text { Acceptable } \\
\text { Levels of Overall } \\
\text { Attrition and } \\
\text { Between-Group } \\
\text { Differences in } \\
\text { Attrition? }\end{array}$ & $\begin{array}{l}\text { Intention- } \\
\text { to-Treat } \\
\text { (ITT) } \\
\text { Analysis }\end{array}$ & $\begin{array}{l}\text { Avoidance } \\
\text { of } \\
\text { Selective } \\
\text { Outcomes } \\
\text { Reporting } \\
\end{array}$ & $\begin{array}{l}\text { Quality } \\
\text { Rating }\end{array}$ & Comments \\
\hline $\begin{array}{l}\text { Tuakli- } \\
\text { Wosornu, } \\
2016 \\
\text { U.S. }\end{array}$ & Unclear & Yes & $\begin{array}{l}\text { No (\% } \\
\text { female) }\end{array}$ & Yes & Yes & Yes & Yes/Yes & No & Yes & Fair & $\begin{array}{l}\text { Doesn't meet } \\
\text { criteria for } \\
\text { ITT since } \\
\text { they didn't do } \\
\text { any } \\
\text { imputation } \\
\text { etc. }\end{array}$ \\
\hline $\begin{array}{l}\text { Voormolen, } \\
2007 \\
\text { the } \\
\text { Netherlands }\end{array}$ & Unclear & Yes & Yes & Unclear & No & No & Yes/Yes & Yes & Yes & Fair & \\
\hline $\begin{array}{l}\text { Wardlaw, } \\
2009 \\
\text { Europe and } \\
\text { U.S. }\end{array}$ & Yes & Unclear & Yes & Unclear & No & No & Yes/No & Yes & Yes & Fair & $\begin{array}{l}\text { At } 3 \text { months } \\
\text { there was } \\
>10 \% \\
\text { different in } \\
\text { loss to } \\
\text { followup } \\
\text { between } \\
\text { groups }\end{array}$ \\
\hline $\begin{array}{l}\text { Yang, } 2016 \\
\text { China }\end{array}$ & Year & Unclear & Yes & No & No & No & $\mathrm{No} / \mathrm{No}$ & No & Yes & Poor & \\
\hline
\end{tabular}

Abbreviations: ODI = Oswestry Disability Index; U.S = United States

See Appendix F, List of Included Studies, for full citations 


\section{Appendix I. Meta-Analysis Results}

Table I-1. Stratified analyses, vertebroplasty versus sham or usual care, pain (continuous) at 1 to 2 weeks and at 2 to 4 weeks*

\begin{tabular}{|c|c|c|c|c|c|c|c|c|c|}
\hline Analysis & Subgroup & $\begin{array}{l}\text { Mean Difference } \\
(95 \% \mathrm{Cl}), 1 \text { to } 2 \\
\text { Weeks }\end{array}$ & $\mathbf{I}^{2}$ & $\begin{array}{l}\text { Number } \\
\text { of Trials } \\
\text { (N) }\end{array}$ & $p^{\dagger}$ & $\begin{array}{l}\text { Mean Difference } \\
(95 \% \mathrm{Cl}), 2 \text { to } 4 \\
\text { Weeks }\end{array}$ & $\mathbf{I}^{2}$ & $\begin{array}{l}\text { Number } \\
\text { of Trials } \\
\text { (N) }\end{array}$ & $p^{\dagger}$ \\
\hline All trials & -- & $-0.53(-1.36$ to 0.24$)$ & $75 \%$ & $10(1093)$ & -- & $-1.05(-1.80$ to -0.32$)$ & $64 \%$ & $8(918)$ & -- \\
\hline \multirow{2}{*}{ Control type } & - $\quad$ Sham & $-0.02(-0.65$ to 0.61$)$ & $14 \%$ & $5(536)$ & 0.14 & $-0.57(-1.09$ to -0.05$)$ & $0 \%$ & $5(536)$ & 0.01 \\
\hline & - Usual care & $-1.22(-2.81$ to 0.23$)$ & $73 \%$ & $5(557)$ & -- & $-2.27(-3.20$ to -0.94$)$ & $0 \%$ & $3(382)$ & -- \\
\hline \multirow{4}{*}{$\begin{array}{c}\text { Pain duration } \\
\text { (inclusion criteria) }\end{array}$} & - $\quad<4$ weeks & $-3.10(-6.57$ to 0.37$)$ & -- & $1(107)$ & 0.18 & $-2.40(-4.79$ to -0.01$)$ & -- & $1(107)$ & 0.79 \\
\hline & - $\quad<6$ to 10 weeks & $-0.75(-2.02$ to 0.59$)$ & $80 \%$ & $4(536)$ & $\begin{array}{ll}- \\
\end{array}$ & $-1.08(-2.43$ to 0.33$)$ & $81 \%$ & $4(536)$ & -- \\
\hline & - $\quad<12$ months & $0.46(-0.30$ to 1.37$)$ & $0 \%$ & $3(327)$ & -- & $-0.62(-1.51$ to 0.29$)$ & $0 \%$ & 2 (199) & -- \\
\hline & - $\quad \geq 4$ to 6 weeks & $-1.55(-2.89$ to -0.21$)$ & $0 \%$ & $2(123)$ & -- & $-1.20(-2.61$ to 0.21$)$ & -- & $1(73)$ & -- \\
\hline \multirow{3}{*}{$\begin{array}{l}\text { Pain duration (mean or } \\
\text { median) }\end{array}$} & - $\quad<4$ weeks & $-1.37(-0.37$ to -0.05$)$ & $0 \%$ & $2(219)$ & 0.49 & $-1.56(-3.14$ to -0.40$)$ & $0 \%$ & $2(219)$ & 0.70 \\
\hline & - 4 to 8 weeks & $-0.60(-2.38$ to 1.28$)$ & $86 \%$ & $3(424)$ & -- & $-0.96(-2.90$ to 1.07$)$ & $86 \%$ & $3(211)$ & -- \\
\hline & - $\quad>8$ weeks & $-0.11(-1.32$ to 0.92$)$ & $58 \%$ & $5(450)$ & $\begin{array}{ll}-- \\
\end{array}$ & $-0.75(-1.48$ to -0.05$)$ & $0 \%$ & $3(275)$ & -- \\
\hline \multirow{2}{*}{$\begin{array}{c}\text { Bone marrow edema } \\
\text { on MRI }\end{array}$} & - $\quad$ Required & $-0.72(-1.91$ to 0.35$)$ & $78 \%$ & $7(779)$ & 0.56 & $-1.17(-2.44$ to 0.04$)$ & $75 \%$ & $5(604)$ & 0.72 \\
\hline & - $\quad$ Not required & $-0.19(-1.42$ to 1.02$)$ & $49 \%$ & $3(314)$ & $\begin{array}{ll}- \\
\end{array}$ & $-0.90(-1.59$ to -0.17$)$ & $0 \%$ & $3(314)$ & -- \\
\hline \multirow{2}{*}{ PMMA volume } & - $\quad>5 \mathrm{ml}$ & $-0.41(-2.09$ to 1.04$)$ & $45 \%$ & $2(288)$ & 0.39 & $-0.75(-2.05$ to 0.28$)$ & $4.3 \%$ & $2(288)$ & 0.77 \\
\hline & - $\quad \leq 5 \mathrm{ml}$ & $-0.80(-1.90$ to 0.19$)$ & $72 \%$ & $7(680)$ & -- & $-1.13(-2.14$ to -0.13$)$ & $66 \%$ & $6(630)$ & -- \\
\hline \multirow{3}{*}{ Study quality } & - Good & $-0.09(-0.89$ to 0.67$)$ & $28 \%$ & $4(490)$ & 0.38 & $-0.70(-1.27$ to -0.19$)$ & $0 \%$ & $4(490)$ & 0.54 \\
\hline & - $\quad$ Fair & $-0.74(-2.14$ to 0.67$)$ & $78 \%$ & $5(496)$ & -- & $-1.25(-3.16$ to 0.78$)$ & $78 \%$ & $3(321)$ & -- \\
\hline & - $\quad$ Poor & $-3.10(-6.57$ to 0.37$)$ & $\begin{array}{ll}- \\
\end{array}$ & $1(107)$ & -- & $-2.40(-4.79$ to -0.01$)$ & $\begin{array}{ll}- \\
\end{array}$ & $1(107)$ & -- \\
\hline
\end{tabular}

Abbreviations: $\mathrm{CI}=$ confidence interval; $\mathrm{ml}=$ milliliter; $\mathrm{MRI}=$ magnetic resonance imaging; $\mathrm{N}=$ number of subjects; PMMA = polymethyl methacrylate

*Pain is on a 0 to 10 scale (higher values indicate more severe pain) and that negative mean difference values indicate less pain with vertebroplasty

${ }^{\dagger}$ For interaction 
Table I-2. Stratified analyses, vertebroplasty versus sham or usual care, pain (continuous) at 1 to 6 months, 6 to 12 months, and 12 months and longer*

\begin{tabular}{|c|c|c|c|c|c|c|c|c|c|c|c|c|}
\hline Analysis & Subgroup & $\begin{array}{l}\text { Mean Difference } \\
(95 \% \mathrm{Cl}), 1 \text { to } 6 \\
\text { Months }\end{array}$ & $\mathbf{I}^{2}$ & $\begin{array}{l}\text { No. of } \\
\text { Trials } \\
\text { (N) }\end{array}$ & $\mathbf{p}^{\dagger}$ & $\begin{array}{l}\text { Mean Difference } \\
(95 \% \mathrm{CI}), 6 \text { to } 12 \\
\text { Months }\end{array}$ & $\mathbf{I}^{2}$ & $\begin{array}{l}\text { No. of } \\
\text { Trials } \\
\text { (N) }\end{array}$ & $\mathbf{p}^{\dagger}$ & $\begin{array}{l}\text { Mean Difference } \\
(95 \% \mathrm{Cl}), 12 \text { Months } \\
\text { and Longer }\end{array}$ & $\mathbf{l}^{2}$ & $\begin{array}{l}\mathbf{N} \\
\mathrm{T} \\
\mathbf{(}\end{array}$ \\
\hline All trials & -- & $-0.76(-1.17$ to -0.38$)$ & $5.5 \%$ & $\begin{array}{l}10 \\
(1094)\end{array}$ & -- & $-0.73(-1.33$ to -0.15$)$ & $43 \%$ & $8(993)$ & -- & $-0.87(-1.43$ to -0.31$)$ & $42 \%$ & 9 \\
\hline \multirow{2}{*}{ Control type } & - Sham & $-0.47(-0.98$ to -0.01$)$ & $0 \%$ & $5(525)$ & 0.09 & $-0.59(-1.16$ to -0.07$)$ & $0 \%$ & $4(470)$ & 0.71 & $-0.64(-1.21$ to -0.08$)$ & $0 \%$ & 4 \\
\hline & - Usual care & $-1.17(-1.71$ to -0.60$)$ & $0 \%$ & $5(569)$ & -- & $-0.87(-2.81$ to 0.23$)$ & $58 \%$ & $4(523)$ & -- & $-1.08(-2.06$ to -0.11$)$ & $51 \%$ & 5 \\
\hline \multirow{4}{*}{$\begin{array}{l}\text { Pain duration } \\
\text { (inclusion criteria) }\end{array}$} & - $\quad<4$ weeks & $-1.80(-3.76$ to 0.16$)$ & -- & $1(107)$ & 0.68 & $-1.20(-3.14$ to 0.74$)$ & -- & $1(107)$ & 0.46 & $-1.20(-2.89$ to 0.49$)$ & -- & 1 \\
\hline & $\begin{array}{ll} & <6 \text { to } 10 \\
& \text { weeks }\end{array}$ & $-0.70(-1.36$ to -0.03$)$ & $29 \%$ & $5(575)$ & -- & $-1.05(-2.02$ to -0.14$)$ & $42 \%$ & $3(480)$ & $\begin{array}{ll}- \\
-\end{array}$ & $-0.91(-1.88$ to 0.15$)$ & $57 \%$ & 4 \\
\hline & - $\quad<12$ months & $-0.67(-1.32$ to -0.03$)$ & $0 \%$ & $3(323)$ & -- & $-0.16(-1.07$ to 0.80$)$ & $14 \%$ & $3(317)$ & -- & $-0.60(-1.61$ to 0.36$)$ & $18 \%$ & 3 \\
\hline & - $\quad \geq 4$ to 6 weeks & $-1.40(-3.09$ to 0.29$)$ & -- & $1(89)$ & -- & $-1.50(-3.46$ to 0.46$)$ & $\begin{array}{ll}- \\
\end{array}$ & $1(89)$ & -- & $-1.60(-3.45$ to 0.25$)$ & -- & 1 \\
\hline \multirow{3}{*}{$\begin{array}{l}\text { Pain duration } \\
\text { (mean or median) }\end{array}$} & - $\quad<4$ weeks & $-1.25(-2.22$ to -0.31$)$ & $0 \%$ & $3(258)$ & 0.54 & $-1.27(-2.52$ to 0.01$)$ & $0 \%$ & $2(209)$ & 0.46 & $-1.03(-2.34$ to 0.24$)$ & $0 \%$ & 2 \\
\hline & - 4 to 8 weeks & $-0.56(-1.48$ to 0.48$)$ & $46 \%$ & $3(424)$ & -- & $-0.99(-2.45$ to 0.47$)$ & $58 \%$ & $2(378)$ & -- & $-0.90(-2.23$ to 0.54$)$ & $68 \%$ & 3 \\
\hline & - $\quad>8$ weeks & $-0.76(-1.37$ to -0.17$)$ & $0 \%$ & $4(412)$ & -- & $-0.30(-1.26$ to 0.51$)$ & $16 \%$ & $4(406)$ & -- & $-0.72(-1.67$ to 0.07$)$ & $17 \%$ & 4 \\
\hline \multirow{2}{*}{$\begin{array}{l}\text { Bone marrow } \\
\text { edema on MRI }\end{array}$} & - $\quad$ Required & $-0.74(-1.40$ to -0.16$)$ & $24 \%$ & $6(745)$ & 0.84 & $-0.73(-1.71$ to 0.17$)$ & $57 \%$ & $5(699)$ & $\begin{array}{l}0.99 \\
5\end{array}$ & $-0.80(-1.65$ to 0.03$)$ & $57 \%$ & 6 \\
\hline & - $\quad$ Not required & $-0.82(-1.44$ to -0.22$)$ & $0 \%$ & $4(349)$ & -- & $-0.74(-1.52$ to 0.05$)$ & $0 \%$ & $3(294)$ & -- & $-1.02(-1.73$ to -0.30$)$ & $0 \%$ & 3 \\
\hline \multirow{2}{*}{ PMMA volume } & - $\quad>5 \mathrm{ml}$ & $-0.48(-1.92$ to 0.50$)$ & $0 \%$ & $2(281)$ & 0.73 & $-0.62(-1.84$ to 0.25$)$ & $0 \%$ & $2(278)$ & 0.19 & $-0.45(-1.25$ to 0.35$)$ & -- & 1 \\
\hline & - $\quad \leq 5 \mathrm{ml}$ & $-0.90(-1.41$ to -0.34$)$ & $0 \%$ & $6(642)$ & -- & $-1.09(-1.72$ to -0.34$)$ & $8.9 \%$ & $5(590)$ & $\begin{array}{ll}-- \\
\end{array}$ & $-1.22(-1.85$ to -0.50$)$ & $24 \%$ & 6 \\
\hline \multirow{3}{*}{ Study quality } & - $\quad$ Good & $-0.56(-1.17$ to -0.07$)$ & $0 \%$ & $4(479)$ & 0.59 & $-0.59(-1.16$ to -0.07$)$ & $0 \%$ & $4(470)$ & 0.89 & $-0.75(-1.45$ to -0.16$)$ & $0 \%$ & 3 \\
\hline & - $\quad$ Fair & $-0.90(-1.58$ to -0.06$)$ & $5.9 \%$ & $4(462)$ & -- & $-0.81(-2.50$ to 0.82$)$ & $68 \%$ & $3(416)$ & -- & $-0.84(-2.14$ to 0.46$)$ & $66 \%$ & 4 \\
\hline & - $\quad$ Poor & $-1.20(-2.86$ to 0.32$)$ & -- & $2(153)$ & -- & $-1.20(-3.14$ to 0.74$)$ & -- & $1(107)$ & -- & $-1.03(-2.32$ to 0.24$)$ & $0 \%$ & 2 \\
\hline
\end{tabular}

Abbreviations: $\mathrm{CI}=$ confidence interval; $\mathrm{ml}=$ millimeter; $\mathrm{MRI}=$ magnetic resonance imaging; $\mathrm{N}=$ number of subjects; PMMA = polymethyl methacrylate

*Pain is on a 0 to 10 scale (higher values indicate more severe pain) and that negative mean difference values indicate less pain with vertebroplasty

${ }^{\dagger}$ For interaction 
Figure l-1. Funnel plot of vertebroplasty versus sham or usual care, pain (continuous), 1 to 2 weeks

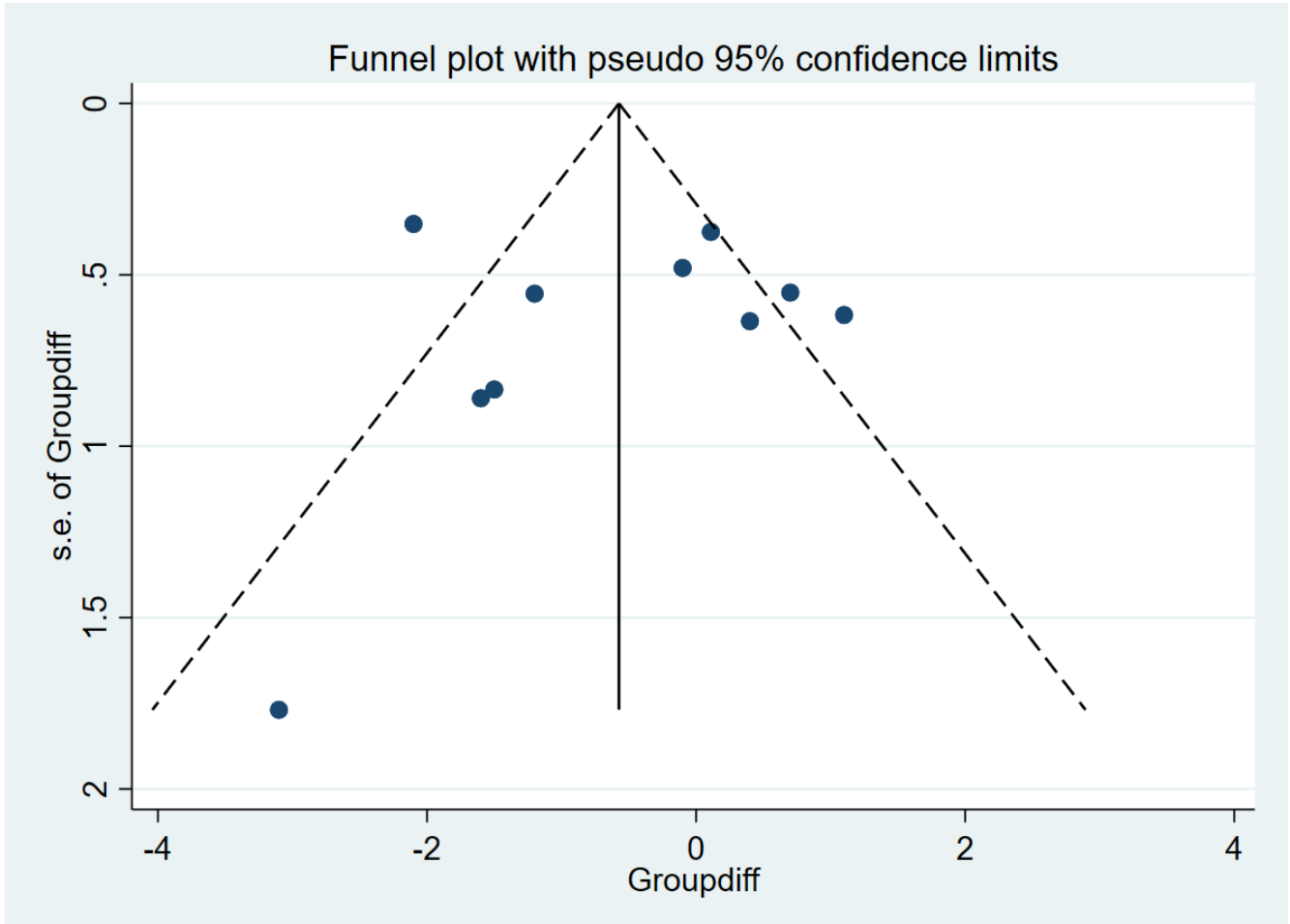

Abbreviations: $\mathrm{SE}=$ standard error 
Figure I-2. Funnel plot of vertebroplasty versus sham or usual care, pain (continuous), 1 to 6 months

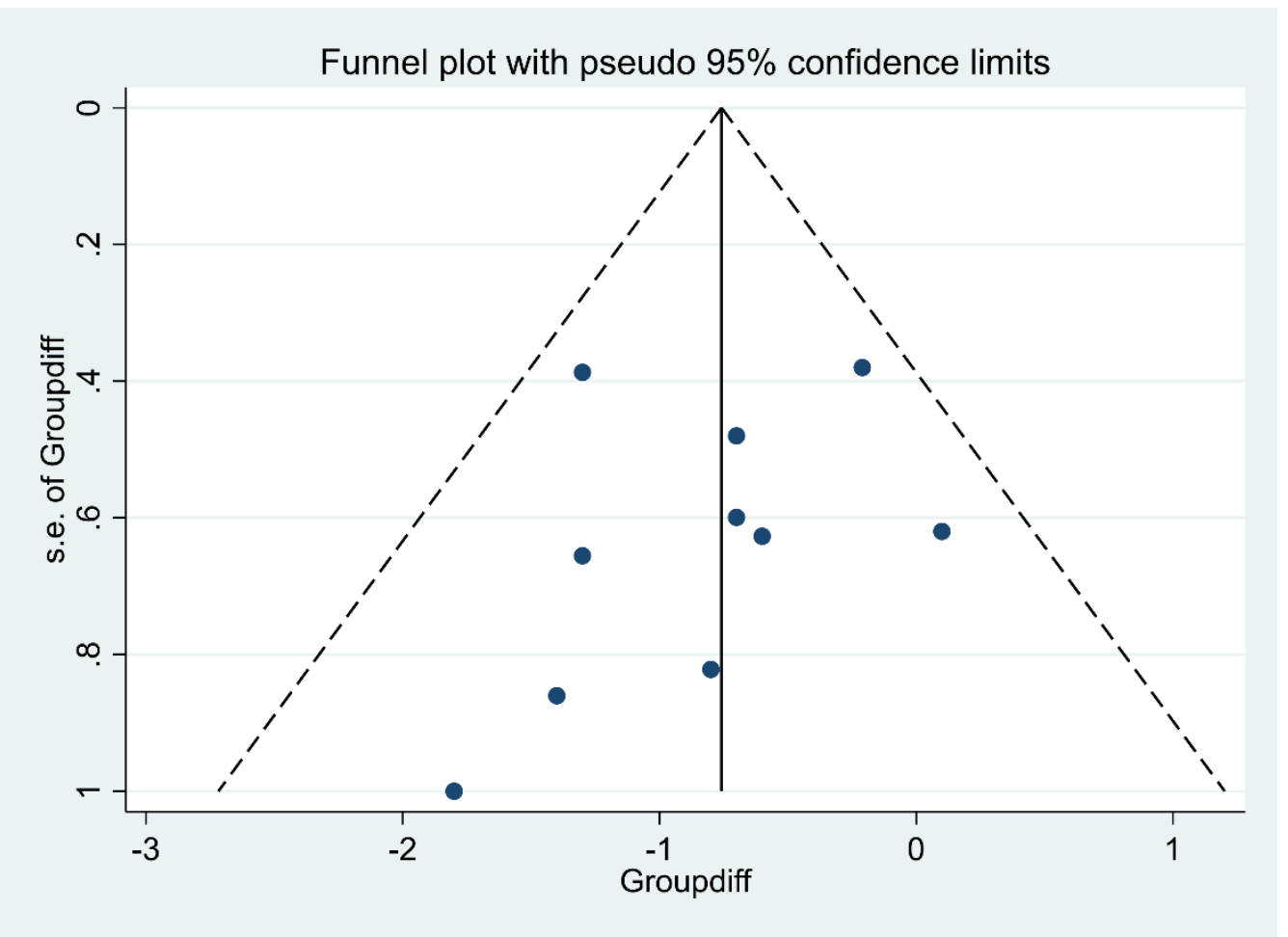


Table 1-3. Vertebroplasty versus sham or usual care, pain, function, and opioid use (dichotomous)

\begin{tabular}{|c|c|c|c|}
\hline Followup Duration & Pain, RR (95\% Cl) & Function, RR (95\% Cl) & Opioid Use, RR (95\% Cl) \\
\hline 1 to 2 weeks & $1.05(0.16$ to 6.02$)$ & - & $0.66(0.30$ to 1.27$)$ \\
\hline$l^{2}$ & $75 \%$ & -- & $0 \%$ \\
\hline No. of trials $(\mathrm{N})$ & $2(186)$ & -- & $2(178)$ \\
\hline 2 to 4 weeks & $1.35(0.51$ to 3.82$)$ & $0.66(0.45$ to 0.97$)$ & $1.08(0.58$ to 1.48$)$ \\
\hline$l^{2}$ & $79 \%$ & -- & $0 \%$ \\
\hline No. of trials $(\mathrm{N})$ & $3(293)$ & $1(108)$ & $3(368)$ \\
\hline 1 to 6 months & $1.46(0.84$ to 2.34$)$ & -- & $1.02(0.60$ to 1.75$)$ \\
\hline$l^{2}$ & $0 \%$ & -- & $0 \%$ \\
\hline No. of trials $(\mathrm{N})$ & $2(176)$ & -- & $2(172)$ \\
\hline 6 to 12 months & $1.32(0.82$ to 1.91$)$ & -- & $0.93(0.44$ to 1.57$)$ \\
\hline$l^{2}$ & $0 \%$ & -- & $0 \%$ \\
\hline No. of trials $(\mathrm{N})$ & $2(175)$ & -- & $2(165)$ \\
\hline 12 months and longer & 1.27 (0.64 to 2.27$)$ & 1.56 (1.12 to 2.18$)$ & $0.72(0.30$ to 1.70$)$ \\
\hline$l^{2}$ & $35 \%$ & -- & -- \\
\hline No. of trials $(\mathrm{N})$ & $2(202)$ & $1(119)$ & $1(83)$ \\
\hline
\end{tabular}

Abbreviations: $\mathrm{CI}=$ confidence interval; $\mathrm{N}=$ number of subjects; $\mathrm{RR}=$ relative risk 
Table I-4. Stratified analyses, vertebroplasty versus sham or usual care, function (continuous) at 1 to 2 weeks and at 2 to 4 weeks*

\begin{tabular}{|c|c|c|c|c|c|c|c|c|c|}
\hline Analysis & Subgroup & $\begin{array}{l}\text { SMD }(95 \% \mathrm{Cl}), 1 \text { to } \\
2 \text { Weeks }\end{array}$ & $\mathbf{1}^{2}$ & $\begin{array}{l}\text { Number } \\
\text { of Trials } \\
\text { (N) }\end{array}$ & $\mathbf{p}^{\dagger}$ & $\begin{array}{l}\text { SMD }(95 \% \mathrm{Cl}), 2 \\
\text { to } 4 \text { Weeks }\end{array}$ & $\mathbf{I}^{2}$ & $\begin{array}{l}\text { Number } \\
\text { of Trials } \\
\text { (N) }\end{array}$ & $p^{\dagger}$ \\
\hline All trials & -- & $-0.21(-0.48$ to 0.04$)$ & $49 \%$ & $7(743)$ & -- & $\begin{array}{l}-0.27(-0.42 \text { to }- \\
0.12)\end{array}$ & $0 \%$ & $6(708)$ & -- \\
\hline \multirow{2}{*}{ Control type } & - $\quad$ Sham & $0.03(-0.36$ to 0.44$)$ & $34 \%$ & $3(311)$ & 0.10 & $\begin{array}{l}-0.26(-0.53 \text { to } \\
0.00)\end{array}$ & $0 \%$ & $3(310)$ & 0.91 \\
\hline & - Usual care & $\begin{array}{l}-0.38(-0.61 \text { to }- \\
0.18)\end{array}$ & $0 \%$ & $4(432)$ & -- & $\begin{array}{l}-0.28(-0.49 \text { to }- \\
0.07)\end{array}$ & $0 \%$ & $3(398)$ & -- \\
\hline \multirow{3}{*}{$\begin{array}{l}\text { Pain duration (mean } \\
\text { or median) }\end{array}$} & - $\quad<4$ weeks & $-0.30(-0.60$ to 0.01$)$ & $0 \%$ & $2(216)$ & 0.85 & $\begin{array}{l}-0.40(-0.72 \text { to }- \\
0.09)\end{array}$ & $0 \%$ & $2(107)$ & 0.55 \\
\hline & - 4 to 8 weeks & $\begin{array}{l}-0.39(-0.67 \text { to }- \\
0.12)\end{array}$ & -- & $1(202)$ & -- & $\begin{array}{l}-0.25(-0.53 \text { to } \\
0.03)\end{array}$ & -- & $1(202)$ & -- \\
\hline & - $\quad>8$ weeks & $-0.11(-0.71$ to 0.39$)$ & $65 \%$ & $4(325)$ & -- & $\begin{array}{l}-0.19(-0.43 \text { to } \\
0.05)\end{array}$ & -- & $3(290)$ & -- \\
\hline \multirow{3}{*}{ Study quality } & - Good & $0.03(-0.36$ to 0.44$)$ & $34 \%$ & $3(311)$ & 0.28 & $\begin{array}{l}-0.26(-0.53 \text { to } \\
0.00)\end{array}$ & $0 \%$ & $3(310)$ & 0.89 \\
\hline & - $\quad$ Fair & $\begin{array}{l}-0.41(-0.78 \text { to }- \\
0.15)\end{array}$ & $0 \%$ & $3(325)$ & -- & $\begin{array}{l}-0.25(-0.52 \text { to } \\
0.02)\end{array}$ & $0 \%$ & $2(291)$ & -- \\
\hline & - $\quad$ Poor & $-0.30(-0.68$ to 0.09$)$ & -- & $1(107)$ & -- & $\begin{array}{l}-0.36(-0.74 \text { to } \\
0.03)\end{array}$ & -- & $1(107)$ & -- \\
\hline Scale & $\begin{array}{l}\text { On original scale RDQ or } \\
\text { modified } \mathrm{RDQ}^{\ddagger}\end{array}$ & $-1.24(-3.30$ to 0.68$)$ & $61 \%$ & $6(636)$ & -- & $\begin{array}{l}-1.64(-2.71 \text { to }- \\
0.60)\end{array}$ & $0 \%$ & $5(601)$ & -- \\
\hline
\end{tabular}

Abbreviations: ODI = Oswestry Disability Index; RDQ = Roland-Morris Disability Questionnaire; SMD = standardized mean difference

*Negative values for SMDs or mean differences indicate less functional impairment with vertebroplasty

$\dagger$ For interaction

$\ddagger R D Q$ is measured on 0 to 24 scale and modified RDQ on 0 to 23 scale, with higher values indicating greater functional impairment (and will need to define RDQ) 
Table I-5. Stratified analyses, vertebroplasty versus sham or usual care, function (continuous) at 1 to 6 months, 6 to 12 months, and 12 months and longer*

\begin{tabular}{|c|c|c|c|c|c|c|c|c|c|c|c|c|}
\hline Analysis & Subgroup & $\begin{array}{l}\text { SMD }(95 \% \mathrm{Cl}), 1 \text { to } \\
6 \text { Months }\end{array}$ & $\mathbf{I}^{2}$ & $\begin{array}{l}\text { No. of } \\
\text { Trials } \\
\text { (N) }\end{array}$ & $p^{\dagger}$ & $\begin{array}{l}\text { SMD }(95 \% \mathrm{Cl}), 6 \text { to } \\
12 \text { Months }\end{array}$ & $\mathbf{I}^{2}$ & $\begin{array}{l}\text { No. of } \\
\text { Trials } \\
\text { (N) }\end{array}$ & $p^{\dagger}$ & $\begin{array}{l}\text { SMD }(95 \% \mathrm{Cl}), 12 \\
\text { Months and Longer }\end{array}$ & $\mathbf{I}^{2}$ & $\begin{array}{l}\text { No. of } \\
\text { Trials } \\
\text { (N) }\end{array}$ \\
\hline All trials & -- & $-0.28(-0.43$ to -0.11$)$ & $0 \%$ & $7(637)$ & -- & $-0.29(-0.45$ to -0.14$)$ & $0 \%$ & $6(690)$ & -- & $-0.23(-0.39$ to -0.06$)$ & $0 \%$ & $6(612)$ \\
\hline \multirow{2}{*}{ Control type } & - Sham & $-0.14(-0.53$ to 0.27$)$ & $27 \%$ & $3(301)$ & 0.21 & $-0.32(-0.70$ to 0.09$)$ & $23 \%$ & $3(292)$ & 0.78 & $-0.17(-0.51$ to 0.22$)$ & $0 \%$ & $2(176)$ \\
\hline & - Usual care & $-0.37(-0.56$ to -0.18$)$ & $0 \%$ & $4(440)$ & $\begin{array}{ll}- \\
\end{array}$ & $-0.27(-0.48$ to -0.07$)$ & $0 \%$ & $3(398)$ & -- & $-0.25(-0.45$ to -0.05$)$ & $0 \%$ & $4(436)$ \\
\hline \multirow{3}{*}{$\begin{array}{l}\text { Pain } \\
\text { duration } \\
\text { (mean or } \\
\text { median) }\end{array}$} & - $\quad<4$ weeks & $-0.40(-0.66$ to -0.14$)$ & $0 \%$ & $3(252)$ & 0.30 & $-0.45(-0.88$ to -0.03$)$ & $0 \%$ & $2(207)$ & 0.27 & $-0.11(-0.50$ to 0.31$)$ & $0 \%$ & $2(145)$ \\
\hline & $\begin{array}{ll} & 4 \text { to } 8 \\
& \text { weeks } \\
\end{array}$ & $-0.37(-0.65$ to -0.09$)$ & NA & $1(202)$ & -- & $-0.26(-0.53$ to 0.02$)$ & NA & $1(202)$ & -- & $-0.28(-0.55$ to 0.00$)$ & NA & $1(202)$ \\
\hline & - $\quad>8$ weeks & $-0.11(-0.43$ to 0.24$)$ & $0 \%$ & $3(287)$ & -- & $-0.21(-0.46$ to 0.06$)$ & $0 \%$ & $3(281)$ & -- & $-0.25(-0.52$ to 0.03$)$ & $0 \%$ & $3(265)$ \\
\hline \multirow{3}{*}{$\begin{array}{l}\text { Study } \\
\text { quality }\end{array}$} & - $\quad$ Good & $-0.14(-0.53$ to 0.27$)$ & $27 \%$ & $3(301)$ & 0.46 & $-0.32(-0.70$ to 0.09$)$ & $23 \%$ & $3(292)$ & 0.54 & $-0.17(-0.51$ to 0.22$)$ & $0 \%$ & $2(176)$ \\
\hline & - $\quad$ Fair & $-0.37(-0.64$ to -0.09$)$ & $0 \%$ & $2(291)$ & -- & $-0.27(-0.55$ to 0.00$)$ & $0 \%$ & $2(291)$ & -- & $-0.32(-0.63$ to -0.05$)$ & $0 \%$ & $2(291)$ \\
\hline & - $\quad$ Poor & $-0.38(-0.76$ to 0.03$)$ & $0 \%$ & $2(149)$ & -- & $-0.29(-0.67$ to 0.09$)$ & $\begin{array}{l}- \\
\end{array}$ & $1(107)$ & -- & $-0.11(-0.50$ to 0.31$)$ & $0 \%$ & $2(145)$ \\
\hline Scale & $\begin{array}{l}\text { On original } \\
\text { scale } \\
\text { RDQ or } \\
\text { modified RDQ }\end{array}$ & $-1.66(-3.05$ to -0.09$)$ & $2 \%$ & $4(592)$ & -- & $-1.90(-3.09$ to -0.73$)$ & $0 \%$ & $5(543)$ & -- & $-1.78(-3.00$ to -0.52$)$ & $0 \%$ & $4(427)$ \\
\hline
\end{tabular}

Abbreviations: $\mathrm{CI}=$ confidence interval; $\mathrm{N}=$ number of subjects; $\mathrm{RDQ}=$ Roland-Morris Disability Questionnaire; $\mathrm{SMD}=$ standardized mean difference

*Negative values for standardized mean differences or mean differences indicate less functional impairment with vertebroplasty

$\dagger$ For interaction

$\ddagger R D Q$ is measured on 0 to 24 scale and modified RDQ on 0 to 23 scale, with higher values indicating greater functional impairment 
Figure I-3. Vertebroplasty versus sham or usual care, EQ-5D (continuous) at 2 to 4 weeks

\begin{tabular}{|c|c|c|c|c|c|c|c|c|}
\hline $\begin{array}{l}\text { Control Type } \\
\text { and Author Year }\end{array}$ & $\begin{array}{l}\text { Pain Duration } \\
\text { Inclusion }\end{array}$ & $\begin{array}{l}\text { Pain Duration } \\
\text { (weeks) }\end{array}$ & $\begin{array}{l}\text { BME MRI } \\
\text { Required }\end{array}$ & $\begin{array}{l}\text { PMMA } \\
\text { Category }\end{array}$ & $\begin{array}{l}\mathrm{N}, \text { Mean(SD), } \\
\text { Vertebroplasty }\end{array}$ & $\begin{array}{l}\text { N, Mean(SD), } \\
\text { Control }\end{array}$ & & $\begin{array}{l}\text { Mean difference } \\
(95 \% \mathrm{Cl})\end{array}$ \\
\hline \multicolumn{9}{|l|}{ Sham } \\
\hline Buchbinder $2009^{*}$ & Up to 12 months & 9.0 to 9.5 & No & $\leq 5 \mathrm{ml}$ & $35,0.10(0.30)$ & $38,0.10(0.30)$ & $-i$ & $0.00(-0.10$ to 0.10$)$ \\
\hline Kallmes 2009* & Up to 12 months & 17.8 & No & $\leq 5 \mathrm{ml}$ & $67,0.70(0.18)$ & $61,0.64(0.20)$ & - & $0.05(-0.01$ to 0.11$)$ \\
\hline Clark 2016 & $<6$ weeks & 2.6 & No & $>5 \mathrm{ml}$ & $47,0.75(0.11)$ & $51,0.70(0.11)$ & $\rightarrow$ & 0.05 (0.01 to 0.09 ) \\
\hline \multicolumn{3}{|c|}{ Subgroup $\left(1^{2}=0.0 \%, p=0.644\right)$} & & & & & $\Delta$ & 0.04 (0.00 to 0.08$)$ \\
\hline \multicolumn{9}{|l|}{ Usual Care } \\
\hline \multirow[t]{2}{*}{ Klazen 2010} & $\leq 6$ weeks & 4 & Yes & $\leq 5 \mathrm{ml}$ & $101,0.60(0.20)$ & $101,0.50(0.30)$ & - & 0.10 (0.03 to 0.17$)$ \\
\hline & & & & & & & $>$ & $0.10(0.03$ to 0.17$)$ \\
\hline \multicolumn{9}{|c|}{ Heterogeneity between groups: $p=0.160$} \\
\hline \multicolumn{7}{|c|}{ Overall $\left(I^{2}=0.0 \%, p=0.415\right)$} & $\diamond$ & 0.05 (0.02 to 0.09$)$ \\
\hline
\end{tabular}

Abbreviations: $\mathrm{BME}=$ bone marrow edema; $\mathrm{CI}=$ confidence interval; $\mathrm{MRI}=$ magnetic resonance imaging; $\mathrm{PMMA}=$ polymethyl methacrylate; $\mathrm{SD}=$ standard deviation

*Adjusted mean difference from a regression model was used

See Appendix F, List of Included Studies, for full citations

Figure I-4. Vertebroplasty versus sham or usual care, EQ-5D (continuous) at 6 to 12 months

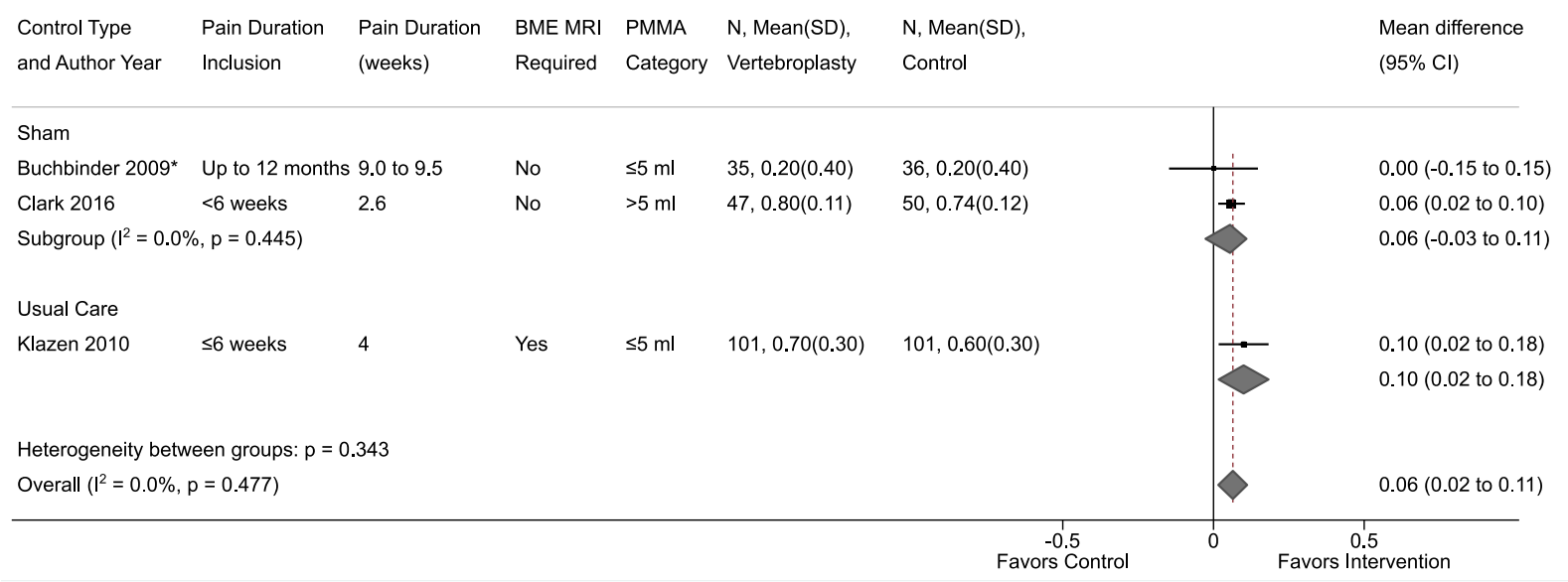

Abbreviations: $\mathrm{BME}=$ bone marrow edema; $\mathrm{CI}=$ confidence interval; $\mathrm{MRI}=$ magnetic resonance imaging; $\mathrm{PMMA}=$ polymethyl methacrylate; $\mathrm{SD}=$ standard deviation

*Adjusted mean difference from a regression model was used

See Appendix F, List of Included Studies, for full citations 
Figure I-5. Vertebroplasty versus sham or usual care, EQ-5D (continuous) at 12 months and longer

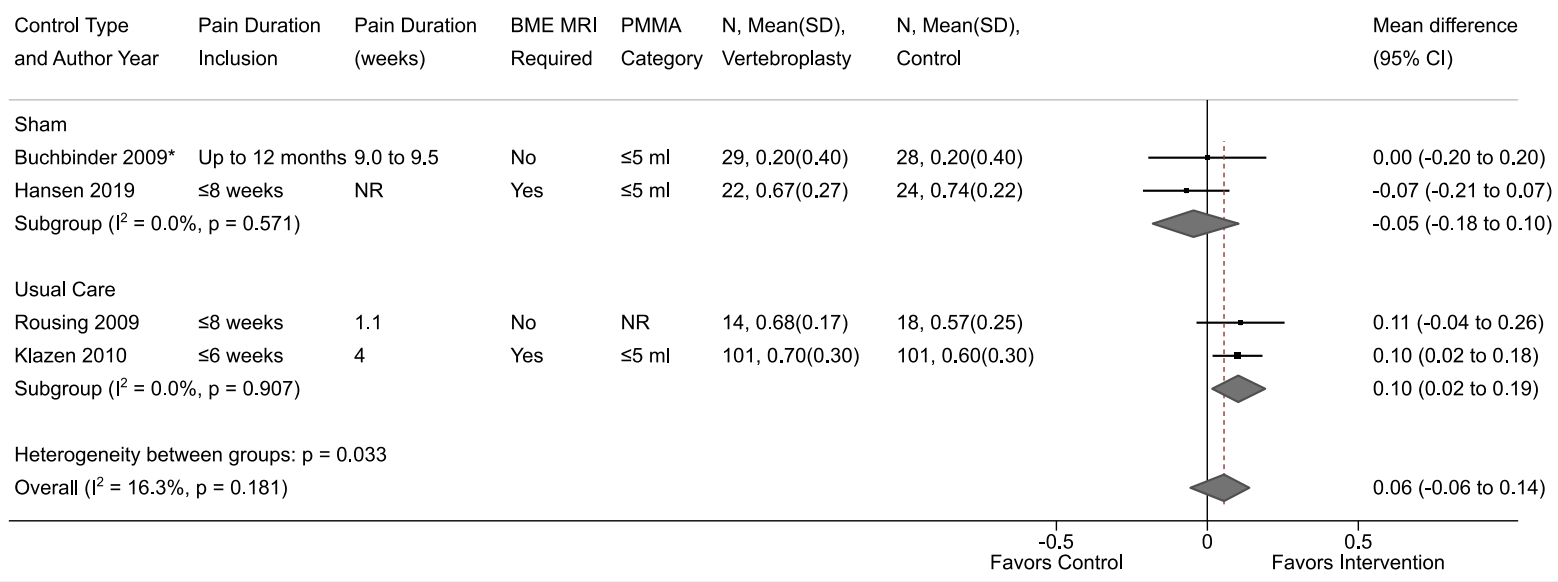

Abbreviations: $\mathrm{BME}=$ bone marrow edema; $\mathrm{CI}=$ confidence interval; $\mathrm{MRI}=$ magnetic resonance imaging; $\mathrm{PMMA}=$ polymethyl methacrylate; $\mathrm{SD}=$ standard deviation

*Adjusted mean difference from a regression model was used

\section{See Appendix F, List of Included Studies, for full citations}

\section{Figure I-6. Vertebroplasty versus sham or usual care, EQ-5D (continuous) at 1 to 2 weeks}

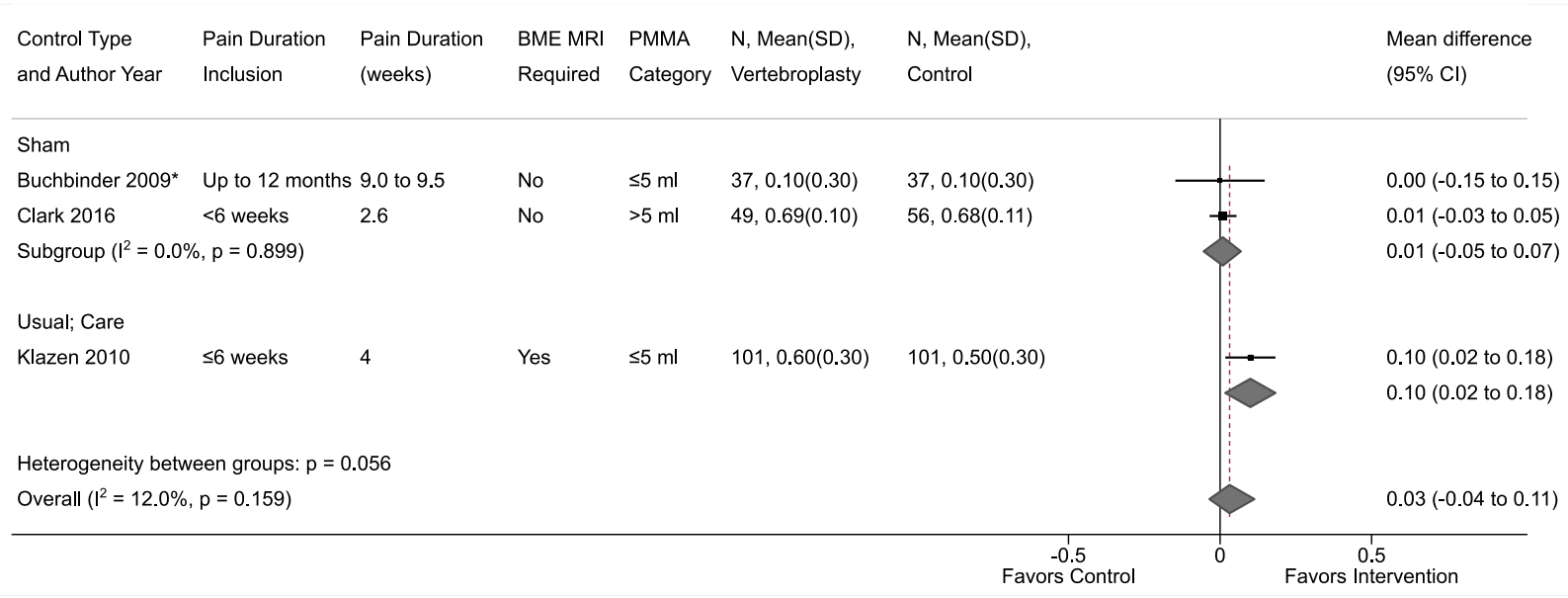

Abbreviations: $\mathrm{BME}=$ bone marrow edema; $\mathrm{CI}=$ confidence interval; $\mathrm{MRI}=$ magnetic resonance imaging; $\mathrm{PMMA}=$ polymethyl methacrylate; $\mathrm{SD}=$ standard deviation

*Adjusted mean difference from a regression model was used 
Figure 1-7. Vertebroplasty versus sham or usual care, EQ-5D (continuous) at 1 to 6 months

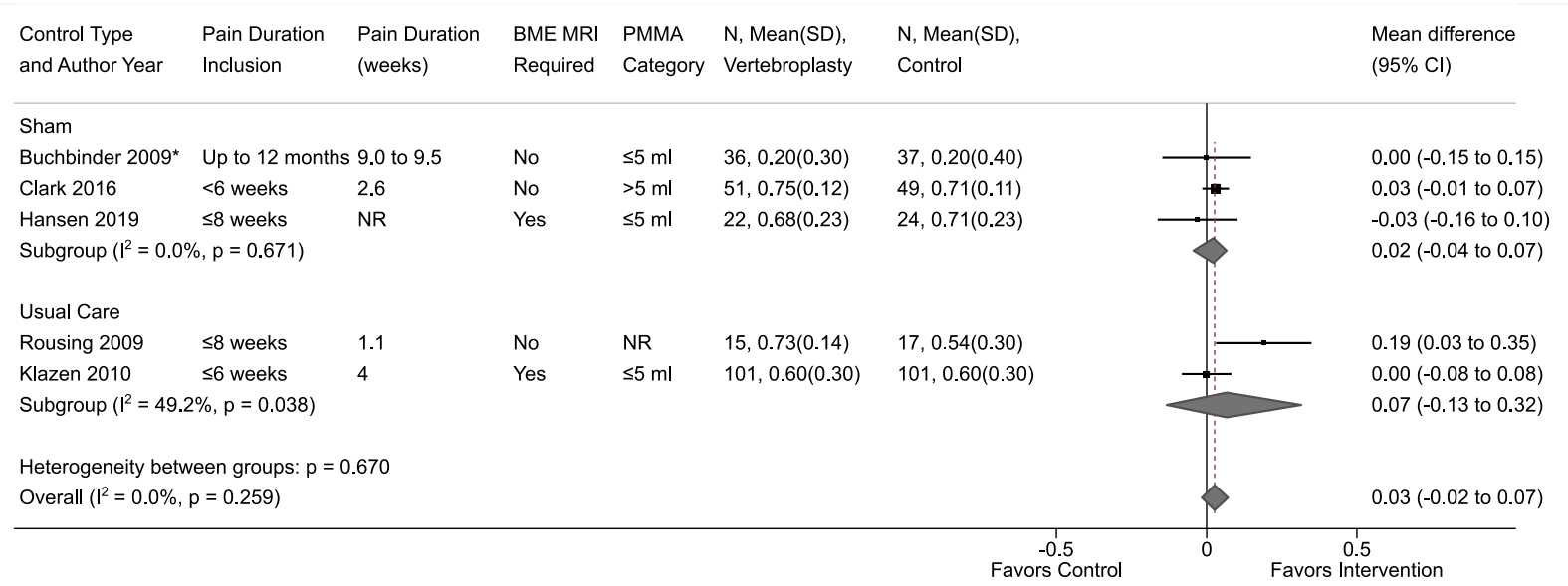

Abbreviations: $\mathrm{BME}=$ bone marrow edema; $\mathrm{CI}=$ confidence interval; $\mathrm{MRI}=$ magnetic resonance imaging; $\mathrm{PMMA}=$ polymethyl methacrylate; $\mathrm{SD}=$ standard deviation

*Adjusted mean difference from a regression model was used

See Appendix F, List of Included Studies, for full citations

Table I-6. Vertebroplasty versus sham or usual care, quality of life (continuous) at 1 to 2 weeks and at 2 to 4 weeks

\begin{tabular}{|c|c|c|c|c|c|c|c|c|c|}
\hline Analysis & Subgroup & $\begin{array}{l}\text { Mean Difference }(95 \% \mathrm{Cl}) \text {, } \\
1 \text { to } 2 \text { Weeks }\end{array}$ & $\mathbf{l}^{2}$ & $\begin{array}{l}\text { Number } \\
\text { of Trials } \\
\text { (N) }\end{array}$ & $\mathbf{p}^{*}$ & $\begin{array}{l}\text { Mean Difference }(95 \% \mathrm{Cl}), 2 \\
\text { to } 4 \text { Weeks }\end{array}$ & $\mathbf{I}^{2}$ & $\begin{array}{l}\text { Number } \\
\text { of Trials } \\
\text { (N) }\end{array}$ & $\mathbf{p}^{*}$ \\
\hline EQ-5D, all trials ${ }^{\dagger}$ & -- & $0.03(-0.04$ to 0.11$)$ & $12 \%$ & $3(381)$ & -- & $0.05(0.02$ to 0.09$)$ & $0 \%$ & $4(501)$ & - \\
\hline \multirow{2}{*}{$\begin{array}{l}\text { EQ-5D, control } \\
\text { type }\end{array}$} & Sham & $0.01(-0.05$ to 0.07$)$ & $0 \%$ & $2(179)$ & 0.31 & $0.04(0.00$ to 0.08$)$ & $0 \%$ & $3(299)$ & 0.29 \\
\hline & - Usual care & $0.10(0.02$ to 0.18$)$ & -- & $1(202)$ & -- & $0.10(0.03$ to 0.17$)$ & $0 \%$ & $1(202)$ & -- \\
\hline \multirow{3}{*}{$\begin{array}{l}\text { EQ-5D, study } \\
\text { quality }\end{array}$} & - Good & $0.01(-0.05$ to 0.07$)$ & $0 \%$ & $2(179)$ & 0.31 & $0.04(0.00$ to 0.08$)$ & $0 \%$ & $3(299)$ & 0.29 \\
\hline & - $\quad$ Fair & $0.10(0.02$ to 0.18$)$ & -- & $1(202)$ & -- & $0.10(0.03$ to 0.17$)$ & $0 \%$ & $1(202)$ & -- \\
\hline & - $\quad$ Poor & -- & -- & -- & -- & -- & -- & -- & -- \\
\hline $\begin{array}{l}\text { QUALEFFO, all } \\
\text { trials }^{\ddagger}\end{array}$ & -- & $-2.55(-9.46$ to 3.16$)$ & $76 \%$ & $6(644)$ & -- & $-2.11(-10.44$ to 3.54$)$ & $63 \%$ & $4(482)$ & -- \\
\hline \multirow{2}{*}{$\begin{array}{l}\text { QUALEFFO, } \\
\text { control type }\end{array}$} & - $\quad$ Sham & $-0.73(-13.01$ to 11.09$)$ & $80 \%$ & $2(176)$ & 0.64 & $0.94(-9.37$ to 9.63$)$ & $52 \%$ & $2(173)$ & 0.36 \\
\hline & - Usual care & $-4.00(-14.59$ to 4.67$)$ & $68 \%$ & $4(468)$ & -- & $-4.95(-17.56$ to 0.72$)$ & $0 \%$ & $2(309)$ & \\
\hline \multirow{3}{*}{$\begin{array}{l}\text { QUALEFFO, study } \\
\text { quality }\end{array}$} & - Good & $-0.73(-13.01$ to 11.09$)$ & $80 \%$ & $2(176)$ & 0.81 & $0.94(-9.37$ to 9.63$)$ & $52 \%$ & $2(173)$ & 0.53 \\
\hline & - $\quad$ Fair & $-3.36(-15.72$ to 7.67$)$ & $76 \%$ & $3(361)$ & -- & $-4.20(-8.60$ to 0.20$)$ & -- & $1(202)$ & -- \\
\hline & - $\quad$ Poor & $-10.00(-29.40$ to 9.40$)$ & -- & $1(107)$ & -- & $-16.00(-32.86$ to 0.86$)$ & -- & $1(107)$ & -- \\
\hline
\end{tabular}

Abbreviations: $\mathrm{CI}$ = confidence interval; EQ-5D = EuroQol-5 Dimension; QUALEFFO = Quality of Life for Osteoporosis

*For interaction 
${ }^{\dagger} \mathrm{EQ}-5 \mathrm{D}$ is on a 0 to 1 scale (higher score indicates better quality of life) and that positive mean difference values indicated better quality of life with vertebroplasty

${ }^{\ddagger}$ QUALEFFO is on a 0 to 100 scale (higher score indicates worse quality of life) and that negative mean difference values indicate better quality of life with vertebroplasty. 
Table I-7. Vertebroplasty versus sham or usual care, quality of life (continuous) at 1 to 6 months, 6 to 12 months, and 12 months and longer

\begin{tabular}{|c|c|c|c|c|c|c|c|c|c|c|c|c|c|}
\hline Analysis & Subgroup & $\begin{array}{l}\text { Mean Difference } \\
(95 \% \mathrm{Cl}), 1 \text { to } 6 \\
\text { Months } \\
\end{array}$ & $\mathbf{I}^{2}$ & $\begin{array}{l}\text { No. of } \\
\text { Trials } \\
\text { (N) }\end{array}$ & $\mathbf{p}^{*}$ & $\begin{array}{l}\text { Mean Difference } \\
(95 \% \mathrm{Cl}), 6 \text { to } 12 \\
\text { Months }\end{array}$ & $\mathbf{I}^{2}$ & $\begin{array}{l}\text { No. of } \\
\text { Trials } \\
\text { (N) }\end{array}$ & $\mathbf{p}^{*}$ & $\begin{array}{l}\text { Mean Difference } \\
(95 \% \mathrm{Cl}), 12 \text { Months } \\
\text { and Longer }\end{array}$ & $\mathbf{I}^{2}$ & $\begin{array}{l}\text { No. of } \\
\text { Trials } \\
\text { (N) }\end{array}$ & $\mathbf{p}^{*}$ \\
\hline $\begin{array}{l}\text { EQ-5D, all } \\
\text { trials }^{\dagger}\end{array}$ & -- & $0.03(-0.02$ to 0.07$)$ & $0 \%$ & $5(433)$ & -- & $0.06(0.02$ to 0.11$)$ & $0 \%$ & $3(370)$ & -- & $0.06(-0.06$ to 0.14$)$ & $16 \%$ & $4(337)$ & - \\
\hline \multirow{2}{*}{$\begin{array}{l}\text { EQ-5D, control } \\
\text { type }\end{array}$} & - $\quad$ Sham & $0.02(-0.04$ to 0.07$)$ & $0 \%$ & $3(199)$ & 0.52 & $0.06(-0.03$ to 0.11$)$ & $0 \%$ & $2(168)$ & 0.52 & $-0.05(-0.18$ to 0.10$)$ & $0 \%$ & $2(103)$ & 0 . \\
\hline & $\begin{array}{ll}\text { - Usual } \\
\text { care }\end{array}$ & $0.07(-0.13$ to 0.32$)$ & $49 \%$ & $2(234)$ & -- & $0.10(0.02$ to 0.18$)$ & $\begin{array}{l}-- \\
\end{array}$ & $1(202)$ & -- & $0.10(0.02$ to 0.19$)$ & $0 \%$ & $2(234)$ & -- \\
\hline \multirow{3}{*}{$\begin{array}{l}\text { EQ-5D, study } \\
\text { quality }\end{array}$} & - Good & $0.03(-0.04$ to 0.08$)$ & $0 \%$ & $2(173)$ & 0.29 & $0.06(-0.03$ to 0.11$)$ & $0 \%$ & $2(168)$ & 0.52 & $0.00(-0.20$ to 0.20$)$ & -- & $1(57)$ & 0 . \\
\hline & - $\quad$ Fair & $-0.01(-0.10$ to 0.07$)$ & $0 \%$ & $2(228)$ & -- & $0.10(0.02$ to 0.18$)$ & -- & $1(202)$ & -- & $0.04(-0.18$ to 0.22$)$ & $47 \%$ & $2(228)$ & -- \\
\hline & - $\quad$ Poor & $0.19(0.03$ to 0.35$)$ & -- & $1(32)$ & -- & -- & -- & -- & -- & $0.11(-0.04$ to 0.26$)$ & -- & $1(32)$ & -- \\
\hline $\begin{array}{l}\text { QUALEFFO, } \\
\text { all trials }\end{array}$ & -- & $-2.16(-7.08$ to 1.81$)$ & $0 \%$ & $4(507)$ & -- & $-2.98(-7.62$ to 0.69$)$ & $15 \%$ & $5(599)$ & -- & $-1.45(-5.12$ to 2.06$)$ & $0 \%$ & $4(491)$ & -- \\
\hline \multirow{2}{*}{$\begin{array}{l}\text { QUALEFFO, } \\
\text { control type }\end{array}$} & - $\quad$ Sham & $-0.70(-5.66$ to 4.26$)$ & -- & $1(73)$ & 0.73 & $-3.63(-11.49$ to 3.94$)$ & $16 \%$ & $2(165)$ & 0.90 & $-2.10(-8.41$ to 4.21$)$ & -- & $1(57)$ & 0 . \\
\hline & $\begin{array}{ll}\text { - } & \text { Usual } \\
\text { care }\end{array}$ & $-2.92(-12.16$ to 3.51$)$ & $17 \%$ & $3(434)$ & -- & $-2.36(-11.42$ to 3.52$)$ & $0 \%$ & $3(434)$ & -- & $-1.21(-6.68$ to 3.54$)$ & $0 \%$ & $3(434)$ & -- \\
\hline \multirow{3}{*}{$\begin{array}{l}\text { QUALEFFO, } \\
\text { study quality }\end{array}$} & - Good & $-0.70(-5.66$ to 4.26$)$ & -- & $1(73)$ & 0.58 & $-3.63(-11.49$ to 3.94$)$ & $16 \%$ & $2(165)$ & 0.44 & $-2.10(-8.41$ to 4.21$)$ & -- & $1(57)$ & 0 . \\
\hline & - $\quad$ Fair & $-2.06(-9.25$ to 6.43$)$ & $22 \%$ & $2(327)$ & -- & $-1.33(-7.25$ to 5.64$)$ & $0 \%$ & $2(327)$ & -- & $-0.77(-6.06$ to 5.33$)$ & $0 \%$ & $2(327)$ & -- \\
\hline & - $\quad$ Poor & $\begin{array}{l}-14.00(-29.31 \text { to } \\
1.31)\end{array}$ & -- & $1(107)$ & -- & $\begin{array}{l}-13.00(-25.55 \text { to }- \\
0.45)\end{array}$ & -- & $1(107)$ & -- & $-8.00(-23.31$ to 7.31$)$ & -- & $1(107)$ & -- \\
\hline
\end{tabular}

Abbreviations: CI = confidence interval; EQ-5D = EuroQol-5 Dimension; $\mathrm{N}=$ number of subjects; QUALEFFO = Quality of Life for Osteoporosis

*For interaction

$\dagger$ EQ-5D is on a 0 to 1 scale (higher score indicates better quality of life) and that positive mean difference values indicated better quality of life with vertebroplasty

\$QUALEFFO is on a 0 to 100 scale (higher score indicates worse quality of life) and that negative mean difference values indicate better quality of life with vertebroplasty. 
Figure I-8. Vertebroplasty versus sham or usual care on the QUALEFFO at 1 to 2 weeks

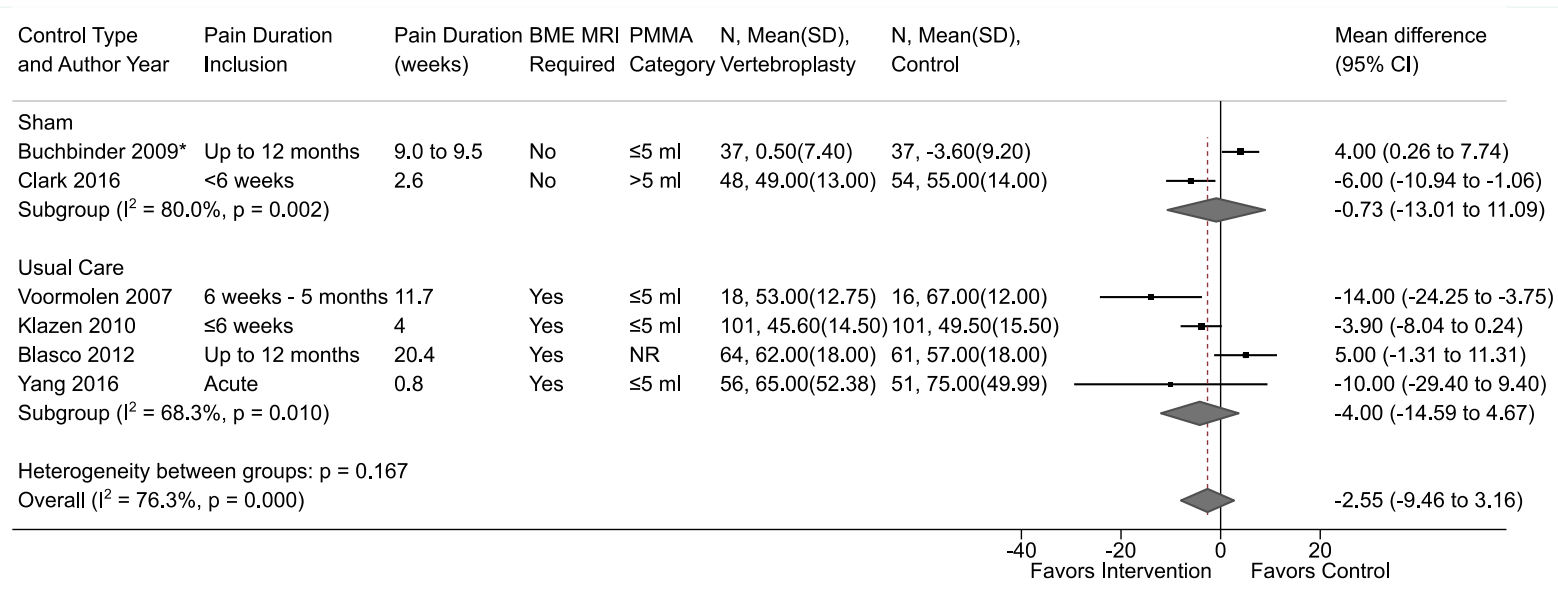

Abbreviations: $\mathrm{BME}=$ bone marrow edema; $\mathrm{CI}=$ confidence interval; $\mathrm{MRI}=$ magnetic resonance imaging; $\mathrm{PMMA}=$ polymethyl methacrylate; $\mathrm{SD}=$ standard deviation

*Adjusted mean difference from a regression model was used

See Appendix F, List of Included Studies, for full citations

Figure I-9. Vertebroplasty versus sham or usual care on the QUALEFFO at 2 to 4 weeks

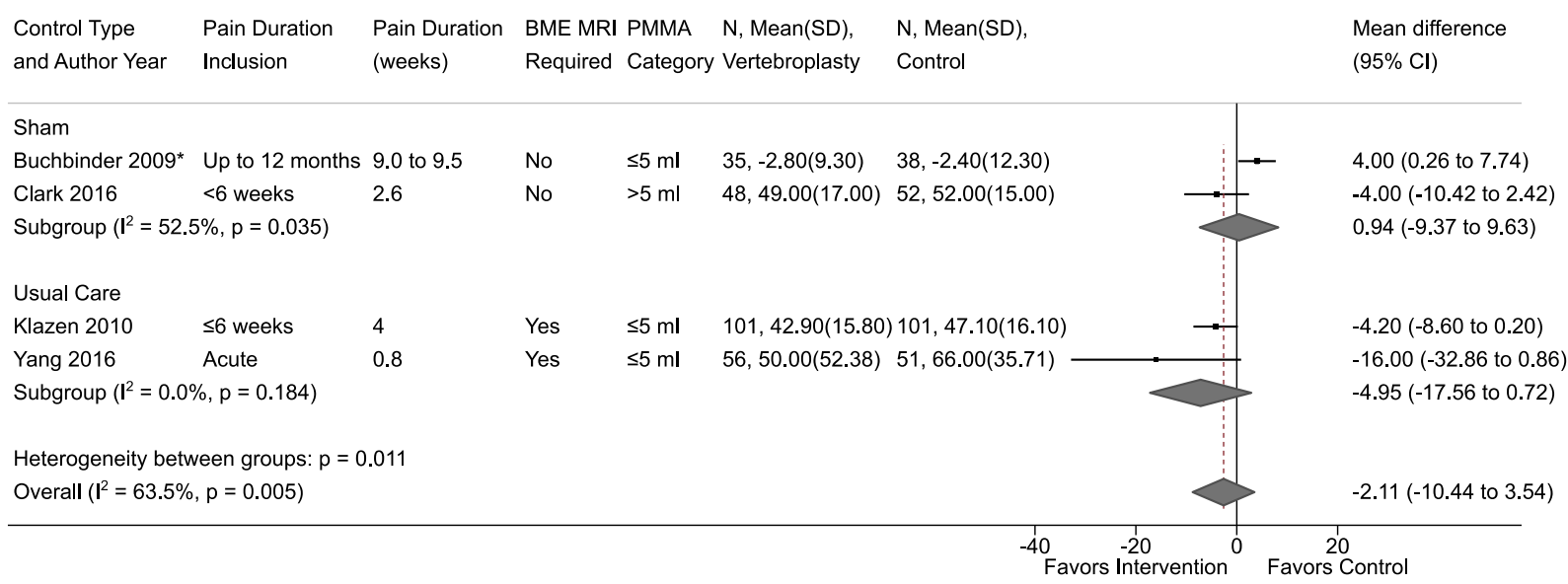

Abbreviations: $\mathrm{BME}=$ bone marrow edema; $\mathrm{CI}=$ confidence interval; $\mathrm{MRI}=$ magnetic resonance imaging; $\mathrm{PMMA}=$ polymethyl methacrylate; $\mathrm{SD}=$ standard deviation

*Adjusted mean difference from a regression model was used 


\section{Figure I-10. Vertebroplasty versus sham or usual care on the QUALEFFO at 1 to 6 months}

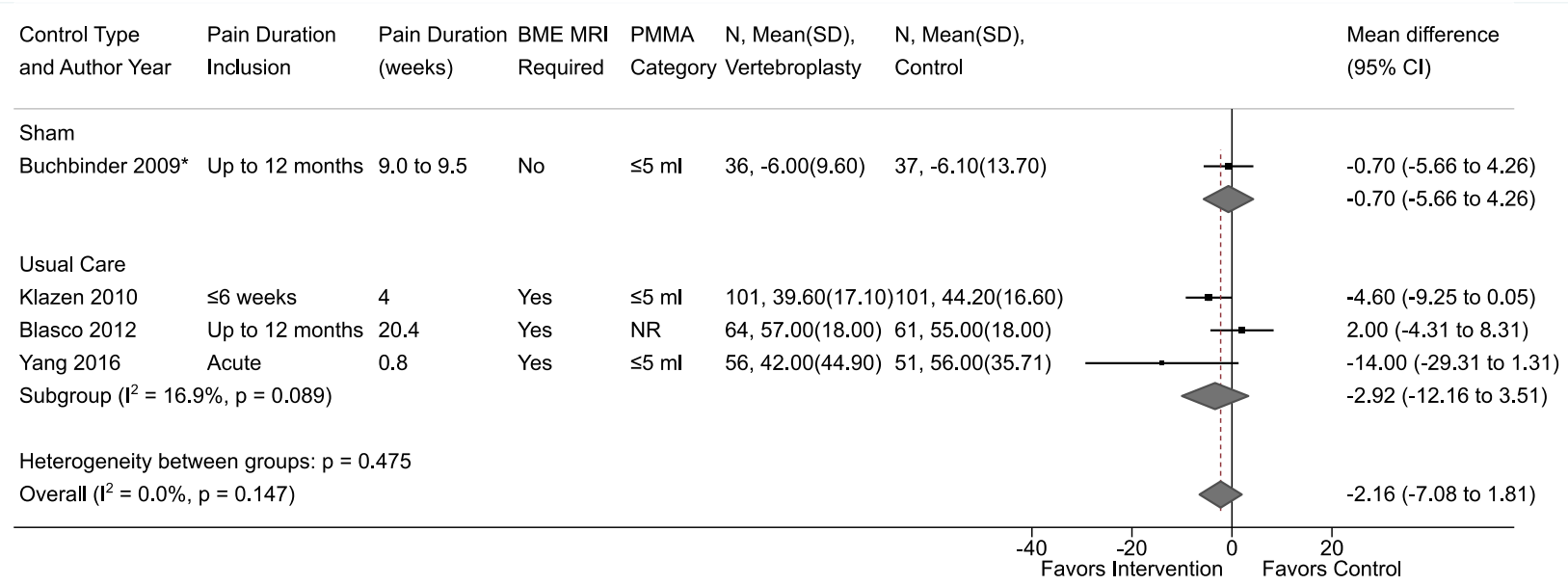

Abbreviations: $\mathrm{BME}=$ bone marrow edema; $\mathrm{CI}=$ confidence interval; $\mathrm{MRI}=$ magnetic resonance imaging; $\mathrm{PMMA}=$ polymethyl methacrylate; $\mathrm{SD}=$ standard deviation

*Adjusted mean difference from a regression model was used

\section{See Appendix F, List of Included Studies, for full citations}

\section{Figure I-11. Vertebroplasty versus sham or usual care on the QUALEFFO at 6 to 12 months}

\begin{tabular}{|c|c|c|c|c|c|c|c|}
\hline $\begin{array}{l}\text { Control Type } \\
\text { and Author Year }\end{array}$ & $\begin{array}{l}\text { Pain Duration } \\
\text { Inclusion }\end{array}$ & $\begin{array}{l}\text { Pain Duration } \\
\text { (weeks) }\end{array}$ & $\begin{array}{l}\text { BME MRI } \\
\text { Required }\end{array}$ & $\begin{array}{l}\text { PMMA } \\
\text { Category }\end{array}$ & $\begin{array}{l}\mathrm{N}, \text { Mean(SD), } \\
\text { Vertebroplasty }\end{array}$ & $\begin{array}{l}\mathrm{N}, \text { Mean(SD), } \\
\text { Control }\end{array}$ & $\begin{array}{l}\text { Mean difference } \\
(95 \% \mathrm{Cl})\end{array}$ \\
\hline \multicolumn{8}{|l|}{ Sham } \\
\hline Buchbinder 2009* & Up to 12 months & 9.0 to 9.5 & No & $\leq 5 \mathrm{ml}$ & $35,-6.40(13.40)$ & $36,-6.10(13.40)$ & $-0.60(-6.15$ to 4.95$)$ \\
\hline Clark 2016 & $<6$ weeks & 2.6 & No & $>5 \mathrm{ml}$ & $46,38.00(15.00)$ & $48,45.00(16.00)$ & $-7.00(-12.92$ to -1.08$)$ \\
\hline Subgroup $\left(I^{2}=16.0\right.$ & $\%, p=0.122)$ & & & & & & $-3.63(-11.49$ to 3.94$)$ \\
\hline \multicolumn{8}{|l|}{ Usual Care } \\
\hline Klazen 2010 & $\leq 6$ weeks & 4 & Yes & $\leq 5 \mathrm{ml}$ & $101,38.90(17.80)$ & $101,42.30(18.30)$ & $-3.40(-8.38$ to 1.58$)$ \\
\hline Blasco 2012 & Up to 12 months & 20.4 & Yes & NR & $64,54.00(18.00)$ & $61,52.00(18.00)$ & $2.00(-4.31$ to 8.31$)$ \\
\hline Yang 2016 & Acute & 0.8 & Yes & $\leq 5 \mathrm{ml}$ & $56,39.00(37.42)$ & $51,52.00(28.57)$ & $-13.00(-25.55$ to -0.45$)$ \\
\hline Subgroup $\left(I^{2}=0.0\right.$ & $\%, p=0.092)$ & & & & & & $-2.36(-11.42$ to 3.52$)$ \\
\hline \multicolumn{8}{|c|}{ Heterogeneity between groups: $p=0.661$} \\
\hline Overall $\left(I^{2}=14.6 \%\right.$ & $p=0.119)$ & & & & & & $-2.98(-7.62$ to 0.69$)$ \\
\hline
\end{tabular}

Abbreviations: $\mathrm{BME}=$ bone marrow edema; $\mathrm{CI}=$ confidence interval; $\mathrm{MRI}=$ magnetic resonance imaging; $\mathrm{PMMA}=$ polymethyl methacrylate; $\mathrm{SD}=$ standard deviation 
*Adjusted mean difference from a regression model was used

See Appendix F, List of Included Studies, for full citations

Figure I-12. Vertebroplasty versus sham or usual care on the QUALEFFO at 12 months and longer

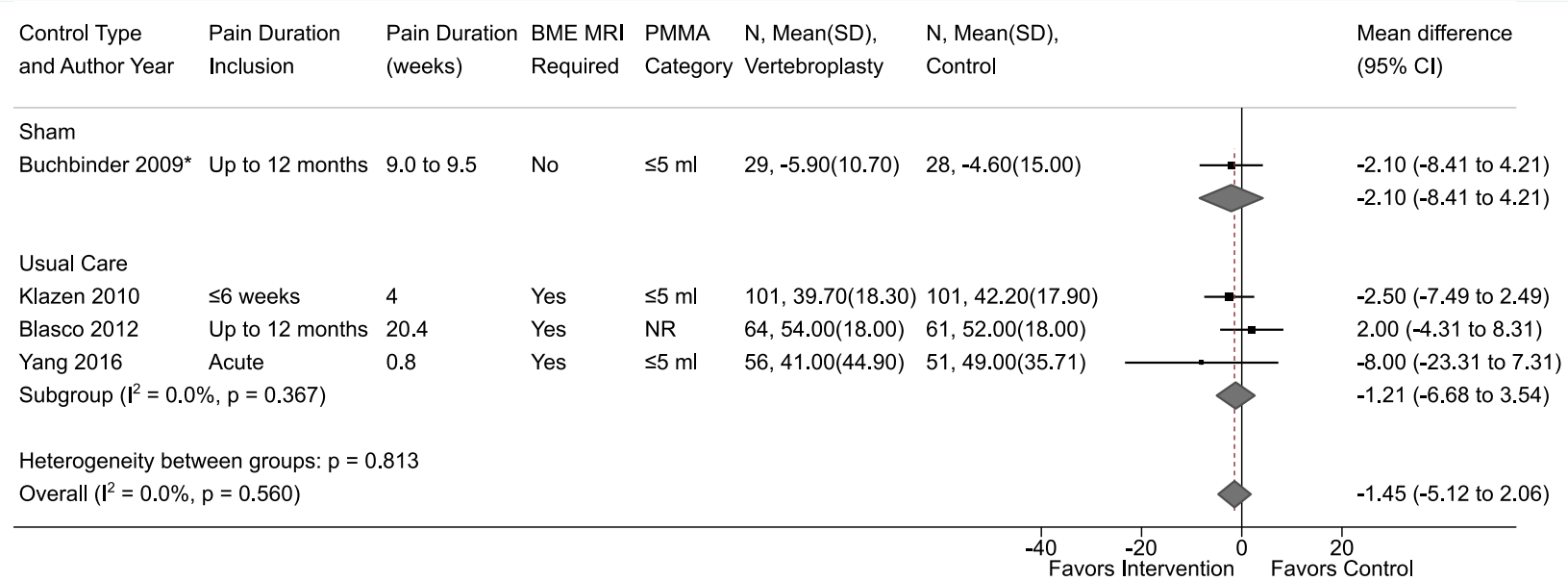

Abbreviations: $\mathrm{BME}=$ bone marrow edema; $\mathrm{CI}=$ confidence interval; $\mathrm{MRI}=$ magnetic resonance imaging; $\mathrm{PMMA}=$ polymethyl methacrylate; $\mathrm{SD}=$ standard deviation

*Adjusted mean difference from a regression model was used

See Appendix F, List of Included Studies, for full citations 
Figure I-13. Vertebroplasty versus sham or usual care on the Short-Form 36 Physical Component Summary Scores

\begin{tabular}{|c|c|c|c|c|c|c|c|c|}
\hline $\begin{array}{l}\text { Outcome duration } \\
\text { category and } \\
\text { Author Year }\end{array}$ & $\begin{array}{l}n \text { Pain Duration } \\
\text { Inclusion }\end{array}$ & $\begin{array}{l}\text { Pain Duration } \\
\text { (weeks) }\end{array}$ & $\begin{array}{l}\text { BME MRI } \\
\text { Required }\end{array}$ & $\begin{array}{l}\text { PMMA } \\
\text { Category }\end{array}$ & $\begin{array}{l}\text { Control } \\
\text { Type }\end{array}$ & $\begin{array}{l}\text { N, Mean(SD), } \\
\text { Vertebroplasty }\end{array}$ & $\begin{array}{l}\mathrm{N}, \text { Mean(SD), } \\
\text { Control }\end{array}$ & $\begin{array}{l}\text { Mean difference } \\
(95 \% \mathrm{Cl})\end{array}$ \\
\hline $\begin{array}{l}>2 \text { weeks to } \leq 1 \mathrm{~m} \\
\text { Kallmes } 2009^{*}\end{array}$ & $\begin{array}{l}\text { nonth } \\
\text { Up to } 12 \text { months }\end{array}$ & 17.8 & No & $\leq 5 \mathrm{ml}$ & Sham & $67,29.70(9.60)$ & $61,28.70(8.00)$ & $\begin{array}{l}1.00(-1.67 \text { to } 3.67) \\
1.00(-1.67 \text { to } 3.67)\end{array}$ \\
\hline $\begin{array}{l}>1 \text { month to }<6 \mathrm{~m} \\
\text { Hansen } 2019 \\
\text { Rousing } 2009 \\
\text { Subgroup }\left(1^{2}=30\right.\end{array}$ & $\begin{array}{l}\text { Oonths } \\
\leq 8 \text { weeks } \\
\leq 8 \text { weeks } \\
.3 \%, p=0.090)\end{array}$ & $\begin{array}{l}\text { NR } \\
1.1\end{array}$ & $\begin{array}{l}\text { Yes } \\
\text { No }\end{array}$ & $\begin{array}{l}\leq 5 \mathrm{ml} \\
\mathrm{NR}\end{array}$ & $\begin{array}{l}\text { Sham } \\
\text { Usual Care }\end{array}$ & $\begin{array}{l}22,31.40(10.00) \\
23,34.00(9.00)\end{array}$ & $\begin{array}{l}24,33.90(10.60) \\
20,29.30(10.30)\end{array}$ & $\begin{array}{l}-2.50(-8.45 \text { to } 3.45) \\
4.70(-1.12 \text { to } 10.52) \\
1.16(-7.58 \text { to } 9.79)\end{array}$ \\
\hline $\begin{array}{l}\geq 12 \text { months } \\
\text { Hansen } 2019 \\
\text { Rousing } 2009 \\
\text { Subgroup }\left(1^{2}=0.0\right.\end{array}$ & $\begin{array}{l}\leq 8 \text { weeks } \\
\leq 8 \text { weeks } \\
0 \%, p=0.275)\end{array}$ & $\begin{array}{l}\text { NR } \\
1.1\end{array}$ & $\begin{array}{l}\text { Yes } \\
\text { No }\end{array}$ & $\begin{array}{l}\leq 5 \mathrm{ml} \\
\mathrm{NR}\end{array}$ & $\begin{array}{l}\text { Sham } \\
\text { Usual Care }\end{array}$ & $\begin{array}{l}22,31.90(9.20) \\
20,32.10(9.10)\end{array}$ & $\begin{array}{l}24,35.20(11.90) \\
21,30.50(11.50)\end{array}$ & $\begin{array}{l}-3.30(-9.42 \text { to } 2.82) \\
1.60(-4.73 \text { to } 7.93) \\
-0.93(-7.18 \text { to } 5.45)\end{array}$ \\
\hline
\end{tabular}

Abbreviations: $\mathrm{BME}=$ bone marrow edema; $\mathrm{CI}=$ confidence interval; $\mathrm{MRI}=$ magnetic resonance imaging; $\mathrm{PMMA}=$ polymethyl methacrylate; $\mathrm{SD}=$ standard deviation

*Adjusted mean difference from a regression model was used

See Appendix F, List of Included Studies, for full citations

Figure I-14. Vertebroplasty versus sham or usual care on the Short-Form 36 Mental Component Summary Scores

\begin{tabular}{|c|c|c|c|c|c|c|c|c|}
\hline $\begin{array}{l}\text { Outcome duration } \\
\text { category and } \\
\text { Author Year }\end{array}$ & $\begin{array}{l}\text { Pain Duration } \\
\text { Inclusion }\end{array}$ & $\begin{array}{l}\text { Pain Duration } \\
\text { (weeks) }\end{array}$ & $\begin{array}{l}\text { BME MRI } \\
\text { Required }\end{array}$ & $\begin{array}{l}\text { PMMA } \\
\text { Category }\end{array}$ & $\begin{array}{l}\text { Control } \\
\text { y Type }\end{array}$ & $\begin{array}{l}\mathrm{N}, \text { Mean(SD), } \\
\text { Vertebroplasty }\end{array}$ & $\begin{array}{l}\mathrm{N}, \text { Mean(SD), } \\
\text { Control }\end{array}$ & $\begin{array}{l}\text { Mean difference } \\
(95 \% \mathrm{Cl})\end{array}$ \\
\hline $\begin{array}{l}>2 \text { weeks to } \leq 1 \mathrm{~m} \\
\text { Kallmes } 2009^{*}\end{array}$ & $\begin{array}{l}\text { month } \\
\text { Up to } 12 \text { months }\end{array}$ & s17.8 & No & $\leq 5 \mathrm{ml}$ & Sham & $67,46.90(12.00)$ & $61,45.60(14.80)$ & $\begin{array}{l}1.00(-3.11 \text { to } 5.11) \\
1.00(-3.11 \text { to } 5.11)\end{array}$ \\
\hline $\begin{array}{l}>1 \text { month to }<6 \mathrm{~m} \\
\text { Hansen } 2019 \\
\text { Rousing } 2009 \\
\text { Subgroup }\left(1^{2}=0 .\right.\end{array}$ & $\begin{array}{l}\text { months } \\
\leq 8 \text { weeks } \\
\leq 8 \text { weeks } \\
.0 \%, p=0.413)\end{array}$ & $\begin{array}{l}\text { NR } \\
1.1\end{array}$ & $\begin{array}{l}\text { Yes } \\
\text { No }\end{array}$ & $\begin{array}{l}\leq 5 \mathrm{ml} \\
\mathrm{NR}\end{array}$ & $\begin{array}{l}\text { Sham } \\
\text { Usual Care }\end{array}$ & $\begin{array}{l}22,49.70(12.00) \\
23,48.90(11.80)\end{array}$ & $\begin{array}{l}24,51.40(11.00) \\
20,46.20(15.00)\end{array}$ & $\begin{array}{l}-1.70(-8.37 \text { to } 4.97) \\
2.70(-5.45 \text { to } 10.85) \\
0.06(-6.32 \text { to } 7.07)\end{array}$ \\
\hline $\begin{array}{l}\geq 12 \text { months } \\
\text { Hansen } 2019 \\
\text { Rousing } 2009 \\
\text { Subgroup }\left(I^{2}=0 .\right.\end{array}$ & $\begin{array}{l}\leq 8 \text { weeks } \\
\leq 8 \text { weeks } \\
.0 \%, p=0.335)\end{array}$ & $\begin{array}{l}\mathrm{NR} \\
1.1\end{array}$ & $\begin{array}{l}\text { Yes } \\
\text { No }\end{array}$ & $\begin{array}{l}\leq 5 \mathrm{ml} \\
\mathrm{NR}\end{array}$ & $\begin{array}{l}\text { Sham } \\
\text { Usual Care }\end{array}$ & $\begin{array}{l}22,48.60(10.80) \\
20,48.70(12.70)\end{array}$ & $\begin{array}{l}24,53.60(10.30) \\
21,49.00(11.20)\end{array}$ & $\begin{array}{l}-5.00(-11.11 \text { to } 1.11) \\
-0.30(-7.64 \text { to } 7.04) \\
-3.08(-9.17 \text { to } 3.65)\end{array}$ \\
\hline
\end{tabular}

Abbreviations: $\mathrm{BME}=$ bone marrow edema; $\mathrm{CI}=$ confidence interval; $\mathrm{MRI}=$ magnetic resonance imaging; $\mathrm{PMMA}=$ polymethyl methacrylate; $\mathrm{SD}=$ standard deviation

*Adjusted mean difference from a regression model was used

See Appendix F, List of Included Studies, for full citations 
Table I-8. Vertebroplasty versus sham or usual care, Short-Form 36 Physical and Mental Component Summary Scores (continuous)

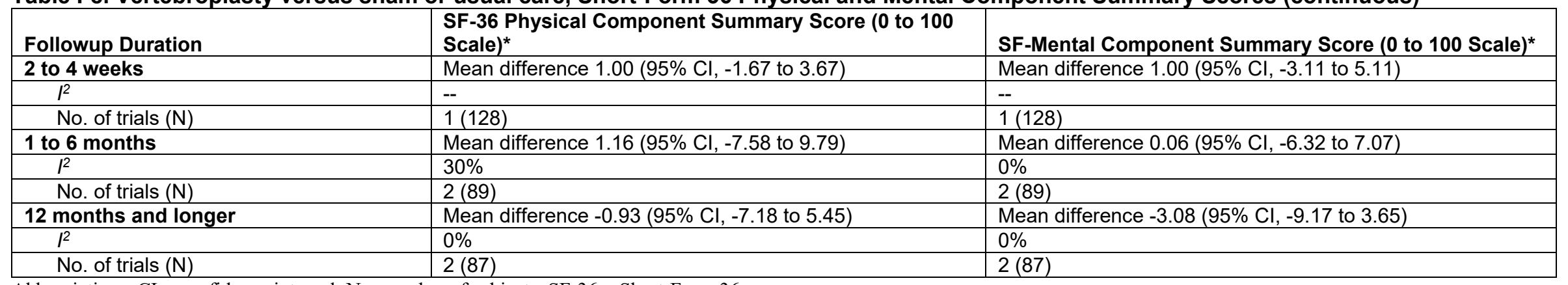

Abbreviations: $\mathrm{CI}=$ confidence interval; $\mathrm{N}$ = number of subjects; $\mathrm{SF}-36$ = Short-Form 36

*Positive values indicate that health status is better in the vertebroplasty arm 
Figure I-15. Vertebroplasty versus sham or usual care and risk of opioid use

\begin{tabular}{|c|c|c|c|c|c|c|c|c|c|}
\hline $\begin{array}{l}\text { Outcome Duration } \\
\text { and Author Year }\end{array}$ & $\begin{array}{l}\text { Pain Duration } \\
\text { Inclusion }\end{array}$ & $\begin{array}{l}\text { Pain Duration } \\
\text { (weeks) }\end{array}$ & $\begin{array}{l}\text { BME MRI } \\
\text { Required }\end{array}$ & $\begin{array}{l}\text { PMMA } \\
\text { Category }\end{array}$ & $\begin{array}{l}\text { Control } \\
\text { Type }\end{array}$ & Outcome definition & $\begin{array}{l}\text { Vertebroplasty } \\
\mathrm{n} / \mathrm{N}\end{array}$ & $\begin{array}{l}\text { Control } \\
n / N\end{array}$ & $\begin{array}{l}\text { Risk Ratio } \\
(95 \% \mathrm{Cl})\end{array}$ \\
\hline $\begin{array}{l}\geq 1 \text { week to } \leq 2 \text { weeks } \\
\text { Buchbinder } 2009 \\
\text { Blasco } 2012 \\
\text { Subgroup } \\
\left(\left.\right|^{2}=0.0 \%, p=0.594\right)\end{array}$ & $\begin{array}{l}\text { Up to } 12 \text { months } \\
\text { Up to } 12 \text { months }\end{array}$ & $\begin{array}{l}9.0 \text { to } 9.5 \\
20.4\end{array}$ & $\begin{array}{l}\text { No } \\
\text { Yes }\end{array}$ & $\begin{array}{l}\leq 5 \mathrm{ml} \\
\mathrm{NR}\end{array}$ & $\begin{array}{l}\text { Sham } \\
\text { Usual Care }\end{array}$ & $\begin{array}{l}\text { Continued opioid use } \\
\text { Major opioid use }\end{array}$ & $\begin{array}{l}3 / 30 \\
13 / 56 \\
16 / 86\end{array}$ & $\begin{array}{l}7 / 34 \\
19 / 58 \\
26 / 92\end{array}$ & $\begin{array}{l}0.49(0.14 \text { to } 1.71) \\
0.71 \text { (0.39 to } 1.29) \\
0.66(0.30 \text { to } 1.27)\end{array}$ \\
\hline $\begin{array}{l}>2 \text { weeks to } \leq 1 \text { month } \\
\text { Buchbinder } 2009 \\
\text { Kallmes } 2009 \\
\text { Firanescu } 2018 \\
\text { Subgroup } \\
\left(I^{2}=0.0 \%, p=0.210\right)\end{array}$ & $\begin{array}{l}\text { Up to } 12 \text { months } \\
\text { Up to } 12 \text { mons } \\
\leq 9 \text { weeks }\end{array}$ & $\begin{array}{l}9.0 \text { to } 9.5 \\
17.8 \\
5 \text { to } 8\end{array}$ & $\begin{array}{l}\text { No } \\
\text { No } \\
\text { Yes }\end{array}$ & $\begin{array}{l}\leq 5 \mathrm{ml} \\
\leq 5 \mathrm{ml} \\
>5 \mathrm{ml}\end{array}$ & $\begin{array}{l}\text { Sham } \\
\text { Sham } \\
\text { Sham }\end{array}$ & $\begin{array}{l}\text { Continued opioid use } \\
\text { Opioid use } \\
\text { Strong opioid use }\end{array}$ & $\begin{array}{l}4 / 30 \\
36 / 67 \\
18 / 90 \\
58 / 187\end{array}$ & $\begin{array}{l}9 / 34 \\
26 / 61 \\
19 / 86 \\
54 / 181\end{array}$ & $\begin{array}{l}0.50(0.17 \text { to } 1.47) \\
1.26(0.87 \text { to } 1.82) \\
0.91(0.51 \text { to } 1.61) \\
1.08(0.58 \text { to } 1.48)\end{array}$ \\
\hline $\begin{array}{l}\text { 1 month to <6 months } \\
\text { Buchbinder } 2009 \\
\text { Blasco } 2012 \\
\text { Subgroup } \\
\left(\left.\right|^{2}=0.0 \%, p=0.691\right)\end{array}$ & $\begin{array}{l}\text { Us } \\
\text { Up to } 12 \text { months } \\
\text { Up to months }\end{array}$ & $\begin{array}{l}9.0 \text { to } 9.5 \\
20.4\end{array}$ & $\begin{array}{l}\text { No } \\
\text { Yes }\end{array}$ & $\begin{array}{l}\leq 5 \mathrm{ml} \\
\mathrm{NR}\end{array}$ & $\begin{array}{l}\text { Sham } \\
\text { Usual Care }\end{array}$ & $\begin{array}{l}\text { Continued opioid use } \\
\text { Major opioid use }\end{array}$ & $\begin{array}{l}11 / 30 \\
14 / 52 \\
25 / 82\end{array}$ & $\begin{array}{l}11 / 34 \\
16 / 56 \\
27 / 90\end{array}$ & $\begin{array}{l}1.13(0.58 \text { to } 2.23) \\
0.94(0.51 \text { to } 1.73) \\
1.02(0.60 \text { to } 1.75)\end{array}$ \\
\hline $\begin{array}{l}\geq 6 \text { months to }<12 \text { mont } \\
\text { Buchbinder } 2009 \\
\text { Blasco } 2012 \\
\text { Subgroup } \\
\left(I^{2}=0.0 \%, p=0.194\right)\end{array}$ & $\begin{array}{l}\text { ths } \\
\text { Up to } 12 \text { months } \\
\text { Up to } 12 \text { months }\end{array}$ & $\begin{array}{l}9.0 \text { to } 9.5 \\
20.4\end{array}$ & $\begin{array}{l}\text { No } \\
\text { Yes }\end{array}$ & $\begin{array}{l}\leq 5 \mathrm{ml} \\
\mathrm{NR}\end{array}$ & $\begin{array}{l}\text { Sham } \\
\text { Usual Care }\end{array}$ & $\begin{array}{l}\text { Continued opioid use } \\
\text { Major opioid use }\end{array}$ & $\begin{array}{l}17 / 30 \\
8 / 49 \\
25 / 79\end{array}$ & $\begin{array}{l}18 / 34 \\
14 / 52 \\
32 / 86\end{array}$ & $\begin{array}{l}1.07(0.69 \text { to } 1.67) \\
0.61(0.28 \text { to } 1.32) \\
0.93(0.44 \text { to } 1.57)\end{array}$ \\
\hline $\begin{array}{l}\geq 12 \text { months } \\
\text { Blasco } 2012 \\
\text { Subgroup }\end{array}$ & Up to 12 months & 20.4 & Yes & NR & Usual Care & Major opioid use & $\begin{array}{l}7 / 41 \\
7 / 41\end{array}$ & $\begin{array}{l}10 / 42 \\
10 / 42\end{array}$ & $\begin{array}{l}0.72(0.30 \text { to } 1.70) \\
0.72(0.30 \text { to } 1.70)\end{array}$ \\
\hline & & & & & & & & & 4 \\
\hline
\end{tabular}

Favors Intervention Favors Control

Abbreviations: $\mathrm{BME}=$ bone marrow edema; $\mathrm{CI}=$ confidence interval; $\mathrm{MRI}=$ magnetic resonance imaging; $\mathrm{PMMA}=$ polymethyl methacrylate; $\mathrm{SD}=$ standard deviation

See Appendix F, List of Included Studies, for full citations 
Table 1-9. Vertebroplasty versus sham or usual care and risk of mortality, incident vertebral fracture, and serious adverse events

\begin{tabular}{|c|c|c|c|}
\hline Followup Duration & $\begin{array}{l}\text { Mortality } \\
\text { RR }(95 \% \mathrm{Cl})\end{array}$ & $\begin{array}{l}\text { Vertebral Fracture } \\
\text { RR }(95 \% \mathrm{Cl})\end{array}$ & $\begin{array}{l}\text { Serious Adverse Events } \\
\text { RR }(95 \% \mathrm{Cl})\end{array}$ \\
\hline All trials & $0.88(0.50$ to 1.53$)$ & $1.02(0.66$ to 1.62$)$ & -- \\
\hline$I^{2}$ & $0 \%$ & $9.6 \%$ & -- \\
\hline No. of trials $(\mathrm{N})$ & $7(1159)$ & $10(1380)$ & -- \\
\hline 1 to 2 weeks & -- & $4.47(0.23$ to 86.77$)$ & -- \\
\hline$l^{2}$ & -- & -- & -- \\
\hline No. of trials $(\mathrm{N})$ & -- & $1(34)$ & -- \\
\hline 2 to 4 weeks & -- & $1.90(0.59$ to 7.22$)$ & -- \\
\hline$l^{2}$ & -- & $0 \%$ & -- \\
\hline No. of trials $(\mathrm{N})$ & -- & $3(598)$ & -- \\
\hline 6 to 12 months & $0.76(0.23$ to 2.65$)$ & -- & $0.67(0.12$ to 3.79$)$ \\
\hline$l^{2}$ & $0 \%$ & -- & $0 \%$ \\
\hline No. of trials $(\mathrm{N})$ & $3(598)$ & -- & $1(86)$ \\
\hline 12 months and longer* & $0.98(0.51$ to 1.87$)$ & $0.94(0.55$ to 1.49$)$ & $0.95(0.06$ to 14.90$)$ \\
\hline$l^{2}$ & $0 \%$ & $15 \%$ & -- \\
\hline No. of trials $(\mathrm{N})$ & $5(639)$ & $7(826)$ & $1(125)$ \\
\hline
\end{tabular}

Abbreviations: $\mathrm{CI}=$ confidence interval; $\mathrm{N}=$ number of subjects; $\mathrm{RR}=$ relative risk

*1 trial reported vertebral fractures through 24 months

\section{Figure I-16. Vertebroplasty versus sham or usual care and risk of mortality}

\begin{tabular}{|c|c|c|c|c|c|c|c|c|}
\hline $\begin{array}{l}\text { Control Type } \\
\text { and Author Year }\end{array}$ & $\begin{array}{l}\text { Pain Duration } \\
\text { Inclusion }\end{array}$ & $\begin{array}{l}\text { Pain Duration } \\
\text { (weeks) }\end{array}$ & $\begin{array}{l}\text { BME MRI } \\
\text { Required }\end{array}$ & $\begin{array}{l}\text { PMMA } \\
\text { Category }\end{array}$ & $\begin{array}{l}\text { Vertebroplasty } \\
\mathrm{n} / \mathrm{N}\end{array}$ & $\begin{array}{l}\text { Control } \\
\mathrm{n} / \mathrm{N}\end{array}$ & & $\begin{array}{l}\text { Risk Ratio } \\
(95 \% \mathrm{Cl})\end{array}$ \\
\hline $\begin{array}{l}\text { Sham } \\
\text { Klazen } 2010 \\
\text { Clark 2016 } \\
\text { Firanescu } 2018 \\
\text { Subgroup } \\
\left(1^{2}=0.0 \%, p=0.629\right)\end{array}$ & $\begin{array}{l}\leq 6 \text { weeks } \\
<6 \text { weeks } \\
\leq 9 \text { weeks }\end{array}$ & $\begin{array}{l}4 \\
2.6 \\
5 \text { to } 8\end{array}$ & $\begin{array}{l}\text { Yes } \\
\text { Yes } \\
\text { Yes }\end{array}$ & $\begin{array}{l}\leq 5 \mathrm{ml} \\
>5 \mathrm{ml} \\
>5 \mathrm{ml}\end{array}$ & $\begin{array}{l}5 / 101 \\
3 / 61 \\
8 / 91 \\
16 / 253\end{array}$ & $\begin{array}{l}6 / 101 \\
4 / 59 \\
5 / 89 \\
15 / 249\end{array}$ & $\begin{array}{l:}7 \\
\end{array}$ & $\begin{array}{l}0.83(0.26 \text { to } 2.64) \\
0.73(0.17 \text { to } 3.10) \\
1.56(0.53 \text { to } 4.60) \\
1.05(0.48 \text { to } 2.18)\end{array}$ \\
\hline $\begin{array}{l}\text { Usual Care } \\
\text { Rousing } 2009 \\
\text { Farrokhi } 2011 \\
\text { Blasco } 2012 \\
\text { Leali 2016 } \\
\text { Subgroup } \\
\left(1^{2}=0.0 \%, p=0.654\right)\end{array}$ & $\begin{array}{l}\leq 8 \text { weeks } \\
4 \text { weeks - } 1 \text { year } \\
\text { Up to } 12 \text { months } \\
\text { Acute }\end{array}$ & $\begin{array}{l}1.1 \\
27 \text { to } 30 \\
20.4 \\
N R\end{array}$ & $\begin{array}{l}\text { No } \\
\text { Yes } \\
\text { Yes } \\
\text { Yes }\end{array}$ & $\begin{array}{l}\mathrm{NR} \\
\leq 5 \mathrm{ml} \\
\mathrm{NR} \\
\leq 5 \mathrm{ml}\end{array}$ & $\begin{array}{l}2 / 26 \\
2 / 40 \\
3 / 64 \\
1 / 200 \\
8 / 330\end{array}$ & $\begin{array}{l}2 / 24 \\
1 / 42 \\
6 / 61 \\
3 / 200 \\
12 / 327\end{array}$ & \begin{tabular}{l|l} 
& \\
$\because$ & \\
&
\end{tabular} & $\begin{array}{l}0.92(0.14 \text { to } 6.05) \\
-2.10(0.20 \text { to } 22.26) \\
0.48(0.12 \text { to } 1.22) \\
0.33(0.03 \text { to } 3.18) \\
0.65(0.26 \text { to } 1.79)\end{array}$ \\
\hline $\begin{array}{l}\text { Heterogeneity betweer } \\
\text { Overall } \\
\left(L^{2}=0.0 \%, p=0.782\right)\end{array}$ & groups: $p=0.41$ & & & & $24 / 583$ & $27 / 576$ & & 0.88 (0.50 to 1.53$)$ \\
\hline
\end{tabular}

Abbreviations: $\mathrm{BME}=$ bone marrow edema; $\mathrm{CI}=$ confidence interval; $\mathrm{MRI}=$ magnetic resonance imaging; $\mathrm{PMMA}=$ polymethyl methacrylate; $\mathrm{SD}=$ standard deviation

See Appendix F, List of Included Studies, for full citations 


\section{Appendix J. Strength of Evidence}

Table J-1. Strength of evidence

\begin{tabular}{|c|c|c|c|c|c|c|c|c|c|}
\hline Intervention & Outcomes & $\begin{array}{l}\text { Number of } \\
\text { Studies }\end{array}$ & $\begin{array}{l}\text { Number of } \\
\text { Subjects }\end{array}$ & Directness & Precision & $\begin{array}{l}\text { Study } \\
\text { Limitations }\end{array}$ & Consistency & Findings $(95 \% \mathrm{Cl})$ & SOE \\
\hline \multirow{9}{*}{$\begin{array}{l}\text { Vertebroplasty } \\
\text { vs. sham or usual } \\
\text { care for vertebral } \\
\text { compression } \\
\text { fractures }\end{array}$} & Pain $(\geq 1$ to $\leq 2 \mathrm{w})$ & 10 RCTs & 1093 & Direct & Imprecise & Low & Inconsistent & $\begin{array}{l}\text { Overall: MD }-0.53(-1.36 \text { to } 0.24) \\
\text { Vs. sham: MD }-0.02(-0.65 \text { to } 0.61) \\
\text { Vs. usual care: MD }-1.22(-2.81 \text { to } \\
0.23)\end{array}$ & $\begin{array}{l}\text { Low for } \\
\text { benefit }\end{array}$ \\
\hline & $\begin{array}{l}\text { Pain }(>2 w \text { to } \leq 1 \\
m)\end{array}$ & 8 RCTs & 918 & Direct & Precise & Low & Inconsistent & $\begin{array}{l}\text { Overall: MD }-1.05(-1.80 \text { to }-0.32) \\
\text { Vs. sham: MD }-0.57(-1.09 \text { to }-0.05) \\
\text { Vs. usual care: MD }-2.27(-3.20 \text { to }- \\
0.94)\end{array}$ & $\begin{array}{l}\text { Moderate } \\
\text { for benefit }\end{array}$ \\
\hline & $\begin{array}{l}\text { Pain }(>1 \text { to }<6 \\
\text { m) }\end{array}$ & 10 RCTs & 1094 & Direct & Precise & Low & Inconsistent $^{*}$ & $\begin{array}{l}\text { Overall: MD }-0.76(-1.17 \text { to }-0.38) \\
\text { Vs. sham: MD }-0.47(-0.98 \text { to }-0.01) \\
\text { Vs. usual care: MD }-1.17(-1.71 \text { to }- \\
0.60)\end{array}$ & $\begin{array}{l}\text { Moderate } \\
\text { for benefit }\end{array}$ \\
\hline & $\begin{array}{l}\text { Pain }(\geq 6 \text { to }<12 \\
\text { m) }\end{array}$ & 8 RCTs & 993 & Direct & Precise & Low & Inconsistent & $\begin{array}{l}\text { Overall: MD }-0.73(-1.33 \text { to }-0.15) \\
\text { Vs. sham: MD }-0.59(-1.16 \text { to }-0.07) \\
\text { Vs. usual care: MD }-0.87(-2.81 \text { to } \\
0.23)\end{array}$ & $\begin{array}{l}\text { Moderate } \\
\text { for benefit }\end{array}$ \\
\hline & Pain $(\geq 12 \mathrm{~m})$ & 9 RCTs & 965 & Direct & Precise & Low & Inconsistent & $\begin{array}{l}\text { Overall: MD }-0.87(-1.43 \text { to }-0.31) \\
\text { Vs. sham: MD }-0.64(-1.21 \text { to }-0.08) \\
\text { Vs. usual care: }-1.08(-2.06 \text { to }-0.11)\end{array}$ & $\begin{array}{l}\text { Moderate } \\
\text { for benefit }\end{array}$ \\
\hline & $\begin{array}{l}\text { Function ( } \geq 1 \text { to } \\
\leq 2 \mathrm{w})\end{array}$ & 7 RCTs & 743 & Direct & Imprecise & Low & Inconsistent & $\begin{array}{l}\text { Overall: SMD }-0.21(-0.48 \text { to } 0.04) \\
\text { Vs. sham: SMD } 0.03(-0.36 \text { to } 0.44) \\
\text { Vs. usual care: SMD }-0.38(-0.61 \text { to }- \\
0.18)\end{array}$ & Insufficient \\
\hline & $\begin{array}{l}\text { Function (>2 w } \\
\text { to } \leq 1 \mathrm{~m})\end{array}$ & 6 RCTs & 708 & Direct & Precise & Low & Consistent & $\begin{array}{l}\text { Overall: SMD }-0.27(-0.42 \text { to }-0.12) \\
\text { Vs. sham: SMD }-0.26(-0.53 \text { to } 0.00) \\
\text { Vs. usual care: SMD }-0.28(-0.49 \text { to }- \\
0.07)\end{array}$ & $\begin{array}{l}\text { High for } \\
\text { benefit }\end{array}$ \\
\hline & $\begin{array}{l}\text { Function (>1 to } \\
<6 \mathrm{~m})\end{array}$ & 7 RCTs & 741 & Direct & Precise & Low & Inconsistent ${ }^{*}$ & $\begin{array}{l}\text { Overall: SMD }-0.28(-0.43 \text { to }-0.11) \\
\text { Vs. sham: SMD }-0.14(-0.53 \text { to } 0.27) \\
\text { Vs. usual care: SMD }-0.37(-0.56 \text { to }- \\
0.18)\end{array}$ & $\begin{array}{l}\text { Moderate } \\
\text { for benefit }\end{array}$ \\
\hline & $\begin{array}{l}\text { Function ( } \geq 6 \text { to } \\
<12 \text { m) }\end{array}$ & 6 RCTs & 690 & Direct & Precise & Low & Consistent & $\begin{array}{l}\text { Overall: SMD }-0.29(-0.45 \text { to }-0.14) \\
\text { Vs. sham: SMD }-0.32(-0.70 \text { to } 0.09) \\
\text { Vs. usual care: SMD }-0.27(-0.48 \text { to }- \\
0.07)\end{array}$ & $\begin{array}{l}\text { High for } \\
\text { benefit }\end{array}$ \\
\hline
\end{tabular}




\begin{tabular}{|c|c|c|c|c|c|c|c|c|c|}
\hline \multirow{12}{*}{$\begin{array}{l}\text { Intervention } \\
\text { Vertebroplasty } \\
\text { vs. sham or usual } \\
\text { care for vertebral } \\
\text { compression } \\
\text { fractures, } \\
\text { continued }\end{array}$} & Outcomes & $\begin{array}{l}\text { Number of } \\
\text { Studies }\end{array}$ & $\begin{array}{l}\text { Number of } \\
\text { Subjects }\end{array}$ & Directness & Precision & $\begin{array}{l}\text { Study } \\
\text { Limitations }\end{array}$ & Consistency & Findings $(95 \% \mathrm{Cl})$ & SOE \\
\hline & Function $(\geq 12 \mathrm{~m})$ & 6 RCTs & 612 & Direct & Precise & Low & Inconsistent* ${ }^{*}$ & $\begin{array}{l}\text { Overall: SMD }-0.23(-0.39 \text { to }-0.06) \\
\text { Vs. sham: SMD }-0.17(-0.51 \text { to } 0.22) \\
\text { Vs. usual care SMD }-0.25(-0.45 \text { to }- \\
0.05)\end{array}$ & $\begin{array}{l}\text { Moderate } \\
\text { for benefit }\end{array}$ \\
\hline & $\begin{array}{l}\text { Quality of life } \\
\text { (general) }(\geq 1 \text { to } \\
\leq 2 \mathrm{w})\end{array}$ & 3 RCTs & 381 & Direct & Imprecise & Low & Inconsistent $^{*}$ & $\begin{array}{l}\text { Overall: MD } 0.03(-0.04 \text { to } 0.11) \\
\text { Vs. sham: } 0.01(-0.05 \text { to } 0.07) \\
\text { Vs. usual care: } 0.10(0.02 \text { to } 0.18)\end{array}$ & $\begin{array}{l}\text { Low for no } \\
\text { benefit }\end{array}$ \\
\hline & $\begin{array}{l}\text { Quality of life } \\
\text { (general) }(>2 \mathrm{w} \\
\text { to } \leq 1 \mathrm{~m})\end{array}$ & 4 RCTs & 501 & Direct & Imprecise & Low & Inconsistent* & $\begin{array}{l}\text { Overall: MD } 0.05(0.02 \text { to } 0.09) \\
\text { Vs. sham: MD } 0.04(0.00 \text { to } 0.08) \\
\text { Vs. usual care: MD } 0.10 \text { (0.03 to } 0.17)\end{array}$ & $\begin{array}{l}\text { Low for } \\
\text { benefit }\end{array}$ \\
\hline & $\begin{array}{l}\text { Quality of life } \\
\text { (general) (>1 to } \\
<6 \mathrm{~m})\end{array}$ & 5 RCTs & 453 & Direct & Imprecise & Low & Inconsistent & $\begin{array}{l}\text { Overall: MD } 0.03(-0.02 \text { to } 0.07) \\
\text { Vs. sham: MD } 0.02(-0.04 \text { to } 0.07) \\
\text { Vs. usual care: } 0.07(-0.13 \text { to } 0.32)\end{array}$ & $\begin{array}{l}\text { Low for no } \\
\text { benefit }\end{array}$ \\
\hline & $\begin{array}{l}\text { Quality of life } \\
\text { (general) ( } \geq 6 \text { to } \\
<12 \mathrm{~m} \text { ) }\end{array}$ & 3 RCTs & 370 & Direct & Precise & Low & Consistent & $\begin{array}{l}\text { Overall: MD } 0.06(0.02 \text { to } 0.11) \\
\text { Vs. sham: MD } 0.06(-0.03 \text { to } 0.11) \\
\text { Vs. usual care: MD } 0.10(0.02 \text { to } 0.18)\end{array}$ & $\begin{array}{l}\text { High for } \\
\text { benefit }\end{array}$ \\
\hline & $\begin{array}{l}\text { Quality of life } \\
\text { (general) }(\geq 12 \\
\text { m) }\end{array}$ & 4 RCTs & 337 & Direct & Imprecise & Low & Inconsistent* & $\begin{array}{l}\text { Overall: MD } 0.06(-0.06 \text { to } 0.14) \\
\text { Vs. sham: MD }-0.05(-0.18 \text { to } 0.10) \\
\text { Vs. usual care: MD } 0.10(0.02 \text { to } 0.19)\end{array}$ & Insufficien $^{\dagger}$ \\
\hline & \begin{tabular}{|l|} 
Quality of life \\
(condition- \\
specific) $(\geq 1$ to \\
$\leq 2 \mathrm{w}$ ) \\
\end{tabular} & 6 RCTs & 644 & Direct & Imprecise & Low & Inconsistent & $\begin{array}{l}\text { Overall: MD }-2.55(-9.46 \text { to } 3.15) \\
\text { Vs. sham: }-0.73(-13.01 \text { to } 11.09) \\
\text { Vs. usual care: }-4.00(-14.59 \text { to } 4.67)\end{array}$ & $\begin{array}{l}\text { Low for no } \\
\text { benefit }\end{array}$ \\
\hline & \begin{tabular}{|l|} 
Quality of life \\
(condition- \\
specific) (>2 w to \\
$\leq 1 \mathrm{~m}$ )
\end{tabular} & 4 RCTs & 482 & Direct & Imprecise & Low & Inconsistent & $\begin{array}{l}\text { Overall: MD }-2.11(-10.44 \text { to } 3.54) \\
\text { Vs. sham: } 0.94(-9.37 \text { to } 9.63) \\
\text { Vs. usual care: }-4.95(-17.56 \text { to } 0.72)\end{array}$ & $\begin{array}{l}\text { Low for no } \\
\text { benefit }\end{array}$ \\
\hline & \begin{tabular}{|l|} 
Quality of life \\
(condition- \\
specific) $(>1$ to \\
$<6 \mathrm{~m}$ ) \\
\end{tabular} & 4 RCTs & 507 & Direct & Imprecise & Low & Consistent & $\begin{array}{l}\text { Overall: MD }-2.16(-7.08 \text { to } 1.81) \\
\text { Vs. sham: MD }-0.70(-5.66 \text { to } 4.26) \\
\text { Vs. usual care: MD }-2.92(-12.16 \text { to } \\
\text { 3.51) }\end{array}$ & $\begin{array}{l}\text { Moderate } \\
\text { for no } \\
\text { benefit }\end{array}$ \\
\hline & $\begin{array}{l}\text { Quality of life } \\
\text { (condition- } \\
\text { specific) ( } \geq 6 \text { to } \\
<12 \mathrm{~m} \text { ) } \\
\end{array}$ & 5 RCTs & 599 & Direct & Imprecise & Low & Consistent & $\begin{array}{l}\text { MD -2.98 (-7.62 to } 0.69) \\
\text { Vs. sham: }-3.63(-11.49 \text { to } 3.94) \\
\text { Vs. usual care: }-2.36(-11.42 \text { to } 3.52)\end{array}$ & $\begin{array}{l}\text { Moderate } \\
\text { for no } \\
\text { benefit }\end{array}$ \\
\hline & $\begin{array}{l}\text { Quality of life } \\
\text { (condition- } \\
\text { specific) }(\geq 12 \mathrm{~m})\end{array}$ & 4 RCTs & 491 & Direct & Imprecise & Low & Consistent & $\begin{array}{l}\text { Overall: }-1.45(-5.12 \text { to } 2.06) \\
\text { Vs. sham: MD }-2.10(-8.41 \text { to } 4.21) \\
\text { Vs. usual care: MD }-1.21 \text { (-6.68 to } \\
\text { 3.54) }\end{array}$ & $\begin{array}{l}\text { Moderate } \\
\text { for no } \\
\text { benefit }\end{array}$ \\
\hline
\end{tabular}




\begin{tabular}{|c|c|c|c|c|c|c|c|c|c|}
\hline Intervention & Outcomes & $\begin{array}{l}\text { Number of } \\
\text { Studies }\end{array}$ & $\begin{array}{l}\text { Number of } \\
\text { Subjects }\end{array}$ & Directness & Precision & $\begin{array}{l}\text { Study } \\
\text { Limitations }\end{array}$ & Consistency & Findings $(95 \% \mathrm{Cl})$ & SOE \\
\hline \multirow{4}{*}{$\begin{array}{l}\text { Vertebroplasty } \\
\text { vs. sham or usual } \\
\text { care for vertebral } \\
\text { compression } \\
\text { fractures, } \\
\text { continued }\end{array}$} & $\begin{array}{l}\text { Health status } \\
(\text { SF-36 PCS and } \\
\text { MCS) }(>2 \text { w to } \\
\leq 1 \mathrm{~m},>1 \text { to } 6 \mathrm{~m} \text {, } \\
\text { and } \geq 12 \mathrm{~m})\end{array}$ & 1 to 2 RCTs & 87 to 128 & Direct & Imprecise & Low & Consistent & $\begin{array}{l}\text { Mean differences ranged from }-0.93 \text { to } \\
1.16 \text { points on the SF-36 PCS and } \\
\text { from }-3.08 \text { to } 1.00 \text { points on the SF-36 } \\
\text { MCS }\end{array}$ & $\begin{array}{l}\text { Low for no } \\
\text { benefit }\end{array}$ \\
\hline & Mortality & 7 RCTs & 1159 & Direct & Imprecise & Low & Consistent & $\operatorname{RR} 0.88$ (0.50 to 1.53$)$ & $\begin{array}{l}\text { Moderate } \\
\text { for no } \\
\text { increased } \\
\text { risk }\end{array}$ \\
\hline & $\begin{array}{l}\text { Incident vertebral } \\
\text { fractures }\end{array}$ & 10 RCTs & 1380 & Direct & Imprecise & Low & Consistent & RR 1.02 (0.66 to 1.62) & $\begin{array}{l}\text { Moderate } \\
\text { for no } \\
\text { increased } \\
\text { risk } \\
\end{array}$ \\
\hline & $\begin{array}{l}\text { Serious adverse } \\
\text { events }\end{array}$ & 2 RCTs & 211 & Direct & Imprecise & Low & $\begin{array}{l}\text { Unable to } \\
\text { assess }\end{array}$ & $\begin{array}{l}\geq 6 \text { to }<12 \text { m (1 trial): RR } 0.67 \text { (0.12 to } \\
3.79) \\
\geq 12 \text { m (1 trial): RR } 0.95 \text { (0.06 to } 14.90)\end{array}$ & $\begin{array}{l}\text { Low for no } \\
\text { increased } \\
\text { risk }\end{array}$ \\
\hline \multirow{6}{*}{$\begin{array}{l}\text { Kyphoplasty vs. } \\
\text { usual care for } \\
\text { vertebral } \\
\text { compression } \\
\text { fractures }\end{array}$} & $\begin{array}{l}\text { Pain }(1 \mathrm{w} \text { and } 1 \\
\mathrm{m})\end{array}$ & 2 RCTs & 434 & Direct & Precise & Moderate & Consistent & Large reductions & $\begin{array}{l}\text { Moderate } \\
\text { for benefit }\end{array}$ \\
\hline & $\begin{array}{l}\text { Pain (3 m, } 6 \mathrm{~m}, 1 \\
\mathrm{y}, 2 \mathrm{y})\end{array}$ & $1 \mathrm{RCT}$ & 300 & Direct & Precise & Moderate & $\begin{array}{l}\text { Unable to } \\
\text { assess }\end{array}$ & $\begin{array}{l}3 \mathrm{~m}, 6 \mathrm{~m}, 1 \mathrm{y}: \text { Moderate reduction } \\
2 \mathrm{y}: \text { Small reduction }\end{array}$ & $\begin{array}{l}\text { Low for } \\
\text { benefit }\end{array}$ \\
\hline & $\begin{array}{l}\text { Function (1 w } \\
\text { and } 1 \mathrm{~m})\end{array}$ & 2 RCTs & 434 & Direct & Precise & Moderate & $\begin{array}{l}\text { Unable to } \\
\text { assess at } 1 \mathrm{w} ; \\
\text { consistent at } 1 \\
\mathrm{~m}\end{array}$ & $\begin{array}{l}1 \mathrm{w} \text { : Moderate improvement ( } 1 \text { trial) } \\
1 \mathrm{~m} \text { : Moderate to large improvement }(2 \\
\text { trials) }\end{array}$ & $\begin{array}{l}\text { Low for } \\
\text { benefit at } 1 \\
\mathrm{w}, \\
\text { moderate } \\
\text { for benefit } \\
\text { at } 1 \mathrm{~m}\end{array}$ \\
\hline & $\begin{array}{l}\text { Function (3 m, } 6 \\
\mathrm{~m}, 1 \mathrm{y}, 2 \mathrm{y})\end{array}$ & $1 \mathrm{RCT}$ & 300 & Direct & Precise & Moderate & $\begin{array}{l}\text { Unable to } \\
\text { assess }\end{array}$ & $\begin{array}{l}3 \mathrm{~m}, 6 \mathrm{~m}, 1 \mathrm{y}: \text { Moderate improvement } \\
2 \mathrm{y}: \text { Small improvement }\end{array}$ & $\begin{array}{l}\text { Low for } \\
\text { benefit }\end{array}$ \\
\hline & $\begin{array}{l}\text { SF-36 Health } \\
\text { status }(\geq 1 \mathrm{~m})\end{array}$ & 2 RCTs & 434 & Direct & Precise & Moderate & Consistent & $\begin{array}{l}\text { Small to moderate improvement at up } \\
\text { to } 1 \mathrm{~m} \text {, no difference at } 1 \mathrm{y}\end{array}$ & $\begin{array}{l}\text { Moderate } \\
\text { for benefit } \\
\text { at up to } 1 \\
\text { m, low for } \\
\text { no benefit } \\
\text { at } \geq 1 \text { y }\end{array}$ \\
\hline & $\begin{array}{l}\text { Quality of life }(\geq 1 \\
\text { m) }\end{array}$ & $1 \mathrm{RCT}$ & 300 & Direct & Precise & Moderate & $\begin{array}{l}\text { Unable to } \\
\text { assess }\end{array}$ & $\begin{array}{l}\text { Moderate improvement at } 1 \mathrm{~m} \text {, no } \\
\text { difference at } 1 \text { to } 2 \mathrm{y}\end{array}$ & $\begin{array}{l}\text { Low for } \\
\text { benefit at } 1 \\
m \text {, low for } \\
\text { no } \\
\text { difference } \\
\text { at } \geq 1 \text { y }\end{array}$ \\
\hline
\end{tabular}




\begin{tabular}{|c|c|c|c|c|c|c|c|c|c|}
\hline Intervention & Outcomes & $\begin{array}{l}\text { Number of } \\
\text { Studies }\end{array}$ & $\begin{array}{l}\text { Number of } \\
\text { Subjects }\end{array}$ & Directness & Precision & $\begin{array}{l}\text { Study } \\
\text { Limitations }\end{array}$ & Consistency & Findings $(95 \% \mathrm{Cl})$ & SOE \\
\hline \multirow{3}{*}{$\begin{array}{l}\text { Kyphoplasty vs. } \\
\text { usual care for } \\
\text { vertebral } \\
\text { compression } \\
\text { fractures, } \\
\text { continued }\end{array}$} & Mortality & 2 RCTs & 434 & Direct & Imprecise & Moderate & Inconsistent & $\begin{array}{l}\text { No difference in one trial and } \\
\text { increased risk in one trial }\end{array}$ & Insufficient \\
\hline & $\begin{array}{l}\text { Incident or } \\
\text { worsening } \\
\text { vertebral fracture }\end{array}$ & 2 RCTs & 434 & Direct & Imprecise & Moderate & Inconsistent & $\begin{array}{l}\text { Increased risk in one trial and few } \\
\text { events with imprecise estimate in one } \\
\text { trial }\end{array}$ & Insufficient \\
\hline & $\begin{array}{l}\text { Serious adverse } \\
\text { events }\end{array}$ & 2 RCTs & 434 & Direct & Imprecise & Moderate & $\begin{array}{l}\text { Unable to } \\
\text { assess }\end{array}$ & No difference in risk & $\begin{array}{l}\text { Low for no } \\
\text { increased } \\
\text { risk }\end{array}$ \\
\hline \multirow{6}{*}{$\begin{array}{l}\text { Cooled } \\
\text { radiofrequency } \\
\text { denervation vs. } \\
\text { sham for } \\
\text { sacroiliac pain }\end{array}$} & Pain (1 and $3 \mathrm{~m}$ ) & 2 RCTs & 79 & Direct & Precise & Moderate & Consistent & $\begin{array}{l}1 \mathrm{~m} \text { : Moderate to large improvement } \\
3 \mathrm{~m} \text { : Moderate improvement }\end{array}$ & $\begin{array}{l}\text { Moderate } \\
\text { for benefit }\end{array}$ \\
\hline & $\begin{array}{l}\text { Function (1 and } \\
3 \mathrm{~m})\end{array}$ & 2 RCTs & 79 & Direct & Precise & Moderate & Inconsistency§ & $\begin{array}{l}1 \mathrm{~m} \text { : Small to large improvement } \\
3 \mathrm{~m} \text { : Moderate improvement }\end{array}$ & $\begin{array}{l}\text { Low for } \\
\text { benefit at } 1 \\
\text { m; } \\
\text { moderate } \\
\text { for benefit } \\
\text { at } 3 \mathrm{~m} \\
\end{array}$ \\
\hline & $\begin{array}{l}\text { Health status, } \\
\text { quality of life ( } 3 \\
\text { m) }\end{array}$ & $1 \mathrm{RCT}$ & 28 & Direct & Precise & Moderate & $\begin{array}{l}\text { Unable to } \\
\text { assess }\end{array}$ & $3 \mathrm{~m}$ : Moderate improvement & $\begin{array}{l}\text { Low for } \\
\text { benefit at } 3 \\
\text { m }\end{array}$ \\
\hline & Opioid use $(1 \mathrm{~m})$ & $1 \mathrm{RCT}$ & 51 & Direct & Precise & Moderate & $\begin{array}{l}\text { Unable to } \\
\text { assess }\end{array}$ & $1 \mathrm{~m}$ : Large reduction & $\begin{array}{l}\text { Low for } \\
\text { benefit at } 1 \\
m\end{array}$ \\
\hline & $\begin{array}{l}\text { Treatment } \\
\text { success } \\
\text { (composite } \\
\text { outcome) (1 and } \\
3 \mathrm{~m}) \\
\end{array}$ & 2 RCTs & 79 & Direct & Precise & Moderate & $\begin{array}{l}\text { Unable to } \\
\text { assess (1 } \\
\text { study at each } \\
\text { time point) }\end{array}$ & $\begin{array}{l}1 \mathrm{~m}: \text { Large benefit } \\
3 \mathrm{~m} \text { : Large benefit }\end{array}$ & $\begin{array}{l}\text { Low for } \\
\text { benefit }\end{array}$ \\
\hline & Harms & $1 \mathrm{RCT}$ & 28 & Direct & Imprecise & Moderate & $\begin{array}{l}\text { Unable to } \\
\text { assess }\end{array}$ & $\begin{array}{l}\text { No serious complications and } \\
\text { temporary worsening of pain reported }\end{array}$ & Insufficient \\
\hline \multirow[t]{2}{*}{$\begin{array}{l}\text { Cooled vs. } \\
\text { continuous } \\
\text { radiofrequency } \\
\text { denervation for } \\
\text { presumed lumbar } \\
\text { facet joint pain }\end{array}$} & $\begin{array}{l}\text { Pain }(1,3 \text {, and } 6 \\
\text { m) }\end{array}$ & $1 \mathrm{RCT}$ & 43 & Direct & Imprecise & Low & $\begin{array}{l}\text { Unable to } \\
\text { assess }\end{array}$ & $\begin{array}{l}1 \text { and } 3 \mathrm{~m}: \text { No difference } \\
6 \mathrm{~m}: \text { Small reduction }\end{array}$ & $\begin{array}{l}\text { Low for } \\
\text { benefit at } 6 \\
m \text { and for } \\
\text { no benefit } \\
\text { at } 1 \text { and } 3 \\
\text { m }\end{array}$ \\
\hline & $\begin{array}{l}\text { Function }(1,3, \\
\text { and } 6 \mathrm{~m})\end{array}$ & $1 \mathrm{RCT}$ & 43 & Direct & Imprecise & Low & $\begin{array}{l}\text { Unable to } \\
\text { assess }\end{array}$ & No differences & $\begin{array}{l}\text { Low for no } \\
\text { benefit }\end{array}$ \\
\hline
\end{tabular}




\begin{tabular}{|c|c|c|c|c|c|c|c|c|c|}
\hline Intervention & Outcomes & $\begin{array}{l}\text { Number of } \\
\text { Studies }\end{array}$ & $\begin{array}{l}\text { Number of } \\
\text { Subjects }\end{array}$ & Directness & Precision & $\begin{array}{l}\text { Study } \\
\text { Limitations }\end{array}$ & Consistency & Findings $(95 \% \mathrm{Cl})$ & SOE \\
\hline \begin{tabular}{l|} 
Cooled vs. \\
continuous \\
radiofrequency \\
denervation for \\
presumed lumbar \\
facet joint pain, \\
continued
\end{tabular} & Harms & $1 \mathrm{RCT}$ & 43 & Direct & Imprecise & Low & $\begin{array}{l}\text { Unable to } \\
\text { assess }\end{array}$ & $\begin{array}{l}\text { No serious adverse events; self-limited } \\
\text { post-procedural pain in two patients }\end{array}$ & $\begin{array}{l}\text { Low for no } \\
\text { increased } \\
\text { risk }\end{array}$ \\
\hline \multirow{4}{*}{$\begin{array}{l}\text { Pulsed } \\
\text { radiofrequency } \ddagger \\
\text { denervation vs. } \\
\text { sham for } \\
\text { presumed lumbar } \\
\text { facet joint pain }\end{array}$} & Pain (6 m, 1 y) & $1 \mathrm{RCT}$ & 40 & Direct & Imprecise & Moderate & $\begin{array}{l}\text { Unable to } \\
\text { assess }\end{array}$ & No differences & Insufficient \\
\hline & $\begin{array}{l}\text { Function (6 m, } 1 \\
\text { y) }\end{array}$ & $1 \mathrm{RCT}$ & 40 & Direct & Imprecise & Moderate & $\begin{array}{l}\text { Unable to } \\
\text { assess }\end{array}$ & No differences & Insufficient \\
\hline & $\begin{array}{l}\text { Analgesic use (1 } \\
\text { year) }\end{array}$ & $1 \mathrm{RCT}$ & 40 & Direct & Imprecise & Moderate & $\begin{array}{l}\text { Unable to } \\
\text { assess }\end{array}$ & No difference & Insufficient \\
\hline & Harms & No evidence & - & - & -- & -- & - & -- & $\begin{array}{l}\text { No } \\
\text { evidence }\end{array}$ \\
\hline \multirow{4}{*}{$\begin{array}{l}\text { Pulsed vs. } \\
\text { continuous } \\
\text { radiofrequency } \\
\text { denervation for } \\
\text { presumed lumbar } \\
\text { facet joint pain } ¥\end{array}$} & Pain (6 m, 1 y) & $1 \mathrm{RCT}$ & 40 & Direct & Imprecise & Moderate & $\begin{array}{l}\text { Unable to } \\
\text { assess }\end{array}$ & $\begin{array}{l}6 \mathrm{~m}: \text { No difference } \\
1 \mathrm{y}: \text { Moderate increase }\end{array}$ & Insufficient \\
\hline & $\begin{array}{l}\text { Function (6 m, } 1 \\
\text { y) }\end{array}$ & $1 \mathrm{RCT}$ & 40 & Direct & Imprecise & Moderate & $\begin{array}{l}\text { Unable to } \\
\text { assess }\end{array}$ & No differences & Insufficient \\
\hline & $\begin{array}{l}\text { Analgesic use (1 } \\
\text { y) }\end{array}$ & $1 \mathrm{RCT}$ & 40 & Direct & Imprecise & Moderate & $\begin{array}{l}\text { Unable to } \\
\text { assess }\end{array}$ & Increased analgesic use & Insufficient \\
\hline & Harms & No evidence & - & - & -- & -- & - & -- & $\begin{array}{l}\text { No } \\
\text { evidence }\end{array}$ \\
\hline \multirow{3}{*}{$\begin{array}{l}\text { Platelet rich } \\
\text { plasma vs. sham } \\
\text { for presumed } \\
\text { discogenic back } \\
\text { pain }\end{array}$} & $\begin{array}{l}\text { Pain }(1,4 \text {, and } 8 \\
\text { weeks) }\end{array}$ & $1 \mathrm{RCT}$ & 58 & Direct & Imprecise & Moderate & $\begin{array}{l}\text { Unable to } \\
\text { assess }\end{array}$ & $\begin{array}{l}1 \text { and } 4 \mathrm{w} \text { : Small reductions } \\
8 \mathrm{w} \text { : Moderate reduction }\end{array}$ & Insufficient \\
\hline & $\begin{array}{l}\text { Function }(1,4, \\
\text { and } 8 \text { weeks) }\end{array}$ & $1 \mathrm{RCT}$ & 58 & Direct & Imprecise & Moderate & $\begin{array}{l}\text { Unable to } \\
\text { assess }\end{array}$ & No differences & Insufficient \\
\hline & Harms & $1 \mathrm{RCT}$ & 58 & Direct & Imprecise & Moderate & $\begin{array}{l}\text { Unable to } \\
\text { assess }\end{array}$ & $\begin{array}{l}\text { No cases of disc space infection, } \\
\text { neurologic injury, or progressive } \\
\text { herniation }\end{array}$ & Insufficient \\
\hline \begin{tabular}{|l|} 
Intradiscal stem \\
cells vs. sham for \\
presumed \\
discogenic back \\
pain
\end{tabular} & $\begin{array}{l}\text { Pain }(1,3, \text { and } 6 \\
\mathrm{m})\end{array}$ & $1 \mathrm{RCT}$ & 100 & Direct & Imprecise & Moderate & $\begin{array}{l}\text { Unable to } \\
\text { assess }\end{array}$ & Small reductions & Insufficient \\
\hline
\end{tabular}




\begin{tabular}{|c|c|c|c|c|c|c|c|c|c|}
\hline Intervention & Outcomes & $\begin{array}{l}\text { Number of } \\
\text { Studies }\end{array}$ & $\begin{array}{l}\text { Number of } \\
\text { Subjects }\end{array}$ & Directness & Precision & $\begin{array}{l}\text { Study } \\
\text { Limitations }\end{array}$ & Consistency & Findings (95\% Cl) & SOE \\
\hline \multirow{5}{*}{$\begin{array}{l}\text { Intradiscal stem } \\
\text { cells vs. sham for } \\
\text { presumed } \\
\text { discogenic back } \\
\text { pain, continued }\end{array}$} & $\begin{array}{l}\text { Pain }(1,2 \text {, and } 3 \\
y)\end{array}$ & $1 \mathrm{RCT}$ & 100 & Direct & Precise & Moderate & $\begin{array}{l}\text { Unable to } \\
\text { assess }\end{array}$ & Moderate to large reductions & Insufficient \\
\hline & $\begin{array}{l}\text { Function }(1,3, \\
\text { and } 6 \mathrm{~m})\end{array}$ & $1 \mathrm{RCT}$ & 100 & Direct & Imprecise & Moderate & $\begin{array}{l}\text { Unable to } \\
\text { assess }\end{array}$ & No differences & Insufficient \\
\hline & $\begin{array}{l}\text { Function }(1,2, \\
\text { and } 3 \mathrm{y})\end{array}$ & $1 \mathrm{RCT}$ & 100 & Direct & Precise & Moderate & $\begin{array}{l}\text { Unable to } \\
\text { assess }\end{array}$ & Small to moderate improvements & Insufficient \\
\hline & $\begin{array}{l}\text { Treatment } \\
\text { success }(6 \mathrm{~m} \text { to } \\
3 \mathrm{y})\end{array}$ & $1 \mathrm{RCT}$ & 100 & Direct & Imprecise & Moderate & $\begin{array}{l}\text { Unable to } \\
\text { assess }\end{array}$ & Moderate benefit & Insufficient \\
\hline & Harms & $1 \mathrm{RCT}$ & 100 & Direct & Imprecise & Moderate & $\begin{array}{l}\text { Unable to } \\
\text { assess }\end{array}$ & $\begin{array}{l}\text { No differences in risk of serious } \\
\text { adverse events or any adverse event }\end{array}$ & Insufficient \\
\hline \multirow{8}{*}{$\begin{array}{l}\text { Intradiscal } \\
\text { methylene blue } \\
\text { vs. sham for } \\
\text { presumed } \\
\text { discogenic back } \\
\text { pain }\end{array}$} & Pain (6 m) & 2 RCTs & 153 & Direct & Precise & Moderate & Inconsistent & $\begin{array}{l}\text { Large benefit in initial trial but no } \\
\text { benefit in subsequent trial }\end{array}$ & $\begin{array}{l}\text { Low for no } \\
\text { benefit }\end{array}$ \\
\hline & $\begin{array}{l}\text { Pain }(6 \mathrm{w} \text { and } 3 \\
\mathrm{m})\end{array}$ & $1 \mathrm{RCT}$ & 81 & Direct & Imprecise & Low & $\begin{array}{l}\text { Unable to } \\
\text { assess }\end{array}$ & No differences & $\begin{array}{l}\text { Low for no } \\
\text { benefit }\end{array}$ \\
\hline & $\begin{array}{l}\text { Pain (12 and } 24 \\
\text { m) }\end{array}$ & $1 \mathrm{RCT}$ & 72 & Direct & Precise & Moderate & $\begin{array}{l}\text { Unable to } \\
\text { assess }\end{array}$ & Large benefit & Insufficient \\
\hline & Function (6 m) & 2 RCTs & 153 & Direct & Precise & Moderate & Inconsistent & $\begin{array}{l}\text { Large benefit in initial trial but no } \\
\text { benefit in subsequent trial }\end{array}$ & $\begin{array}{l}\text { Low for no } \\
\text { benefit }\end{array}$ \\
\hline & $\begin{array}{l}\text { Function }(6 \mathrm{w} \\
\text { and } 3 \mathrm{~m})\end{array}$ & $1 \mathrm{RCT}$ & 81 & Direct & Imprecise & Low & $\begin{array}{l}\text { Unable to } \\
\text { assess }\end{array}$ & $6 \mathrm{w}$ and $3 \mathrm{~m}$ : Small improvement & $\begin{array}{l}\text { Low for } \\
\text { benefit }\end{array}$ \\
\hline & $\begin{array}{l}\text { Function (12 and } \\
24 \mathrm{~m})\end{array}$ & \begin{tabular}{|l|l|} 
& RCT \\
\end{tabular} & 72 & Direct & Precise & Moderate & $\begin{array}{l}\text { Unable to } \\
\text { assess }\end{array}$ & Large benefit & Insufficient \\
\hline & Opioid use & 2 RCTs & 153 & Direct & Precise & Moderate & Inconsistent & $\begin{array}{l}\text { Large reduction in initial trial but no } \\
\text { difference in subsequent trial }\end{array}$ & Insufficient \\
\hline & Harms & 2 RCTs & 153 & Direct & Imprecise & Moderate & Consistent & $\begin{array}{l}\text { No serious adverse events related to } \\
\text { procedure and no difference in risk of } \\
\text { any adverse event }\end{array}$ & $\begin{array}{l}\text { Low for no } \\
\text { increased } \\
\text { risk }\end{array}$ \\
\hline $\begin{array}{l}\text { Intradiscal ozone } \\
\text { + corticosteroid } \\
\text { vs. corticosteroid } \\
\text { for radiculopathy } \\
\text { due to herniated } \\
\text { disc }\end{array}$ & $\begin{array}{l}\text { Pain }(1 \mathrm{w}, 2 \mathrm{w}, 3 \\
\mathrm{m}, 6 \mathrm{~m})^{\ddagger}\end{array}$ & $1 \mathrm{RCT}$ & 159 & Direct & Imprecise & High & $\begin{array}{l}\text { Unable to } \\
\text { assess }\end{array}$ & $\begin{array}{l}1 \text { and } 2 \mathrm{w}: \text { No differences } \\
3 \text { and } 6 \mathrm{~m} \text { : Moderate reduction }\end{array}$ & Insufficient \\
\hline
\end{tabular}




\begin{tabular}{|c|c|c|c|c|c|c|c|c|c|}
\hline Intervention & Outcomes & $\begin{array}{l}\text { Number of } \\
\text { Studies }\end{array}$ & $\begin{array}{l}\text { Number of } \\
\text { Subjects }\end{array}$ & Directness & Precision & $\begin{array}{l}\text { Study } \\
\text { Limitations }\end{array}$ & Consistency & Findings $(95 \% \mathrm{Cl})$ & SOE \\
\hline \multirow{2}{*}{$\begin{array}{l}\text { Intradiscal ozone } \\
\text { + corticosteroid } \\
\text { vs. corticosteroid } \\
\text { for radiculopathy } \\
\text { due to herniated } \\
\text { disc, continued }\end{array}$} & $\begin{array}{l}\text { Function }(2 \text { or } 3 \\
\mathrm{w}, 6 \mathrm{~m})^{\ddagger}\end{array}$ & $1 \mathrm{RCT}$ & 159 & Direct & Imprecise & Moderate & $\begin{array}{l}\text { Unable to } \\
\text { assess }\end{array}$ & $\begin{array}{l}2 \text { or } 3 \text { w: No difference } \\
6 \text { m: Moderate improvement }\end{array}$ & Insufficient \\
\hline & Harms & $3 \mathrm{RCT}$ & 339 & Direct & Imprecise & High & $\begin{array}{l}\text { Unable to } \\
\text { assess }\end{array}$ & $\begin{array}{l}\text { No serious adverse events in any trial; } \\
\text { increased risk of any adverse event in } \\
\text { one trial }\end{array}$ & Insufficient \\
\hline \multirow{3}{*}{$\begin{array}{l}\text { Sphenopalatine } \\
\text { block vs. sham } \\
\text { for chronic } \\
\text { migraine }\end{array}$} & Pain (1 and $6 \mathrm{~m}$ ) & $1 \mathrm{RCT}$ & 41 & Direct & Imprecise & Moderate & $\begin{array}{l}\text { Unable to } \\
\text { assess }\end{array}$ & $\begin{array}{l}1 \mathrm{~m}: \text { Small benefit }(p>0.05) \\
6 \mathrm{~m}: \text { Moderate benefit }(p>0.05)\end{array}$ & Insufficient \\
\hline & $\begin{array}{l}\text { Function (1 and } \\
6 \mathrm{~m})\end{array}$ & $1 \mathrm{RCT}$ & 41 & Direct & Imprecise & Moderate & $\begin{array}{l}\text { Unable to } \\
\text { assess }\end{array}$ & 1 and $6 \mathrm{~m}$ : Small benefit $(p>0.05)$ & Insufficient \\
\hline & $\begin{array}{l}\text { Any adverse } \\
\text { event }\end{array}$ & $1 \mathrm{RCT}$ & 41 & Direct & Imprecise & Moderate & $\begin{array}{l}\text { Unable to } \\
\text { assess }\end{array}$ & No difference & Insufficient \\
\hline \multirow{3}{*}{$\begin{array}{l}\text { Occipital nerve } \\
\text { stimulation vs. } \\
\text { sham for chronic } \\
\text { migraine }\end{array}$} & Pain (12 w) & $1 \mathrm{RCT}$ & 157 & Direct & Imprecise & Moderate & $\begin{array}{l}\text { Unable to } \\
\text { assess }\end{array}$ & $\begin{array}{l}\text { Similar likelihood of } \geq 50 \% \text { reduction in } \\
\text { pain intensity, increased likelihood of } \\
\geq 30 \% \text { reduction in pain intensity }\end{array}$ & Insufficient \\
\hline & Function (12 w) & $1 \mathrm{RCT}$ & 157 & Direct & Imprecise & Moderate & $\begin{array}{l}\text { Unable to } \\
\text { assess }\end{array}$ & Large improvement & Insufficient \\
\hline & $\begin{array}{l}\text { Headache days } \\
(12 \mathrm{w})\end{array}$ & $1 \mathrm{RCT}$ & 157 & Direct & Imprecise & Moderate & $\begin{array}{l}\text { Unable to } \\
\text { assess }\end{array}$ & Small improvement & Insufficient \\
\hline \multirow{3}{*}{$\begin{array}{l}\text { Occipital nerve } \\
\text { stimulation vs. } \\
\text { usual care for } \\
\text { chronic migraine }\end{array}$} & Pain (3 m) & $1 \mathrm{RCT}$ & 67 & Direct & Imprecise & Moderate & $\begin{array}{l}\text { Unable to } \\
\text { assess }\end{array}$ & $\begin{array}{l}\text { Small improvement for stimulation with } \\
\text { adjustable parameters; no difference } \\
\text { for stimulation using parameter } \\
\text { parameters }\end{array}$ & Insufficient \\
\hline & Function (3 m) & $1 \mathrm{RCT}$ & 67 & Direct & Imprecise & Moderate & $\begin{array}{l}\text { Unable to } \\
\text { assess }\end{array}$ & $\begin{array}{l}\text { Large improvement for stimulation with } \\
\text { adjustable parameters; no difference } \\
\text { for stimulation using preset parameters }\end{array}$ & Insufficient \\
\hline & $\begin{array}{l}\text { Headache days, } \\
\text { mood }\end{array}$ & $1 \mathrm{RCT}$ & 67 & Direct & Precise & Moderate & $\begin{array}{l}\text { Unable to } \\
\text { assess }\end{array}$ & $\begin{array}{l}\text { Small improvement for stimulation with } \\
\text { adjustable parameters for headache } \\
\text { days and mood; no differences for } \\
\text { stimulation using present parameters }\end{array}$ & $\begin{array}{l}\text { Low for } \\
\text { benefit for } \\
\text { stimulation } \\
\text { with } \\
\text { adjustable } \\
\text { parameters }\end{array}$ \\
\hline
\end{tabular}




\begin{tabular}{|c|c|c|c|c|c|c|c|c|c|}
\hline Intervention & Outcomes & $\begin{array}{l}\text { Number of } \\
\text { Studies }\end{array}$ & $\begin{array}{l}\text { Number of } \\
\text { Subjects }\end{array}$ & Directness & Precision & $\begin{array}{l}\text { Study } \\
\text { Limitations }\end{array}$ & Consistency & Findings $(95 \% \mathrm{Cl})$ & SOE \\
\hline $\begin{array}{l}\text { Occipital nerve } \\
\text { stimulation vs. } \\
\text { usual care for } \\
\text { chronic migraine, } \\
\text { continued }\end{array}$ & Harms & 2 RCTs & 224 & Direct & Imprecise & Moderate & Consistent & $\begin{array}{l}\text { Lead migration occurred in } 14 \text { to } 24 \\
\text { percent of patients in two trials. } \\
\text { Few serious device-related adverse } \\
\text { events }\end{array}$ & $\begin{array}{l}\text { Low for risk } \\
\text { of lead } \\
\text { migration } \\
\text { and no } \\
\text { increased } \\
\text { risk of } \\
\text { serious } \\
\text { harms } \\
\end{array}$ \\
\hline \multirow[t]{4}{*}{$\begin{array}{l}\text { Piriformis } \\
\text { injection with } \\
\text { corticosteroid } \\
\text { and local } \\
\text { anesthetic vs. } \\
\text { local anesthetic } \\
\text { for piriformis } \\
\text { syndrome }\end{array}$} & $\begin{array}{l}\text { Pain at rest }{ }^{\ddagger}(1 \mathrm{w} \\
\text { to } 3 \mathrm{~m})\end{array}$ & $1 \mathrm{RCT}$ & 50 & Direct & Imprecise & Moderate & $\begin{array}{l}\text { Unable to } \\
\text { assess }\end{array}$ & $\begin{array}{l}\text { No difference at } 1 \text { week, moderate } \\
\text { improvement at } 1 \text { and } 3 \text { months, but } \\
\text { only statistically significant at } 1 \text { month }\end{array}$ & $\begin{array}{l}\text { Low for no } \\
\text { benefit at } 1 \\
w \text { and } \\
\text { benefit at } 1 \\
m \text {, } \\
\text { insufficient } \\
\text { at } 3 \mathrm{~m} \\
\end{array}$ \\
\hline & Function & $1 \mathrm{RCT}$ & 50 & Direct & Imprecise & High & $\begin{array}{l}\text { Unable to } \\
\text { assess }\end{array}$ & Insufficient & Insufficient \\
\hline & $\begin{array}{l}\text { Transient sciatic } \\
\text { nerve block }\end{array}$ & $1 \mathrm{RCT}$ & 50 & Direct & Imprecise & Moderate & $\begin{array}{l}\text { Unable to } \\
\text { assess }\end{array}$ & No difference & $\begin{array}{l}\text { Low for no } \\
\text { difference }\end{array}$ \\
\hline & $\begin{array}{l}\text { Serious adverse } \\
\text { events }\end{array}$ & $1 \mathrm{RCT}$ & 50 & Direct & Imprecise & High & $\begin{array}{l}\text { Unable to } \\
\text { assess }\end{array}$ & Insufficient & Insufficient \\
\hline $\begin{array}{l}\text { Peripheral nerve } \\
\text { stimulation vs. } \\
\text { sham or control } \\
\text { for ulnar, radial, } \\
\text { or median } \\
\text { neuropathy } \\
\end{array}$ & $\begin{array}{l}\text { Pain, function, } \\
\text { harms }(3 \mathrm{~m})\end{array}$ & $\begin{array}{l}1 \text { subgroup } \\
\text { analysis from } \\
\text { RCT }\end{array}$ & 94 & Indirect & Imprecise & Moderate & $\begin{array}{l}\text { Unable to } \\
\text { assess }\end{array}$ & Insufficient & Insufficient \\
\hline
\end{tabular}

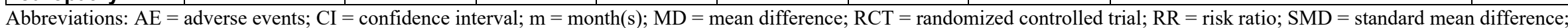

$\mathrm{SOE}=$ strength of evidence; $\mathrm{w}=$ week $(\mathrm{s}) ; \mathrm{y}=$ year(s)

*Statistical heterogeneity low, but inconsistency in magnitude of benefit between trials of sham and usual care

$\uparrow$ SOE graded as insufficient due to marked inconsistency (different directions of effect) between estimates from trials of sham and trials of usual care

$\ddagger$ SOE assessment excludes poor-quality trials

§inconsistency in magnitude of benefit at 1 month 
